\title{
int
}

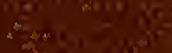

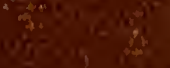

4

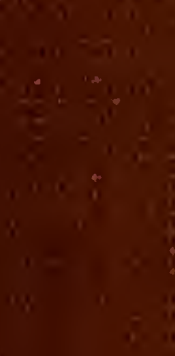

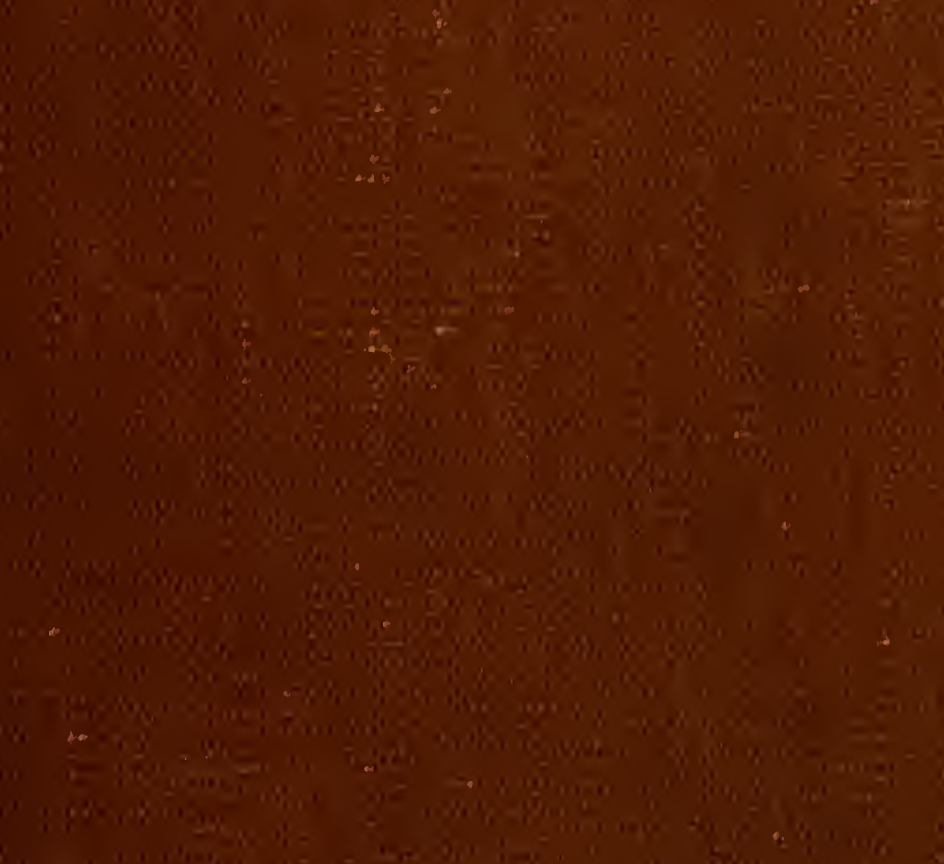

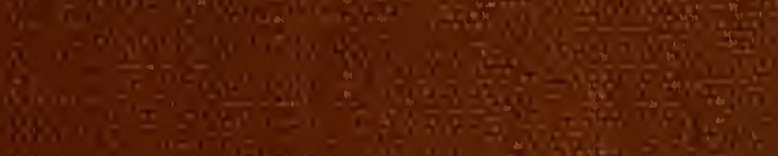

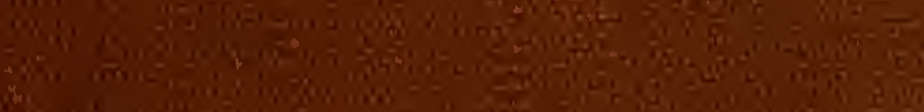

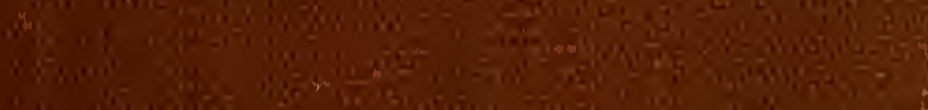

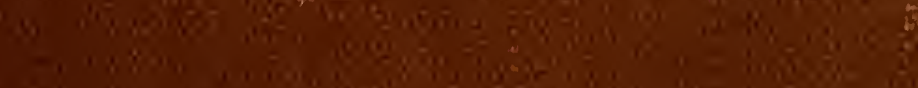

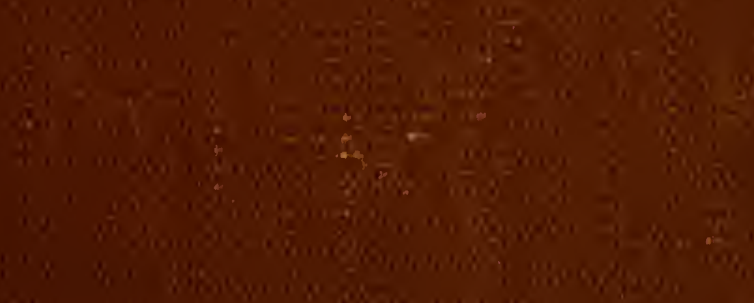
Nos

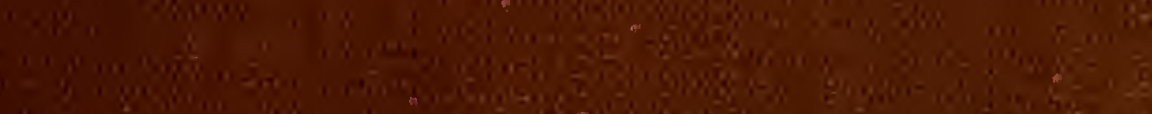

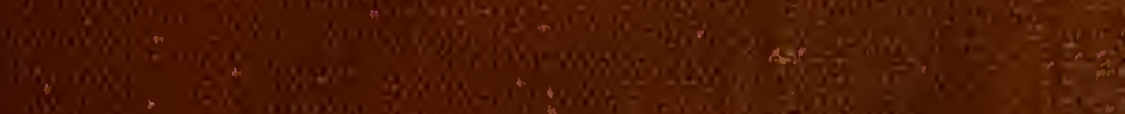

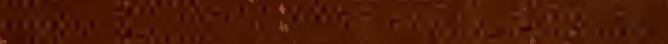

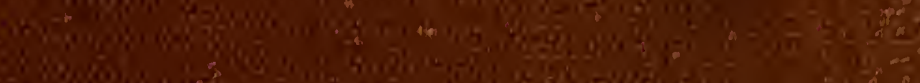

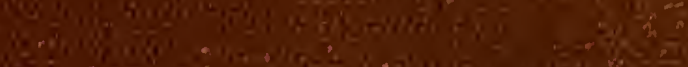

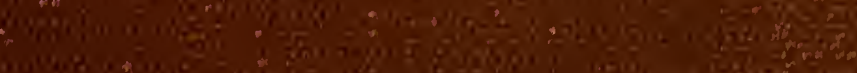
: : 10.

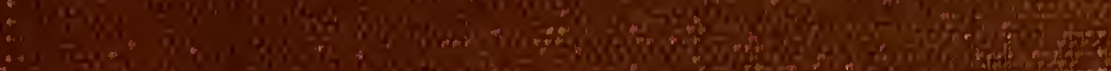

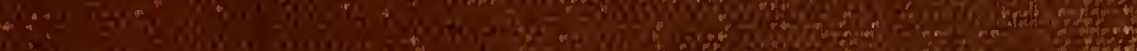
$\therefore$ :

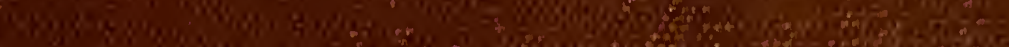











\section{BIRDS OF MICRONESIA.}

B Y

Tokutarū Momiyama, M. O.S.J.

A LIST OF THE BIRDS OF MICRONESIAN GROUP, WITH DESCRIPTIONS OF TWO NEW FORMS.

\section{B Y}

Nagamichi Kuroda, Rigakushi, M.O S.J.

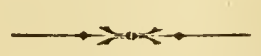

\section{9}

THE ORNITHOLOGICAL SOCIETY OF JAPAN. 



\section{CONTENTS:}

PART I.

Descriptions of two new Genera and nine new Subspecies of

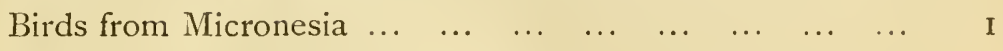

Descriptions of two new Forms of Birds from Pelew Islands, $\begin{array}{lllllllll}\text { Micronesia (by N. Kuroda) } & \ldots & \ldots & \ldots & \ldots & \ldots & \ldots & \ldots & 25\end{array}$

A List of the Birds of Micronesian group, exclusive of Magalhaes, Gilbert and Ellice islands (by N. Kuroda) $\ldots \quad 3$ I

$$
\begin{gathered}
\text { PART II. } \\
\text { (JAPANESE 'ГEXT). }
\end{gathered}
$$

$\begin{array}{llllllllllll}\text { Chapter I. Introduction } & \ldots & \ldots & \ldots & \ldots & \ldots & \ldots & \ldots & \ldots & \text { I }\end{array}$ Chapter II. Special Parts :

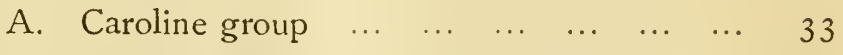
B. Marianne group $\ldots \begin{array}{llllll}\ldots & \ldots & \ldots & \ldots & \ldots & 275\end{array}$
C. Pelew group... $\ldots \begin{array}{lllllll} & \ldots & \ldots & \ldots & \ldots & \ldots & 302\end{array}$

Chapter III. A table of birds known at present from the various islands and island-groups of Micronesia, exclusive of Magalhaes, Gilbert and Ellice archipelagoes... $\quad \ldots \quad \ldots \quad 339$ 


\section{A LIST OF PLATES.}

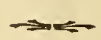

PAGE.

(in Japanese text)

I. Sketch-map of Pelew and Caroline groups $\ldots \begin{array}{llll}\ldots & \ldots & \ldots & 33\end{array}$

II. (I) White Spots on throat in grey-phase of D. s. sacra

(2) Nest and eggs of Demicgretta s. sacra ... ...

(3) White, Grey and Piebald phases of D. s. sacra ... 4

III. (I) Nestling of Leptophathon l. lepturus from Pelew Is. ...

(2) Young birds of Anous melanogcnys, from Oleai Is.,

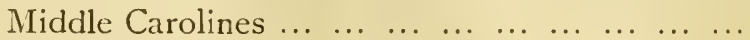

(3) Nestling of Gygis albus kittlitzi, from Ruk Is.,

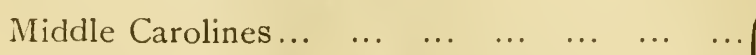

(4) Gygisterna sumatrana from Ponape Is., Eastern Carolines, (wounded by a shot)...

(5) Young bird of Thalasscus bergii pelecanoides, from Ngoli Is., Western Carolines

IV. I \& 2. Phlegonas xanthonurus yapensis. 우 2nd year) and $\hat{\sigma}$ adult

3. Ph. kubaryi.

今 adult

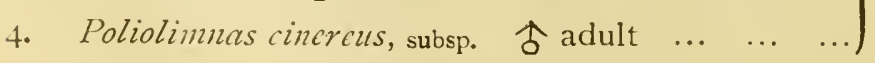


VI. I. Enopsittacus rubiginosus, 우 adult (A partial) Rubious phase

2. Ptilinopus p. ponapensis. $\hat{\sigma}$ adult

3. Globicera oceanica monacha, subsp. nov. $\hat{0}$ aduit

4. Ptilinopus p.hirnshcimi. 우 juv.... $\ldots$... $\ldots$...

VII. I-3. Mctabolus rugcnsis. 우 2nd year (moulting) stages), 令s adult and juv.

4. Kubaryum (n.g.) olcaginum. 우 adult

5. Rukia (n.g.) ruki. 우 adult .. 


\title{
A LIST OF TEXT FIGURES.
}

\begin{abstract}
$\rightarrow$
Japanese

т. Heads of two forms of Poliolimnas cincreus ... ...

2. Heads of two species of Anous from Micronesia $\quad \ldots \quad \ldots \quad$ I 12

3. Three outer primaries of adult and young of Ptilinopus ... 155

4. Two forms of Ptilinopus ponapcnsis

5. Spots on primaries and wing-coverts of Urodynamis

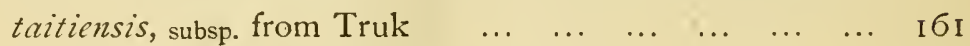

6. Heads of Mctabolus rugensis, adult males, from Truk $\quad \ldots \quad$ I 83

7. Heads of the forms of Aplonis opaca. Ss ad.... $\quad \ldots \quad \ldots 221$

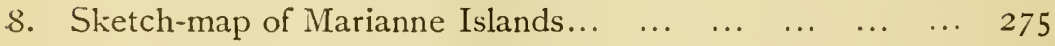

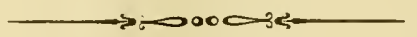

\section{CORRECTIONS.}

On p. I, 2nd line from below, read "oleaginus" instead of "oleaginum." On p. 2, sth line from above, read " fig." instead , "figs." 


\title{
DESCRIPTIONS OF TWO NEW GENERA AND NINE NEW SUBSPECIES OF BIRDS FROM MICRONESIA.
}

\author{
BY
}

TOKUTAR̄̄ MOMIYAMA, M.O.S.F.

The following descriptions of birds from some Micronesian islands are based on specimens contained in the collections of the Ornithological Society of Japan, of Mr. K. Kobayashi in Yokohama, and of the present author. I was engaged in ornithorogical collecting in Micronesia during the last year.

Here I beg to tender sincere thanks to Mr. N. Kuroda for his kind help on this work and publication of this manuscript. Further my thanks are due to the late Dr. I. Ijima for the valuable advice given me on several occasions.

$$
\begin{aligned}
& \text { Kubaryum, gen. nov. (Plate VII, fig. 4). } \\
& \text { (Zosteropidæ). }
\end{aligned}
$$

Description. - Ridge of lower mandible almost straight and flat, and curving down very gently towards the end; silky eye-ring pure white and broad, under-parts of body neither white nor whitish.

Type.- Zostcropus oliagina Hartlaub \& Finsch, I872= Kubaryum olcaginus from Yap island, one of the Western Caroline islands. 
Rukia, gen. nov. (Plate VII. fig. 5).

(Zosteropidie).

Description.-- Bill very strong, blackish; tarsus and toes also strong, orange colour not black or brown ; silky eye-ring on lower edge of eyelid only

Type. - Tcphras nuki Hartert, I897=Rikia miki from Ruk, Caroline Islands.

Globicera oceanica teraokai, subsp. nov. (PL. V. fig. 2 \& 3 ) (Columbidæ).

Carpopinaga oceanica Wiglesworth, Aves Polyn., 1891, p. 52 (part.) ; Takatsukasa \& Kuroda, "Tori," Vol. i, No. 2, I91 5, pp. 52, 62 (part.).

合 ad.-Similar to G. o. occanica (Lesson) from Kusaie island, but head, neck and breast somewhat paler (pale bluish-grey), except the crown, occiput and hind-neck which are of a deeper hue than the breast ; the chestnut colour.on lower parts of body somewhat deeper than that of the typical form; the ontermost tail-feather without rufous on tip; length of bill much shorter than in the typical form.

우 ad.-Head, neck and breast somewhat darker than in adult male, the chestnut colour on lower parts rather paler, and knob on base of upper mandible smaller.

Types.-Adult male and adult female. Tol, Ruk (Truk) islands, a small group of islands in Middle Caroline, Micronesia. May 25 \& 18, I919. Nomiyama's coll. nos. 95 and 57.

Iris purplish-carmine or pink-madder; bill black; knob on upper mandible purplish-black or brownish-black; foot rosecarmine; claw horny-black.

Habitat.-Tol, Wman, Toroas, etc., etc., Ruk Islands, one of the small group of Middle Carolines.

Measurements. 


\begin{tabular}{|c|c|c|c|c|c|c|c|c|}
\hline Measured by : & 完 & $\dot{\jmath}$ & $\dot{\jmath}$ & $\dot{\Xi}$ & $\dot{3}$ & $\dot{\circ}$ & $\dot{8}$ & $\dot{8}$ \\
\hline Sex & $\begin{array}{l}\dot{\vec{E}} \\
\text { fo }\end{array}$ & 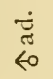 & $\begin{array}{l}\vec{\pi} \\
\text { \&ँ }\end{array}$ & $\begin{array}{l}\dot{\vec{\pi}} \\
\ll 0 \\
\ll\end{array}$ & 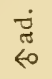 & $\begin{array}{l}\dot{\pi} \\
\text { of }\end{array}$ & $\begin{array}{l}\text { 䒕 } \\
\text { of }\end{array}$ & 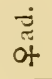 \\
\hline Number of tail-feathers & $=$ & $\cong$ & $=$ & $\stackrel{m}{-}$ & $\Xi$ & $\simeq$ & $\stackrel{m}{-}$ & $\nexists$ \\
\hline Middle claw & $\dot{\vec{E}} \cong$ & $\cong$ & $\stackrel{+}{\Im}$ & 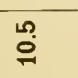 & ָ̃ & $\stackrel{\infty}{=}$ & $\stackrel{\mathscr{m}}{\underset{\sim}{+}}$ & $\cong$ \\
\hline Middle toe with claw & | & 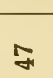 & $\begin{array}{l}\infty \\
\dot{\infty} \\
\phi \infty\end{array}$ & ন্] & 녕 & 尔 & $\begin{array}{l}0 \\
\mathscr{6} \\
\mathscr{6}\end{array}$ & $\approx$ \\
\hline Tarsus & 宫 & นึ.ల్ల & $\mathscr{m}$ & 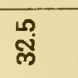 & బ్ & $\ddot{m}$ & $\bar{m}$ & న్ల \\
\hline Tail & 葛 & 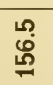 & 尔 & 望 & 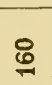 & 온 & $\stackrel{\mathscr{R}}{\stackrel{2}{2}}$ & 苗 \\
\hline Wing & 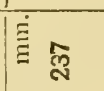 & 峞 & 莡 & สู้ & ల్ల & 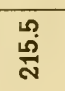 & 岗 & สี \\
\hline $\begin{array}{l}\text { Depth of knob from } \\
\text { edge of upper mandible }\end{array}$ & 蓄 & I & 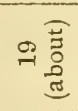 & 1 & 1 & 1 & 1 & 1 \\
\hline Eill from gape & 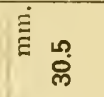 & I & 1 & 㐫 & ले & ஜ̊ & $\bar{m}$ & I \\
\hline $\begin{array}{l}\text { Culmen from tip to hind } \\
\text { edge of knob }\end{array}$ & ह & 1 & స广 & 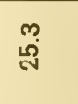 & 1 & นึ & 1 & 1 \\
\hline Total length & हो & 1 & 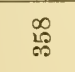 & $\stackrel{\infty}{\stackrel{N}{*}}$ & 1 & 1 & 1 & 1 \\
\hline Date & $\frac{\stackrel{\infty}{a}}{30}$ & $\dot{g}$ & $\frac{2}{30}=\frac{9}{90}$ & $\dot{\dot{y}}$ & $\dot{g}$ & $\stackrel{\infty}{\infty}$ & $\sum_{\frac{2}{a}}^{\frac{2}{9}}$ & $\dot{8}$ \\
\hline Loc. & $\begin{array}{l}\stackrel{\dot{m}}{\vec{u}} \\
\ddot{\ddot{z}}\end{array}$ & $\stackrel{\circ}{\because}$ & 它 & $\dot{8}$ & $\dot{g}$ & $\dot{8}$ & 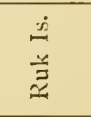 & $\stackrel{\circ}{\circ}$ \\
\hline No. & $\stackrel{1}{9}$ & $\stackrel{\mathscr{g}}{\mathfrak{G}}$ & $\begin{array}{l}20 \\
\substack{20 \\
10 \\
\infty \\
-1}\end{array}$ & 3 & $\check{~}$ & 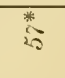 & $\stackrel{\infty}{\stackrel{\infty}{*}}$ & 악 \\
\hline Preserved in: & 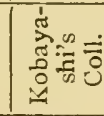 & $\dot{8}$ & 要 & 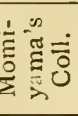 & $\dot{z}$ & $\dot{g}$ & 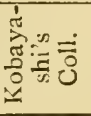 & $\dot{\delta}$ \\
\hline
\end{tabular}


Inmature.-Resembles the adult female, but mantle less greenish, the colour of breast not sharply defined from that of abdomen, and the chestnut colour on abdomen paler; pale rufous edge to the tip of scapulars and wing-coverts; knob on upper mandible but little developed or entirely undeveloped.

Remark.-The species from Mortlock and Nukuor Islands has. not yet come under my examination, but probably belongs to this new form.

The subspecific name is given in honour of Mr. N. Teraoka who collected the specimens.

\section{Globicera oceanica monacha, subsp. nov.} (PL. V. figs. 4 \& 5 ; PL. VI, fig. 3).

(Columbidæ).

A ad.-Similar to G. o. tcraokai, from Ruk group, but head, neck and breast paler (pale blue-greyish white); feathers on side of neck covering the bend of wing particularly paler so that the colour of hind-neck is well defined from that of the back; mantle less bluish, but somewhat bronzy.

우 ad.-Much darker than the adul male, but not darker than the female of G.o.tcraokai; feathers on side of neck which cover the bend of wing also paler than in the female of traokai; knob on upper mandible somewhat smaller than in the adult male.

Types.-Adult male and adult female. Yap island, Yap islands, Western Carolines. June 24 \& 26, 1919. Momiyama's coll. nos. $278 \& 288$.

Iris pink-madder; bill slate-black; knob on upper naandible purplish-black $(\hat{\delta})$ or brownish-black $(ㅇ)$; foot purplish-carmine (合) or purplish-crimson (우); claw horny-black. 
Habitat-Yap island, Western Carolines.

Measurements.

\begin{tabular}{|c|c|c|c|c|}
\hline Measured by: & 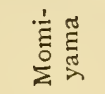 & $\dot{8}$ & $\dot{8}$ & $\dot{\dot{U}}$ \\
\hline Sex & $\begin{array}{l}\dot{\pi} \\
\operatorname{ro}_{0}\end{array}$ & $\begin{array}{l}\dot{\vec{\pi}} \\
\leftrightarrow 0\end{array}$ & $\begin{array}{l}\stackrel{\vec{\pi}}{\pi} \\
\text { or }\end{array}$ & 高 \\
\hline $\begin{array}{c}\text { Number } \\
\text { of tail-feathers }\end{array}$ & N & $\stackrel{m}{m}$ & $\simeq$ & $\simeq$ \\
\hline Middle claw & $\dot{E}$ 政 & $\stackrel{?}{\stackrel{0}{i ̣}}$ & $\stackrel{n}{=}$ & $\stackrel{n}{=}$ \\
\hline $\begin{array}{l}\text { Middle toe with } \\
\text { claw }\end{array}$ & ह & $\dddot{q}$ & के & 앙 \\
\hline Tarsus & 离 & $\bar{m}$ & $\bar{m}$ & 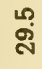 \\
\hline Tail & $\stackrel{\Xi}{\Xi}$ & $\stackrel{\leftrightarrow 0}{\oplus}$ & 员 & 쬼 \\
\hline Wing & 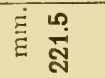 & ลี & $\stackrel{9}{\mathrm{~N}}$ & 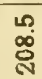 \\
\hline $\begin{array}{l}\text { Depth of knob } \\
\text { from edge of } \\
\text { upper mandible }\end{array}$ & $\stackrel{E}{E} \mathscr{\sim}$ & $\approx$ & g] & $\stackrel{10}{5}$ \\
\hline Bill from gape & 官 & 夢 & חृ & $\stackrel{\text { ก }}{\text { ก }}$ \\
\hline $\begin{array}{c}\text { Culmen from tip } \\
\text { to hind edge } \\
\text { of knob }\end{array}$ & E & 29 & $\stackrel{3}{3}$ & $\stackrel{10}{90}$ \\
\hline Total length & 豆 & $\begin{array}{l}0 \\
10 \\
\text { con }\end{array}$ & 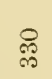 & बิ่ \\
\hline Date (I9I9) & $\underset{\substack{\infty \\
-1}}{5}$ & $\frac{2}{31}$ & $\frac{5}{60}$ & $\frac{5}{\infty}$ \\
\hline Loc. & 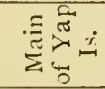 & $\dot{8}$ & $\dot{8}$ & $\dot{g}$ \\
\hline No. & $\begin{array}{l}\infty \\
\substack{\infty \\
:}\end{array}$ & 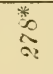 & $\begin{array}{l}* \\
3 \\
3 \\
0 \\
: 3\end{array}$ & \\
\hline Preserved in: & 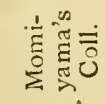 & $\dot{巳}$ & $\dot{0}^{\circ}$ & $\dot{8}$ \\
\hline
\end{tabular}

Immature-Similar to the adult bird, but darker in general colouration; back and rump much less greenish, but lustrous metallic bronzy tinge; the colour of breast extending backward to the middle abdomen where it changes into brownish pale rufous; knob on upper mandible little developed or entirely absent. In the fresh state, the iris was dark chestnut-brown, and the tarsus and toe black.

A list of the subspecies of Globicera oceanica from Micronesia.

I. G. occanica oceanica (Lesson). Type loc. Kusaie, Eastern Carolines.

Habitat. -Caroline Is. : Kusaie ; ?Marshall 
Is. : Jaluit, Arhno; ? Gilbert Is.

(I have no specimens from Marshall and Gilbert Islands).

2. G. occanica torunscndi Wetmore. Type loc. Ponapé, Eastern Carolines.

Habitat.-Caroline Is.: Ponapé.

3. G. oceanica teraokai Momiyama, subsp. nov. Type loc. Tol, one of the small islands in Ruk group, Middle Carolines.

Habitat.- Caroline Is.: Ruk, Mortlock (no specimen),? Nukuor.

4. G. occanica monacha Momiyama, subsp. nov. Type loc. Main island of Yap, Western Carolines.

Habitat.-Caroline Is.: Yap.

5. G. occanica momiyamai Kuroda, subsp. nov. Type loc. Angaur, Pelew Islands. (See pp. 25-27)

Habilat.-Pelew Is.: Angaur and main island of Pelew or Palau.

Aplonis opaca anga, subsp. nov.

(Eulabetidæ).

A. Kittlitzi Hartert, Nov, Zool., Vol. vii, I900, p. 6 (part.); Kuroda, "Dōbutsugaku Zasshi " (=Tokio Zool. Mag.), Vol xxvii, 1915, pp. 330, 332, 392 (part.) ; Takatsukasa \& Kuroda, "Tori," Vol. i, No. 2, I9I 5, pp. 55, 64 (part.) ; Kuroda, "Dōbut tugaku Zasshi" (=Tokio Zool. Mag.) Vol. xxviii, I9I6, p. 7 I (port.).

$\hat{\circ}$ ad.-Very similar to A. o opaca. (Kittlitz) from Kusaie island, but distinguishable from it by the distinct bronzy-green lustre on the edge of feathers of the upper and under surfaces of body.

Type.-Adult male. Toroas, Ruk island, one of the small group of Middle Carolines. July 17, 1919. Momiyama's coll. no. 336.

Iris chrome-lemon, with an outer ring of pale cadiniumyellow; bill black; foot black; claw black.

Habitat.-Ruk group and Wolea (Ulie) islands, Middle Carolines. 
Measurements.

\begin{tabular}{|c|c|}
\hline Measured by: & 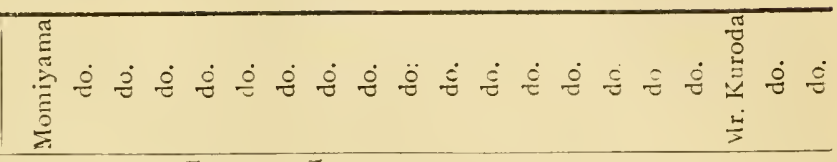 \\
\hline Sex & 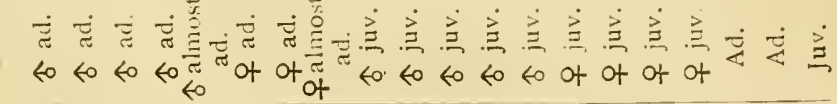 \\
\hline Tarsus & 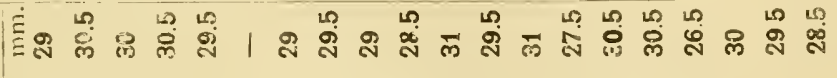 \\
\hline Tail & 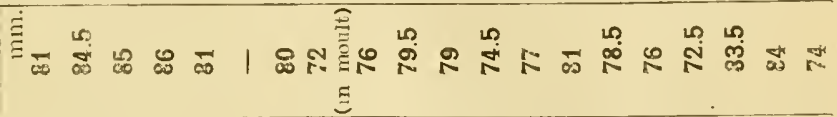 \\
\hline Wing & 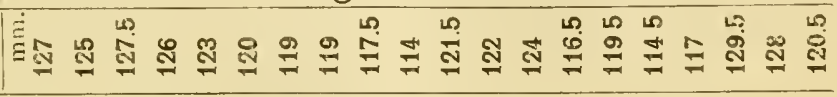 \\
\hline $\begin{array}{l}\text { Depth of bill } \\
\text { at base }\end{array}$ & 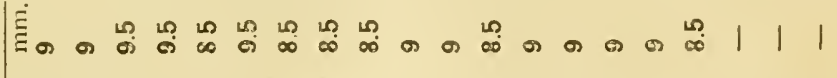 \\
\hline $\begin{array}{l}\text { Exposed } \\
\text { culmen }\end{array}$ & 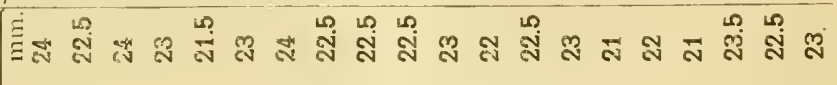 \\
\hline ngth & 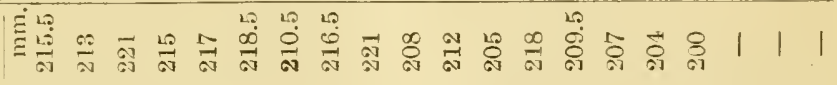 \\
\hline Date & 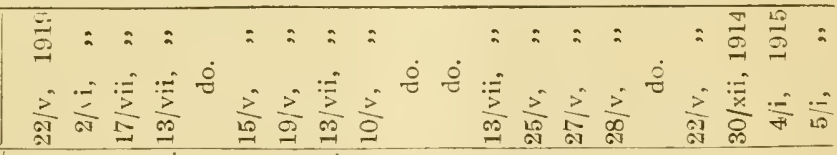 \\
\hline Loc. & 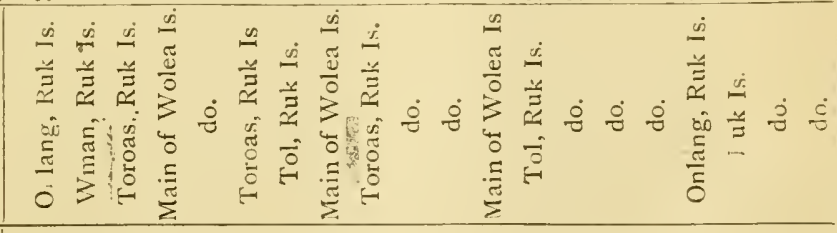 \\
\hline No. & 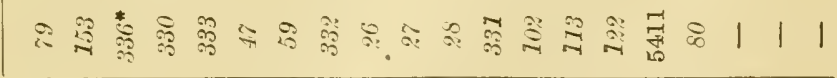 \\
\hline Preserved in: & 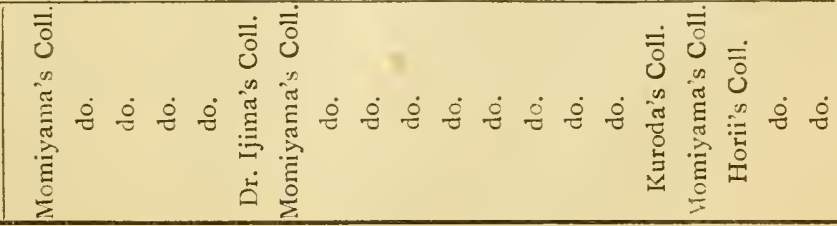 \\
\hline
\end{tabular}


There are colour variations among many adult birds, viz. : The bronzy-green lustre on both sides of body very distinct in some examples, but indistinct in others, which are probabiy tne older birds. The lustre is probably duller in the female than in the male. The length of wing is in average shorter in this than in the typical form; it measures I $16.5-129.5 \mathrm{~mm}$. instead of $121.5-\mathrm{I} 34.5 \mathrm{~mm}$. as in the latter. Iris pale yellow, with a narrow outer ring of deeper colour ; bill black; foot black; clour black.

Immature.-Upper parts of body deep brownish ashy colour, the edge of feathers faintly tinged with lustrous bronzy-green ; feathers on forehead, crown, occiput, hind neck and sides of ne : with dark shaft streaks; edge of feathers on rump and upper tail-coverts pale; quills of wing and tail blackish-brown or dark brown; outer edge of the outer web of flight-feathers pale colour ; lower parts of body pale yellowish with distinct brownish ashy shaft streaks which are broadest on chest and much narrower on abdomen, where the pale yellowish colour predominates; under wing-coverts dull ashy; flanks and under tail-coverts with dark shaft streaks, round spots and pale yellowish lace.

Young.- Very similar to the young of the typical form, but the edge of feathers somewhat more strongly tinged with bronzy-green.

Irides -is immature and young examples of the form are of a pale lemon-green, alizarin-green, deep cobalt-green, etc. They acquire the colour of the irides of adult birds with change of the immature dress into that of the adult. 
Aplonis opaca guami, subsp. nov.

(Eulabetidæ).

A kittlitsi Oustalet, Nouv. Archiv. Mus., 1895, p. 213 (part.); Hartert, Nov. Zool., Vol. v, r898, pp. 58, 69 (part,).

Ad.--Very similar to $A$. o. anga, but distinguishable from it by the edge of feathers of both body sides being much less bronzygreen and by the bill and tarsus being shorter. It differs from $A . o$. opaca by the edge of feathers of both body sides being much more bronzy-green and by the bill and tarsus being again shorter.

Type.-Adult ( $\hat{\delta}$ ?). Guam, one of the southernmost islands of the Marianne chain. 1907. Momiyama's collection no. I 309. Collected by Mr. Masatarō Uchiyama.

Habitat.-Guam, Marianne Islands.

Measurements.

\begin{tabular}{|c|c|c|c|c|c|c|c|c|c|c|}
\hline 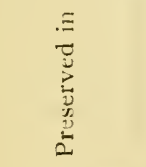 & $\dot{0}$ & ¿্் & $\stackrel{\text { ขै }}{\text { こ }}$ & 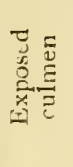 & 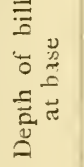 & $\stackrel{\equiv 0}{\vdots}$ & $\bar{\pi}$ & 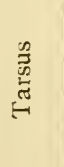 & 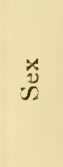 & 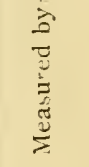 \\
\hline $\begin{array}{c}\text { Momiyama's } \\
\text { Coll. }\end{array}$ & 1306 & Guam & 1907 & $\begin{array}{l}\mathrm{mm} \\
22.5\end{array}$ & $\underset{9}{\mathrm{~mm}}$ & $\frac{\mathrm{mm}}{121.5}$ & $\begin{array}{l}\mathrm{mm} \\
\mathbf{8 0}\end{array}$ & $\begin{array}{l}\text { Inm. } \\
29.5\end{array}$ & $\begin{array}{l}\hat{\delta} ? \\
\text { ad }\end{array}$ & $\begin{array}{l}\text { Mom - } \\
\text { yama }\end{array}$ \\
\hline Kuroda's & 5410 & do. & do. & 22.5 & 9 & 122 & 80 & 27 & $\begin{array}{l}\hat{\delta} ? \\
\text { ad. }\end{array}$ & do. \\
\hline $\begin{array}{c}\text { Momiyama's } \\
\text { Coll. }\end{array}$ & 1309 & do. & do. & 21 & 9 & 127 & 87 & 28.5 & $\begin{array}{l}\hat{\delta} ? \\
\text { ad. }\end{array}$ & do. \\
\hline do. & 1310 & do. & do. & 23 & 9 & 122.5 & 84.5 & 29 & $\begin{array}{l}\text { 今 ? } \\
\text { ad. }\end{array}$ & do. \\
\hline do. & 1245 & do. & do. & 23 & - & - & 80 & 29 & $\begin{array}{l}\text { 今 ? } \\
\text { ad. }\end{array}$ & do. \\
\hline do. & 1311 & do. & do. & 23 & 8.5 & 120 & 75.5 & 29 & $\begin{array}{l}\text { की ? } \\
\text { juv. }\end{array}$ & do. \\
\hline do. & 1305 & do. & do. & 21 & 9 & 122 & 79 & 28.5 & 우? & do. \\
\hline do. & 1307 & do. & do. & 21 & 9 & 119 & 79.5 & 27.5 & $\begin{array}{l}\text { 우? } \\
\text { ad. }\end{array}$ & do. \\
\hline
\end{tabular}

* indicates the type specimen.

Young.-Very similar to the young of $A$.o. anga, but the bronzy-green lustre on mantle is less manifest. 
Aplonis opaca harterti, subsp, nov.

(Eulabetidæ).

A. kttlitsi (nec Finsch \& Hart1.), Oustalet, Nouv. Archiv. Mus., 1895, p. 213 (part.); Hartert, Nov. Zool., Vol. v, r898, pp. 58, 69 (part.); Kuroda, "Dōbutsugaku Zasshi "(= Tokio Zool. Mag.), Vol. vii, I915, pp. 330, 332 (part.) ; Takatsukasa \& Kuroda, "Tori," Vol. i, No. 2, rgr 5, p. 64 (part.) ; A. kitulitzi kurodai, Momiyama, op. cit., Vol. ii, No. 9, 1920, p. I (part.).

今 ad.- Similar to $A$. o. anga from Ruk group, but distingiushable from it by the bronzy-green lustre of the upper parts being somewhat less distinct and by the bill being much thicker. It differs from typical opaca by the edge of feathers of the under parts being somewhat more deeply tinged with bronzy-green, by the green lustre of the upper parts being rather distinct, and alıo by the bill being thicker. It differs from A. o. kurodai Momiyama from Yap islands, by the green lustre on both sides of body being less distinct and showing tendency to be a purplish lustre, by the bill being dicidedly shorter, and by the same thickness. It differs from $A .0$. guami from Guam island, by the bill and wing being distinctly longer.

Type.-Adult male. Saipan island, one of the Marianne chain. May 5, r9I9. Momiyana's coll. no. Is.

Habitat.-Saipan, Marianne islands.

Measurements.

\begin{tabular}{|c|c|c|c|c|c|c|c|c|c|c|c|}
\hline 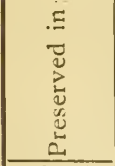 & $\dot{0}$ & ن̊ & $\frac{0}{\pi}$ & 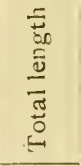 & 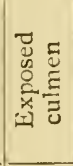 & 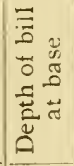 & $\stackrel{80}{\Xi}$ & $\overline{\bar{\pi}}$ & 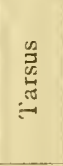 & 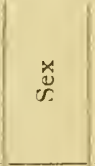 & 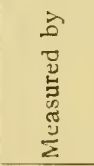 \\
\hline $\begin{array}{l}\text { Momi- } \\
\text { yama's } \\
\text { Coll. }\end{array}$ & $1 \varsigma^{*}$ & Saipan & $5 / \mathrm{v}, 1919$ & $\begin{array}{c}\mathrm{mm} . \\
229\end{array}$ & $\begin{array}{l}\mathrm{mm} \\
24\end{array}$ & $\begin{array}{l}\mathrm{mm} \\
\mathbf{1 0 . 5}\end{array}$ & ${ }_{130}^{\mathrm{mm}}$ & $\begin{array}{l}\mathrm{mm} . \\
89\end{array}$ & $\begin{array}{l}\mathrm{mm} . \\
31\end{array}$ & 今 ad. & $\begin{array}{l}\text { Mumi- } \\
\text { yama }\end{array}$ \\
\hline do. & 6 & do. & $4 / \mathrm{v}, \quad$, & 218.5 & 25 & 10 & 124.5 & 84 & 31.5 & 今 juv. & do. \\
\hline do. & 19 & do. & $5 / \mathrm{v} .$, & 225.5 & 23 & 10 & 122 & 83 & 29 & 우 uv. & do. \\
\hline $\begin{array}{l}\text { Kuroda's } \\
\text { Coll. }\end{array}$ & 4863 & do. & $4 / v, \quad$, & 214.5 & 245 & 10 & 125 & 87 & 30.5 & 今 juv. & do. \\
\hline do. & 1374 & do. & ${ }_{1915}^{\text {Feb., }}$ & - & 25 & 9.5 & 132 & 88.5 & 30.5 & Ad. & $\begin{array}{l}\text { Mr. } \\
\text { Kuroda }\end{array}$ \\
\hline
\end{tabular}

* indicates the type specimen. 
Immature.-Similar to the young of $A . o$. anga, but the bill distinctly thicker.

Remark.-Specimens from Pagan and Agrigan were not examined but seem to belong to this new form. The subspecific name is given in honour of Dr. E. Hartert.

\section{Aplonis opaca kurodai IIomiyama. \\ (Eulabetidx).}

A. Killititi Wiglesworth, Aves Polyn., r8gr, p. 44 (part.); Kuroda, " Dōbutsugaku Zas:hi" (=Tokio Zool. Mag.), Vol. xxvii, I9I5, pp, 330, 332 (part.); Takatsukasa \& Kuroda, "Tori," Vol. i, No. 2, (part.); A. kitllitsi kurodai Momiyama, op. cit., Vol. ii, No. 9, I920, P. I (part.).

Adult.-Similar to $A$. o. anga from Ruk group, but the bill thicker $(9-10.5 \mathrm{~mm}$.; that of the latter $8.5-9.5 \mathrm{~mm}$.) and much longer $(24-27.5 \mathrm{~mm}$.; that of the latter $21.5-25 \mathrm{~mm}$.) and the wing also longer in averase (1 $19.5-130 \mathrm{~mm}$. instead of $116.5-129.5 \mathrm{~mm}$.) It differs from typical opaca by the edge of feathers of both body sides being very distinctly tinged with a bronzy-green lustre, by the bill being longer and thicker (in typical opaca exposed culmen $21.5-24.5$ mm., depth of bill 9-9.5 mm.).

Immature.-Similar to the immature of the typical form, but both sides of body somewhat deeper in colour and the edge of feathers distinctly tinged with lustrous bronzy-green. It differs from the same stage of $A$. o. anga, by the under-parts being without pale-yellowish area.

Young.--Similar to the young of typical bird, but differs from it by the mantle being very faintly tinged with bronzy-green and by the under-parts being somewhat tinged with brown. In the same stage of the typical form, the under-parts are much more greyishashy in colour. 
Habitat.-Yap Islands, Western Carolines.

Measurements.

\begin{tabular}{|c|c|c|c|c|c|c|c|c|c|c|c|}
\hline 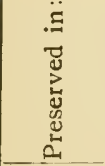 & $\dot{0}$ & ذై & 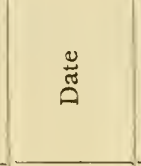 & 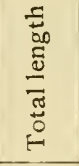 & 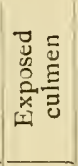 & 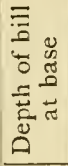 & $\stackrel{\bullet 0}{3}$ & "ह & 营 & $\begin{array}{l}\text { 㐅े } \\
\text { ஸे }\end{array}$ & 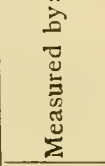 \\
\hline $\begin{array}{l}\text { Momi- } \\
\text { yama's } \\
\text { Coll. }\end{array}$ & $\% 65^{*}$ & $\begin{array}{l}\text { Main } \\
\text { of } \\
\text { Yap Is, }\end{array}$ & $22 / v i, 1919$ & $\begin{array}{l}1 \mathrm{~nm} . \\
232\end{array}$ & $\begin{array}{l}\mathrm{mm} \\
27\end{array}$ & $\begin{array}{l}\mathrm{mm} \\
10.5\end{array}$ & ${ }_{130}^{\mathrm{mm}}$ & $\begin{array}{l}\mathrm{mm} \\
88.5\end{array}$ & $\begin{array}{l}\mathrm{mm} . \\
30.5\end{array}$ & 个ิ ad. & $\begin{array}{l}\text { Momi- } \\
\text { yama }\end{array}$ \\
\hline do. & 305 & do. & $4: / v i i$, ," & 211.3 & 27.5 & 10 & 120.5 & 85 & 28.5 & 今ิ ad. & do \\
\hline do. & $2: 20$ & do. & $17 / \mathrm{vi}, \quad$, & 226.5 & 26.5 & 10 & 123.5 & 85 & 28.5 & 우 ad. & do. \\
\hline do. & 300 & do. & $29 / \mathrm{vi}$, & 206 & 25.5 & 9 & 120.5 & 83 & 28 & 우 ad. & do. \\
\hline do. & $25 ?$ & do. & $20 / v i \quad$, & 200 & 23 & 9 & 115.5 & 80 & 27.5 & 今 juv. & do. \\
\hline do. & 269 & do. & $22 / v i$, ," & 209.5 & 24 & 9 & 1135 & 72 & 30.5 & 个ิ juv. & do. \\
\hline do. & 158 & do. & $10 / v$, & 208 & 24 & 9.5 & 113 & 82 & 27.5 & 우 juv. & do. \\
\hline do. & $17 t$ & do. & $12 / \mathrm{v} \cdot$ & 217.5 & 24 & 8.5 & 117.5 & 74.5 & 29.5 & 우 juv. & do. \\
\hline do. & 190 & do. & $13 \mathrm{vi}$, ," & 159.5 & 20.5 & 8 & 97 & 48.5 & 27.5 & young & do. \\
\hline $\begin{array}{l}\text { Kuroda's } \\
\text { Coll. }\end{array}$ & 4864 & do. & $20 / v i,$, & 214.5 & 25 & 10 & 116.5 & 78.5 & 28 & 우 ad. & $\begin{array}{l}\text { Mr. } \\
\text { Kuroda }\end{array}$ \\
\hline $\begin{array}{l}\text { Horii's } \\
\text { Coll. }\end{array}$ & - & YapIs. & $5 / \mathrm{ii}, 1915$ & - & 24 & - & 128 & 82.5 & 29.5 & Ad. & do. \\
\hline do. & - & do. & do. & & 25.5 & - & 126.5 & 87.5 & 29.5 & Ad. & do. \\
\hline do. & - & do. & do. & - & 25.5 & - & 129 & 86.5 & 30 & Ad. & do. \\
\hline
\end{tabular}

* indicates the type specimen.

Remark.-The subspecies is known only from Yap Islands, but I may say that it probably occurs also on the Mackenzie group (one of the small groups of islands in Western Carolines).

A list of the subspecies of Aplonis opaca in the islands of Micronesia.

1. Aplonis opaca opcia (Kittlitz). Type loc. Kusaie, Eastern Carolines.

Habitat.-Caroline Is.: Kusaie, Ponapé (not typical).

2. A. ofaca ans Momiyama, subsp. nov. Type loc. Toroas, 
one of the islands of Ruk group Middle Carolines.

Habitat.-Caroline Is.: Ruk, Wolea or Ulie.

3. A. opaca guami Momiyama, subsp. nov. Type loc. Guam, Mariannes.

Habitat.-Marianne Is.: Guam, the subspecies is probably peculiar to the island.

4. A. opaca harterti Momiyama, subsp. nov. Type loc. Saipan, Marianne Is.

Habitat.-Marianne Is.: Saipan.

5. A. opaca kurodai Momiyama. Type loc. Main island of Yap, Western Carolines.

Habitat.-Caroline Is.: Yap.

6. A. opaca, subsp. nov.

Habitat.-Pelew Is.: Main island of Pelew and Angaur.

Very similar to $A$. o. anga, but the bronzy-green lustre on both sides of body stronger. In the immature, the under-parts show distinct streaks as the same stage of $A$. o. ang $a$ do.

Key to the subspiecies (excluding the no. 6).

(A). Edge of feathers on body sides in adul distinctly tinged with bronzy-green lustre.

(a). Exposed culmen nearly always exceeding $25 \mathrm{~mm}$. (with rare exceptions). Immature bird without distinct streaks on abdomen [Western Carolines].......... o. kurodai.

(b. Exposed culmen nearly always not exceeding $25 \mathrm{~mm}$.

Immature with very distinct streaks on abdomen.

(a') Bill rather thicker than b', not rarely exceeding io mm. [Middle Mariannes].-........... o harterti.

(b') Bill rather less thick than $\mathrm{a}^{\prime}$, not exceeding $9.5 \mathrm{~mm}$. $\left(a^{\prime \prime}\right)$ Upper parts of adult with very distinct bronzy- 
green lustre. Bill in average longer and stouter than $\mathrm{b}^{\prime \prime}$ [Middle Carolines].............. o. anga. $\left(b^{\prime \prime}\right)$ Upper parts of adult somewhat duller than $a^{\prime \prime}$. Bill in average shorter and less stout than $\mathrm{a}^{\prime \prime}$ [South Mariannes].................... o. suami. -

(B). Edge of feathers on body sides in adult faintly or not at all tinged with bronzy-green. Exposed culmen nearly always not exceeding $25 \mathrm{~mm}$. Depth of bill not exceeding $9.5 \mathrm{~mm}$. Immature bird without distinct streaks on abdomen [Eastern

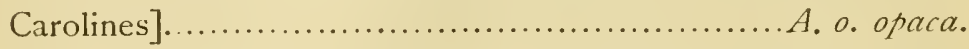

Differential measurements of the subspecies of Aplonis opaca.

\begin{tabular}{|c|c|c|c|c|c|c|c|}
\hline Subsp. & Loc. & $\begin{array}{l}\text { Sex } \\
\text { (ad.) }\end{array}$ & $\begin{array}{c}\text { Exdosed } \\
\text { culmen }\end{array}$ & $\begin{array}{c}\text { Depth of } \\
\text { bill at } \\
\text { base }\end{array}$ & Wing & Tai & Tarsus \\
\hline A. o. of aca. & $\begin{array}{l}\text { Ku aie } \\
\& \\
\text { Ponapé }\end{array}$ & $\begin{array}{l}3 \text { 소 } 5 \\
2 \text { 우 s }\end{array}$ & $\begin{array}{r}\mathrm{mm} . \\
24-24.5 \\
21.5-23\end{array}$ & $\begin{array}{c}\mathrm{mm} . \\
9-9.5 \\
\\
9 \\
(9.5)\end{array}$ & $\begin{array}{c}\mathrm{mm} \\
130-134.5 \\
121.5 \\
\text { one exam. }\end{array}$ & $\begin{array}{l}89.5-90 \\
77.5-81\end{array}$ & $\begin{array}{l}\quad \mathrm{mm} . \\
29-31 \\
(31.5) \\
27-28\end{array}$ \\
\hline A. o. anga. & $\begin{array}{c}\text { Ruk } \\
\& \\
\text { Wolea }\end{array}$ & $\begin{array}{c}6 \text { 소 } \\
\text { with two } \\
\text { suppos. } \\
3 \text { 우 s }\end{array}$ & $\begin{array}{l}22.5-24 \\
21.5-24\end{array}$ & $\begin{array}{c}9-9.5 \\
\text { fore } \\
\text { exam. } \\
8.5-9.5\end{array}$ & $\mid \begin{array}{c}125-129.5 \\
116.5-123 \\
(124)\end{array}$ & $\begin{array}{c}81-81 j \\
80-81 \\
\text { :wo exam. }\end{array}$ & $\begin{array}{l}29-30.5 \\
29-30.5 \\
\text { do. }\end{array}$ \\
\hline A $\quad$ o. stami. & Guam & $\begin{array}{c}7 \text { s s } \\
\text { with five } \\
\text { suppos. } \\
2 \text { \& s } \\
\text { suppos. }\end{array}$ & $=\mid \begin{array}{c}21-23 \\
\text { five exam. } \\
21\end{array}$ & $\begin{array}{c}9 \\
\text { do. } \\
9\end{array}$ & $\begin{array}{l}118-121 \\
119-122\end{array}$ & $\begin{array}{c}80-87 \\
\text { five exam } \\
79-79.5\end{array}$ & $\begin{array}{c}27-29.5 \\
\text { do. } \\
27.5-285\end{array}$ \\
\hline A. o. harterti. & Saipan & $\begin{array}{c}2 \hat{s} \mathrm{~s} \\
\text { with one } \\
\text { suppos. }\end{array}$ & $\begin{array}{c}24-25 \\
\text { two exam. }\end{array}$ & $\begin{array}{l}10.5 \\
\text { one } \\
\text { exam. }\end{array}$ & $\begin{array}{c}122-133 \\
\text { four exam. }\end{array}$ & $\begin{array}{l}88.5-89 \\
\text { two exam. }\end{array}$ & $\begin{array}{c}30.5-31 \\
\text { do. } \\
(31.5)\end{array}$ \\
\hline A. o. kurodai. & Yap & $\begin{array}{l}3 \text { 소 s } \\
4 \text { 우 s }\end{array}$ & $\begin{array}{r}25.5-27.5 \\
25-26.5\end{array}$ & $\begin{array}{c}10-10.5 \\
9-10\end{array}$ & $\begin{array}{l}120.5-130 \\
119.5-123.5\end{array}$ & $\begin{array}{l}85-88.5 \\
80-85\end{array}$ & $\begin{array}{c}28.5-30.5 \\
28-28.5 \\
(30)\end{array}$ \\
\hline
\end{tabular}


The figures in parenthesis refer to the exceptional larger immature examples.

\section{Myzomela rubratra wetmorei, subsp. nov.}

(Meliphagidæ).

M. rubratra Wiglesworth, Aves Polyn, I 9r. p. 3I (part.); M. mbrata (nec. Less) Hartert, Nov. Zool., Vol. vii, rgoo, p. 2; Kuroda, "Dōbutsugaku Zasshi" (=Tokio Zool. Mag.), Vol. xxvii, I 91 5, p. 28; Takatsukasa \& Kuroda, "Tori”, Vol. i, No. 2, I9I 5, p. 55; iid., op. cit., p. 64 (part.!); Kuroda, "Dōbutsugaku Zasshi”, Vol. xxviii, I9r6, p. 7 I (part.); M. r. rabratra (nec Less.), Wetmore, Bull. Mus. Comp. Zoöl., Vol. 1xiii, I9I9, p. $2 \mathbf{I g}$ (not typical!).

今 ad.-Similar to M.r. nubratra (I-esson) from Kusaie island, but distinguishable from it by the bill being smaller and shorter, the length of culmen and bill from gape not exceeding $20.5 \mathrm{~mm}$., and by the scarlet colour of body being somewhat paler and approaching vermilion. It differs from $M . r$. dichromatc Wetmore* by the vermilion colour being less prominent.

Type.-Adult male. Uman, Ruk Islands, one of the small groups of Middle Carolines. June 2, 1919. Momiyama's collection no. I 54 .

Iris turner-brown; bill black; foot blackish-slate ; claw black. Habitat.-Ruk Islands, Middle Carolines.

Measurements.

* Type localty and Habitat-Ponapé, Eastern Carolines (Alexander, Wetmore, Bull. Mus. Comp. Zoöl., Vol. Ix ii, No. 4, Aug., rgrg, p. 220). 


\begin{tabular}{|c|c|}
\hline Measured by: & 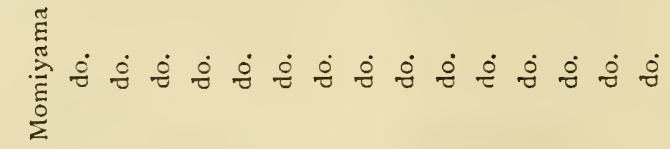 \\
\hline Se $x$ & 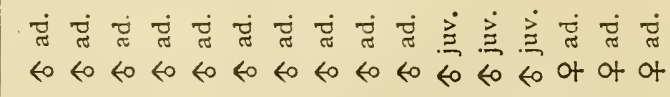 \\
\hline Tarius & 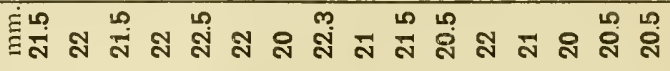 \\
\hline Tail & 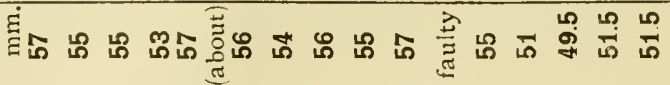 \\
\hline Wing & 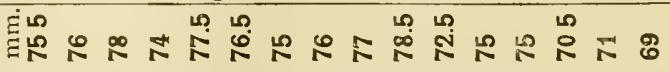 \\
\hline Bill from gape & | \\
\hline Culmen & 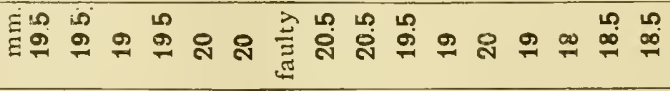 \\
\hline Total length & 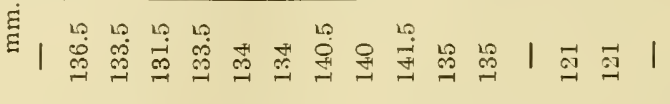 \\
\hline Date & 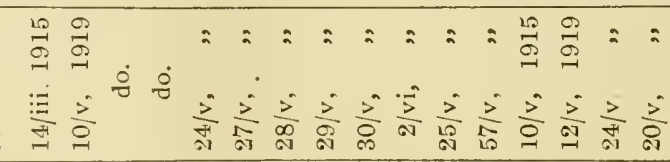 \\
\hline Loc. & 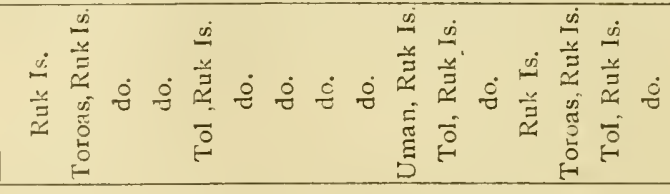 \\
\hline No. & 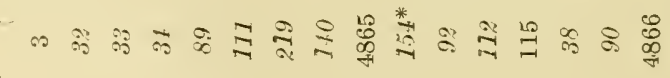 \\
\hline Preserved in: & 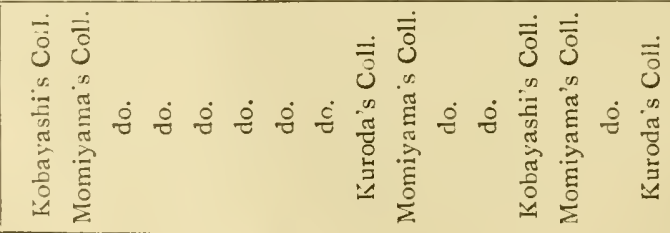 \\
\hline
\end{tabular}


In the series of adult males of this new form, some are more deeply coloured than others. Even the deeper-coloured specimens of the form are somewhat paler than typical rubratrr.

Qad.- - Resembles the adalt male, but the scarlet colour is rather dull and not so beautiful, besides being distinctly smaller

Immature. - Similar to the adult female, but the olive margin to the outer web of quills and the gape generally yellowish.

The subspecific name is given in honour of $\mathrm{Mr}$. Alexander Wetmore who studied different forms of the species.

Myzomela rubratra kurodai, subsp, nor. (Meliphagidæ).

M. rubratra Wiglesworth, Aves Polyn., I891, p. 31 (part.): M. rubrata (nec Less.), Kuroda, "Dōbutsugaku Zasshi" (= Tokio Zool. Mag.), Vol. xxvii, 19r5, pp. 331, 332 (Yap); Takatsukasa \& Kuroda, "Tori" Vol. i, No. 2, 1915, p. 64 (part.).

今 ad.-Similar to MI.r. saffordi Wetmore from Southern Marianne islands, but the tarsus is decidedly shorter, not exceeding $2 \mathrm{Imm}$. (more than $2 \mathrm{Imm}$. in $M . r$. suffordi), and the colour of plumage is not so much tinged with vernilion. It differs from $1 \%$. $r$. rubratra, M. r. dichromata and $M . r$. wimorci by the body measuring much shorter and by the scarlet colour of plumage being less pronounced. The length of bill in .M.r. avtmorci and kurodai is nearly the same.

ㅇ ad.-Upper-parts of body dark olivaceous brown; underparts, including chin, throat and fore neck like upper-parts, but somewhat paler; breast and abdomen yellowish ashy-white; head, lower back, rump, upper tail-coverts, chin, throat as well as lower breast tinged with scarlet (the red colour more distinct on lower back but less so on lower breast); pale olive margin to the outer web of flight-feathers. 
Types.-Adult male and adult female. Yap island, Yap islands, Western Carolines. June 20 \& I3, IgI9. Nomiyama collection, nos. $253 \& 193$.

Iris deep vandyke-brown or vandyke-brown; bill black; foot deep purplish slate or slate gray ; claw black or horny-black.

Habitat.-Yap Islands, Western Carolines.

Measurements.

\begin{tabular}{|c|c|c|c|c|c|c|c|c|c|c|c|c|c|c|}
\hline Measured by: & 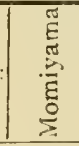 & $\dot{\tau}$ & $\dot{0}$ & $\dot{0}$ & $\dot{0}$ & $\dot{\Xi}$ & $\stackrel{0}{\div}$ & $\stackrel{0}{\square}$ & $\dot{0}$ & $\stackrel{\circ}{\check{0}}$ & $\dot{c}$ & $\dot{8}$ & $\dot{0}$ & $\dot{\Xi}$ \\
\hline Sex & 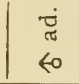 & $\begin{array}{l}\text { गु } \\
\text { \&0 }\end{array}$ & $\begin{array}{l}\vec{\pi}_{\pi} \\
\text { \& }\end{array}$ & $\underset{0}{3}$ & $\underset{<0}{\stackrel{3}{J}}$ & $\stackrel{\vec{J}}{\stackrel{3}{0}}$ & 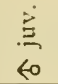 & 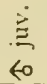 & $\begin{array}{l}\text { ¿्र } \\
\text { of }\end{array}$ & $\begin{array}{l}\tilde{r}^{0} \\
\text { of }\end{array}$ & $\begin{array}{l}\dot{\pi} \\
\text { of }\end{array}$ & $\frac{3}{\text { of }}$ & $\frac{\dot{亠}}{\text { of }}$ & 열 \\
\hline Tarsus & ह & $\bar{N}$ & $\overline{\text { n }}$ & $\overline{\text { స }}$ & 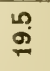 & ส & $\stackrel{\sim}{\operatorname{m}}$ & $\bar{N}$ & 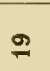 & 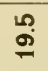 & 욤 & $\stackrel{\sim}{9}$ & $\underset{\infty}{\infty}$ & $\stackrel{2}{-}$ \\
\hline 'Tail & Eี & นี & L & חึ & $\mathscr{q}$ & 운 & $\approx$ & ชี & 趈 & ஜ̊ & $\stackrel{40}{7}$ & 尔 & $\stackrel{20}{7}$ & $\mp$ \\
\hline Wing & E⿱一彑 & $\stackrel{n}{i}$ & $\mathbb{N}$ & $\stackrel{\text { no }}{\pi}$ & $\mathscr{\bullet}$ & $\stackrel{2}{\circ}$ & $\mathscr{8}$ & $\mathfrak{N}$ & 电 & L & চ & $\begin{array}{l}10 \\
18\end{array}$ & 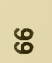 & $\mathscr{8}$ \\
\hline $\begin{array}{l}\text { Bill from } \\
\text { gape }\end{array}$ & 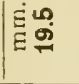 & $\frac{\vec{J}}{3}$ & 오 & $\stackrel{\sim}{\circ}$ & $\stackrel{\Xi}{\Xi}$ & $\stackrel{0}{\stackrel{8}{8}}$ & $\stackrel{\infty}{-}$ & $\stackrel{\leftrightarrow}{\oplus}$ & $\stackrel{2}{N}$ & $\stackrel{\infty}{\sim}$ & $\stackrel{\infty}{=}$ & $\stackrel{\mathscr{2}}{=}$ & $\stackrel{\infty}{\rightleftharpoons}$ & $\stackrel{\infty}{\sim}$ \\
\hline Culmen & E் & 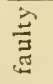 & ถి & مึ & 워 & 오 & $\stackrel{\infty}{-}$ & 유 & $\begin{array}{l}\infty \\
\infty \\
\infty\end{array}$ & $\stackrel{2}{\sim}$ & $\stackrel{\substack{\infty \\
\infty}}{0}$ & $\stackrel{\infty}{+}$ & $\stackrel{+\infty}{\infty}$ & $\stackrel{2}{-}$ \\
\hline Total length & 忘 & 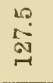 & 总 & 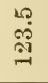 & $\stackrel{\circ}{=}$ & $\underset{-1}{9}$ & $\stackrel{10}{\stackrel{8}{8}}$ & $\stackrel{\text { a }}{\text { I }}$ & $\Xi$ & $\stackrel{g}{=}$ & $\cong$ & 1 & $\underset{ت}{\stackrel{\#}{二}}$ & $\stackrel{\infty}{=}$ \\
\hline Date (Igrg) & $\underset{m}{-\infty}$ & $\sum_{\substack{\infty \\
r-1}}^{5}$ & $\frac{3}{8}$ & $\frac{2}{2}$ & 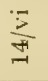 & $\stackrel{5}{5}$ & $\frac{\bar{z}}{9}$ & $: \frac{1}{20}$ & $\frac{5}{3}$ & $\bar{s}$ & $\stackrel{\circ}{\square}$ & $\frac{3}{31}$ & $\sum_{10}$ & $\dot{\nabla}$ \\
\hline Loc. & $\frac{\pi}{\pi} \frac{\pi}{\pi}$ & $\dot{\nabla}$ & $\dot{0}$ & $\dot{0}$ & $\dot{8}$ & $\dot{8}$ & $\dot{ர}$ & $\dot{D}$ & $\dot{8}$ & $\stackrel{0}{-}$ & $\dot{8}$ & $\dot{0}$ & $\dot{\Xi}$ & $\dot{8}$ \\
\hline No. & ڤें & $\hat{0}$ & 粦 & 8 & $\underset{\Im}{\approx}$ & 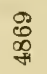 & 太خ & คิ & $\hat{\approx}$ & $\underset{\infty}{\infty}$ & 尊 & 2 & $\stackrel{9}{B}$ & 令 \\
\hline Preserved in: & 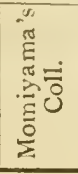 & 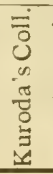 & 宽 & $\dot{\circ}$ & $\dot{I}$ & 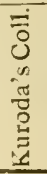 & ن & $\dot{\overbrace{}}$ & $\dot{c}$ & 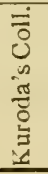 & 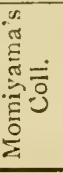 & $\dot{\nabla}$ & $\dot{0}$ & $\dot{8}$ \\
\hline
\end{tabular}


Old male.-Similar to the same stage of the typical form, but a hue of the scarlet colour darker and somewhat distinct.

Immature male.-Resembles the adult female, but forehead, crown of head, lower back, rump and upper tail-coverts much deeper scarlet, especially on forehead and crown of head which are deeply tinged with dull scarlet; whole lower parts tinged with scarlet colour, but distinctly paler than those of the adult male; fore-neck only very faintly tinged with that colour so that it shows a dark transverse band; in some specimens, the edge of wirg-coverts faintly margined with scarlet; very narrow olivaceous margin to the quills.

Immature female, young male and female,-Resembles the adult female, but the scarlet tinge is weeker.

The subspecific name is given in honour of Mr. N. Kuroda who studied different forms of the species.

Myzomela rubratra kobayashii, subsp. nov.

(Meliphagidæ)

M. rubratra Wiglesworth, Aves Polyn., r89r, p. 3 I (pari.); Gadow, Cot. B. Br. Mus., Vol. ix, 1884, p. 129 (part.); M. rubrata Takatsukasa \& Kuroda, "Tori," Vol. i, No. 2. 1915, pp. 55, 64 (part.); Kuroda, "Dōbutsugaku Zasshi" (=Tokio Zool, Mag.), Vol. xxviii, rgr6, p. 7 I (part.).

今 ad.-Very similar to $M$. r. mbratra, but distinguishable from it by the wing and tail being shorter and smaller, by the tarsus being in avarage shorter, and by the scarlet colour being less distinct and faintly tinged with vermilion. It also differs from $M . r$. zectmorei from Ruk, by the longer bill and shorter wing and tail, and by the colour of body which incline towards being vermilion.

Type.-Adult male. Pelew (Palau), Pelew Islands. May 22, 1915. Kobayashi's collection, no. 161. Coll. by Mr. N. Teraoka. 
Measurements.

\begin{tabular}{|c|c|c|c|c|c|c|c|c|c|c|}
\hline 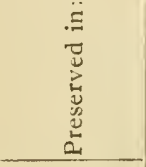 & $\dot{0}$ & ن & 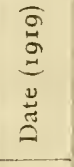 & $\frac{\bar{\Xi}}{\Xi}$ & 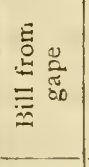 & $\stackrel{50}{\sum}$ & 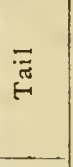 & 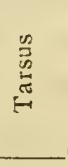 & 苛 & 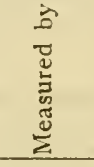 \\
\hline $\begin{array}{c}\text { Kobayashi's } \\
\text { Coll. }\end{array}$ & $161 *$ & Palau & $22 / v$ & $\begin{array}{l}\mathrm{mm} \\
21.5\end{array}$ & $\begin{array}{l}\mathrm{mm} \\
21\end{array}$ & $\mathrm{~mm}_{74}$ & $\begin{array}{l}\mathrm{mm} \\
53\end{array}$ & nim. & 송. & $\begin{array}{l}\text { Momi- } \\
\text { yama }\end{array}$ \\
\hline do. & 186 & do. & $27 / v$ & faulty & faulty & 72 & 51 & 20.5 & 今 ad. & do. \\
\hline
\end{tabular}

* indicates the type specimen.

On the basis of field observation it is probable that the female of the form is dark coloured like that of $\% r$. kurodai of Yap, island. It may on that account be separated from M. $r$ vetmori of Ruk island. However, no female specimens of the form have yet been obtained for examination.

On Angaur island of Pelew Islands, W. rubratra scems to be very rarely seen. It is probably belong of this form.

A list of the subspecies of M. mbratra on Micronesian islands.

I. M. rubutra nubatra (Lesson). Type loc. Kusaie, Eastem Carolines.

Jabitat.-Caroline Is, : Kusaie.

2. M. meratra dichromatio Wetmore. Type loc. Ponapé, lieastern Carolines.

Habitat.-Caroline Is.: l'onapé.

3. M. mbratre auctmorci Momiyama, subsp. nov. Type loc. Unan, one of the islands in Ruk group, Middle Carolines.

Habitat.-Caroline 1s. : Ruk group.

4. M. mbratre saffordi Wetmore. Type loc. Guam, Marian. nes.

Habitat.-Marianne Is.: Guam and Saipan. 
5. M, moratra kurodai Momiyama, subsp. nov. Type loc, Main island of Yap, Wistern Carolines.

Haditat.-Caroline Is.: Yap.

6. H. rubratra kobayashii Momiyama, subsp. nov. Type loc. Pelew (Palau), Pelew Islands.

Habitat.-Pelew Is.: Main island of Pelew and Angaur (not examined).

Key to the subspecies (all adult males).

(A). Wing long, usually exceeding $74 m m$. in length (with some exception).

(a). Bill long and stout, $20.5-22.5 \mathrm{~mm}$. long from gape.

(a') General colour more scarlet than in b'; tip of under tail-coverts without scarlet; dark area in front of eye narrower than in $\mathrm{b}^{\prime}$ [Kusaie]........... $/ . r$. mbratra.

$\left(b^{\prime}\right)$ General colour somewhat less scarlet than in a'; in deeply scarlet examples tip of under tail-coverts, with some scarlet; dark area in front of eye broader than in a' [Ponapé]. ................. I. r. dichromat $r$.

(b). Bill short und not stout; $19-20.5 \mathrm{~mm}$. long from gape; under tail-coverts without scarlet; dark area in front of eye narrow [Ruk group]............... $1 \%$. wetmorci:

(B). Wing short, usually not exceeding $74 \mathrm{~mm}$. in length (with some exception).

(c). Bill short and not stout; 19.5-20mm. long from gape.

(c') General colour somewhat less scarlet than in $\mathrm{d}^{\prime}$; tarsus longer than $2[\mathrm{~mm}$. [Guam and Saipan]....... ....................................... 1/. r. sciffordi.

$\left(d^{\prime}\right)$ General colour more scarlet than in $c^{\prime}$, especially in old bird; tarsus short not exceeding $21 \mathrm{~mm}$. [Yap] ..ri, r. kurodai.

(d). Bill long and stout; reaching to $2 \mathrm{Imm}$. in length from 
gape; general colour somewhat more scarlet than in $\mathrm{d}^{\prime}$ [Pelew group].......................... robay'rshiii.

Differential measurements of the subspecies of $M$. rubratra:

\begin{tabular}{|c|c|c|c|c|c|c|}
\hline Subsp. & Loc. & Sex (ad.) & $\begin{array}{l}\text { Bill from } \\
\text { gape }\end{array}$ & Wing & Tail & Tarsus \\
\hline M. r. nubratra. & Kusaie & $4 \hat{\mathrm{s}} \mathrm{s}$ & $\begin{array}{r}\mathrm{mm} \\
21-22.5\end{array}$ & $\begin{array}{r}\mathrm{mm} . \\
77.5-79.5\end{array}$ & $\begin{array}{c}\mathrm{mm} . \\
55-57\end{array}$ & $\begin{array}{c}\mathrm{mm} \\
21-22\end{array}$ \\
\hline M. r. dichromatr. & Ponapé & $\begin{array}{l}12 \text { ㅇs } \\
3 \text { 오 s }\end{array}$ & $\begin{array}{l}20.5-22 \\
\text { ten exam. } \\
19-19.5 \\
\text { two exam. }\end{array}$ & $\begin{array}{l}76-79 \\
69-70\end{array}$ & $\begin{array}{l}50-56.5 \\
45-48\end{array}$ & $\begin{array}{c}21-23 \\
19.5-20.5\end{array}$ \\
\hline M. r. wetmorei. & Ruk & $\begin{array}{l}10 \text { 소 s } \\
3 \text { 우 s }\end{array}$ & $\begin{array}{r}19-20.5 \\
\text { nine exam. } \\
18-18.5\end{array}$ & $\begin{array}{l}74-78.5 \\
63-71\end{array}$ & $\begin{array}{c}53-57 \\
49.5-51.5\end{array}$ & $\begin{array}{l}30-22.5 \\
20-20.5\end{array}$ \\
\hline M. r. saffordi. & $\begin{array}{l}\text { Guam } \\
\& \\
\text { Saipan }\end{array}$ & 10 今 $\mathrm{s}$ & $\begin{array}{c}19.5 \\
\text { one exam. }\end{array}$ & $73.3-75$ & $50-54.5$ & $21.3-23$ \\
\hline M. r. kurodizi. & Yap & $\begin{array}{l}3 \text { 소 s } \\
3 \text { 우 s }\end{array}$ & $\begin{array}{l}19.5-20 \\
\text { two exam. } \\
17.5-18\end{array}$ & $\begin{array}{l}71-74 \\
64-66.5\end{array}$ & $\begin{array}{l}52-54.5 \\
45-38.5\end{array}$ & $\begin{array}{l}20.5-21 \\
19-19.5\end{array}$ \\
\hline M. r. kobayashii. & Palau & $2 \widehat{s} \mathrm{~s}$ & $\begin{array}{c}21 \\
\text { one exam. }\end{array}$ & $72-74$ & $51-53$ & $20.5-21$ \\
\hline
\end{tabular}

Zosterops semperi takatsukasai, subsp, nov.

(Zosteropida).

Z. semperi Wiglesworth, Aves Polyn., r\$9r, p. 37 (part.); Takatsukasa \& Kuroda, "Tori," Vol. i, No. 2, IgI 5, pp. 55, 64 (part.).

$\sigma^{\bigcap}$ ad.-Similar to Z. scmperi scmperi from Pelew Islands, but distinguishable from it by the yellow streak from the posterior end of nasal opening to the upper side of eye being rather deeper in tone, by the forehead being much yellower, and by the narrow dark line from front of eye to the under side of eye scarcely deeper than in typical 
somperi. In the new form, wing longer, and tail and tarsus shorter than in the typical form.

Type.-Adult male Ponapé, Seniavina Islands, Eastern Carolines. July 31, I919. Momiyama's collection, no. 395.

Iris burnt-umber mixed with reddish, with an outer ring of venetian-red; bill horny black (upper mandible), soiled pale chromeyellow (lower mandible); foot yellowish slate; claw horny-brown.

Habitat.-Ponapé, Eastern Carolines.

Measurements.

\begin{tabular}{|c|c|c|c|c|c|c|c|c|c|c|}
\hline $\begin{array}{l}\ddot{\Xi} \\
\vec{d} \\
己 \\
\vec{y} \\
0 \\
0 \\
0\end{array}$ & $\dot{0}$ & 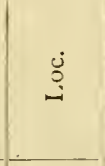 & 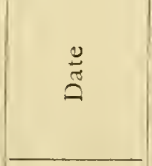 & 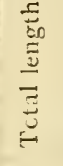 & 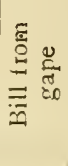 & $\stackrel{20}{\equiv}$ & $\tilde{\pi}^{\bar{\pi}}$ & 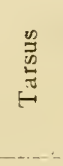 & $\stackrel{x}{\varpi}$ & 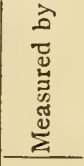 \\
\hline $\begin{array}{c}\text { Kobayashi's } \\
\text { Coll. }\end{array}$ & 16 & Ponapé & $10 / \mathrm{iv}, 1915$ & mm. & $\begin{array}{l}\mathrm{mm} . \\
14.5\end{array}$ & $\begin{array}{l}\operatorname{nim} . \\
54.3\end{array}$ & $\begin{array}{l}\mathrm{mm} \\
35\end{array}$ & $\begin{array}{l}\mathrm{mm} . \\
19.3\end{array}$ & $\hat{\sigma}$ ad. & $\begin{array}{l}\text { Momi- } \\
\text { yama }\end{array}$ \\
\hline $\begin{array}{c}\text { Momiyama's } \\
\text { Coll. }\end{array}$ & 391 & do. & 31/vii, 1919 & 93.5 & 14.2 & 52.5 & 35 & 17.5 & 个 ad. & do. \\
\hline do. & $395 *$ & do. & do., & 94.5 & 14 & 54 & 35.5 & 18.5 & $\hat{\delta}$ ad. & do. \\
\hline $\begin{array}{c}\text { Prince } \\
\text { Taliatsukasa's } \\
\text { Coll. }\end{array}$ & 1722 & do. & do. & 93 & 14.2 & 52 & $\left(\begin{array}{c}33.3 \\
\text { in } \\
\text { noult }\end{array}\right)$ & 19 & $\hat{\delta} \mathrm{ad}$. & do. \\
\hline Kuroda's Coll & 4870 & do. & 6/viii, ", & 91.3 & 14 & 53.8 & 34.5 & 19 & $\hat{\delta}$ ad. & do. \\
\hline $\begin{array}{c}\text { Momiyama's } \\
\text { Coll. }\end{array}$ & 430 & do. & 7/viii, ", & 93.5 & 14 & 53.5 & 36.5 & 17.7 & $\hat{\delta}$ ad. & do. \\
\hline do. & 409 & do. & $3 /$ viii, , & 85 & 13.5 & 53.2 & 36 & 18 & 오 ad. & do. \\
\hline
\end{tabular}

* indicates the type specimen.

오 ad.- Similar to the adult male, but under parts less yellowish, breadth of silky eye-ring narrower, and face less dark.

The subspecific name is given in honour of Prince N. Takatsukasa.

A list of the subspecies of Zosterops scmpcri in the Micronesian islands.

I. Z. semperi scmperi Hartlaub. Type loc. Pelew (Palau), Pelew Islands. 
Habitat.-Pelew Is.: Main island of Pelew; Marianne Is.: Rota.

Oustalet reported Z. semperi from Rcta, but I consider the Rota bird to be not the typical form, but as probably representing a local subspecies. No specimen from Rota has yet been examined by me.

2. Z. scmperi avestoni Hartart. Type loc. Ruk group, Middle Carolines.

Habitat.-Caroline Is.: Ruk group.

3. Z. scmperi takatsukasai Momiyama, subsp. nov. Type loc. Ponapé, Seniavina Islands, Eastern Carolines.

Habitat.-Caroline Is.: Ponapé.

Key to the subspecies.

(A). Bill from gape longer than I $3 \mathrm{~mm}$; wing short not exceeding $55 \mathrm{~mm}$.

(a). Yellow streak from the posterior end of nasal opening to over eye paler; yellow patch in front very faintly indicated; a narrow dark line from front of eye to under eye indistinct; wing in average short $(5 \mathrm{I}-55 \mathrm{~mm})$, tarsus and bill longer than in b [Pelew group]...Z. s. scmperi.

(b). Yellow streak from the posterior end of nasal opening to over eye somewhat deeper; yellow patch in front rather broad; a narrow dark line from front of eye to under eye rather distinct; wing in average long $(5=-54.3 \mathrm{~mm})$, tarsus and bill shorter than in a [Ponapé]................ Z. s. takatsukasai.

(B). Bill from gape not exceeding $13 \mathrm{~mm}$; wing long generally exceeding $55 \mathrm{~mm}$. (54-5; $\mathrm{mm}$.); a narrow dark line from front of eye to under eye blackish ashy colour and very distinct

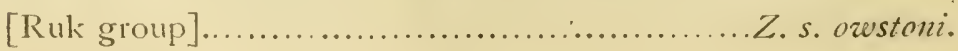




\title{
DESCRIPTIONS OF TWO NEW FORMS OF BIRDS FROM PELEW ISLANDS, MICRONESIA.
}

\author{
$B Y^{Y}$ \\ NAGAMICHI KURODA, Rigakushi, M. O.S. 7.
}

Globicera oceanica momiyamai, subsp. nov.

(Columbida).

今 ad.-Closely resembles G. ocianica monacha (see p. 4)

from Iap Island, but distinguishable from it by the upper parts of body being decidedly tinged with bronzy colour as well as glossed with some purplish lustre in some light; the tail is much greener than that of monacher.

Type.-Adult male. Angaur, one of the Pelew group, Micronesia. Aug. 12, 1915. Kuroda's collection 110. I501. Collected by Mr. E. Horii.

Habitat.-Pelew Islands, including the island of Angaur.

Measurements. 


\begin{tabular}{|c|c|c|c|c|c|c|c|c|}
\hline$\therefore$ ¿q pəsnseวN & 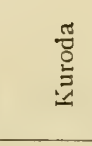 & $\dot{\check{\Xi}}$ & $\dot{3}$ & 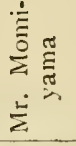 & $\dot{\ddot{t}}$ & $\dot{\square}$ & $\dot{9}$ & $\dot{\ominus}$ \\
\hline $\mathrm{x} \partial \mathrm{S}$ & 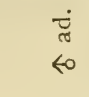 & $\begin{array}{l}\dot{\tilde{n}} \\
\text { of }\end{array}$ & $\dot{u}$ & 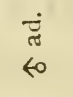 & $\stackrel{\grave{D}}{\text { of }}$ & $\stackrel{3}{\text { of }}$ & $\stackrel{\vec{\partial}}{\text { of }}$ & 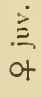 \\
\hline 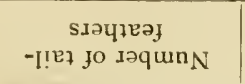 & $\begin{array}{l}E \\
=1\end{array}$ & 1 & 1 & $\stackrel{m}{=}$ & 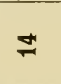 & \pm & \pm & \pm \\
\hline . & $\dot{\Xi} 1$ & 1 & 1 & $\stackrel{\sim 0}{\sim}$ & $\stackrel{n}{=}$ & $=$ & $\stackrel{5}{=}$ & $=$ \\
\hline 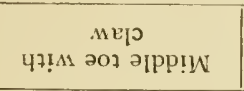 & E .1 & 1 & 1 & $\mathscr{q}$ & $\mathbb{Z}$ & $\mathscr{m}$ & m & $\ddot{8}$ \\
\hline SnSIE $L$ & ह ले & $\bar{m}$ & mุ & స్ల & ஓి & $\stackrel{10}{0}$ & 유 & $\stackrel{\infty}{\sim}$ \\
\hline I! $\mathbb{E}_{. \mathrm{L}}$ & $\stackrel{\dot{E}}{\Xi}$ & $\stackrel{\circ}{=}$ & 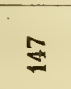 & ฮั & $\stackrel{20}{Z}$ & 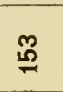 & $\underset{\mathscr{L}}{\mathbb{2}}$ & $\stackrel{m}{=}$ \\
\hline : & ๕ี สู & สี & สั้ & $\overline{\tilde{N}}$ & $\stackrel{\varpi}{N}$ & ลี & $\stackrel{\text { ลे }}{\text { ลे }}$ & 옹 \\
\hline ade: uosy II!A & छำ & $\mathscr{m}$ & $\bar{m}$ & లิ & ำ & ลุ & $\bar{m}$ & 요 \\
\hline $\begin{array}{l}\text { qouy jo ə8рว pu!̣ } \\
\text { of d!̣ uory uəu[nว }\end{array}$ & $\stackrel{\dot{\Xi}}{\Xi} 1$ & 1 & 1 & జ & สิ & $\mathscr{N}$ & मึ & เి \\
\hline$\stackrel{\frac{2}{\pi}}{=}$ & $\begin{array}{l}\frac{10}{6} \\
\stackrel{-}{3} \\
\frac{a}{-1}\end{array}$ & $\begin{array}{l}: \\
\vdots \vdots \\
\vdots \\
\bar{\theta}\end{array}$ & $\begin{array}{l}= \\
:=\end{array}$ & $\begin{array}{l}= \\
\frac{j}{\hat{\sigma}}\end{array}$ & $\begin{array}{l}= \\
\overline{a r}\end{array}$ & $\stackrel{0}{0}$ & $\begin{array}{l}: \\
\underset{\infty}{\infty}\end{array}$ & $=$ \\
\hline ju & 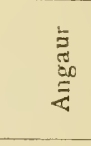 & $\dot{8}$ & $\begin{array}{l}\dot{0} \\
\frac{2}{2} \\
\frac{2}{2}\end{array}$ & $\stackrel{\check{2}}{\circ}$ & $\dot{9}$ & $\dot{8}$ & $\dot{\theta}$ & $\dot{0}$ \\
\hline$\dot{0}$ & 誊 & 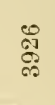 & $\underset{\mathscr{D}}{\mathscr{P}}$ & $\stackrel{\oplus}{\infty}$ & $\overrightarrow{\mathscr{N}}$ & హ్ & $\stackrel{g}{\stackrel{g}{c}}$ & id \\
\hline 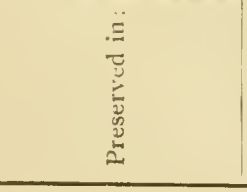 & 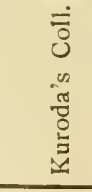 & $\dot{z}$ & 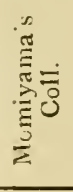 & $\begin{array}{l}\dot{\tilde{\Xi}} \\
\dot{0} \\
\dot{0} \\
\dot{5} \\
\dot{\Xi}\end{array}$ & 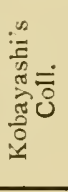 & $\dot{\Xi}$ & $\dot{0}$ & $\dot{\square}$ \\
\hline
\end{tabular}


Remark.-This new pigeon differs from any other allied form of the species from Caroline Islands by the more deeply bronzy colour of upper parts.

This subspecific name is given in honour of Mr. T. Momiyama.

Erythrura trichroa pelewensis, subsp. nov.

(Ploceidæ).

Erythrura trichroa Kuroda, "Dōbutsugaku Zasshi" (=Tokyo Zool. Mag.), Vol. xxviii, I9I6, p. 7 I (part.).

今 ad.-Resembles E. trichroa trichroa (Kittlitz) from Carolines (the type from Kusaie), but distinguishable from it by the bill being much thicker and stouter, by the chin being tinged with blue, by the under-parts being paler throughout and somewhat tinged with bluish, by the rump and upper tail-coverts being bright crimson instead of dull crimson, by the central tail-feathers brownish red instead of dull crimson, by the distinct shafts of central tail-feathers and by the longer wing and tail. It differs from $E . t$ goodfcllowi OgilvieGrant from British New Guinea by the paler under parts and by the chin being tinged with blue. It differs from E. t.pinaice Stresemann from Ceram by the outer edge of secondaries being green instead of greyish-blue.

Type.-Adult male. Pelew Island, Pelew Islands, Micronesia. Aug. 29, 1915. Kuroda's collection no. I 513. Coll. by Mr. E. Horii.

Habitat.-Probably confined to the Pelew Islands.

Measurements.-Differential measurements of the Micronesian forms of the species as follows: 


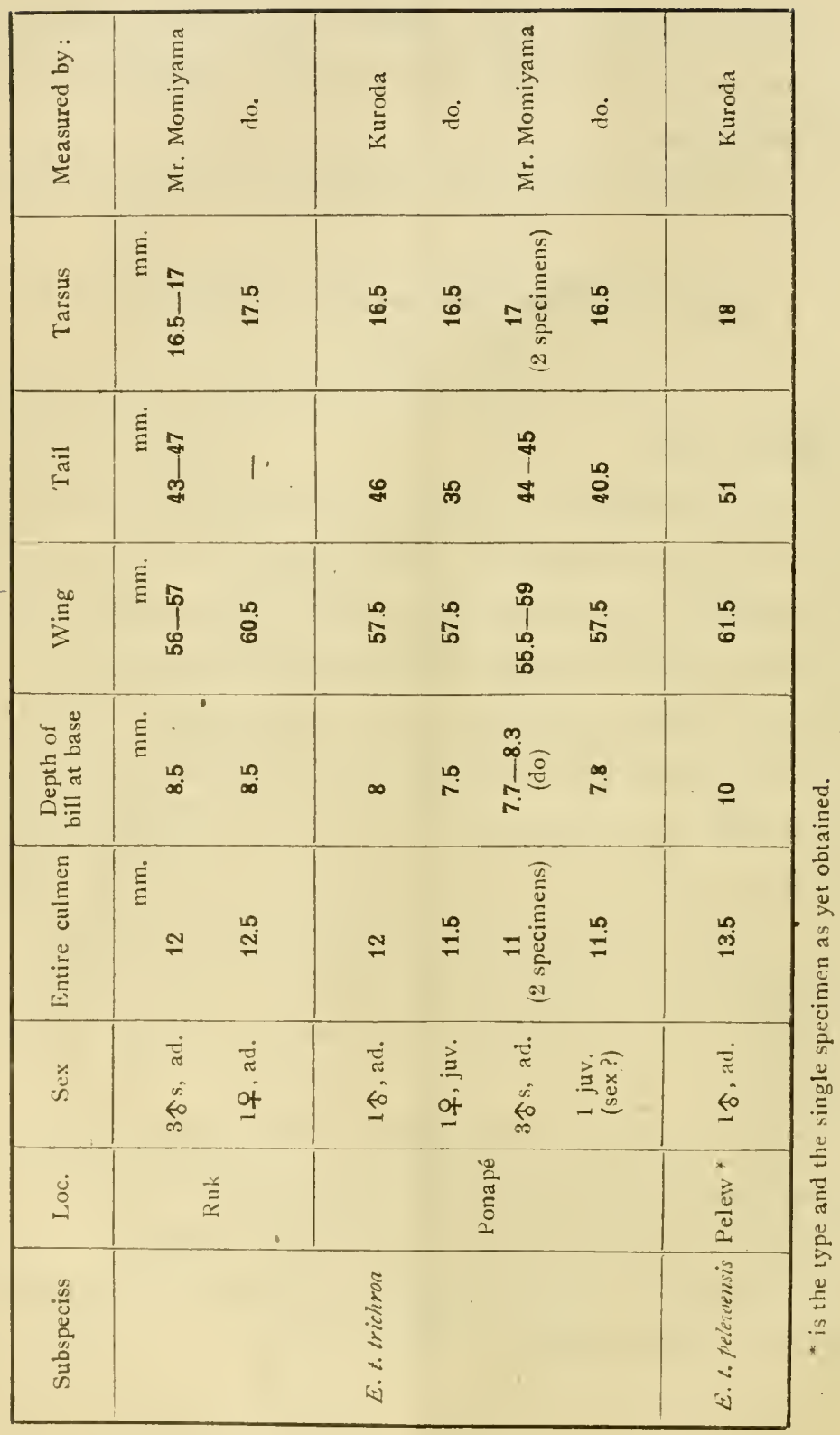




\section{Key to the subspecies.}

(A). Wing not over 6omm.; general colour dark green.

(a). Larger ; wing 55.5-60 mm. (exceptionally $60.5 \mathrm{~mm}$.) ; chin green [Caroline Is. : Kusaie ; Ponapé ; Ruk].............. E. t. trichron (Kittlitz).

(b). Smaller; wing 54-55mm; chin blue [New Hebrides].... E. t. cyanifrons E. L. I ayard.

(B). Wing over 6omm.

(c). Bill not thicker than in d; wing 60-65mm.; general colour not deep, and yellowish-green, especially on underside.

$\left(\mathrm{a}^{\prime}\right)$ Frontal blue band broad ; wing $60-65 \mathrm{~mm}$. [Moluc-

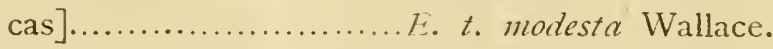

(b') Frontal blue band narrow; wing 63-54mm. [Solomon Islands]

E. t. woodfordi Rothschild \& Hartert.

(d). Bill much thicker thah in c.

$\left(c^{\prime}\right)$ Larger ; wing $67 \mathrm{~mm}$. ; general colour deep green; entire crown of head blue $[$ Arfak $] .. . \ldots \ldots \ldots \ldots \ldots . . . . .$. E. t. papuana Rothschild \& Hartert.

(d') Smaller; wing 60-62mm. (exceptionally 68 or 70 ), general colour deep or pale green; only fore part of crown blue.

$\left(a^{\prime \prime}\right)$ General colour of under-parts de ep green ; chin also green.

$\left(\mathrm{a}^{\prime \prime \prime}\right)$ Outer edge of secondaries green. [British N. Guinea]................

.......... t. soodfellowi O.-Grant. 
$\left(b^{\prime \prime \prime}\right)$ Outer edge of secondaries greyish blue [Ceram]

............ E. pinaice Stresemann.

$\left(b^{\prime \prime}\right)$ General colour of under-parts pale green tinged with bluish; chin also tinged with blue; outer edge of secondaries green [Pelew Islands]

E. t. pelcze'tusis, subsp. nov. -

There is still another form of the species found in N. Queensland, Australia, which was separated by Mathews (Austr. Av. Rec., Vol. II, p. I03, 1914) under the name of E. trichroa macgillivrayi. 


\section{南洋諸島產鳥類目錄}

理學士 黑田長禮編

本目録は籾山氏の依賴により日本鳥學會臨時刊行物第九編「邦 領南洋諸島產鳥類」の附錄として從承南洋諸島にて探集せられて る種類全部を列舉せるものなり、找領島以外の Guam 島にのみ 產する鳥類をる含有せしめたり、而して此島にのみ發見せらる3 もの及ひ他地より輸入せられてる種類には［]括弧を附し置けら 主なる參考書は下の如し。

Finsch, O.: Zur Ornithologie der Südsee-Inseln. I. Die Vögel der Palau-Gruppe. Journ. Mus. Godef., Heft VIII, 1875. II. Ueber neue und weniger gekannte Vögel von den Viti-, Samoaund Carolinen- Inseln. Journ. Mus. Godef., Heft XII, 1876.

Wiglesworth, L. W.: Aves Polynesiae. A Catalogue of the Birds of the Polynesian Subregion. Abhandl. und Berich. Kögniglich. Zool. und Anthropologisch-Ethnographisch. Mus. Dresden, IS90-I89I, No. 6, I89I.

Oustalet, M. E.: Les Mammifères et les Oiseaux des Iles Mariannes. Nouvelles Archives du Muséum d'Histoire Naturelle de Paris, Vol. VII. I895; Vol. VIII, I896.

Hartert, E.: On the Birds of the Marianne Islands. Nov. Zool., Vol. V, i 898, pp. 5 I-69.

Hartert, E. : The Birds of Ruk in the Central Carolines. Nov. Zool., Vol. VII, 1900, pp. I-II.

鷹司及び黑田：新占領南洋諸島產鳥類目錄及ひ分乍表.「鳥」 第一卷, 第二號 大正四年, 六O一六四頁. (1915).

Townsend, C.H. \& Wetmore, A.: Report on the Scientific Results of the Expedition to the Tropical Pacific in charge of 
Alexander Agassiz, on the U. S. Fish Commission Steamer "Albatross," from August, I S99, to March, 1900, Commander Jefferson F. Moser, U.S. N., Commanding. XXI. The Birds. Bull. Mus. Comp. Zoöl., Vol. LXIII, No. 4, I9I9, pp. I 5 I-225.

以上の外の參考書名は適當の筒所にのみ揭載せり.

\section{DIOMEDEIDAE. 信 天 翁科}

I. Diomedea nigripes Audubon.

$$
\text { クロアシアハウドリ }
$$

Oustalet, Nouv. Archiv. Mus., I 896, p. 5 I ; Hartert, Nov. Zool., Vol. V, IS9S, p. 69; 鷹司及び黑田,「鳥」, 第一卷, 第二號, 六○頁. 探集地. Marianne Is. (Marche).

\section{PUFFINIDAE. 水凪鳥科}

2. Puffinus obscurus obscurus (Gmclin).

$$
\text { セグロミズナギドリ（新稱） }
$$

Hartert, Nov. Zool., Vol. VII, I900, p. Io; P.obscurus Wiglesworth, Aves Polyn., ISgr, p. 79 (part.); Oustalet, Nouv. Archiv. Mus., I896, p. 54; Hartert, Nov. Zool., Vol. V, Is98, p. 69 ; 鸜司 及び黑田,「鳥」第一卷第二號六○頁; P. dichrous Hartl. \& Finsch,

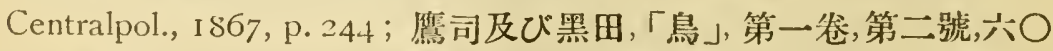
頁; I'. tencbrosus Natterer, Pelz., Ibis, IS73, p. 47 ; Oustalet, Nouv. Archiv. Mus., I 896, p. 55 ; Hartert, Nov. Zool., Vol. V, I898, p. 69 ; Godman, Monogr. Petrels, 1907-I9IO, p. VI；鷹司及び黑田，「鳥」, 第一炝, 第二號, 六○頁. 
探集地. Marianne Is. : Saipan (Marche); Caroline Is : Ruk, Ponapé (Kubary); Pelew Is. (Tetens, Kubary).

附記. 從來本種と $P$. dichrous 及びP. tenebrosusの三種に分たれだれどる Wiglesworth 氏及び Godman 氏に從ひ全部か同一に認めHartert 氏に從ひ上訅の丝種となせり。

\. ? Puffinus chlororhynchus Lesson.

$$
\text { アカハシミズナギドリ（新稱？ }
$$

Wiglesworth, Aves Polyn., IS91, p. 80.

探集地. ? Caroline Is. : Luganor or Ruk(Kubary).

$$
\begin{aligned}
& \text { 4. Pterodroma rostrata (P'alc). } \\
& \text { セグロシロハラミズナギドリ（新稱） }
\end{aligned}
$$

(Estrelata rostrata (Peale), Wiglesworth, Aves Polyn., I89I, p. S2 ; Godman, Monogr. Petrels, I907-19ro, p. I90, pl. 5 I. ProcelLaria, disolata (nec Gm.) Jacq. \& Pucher. Vog. Pôle Sud, Zool., III, p. 158,1853 .

探集地. Caroline Is. (Hombr. \& Jacq.).

\section{PHAËTONTIDAE. 熱帶鳥科}

5. Leptophrethon lepturus lepturus (Dandin).

$$
\text { ・シラョネッタイテウ }
$$

Phaiton candidus Wiglesworth, Aves Polyn., 1891, p. 73; Oustalet, Nouv. Archiv. Mus., Isg6, p. 62 ; Hartert, Nov. Zool., Vol. V. I 898, p. 69. Phaïthon candidus Temm., 鷹司及び黑田「鳥」, 第一尖, 第二號, 五○頁, 六○頁; Phacthon lcpturus Daudin, Hartert, Nov. Zool., Vol. VII, I900, p. IO.

探集地. Pelew Is. (Mus. Godef., 堀并, 寺岡, 藤田及び青木, 大渡); Caroline Is. : Ruk(粐山), Luganor, Nukuor, Ponapé (Kubary, 寺岡, 堀井, 粐山), Ualan or Kusaie (Kittlitz, Finsch); Marshall Is. (Finsch); Marianne Is. : Agrigan (Marche), Saipan (粐川). 
6. Phaëton æthereus Linné.

ヨナガネッタイテウ（新稱）

Wiglesworth, Aves Polyn., IS9I, p. 73.

探集地 Caroline Is. : Kusaie or Ualan (Finsch); Marshall Is. (Finsch).

7. Scæophæthon rubricauda (Boddacrt).

$$
\text { アカタネッタイウ }
$$

Phä̈ton mubricauda Boddart, Wiglesworth, Aves Polyn., I89I, p. 73 ; Phaëthon rubricanda Hartert, Nov. Zool., V'ol. VII, 1900, p. I I ; 鷹司及び黑田,「鳥」第一柲, 第二號, 六○頁.

探集地. Caroline Is. : Ruk, Ponapé (Kubary); Marshall Is. (Finsch); Marianne Is. .

\section{SULID瓜，䚫鳥魚科}

S. Sula leucogaster plotus (Forster).

カッヨドリ,リウキウカッタドリ .

S. sula (L.), Hartert, Nov. Zool., Vol. V, I S98, p. 69；鷹司及 び黑田,「鳥」第一第二號, 五○頁, 六○頁; S. luucogastra IViglesworth, Aves Polyn., I891, p. 72 ; Oustalet, Nouv. Archiv. Mus., IS96, p. 63; Dysporzs sula Hartert, Nov. Zool., Vol. VII. I900, p. I I.

探集地. Pelew Is. (Tetens, Kubary); Caroline Is. : Ruk (Kubary), Grimes (大渡), West Faiu (粐山); Marshall Is. (Finsch); Marianne Is. (Marche, 寺阙): Saipan (堀井), Vicinity of Uracas (粐山).

9. Piscatrix sula rubripes (Gould).

$$
\text { アカアシカッョドリ }
$$

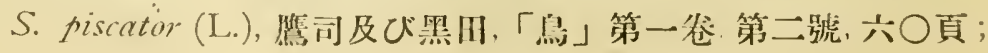


S. piscatrix Wiglesworth, Aves Poly1l., IS9I, p. 72 ; Oustalet, Nouv. Archiv. Mus., I 896, p. 64; Hartert, Nov. Zool., Vol. V. I898, p. 69.

探集地. Pelew Is. (Tetens); Caroline Is. : Luganor (Kittliz); Marianne Is. : Rota (Marche).

10. Parasula dactylatra personata (Gould').

$$
\text { アラッラカッヨドリ }
$$

Sula cyanops (Sundev.), Wiglesworth, Aves P'olyn., 1891, p. 72. 探集地. Marshall Is. (Finsch).

\section{PHALACROCORACID正。虜㬎科}

Ir. Microcarbo melanoleucus melanoleucus (Vicill.).

$$
\text { ナンョウヒメウ（新䊈） }
$$

IViglesworth, Aves, Polyn., I891, p. 72. Phalacrocorax milanolcucus (V.), 鷹司及び黑田,「鳥」第一晦, 第二號, 五○頁, 六○頁.

探集地. Pelew Is. (Tetens, Kubary, 堀井, 寺岡).

\section{FREGATID.E。軍艦鳥科}

I2. Fregat ss aquila palmerstoni (Gmelin).

$$
\text { オホグンカンドリ }
$$

Fregata aquila (nec L.), Wiglesworth, Aves Polyn., IS91, p.

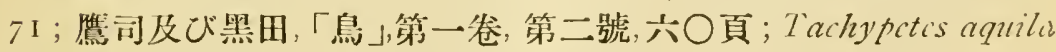
Hartert, Nov. Zool., Vol. VII, I900, P. I I.

採集地. Caroline Is.: Luganor, Ruk (Kubary), Ponapé, Ualan or Kusaie (Kittlitz, Finsch), Yap (粐川); Marshall Is. (Finsch). 
I3. Fregata ariel ariel (Gould).

$$
\text { グンカンドリ }
$$

$F$. aricl, (Gould), 䉆司及び黑田,「鳥」第一怣, 第二號, 六一頁; F. minor (nec. Gm.), IViglesworth, Aves I’olyn., ISgI, p. 71 ; Tachypctes aquila var. minor Oustalet, Nouv. Archiv. Mus., I\$g6, p. 65 ; Tachypites minor (Schleg.), Hartert, Nov. Zool., Vol. V ; IsgS, p. 69 .

探集地. Caroline Is. : Uap or Yap (Kubary), Ngoli or Matelotas (Hartlaub), Mackenzie group (Hartlaub); Marianne Is. Rota (Marche).

\section{ARDEID $A$ 䉆 科}

14. Demiegretta sacra sacra (Gmolin).

$$
\text { ナンョウクロサギ（栦川） }
$$

Demiesreta sare (Gm.), Wiglesworth, Aves I'olyn., I SyI, p. 67; I Jartert, Nov. Zool., Vol. V, IS9S, p. 69; id., op. cit., VII, 1900, p. I I ; Ardea sacra Oustalet, Nouv. Archiv. Mus., is96, p. 36 ; Demicgretta

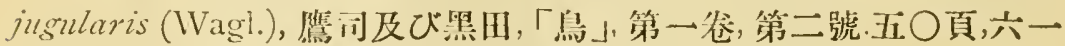
頁；D. jusularis grayi (Gray), 同, 五○頁, 六一頁.

探集地. Pelew Is. (Kubary, 专凮, 藤川及青术, 堀井) Angaur (版井); Marianne Is. (Quoy \& Gaim.)：Guam, Saipan (Marche); Caroline Is.: Luganor, Yap, Ngoli, Ruk, I'onapé, Kusaic (Kubary, Kittlitz, 堀井, 寺成, 大渡, 粐山); Marshall Is. : Taluit (Finsch).

15. Nycticorax nycticorax nycticorax (Linné).

$$
\text { ゴキサギ }
$$

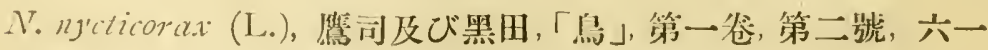
If; L. grisens IViglesworth, . Ives Polyn., 1391, p. 69. 
探集地. Caroline Is. : Mackenzie, Yap (Kubary).

I6. Nycticorax caledonicus (Gmelin), subsp.

$$
\text { ナンヨウハシブトゴキ（新稱） }
$$

1. culedonicus Hartert, Nov. Zool., Vol. VII, I900, p. 10 ; 鷹司 及び黑田,「鼠」, 第一卷, 第二號, 五○頁, 六一頁; $N$. manillensis (nec. Vig.), Wiglesworth, Aves Polyn., I \&g I, p. 69.

探集地. Pelew Is. (Kubary, 寺岡. 藤田及び青木, 大渡, 堀井); Caroline Is. : Ruk (Kubary, 粐川).

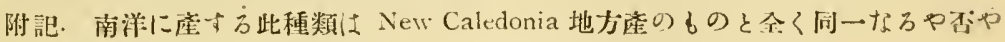
疑仿しさ點むり网て上訅つ如くなし畋くことるせり。

$$
\begin{aligned}
& \text { 17. Butio melanolopha (Raffles). } \\
& \text { タイワンミゾゴキ }
\end{aligned}
$$

Gorsachius molonolopluts (Raffle's), Sharpe, Cat. B. Br. Mus., Vol. XXVI, ISgS, p. I6S; Nycticorax goisagi (nec Temm.), I Iartl. \& Finsch, P.Z.S. 1S68, p. 8; Wiglesworth, Aves I'olyn., 189I, p. $6 \$$ (Part.); Gorsachius soisagi (nec. Temm.), 鷹司及ひ黑田,「鳥」, 第一密. 第二號, 六一頁.

探集地. Pelew Is. (Tetens).

$$
\begin{aligned}
& \text { IS. Ixobrychus sinensis bryani (Siale). } \\
& \text { マリアナョシゴキ(新稱), ?ヤップョシゴキ(粐川) }
\end{aligned}
$$

IVetmore, Bull. Mus. Comp. Zoöl., Vol. LXIII, No. 4, I9I9, p. I73; Ardctta brayani Seale, Occas. papers Bernice Pauahi Bishop mus., I900, 1, no. 3, p. 27 (Guam); Ardetta sincnsis (nec Gm.), IViglesworth, Aves Polyn., I891, p. 68 (part.); Oustalet, Nouv. Archiv. Alus., I \$96, p. 3 S. Hartert, Nov. Zool., Vol. V, IS9S, p. 69 ; 鷹司及び黑田,「鳥」,第一卷, 第二號, 六一頁 (part.).

探集地. Marianne Is. (Quoy \& Gaim.): Guam; Caroline Is. : ?Yap (粐川), ? Mackenzie group ; ? Pelew Is. (Kubary, 寺岡,藤田及び青木). 
-19. Ixobrychus sinensis moorei Hetruore.

$$
\text { モリョシゴキ(粐山) }
$$

Wetmore, Bull. Mus. Comp. Zoöl., Vol. LXIII, No. 4, 1919, p. I73 (Uala, Ruk group); Ardette sincnsis (nec Gm.), Wiglesworth, Aves Polyn., I89I, p. 68 (part.); 鷹司及び黑田,「鳥」第一卷, 第二 號, 五O頁, 六一頁, (part.); Hartert, Nov. Zool., Vol. VII, 1900. p. II.

探集地. Caroline Is. : Ruk (Kubary, Moore, 堀井, 寺岡. 大渡, 粐山)

\section{ANATIDA. 维鴨科}

20. Fuligula fuligula (Limné).

$$
\text { キンクロハジロ }
$$

Hartert, Nov. Zool., Vol. V., I898, p. 69; F. cristata Wiglesworth, Aves Polyn., 1891, p. 71 ; Oustalet, Nouv. Archiv; Mus.,

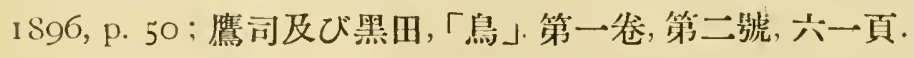

探集地. Mariane Is. ; Caroline Is. : Yap (籾川); Pelew Is. (Tetens).

21. Mareca penelope (Limí).

$$
\text { ヒドリガモ }
$$

Wiglesworth, Aves l'olyn., I 891 , p. 7 I.

探集地. Marshall Is. : Taluit or Bonham (Finscli).

22. Polionetta supcrciliosa pelewensis (Hartl. \& Finsch).

$$
\text { ナンョウカルガモ（新稃） }
$$

Anas. superiliose Gmel. var. felcruensis Hartl. and Finsch, 
P. Z. S., I872, p. 10S. (Pelew Is.); A. supirciliosa (nec Gm.), Wiglesworth, Aves Polyn., ISgI, p. 70 (part.)；鷹司及び黑田,「鳥」, 第一悆, 第二號, 六一頁.

探集地. Pelew Is. (Tetens, Kubary).

23. Polionetta oustaleti (Saliadori).

マリアナカルガモ（新稱）

Ancrs oustaleti Salvadori, Bull. B. O. C., 1874, p. I ; Oustalet, Nouv. Archiv. Mus., I 896. p. 49 ; Hartert, Nov. Zool., Vol. V, ISgS, pp. 66, 69. 䉆司及び黑田,「鳥」, 第一敀, 第二號. 六一頁.

探集地. Marianne Is. : Guam, Saipan (Marche).

\section{FALCONID $A$. 驚 鷹 科}

24. Astur sharpei Oustalct.

マリアナダカ（新䊈）

Oustalet, Bull. Soc. Philom., I\$75 (6), I I, p. 25 ; id., Nouv. Archiv. Mus., I895, p. I6 I ; Hartert, Nov. Zool., Vol. V, I 898, pp. 5 I, 68 ; 䉆司及び黑田,「鳥」, 第一第二第二號, 六一頁；A. sharpii Wiglesworth, Aves Polyn., I S9I, p. 2.

採集地. Marianne Is. (Astrolabe).

25. [Accipiter gularis (Timm. \& Schl.)]

ツ ミ

A. misoidis Blyth, Oustalet, Nouv. Archiv., I 895, p. I66; Hartert, Nov. Zool., Vol. I\&98, V, pp. 5 I, 68; 鷕司及び黑田,「鳥」第一卷, 第二號, 六一頁.

探集地 Marianne Is. : Guam (Marche). 
26. ? Falco peregrinus calidus Lathani.

$$
\text { ハヤブサ? }
$$

F. peregrinus (nec Tunst.), Wiglesworth, Aves Polyn., IS9I, p.

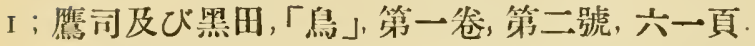

探集地. Caroline Is. : Yap (Hartl. \& Finsch); Pelew Is. (Finsch)

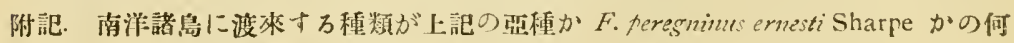

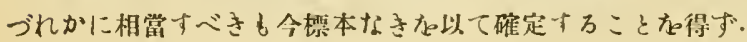

\section{PANDIONIDAE. 㗪 科}

- 27. Pandion haliaëtus cristatus (I'icillot).

$$
\text { カンムリミサゴ (新稱) }
$$

P. haliaitus lencocthalus Gould, Wiglesworth, Ares Polyn., ISgI, p. I.

探集地. Pelew Is. (Mus. Godef.).

\section{MEGAPODIIDAE. 茨 造科}

2S. Megapodius laperousei laperousei Quoy \& Gaimard.

$$
\text { マリアナッカックリ（新稱） }
$$

11. Lapirousci Oustalet, Nouv. Archiv. Mus., I 896, p. 26 (part.); M. perousi i Wiglesworth, Aves Polyn., IS9I, p. 58 ; M. lapcrouse Hartert, Nov. Zool., Vol. V, IS98, pp., 6r, 69; M. laferousii Temm.,

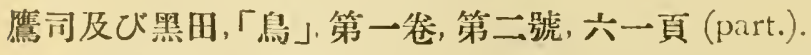

探集地. Marianne Is. : Guam, Saipan, Rota, Tinian, (Quoy \& Gaim.), Pagan, Agrigan (Marche).

129. Megapodius laperousei senex Hartlauh.

$$
\text { ッカックリ }
$$

11. sencx Hartl., P.Z.S. I 867 , p. 830 ; Wiglesworth, Aves 
Polyn., I S9I, p. 5S; M.laperousii (nec Temm.), 黑田, 動物學雜䓌 第三

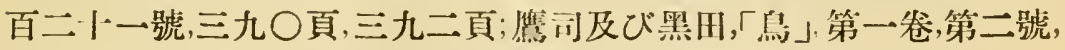
五一頁,六一頁 (part.), 岡田,「科學知識」,第一卷,第四號,九二頁(I92 I). 探集地. Pelew Is. (Kubary, 藤田及び青木, 寺岡, 堀井, 五島博 士及び岡用).

\section{PHASIANIDAE. 雉 科}

30. [Gallus gallus bankiva Trmm.]

$$
\text { ヤケイ (新稱). }
$$

Bangs, Proc. N. E. Zool. Club, Vol. VII, p. 24, I9I9; G. bankiva Temm., Oustalet, Nouv. Archiv. Mus., IS96, p. 25 ; Hartert, Nov. Zool. Vol. V, IS98, p. 69 ; 鷹司及び黑田,「鳥」, 第一尖,第二號,六一 頁 ; G. bankian var., Wiglesworth, Aves Polyn., IS9I, p. 59.

探集地. Marianne Is. : Saipan (Marche); Pelew Is.; Caroline Is. ; Ponopé (寺岡); Marshall Is.

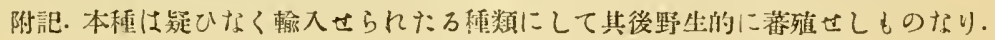

3r. [Excalfactoria chinensis lineata (Scopoli)]

$$
\text { ルゾンヒメウッ゙ラ（新梅） }
$$

IVetmore, Bull. Mus. Comp. Zoöl., Vol. LXIII, I9ı9, p. I76 (Guam); İ.sincusis(Gm.) Hartert, Nov. Zool., Vol. V, I S9S, pp. 6r, 69.

探集地. Marianne Is. Guam.

附訅 本種は Seale 氏によクば 1894 年 Manila より Captain Pedro Duarty 氏が Guamに輸入せしものなりと云ふ.

\section{RALLID $Æ$. . 䅚 鵄 科}

32. Rallina fasciata ( $R$ afft.)

$$
\text { ナンョウオホクキナ（新稱） }
$$

Wiglesworth, Aves Polyn., I89I, p. 60 ; 鷹司及び黑田「悬」第 一笑, 第二號, 六一頁. 
探集地. Pelew Is. (Tetens).

3. 33. Hypotanidia philippensis (Linné).

$$
\text { ナンヨウクキナ（新䊈） }
$$

Rallus philippensis Wiglesworth, Aves Polyn., IS9I, p. 59 (part.)；R.pcctoralis Less，鷕间及び黑田、「鳥」, 第一第二號 六 一頁.

探集地. Pelew Is. (Kubary).

34. [Hypotrenidia owstoni Kothschild.]

$$
\text { オーストンクキナ（新稱） }
$$

Rothschild, Nov. Zool. Vol. II, 1595 , p. 4SI ; Hartert, Nov. Zool. Vol. V, 1899, pp. 62,69; H. marchei Oustalet, Nouv. Archiv., I \$96, p. 32 ; Rallus philippensis Wigledworth, Aves Polyn., 1891, p. 59. (part.).

探集地. Marianne Is. : Guam (Quoy \& Gainard, Marche).

35. Porzana tabuensis tabuensis (Gmilin).

$$
\text { ナンョウコクキナ (澵稱) }
$$

Ortysometra tabuensis Wigleseworth, Aves Polyn., iS91, p. 60. 探集地. Caroline Is. : Kusaie or Ualan (Kittlitz).

36. Poliolimnas cinereus (Vieillot), subsp.

$$
\text { ナンョウマミジロクキナ（新稱） }
$$

P. ciencrcus Hartert, Nov. Zool., I $\$ 98$, pp. 64, 69; id., op. cit., Vol. VII, 1900, P. 9; 鷹司及び黑田,「鳥」, 第一尖, 第二號, 六一頁; Ortygometra cinerea Wiglesworth, Aves Polyn., IS9I, p. 6I.

探集地. Marianne Is. : Guam; Pelew Is. (Tetens); Caroline Is. : Yap (粐ןl), Ruk (Kubary). 
37. Callinula chloropus guami Hortirt.

$$
\text { ナンヨウバン（新稱） }
$$

Hartert, Nov. Zool., Vol. XXIV, 1917, p. 268 ; G. chloropus, id., op. cit., I\$9\$, pp. 62,69; G. galeata var. sandwichusis (nec Streets), Oustalet, Nouv. Archiv. Mus., I 896, p. 34.

探集地. Marianne Is. : Guam, Saipan, Tinian (Marche).

38. Porplyyio melanonotus pelewensis Hartl. \& Finsih.

$$
\text { ナンョウセイケイ（新稱） }
$$

Wiglesworth, Aves Polyn., IS9I, p. 6I; $P$. melanotus var. pclivinsis Hart1. \& Finsch, P. Z. S., 1S72, p. 107 ; P. pelezunsis 鷹 司及び黑田,「悬」第一卷, 第二號, 六一頁.

探集地. Pelew Is. (Tetens, 堀井, 寺洞：

39. [Fulica atra $($ Limné $)$, subsp.]

$$
\text { オホバン? }
$$

Hartert, Nov. Zool., Vol. V, isg\$, pp. 64, 69.

探集地. Marianne Is. : Guam.

附訅. Hartert ヒヒによれば恐らく偶然渡來せしならんとでふ。

\section{CHARADRIID在，䧦科}

40. Squatarola squatarola hypomelæna (Pallas).

$$
\text { ダイビン }
$$

Charadrins squatarola (nec. L.), Hartert, Nov. Zool., I898, pp. 66, 69; Sqnatarola squatarola Hartert, op. cit, I900, p. 9; S. helictica (nec. L.), 鹰司及ひ黑田「「鳥」第一卷, 第二號, 六一頁.

探集地. Mariane Is. : Saipan; Caroline Is. : Ruk. 
41. Pluvialis dominicus fulvus (Gmelin).

\section{ムナグロ}

Charadrius fulous Wiglesworth, Aves. Polyn., IS91, p. 63; Oustalet, Nouv. Archiv. Mus., I\$96, p. 46 ; Hartert, Nov. Zool., I 998, pp. 66, 69; id., op. cit., Vol. VII, I900, p. 9：鷹司及び黑田, 「鳥」, 第一卷, 第二號, 六二頁.

探集地. Marianne Is (Quoy \& Gaim.). : Guam (Marche); Pelew Is. (Kubary, 藤田及青木, 堀井): Angaur (堀井); Caroline Is. Ualan or Kusaie (Kittlitz, Finsch, 粐山), Luganor (Kittlitz, Finsch); Ponapé (Kuabry，寺葥，堀井，粐川）, Ruk (Kubary, 堀井. 粐山), Yap (Kubary, 粐山); Marshall Is. (Finsch) : Arhno Atoll.

\section{Pagoa leschenaulti (Lesson).}

$$
\text { オホメダイチドリ }
$$

Acgialitis gcoffroyi Wiglesworth, Aves Polyn., Isgr, p. 64; Ochthodromus scoffroyi (Wagl.), 鹰司及び黑田,「鳥」第一参, 第二 號, 六二頁.

探集地. Pelew Is. (Semper); Caroline Is. : Kusaie (Lesson), Yap (粐山).

43. Cirrepidesmus mongolus mongolus (Pallas).

$$
\text { メダイチドリ }
$$

Charadrius mongolicus Oustalet, Nour. Archiv. Mus., I896, p. 48; Hartert, Nov. Zool., Vol. V, r\$o\$, pp. 66, 69; Acgialitis mongolus (T'all.), Hartert, op. cit., Vol. VII, Igoo, p. 9; Ochthodromus monsolicus (Pall.), 鷹司及び黑田,「鼠」第一笑, 第二號, 六二頁.

探集地. Marianne Is. : Guam (Marche); Caroline Is. : Ruk. 
44. Egialophilus alexandrinus dealbatus (Szinhoe).

$$
\text { シロチドリ }
$$

Argialitis cantianus (nec Lath.), Wiglesworth, Aves Polyn., 1891，p.64; 鷹司及び黑田，「鳥」第一卷,第二號,六二頁.

探集地. Pelew Is. (Mus. Godef.).

附訑. Finsch 博士仿 Marshall 群島中の Taluit 島に於て Charadries hiaticula Gm. た見たるる疑ひおりとの意が訅せり (Ibis, 1880, p. 331).

45. Arenaria interpres oahuensis (Bloxam'.

$$
\text { キャウジョシギ }
$$

Stripsilas intirpre's (nec L.) Wiglesworth, Aves Polyn., IS9I, p. 63 ; Oustalet, Nouv. Archiv. Mus., 1896, p. 45 ; Hartert, Nov. Zool., Vol. V, I \$9\$,pp. 66, 69; id, op. cit., Vol. VII, I900, p. 9 ; 鷹 司及び黑田,「烏」, 第一卷,第二號,六二頁.

探坚地. Marianne Is. (Novara): Guam, Saipan (Marche); Pelew Is. (Hartlaub \& Finsch): Angaur (堀井); Caroline Is. : Kusaie (Kittlitz, Finsch, 堀井, 粐山), Ponapé, Luganor, Nukuor, Ruk, (Kubary, 堀井, 粐山), Yap, (粐山), Mackenzie (Hartl. \& Finsch); Marshall Is.: Taluit (Finsch), Rongelab.

46. [Numenius cyanopus Vicillot.]

ホウロクシギ

Hartert, Nov. Zool., Vol. V, is98, pp. 65, 69.

探集地. Marianne Is. : Guam.

47. Phropus phropus variegatus (Scop.).

チウシャクシギ

Vuminius varigatus Wiglesworth, Aves Polyn., I\$91, p. 66 ; N. phacopus var. varigatus Oustalet, Nouv. Archiv. Mus., I896, p. 
39; N. theopus varicgatus (Scop.), Hartert, Nov. Zool., Vol. V, I898, pp. 65, 69 ; id., op. cit., Vol. VII, I900, p. S；鷹司及び黑田, 「真」第一然 第二號 六二頁.

探集地. Marianne Is. : Guam; Pelew Is. (Tetens); Caroline Is. : Mackenzie, Matalotas (Hartl.), Yap (䊅山), Ngoli, Lıtganor and Ruk (Kubary), Ponapé (Finsch), Kusaie (Kittl., Finsch).

48. Phæopus tahitiensis (Gmclin).

$$
\text { ハリモモチウシャク }
$$

Numenius tahiticnsis Wiglesworth, Aves Polyn., 1891, p. 66; 鹰司及ひ黑田,「鳥」, 第一卷,第二號,六二頁.

探集地. ? Marianne Is. (Quoy and Gaim.); Marshall Is.: Taluit and Arno (Finsch), Rongelab.

49. Limosa lapponica baueri (Natm.).

$$
\text { オホソリハシシギ }
$$

Hartert, Nov. Zool., Vol. V, 1898, pp. 65, 69; L. Iapponica nove-zealandice, id., op. cit., I900, p. S ; L. nova-zealandice Wiglesworth, Aves Poly1., IS91, p. 66; L. mfa uropygialis Gould, 鷕司及 び黑田、「鳥了,第一参,第二號,六二頁.

探集地 Caroline Is. : Luganor or Ruk (Kubary); Marianne Is. : Guam.

50. Heteroscelus incanus incanus (Gmelin).

$$
\text { メリケンキフシシギ }
$$

Totames incamus Wiglesworth, Aves Polyn., I\$9I, p. 65 (part.); Oustalet, Nouv. Archiv. Mus., I \&g6, p. 4I (part.); Hartert, Nov. Zool., Vol. V, pp. 65, 69; id., op. cit., I 900, p. \&; Hetcractitis

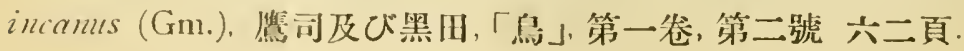


採集地. Marsh all Is: Mulgrave and Taluit (Finsch); Caroline Is. : Kusaie (数山), Ponapé, Ruk (Kittlitz, Kubary, 堀井, 数川)； Yap (Kittl. Kubary); Marianne Is. (Quoy \& Gaim.): Guam ; Pelew Is. (Kubary): Angaur (堀井).

附記. 上訅の探集地名中には次の亞種の塲合な混ずることあり。

51. Heteroscelus incanus brevipes (1 icillot).

$$
\text { キアシシギ }
$$

Totanis incanus Wiglesworth, Aves Polyn. I S9I, p. 65 (part.); Oustalet, Nouv. Archiv. Mus., I\$96, p. 4 I (part.); Hetcractitis

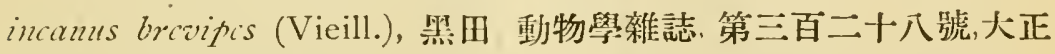
五华，六九頁；Hetcractitis braifics (Vieill.), Wetmore, Bull. Mus. Comp. Zoöl., Vol. LXIII, I919, p. ISo (Uala, Middle Caroline).

探集地. Pelew Is.: Angaur (堀井); Caroline Is. : Iap \& Ruk (粐门1).

52. Actitis hypoleucos (Limn').

$$
\text { イソシギ }
$$

Wigleswortl, Aves Polyn., I89I, p. 64; Oustalet, Nouv. Archir. Mus., I896́, p. 4.3; Totamus hypolincus (L.), Hartert, Nor. Zool., Vol. V, 1S9S, pp. 65, 69 ; Tringoides hypolcucus (L.), 鷹间及 び黑田,「鼠」第一参第二號,五一頁六二頁.

探集地. Marianne Is. (Lesson): Saipan; Pelew Is. (Hartl. \& linsch, 寺岡): Angaur (大渡, 堀井); Caroline Is.: Luganor or Kuk (Kubary), Ruk (粐山).

53. Glottis nebularius (Gumems).

$$
\text { アラアシシギ }
$$

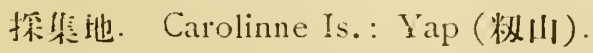


54. Rhyacophilus glareola (Limnc).

タカブシギ

黑田, 動物學雜誌, 第三百二十八號 六九頁; Totamis glarcola Oustalet, Nouv. Archiv. Mus., IS96, p. 43; Hartert, Nov. Zool., Vol. V, is9S, p. 69.

探集地. Marianne Is. : Guam (Marche); Pelew Is.(堀井,) : Angaur (大渡).

55. Crocethia alba (Pallas).

$$
\text { ミュビシギ }
$$

Tringa arinaria Wiglesworth, Aves Polyn., 1S9I, p. 64; Hartert, Nov. Zool., Vol. V, is9s, pp. 65, 69.

探集地. Marshall Is.: Taluit (Finsch); Marianne Is. : Guam.

56. Pisobia minuta ruficollis (Pallas).

$$
\text { トウネン }
$$

Tringa albescens Wiglesworth, Aves Polyn., is9i, p. 64; Limonitis Minnta (nec Leisl.), 鹪司及び黑田,「鳥」, 第一管第二號, 六二頁.

探集地. Pelew Is. (Hartl. \& Finsch).

57. Heteropygia acuminata (Horsficld).

$$
\text { ウッ゙ラシギ }
$$

Hartert, Nov. Zool. Vol. VII, I900, p. S; 鹰司及び黑田,「悬」, 第一敀第二號六二頁; Tringa acuminata iviglesworth, Aves Polyn., ISgs, p. 64; Hartert, Nov. Zool. Vol. V., ISgS, p. 69. T. macnlata var. acuminata Oustalet, Nouv. Archiv. Mus., ISg6, p. 
探集地. Marianne Is. : Pagan (Marche); Pelew Is. : (Hartl. \& Finsch); Caroline Is. : Ruk (堀井).

\section{S. Subspilura megala Sivinhoe.}

$$
\text { チウシギ }
$$

Gallinago megala Wiglesworth, Aves Pölyn., r89r, p. 67; Hartert, Nov. Zool., Vol. V, rS9S, pp. 65, 69.

探集地. Marianne Is. : Guam; Pelew Is. (Kubary).

\section{LARIDAE. 鶚科}

59. Larus argentatus vegæ Palmén.

$$
\text { セグロカモカ }
$$

L. vege Oustalet, Nouv. Archiv. Mus., I896, p. 56 ; Hartert, Nov. Zool., Vol. V; I898, p. 69; 鷹司及び黑田,「鳥」第一卷,第二 號,六二頁.

探集地. Marianne Is. : Agrigan (Marche).

†. 60. Anous stolidus pileatus (Scopoli).

$$
\text { クロアチ゚サシ }
$$

Hartert, Nov. Zool., Vol. VII, I900, p. Iо ; A. stolidhs (nec L.), Wiglesworth, Aves Polyn., i891, p. 76; Oustalet, Nouv. Archiv. Mus., I\$96, p. 89 ; Hartert, Nov. Zool., Vol. V. I\$9S, pp. 68, 69; 鷹 司及び黑田、「量」，第一第二號，六二頁.

一探集地. Marianne Is. : Guam, Sapan (大渡); Pelew Is. (Tetens, 藤田及び靑木, 堀井): Angaur (堀井); Caroline Is.:? Mortlock, Ruk, Wolea, Nukuor, Ponapé, Kusaie (Kittl., Kubary, Finsch, 堀井,寺岡,粐川); Marshall Is. (Finsch). 
- 61. Anous melanogenys G. R. Gral. シロビタへクロアヂサシ（新䊈）

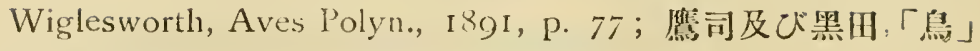
第一柋第二號公二頁.

探集地. Marshall I‥(Bonham, Finsch); Caroline Is. : Kusaie, Ponapé (粐lif), Nukuor, Luganor, Wolea (粐II), Ruk (Kittl., Kubary, Finsch, 柿絲, 粐川I); Pelew Is. (Finsch).

> 62. Megalopterus tenuirostris leucocapillus (Gonld.

$$
\text { ヒメクロアヂサシ(粐川) }
$$

Anours liucocapillus Wiglesworth, Ares Polyn., IS91, p. 77 ; Oustalet, Nouv. Archiv. Mus., i Sg6, p. 6 r ; Hartert, Nov. Zool., Vol. V, IS98, p. 69; Micranous lcucocapillus (Gould), id., op. cit.,

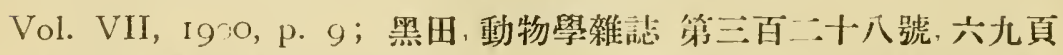

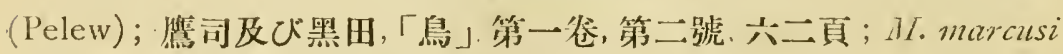
(nec Bryan), 㫮田, 動物學雑点, 第三百二十號, 三三三面 (Kusaie); 同，同調，第三百二十一號，三九二頁 (l'elew).

箖集地. Marianne Is. : Saipan (Marche); Pelew Is.(藤田区心 青木, 寺阔, 大渡, 堀井); Ciroline Is. : Ruk (称川), Kusaie (堀井, 粐川), Ponapé (粐川).

附訅. Mathews 氏 (Nov. Zool., Vol. XVIII, I9I1, p. 4)によれば Nesalopterus

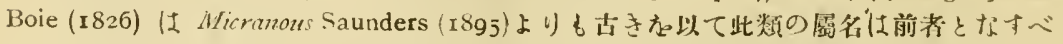
しと云ふ.

63. Gygis albus kittlitzi Herrtert.

$$
\text { シロアヂサシ }
$$

Hartert, Nov. Zool., Vol. T', I 898, pp. 67, 69 ; id., op. cit., Vol. VII, Igoo, p. Io; G. alba (nec Sparrm.), Wiglesworth, Aves Polyn., IS9I, p. 78 ; Oustalet, Nouv. Archiv. Mus., I 896, p. 5s ; G. candide

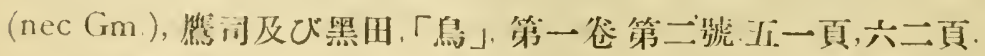

採集地. Marianne Is. : Guam, Saipan, I'agan, Agrigan (Mar- 
che)；Pelew Is.（藤田及び青木. 击阔, 堀井)：Angaur (堀井); Caroline Is.: Yap, Wolea, Luganor, Nukuor, Ruk, Ponapé, Kúsaie (Kubary, Kit:l., Finsch, 堀井, 寺阔, 大渡, 杮澤, 粐山) ; Marshall Is. (Finsch).

64. [Hydrochelidon leucoptera (Temminck)]

ハジロクロハラアヂサシ

Oustalat, Nouv. Archiv. MIus., 1S96, p. 57 ; Hartert, Nov. Zool., Vol. V, r 898, pp. 67,69 .

探集地. Marianne Is. : Guam (Marche).

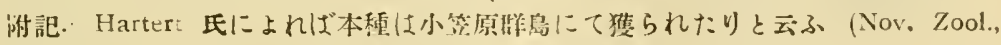
Vol. V, p. 67).

- 65. Thalasseus bergii pelecanoides (King).

$$
\text { ナンョウオホアヂサシ(新稱) }
$$

Oberholser, Proc. U.S. Nat. Mus., Vol. IL, p. 523, (1915); S. bergii (nec Licht.), Wiglesworth, Aves Polyn., I891, p. 74; Hartert, Nov. Zool., Vol. VII, I900, p. Io ; S. bergii Licht., subsp., 鷹司及び黑田,「鳥」, 第一尖,第二號，五二頁,六二頁.

探集地. ? Pelew Is. (Kubary); Caroline Is. : Luganor, Nukuor, Ruk（柿澤,粐山), Ponapé (Kubary, 寺岡, 粐山); Marshall Is. (Finsch).

- 66. Sterna longipennis Nordmann.

$$
\text { ブチ゚サシ }
$$

Wiglesworth, Aves Polyn., IS9I, p. 74; 鷹司及び黑田,「鳥」, 第一笑第二號,六二頁.

採集地. Pelew Is. (Heins.).

67. Onychoprion fuscata infuscata (Lichtenstein).

$$
\text { セグロアヂサシ }
$$

Sterna fuliginosa (nec Gm.), Finsch, Journ. Mus. Godef., 1876, 
XII, p. 39; 䳡司及び黑田,「鳥」第一参,第二號,六二頁; Onychoprion fuliginosus (nec Gm.), Wiglesworth, Aves Polyn., I891, p. 75.

探集地. Caroline Is. : Ponapé (Kubary).

- 6S. Melanosterna anæstheta anæstheta (Scopoli).

$$
\text { マミジロアヂサシ }
$$

Onychoprion ancesthctus Wiglesworth, Aves Polyn., I89I, p. 76; Stcrna ancestheta Scop., 鷹司及び黑田, 「鳥」, 第一卷, 第二號, 六二二頁.

探集地. Pelew Is.

$$
\begin{aligned}
& \text { 69. Melanosterna lunata (Pcalc). } \\
& \text { ナンョウマミジロアヂサシ(新稱) }
\end{aligned}
$$

Sterna lunata Finsch, Joum. Mus. Godef., I\$75, VIII, p. 41 ; 鷹司及び黑田,「鳥」, 第一卷, 第二號, 六二頁; Onychoprion lunatus Wiglesworth, Aves Poly11., IS9I, p. 76.

探焦地. Pelew Is. (Tetens, Kubary).

a: 70. Gygisterna sumatrana (Raffles).

$$
\text { エリグロアヂサシ }
$$

S. mclanauchin Wiglesworth, Aves Polyn., 1891, p. 74; Hartert, Nov. Zool., Vol. VII, Igoo, p. IO；鹪司及び黑田，「舁」第一 尖,第二號五二頁共二頁.

探集地. Pelew Is. (Heinsohn, Kubary 堀井); Caroline Is..: Mackenzie, Yap (柲山), Ruk (Kubary, 寺觙), Luganor, Nukuor (Kubary), Ponapé (Finsch, 寺阔, 粐川); Marshall Is. : Taluit (Finsch), Arhno Atoll.

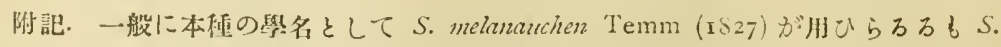
sumatram Raffles (IS2I)の方古きによりこれを用ふらことうせり. Mathews 氏 (Nov.

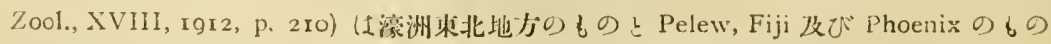

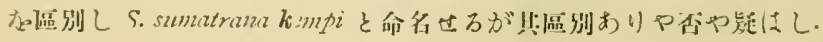




\section{COLUMBID $A$. 鳩 鵒 科}

7I. Calonas nicobaricus pelewensis Finsch.

\section{ミノバト(新稱)}

C. nicobarica var. pelezvensis Finsch, Journ. Mus. Godef., I 875 , VIII, p. 27; C. pclerensis Finsch, 鷹司及び黑田,「鳥」, 第一卷第二 號,五二頁,六二頁；C. nicoburica (nec L.), Wiglesworth, Aves Polyn., I 89I, p. 57 (part).

探集地. Pelew Is. (Heinsohn, Kubary，藤田及び靑木，寺阔， 堀井).

72. Phlegcenas canifrons Hurtlanb \& Finsch.

$$
\text { パラウムナジロバト(新㛵) }
$$

Hartl. \& Finsch, P. Z. S., I872, p. IOI ; Wiglesworth, Aves Polyn., IS9I, p. 57 ; Finsch, Journ. Mus. Godef., IS75, VIII, Pl. V, fig I ; Phloganas canifrons Hartl. \& Finsch, 鷹司及び黑田,「鳥」第 一卷,第二號,六二頁.

探集地. Pelew Is. (Kubary).

73. Phlegœnas kubaryi Finsch.

$$
\text { マミムナジロバト(粐川) }
$$

Wiglesworth, Aves Polyn. I891, p. 55 ; Hartert, Nov. Zool., Vol. VII, I900, p. S; Phlogxnas kubaryi Finsch, 鷹司及び黑田, 「鳥」, 第一卷,第二號 六二頁; Phloganas erythroptera (nec Gm.), 同, 「鳥」,第一卷,第二號,五二頁,六二頁.

探集地. Caroline Is.：Ruk (Kubary, 寺岡, 柿澤), Ponapé (Kubary, 粐山). 
7 . Phleguenas xanthonura xanthonura (Tcmminci). マリアナムナジロバト(粐川)

Hartert, Nov. 7,ool., Vol. V, pp. 60, 69; P. pampsen IViglesworth, Aves Polyn. I891, p. 55; Phloganas pimipan Onstalet, Nouv, Archiv. Mus., I895, p, 224; 鷕司及び黑田,「点」, 第一参, 第 二號,共二頁； Phleginnas virgo Rchnw., Wiglesworth, Aves l'ulyn., IS9 I, p. 57 (not Pelew Is. !).

探集地. Marianne Is. (Quoy \& Gaim.): Guam, Rota (Marche), Saipan; ? Coroline Is. : Mackenzie.

75. Phlegcenas xanthonura yapensis Ifartlaut \& Finsch.

$$
\text { ムナジロバト(粐け) }
$$

Hartl. \& Finsch, P. Z. S., I872, p. I02; Wiglesworth, Aves

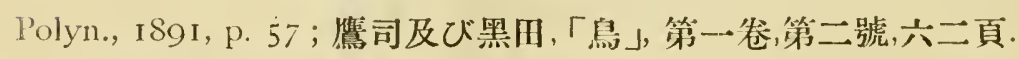

探集地. Caroline Is. : Mackenzie, Iap or Uap (Kubary, 籽川).

76. [Streptopelia dussumieri (Timminck)]

$$
\begin{gathered}
\text { ナンヨウジュヅカケバト(新梅) } \\
\text { カホベニバト(然司) }
\end{gathered}
$$

Turtur dussumicri Wiglesworth, Aves l'olyn., I89 I, p. 54; Oustalet, Nouv. Archiv. Mus., 1 S94, p. 222; Hartert, Nov. Zool., Vol.

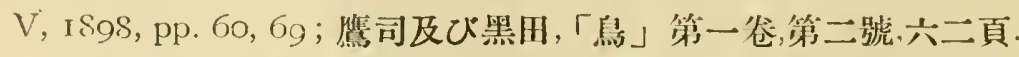

探集地. Marianne Is. (Quoy \& Gaim.): Guam (Marche), Saipan (大渡).

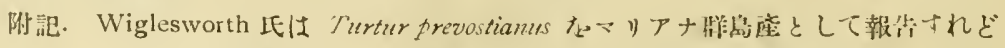
もこの種は Seychelles 群馬りのマリアナ鳥 (Marianne Island)にて隻られたるることおる のみにしてへく別の島の誤りなりと云ふ(Cat. B. 13r. Mus., XXI, p. 4ro) x Hartert 氏 (Nov. Zool., Vol. V, I898, p. 69) もこは誤りなりを指示す. S. dussumieriは元來フヒり

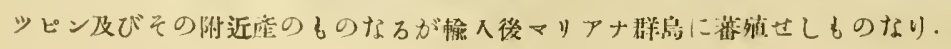


7\%. Globicera oceanica oceanica (Lesson). ハシナガコブバト（粐山）

G. acianiad acanica (Desnorest), Wetmore, Bull. Mus. Comp. Zoöl., Vol. LXIII, 1919, p. 191 ; Carpophaga vieanica Finsch, Ibis, ISsi, pp. 106, 109, II 3 ; G. dianica (Less.). Wiglesworth, Aves Polyn., rSg1, p. 52 (part. !) : Hartert, Nov. Zool., Vol. VII, 1900, p. 8: 鹤司及び黑田,「鳥」, 第一尖, 第二號, 六二頁 (part.).

探集地. Caroline Is. Kusaie or Ualan (Coquille, Kittlitz, Finsch, 粐川); Marshall Is. : Taluit, Arno (Finsch).

78. Globicera oceanica townsendi Vitmort.

$$
\text { クロコブバト（新稱） }
$$

Wetmore, Bull. Mus. Comp. Zoöl., Vol. LXIII, 1919, p. I91. Carpophaga occania Wiglesworth, Aves Polyn., I89I, p. 52 (part.); 鹰司及び黑田, 「是上, 第一卷, 第二號, 六二頁 (part.)

探集地. Caroline Is. : Ponape (Kubary, Moore).

79. Globicera oceanica teraokai Momiyama, subsp. nov.

$$
\text { コプバト（粐け） }
$$

Carpoplagar occanica, Wiglesworth, Aves Polyn., 1891, p. 52

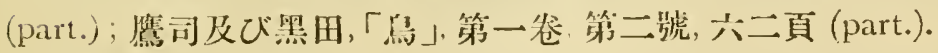

探紧地. Caroline Is.：Ruk (Kubary, 寺阙, 粐山), ? Luganor, Nukuor or Mortlock.

So. Globicera oceanica monacha Nomyama, subsp. nov.

$$
\text { ハイガシラコブバト.(粐川) }
$$

探集地 Caroline Is. : Yap (粐川)

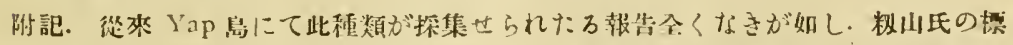

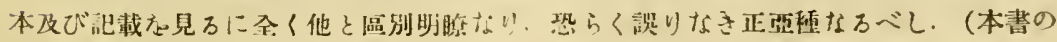

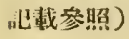


SI. Globicera oceanica momiyamai Kuredur, subsp. not.

$$
\text { モミヤマコブバト（新称） }
$$

Carpophaga oceanica (nec. Less.) Hartlaub, P. Z. S., IS67, p. 830 (Pelew); Wiglesworth, Aves Polyn., I89I, p. 52 (part.!); Globicra occanica (nec Less.), 黑田, 動物學猚誌 第三百十九號, 大 正四年, 三二六頁, 三三二頁 (Pelew); 黑田, 同. 第三百二十一號, 大 正四年, 三九二頁, (Pelew)；鷹司及び黑田,「具」第一卷, 第二號, 大 正四年, 五二頁, 六二頁 (part.)；黑田，動物學雜誌，第三百二十八號， 大正五年二月, 七○頁 (Pelew \& Angaur).

探集地. Pelew Is. (Gray, Kubary 堀井, 藤!四清木, 寺洞)： Angaur (大渡, 堀井).

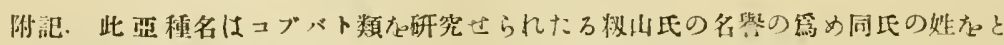
りししのなり(本其の記载參照)。

- 82. I'tilinopus roseicapillus (Lcsson).

$$
\text { コハシヒタアョバト（粐川） }
$$

Hartert, Nov. Zool., Vol. V, IS98, pp. 60, 69: Ptilopus rosicapillus Wiglesworth, Aves Polyn. rS9I, p. 4S; Oustalet, Nour. Archiv. Mus., I 895, p. 2 I S ; 鷹司及び黑田, 「黒」第一䉥第二號. 六 二頁.

探集地. Marianne Is. : Guam (Kittl.), Saipan, Rota (Marche).

8. Ptilinopus pelewensis Hartlaub \& Finsch.

$$
\text { ホリキヒメアラバト（粐山） }
$$

Hartl. \& Finsch, P. Z. S.. 1868, pp. 7, i I ; Ptilopus pdcivinsis

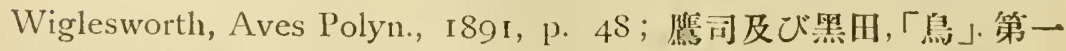
管第二跟, 五二頁, 六二頁.

採集地. Pelew Is. (Kubary, 堀井, 藤田及び洁木, 表岡). 
\$4. Ptilinopus ponapensis ponapensis (Finsch).

$$
\text { ヒメアラバト (粐山) }
$$

I'tilonopus ponapensis Finsch, 1'. Z. S., IS77, p. 779 ; Ptilinopus ponapinsis Finsch, Hartert, Nov. Zool., Vol. VII, I900, p. 7 ; Ptilopus poncrponsis Wiglesworth, Aves Polyn., I89I, p. 50; 䳡司及び黑田, 「鳥」, 第一第二號, 五二頁, 六二頁.

探集地. Caroline Is. : Ponapé (Kubary, Finsch, 寺洞, 大渡, 粐川), Ruk (Kubary, Finsch, 寺洞, 粐川).

\$5. Ptilinopus ponapensis hernsheimi (Finsch).

$$
\text { フナシヒメアタバト（粐山） }
$$

Ptilopus hernslucimi Finsch, P. Z. S., I SSo, p. 577 ; Wiglesworth,

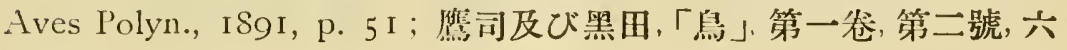
二頁.

探集地. Caroline Is. : Kusaie or Ualan (Finsch, 籾[1).

\section{CUCULID $A$. 杜 鵑 科}

S6. Cuculus canorus telephonus Heinc.

$$
\text { クャクコウ }
$$

C. canorus (nec L.), Hartl. \& Finsch, I. Z. S., IS72, p. I00; Finsch, J. Mus. Godef. I875, VIII, p. 12 ; Wiglesworth, Aves l'oly11., IS9I, p. IO (part.)；鹰司及び黑田,「悬」, 第一卷, 第二號, 六三頁.

探集地. Pelew Is. (Heinsohn).

S7. Cuculus optatus optatus Gould.

$$
\text { ッッドリ }
$$

C. striatus (nec Drap. ?), Hartl. \& Finsch, P. Z. S., 187̨2, p. 100; Finsch, J. Mus. Godef., IS75, VIII, p. I 2 ; C. striatus (nec Gray), 鷹 
司及び黑田，「鳥」，第一卷，第二號、六三頁；C. intirmedius (nec Vahl). Wiglesworth, Aves Polyn., isgi, p. 10.

探集地. Pelew Is. (Heinsohn).

Ss: Urodynamis taitiensis (Sparmanan), subsp.

$$
\text { キジクゥクコウ（新稱） }
$$

U. taiticnsis Wiglesworth, Aves Polyn., ISgI, p. I I ; Hartert, Nov., Zool., Vol. VII, 1900, p. 7 ；隼司及び黑田,「鳥」, 第一参, 第 二號, 五二頁, 六三頁.

探集地. Pelew Is. (Peters); Caroline Is. : Ualan (Kittl.), Ponapé and Luganor (Kubary), Ruk (寺岡); Marshall Is. : Taluit (Finsch).

\section{TRICHOGLOSSID E. 緋賏鳥鵸科}

S9. (Enopsittacus rubiginosus (Bonaparti).

$$
\text { ポナへインコ（粐山） }
$$

Domicella rubiginosa Hartl. \& Finsch, P. Z. S., IS72, p. SS; Trichoglossus ruliginosus Finsch, J. Mus. Godef., I $\$ 76$, XII, p. IS ; Wiglesworth, Aves Polyn., I 891, p. 8; lios rubiginosus (Bp.), 䉆司及 び黑田,「學」第一然, 第三號, 五三頁, 六三頁.

探集地. Carolne Is. : Ponapé (Danaide Exp., Kubary, 堀井, 寺岡, 大渡, 粐山!

\section{ALCEDINIDAE。辈㬅科}

90. Sauropatis albicillus (Dumont).

$$
\text { シロガシラセウビン（新稱） }
$$

Halcyon albicilla Wiglesworth, Aves Polyn., IS91, p. I4; () ustalet, Nouv. Archiv. Mus., 1895, p. I69; Hartert, Nov. Zool., 
Vol. V, ISgS, pp. 52, 6S；H. alhicillus (Cuv.). 㫮田, 動物學雜誌 第 三百二十號 三二七頁, 三三二頁 (Saipan)；同, 同誌, 第三百二十八

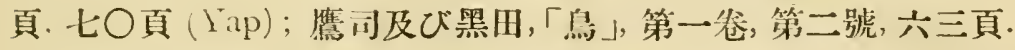

探集地. Marianne Is. (Quoy \& Gaim., Marche)：Saipnn(堀井, 料川), Rotal, Pagan, Agrigan ; Caroline Is. : ? Yap (大渡).

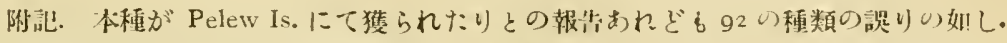

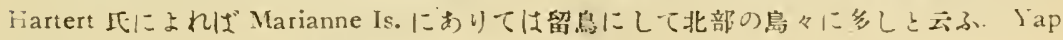

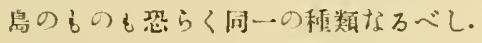

91. Sauropatis chloris owstoni (Kothschild).

$$
\text { シロビターアヨセ少ビン（新稱） }
$$

Hation owstoni Roths., Bull. H. O. C., XV, p. 6 (1904).

探集地. Mariane Is. Asuncion or Assmpion (OMston $の$ 探勧人).

92. Sauropatis chloris teraokai (Kurcra).

$$
\text { テラヨカセウビン }
$$

Halcyon chloris (nec Bodi.), Finsch, J. Mius. Godef. VIII, 1\$75, p. Io; Wiglesworth, Ives Polyn., I89I, p. I4 (part.); it. sordidus (nec Gould), 黑田, 動物學雜誌, 第三百十九號, 三二七頁, 三三二頁;

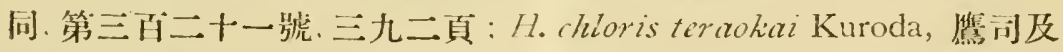

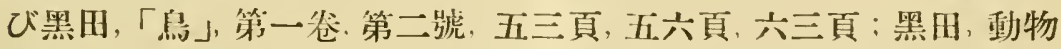
學﨎誌, 第三百二十八號, 七○頁.

探集地 Pelew Is. (Kubry, Tetens, Heinsohi), Kubary, 堀井, 藤田及び青木. 寺岡, 秋川): Angaur (大渡, 堀并).

93. Squropatis cinnamominus (Sivonson).

$$
\text { アカハラッウビン（新稱） }
$$

Halcyon cinnamomina Wiglesworth, Aves Polyn., IS9I, p. I6; Oustalet, Nouv. Irchiv. Mus., I\$95, p. 175 ; Hartert, Nov. Zool., Vol. V, IS9S, pp. 52, 68; H. cinnamominus Swins. (part.), 鷹司及び 


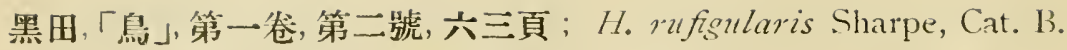
Br. Mus., Vol. XVII, p. 260 (ㅇ!).

探集地. Marianne Is. : Guam (Quoy \& Gaim., Kittl., Marche)

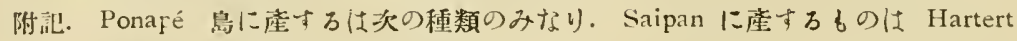
比によれば別種なりと云ふも學名末定の如し。

94. Sauropatis reichenbachii reichenbachii (Hartlaub).

$$
\text { ヅァカセウビン（新稱） }
$$

Halcyon rcichonbachi Wiglesworth, Ares Polyn., IS9I, p. I5;

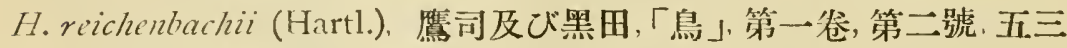
頁，尣三頁；H. cimamominus Finch, J. Mus. Godef., is76 XII, 20, pt. (Ponapé); H. matiocris Sharpe, Cat. B. Br. Mus., XVII, I Sq2, p. 260 ; Wiglesw., Ares Polyn., isgr, p. I6.

探集地. Caroline Is. I'onapé (Kubary, Finsch, 寺凮, 大渡, 堀 井, 粐山).

附汁. Pelew Is.に座すろ赤䫑のものは本亞種にむるず炏の種類なり。

95. Sauropatis reichenbachii pelewensis (I/ igleswort/l).

$$
\text { ヒメッ゙アカセウビン (新稱) }
$$

Halcyon reichcubachii (nec. Hartl.) Hartl. \& Finsch, P. Z. S.. I 868 , pp. 4, I IS (Pelew) ; Finsch, J. Nus. Godef., I875, VIII, p. I I (Pelew); Sharpe, Cat. B. Br. Mus., XVII, 1So2, p. 261 (Pelew); 黑 田，動物學雜誌，第三百二十號，三二八頁，三三二頁 (Pelew)；H. pclcrucnsis IViglesworth, Aves Polyn., I891, p. I 5 (Pelew); 鷹司及

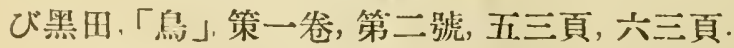

探集地. l'elew Is. (Tetens, Heinsohn, Kubary，堀井，寻阙） Angaur (堀井)

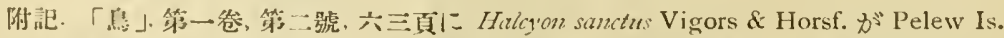

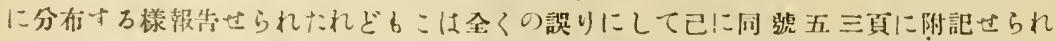
けろ如く南太平洋上來經百六十二度. 南緯二度の地點に於て二個の6の船中に飛び入り

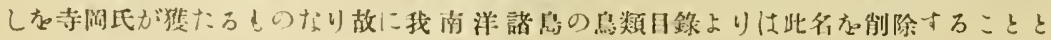
t. 


\section{STRIGIDE。香鴟科}

96. Ninox podargina (Hartlaub \& Finsih).

$$
\text { カキイロヅク（新䊈） }
$$

Sharpe, Cat. B. Br. Mus., II, 1875, p. 15 I (Note); 黑田, 動物 學雜誌, 第三百二十八號, 七○頁; 鷹司及び黑田, 「鳥」, 第一卷, 第 二號, 六三頁; Noctuc podargina Hartl. \& Finsch, P. Z. S., 1S72, p. 90 ; Finsch, J. Mus. Godef. IS75, VIII, p. S, pl. I ; Scops podargina Wiglesworth, Aves Polyn., I S91, p. 3.

探集地. Pelew Is. (Hartl. \& Finsch, 堀井): Angaur (堀井).

97. Asio flammeus sandwichensis (Bloram.)

$$
\text { ナンョウコミミッ゙ク (新稱) }
$$

A. accipitrimus (nec Pall.), IViglesworth, Aves Polyn., IS9I, p. 3 ; Oustalet, Nouv. Archiv. Mus., IS95, p. I68; Hartert, Nov. Zool., Vol. V, I S9S, pp. 5 I, 68; 隼司及び黑田,「鳥」, 第一卷, 第二號, 六三頁.

採集地. Marianne Is. (Hartlaub); Caroline Is.： Ponapé (Finsch, 粐川).

\section{CAPRIMULGIDAE。怪鴟科}

9S. Caprimulgus indicus phalæna Hartlanb \& Finsih.

$$
\text { ナンョウョタカ（新稱） }
$$

C. phalcena Hartl. \& Finsch, P. Z. S., 1872, p. 91 ; Finsch, J. Mus. Godef., I\$75, VIII, p. I3, pl. II, Wiglesworth, Aves Polyn,

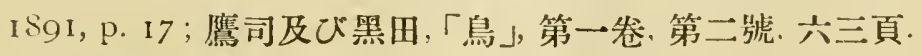

探集地. Pelew Is. (Heinsohn, Kubary). 


\section{CYPSELIDA. 雨 澡 科}

99. Collocalia fuciphaga inquieta (Kíttlitz).

\section{アナッバメ（粐川）}

C. fuciphaga vanikorcnsis (Quoy G. Gaim.), Oberholser, Proc. U.S. Nat. Mus., Vol. 42, 1912, p. 19；鷹司及び黑田,「鳥」, 第一卷, 第二號，五三頁，共三頁；C. vanikorensis IViglesw., Aves I'olyn., IS9I, p. I8; Hartert, Nov. Zool., Vol. VII, I900, p. 11 .

探集地. Pelew Is. (Tetens, Semper, Kubary); Caroline Is. : Ualan or Kusaie (Kittl, Finsch, 粐川); Ponapé (Kubary，寺岡.粐川); Ruk (Kubary, 寺岡, 粐山), Yap (Kubary).

- roo. Collocalia fuciphaga rukensis Surrodu.

$$
\text { クロアナッバメ（粒山） }
$$

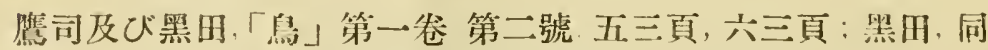
五八頁; Collocalia sp., 黑田, 動物學雜誌, 第三有二十號, 三二八貣, 三三二頁.

探集地. Caroline Is. : Ruk (堀井, 寺岡, 粐川).

- ror. Collocalia fuciphaga tachyptera Obcrholsir.

$$
\text { マリアナアナッバィ（新稃） }
$$

Oberholser, Proc. U.S. Nat. Mus., Vol. 42, I912, p. 20 (Guam);

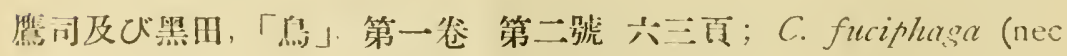
Thunberg), Oustalet, Nouv. Archiv. Mus, I895, p. IS7 ; Hartert Nov. Zool., rs98, pp. 53, 6S ; C. aanicorcnsis (nec Quoy \& Gaim.), IViglesworth, Aves I'olyn., Is9 r, p. Is (pt.).

探集地. Marianne Is. : Guam, (Kittlitz, Marche), Saipan (粐II), Rota (Marche). 
102. [Collocalia unicolor bartschi Micarns.]

$$
\text { グアムアナッバメ (新稱) }
$$

C. bartschi Mearns, Proc. U.S. Nat. Mus., Vol. XXXVI, I909, p. 476 (Guam).

採集地. Marianne Is. : Guam (Dr. P. Bartsch).

103. Callocalia unicolor amelis Obcrholser.

$$
\text { パラウアナッバメ（新稱） }
$$

C. francica (nec Gm.), Oberholser, Proc. Acad. Nat. Sci. Phil., I906, p. 193; 黑田, 動物學雜誌 第三门二十一號 三九 ○頁, 三九 二頁 : 同, 同誌, 第三百二十八號, 七○頁; 鷹司及び黑田,「鳥」第 一卷, 第二號, 五三頁, 共三頁.

探集地. Pelew Is. (藤甶及び青木, 堀井, 寺洞)：Marianne Is.： Guam.

\section{MUSCICAPID $A$. 鵄 科}

104. Metabolus rugensis (Hombron \& Jacquinot).

$$
\text { カハリヒタキ（粐山） }
$$

Wiglesworth, Aves Polyn., IS91, p. 19; Hartert, Nov. Zool.,

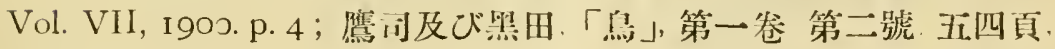
六三頁.

探集地. Caroline Is. : Ruk or Hogoleu (Hombr. \& Jacq., Kubary, 寺誾, 大渡, 粐【|).

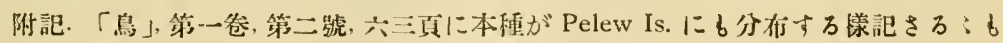
こは印刷の铞りなり。

105. Monarches godeffroyi Hartlaut.

$$
\text { カササギヒタキ(粐山) }
$$

Hartl., I'.Z.S., IS67, p. S29, pl. XXXVIII；鷹司及び黑田， 
「鳥」, 第一卷, 第二號, 六三頁; Pomarea godeffroyi Wiglesworth, Aves Polyn., I 89 I, p. I9.

探集地. Caroline Is. Mackenzie, Yap or Uap (Kubary, 粐山).

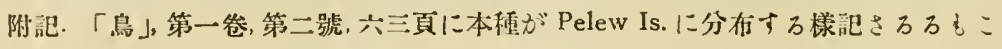
は印刷の誤りなり.

Io6. Myiagra erythrops Hartlaub \& Finsch.

$$
\text { ヒメヒラハシ(新稱) }
$$

Hartl. \& Finsch, P.Z.S., I 868, pp. 6, I I 7 ; Wiglesworth, Aves Polyn., I89I, p. 23 ; 鷹司及び黑田, 「鳥」, 第一卷,第二號,五四頁,六 三頁.

探集地. Pelew Is. (Tetens, Heinsohn, Semper, Kubary，寺岡， 堀井).

107. Myiagra oceanica Jacquinot \& Pucheran.

$$
\text { ヒラハシ (新稱) }
$$

Wiglesworth, Aves Polyn., IS9I, p. 23 ; Hartert, Nov. Zool., Vol. VII, 1900, p. 5 ; 鷹司及び黑田,「鳥」第一卷,第二號,五四頁,六 三頁.

探集地. Caroline Is.; Ruk or Hogoleu (Hombr. \& Jacq., Kubary, 堀井, 藤田及び青木, 寺岡, 大渡, 粐山).

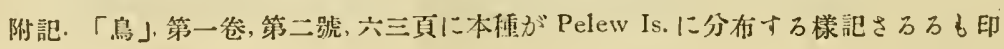
刷の誤りなり.

roS. Myiagra pluto Finsil.

$$
\text { クロヒラハシ(新稱) }
$$

Finsch, P. Z. S., I 875, p. 644; Wiglesworth, Aves l'olyn., IS9I，p. 23; 䉆司及び黑田,「鳥」第一䉥,第二號,五四頁,六三頁.

探集地. Caroline Is. : Ponapé (Kubary, 㳫岡, 料山).

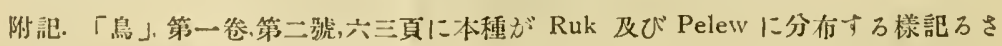
ろろし印刷の談りなり。 
I09. [Myiagra freycineti Oustalet.] マリアナヒラハシ(新稱)

Wiglesworth, Aves Polyn., IS9I, p. 24 ; Oustalet, Nouv. Archiv. Mus., I S95, p. I 94 ; Hartert, Nov. Zool., Vol. V, IS98, pp. 54,68 .

探集地. Marianne Is. (Quoy \& Gaim.): Guam (Marche).

I IO. [Rhipidura uranix Oustalct.]

$$
\text { グアムアフギヒタキ(新稱) }
$$

Wiglesworth, Aves Polyn., I891, p. 20; Hartert, Nov. Zool., Vol. V, I\$98, pp. 53, 68: R. atrigularis Reich., Wiglesworth, Aves Polyn., :S9I, p. 2I (not Pelew Is. !) ; 鷹司及び黑田,「鳥」第一夋, 第二號,六三頁; R. versicolor (nec Hartl. \& Finsch), Oust., Nour. Archiv. Mus., I S95, p. I90.

探集地. Marianne Is. : Guam (Narche).

附訅. Hartert 氏 (Nor. Zool. Voi. V, I889)によればR.atrigullaris Reich.は Pelew に集せず Guam 㡾なりと云ふ。

III. Rhipidura rufifrons saipanensis Hartert.

$$
\text { サイパンアフギヒタキ(新稱) }
$$

K. saipancnsis Hartert, Nov. Zool., Vol. V, isgs, pp. 54, 6s; 鹰司及び黑田,「鳥」第一第二號,六三頁.

探集地. Marianne ls.; Saipan (粐川).

112. Rhipidura kubaryi Finsch.

$$
\text { クロアフギヒタキ(籾川) }
$$

Finsch, P. Z. S., I875, p. 644, Wiglesworth, Aves Polyn. IS9I, p. 20 ; 鷹司及び黑田,「㼂」, 第一卷,第二號,五四頁六四頁. 
探集地. Caroline Is. : Ponapé (Kubary, 堀井,寺岡,粐川).

I I3. Rhipidura lepida Hartlaub \& Finsch.

\section{アカアフギヒタキ(新稱)}

Hartl. \& Finsch, P. Z. S., IS6S, pp. 6, 117 ; Finsch, J. Mus. Godef., VIII, p. 2I, pl. IV; IViglesworth, Aves Polyn., I \$9ı, p. 2 I ; 鷹司及び黑田,「鳥」, 第一卷, 第二號,五四頁,六四頁; R. torrida (nec Wall.), 同,「鳥」, 第一卷,第二號,六四頁.

探集地. Pelew Is. (Tetens, Semper, Kubary, 寺岡,堀井).

- II4. Rhipidura versicolor Hartlaub \& Finsch.

$$
\text { アフギヒタキ(粐山) }
$$

Hartl. \& Finsch, P. Z. S., IS72, p. 96; Wiglesworth, Aves Polyn., ISgI，p. 2I (pt. ?); 鷹司及び黑田,「鳥」, 第一卷,第二號,枀四 頁.

採集地. Caroline Is. : Mackenzie, Yap or Uap (Kubary, 粐山).

附記. Wiglesworth 氏 (Aves Polyn., I89I， p. 2I)によれば Marianne Is. にも産す

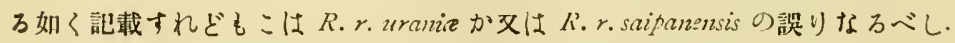

\section{TURDID $A$ ． 鵣 科}

I 5. Turdus obscurus Gmelin.

$$
\text { マミチヤジナイ }
$$

Hartl. \& Finsch, P. Z. S., I 872 , p. 95 ; Einsch. J. Mus. Godef,,

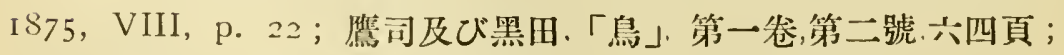
Mernla hoscura Wiglesworth, Aves Polyn., I89I, p. 39.

探鉴地. Pelew Is. (Heinsohn). 


\section{SYLVIIDAE. 篔 科}

116. Acrocephalus stentoreus syrinx (Kittlitz).

$$
\text { ナンョウョシキリ(新稱) }
$$

Tatare syrinx Wiglesworth, Aves Polyn., IS9I, p. 4 I ; Oustalet, Nouv. Archiv. Mus., I S95, p. 210 ; Acroccphalus syrinx Hartert, Nov. Zool., Vol. V, IS9S, p. 6S ; id., op. cit., Vol. VII, I900, p. 3 ; 鷹司及び黑田、「鳥」第一卷, 第二號, 五四頁, 六四頁; Conopoderas syrinx (Kittl), Wetmore, Bull. Mus. Comp. Zoöl., LXIII, I919, p. 214.

探集地. Marianne Is.: Pagan (Marche); Caroline Is.: Ruk (Hombr. and Jacq., Kubary, 藤田及び青木,寺岡,堀井,粐山), Ualan (Kittl.), Luganor, Ulie or Wolea (粐!I), Nukuor (Kubary), l'onapé (Novara, Kubary, 堀井,寺岡.大渡,粐山).

附記.「鳥」第一叁,第二號六四頁に本種が Pelew Is。に分布す万栐訅さろるも Kusaie or Ualan の誤りなり.

I17. Acrocephalus luscinia (Quoy \& Gaimard).

$$
\text { マリアナヨシキリ(新稱) }
$$

Hartert, Nov. Zool., Vol. V, I S99, pp. 57,68; 鷹司及び黑田, 「鳥」, 第一第二躆,六四頁; A. mariannce Tristram, Ibis， ISS3 45 ; Tatare huscinia Wiglesworth, Aves Polyn., IS9I, p. 4 I ; Oustalet, Nouv. Archiv. Mus., I S95, p. 209.

探集地. Marianne Is.: Guam (Quoy \& Gaim., Marche), Saipan.

$\backslash$ IIS. Psamathia annæ Hartlaub \& Finsch.

$$
\text { ナンョウウグヒス(新稱) }
$$

Hartl. \& Finsch, P. Z. S., Is6S, pp. 5, IIS, pl. II ; Finsch, J. 
Mus. Godef., I S75, VIII, p. 22; Wiglesworth, Aves Polyn., iS91, p. 40 ；鷹司及び黑田，「藇」第一第二第虎,五四頁,六四頁.

探集地. Pelew Is. (Tetens, Heinsohn, Semper, Kubary，寺䎟).

\section{CAMPEPHAGIDA. 山椒喰科}

1 19. Edoliisoma nesiotis (Har-tlaub \& Finsch).

$$
\text { チャバラサンセウクヒ(粐川) }
$$

Wiglesworth, Aves Polyn., I891, p. 25; 鷕司及び黑田,「真小 第一第二號,六四頁; Campctiaga nesiotis Hartl. \& Finsch, P.Z.S., I872, p. 98 ; Finsch, J. Mus. Godef., 1876, XII, p. 28.

探集地. Caroline Is, ; Mackenzie, Iap (Kubary, 粐山).

$\checkmark$ 120. Lalage monacha (Hartlaub \& Finsch)

$$
\text { ネズミサンセウクヒ(新稱) }
$$

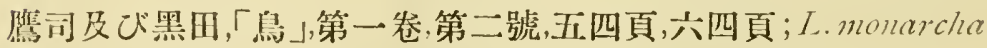
Wiglesworth, Aves Polyn., IS91, p. 25; Campeplutaga monacha Hartl. \& Finsch, P.Z.S., IS72, p. 99; T'dvocizora monacled Finsch, J. Mus. Godef., I875, VIII, p. I9, pl. I1 I, fig. 2-3.

探偗地. I'elew Is. (Heinsohn, I'eters, Kubary, 寺阔,堀井).

$$
\begin{aligned}
& \text { 121. Lalage insperata (Finsch). } \\
& \text { ポナべサンセウクと(新稱) }
\end{aligned}
$$

Wiglesworth, Aves Polyn., IS91, p. 25 ; 鷹司及び黑田,「孯小 第一卷第二號,六四頁; I'oliveivora insperata Finsch., P.Z.S., IS75, p. 643 ; id., J. Mus. Godef. Is76, XII, p. 27.

探尖地. Caroline Is. : P'onapé (Kubary, Finsch). 


\section{ARTAMIDA. 森 苝 科}

$\backslash$ 122. Artamus melanoleucus pelewensis Finsil.

$$
\text { モリッバメ(新稱) }
$$

A. pilawnsis Finsch, J. Mus. Godef., I876, XII, p. 4I ; Wiglesworth. Aves Polyn., IS91, p. 26; 䈍司及び黑田,「鳥」第一卷,第二 號,六四頁; A.lucorluyuchus (nec L.), Hartl. \& Finsch, P.Z.S., IS68, p. 116.

探集地. Pelew Is. (Semper, Kubary, Cohen, 堀井).

\section{PRIONOPIDA. 森 鵙 科}

123. Pinarolestes tenebrosus (Hortlaub \& Finsch).

$$
\text { モリモズ(新稱) }
$$

Sharpe, Cat. B. Br. Mus., Vol. III, p. 29 ；鹪司及び黑田「鼠」 第一兴,第二號.王四頁,六四頁; Rectrs tinebrosus Hartl. \& Finsch, P.Z.S., is68, pp. 6, I Is ; IViglesworth, Aves Polyn., IS91, p. 27.

探集地. Pelew Is. (Tetens, Peters, Kubary, 寺岡,堀井).

\section{CORVIDAE。鴉 科}

- 12.4. Corvus kubaryi Richlenow.

$$
\text { クバリーガラス(新稃) }
$$

Hartert, Nov. Zool., Vol. V, IS9S, pp. 59, 69; 鷹司及び黑田, 「鳥」第一卷, 第二號, 六四頁; Corius solitarius (nec W Württ.), Kittl. Reis. Russ. Amer. Mikronesien, etc., ii, p. 43 I (IS58, desc. nullâ); Oustalet, Nouv. Archiv. Nus., IS95, P. 216; Corone plitlipina (nec 
Bp.), IViglesworth, Aves Polyn., I89 I, p. 46 (part. !) ; Coronc kubary, id., op. cit., p. 46 (not Pelew Is. ?).

探集地. Marianne Is. (Kittl.): Guam, Rota (Marche).

附記. 本程が Pelew Is. にて獲られたりとの報告もれども Hartert 氏 (Nov. Zool. V,r I898 p. 59)によとば大に疑ひおりと云ふ。

\section{EULABETIDAE. 九官鳥科}

125. Aplonis pelzelni Finsch.

ヒメカラスモドキ(粐山)

Finsch, P.Z.S. I 875, p. 644; id., J. Mus. Godef., IS76, XII, p. 32, pl. II ; Wiglesworth, Aves l'olyn., IS9I, p. 43；鷹司及ひ黑田, 「鳥」, 第一怣,第二號,六四頁.

探偗地. Caroline Is. : Ponapé (Mus. Godef.).

126. Aplonis opaca opaca (Kittlits).

ウスグロカラスモドキ(粐山)

A. ofaca (Kittlitz), Wetmore, Bull. Mus. Comp. Zoöl., Vol. LXIII, 19I9, p. 219; A. Kittlitsi Wiglesworth, Aves Polyn., I89ı, p. 44 (part.!); Hariert, Nov. Zool., Vol. VII, Ico0, p. 6 (part.); 鷹司 及び黑田，「烏」，第一卷,第二號，五五頁六四頁 (oart.)；黑田,動物學 雜誌,第三百二十八號,大正五年二月,七一頁 (part.).

探蒩地. Caroline Is. Ualan or Kusaie (Kittlitz, 粐山), I’onapé (Kubary, 寺洞,堀井 粐山!

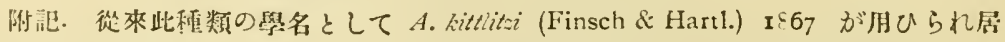
vしも Oterholser 代 (Bull. 98, U. S. Nat. Mus., 1917, p. 59) 及び Wetmore 氏 (Bull.

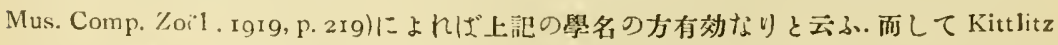
IEの與へし學名は下の如し. Lamfroth [ornis] ofaca Kittlitz (Kupfertafeln naturgesch. Vögel, I\$33, II, F.II, pl.I5. fig. 2, Marianne and Caroline Islands). 
127. Aplon:s opaca anga Momiyama, subsp. nov.

カラスモドキ(粐川)

A. Kittlitzi Hartert, Nov. Zool., Vol. VII, I9co, p. 6 (part.); 黑田, 動物學雜誌, 第三百二十號,大正四年六月 三三○頁,三三二頁 (part.!)；黑田,同,第三百二十一號,大正四年七月，三九二頁 (part. !)； 鷹司及び黑田,「鳥」, 第一参,第二號,五五頁,六四頁:(part.)；黑田,動 物學雜誌第三百二十八號，大正五年二月，七一頁 (part.).

探集地. Caroline Is. : ? Luganor or Ruk (Kubary), Ruk (堀井, 藤田及び青木, 持岡 大渡,粐川)，? Nukuor (Kubary), IVolea or Oleai (粐山).

I2S. [Aplonis opaca guami Momiyama, subsp. nov.]

$$
\text { グアムカラスモドキ(粐山) }
$$

1. Kittlitzi Oustalet, Nouv, Archiv. Mus., I895, p. 2 I 3 ; (part.); Hartert, Nov. Zoo ${ }_{i}$, Vol. V, Isgs, pp. 5s, 69 (part.)

探集地. Marianne Is. : Guam (Marchº, 内山).

I29. Aplonis opaca harterti Momiyama, subsp. nor.

$$
\text { アリアナカラスモドキ(粐山) }
$$

A. Kittlitzi Oustalet, Nouv. Archiv. Mus., 1895, p. 2 I 3 (part.); Hartert, Nov. Zool., Vol. V, ISgS, pp. 58, 69 (part.); 糔田,動物學雜 誌, 第三百二十號, 大正四年六月, 三三○頁三三二頁 (part. !); 鷹司 及び黑田，「真」，第一卷,第二號，六四頁 (part.)；A. kittlitzi kurodai Momiyama, “Tori," Vol. II, No. 9, Apr. 1920, p. I (part. !).

探集地. Marianne Is.: Saipan (Narche, 堀井, 粐山), Pagan, Agrigan (Marche).

1 I30. Aplonis opaca kurodai Momiyana.

$$
\text { ハシナガカラスモドキ(粐山) }
$$

A. kittlitzi Wiglesworth, Ares Polyn., IS9I, p. 44 (part.!); 黑 
田, 動物學雜誌, 第三百二十號, 大正四年六月, 三三○頁, 三三二頁,

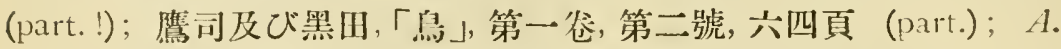
kittlitsi korodai Momiyama, "Tori," Vol. II. No. 9, Apr. 1920, P. I (Yap and Saipan).

探集地. Caroline Is. : Yap (堀井,粐川).

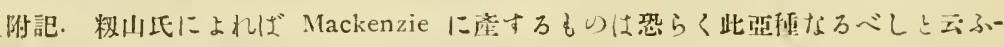

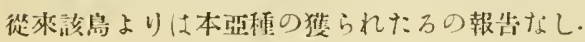

I 3 I. Aplonis opaca, subsp. nov.?

パラウカラスモドキ(粐山)

1. Fittlitai (nec Finsch \& Hart1.), Hartert, Nov. Zool.. Vol. VII, 1900, p. 6 (part.); 黑田 動物學雅誌,第三百二十一號.大正四年七月，

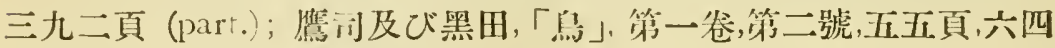
頁 (part.); 黑田, 動物學雜誌, 旌三百二十八號,大正五作二月,七一頁 (part.).

探柋地. Pelew Is. (Tetens, Semper, Kubary, 藤四及び青木, 寺 阔,堀井): Ingaur (堀井).

$$
\begin{aligned}
& \text { I32. Kittlitzia corvina (Kittlitљ). } \\
& \text { テリカラスモドキ(新称) }
\end{aligned}
$$

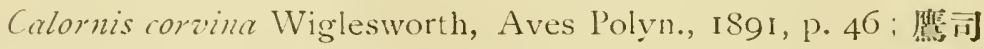

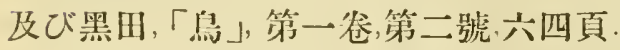

探集地. Caroline Is. : Kusaic or Ualan (Kittlitz).

\section{MELIPHAGID死。蜜 吸 科}

- I33. Myzomela rubratra rubratra (Lesson).

$$
\text { シ ス ヒ }
$$

Wetmore, Bull. Mus. Comp. Zoöl., Vol. LXIII, 1919, p. 219 
(part.!) ; M. mibratra Wiglesworth, Aves l'olyn., IS9I, p. 31 (part.);

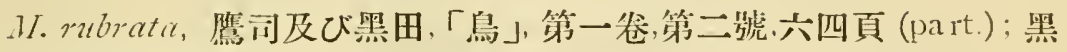
田,動物學猚誌第三百二十八號,大正五年二月, 七一頁 (part).

探集地. Caroline Is. : Kusaie (Kubary, 堀井, 粐山).

$\checkmark$ I34. Nyzomela rubratra dichromata Ilitmori.

$$
\text { ポナぺシスヒ(粐山) }
$$

Wetmore, Bull. Mus. Comp. Zoöl., Vol. LXIII, 1919, p. 220 ; 11. rubratra (nec Less.), Wiglesworth, Aves Polyn., ISgI, p. 31

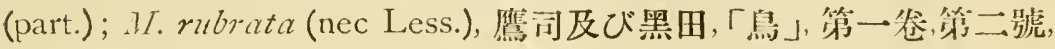
五五頁, 六四頁 (part.)；11. chermesina (nec Gray), Gadow, Cat. B.

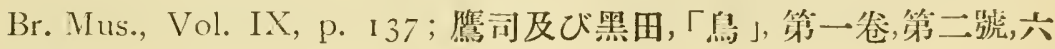
四頁.

探集地. Caroline Is. : Po rapé (Kittlitz, 寺岡,粐山).

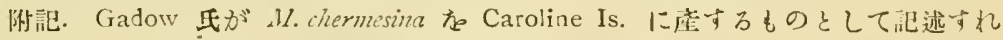
ぞも Wigleswcrth 代によればミッス七の雄幼鳥なりを云ふ・而してPonapé 潼のるのは

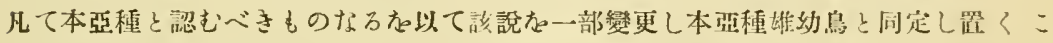
そろせり。

I35. Nyzomela rubratra wetmorei Nomiyama, subsp. nov.

$$
\text { コハシミッスヒ(粐山) }
$$

M. rubratra IViglesworth, Aves Polyn., I\&91, p. 3 I (part.); . M. rubrata (nec Less), Hartert, Nov. Zool., Vol. VII, Igoo, p. 2 ; 黑田, 動物學雜志第三百二十一號，大正四年七月，二八頁；壂司及び黑田， 「鳥」第一尖, 第二號, 五五頁,六四頁 (part.); 黑田,動物學維訫, 第三 百二十八號 大正五年二月, 比一頁 (part. !)；. . r. rubratra (nec Less.), Wetmore, Bull. Mus. Comp. Zoöl., Vol. LXIII, I9I9, p. 2 I 9 (not typical !).

探集地. Caroline Is. : Ruk (Kubary, 藤田及び青木, 寺阔, 大渡, 数山). 
I36. Myzomela rubratra saffordi Wetmore.

マリアナミッスヒ(粐山)

Wetmore, Proc. Biol. Soc. Wash., I9I7, Vol. XXX, p. I 7 (Guam); M. mubatra (nec Less.), Wiglesworth, Aves Polyn., IS9I, p. 31 (part.); Oustalet, Nouv. Archiv. Mus., 1895, p. 197 ; Hartert, Nov. Zool., Vol. V, IS98, pp. 55, 68; 鷹司及び黑田, 「鳥」, 第一参, 第二號,六四頁 (part)；黑田, 動物學雜誌,第三百二十八號,大正五年 二月,七一頁 (part.).

探集地. Marianne Is.: Guam (Kittl., Marche), Saipan (Marche, 大渡,粐川), Rota, Pagan; Agrigan (Marche).

附记. Wetm re 氏 (Bull. Mus. Comp. Zoöl., 19r9, p. 221) によれで Guam と Sai-

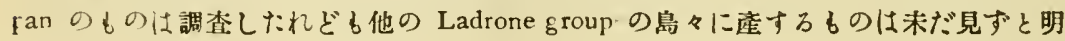
訅す。

- I37. Myzomela rubratra kurodai Momyama, subsp. nov.

$$
\text { クロダミッスヒ(偻山) }
$$

M. rubratra Wiglesworth, Aves Polyn., 1S9I, p. 3 I (part.); M. rubrata (nec Less.), 黑田, 動物學雜誌,第三百二十號,大正四年六月, 三三一頁, 三三二頁 ; 鷹司及び黑田,「鳥」, 第一卷, 第二號、六四頁 (part.)

探集地. Caroline Is. : Yap (Kubary, 堀井, 粐川).

I 38. Myzomela rubratra kobayashii Momiyama, subsp. nov.

$$
\text { パラウミッスヒ(粐山) }
$$

M. mbratra, Wiglesworth, Aves Polyn., I89I, p. 3 I (part.); M. rubrate Gadow, Cat. B. Br. Mus., Vol. IX (part.); 鷹司及び黑 田,「鼠」, 第一卷,第二號,五五頁,六四頁 (part.); 黑田,動物學雜誌, 第 三百二十八號大正五年二月, 七一頁 (part.).

探偗地. Pelew Is. (Lesson, Kubary, Tetens, Heinsohn, Peters, Semper，寺岡,堀井). 
139. Cleptornis marchei Oustalct.

ワウゴンミッスヒ(新稱)

Wiglesworth, Aves Polyn., ISgr, p. 35 ; Hartert, Nov. Zool., IS9S，pp. 56，58；鹰司及び黑田，「鳥」第一無，第二號，六四頁; Ptilotis (Cleptornis) marchei Oust., Nouv. Archiv. Mus., I S95, p. 202, pl. 7 .

探焦地. Marianne Is. : Saipan (Marche).

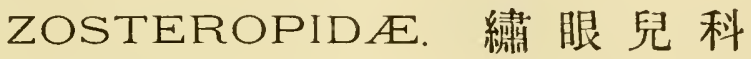

I40. Zosterops semperi semperi Hartlaub.

キメジロ(新稱)

Hartert, Nov. Zool., Vol. VII, I 900, p. 2 ; Z. semperi Wigles worth, Aves Polyn., I891, p. 37 (part.); Oustalet, Nouv. Archiv. Mus., I \$95, p. 207 ; Hartert, Nov. Zool., Vol. V, I \$98, pp. 57, 6S ; 鷹司及じ黑田, 「鳥」, 第一管, 第二號,五五頁,六四頁 (part.)；Z. semperi Hartl. \& Finsch, 黑田,動物學雜誌第三百二十八號, 大正五年二 月, 七一頁.

探集地. Pelew Is. (Heinsohn, Semper, Kubary, 寺岡,堀井,粐 II) ; Mariann Is. : Rota (Marche).

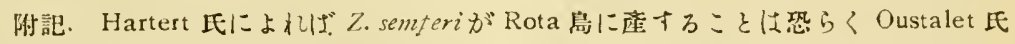
の云ふ约く正しからべきる同氏は他に全くえれに關して知万處なしと云ふ。“The reoccurrence of $Z$. semferi on Rota is very peculiar " (Hartert).

I 4I. Zosterops semperi owstoni Hartert.

$$
\text { コハシキメジロ(粐川) }
$$

Hartert, Nov. Zool. Vol. VII, IgOO, p. 2 (Ruk); 黑田,動物學雜 誌第三百二十八號，大正五年二月，七一頁；Z. ocestoni Hartert, 㕍司 


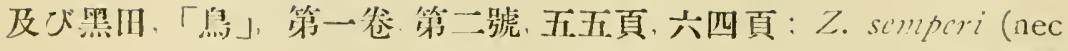
Harti.), Wiglesworth, Aves Polyn., r S9I, p. 37 (part.); 黑田, 動物祭 㫿誌第三百二十號 大正四年六月,三三一面,三三二頁 (Ruk).

探偗地. Caroline Is. : Ruk (Kubary, 堀井,寺岡,大渡,粐川)

I42. Zosterops semperi takatsukasai . 10mıama, subsp. nov.

$$
\text { タカツカサキメジロ(粐川) }
$$

Z. simperi Wiglesworth, Aves I’olyn., I \$91, p. 37 (part.); 鷹司

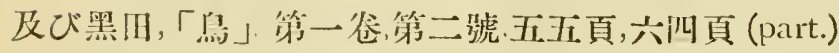

探集地. Caroline 1s. : Ponapé (Finsch, 寺岡, 粐川).

-43. Zosterops conspicillatus (Kittlits).

$$
\text { マリアナメジロ(籾川) }
$$

Zostcrops consficillata (Kitt!.), Wiglesworth, Aves Polyn., IS9I, p. 37 ; Oustalet, Nouv. Archiv. Mus., $1 \$ 95$, p. 205 ; Hartert, Nov.

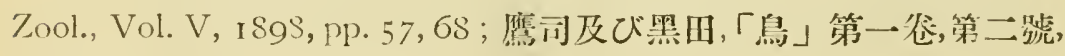
六四頁.

探集地. Marianne Is. : Guam (Kittl., Marche), Saipan (March, 籹川).

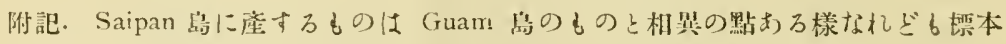
惡しき篇め湂別方なさず (Hartert).

- I44. Zosterops hypolais Hartlaul, \& Finsch.

$$
\text { サメイロメジロ(粐川) }
$$

Hartl. \& Finsch, P. Z. S., 1872, p. 95; IViglesworth, Ives

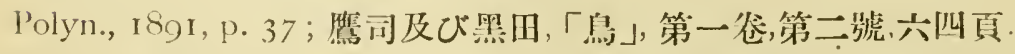

探集地. Caroline Is. : Mackenzie (Kubary), Yap (䊅川). 
145. Tephras cinerea Kittlitz.

ホズミメジロ(新稱)

Zostcrops cincrea Wiglesworth, Aves Polyn., IS91, p. 36; 鷹司 及び黑田,「鳥」, 第一参,第二號,五五頁,六四頁.

探焦地. Caroline Is.: Kusaie or Ualan (Kittl, Finsch, 寺閂, 籺(I).

146. Tephras ponapensis (Finsch).

$$
\text { ポナペメジロ(新稱) }
$$

Zostirops ponafonsis Finsch, P. Z. S., 1875, p. 463: Wigies-

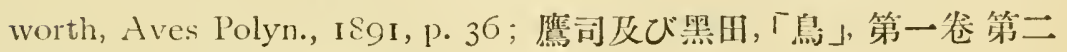
號五五頁,共四頁.

探集地. Caroline Is. Ponapé (Kubary，寺岡,粐山).

147. Tephras finschi Hartlaub.

$$
\text { パラウメジロ(新稱) }
$$

Hartlaub, P. Z. S., IS68, pp. 6, 117 ; Zosterops funschi (Hartl.), Finsch, J. Mus. Godef., IS75, VIII, p. I7; Wiglesworth, Aves Polyn., IS91, p. 36; 鷹间及び黑田, 「烏」, 第一参, 第二號,五五頁, 共四頁.

採集地. Pelew Is. (Tetens, Heinsohn, Semper, Kubary, 寺岡).

14S. Kubaryum oleaginus (Hartlaub \& Finsch).

$$
\text { ミヤマメジロ(粐川) }
$$

Zostcrops oliagina Hartl. \& Finsch, P. Z. S., 1S72, p. 95; IViglesworth, Aves Polyn., 1891, p. 37；Z.oleaginea，潐司及び黑 田, 「皇」, 第一尖第二號,六四頁.

探集地. Caroline Is. : Mackenzie (Kubary), Yap (粐川).

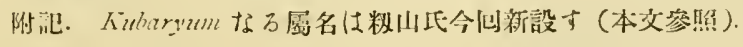


149. Rukia ruki (Hartert).

アカアシメジ(粐山)

Tepharas ruki Hartert, Bull. B. O. C., Vol. VII, IS97, p. V; id., Nov. Zool., Vol. VII, 1900, p. 3 ; Zostcrops ruki (Hart.), 鷹司及び黑 田,「鳥」，第一卷,第二號,六四頁.

探集地. Caroline Is. : Ruk (Owston の探集人姓不明,粐山).

附訅.Rukia屬は今四粐山上の新設けり(本交参照).

\section{PLOCEID $A$. 金 腹 科}

[ 5 0. [Munia punctulata cabanisi Slcarpe]

$$
\text { ルゾンシマキンパラ(新稱) }
$$

探集地. Caroline Is. : Yap (粐山).

I5I. Erythrura trichroa trichron (Kiitlitz).

$$
\text { ナンョウセイコウテウ }
$$

Hartert, Nov. Zool., Vol. VII, 1900, p. 6; E. trichroa Wiglesworth, Aves Polyn., 189I, p. 43 (part.); 鷹司及ひ黑田,「鳥」, 第一 参第二號.五五頁 ; 同書, 六四頁 (part. !) ; 黑田, 動物學雜誌, 第三百 二十八號, 大正五年二月, 七一頁 (part.)； Erythrura sp. ?, Finsch, J. Mus. Godef., I 876 , XII, p. 35 .

探集地. Caroline Is.: Kusaie (Kittlitz), Ponapé (Kubary, 寺風, 大渡,堀井,粐山), Ruk (Kubary, 藤田及び青木,杮澤,籹川).

152. Erythrura trichroa pelewensis, Kuroda, subsp. nov.

$$
\text { ハシブトセイコウテウ(新稱) }
$$

Frytlerura trichroa 黑田,動物學雜誌,第三百二十八號, 大正五 年二月, 七一頁 (part.!).

探集地. Pelew Is. (堀井). 



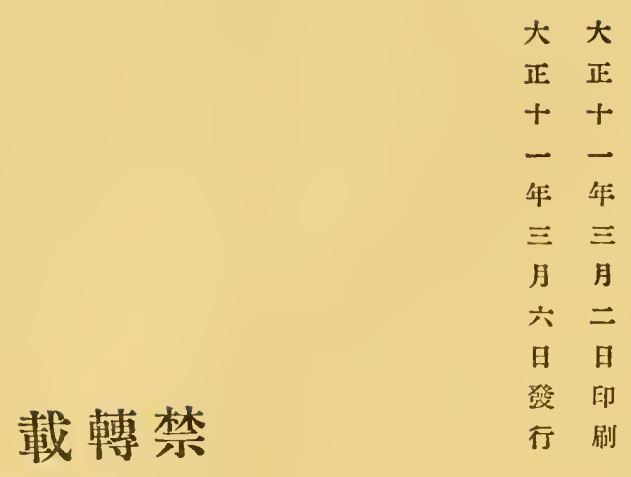

$\begin{array}{lllll}\text { 發 } & \text { 發 } & \text { 印 } & \text { 印 } & \text { 發編 } \\ \text { 賣 } & \text { 行 } & \text { 刷 } & \text { 刷 } & \text { 行輯 } \\ \text { 所 } & \text { 所 } & \text { 所 } & \text { 人 } & \text { 者舞 }\end{array}$

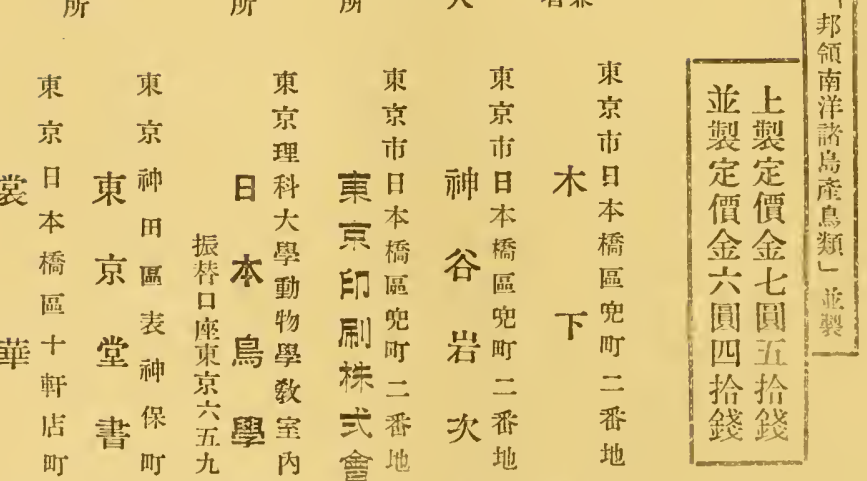
屏店藻會注郎惠 



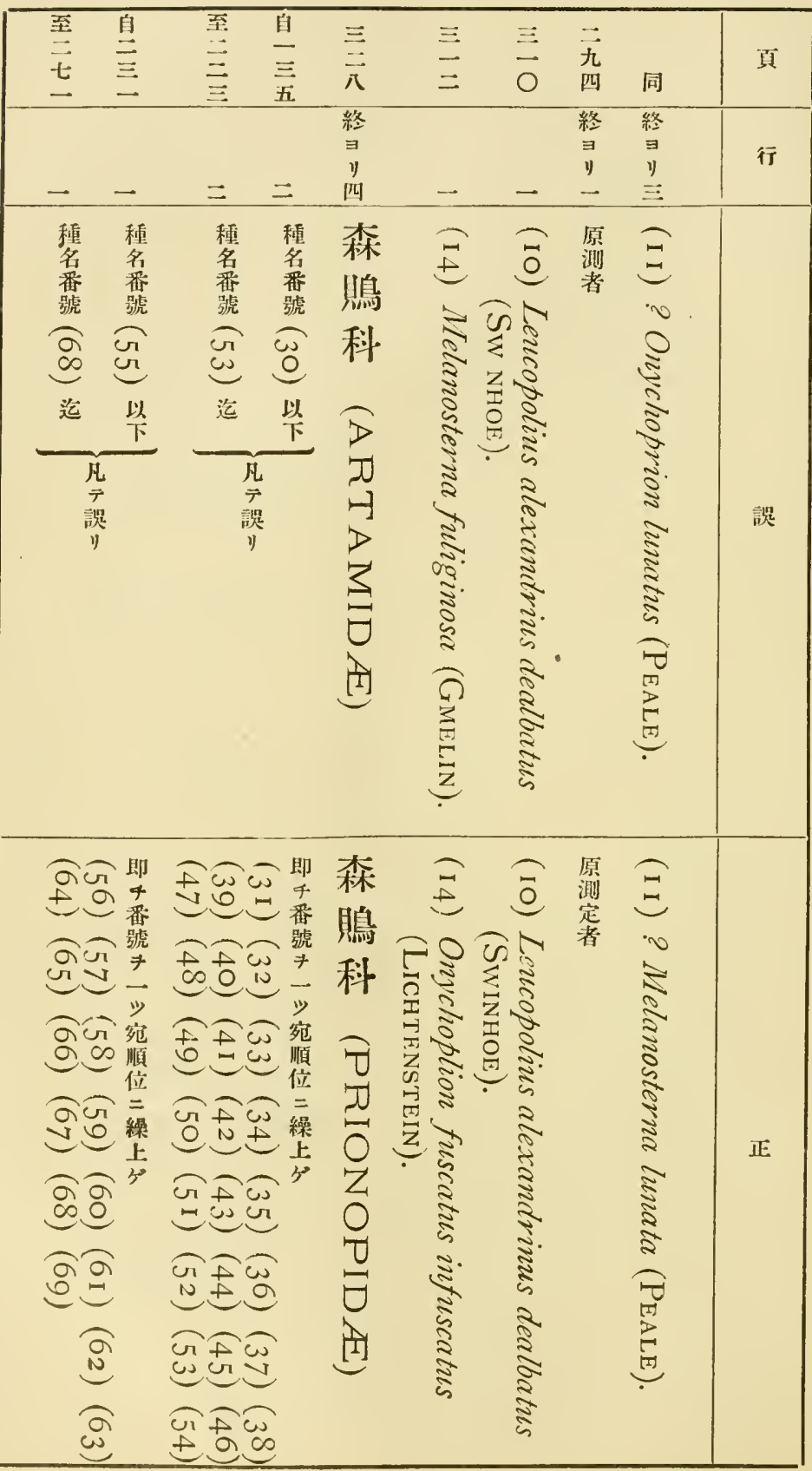





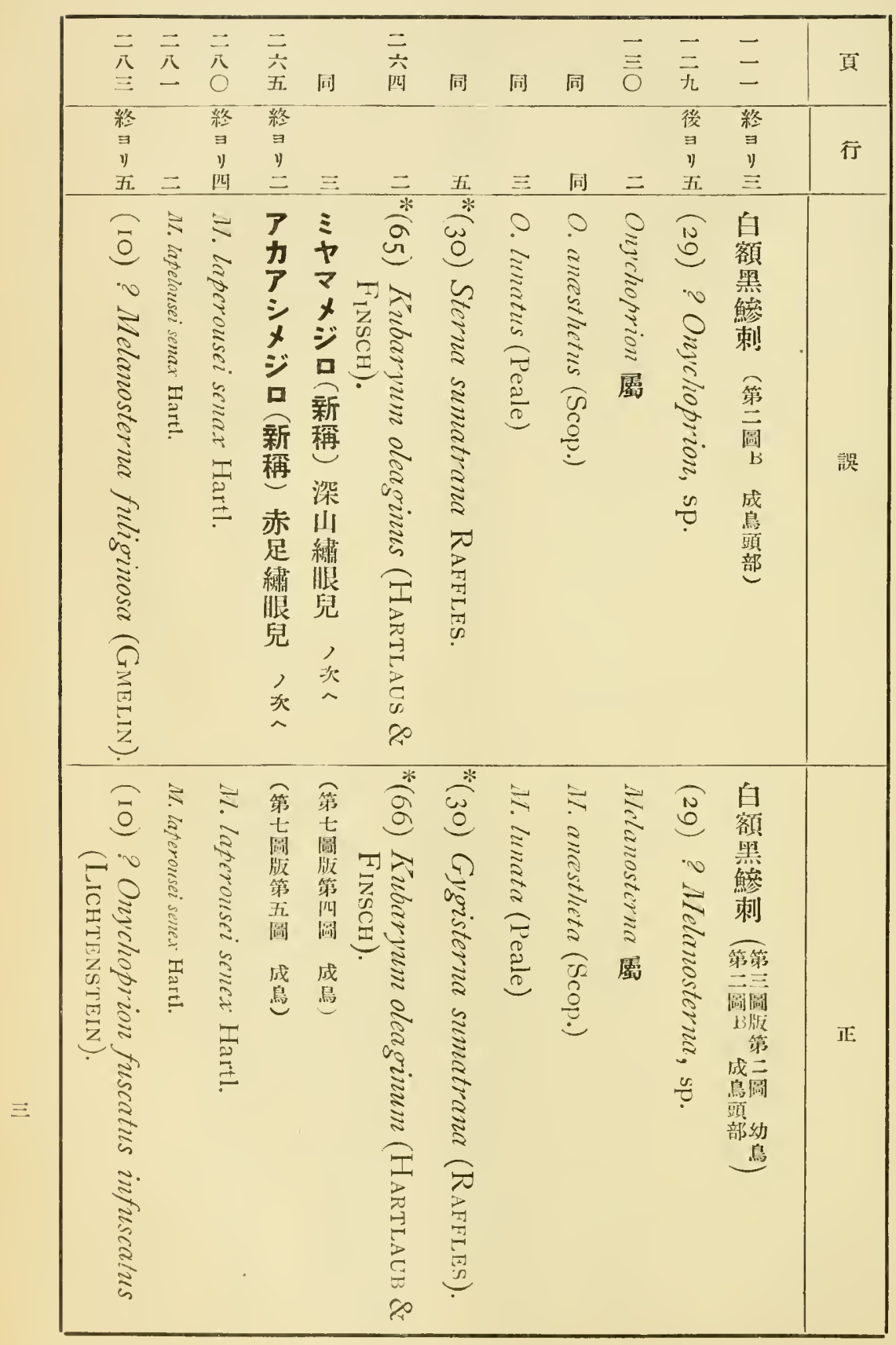





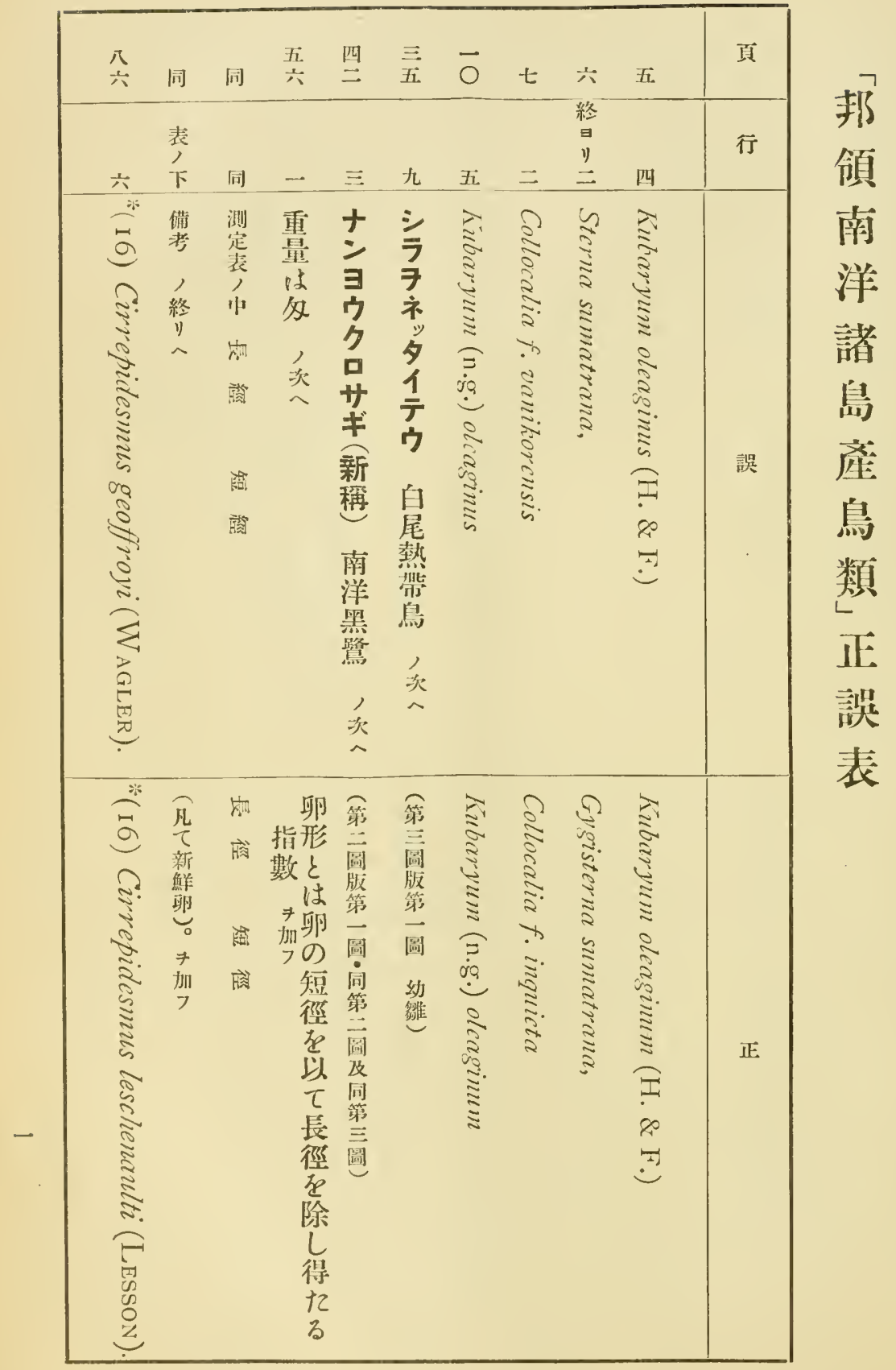




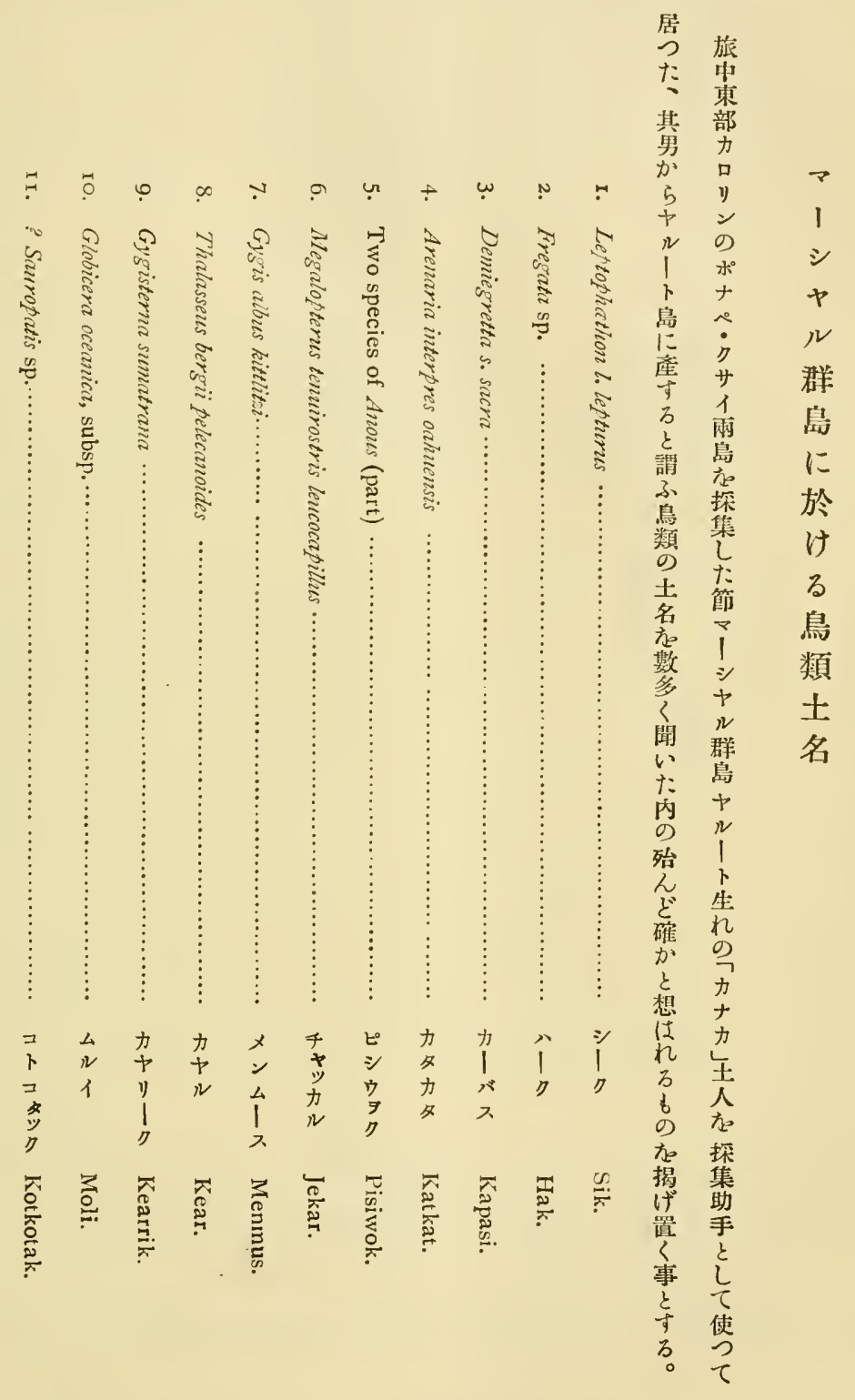




\begin{tabular}{|c|c|c|c|c|c|c|c|c|c|c|c|c|c|c|}
\hline ت્ّ & $\overrightarrow{\mathrm{c}}$ & $\vec{g}$ & & 点 & 空 & 氛 & 葸 & 萤 & 焉 & 虫 & $\equiv$ & $\overrightarrow{\mathrm{\theta}}$ & $\overrightarrow{.0}$ & \\
\hline$\therefore$ & $\div \equiv$ & $y$ & $m$ & ¿ & 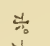 & $\vec{v}$ & * & 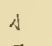 & 4 & w & $*$ & $\exists$ & ji & \multirow{10}{*}{ th } \\
\hline vi & జّ & y & $\overline{4}$ & 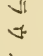 & $\%$ & $\begin{array}{l}y \\
\cdots \\
11\end{array}$ & $\stackrel{x}{x}$ & $\bar{y}$ & 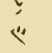 & $\stackrel{3}{3}$ & $e^{x}$ & 4 & 5 & \\
\hline ग & $\div$ & ए" & $\begin{array}{l}x \\
x\end{array}$ & $\begin{array}{c}x \\
x\end{array}$ & $x$ & $\stackrel{x}{u}$ & $\square$ & $x^{4}$ & $\ddot{x}$ & 4 & $\square$ & r & :" & \\
\hline$\rightarrow$ & $\rightarrow \quad 4$ & & 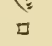 & 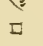 & $\square$ & 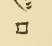 & « & 走 & 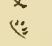 & t & $\vdots$ & $\leftleftarrows$ & $x$ & \\
\hline 4 & $山$ & $\square$ & & & & . & $\square$ & घ & I & $x$ & . & $\ddot{v}$ & $\pi$ & \\
\hline पi & पi ẏi & $\vdots$ & $\vdots$ & : & $\vdots$ & $\vdots$ & $\vdots$ & $\vdots$ & $\vdots$ & a & $\vdots$ & $\pi$ & 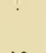 & \\
\hline 7 & $\approx$ & $\vdots$ & $\vdots$ & $\vdots$ & $\vdots$ & $\vdots$ & $\vdots$ & $\vdots$ & $\vdots$ & 点 & $\vdots$ & $\vdots$ & 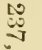 & \\
\hline$\vdots$ & $\vdots$ & $<=$ & & $\vdots$ & $\vdots$ & $\vdots$ & $\vdots$ & $\vdots$ & 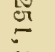 & 空 & 赵 & $\vdots$ & 总 & \\
\hline ה & 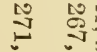 & 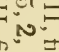 & & 幽 & $\stackrel{\mathscr{I}}{9}$ & $\stackrel{10}{\circ}$ & 焉 & 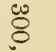 & 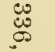 & in & 㐘 & $\vdots$ & 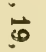 & \\
\hline ब్ల & $\bar{\Phi} \widehat{\Phi}^{0}$ & w. & & ज्ञ & ज् & ב্ & ब్ & త్త & ज & $\bar{d}$ & ज्ञ & 可 & 可 & \\
\hline$\vdots$ & $\vdots$ & $\vdots$ & $\vdots$ & $\vdots$ & $\vdots$ & $\vdots$ & $\vdots$ & $\vdots$ & $\vdots$ & $\vdots$ & $\vdots$ & $\vdots$ & $\vdots$ & $\begin{array}{l}\text { Ca roline } \\
\text { Islands }\end{array}$ \\
\hline$\vdots$ & : & $\vdots$ & $\vdots$ & $\vdots$ & $\vdots$ & $\vdots$ & $\vdots$ & $\vdots$ & $\vdots$ & $\vdots$ & $\vdots$ & $\vdots$ & $\vdots$ & Ngoli \\
\hline$\vdots$ & $\vdots \quad ※$ & $\vdots$ & 0 & $\vdots$ & $\vdots$ & $\vdots$ & 0 & $\vdots$ & $\vdots$ & $\vdots$ & $\vdots$ & $\vdots$ & $\vdots$ & Yap \\
\hline$\vdots$ & $\vdots$ & $\vdots$ & $x$ & $\vdots$ & $\vdots$ & $\vdots$ & $x$ & $\vdots$ & $\vdots$ & $\vdots$ & $\vdots$ & $\vdots$ & $\vdots$ & Mackenzie \\
\hline$\vdots$ & $\vdots$ & $\vdots$ & & $\vdots$ & $\vdots$ & $\vdots$ & & $\vdots$ & $\vdots$ & $\vdots$ & $\vdots$ & $\vdots$ & $\vdots$ & $\begin{array}{l}\text { Wolea } \\
\text { (Ulie) }\end{array}$ \\
\hline$\vdots$ & 0 & 0 & & $\vdots$ & $\vdots$ & $\vdots$ & & $\vdots$ & 0 & $\vdots$ & $\vdots$ & $\vdots$ & $\vdots$ & Truk (Ruk) \\
\hline$\vdots$ & $\vdots$ & & & $\vdots$ & $\vdots$ & $\vdots$ & & $\vdots$ & & $\vdots$ & $\vdots$ & $\vdots$ & $\vdots$ & Luganor \\
\hline$\vdots$ & $\vdots$ & & & $\vdots$ & $\vdots$ & $\vdots$ & & $\vdots$ & & $\vdots$ & $\vdots$ & $\vdots$ & $\vdots$ & Nukuor \\
\hline$\vdots$ & 0 & & & $\vdots$ & 0 & $\vdots$ & & $\vdots$ & & 0 & $\vdots$ & $\vdots$ & $\vdots$ & Ponapé \\
\hline$\vdots$ & 4 & & & $\vdots$ & & 0 & & $\vdots$ & & & $\vdots$ & $\vdots$ & $\vdots$ & $\begin{array}{l}\text { Kusaie } \\
\text { (Walan) }\end{array}$ \\
\hline$x$ & & & & $*$ & & & & $\vdots$ & & & 0 & $\vdots$ & * & $\begin{array}{l}\text { Pelew } \\
\text { Islands }\end{array}$ \\
\hline & & & & & & & & $\vdots$ & & & $\vdots$ & $\vdots$ & & Marıana \\
\hline & & & & & & & & $\vdots$ & & & $\vdots$ & $\vdots$ & & Islands \\
\hline & & & & & & & & 0 & & & $\vdots$ & $x$ & & Saipan \\
\hline & & & & & & & & 0 & & & $\underset{v}{x}$ & & & Rota \\
\hline & & & & & & & & $x$ & & & & & & Guam \\
\hline & & & & & & & & & & & & & & $\begin{array}{l}\text { Marshall } \\
\text { Islands }\end{array}$ \\
\hline
\end{tabular}




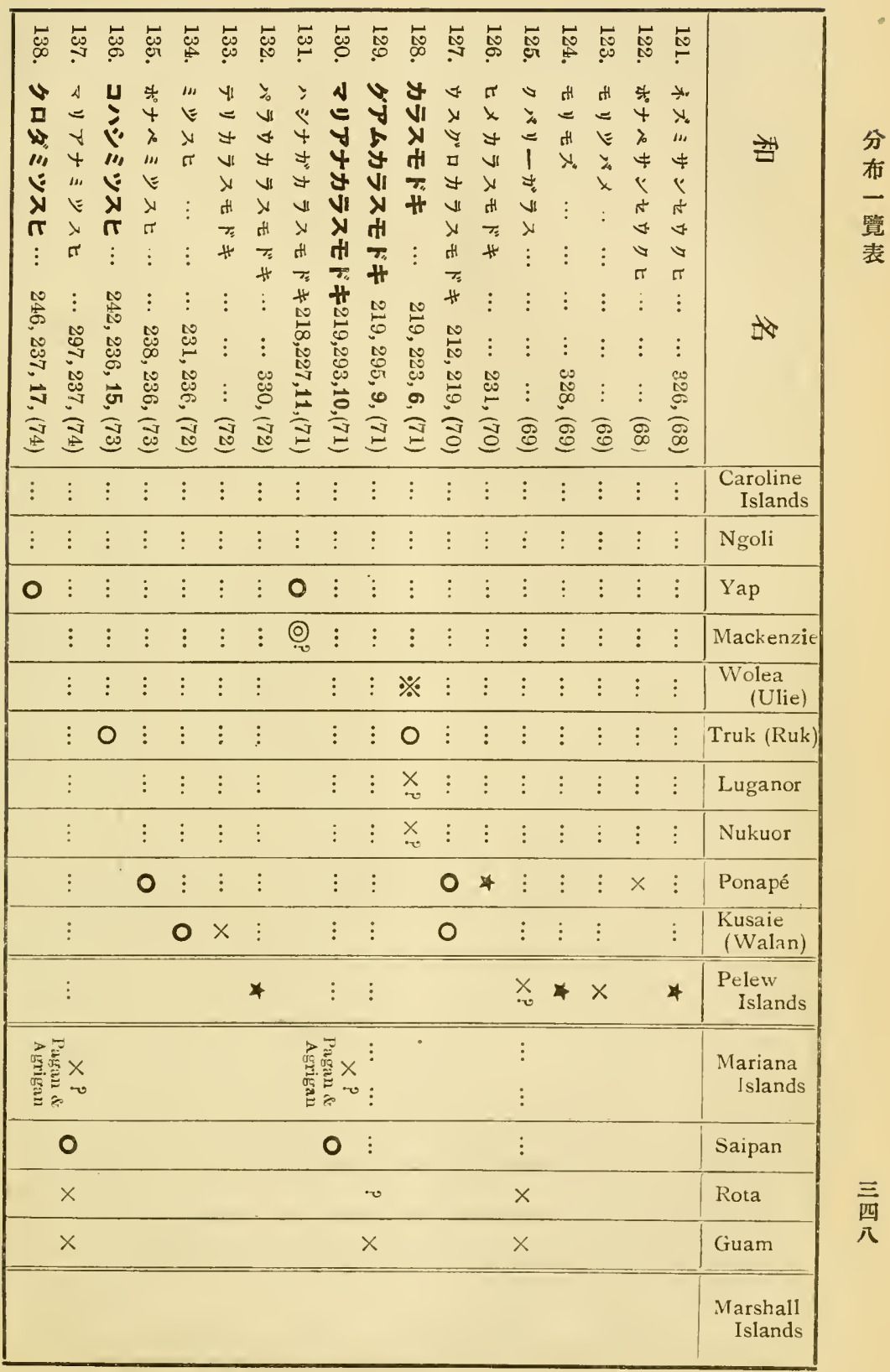




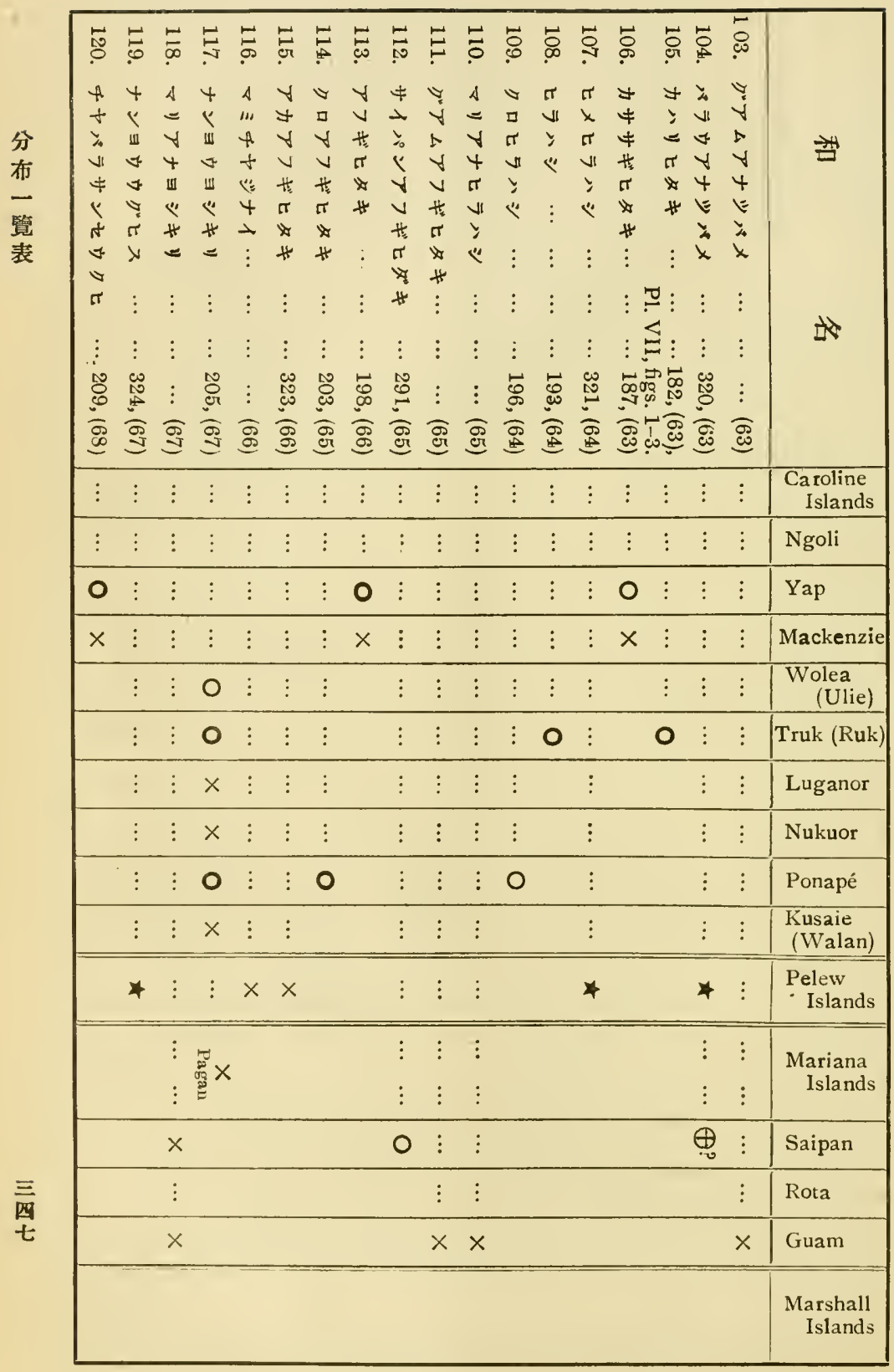




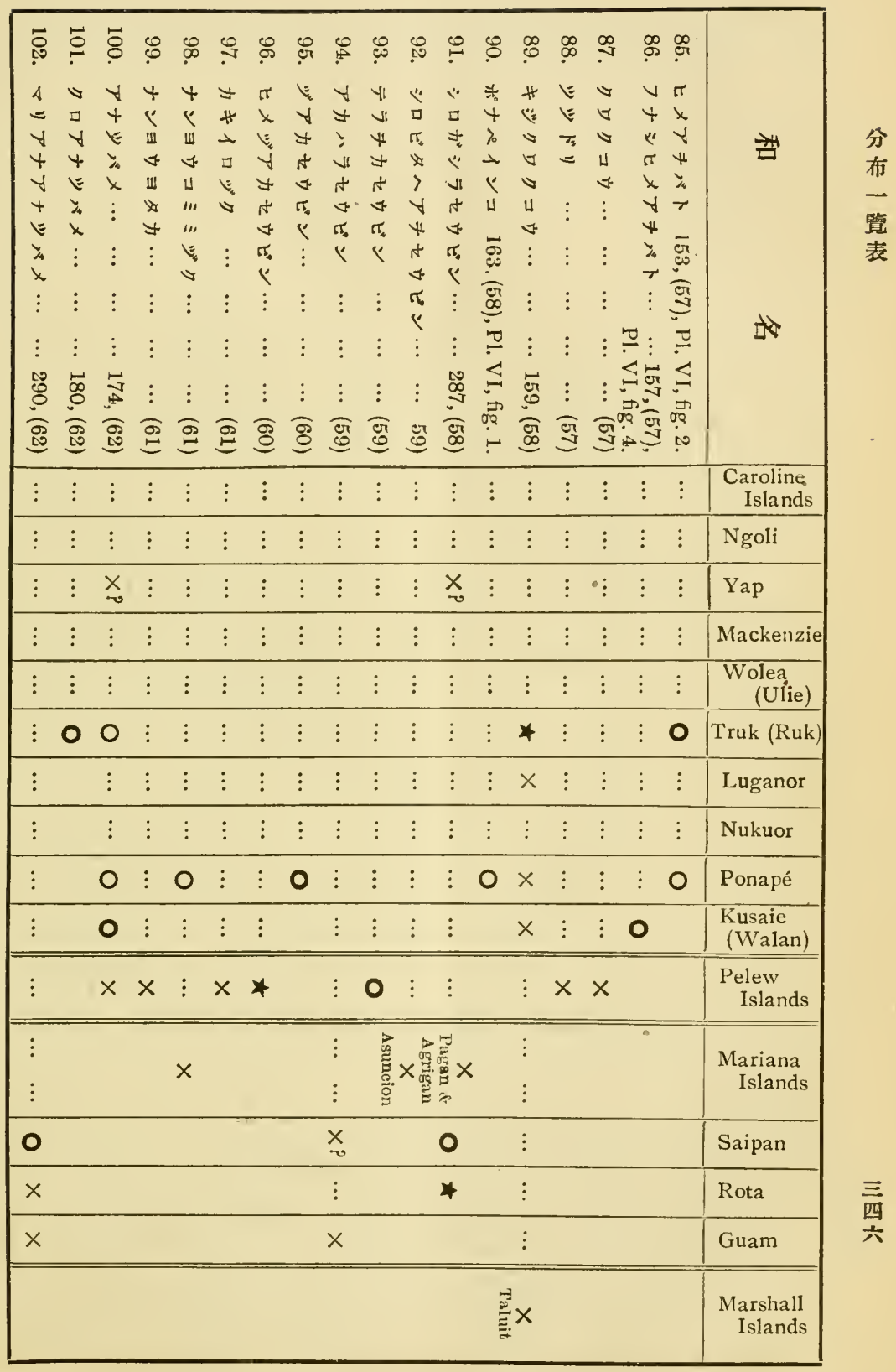




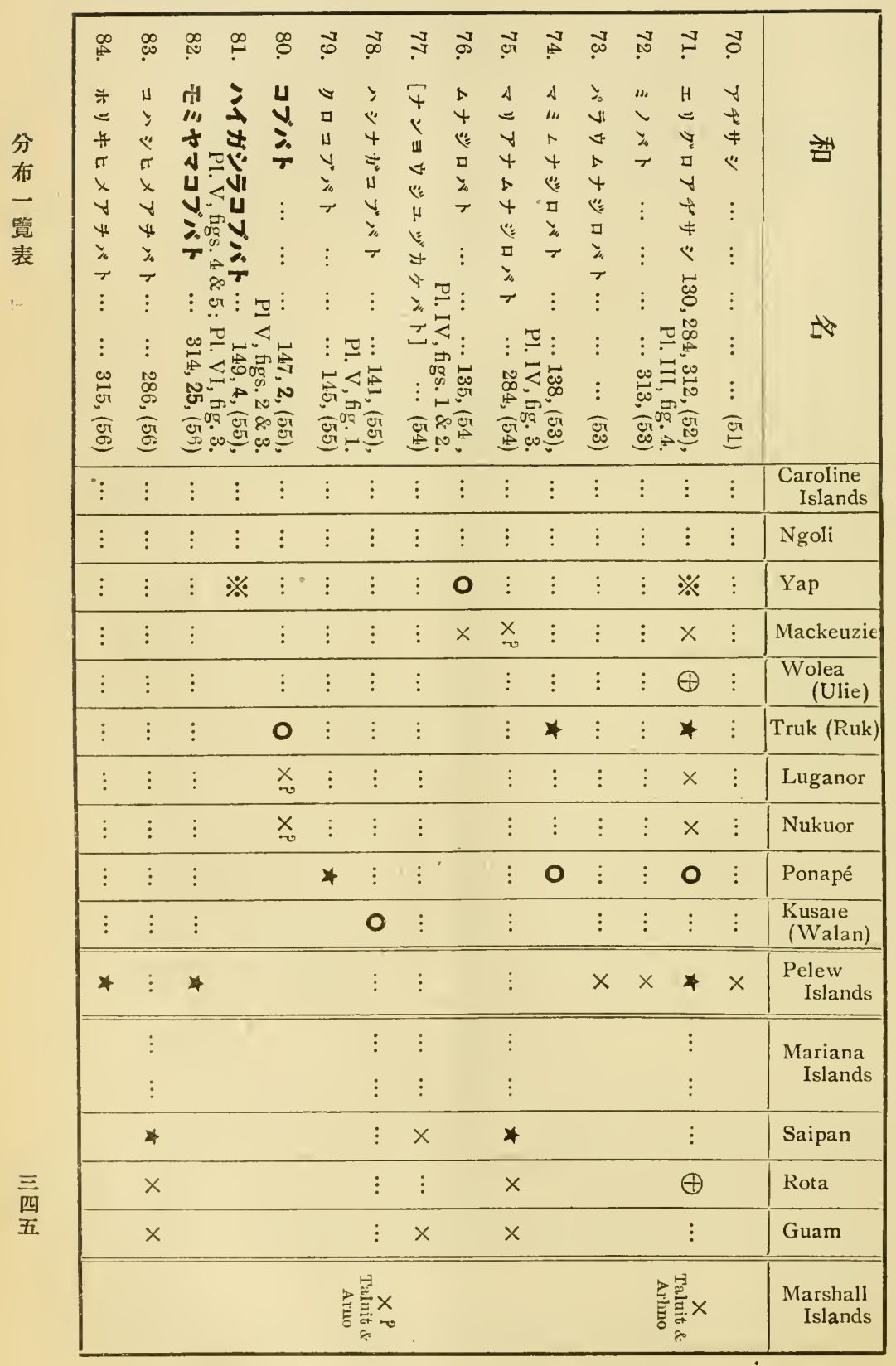




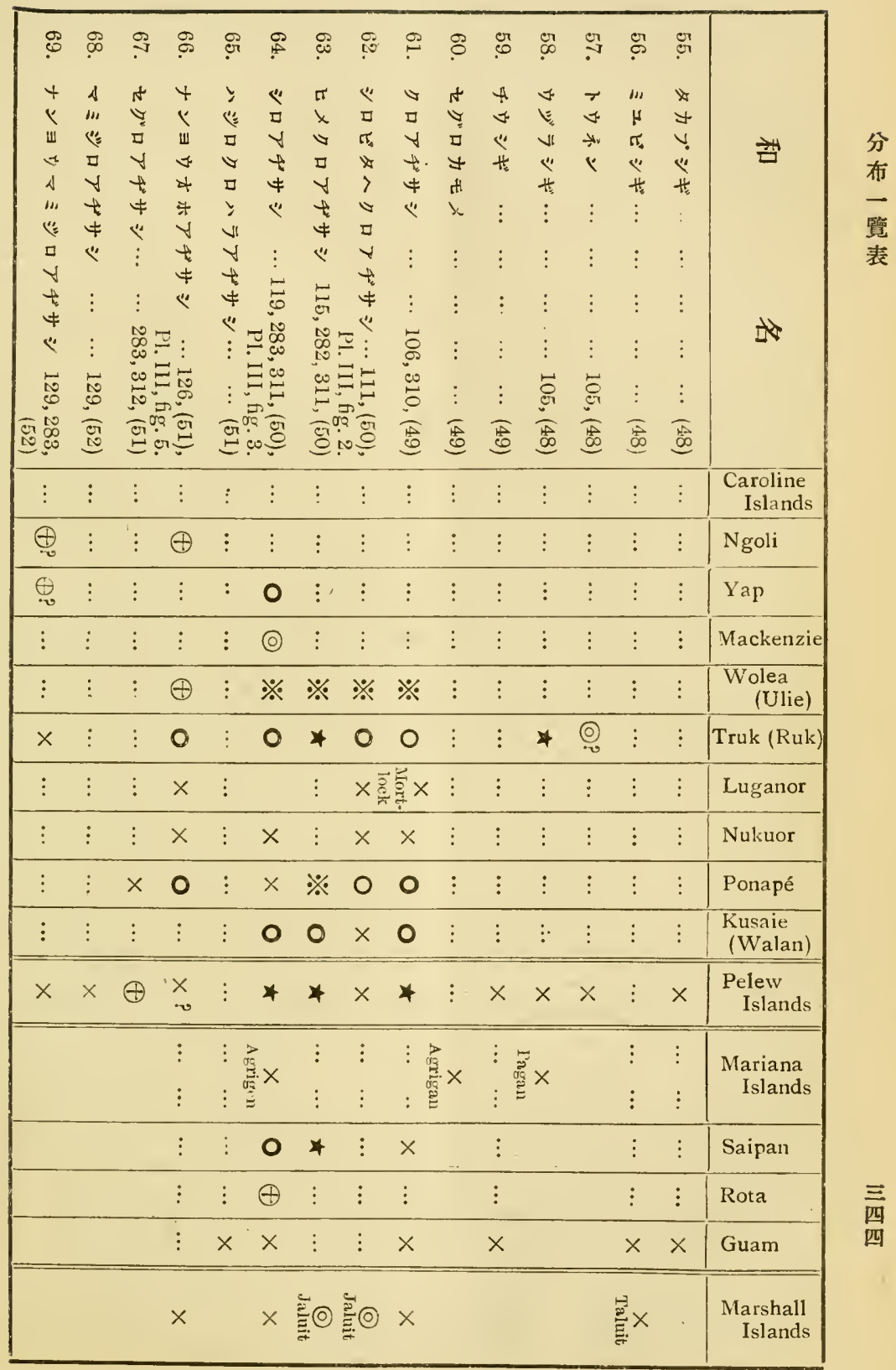




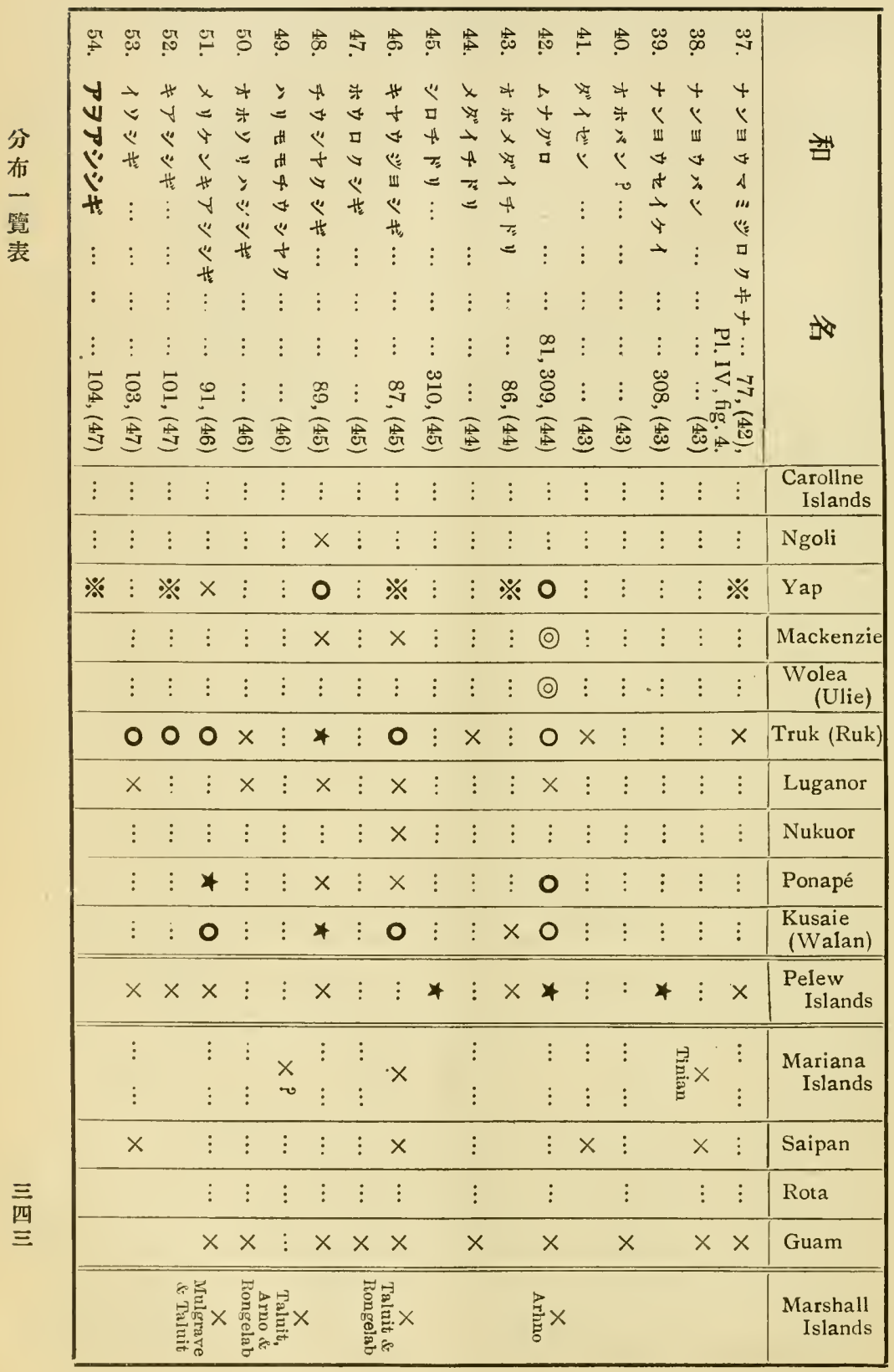




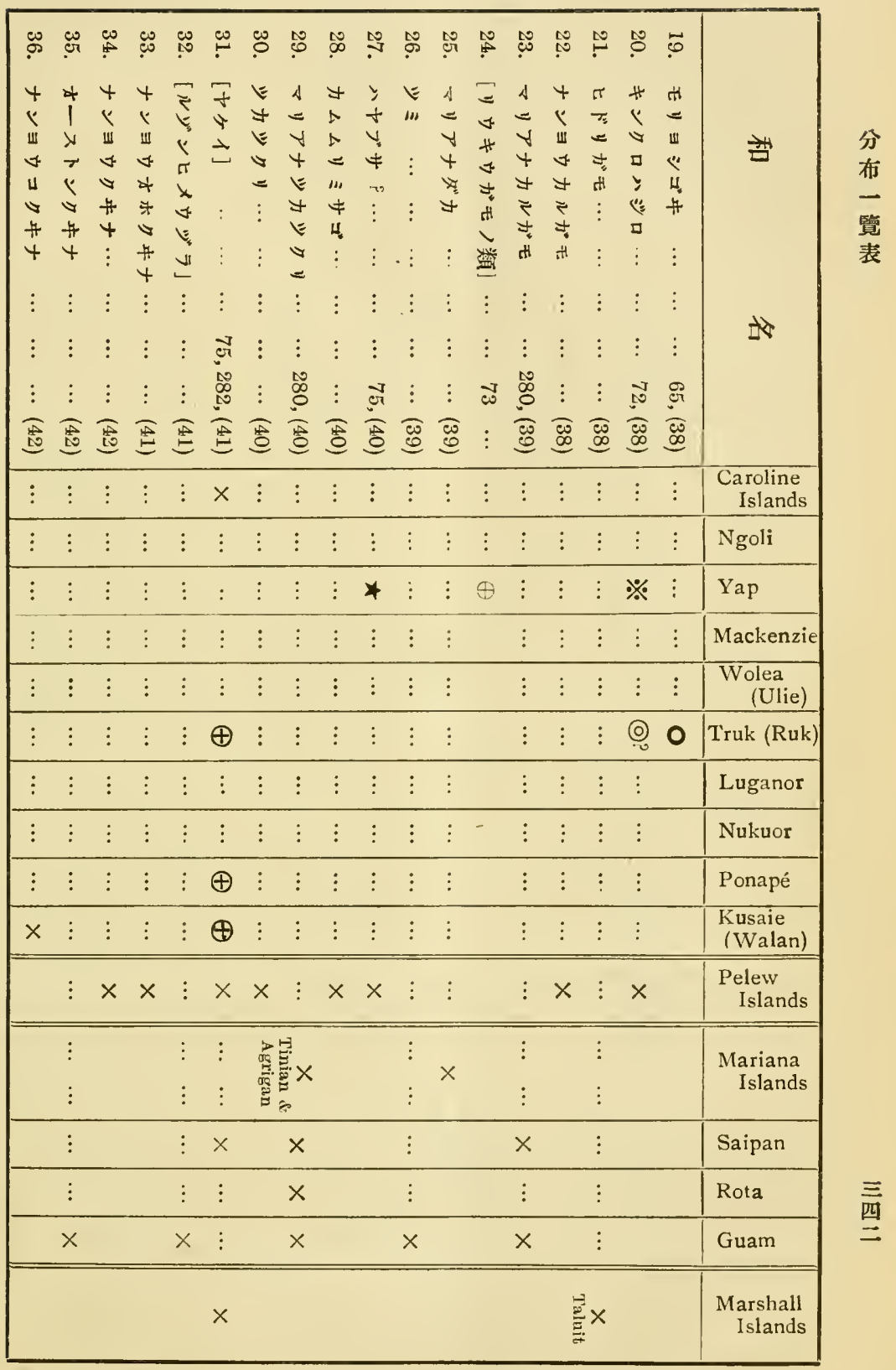




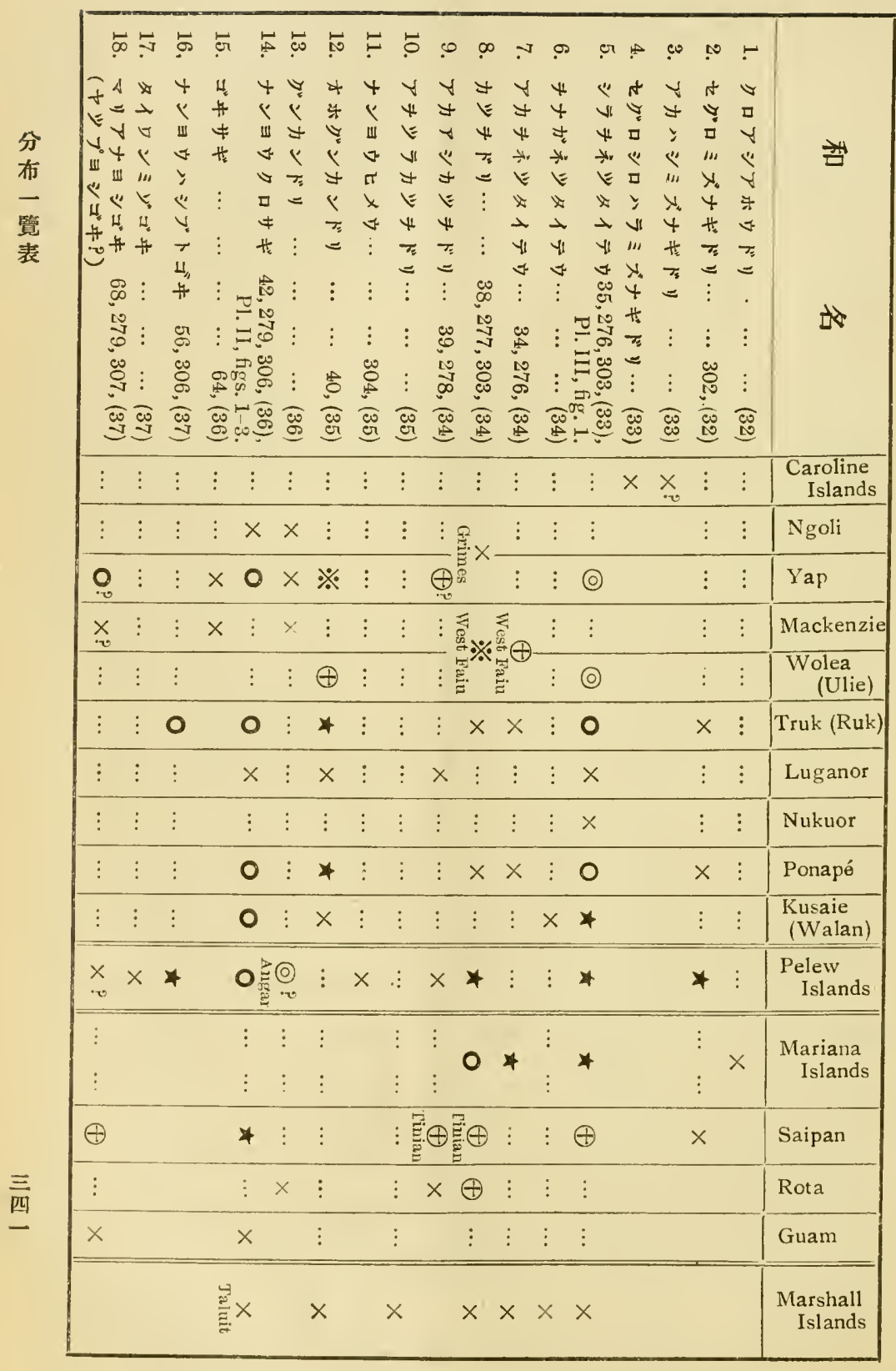


止の 稱

めみ分

たは角布

り主ひ地るはははは

动亦る從從從從

しる○事來來楸來分

てはこ市探探探探布

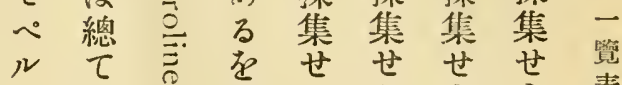

リに

主產泀回れれれれ

部夺离初しししし

をる的め報 報 報

意も音て 告告告告

味のき聞ななな あ

しに异知きききり

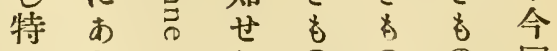

にらなしののの回

フすまににた

ガ

ウ 明。

ル磪

島なた

のる

み分

に布它

見地采

今合今集

る・不方

(5) 明 $\overrightarrow{0}$

の の

は若

回回回守

の

極たは

あ \

$\tau>$

劣但 总

专初初

亦めめ事

觀ててを

察 觀 探 得

站察集

びせせる

にるるる

探学處の

註 訅泀

集探 0

集

る夺の

あ る

け事

は あ

ざけ

り は

しざ

\& b

分 ᄂ

置永な 布

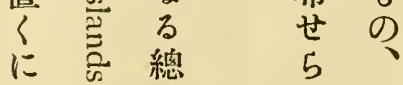




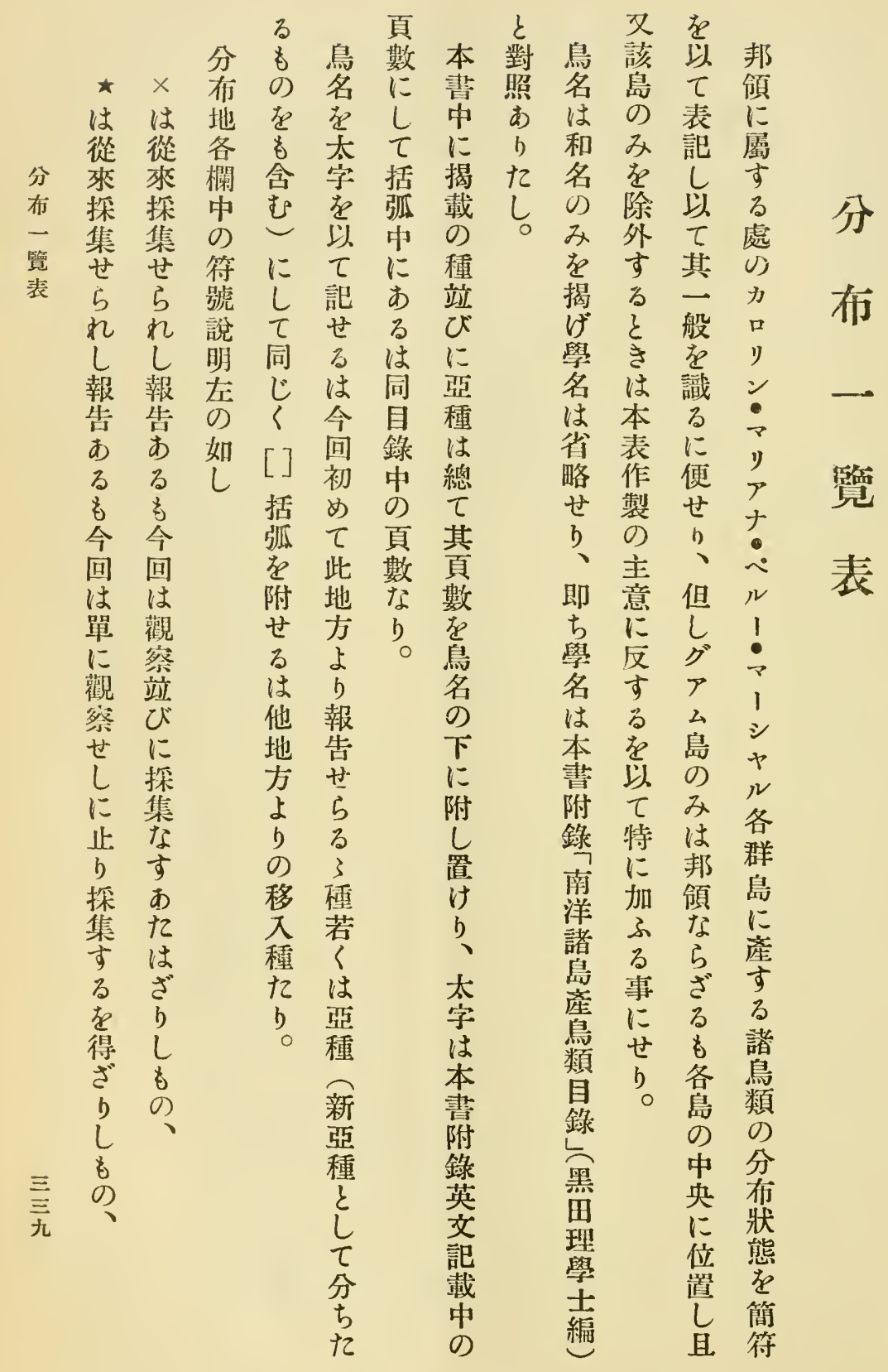




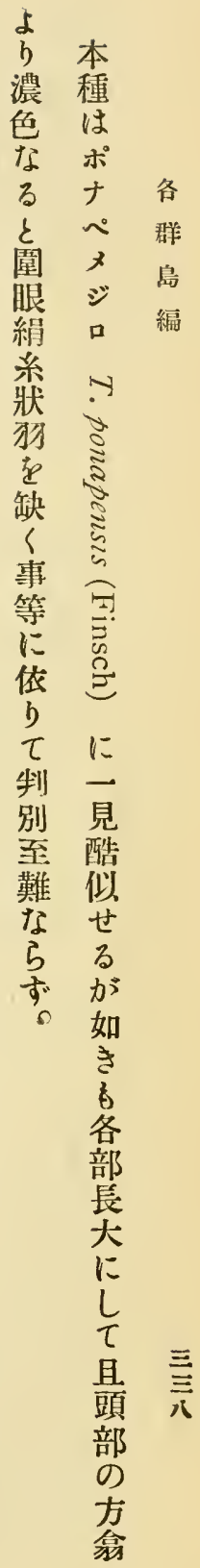




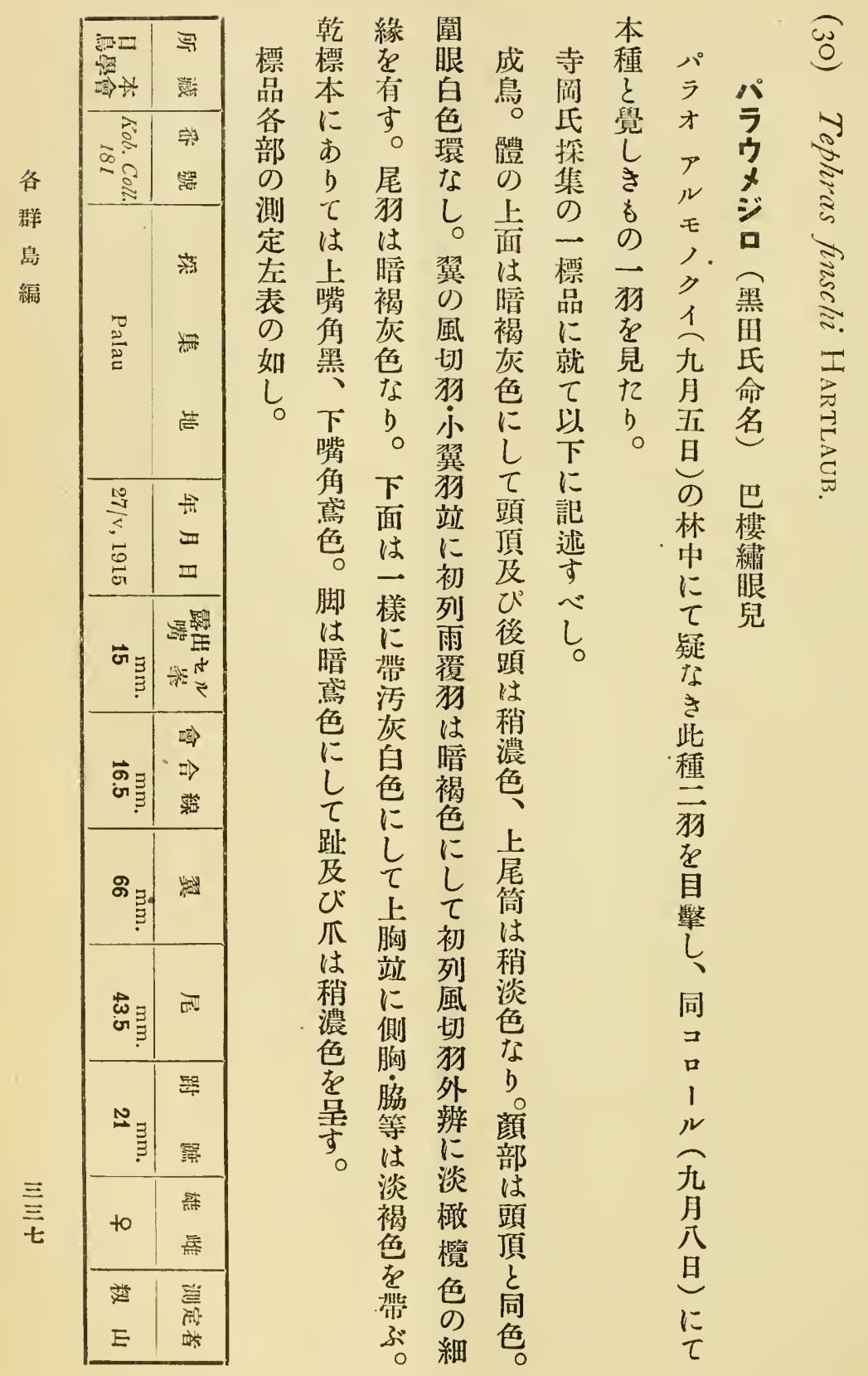




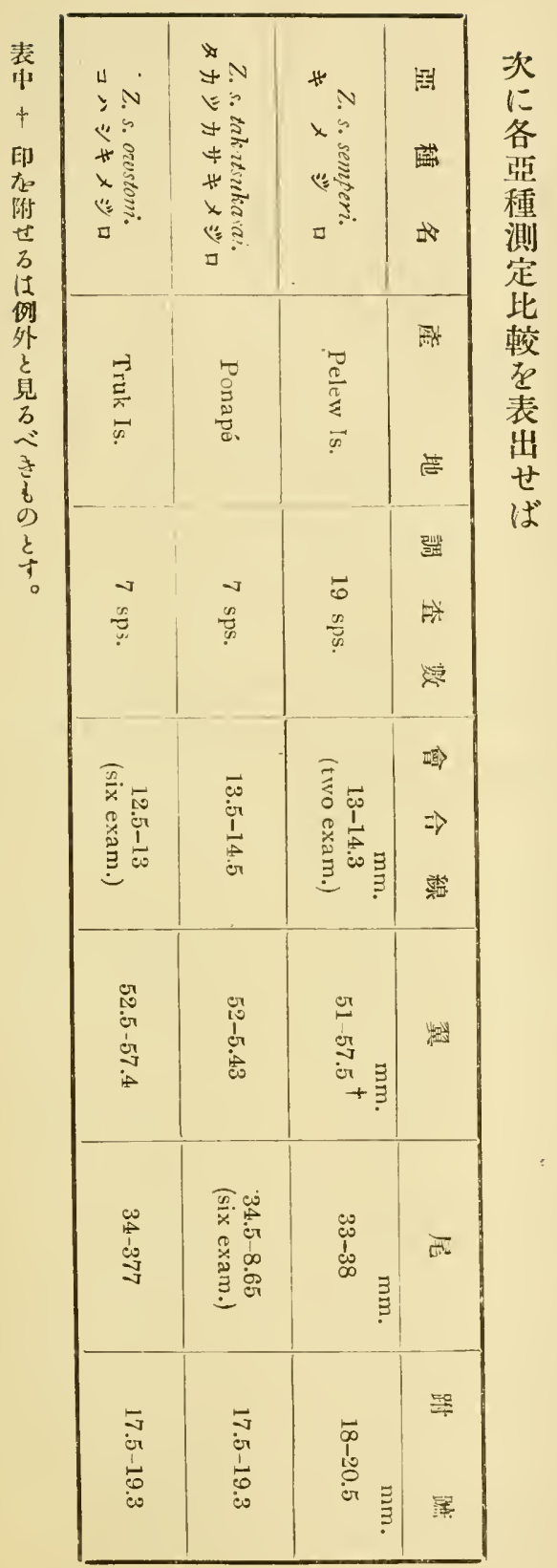

(2)

各通尠合

るらは

小す一粍に群

湢 五 三丨濃島

線西粍息色編

は市る に

黑黑要跗

鼠粍翼跡稍

色粍長文明

表體大嘴 睹

呈下に稫

し 面し短 b

明は交な不

瞅淡五 五 均

り黄饿卡

ト色以ナ墲

ラ 眼上鳥大

多前に澾 齐

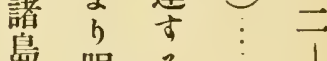

㧥眼る

$i_{N a} に \sigma \overbrace{N s}^{\vdots}$

次的力

シ ま

है 永力

อิ

ジ

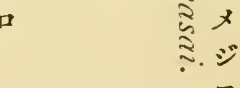

产

吾 吾 


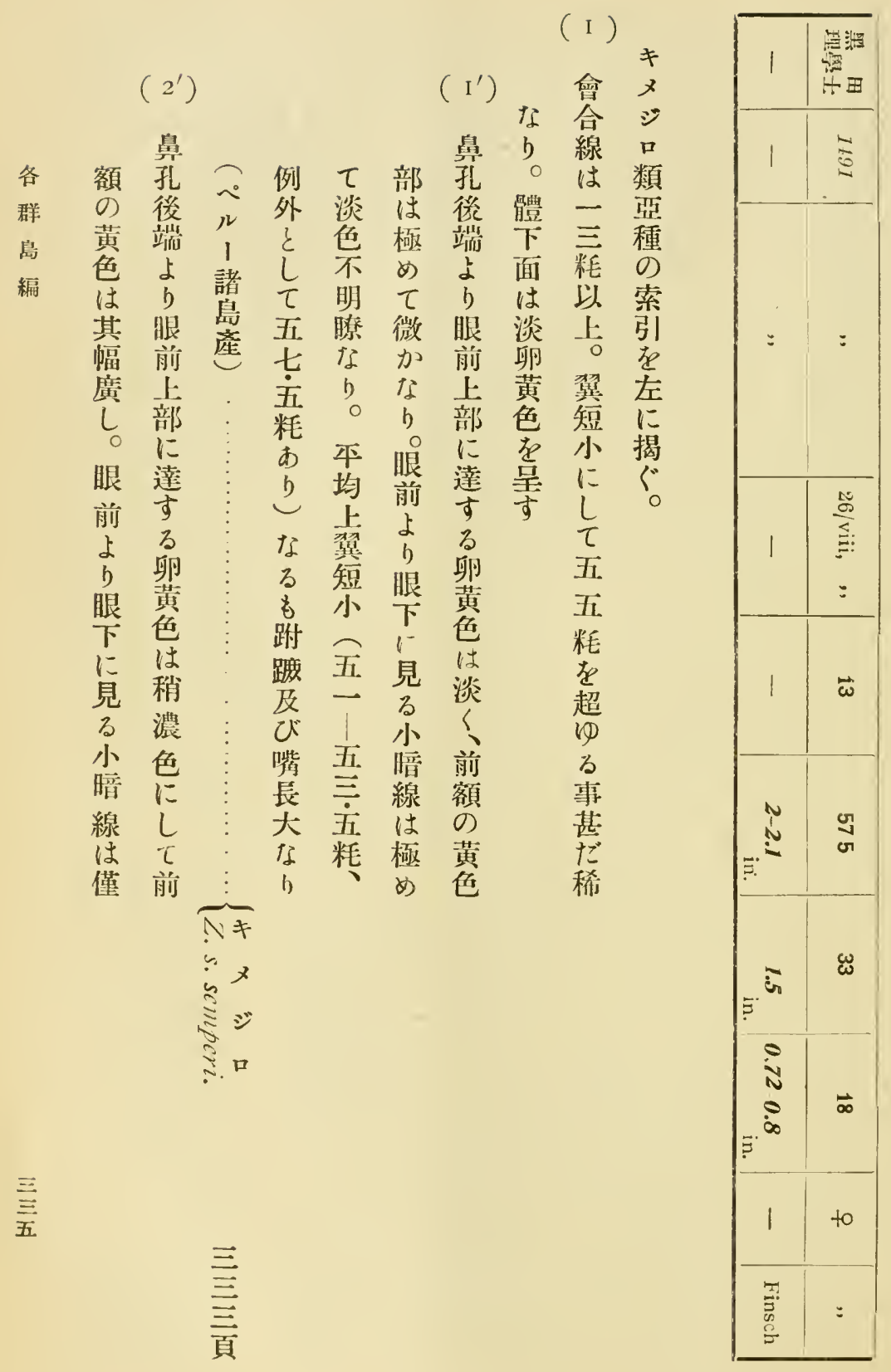




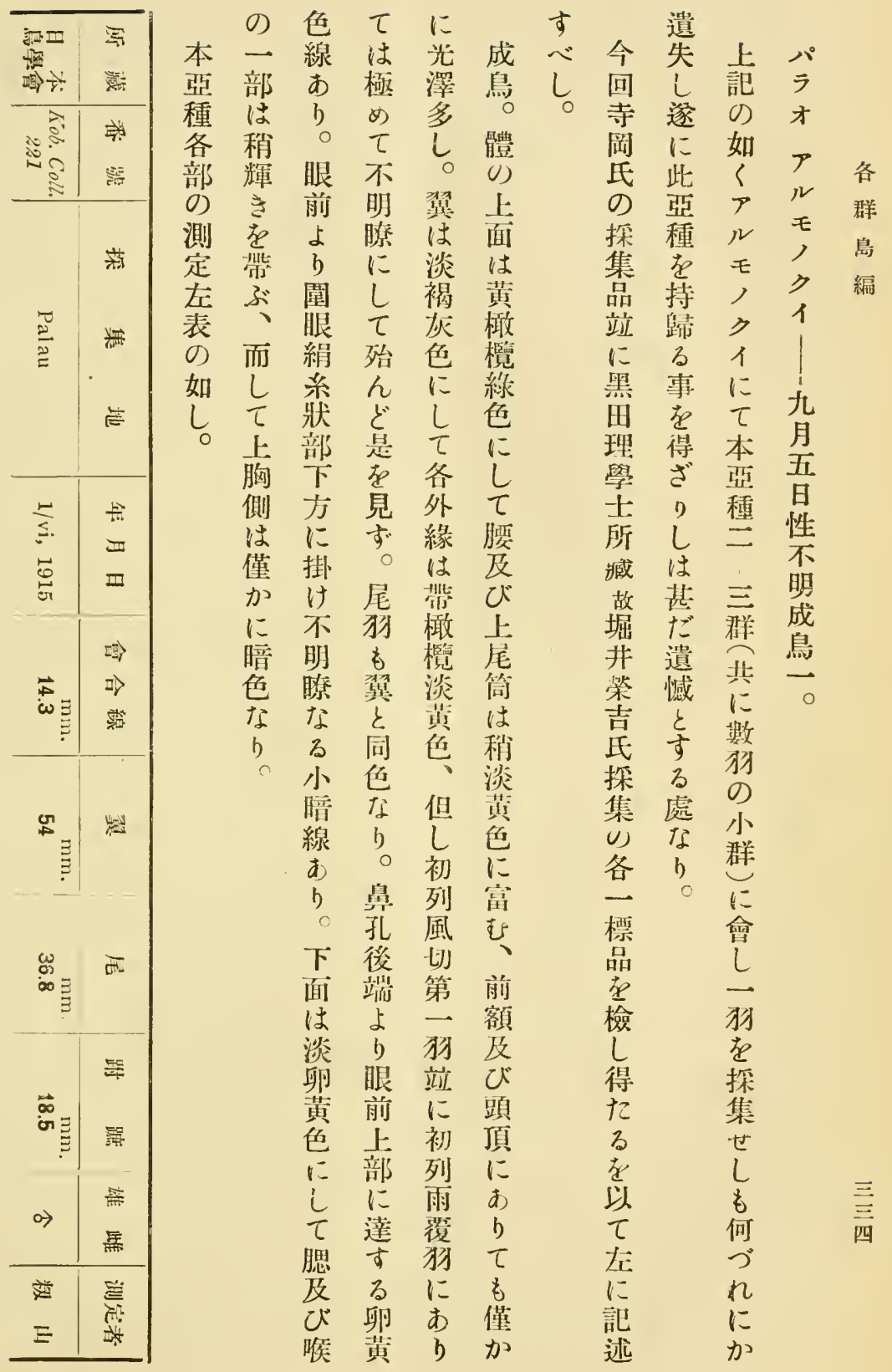




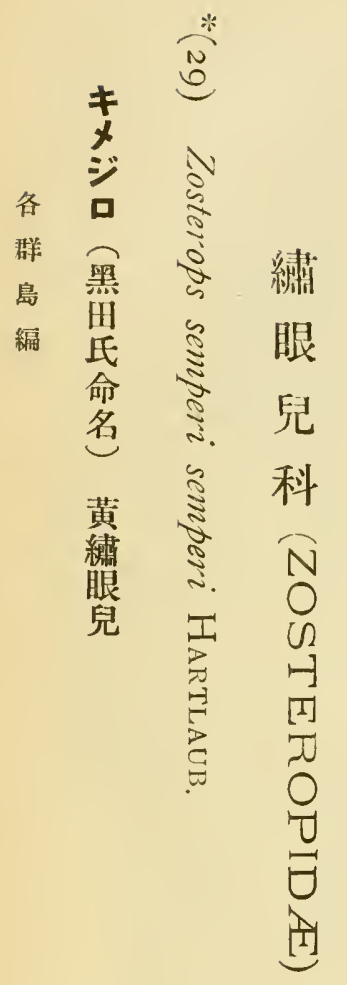

野にべざぎささ雀

外暗さるざパれの本 觀色方るラた雄新 瑤をの症がオる成亞 時呈て あ如 乞 小鳥種 のせるるく林に基 經るべは余、烒し型 驗もし確ははの主の標 にの實該部梁目本 し了因な岛部葸下灾 七如因る 滯總な本大 未くにが在稃る 會正

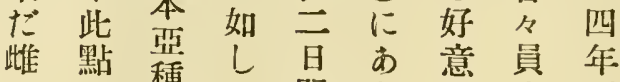

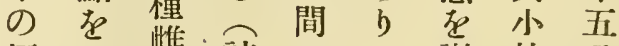

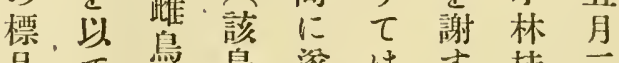
品元点島は遂は桂三

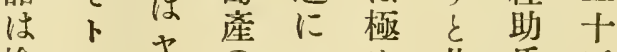
檢亏中心 しップ標影てにの旦

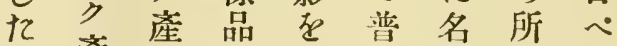
る産名敌基藏ル 事口見見に学中、 なシダざざ屬篇に譪

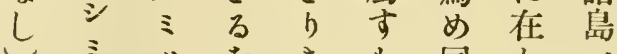

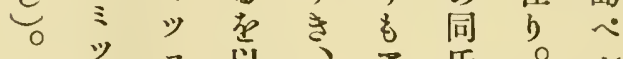

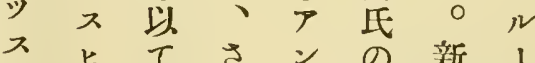
の 新 1

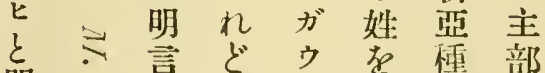
明 探 9 の にし 島島 $b$ 調 何

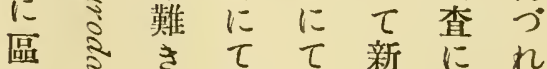

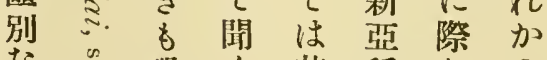
な恐々甚種しの

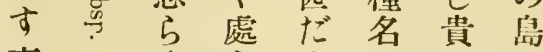

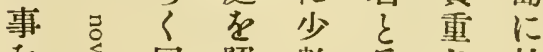
在同照数篇店於

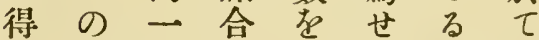
心夫留世宸り標寺 しれ種ばす。品阙 の $\varepsilon$ 多存直 但如認加长袋民

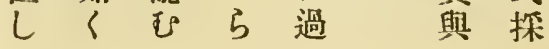




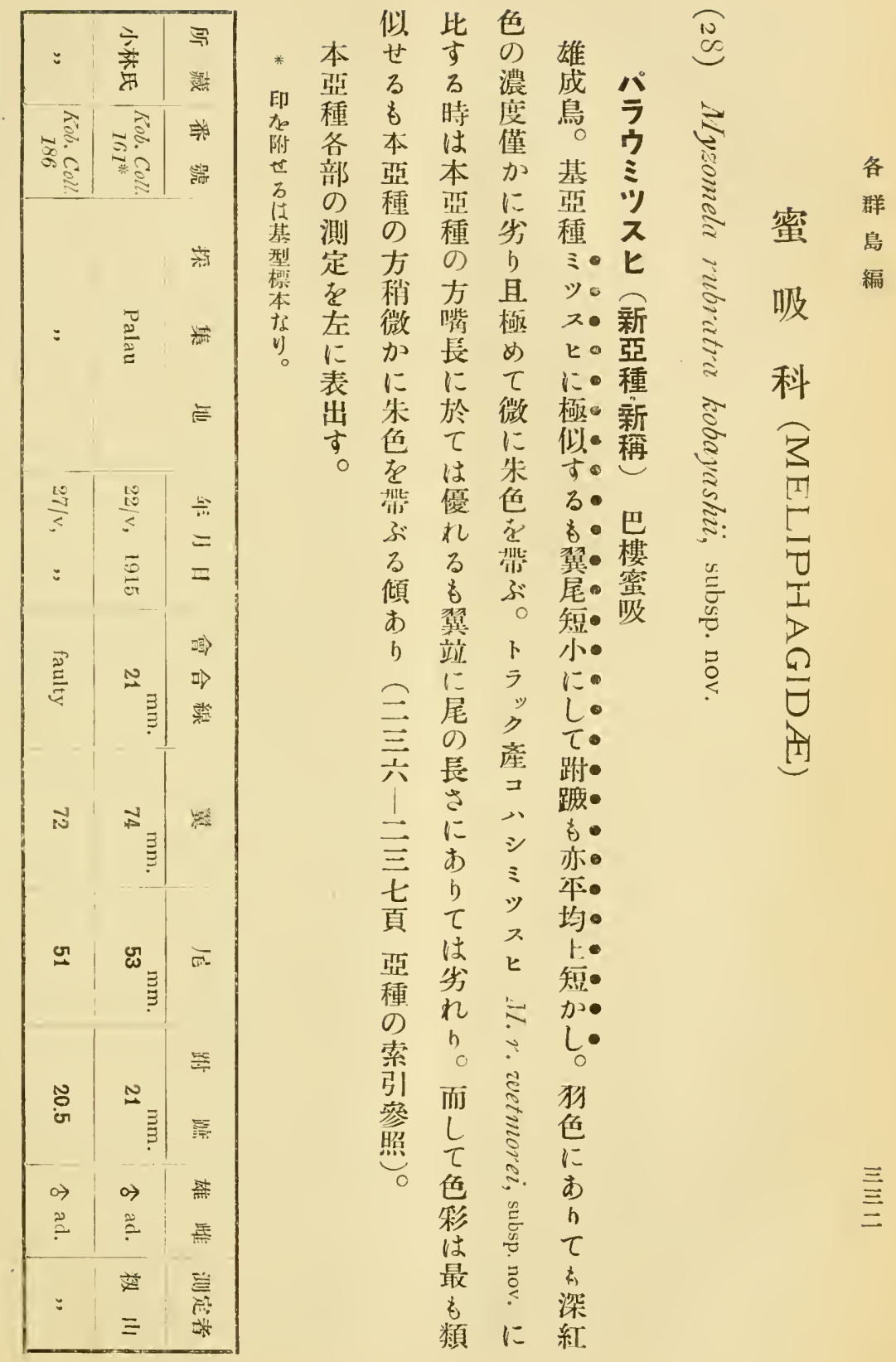




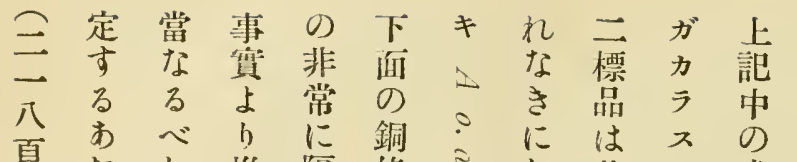

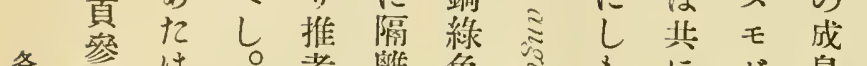
鳥。、併 編

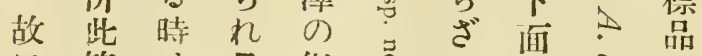

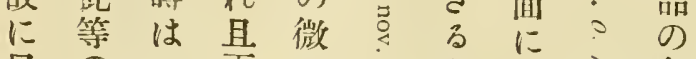

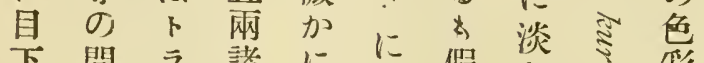
下問亏諸に殆假色染稀 の題”島劣殆に色縱ミ、

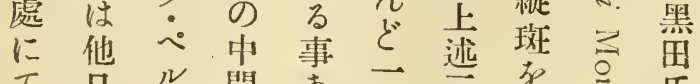

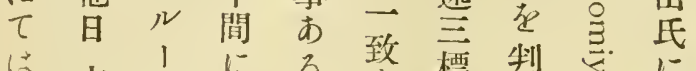

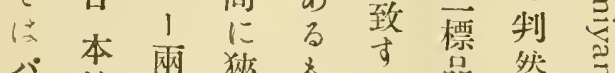

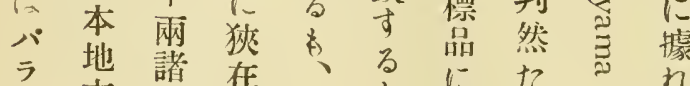

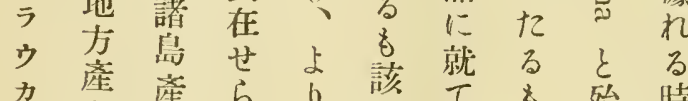

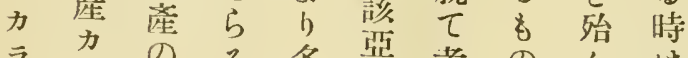
ララのる多鳔考のんは

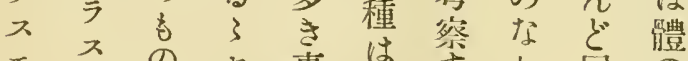

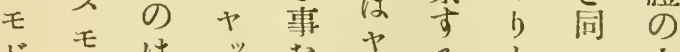

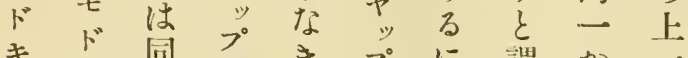
キキ同島きプに謂加下 る 類亞に焦测方若面 假栖種別じ定少は銅

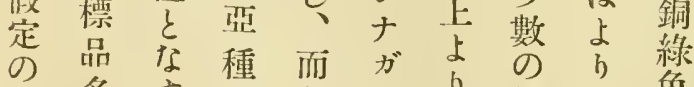
一多市公し力見慓强色 留整方

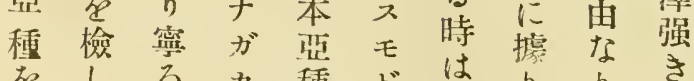

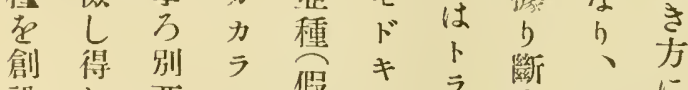

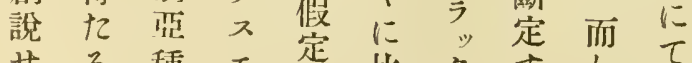

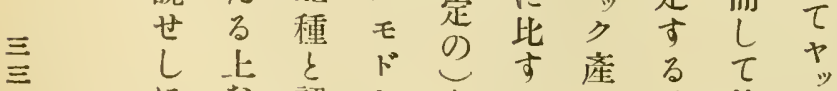
にな認キとる劣他プ 此 5 む存は時亏绝の産 めでる産分はス險幼 羁生方吉布體モの期 く確至る地上ド虞の子

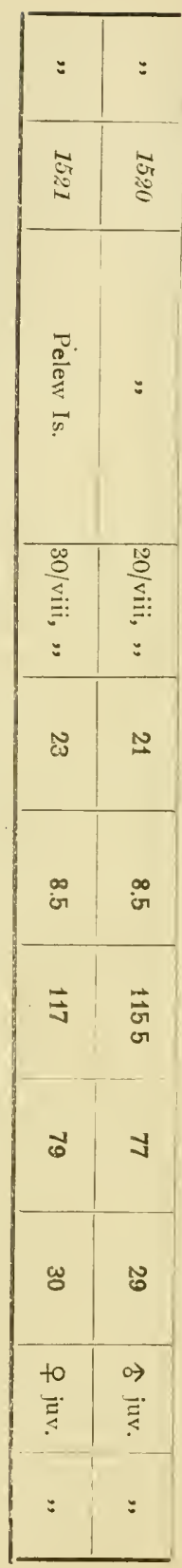




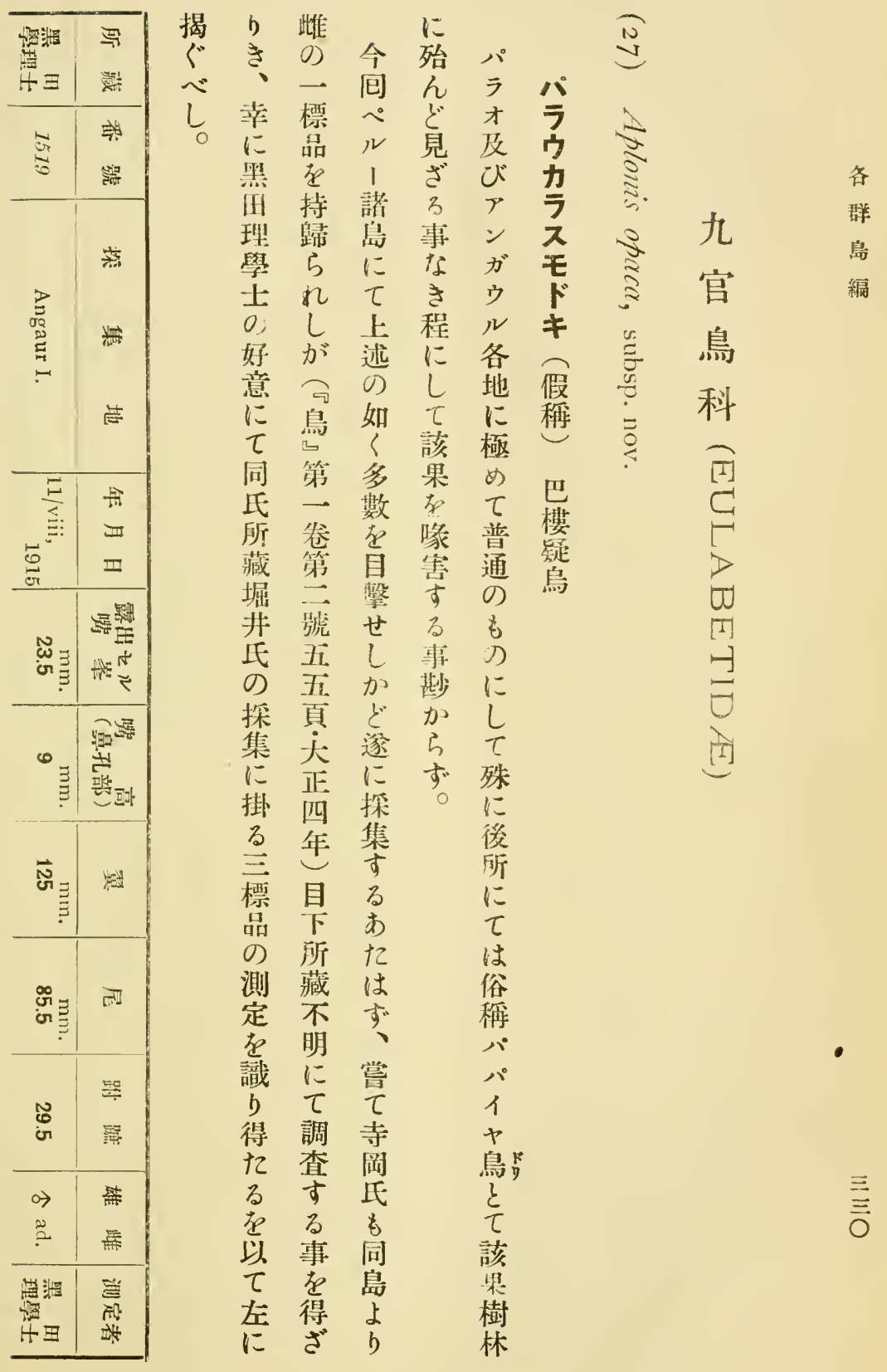




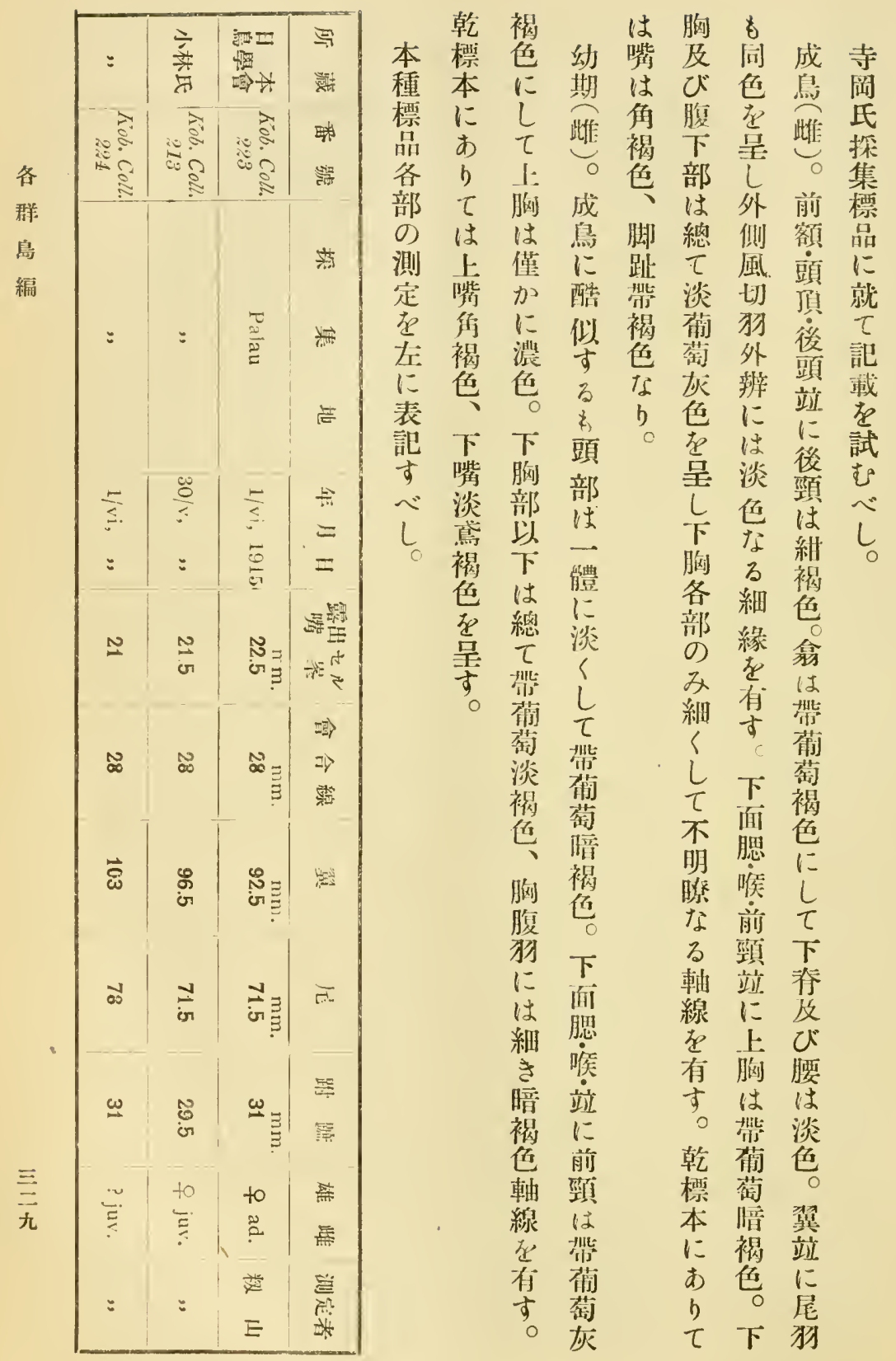




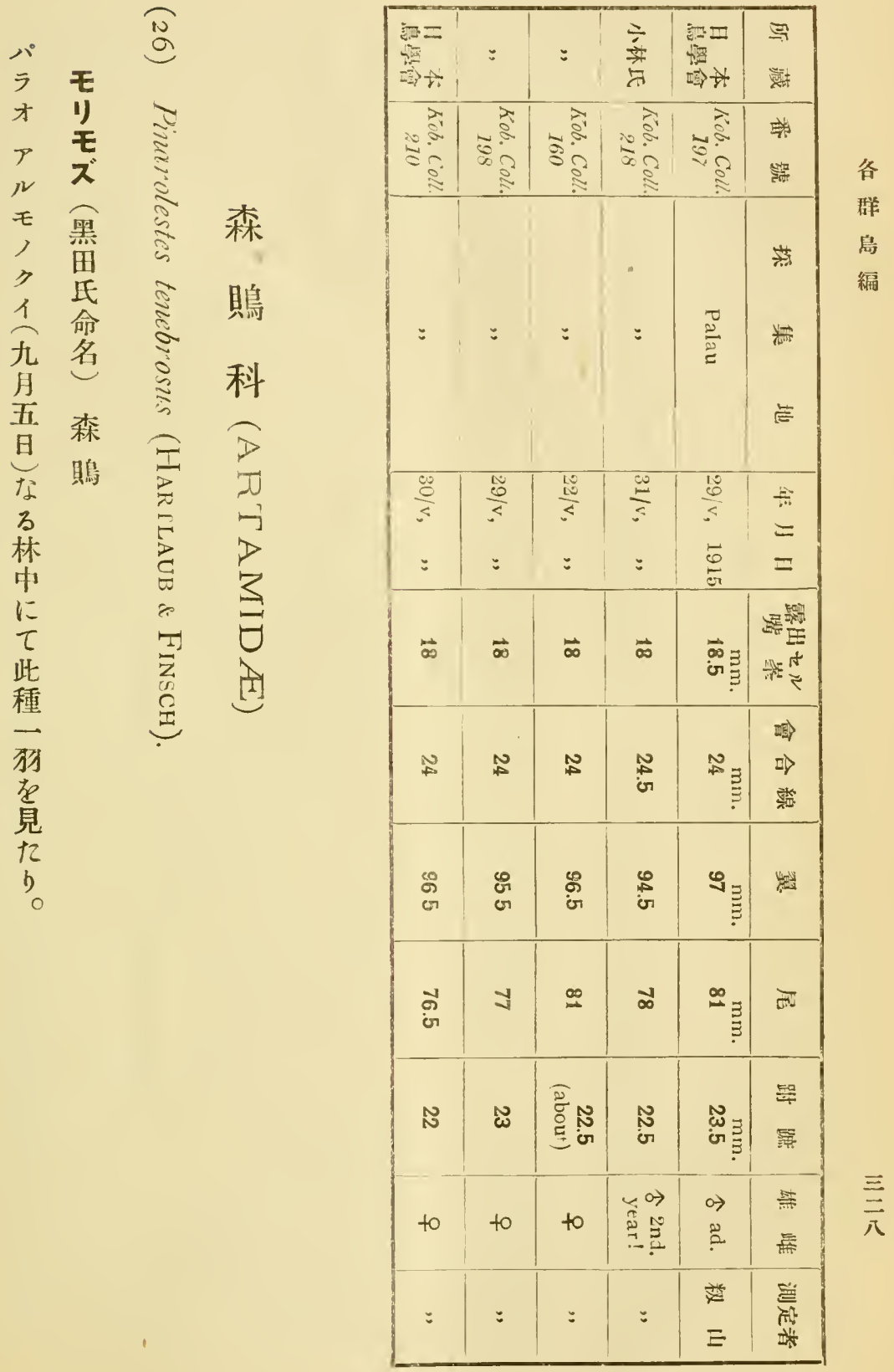


本斑をしにけずてく皮に不 種尠雄呈て あ軟。暗は色軟明 各さ三世脑り皮尾色淡若皮膫 部事年b腹七色旸に黄く色な

各 の 等 鳥

群

島

編
测 を

定 相 䧳

左 堂 成

表すす鼠

如

L

膄

俌。
せ

る

\%

前

額

頭

頂

後

頭

並

に

䧻

等

に

淡

色

和

見

2

牙.

下

面

は

秒

严
脇は字中し赫は若る

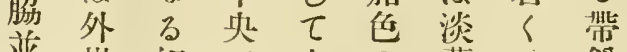
业辩細二中严蛣 腿は緣枚斷分赫淡色 の總踏は色黄横

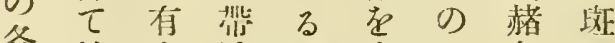
翅軟重淡横有一色 क 乲皮、黄斑す小の 端色此灰等、㻓: 細、 近但細褐! 眼它緣此 く緣色三前有 に基性に條带す，横 灰部外し里黑、、條 鼠侧七有色稀雨の 鱼到第先す。に覆中 の元端 : 眼三旸間 幅生龇近或皮斑には 獭脸展々 き黄狗に㭴後見h活

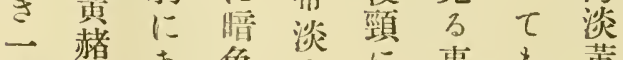

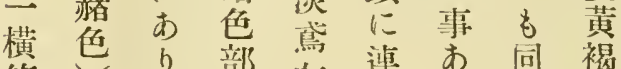
條先占部䈐連 क同褐 先先 て

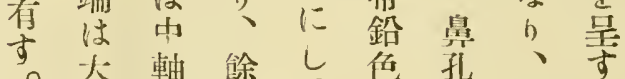

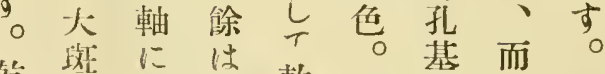
乾添喑軟頸部し翼

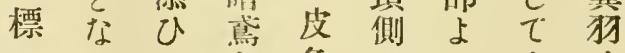
杰方却色色生口小生 下事軟後雨暗

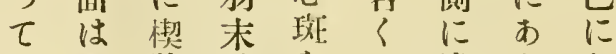

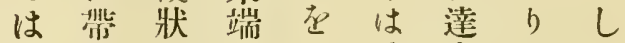

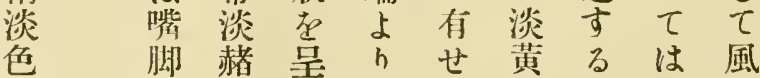

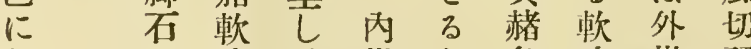
儿板皮最辨点色皮辫旸

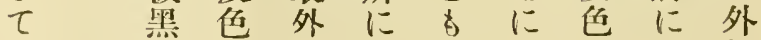
横急に侧脚混し宕軟辨 


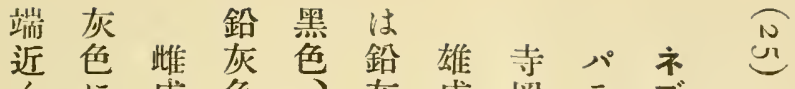

々に成色灰成间

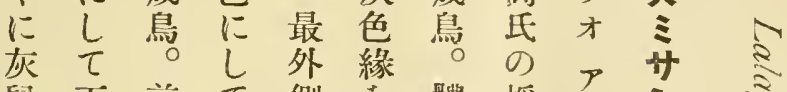

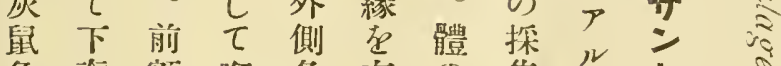

色沶額喉各有の集儿

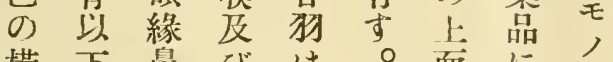

横下畕びは。面に方

斑 の前先屁法就 ク

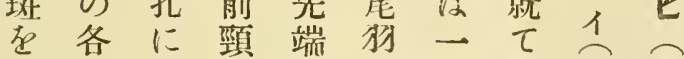

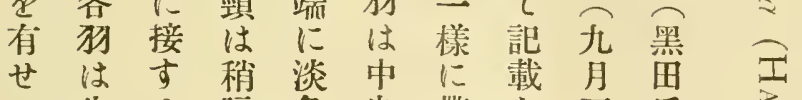

る先る暗色央滞を五氏

端部色尔の藍試自命

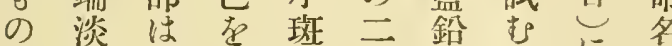

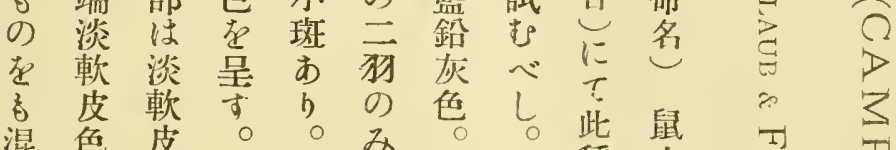

混色皮。”

声。色乾 眼暗翼

上不前本膘前鉛墨

尾明額に㮩色襍

筒瞭殘 あ展に色

はな部り只しに

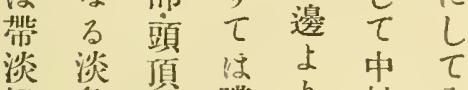

褐色唂唃 b 軸內

灰 の 後脚 腮及 侧

色中頭黑 亚び風

に心站悉掛先切

し 斑 な 端 旸

$\tau$ 市後 b 黑 黑 外

旸可は頸。色色辨

端、带管並

淡或帶褐 殘导恶

軟袺餘し雨

皮淡釷色 の他得

色軟色尔の旸

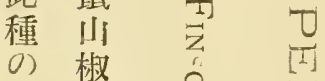

雌喰品

惨

科

2

次色䧻

でに は

二 $\underbrace{\text { 留 }}$

條七 淡

の 先馬

面 各外

は尾辨 


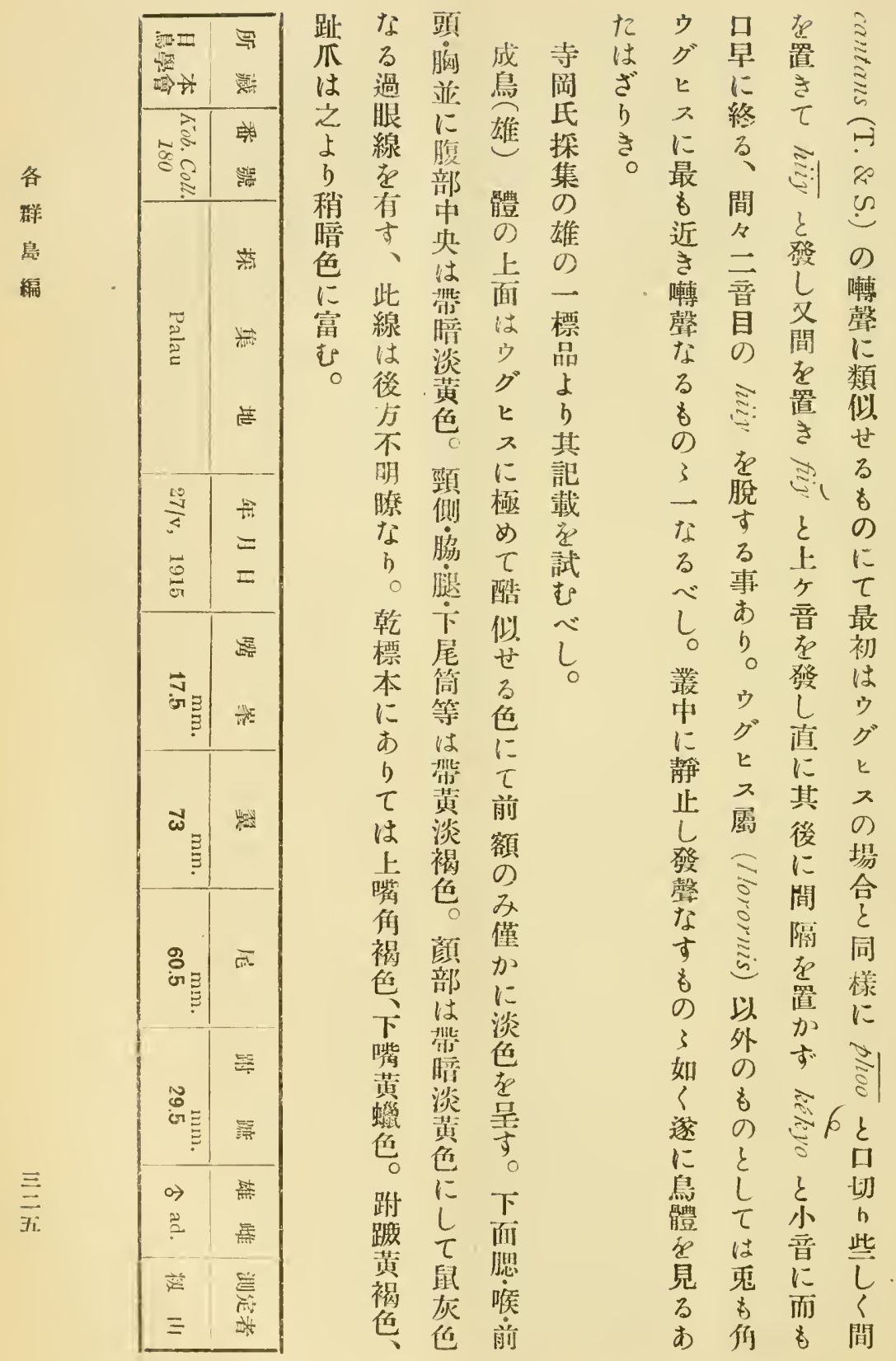




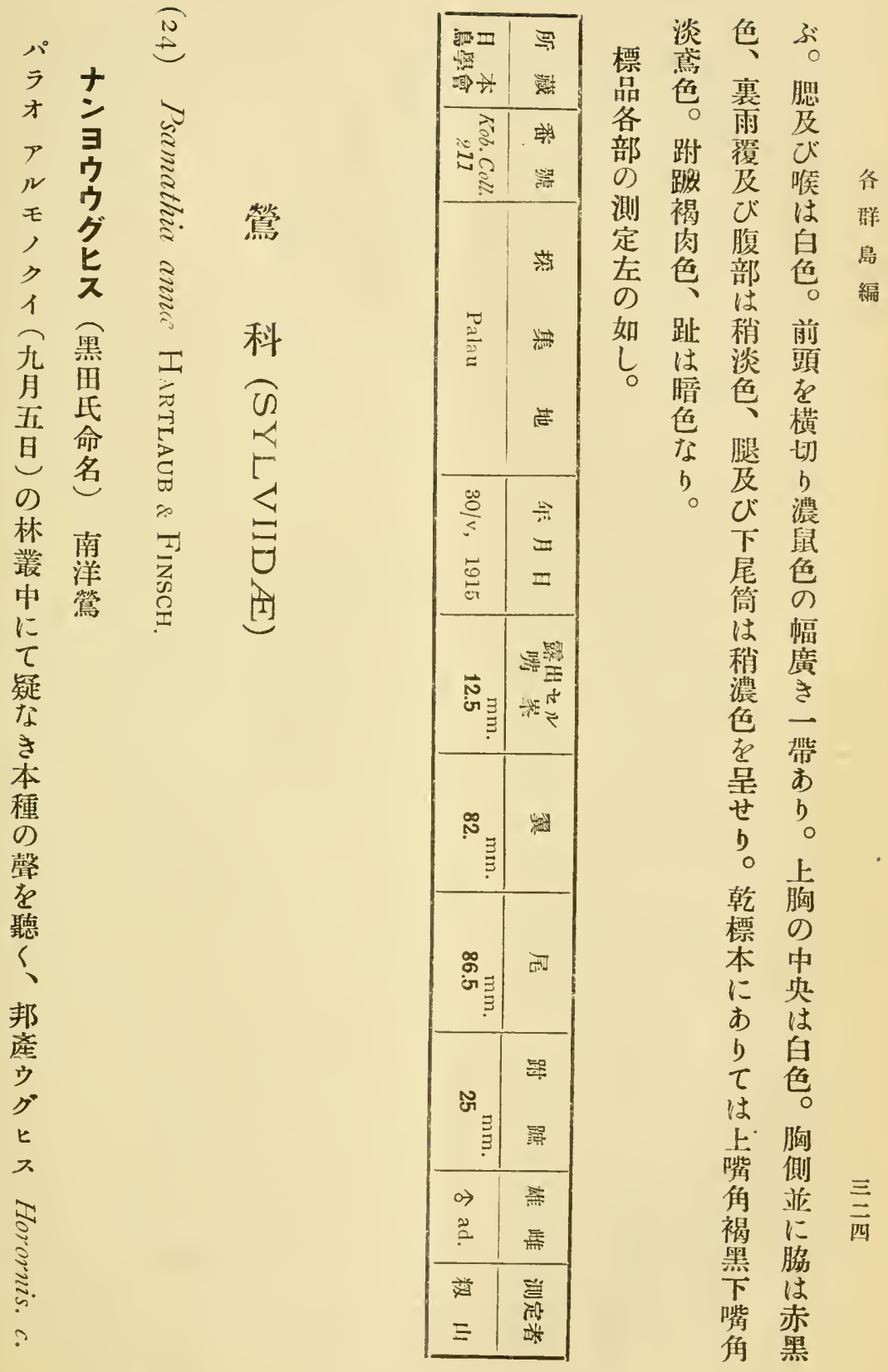




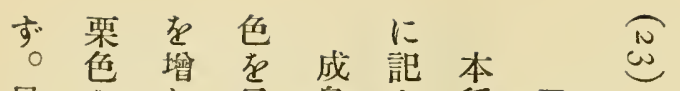

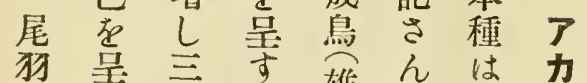

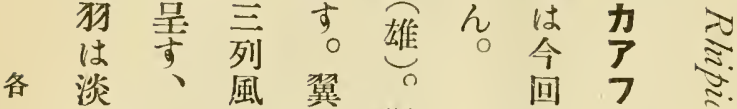

群 黑 但 切弱 體

島褐し最は心

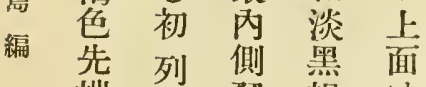

端雨狗褐

に雨に色栗

大覆到、赤

な狗与内色

万 0$) \tau$ 側に

演み殁風主

梁 例 $九$ 狗前

色外落は額

斑に大先 更

をし本端び

有 $\tau$ 淡及頭

高僅 栗 び頂

。色外生

眼にを辨稍

前一以に僅

及 I 淡

ひ二占栗に

眼の起色黄

下

はの雨細存

刺了覆緣乖

黑 先各范

色端狗有、

○ にL上

耳み两訅

狗に方各

は此 $\tau$ 狗

三僅れる到は

三加を外る總

三に自辨に竹

栗る策從基

色にびひ部

存過先其荻

觀

察茫

すे
马

d) इ

ね黑

は田正

ざ氏 颁

b 命

名空

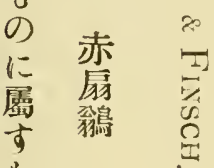

है

寺

岡

死

探

集

の

標

本

に

就

調

查

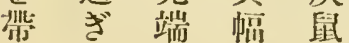

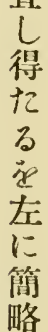

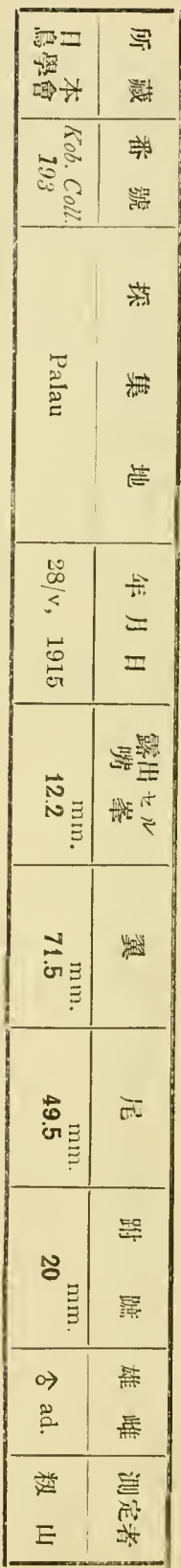


標な 擬 品る白權は眼切淡を鳥岡的 各。色軟一前邪な碓氏步才 部飞皮見法にしす雄探气゙

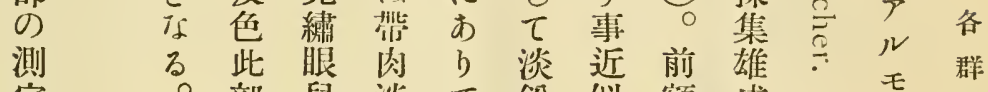
定 to tr: に 部兒淡七 鉛似額成に, 島 脇は類樺は色種は鳥似》編 犽或の色明。に带のたた に光絹に睹翼同淡二元々

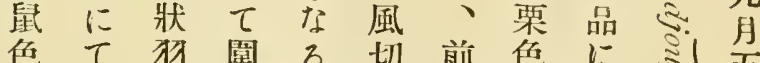
色七 狗園る切前色にミ(五 混非如部尾犽額䫑之旦

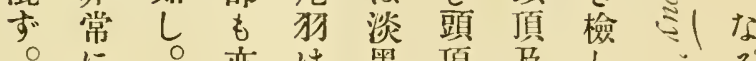

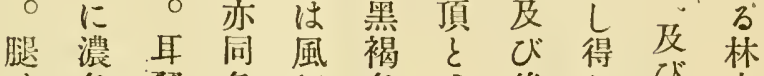

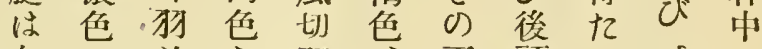
灰に並な狗雨頭るこに 鼠見にれを各色は站地 色ゆ頸 ぞ同外の带以之此

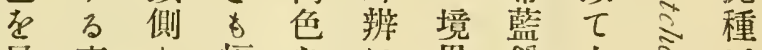
呈事々幅なに界鉛左ミ主 せお眼俯れ極明色に主 りり皮くぞめかに簡發摖 乾下部眼点正不ら

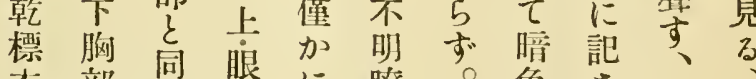
本部任皮に暸。色さ旸 に以色皮灰な後のん惺上 क下腿色方頍中几性亏

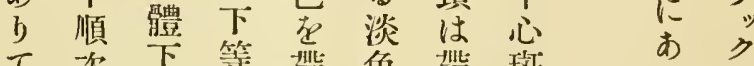

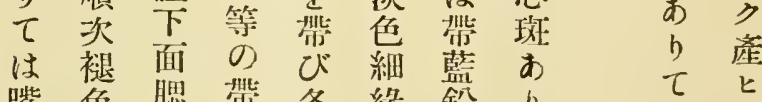

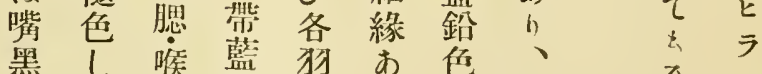

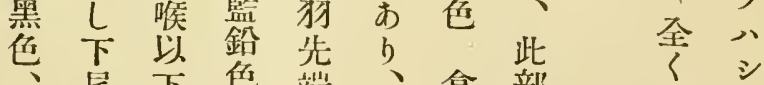
尾下色端、愈部 脚筒胸に但注長 趾: 部包淡 $\iota$ 鉛毛 瓵到迄在色内。鼠に

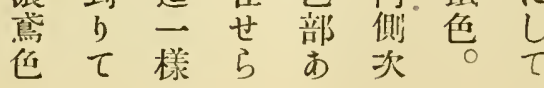

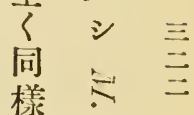

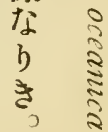




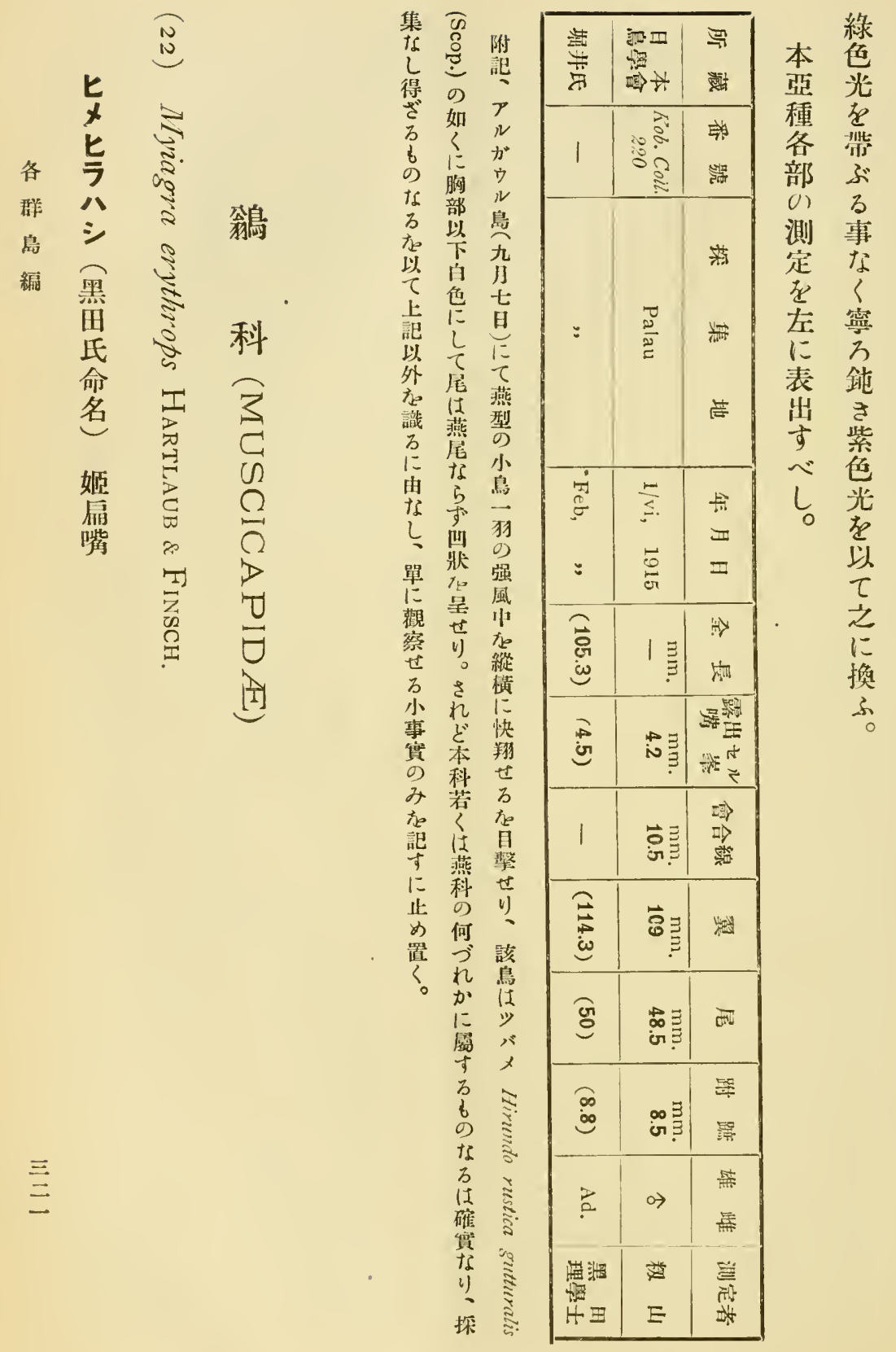




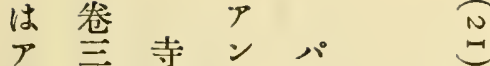

ナ杂咸ガラ

\% ○氏牙 今

※゙!㩁島无吢

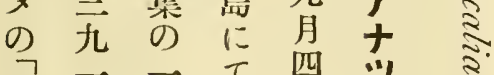

分一七四川六雨

頁標生星心ミ

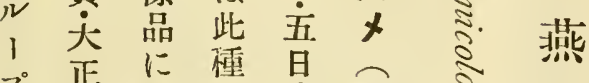

プ西就篦早妾

年原是稱

言缹息六

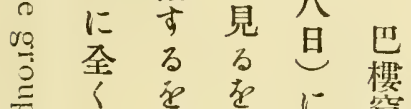

一得得㫖䈎

致皆ざは

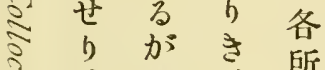

但墨哲

畭理㥜群

气. 乾學其 飛

標士他せ

蛋品の壮了

市調近

$\exists$ क 金似

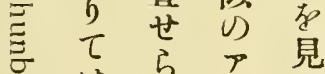

过传号界

に脚 し

比尘分 極

す淡

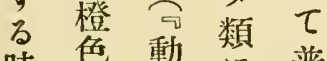

時色動溍

生等學同通

體等雤じに

上茴誌。靎

面に第

体兰

金惡䖽
空

科

$\hat{3}$
0
0
0
0
0
0
$\ddots$
심
型本車供

小亞 严

る種 万黑

をは思

以 ポ 學 各

てナ。声群

區 10 定鳥

別点分編

に產分編

難

מ

万力

ず セ

ウ 氏

且ビ堢

其ン 售

布

$\begin{array}{lll}2 & 5 & 5 \\ j & 5 & 5\end{array}$

見合同

了 它理

時

は る

全文㹉

兩唯動

亞 ミ 物

種 永彩

混导誌

同卞登

3 酷方

事

な似主

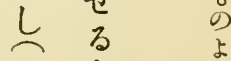

六测 苸

頁 上 粍

參著換 


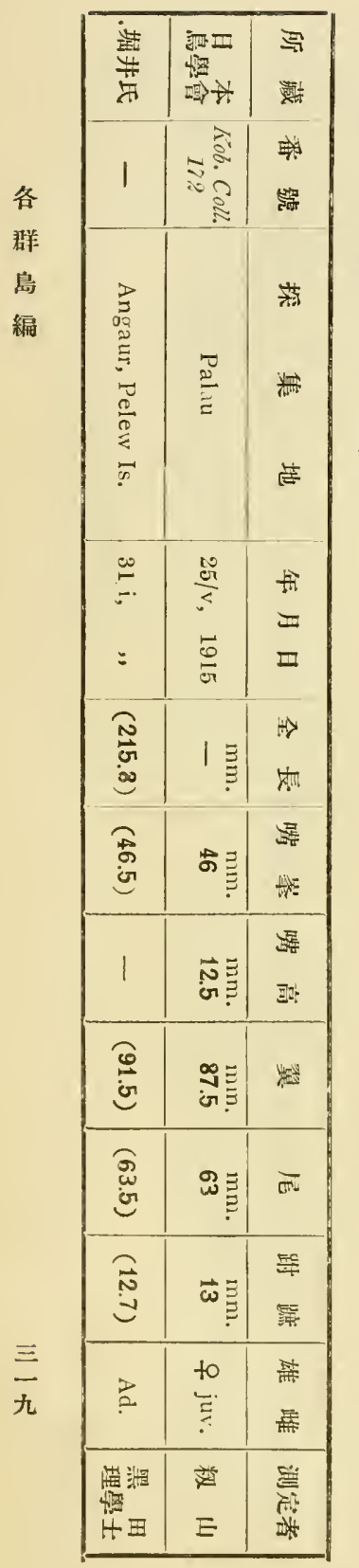

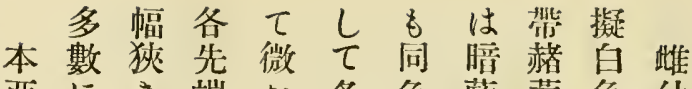
亞にき端か各色藍黄色幼 種散淡はな旸に色褐の期 各在一淡る 外し弆部牛 部す心゙ 黑軟辨て 业 の胸と褐皮の內ぶの環額 测侧药色色二緣。間 定に色なの部 中下にり頂 をあのり細に軸瓷隐。並 左り顛。緣砂亚及れ環に にて 線眼を軟にびたの後 表 は あ前見皮先腰る 後頭 訅稍り圄る色端は黑緣は す幅。眼、のは上罡は帶 へ廣下部同細灰春方焱赫 しく面並第緣黑にり今轱 份はに示市黑比”フ褐

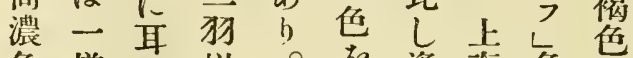

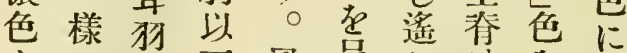
とには下風呈かは素し な白黑三切せに淡組无 る色色列㹦り青黑び頭 にに風は藍褐佔頂 前て 犲黑雨富肩褀

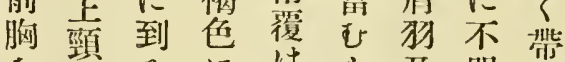
を听るには明黑 橫黑各し喑濃び睹色

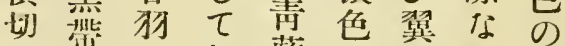
りに外初藍な前る軸 幅連辨列色但緣橫 狹るに風但京は線を $<0$ 淡切し。極尼散 乙此藍第大上め自在 七黑青一雨尾而守 不色色狗覆筒僅。品。 明部部外のはか此後 暸 0)辨み毒に白頸 な下有先淡監橄環を る緣す端色色欖と横 横に、にな、色後切 斑添但極 b 尾若頭 b

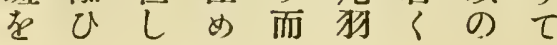




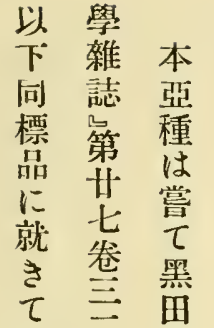

訅分理

述 頁 學

す頁士

心 大 に

し 正㨜

四 b

年 邓

寺

岡

探

集 ミ

\%)

幼 太

期 :

の

標 I

品

に

क $\varepsilon$

b

は 記

該 載

訅 せ

戴 5

机

充记

分

一 が

致

せ、動

亲物
ᄅ

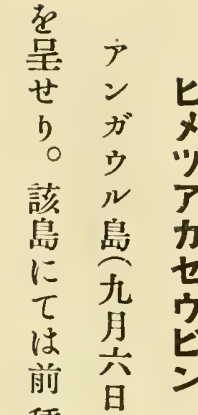

に 種

比林田

ᄂ 中 E

甚に命

だ名

歁多

きな 姬

も卞頭

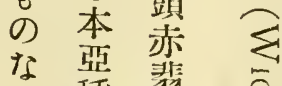

る種柇

が -

如 冴

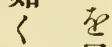

此 目

二 擊

旸す

以 體

外 型

に 小

全に

此

種頭

存

自 社

る 明

あ か

た

は黃

ざ 褐

을

ส.

స

胥

ลั

ล:

$\frac{2}{2}$

¿

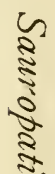

ลั.

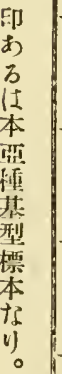

\begin{tabular}{l|l|l} 
क) जु & जू & ज्ञ \\
(1 & &
\end{tabular}

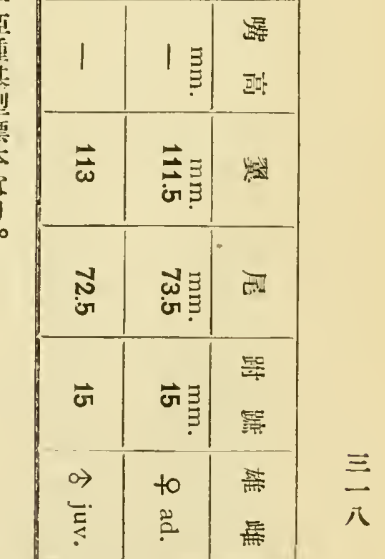

各

群

島

編
ᄂ

七

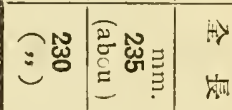

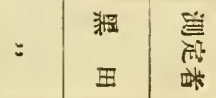




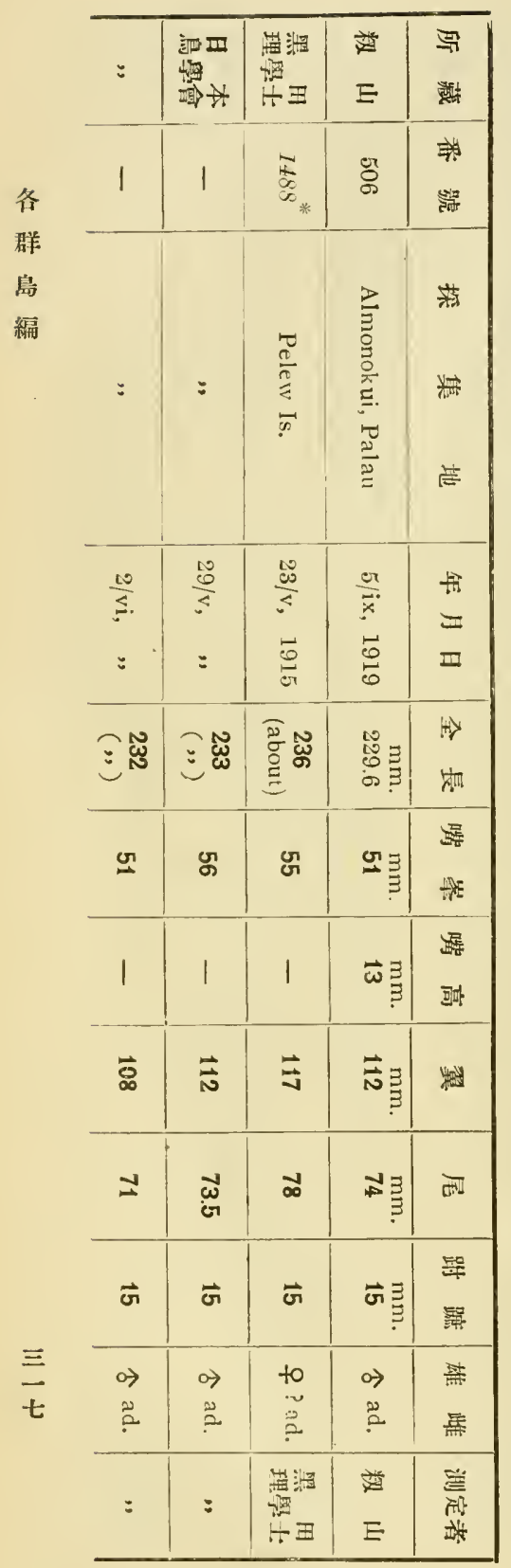

得因るな相號 探灾のる洷五本 集恐黑みがの 六亞 標 弓田、今點 | 種 品々理而回 あ五は 各圖 學 し の る 八 寺 部版士 $\tau$ も 頁盛 の の の 眼の の 天 氏 测方 基のに3 正の 定の型上あ如四探 在誤標部 b し 年集

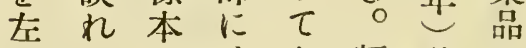
にるを蛙る額基に 表 回白極基型據 示 の示狗め部標 り すなせをてに本黑 べら全小於は田 し几路人形け雌理 乙見にる成學 分るし白鳥上 は事て狗なは 同な基のり調 氏 型部し查 比点標分篇世 訅胸本のめ方 の の大毁 れ 載雨如尔今新 飞 側 か あ 回亞 些にら万探種 しはすは集を く暗單同の拜 色色に理雄說 彩玨鼻學成さ 上な狄學鳥れ 相々基士息れ 違 - 部 8 せ樣に既標が るに僅に品こ 點白加指点鳥 热色に摘聊鳥 見存此せか第 出呈れら其一 寸せ在几色悉 事 品戛處箖第 


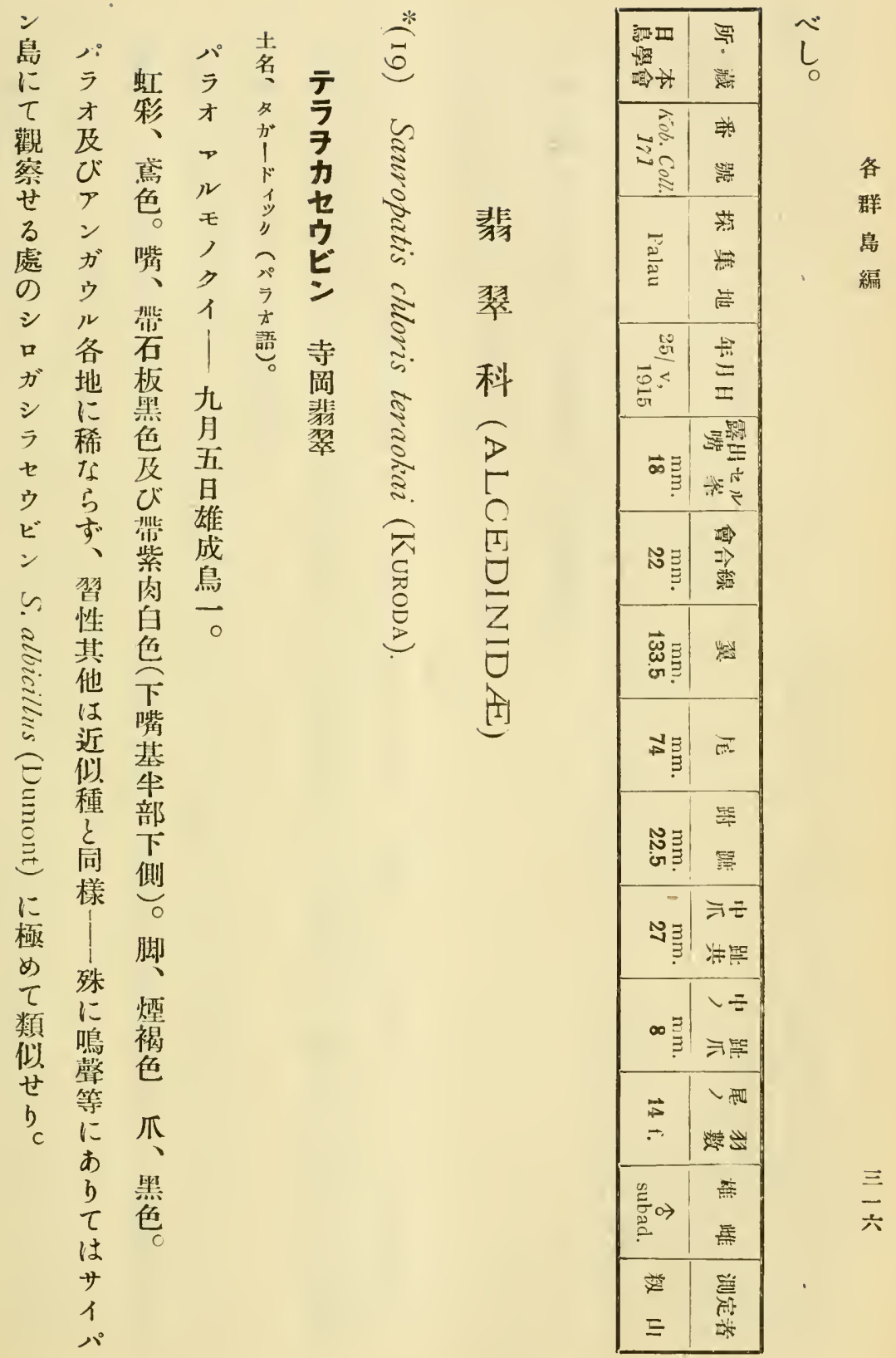




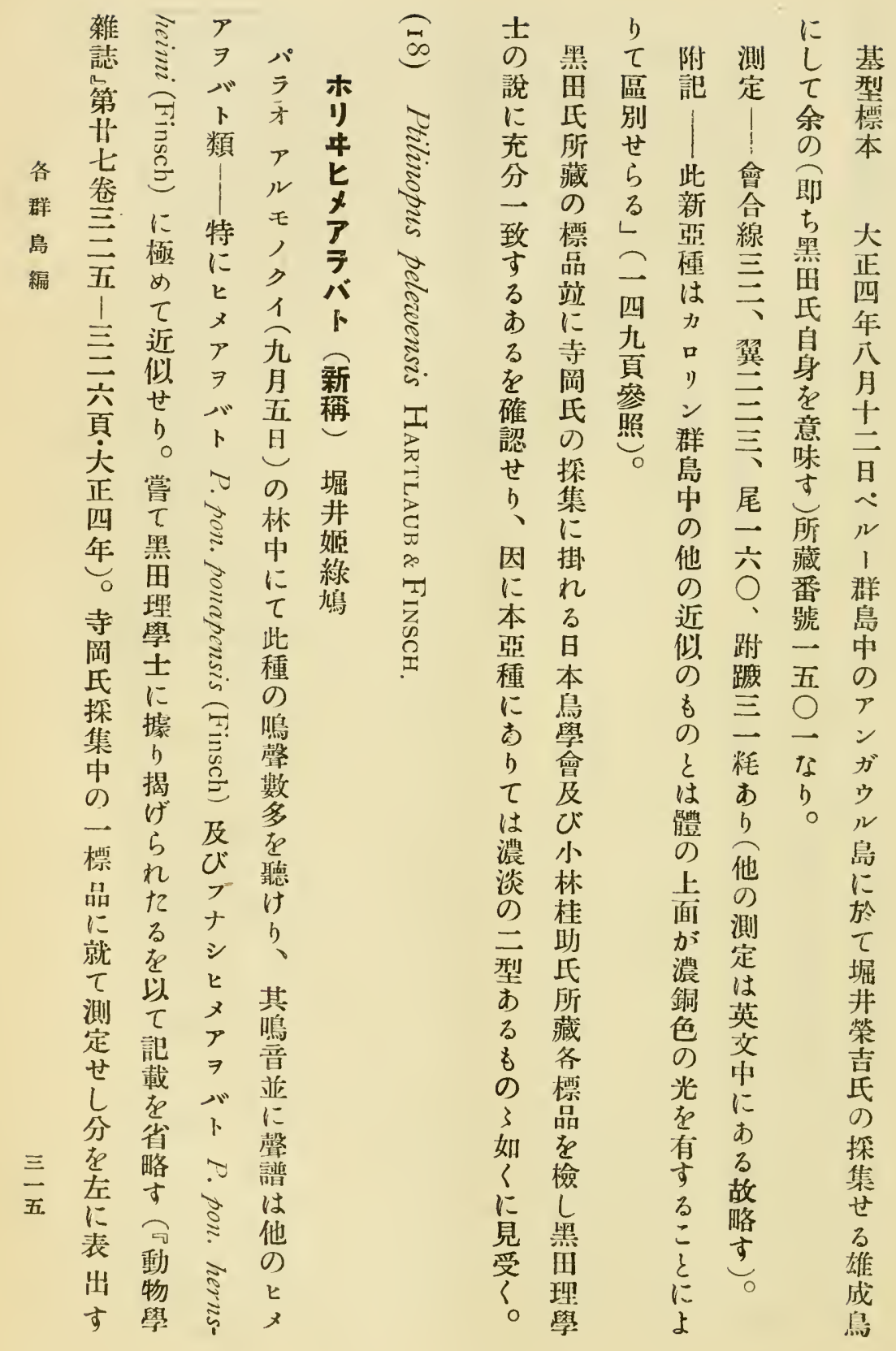




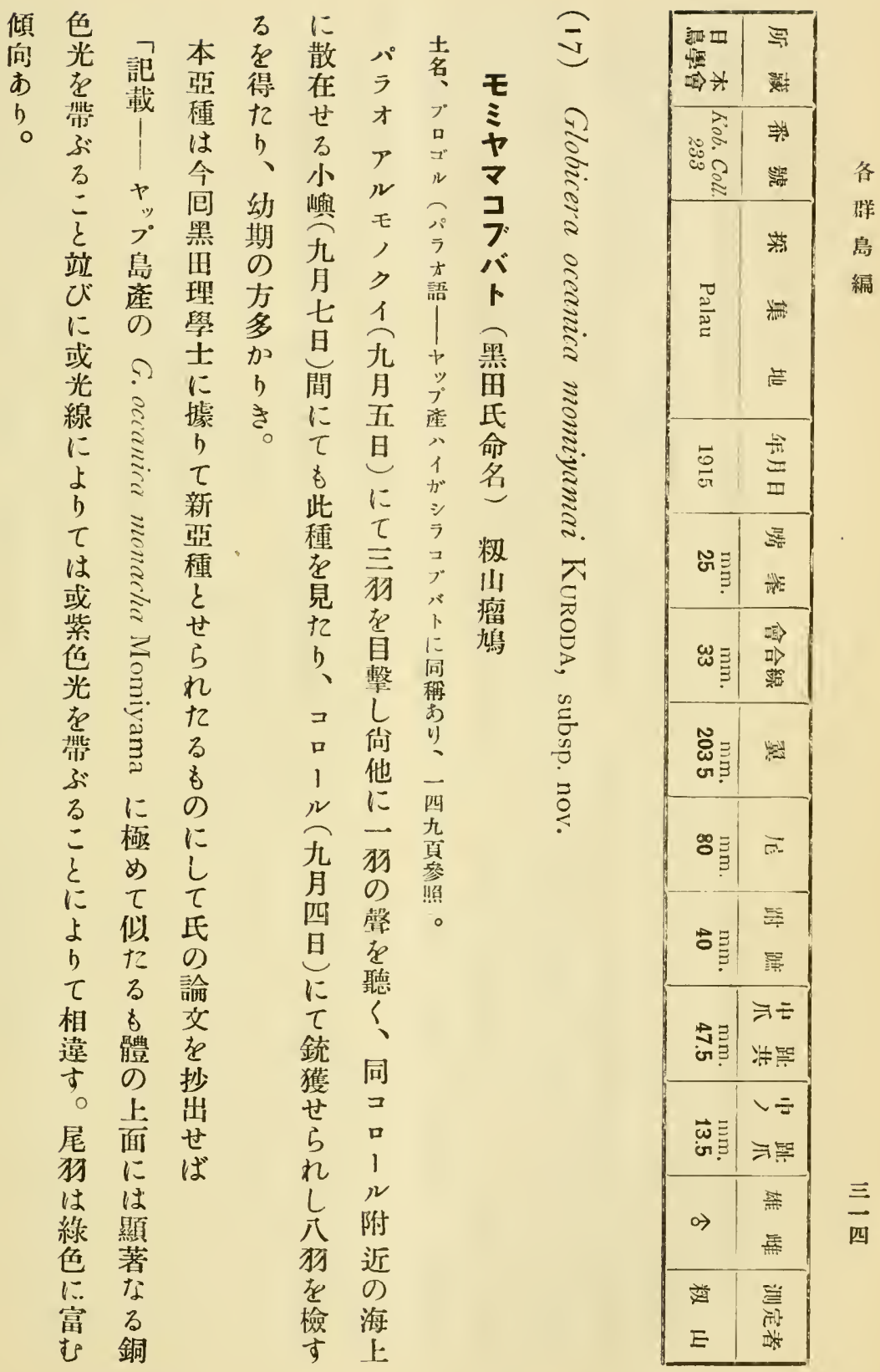




\section{不尾はにず品に}

標板旸外單、據今

品黑 导 側に特部 b 问 各色基兄變爷訅は;

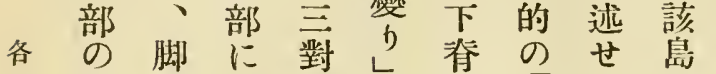
群測趾 あ

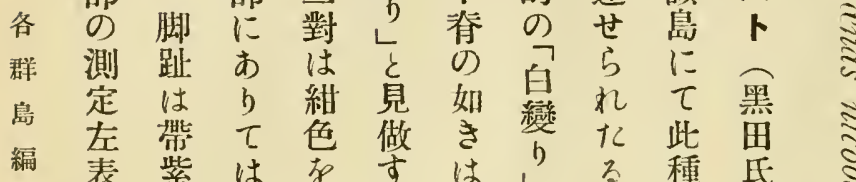

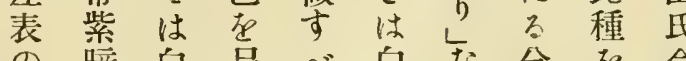
の暗白呈べ白な分度命 如褐色しき俏る主名

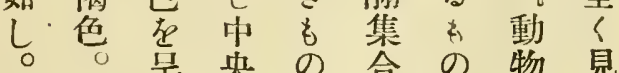
爪せ

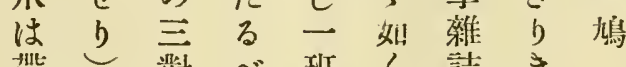

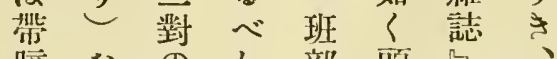
暗なのし部頍举、 隽りみ、尼頣第寺 黄。带黑構唯草岡 色佾肉思生噍劣氏 在嘴白理し 前巷探 呈基色學 甚栭竎集 卞部て士だ後叴の $\circ$ に污美项 頁 栖 其は物記な食貝標

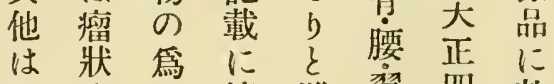
黑突め據踓翼四就

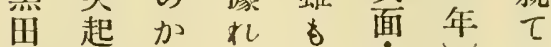
理を了ば白胸子檢 學自る尾班敜些 士季色冴はに些る の。彩は左腹く坆 訅乾在白右等色得 載標呈色必色釈た に本せなず白秋る 全にるるし班趩が くあなが若基嘗 - b 3 如 - 子 致 せはく皇即田 り嘴該此ず少羽ち理 は中標、學 任央品故混標士 


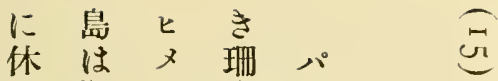

止深》瑚

寸海口礁才

る中面上

特にヂを吕

性突 劣此 了

あ出 三。種ル壬

る 本先変數よ サ

種島出向局

に型海群合襟

は栖る㨇集儿墨き

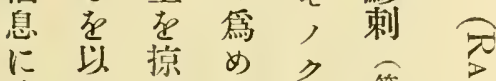

蔐て め殆 亿第

合附るんに圆

せ近少ぞ向脽

ざ海數礁向第

子上色色途诸

なに目路成

ら岩擊覆笿感

几礁すへ九

欺. 屋 0 万

殆アを五

一 $九$ 見 日

三どガれ己

○自少

頁声次点

八故に息同虞

四にて口行

頁好は1

子此次

厂 種 附此

島を近種

よ全无

h 厹數

隔見年に

h ざ 七會

れ旦早

$3 \geqslant に$

礁、宁。

上該 当 遠

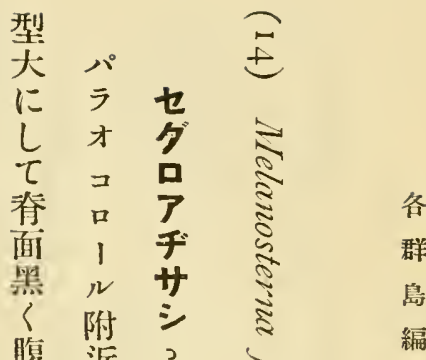

各

群

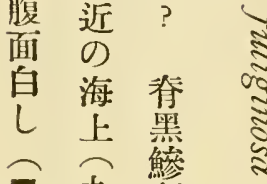

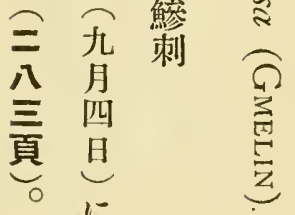

に

七

$x$

$\eta$

마

$>$

チ

$+$

シ

の

群

中

に

混

少

數

v)

此

種

皃箠兰 


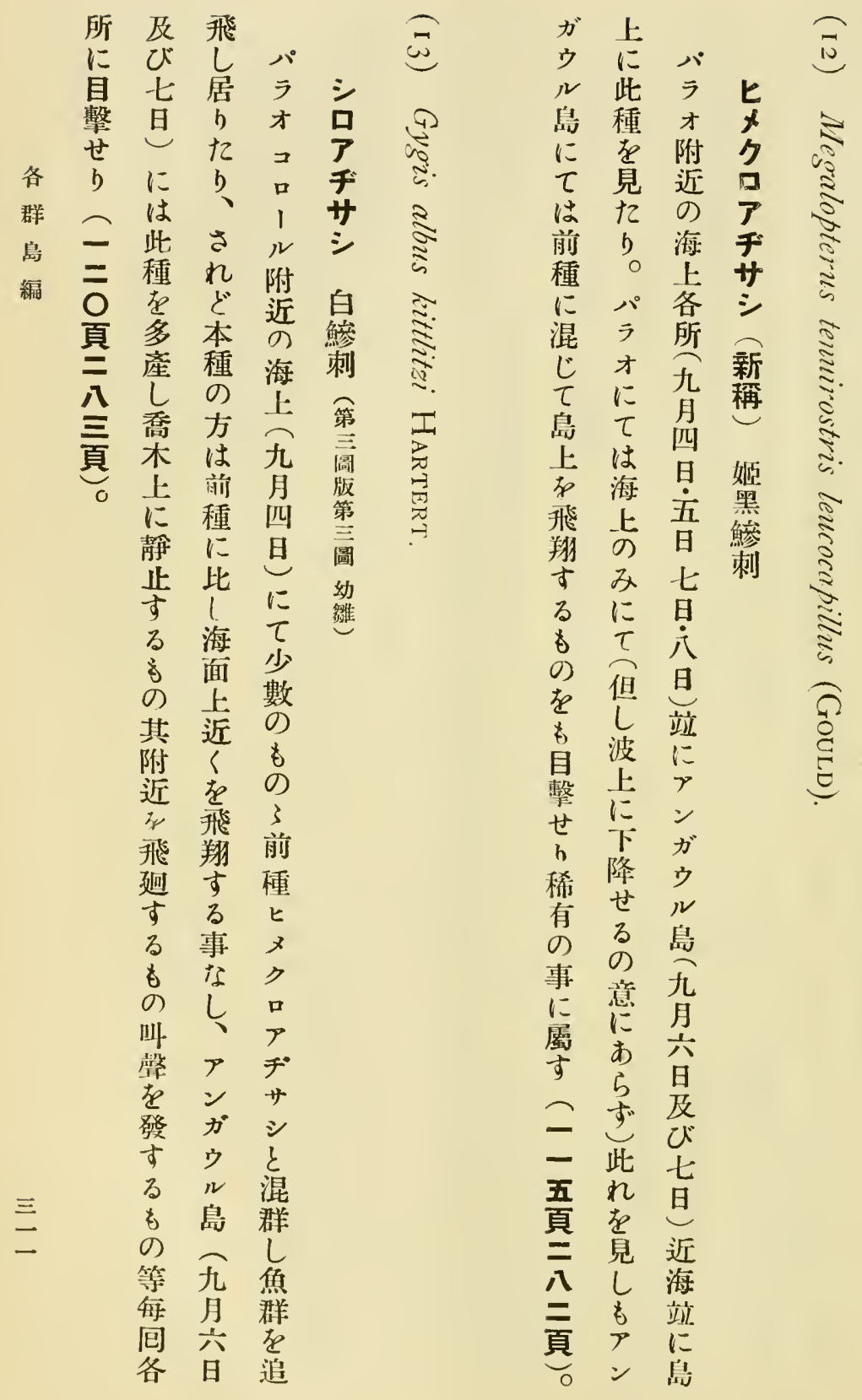




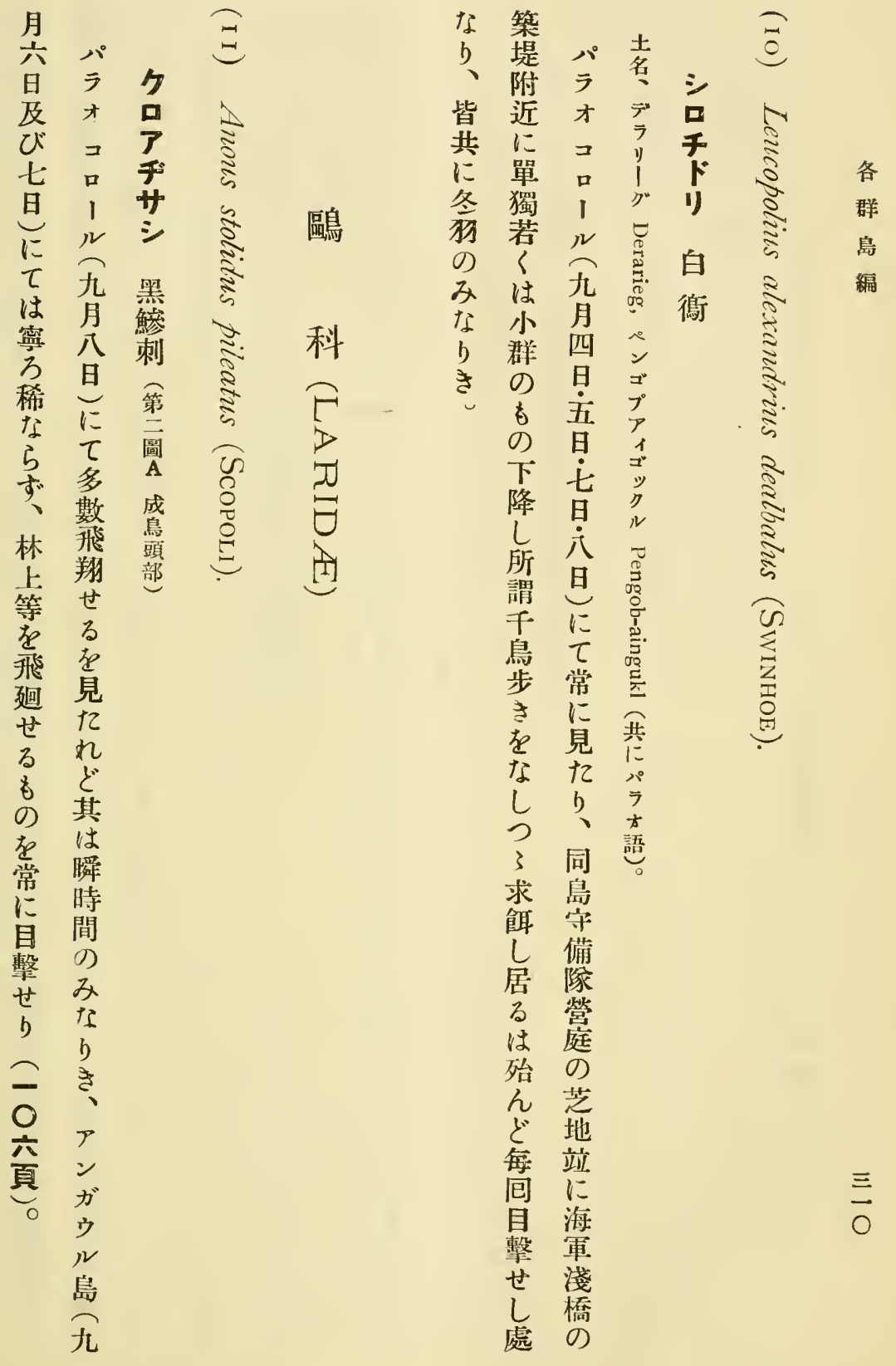




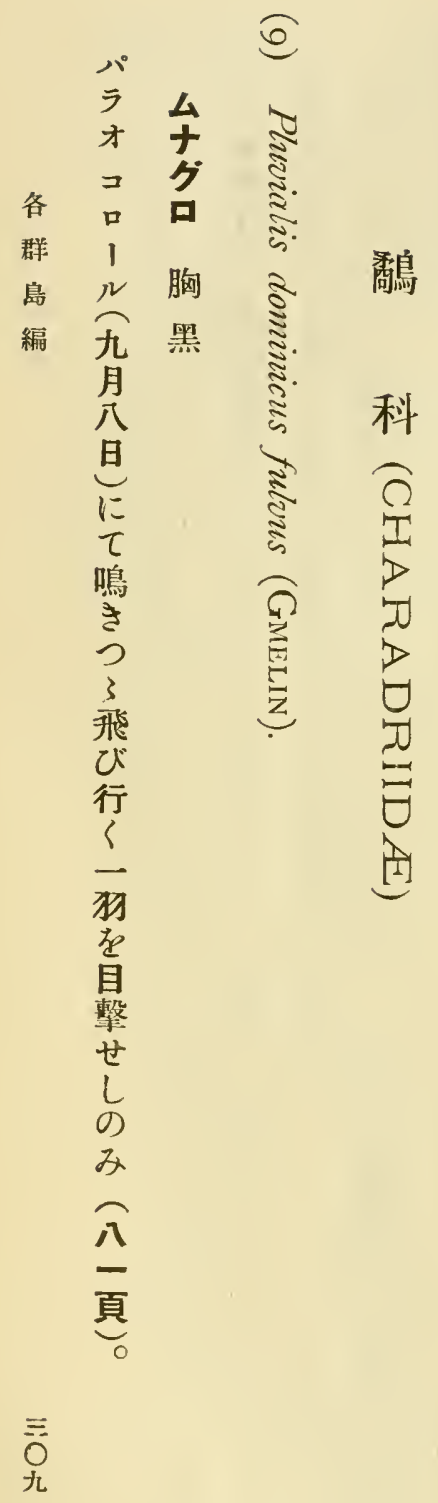

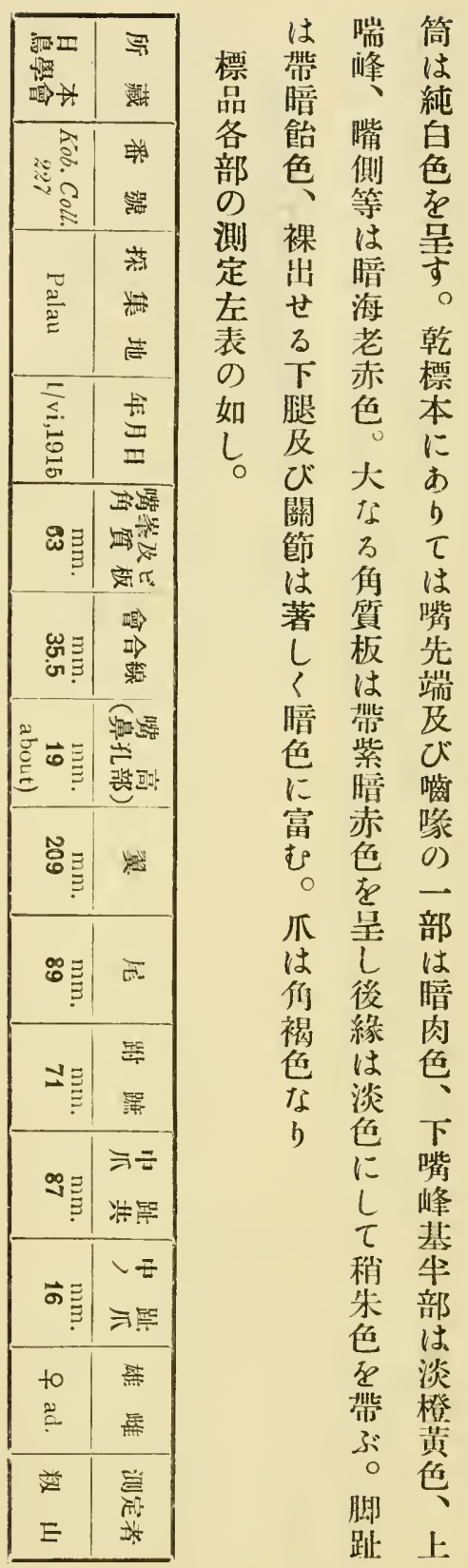


に切々 得气施の

前旸端成寺ざ营了号

胸外は鳥岡りの䳛ラナ

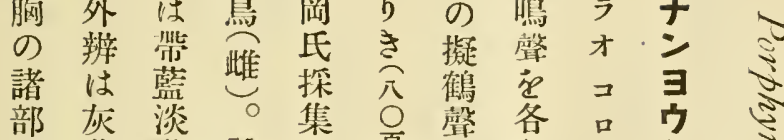

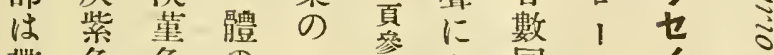

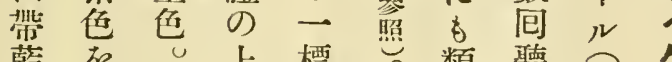

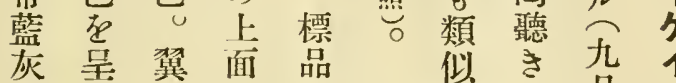

灰草翼面品

色。前び 就

に顔緣尼き

しは糞旸以

七灰角は下

基黑立望に

部色に褐訅

灰、物色述

褐卡列责守

色鼎 雨呈心

下添繁鿖

胸ひ沙は

脇茟 大旸

站加雨 端

にに澓極

腿藍外 各

帶 淡侧僅

藍 董狗か

婜色外に

荤足辨橄

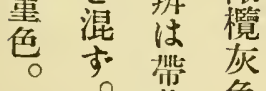

腹。藍色

は面葷兆

带面萝色需

せ合

万 b四黑

點、日畐

あ $ヤ$ 氏

れ プ ひ 命

ぞ島同名

尚にア

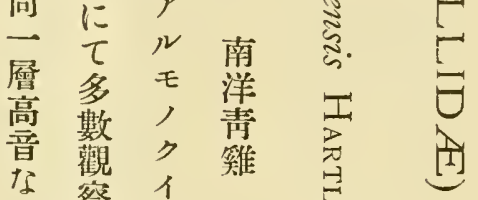

り 祭

樣吕合

积

綈

科

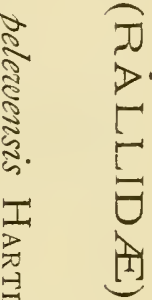

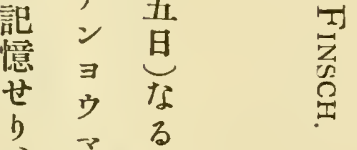

$\underset{0}{\text { 八 }}$

灰 前外而

色頸 侧 頸初上

下 侧列泰

尾站風须

、林

但 ジ 叢

烏口㴡

體年地

はナ队

遂比

に元

一 此

可空種

自踣想

擎っは

す こる

3 


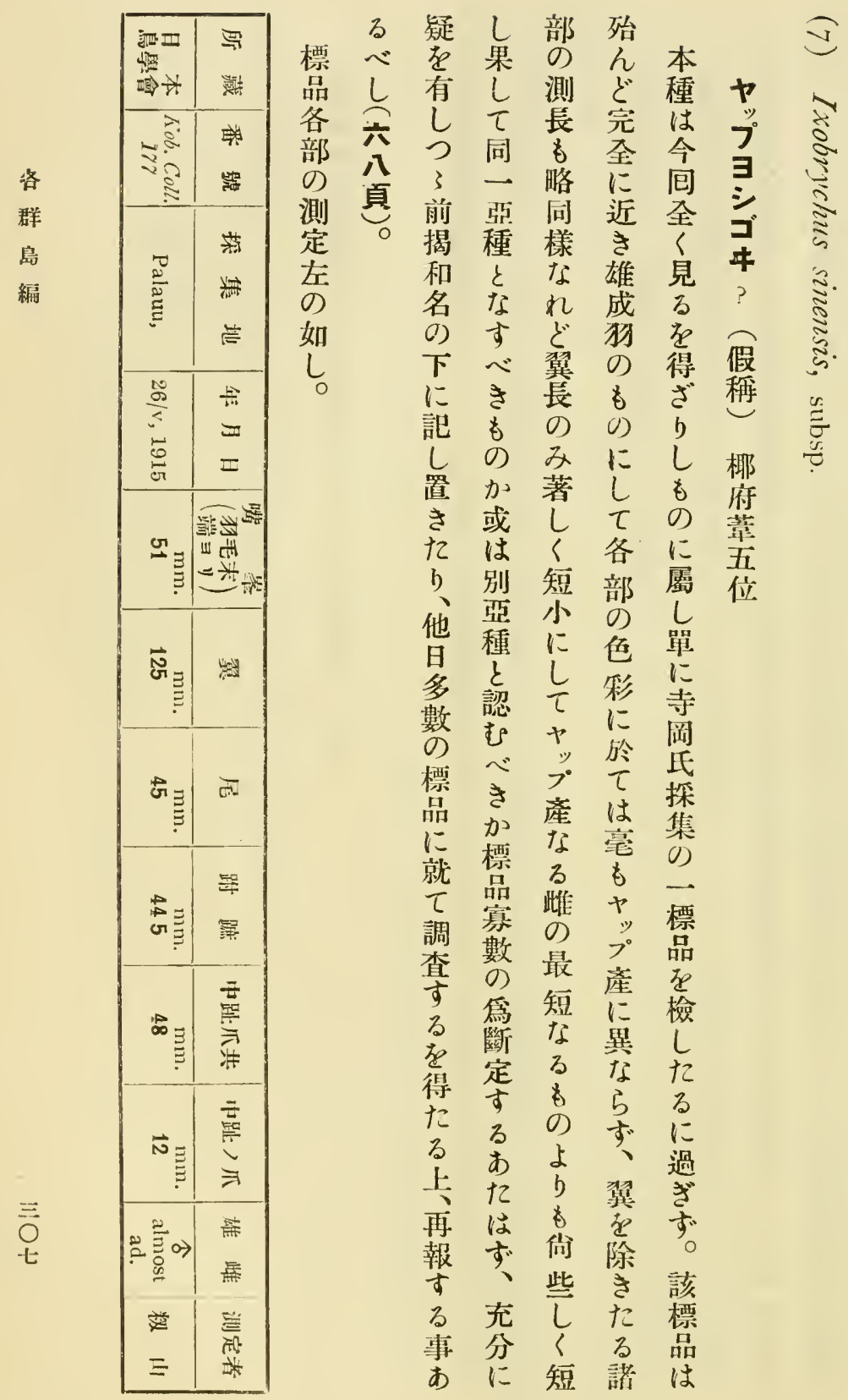


が 產 パ

如 ラ+ 海 ラ

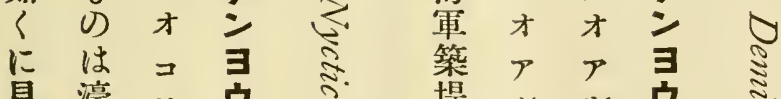

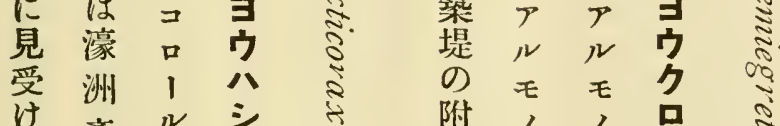

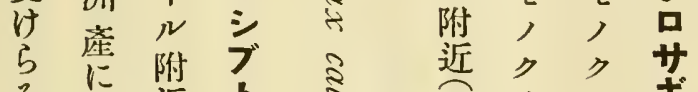

る比近 ト ミ 旮

吾主旮年怘分附 | 新

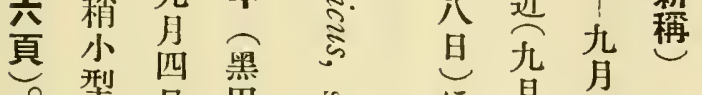

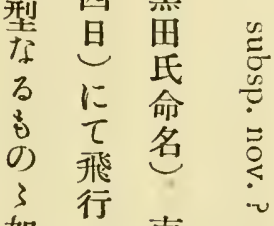

如し 南

ᄂ? 洋

ह

に吾吾南方方

白

牙黑 幼 第 艺过

れる五

老一買

各

督备

科

ぞ 一位

見 び 第

る白䂴

四型向

力邪

口に

頁

ン買

群

岛 但

中

の 余

トは

目

”撃

士 尔

七 目

佘 擊 箅

の せ

है

の き

\&

前

者

te

探

集

せ

?

음

差 本

同

異 地

島

な方 


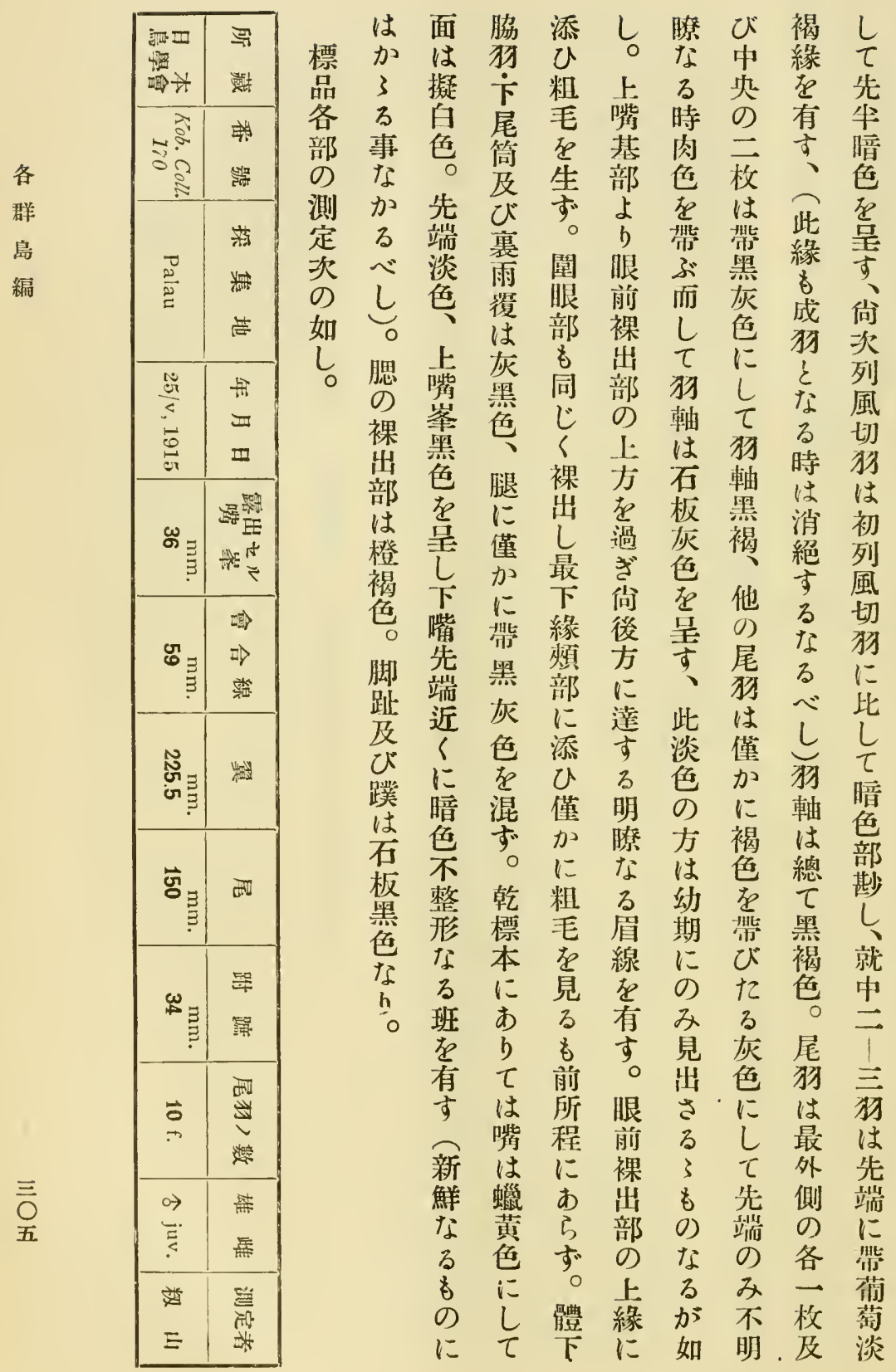




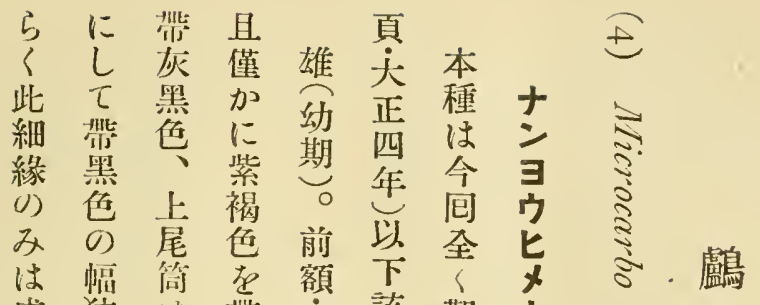

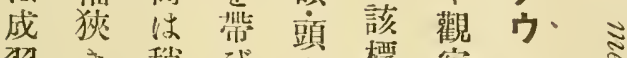

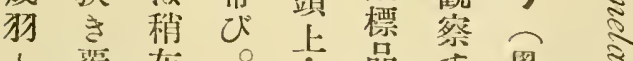
$\varepsilon$ 覆灰。復品禁黑第 な輸色上垎にる䩀に

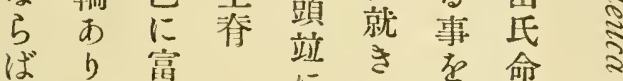
ば り 富些き在命

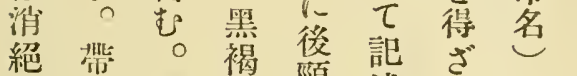
可淡翼色頸述 b

べ褐のに㷌すし南 き灰前し し 需 の色緣 た細滥旸に 5 緣灰に元 几 風苑芭㷋褐 切部雨帶灰 旸に㠅淡色 見狗褐細 微受㞧灰緣 にれ內色 金艺 侧る 屬總等覆特 綠等列輪に 色の風を後 蛋部切有频 带分狗すの 心゙は。み るは光下は 带 お澤苓 緣 黑 5 及 0 灰ずるび幅 色、灰腰 廣 に恐色は它

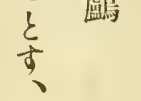

寺

润

E

挆

集

の)

標

品

あ

b

จ

鳥

第

卷

第

科

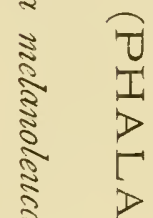

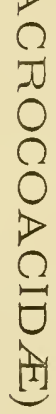

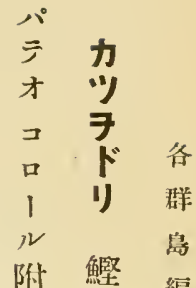

近魚編 岛

元

四

日

15

$\tau$

波

上.

$\alpha$

b

炛

ち

本

種

邪

見

t2

b

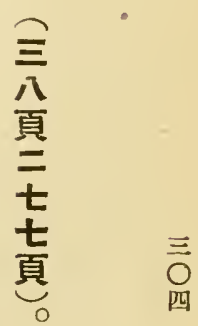




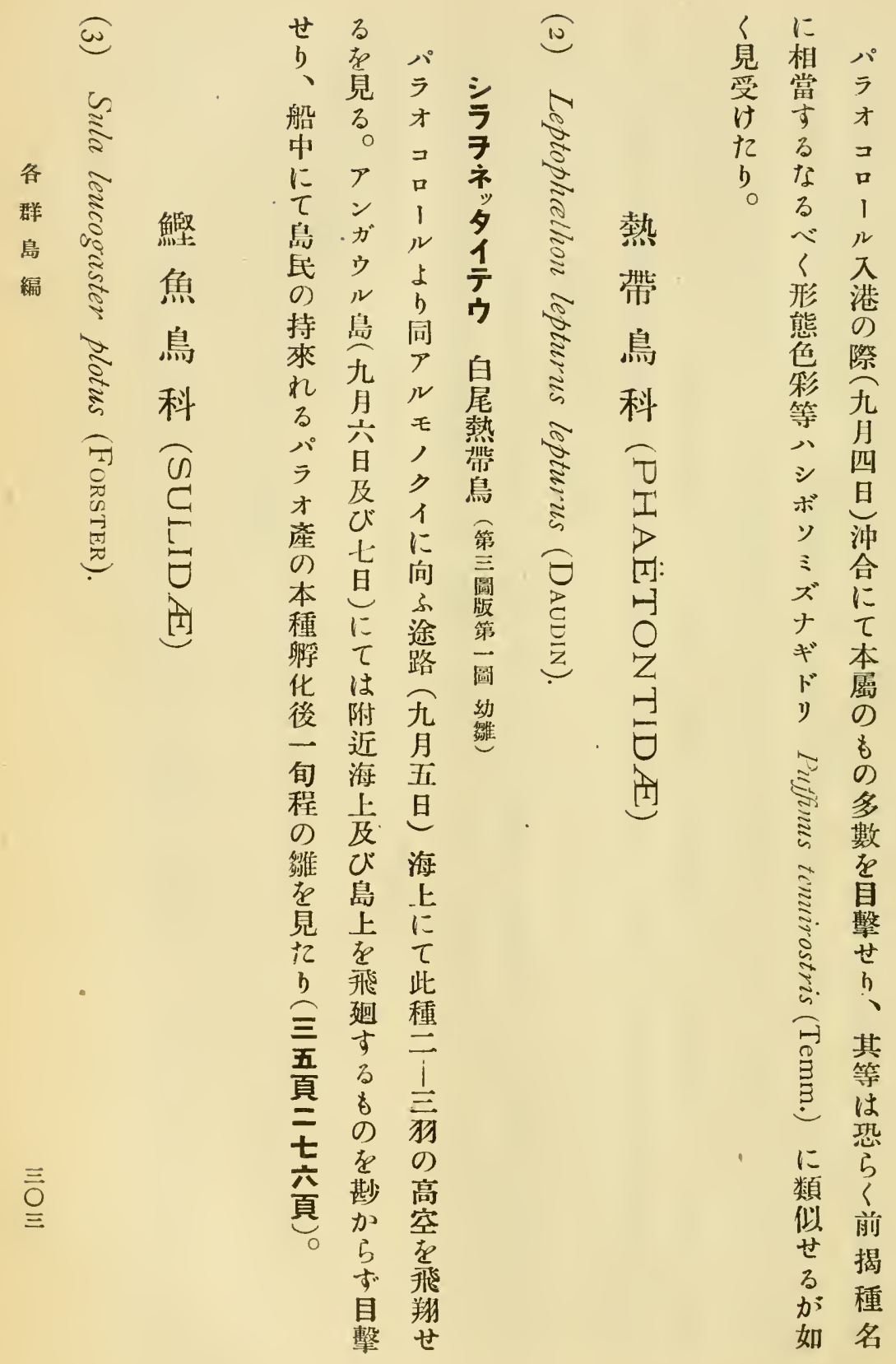




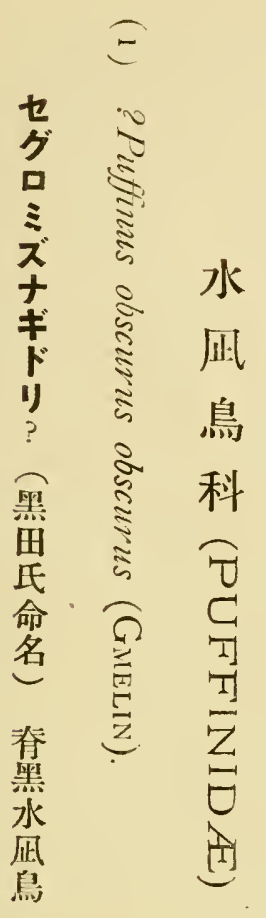

類きの試をウ

のも標み俟 ルカ

一の品ざた島口

班多をりざにり

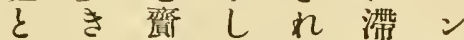

なをさをど留群

す以れ以他、岛

、貝 $\tau$ 地各各

不觀下探方種地

借繁・日集產の旅

不は本品鳥鳥行

全余鳥茫類 類中 1

の の 學 だ の の の

點 旅 會 䭔對 觀 數 群

は誌所 $し$ 照祭 日

威中藏、上占息

によと然特勤 へ

讀 り な

者、れに揭て、箦

諸記る本ぐり群烏

方載当地る、岛

のはの方事素に類

寬寺をにをよ航

怒阙亦はせ りし

を尠特り僅該

乞のし産。少諸

は探々鳥此 日島

ざ集 せ 類 地 時 主

る品すをに間部

心其、夥てにて

加他光産 は過命

らよ等 し 種 ぎ

ずりの前々 ぶ單

○探各问な和に

用種寺る ばラ

亡中岡 事觀 才

以に进情察才

$\tau$ は $の$ の

ルだ集㤠充す

1 邦時 几 分端

群交にどた

岛訑尚探る

產载幾集はン

鳥㫮多を 論 ガ 


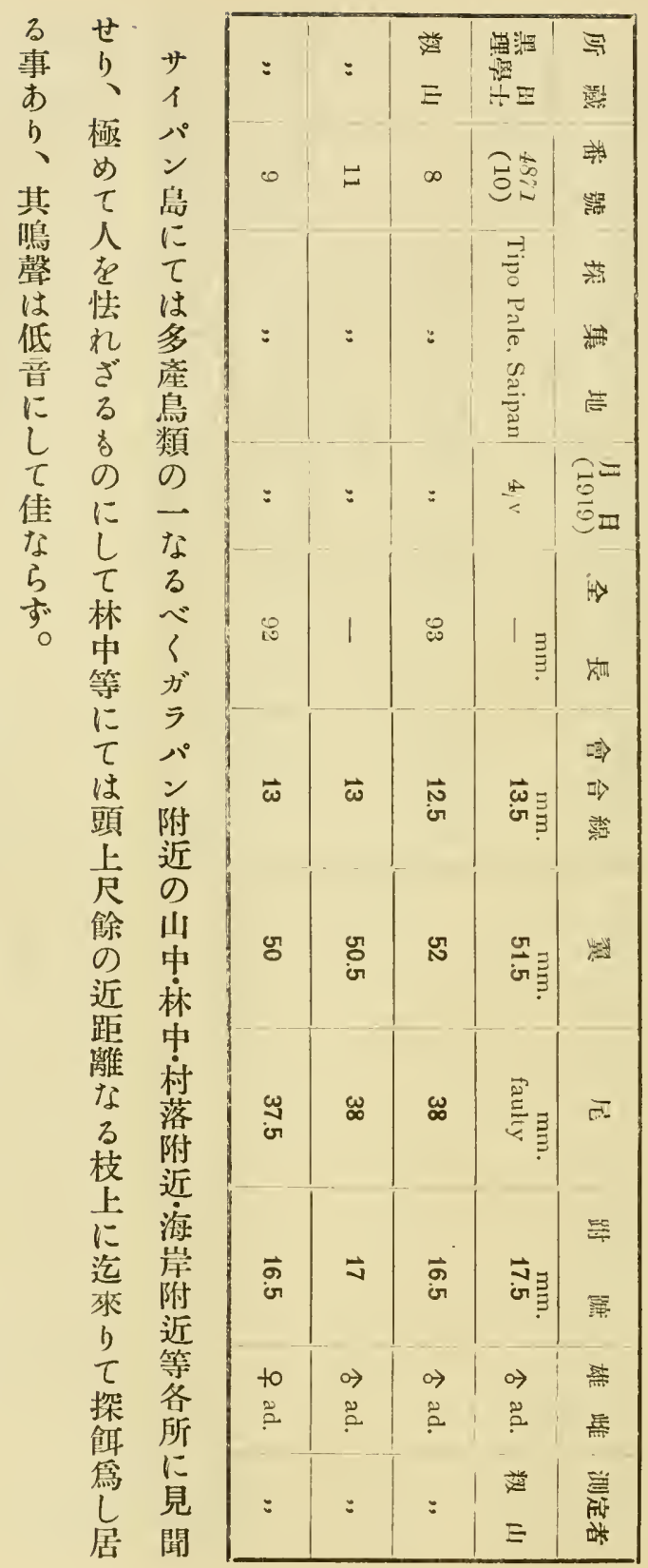


下 黄 b 到の

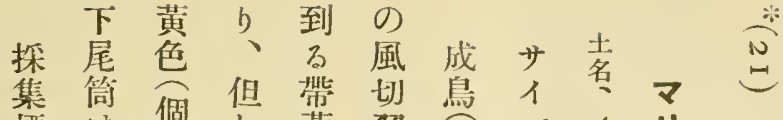

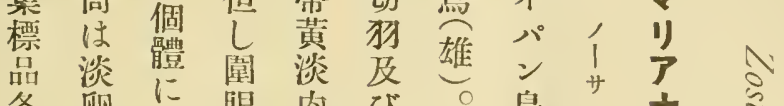

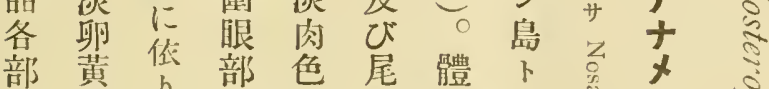

部黄色 り

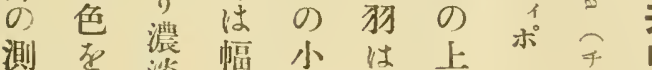

定呈淡猍部暗面ぺ

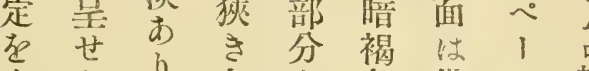

左b白白堡儿族

に。、色るに出山

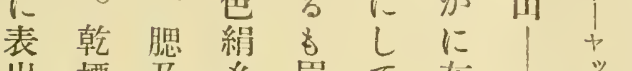

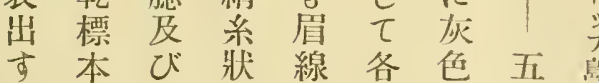

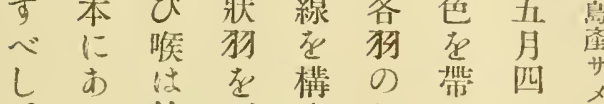

b餘列成外

七程生す緗る雄品

は淡する草言莎

嘴色口事昘維䧳品

褐老尔と色二に

黑呈雅し同に展

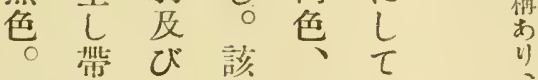

鞠 $\frac{\sqrt{2}}{5}$ 科

脚 白 煩 部 內 前

趾色はに緣额

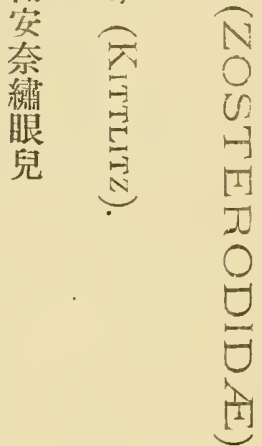

石に上併は嘴

板近面行䓙に

黑き

色同萑古

なの色㙐をる

り お 蓑 黑 極

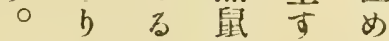

童当色口て

埭稍不上小

䨒 淡 明觜 部

復し 暸基分

は。な 部は

殆下る る 罡

々面過方白

白は眼眼色

色淡線前黉 


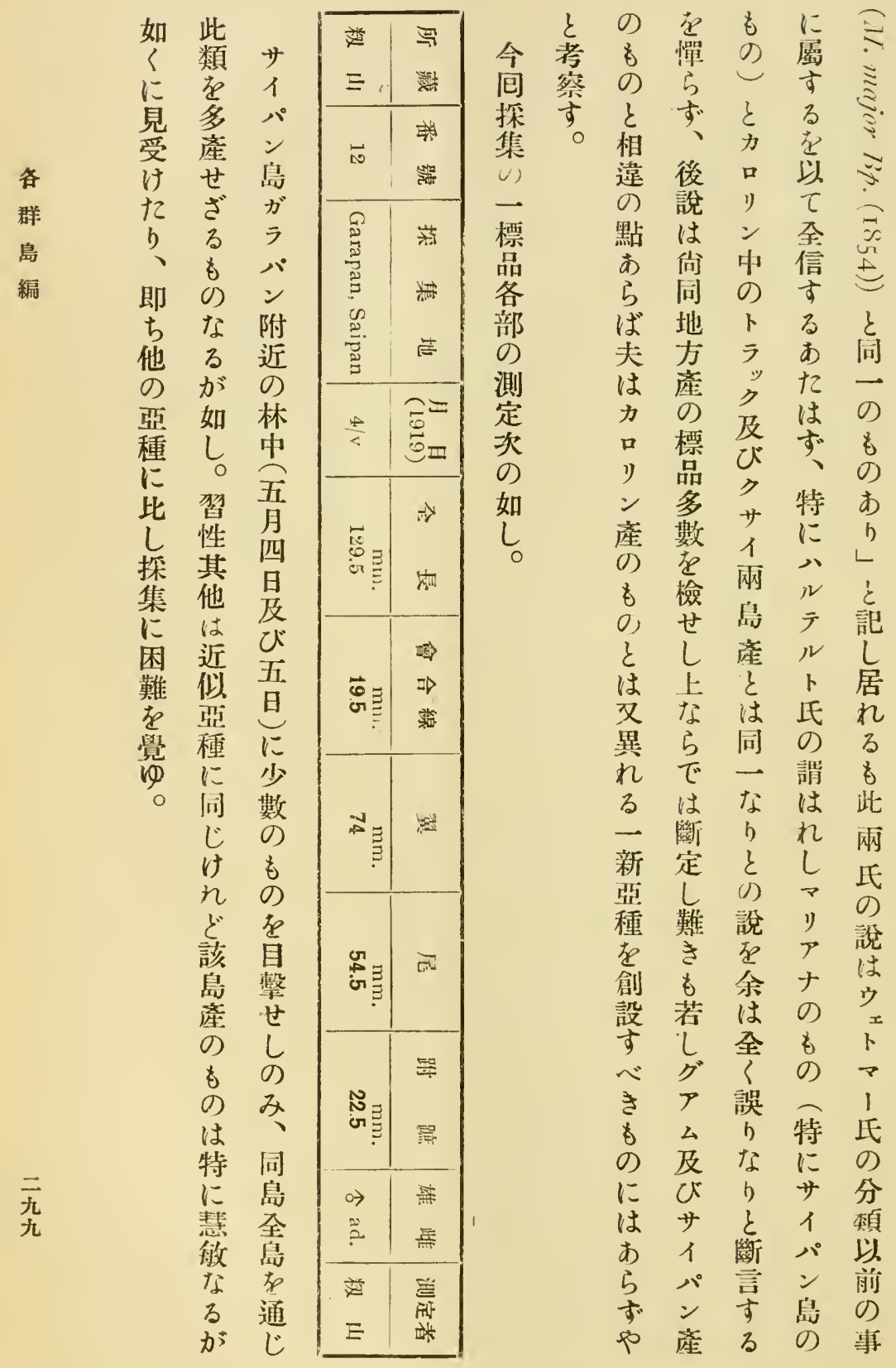




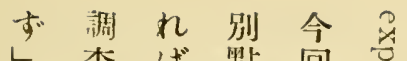

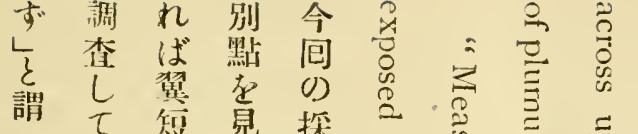

わ田出集采

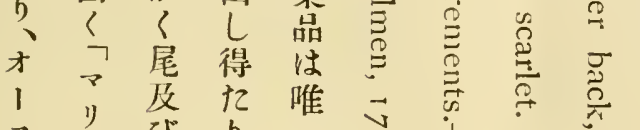

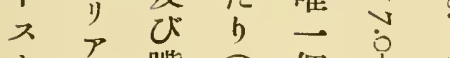

タナ嘴三個市尝

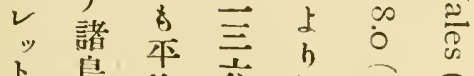

地 岛均六無 $\overrightarrow{6}$ は告短 三 き

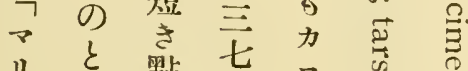

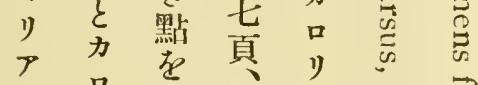

ナ 少指 亞ン

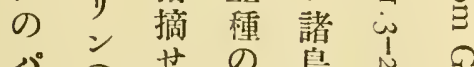

ガハ せ

ン 和引に

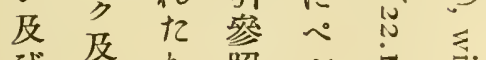

び び

グク裳、磁

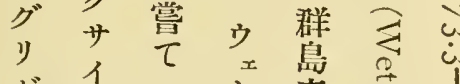

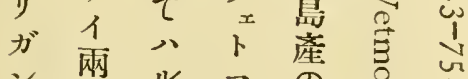

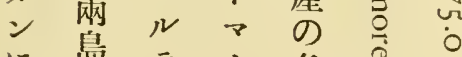

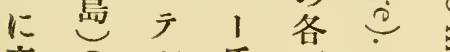

産の的藍导

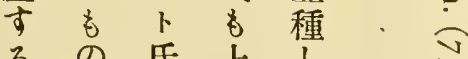

る の 氏 上

子多は訑比

の の五以較

3 間十外

中に個に不

に性の佾充

は其三基分

力差 善な

口在又種が

》認七にら

め類比

產得在夺區

过

范

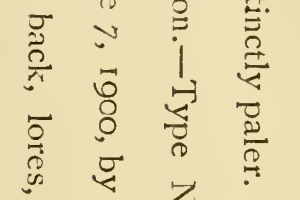

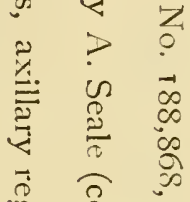

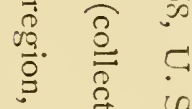

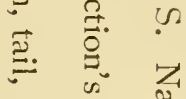

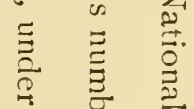

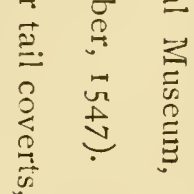

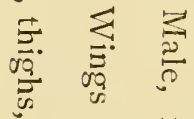

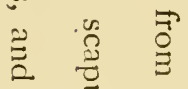

可

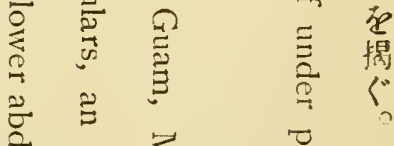

जั

i

?

ำ

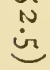

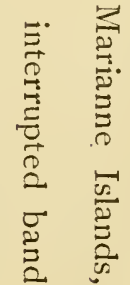

万I

ज住

$\approx$ 別

$\cong$ 亞

㮔

इ

$\approx 5$

:

$\approx L$

$\approx \sigma$

以

$\stackrel{0}{\varrho}$

○左

原

訅

○載

ڤ్

近各

年 群

島

,

政




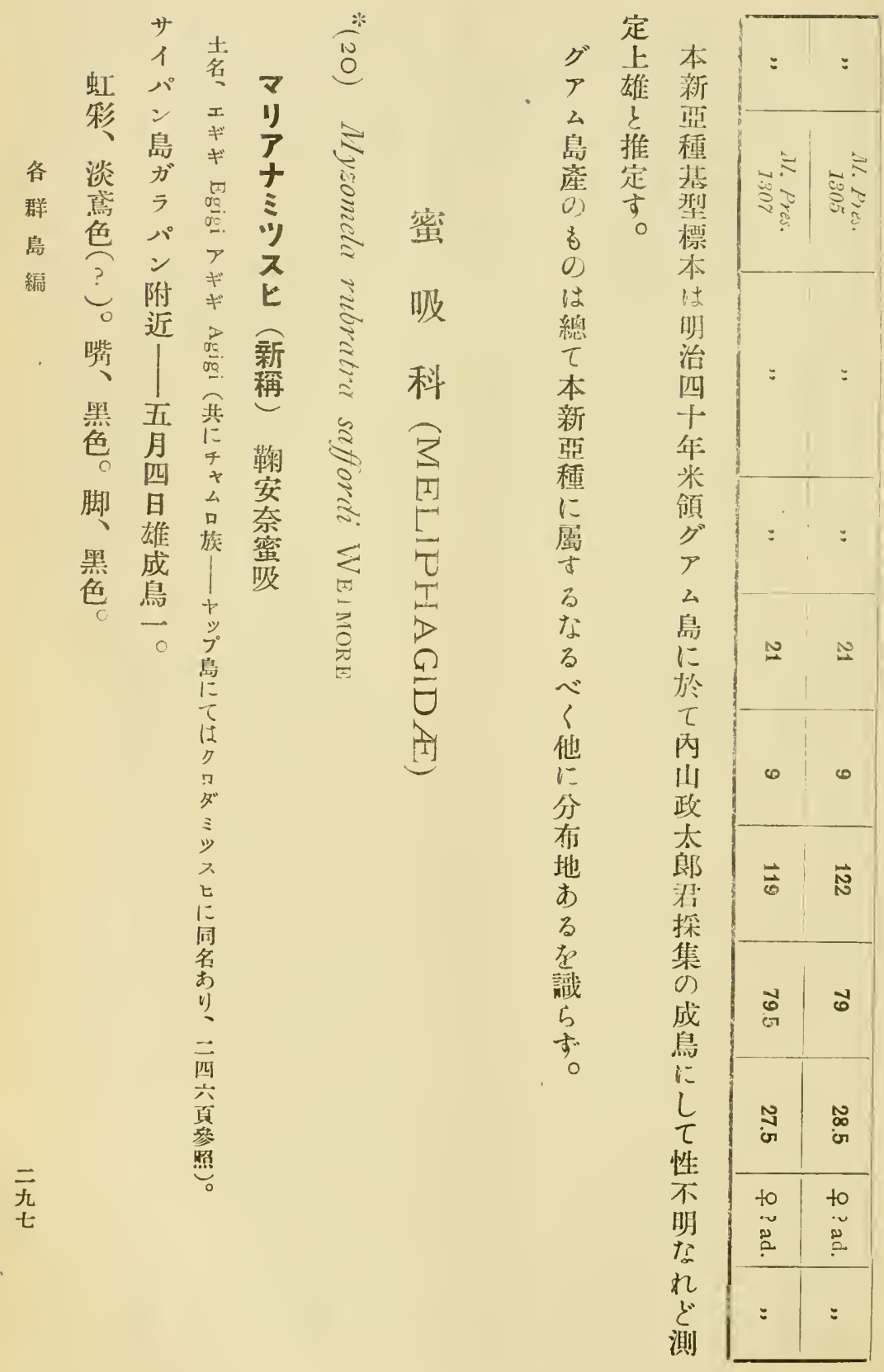




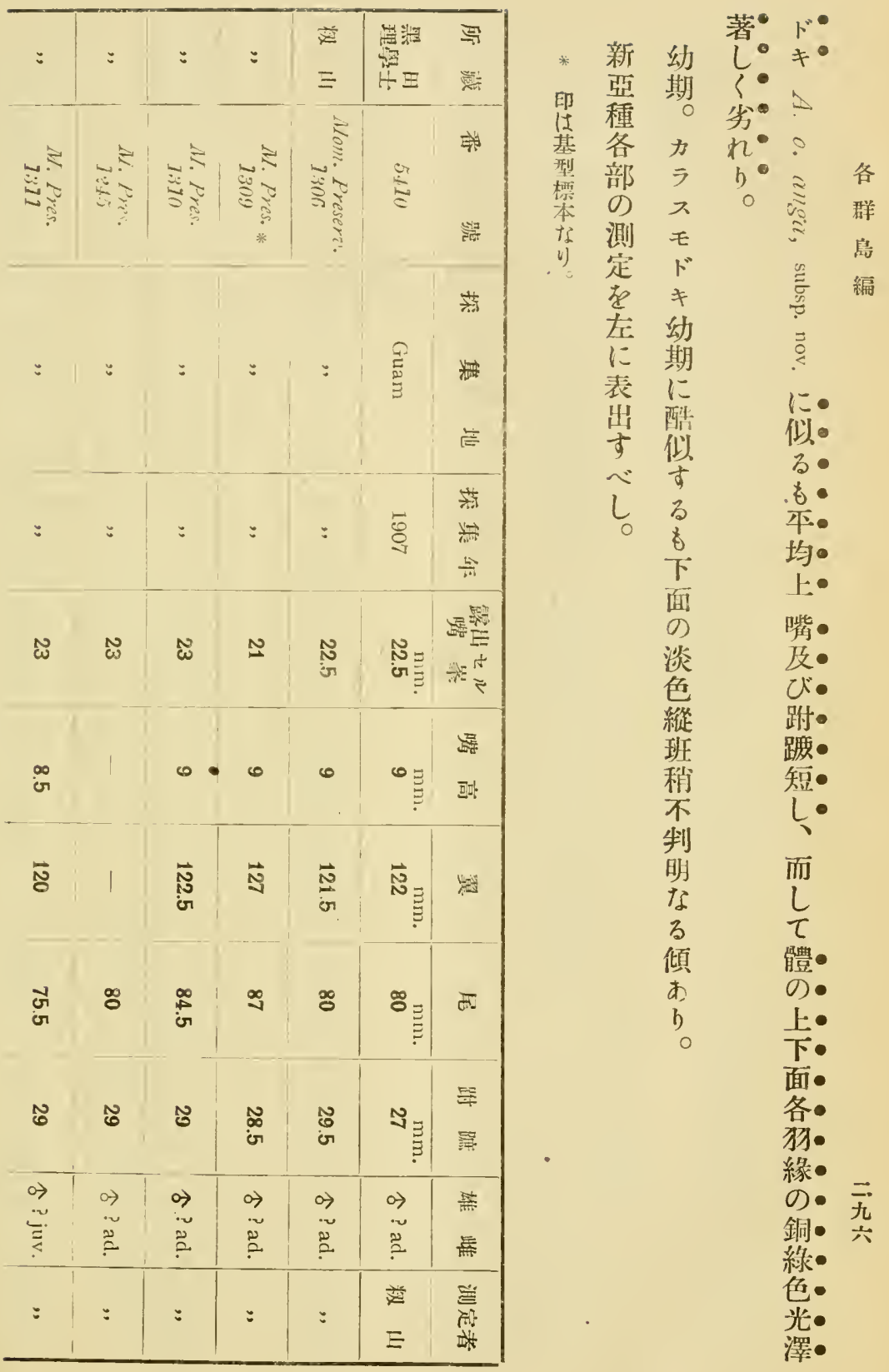


な 成本名

す烏新名

而色種!

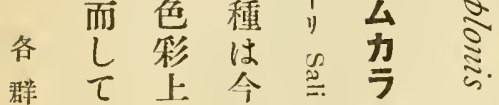

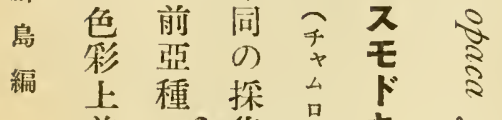

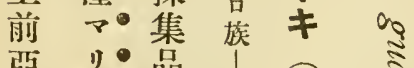

严 尘・品|竞

とナ・あ 1 亞 .

毫力・ら種芯

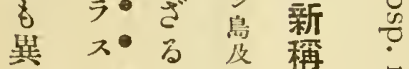

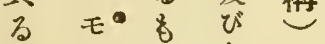

事 ド・同产

なキ・時 プ思

しに・島安

○ 烸・發七舞

各似表は踏

部す・眇烏

の る・る種 第

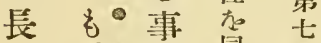

巳嘴之名㘣

は短也世名 $\mathrm{E}$

卜

₹ ᄂ 0 业 成

ッ で ぶ 鳥

及低・云部

オ゙愈页頁

$\checkmark$ 均辛

个短”。頁

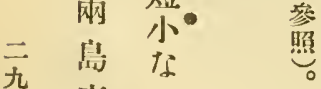

五產了

力・衣

ラ・相

ス・違

モ・點

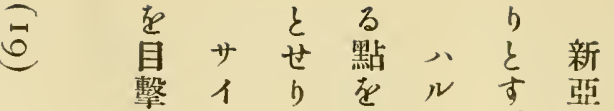

せパ

りン摘 ル 基

に兒 せ $\begin{array}{ccc}\text { 型 } \\ \text { ら }\end{array}$

はれ士本

て しは は

尠 है サ

加 分

5 粠 パ

ざなン

る さ帛

है ऊँ の

の り है

な き

万人教

が 即 グ

如 ち 7

今 幺

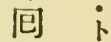

[ii] $\overline{7}$

パ 博 ラッ

ン 士 パ

附 の 站 ン

近

の

林

中

五.

H

थ

日

及

¿

五.

H

vis

$\tau$

栄

に

此

種
名に

譽 ペ

の

め 諸

新岛

留 童

程京

名比

は 較

比

J) $n$

姓嘴

老厚

探〈

用棿

す 長

3

事
意 1 パ
上

如

犬

正

年

7 .

月

五.

日

$+$

パ

力

ラ

附

近

I

ダ

に

$\tau$

獲

た

る

雄

战

量

广5 


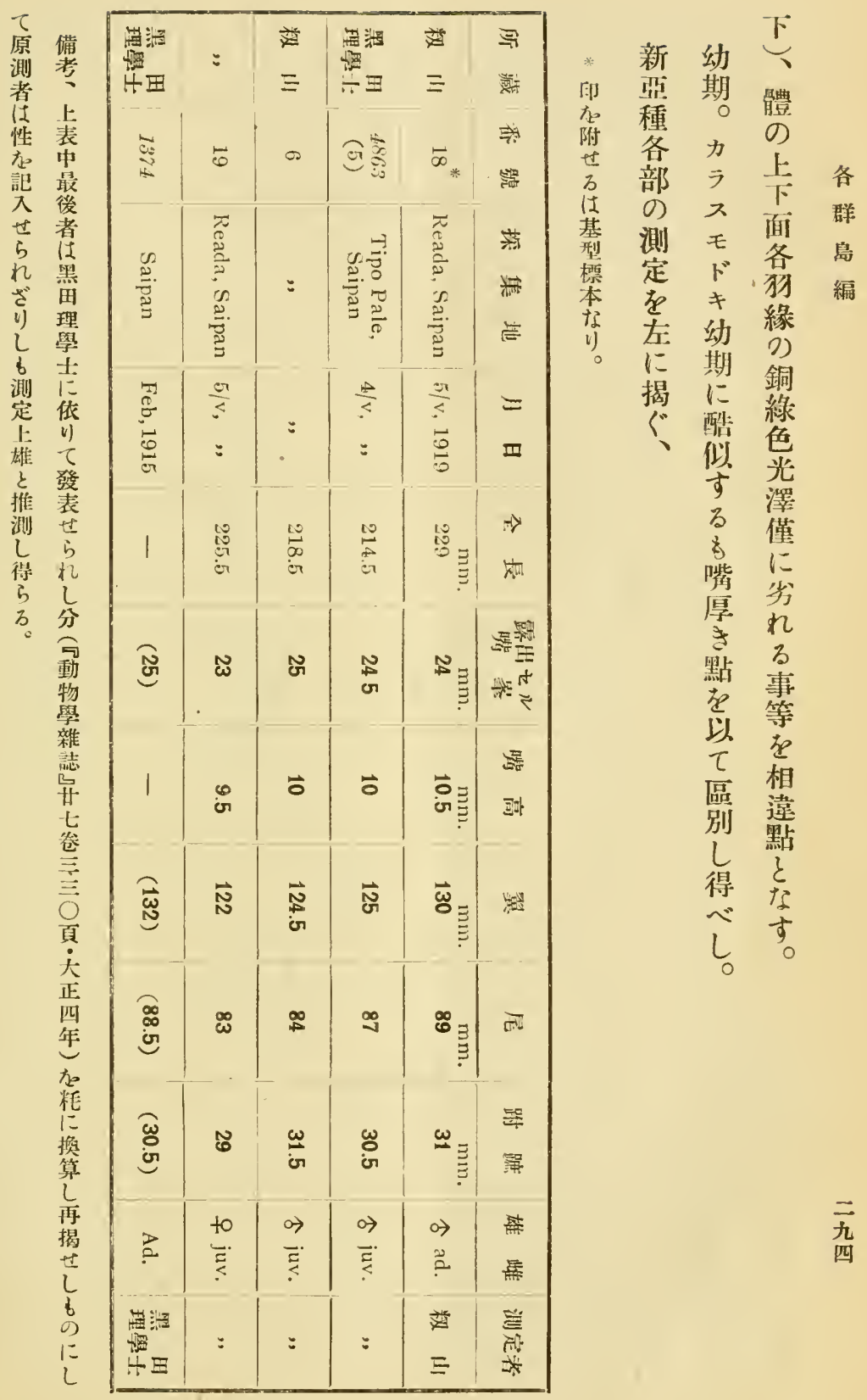


比にあ 恶・銅”1

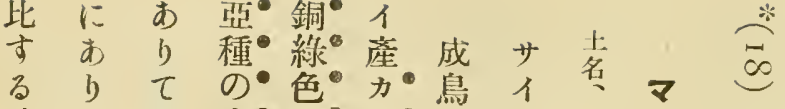

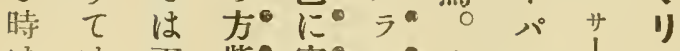

はは兩紫富、ス・クン リ

各嘴九亞色 み・モ・省島

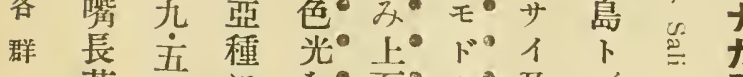

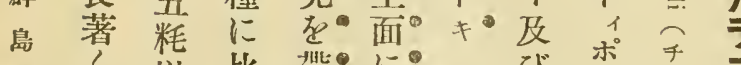

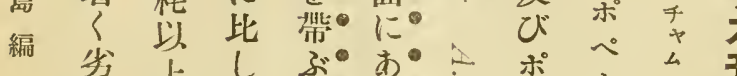

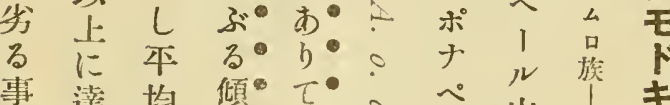

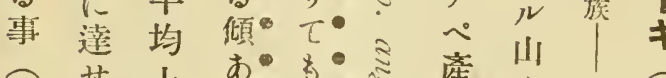

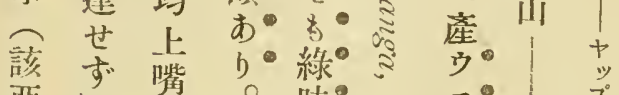

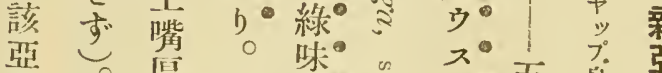

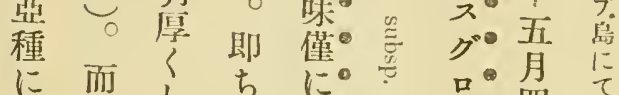

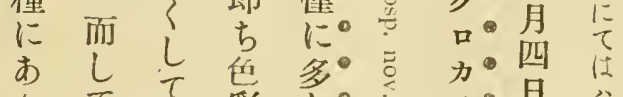

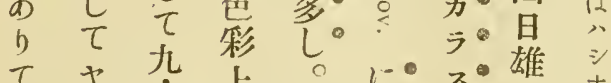

亞 今.

て

はプ三兩後酷・モ・方が鞄

露產 惡留似 ドの方

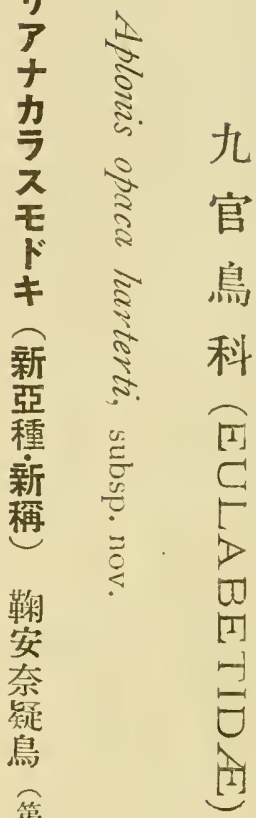

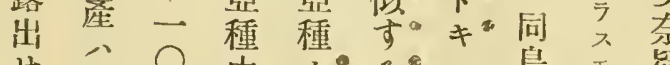

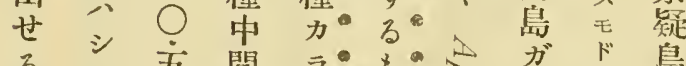

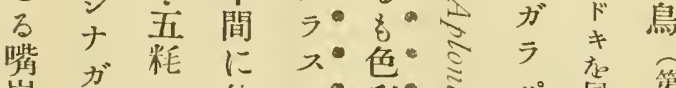

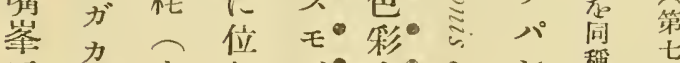

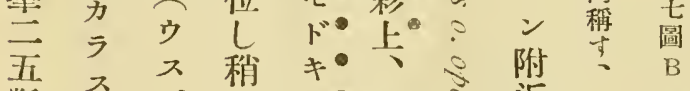

粍スグ力秒キ・附さB

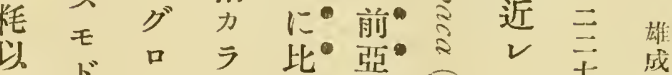

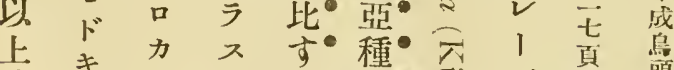

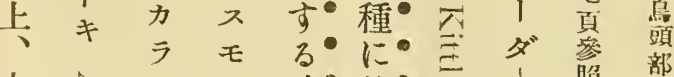

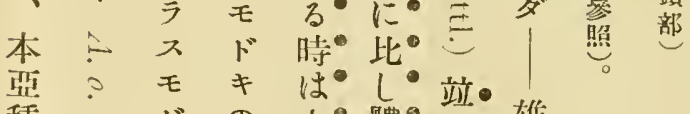

種さドの比體雃

にミキ方唃の・市二

あ ミ站にの・节 ラ

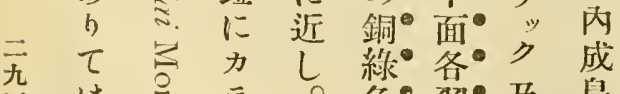

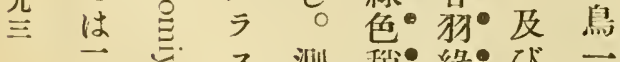

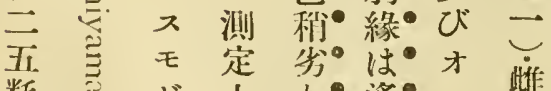

粍こド上り・遥をレ雌

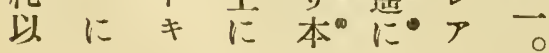




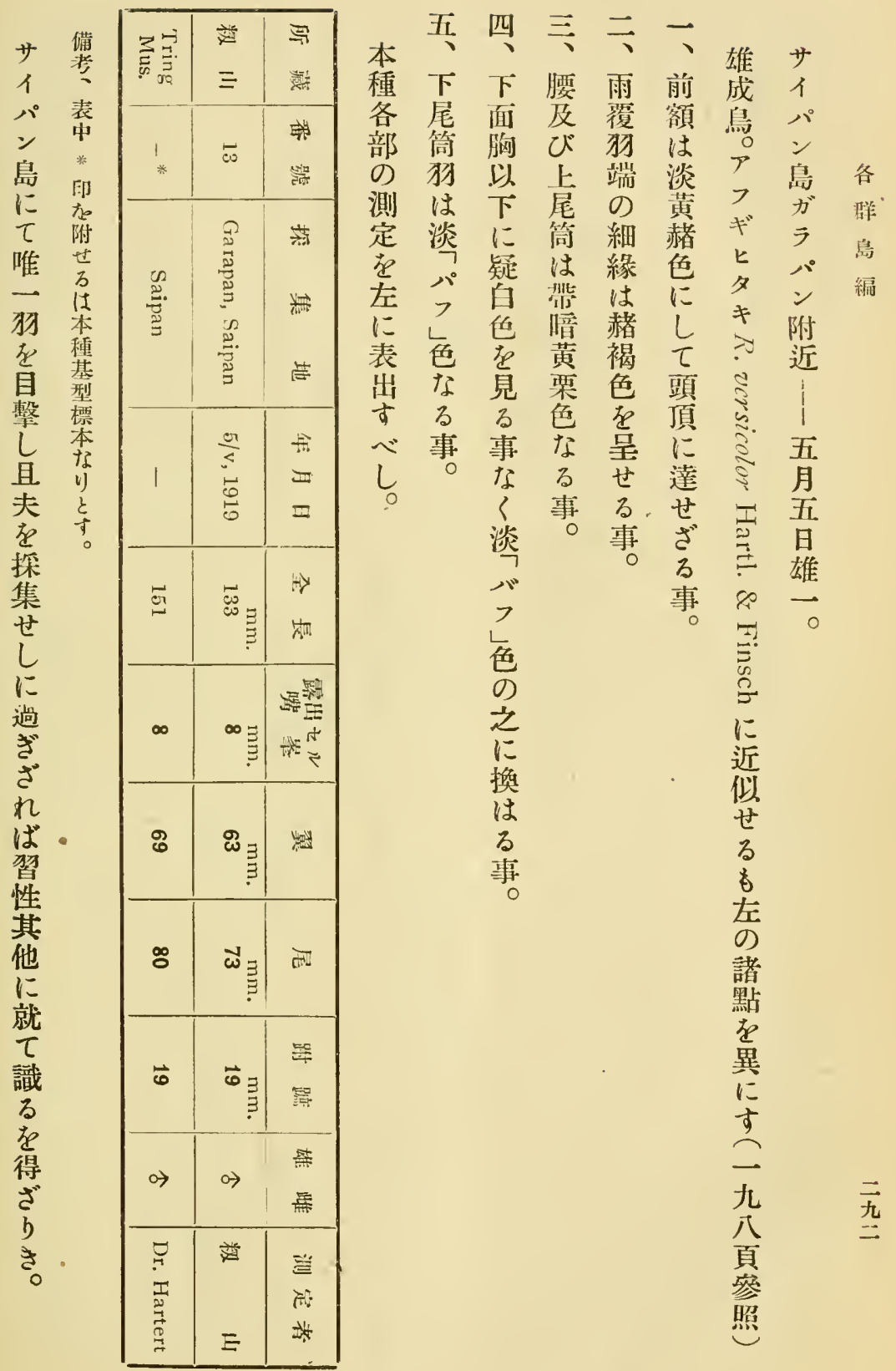




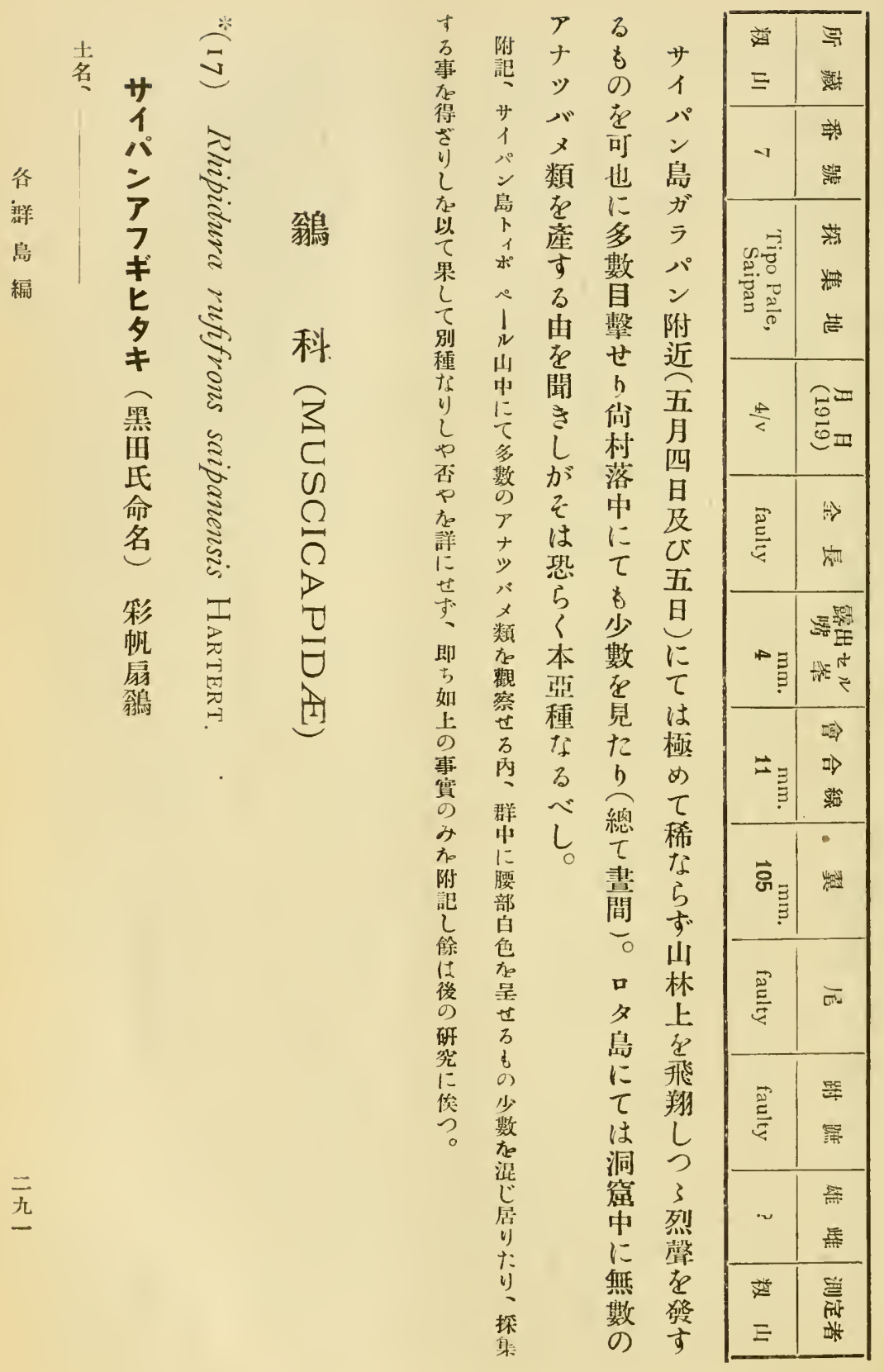




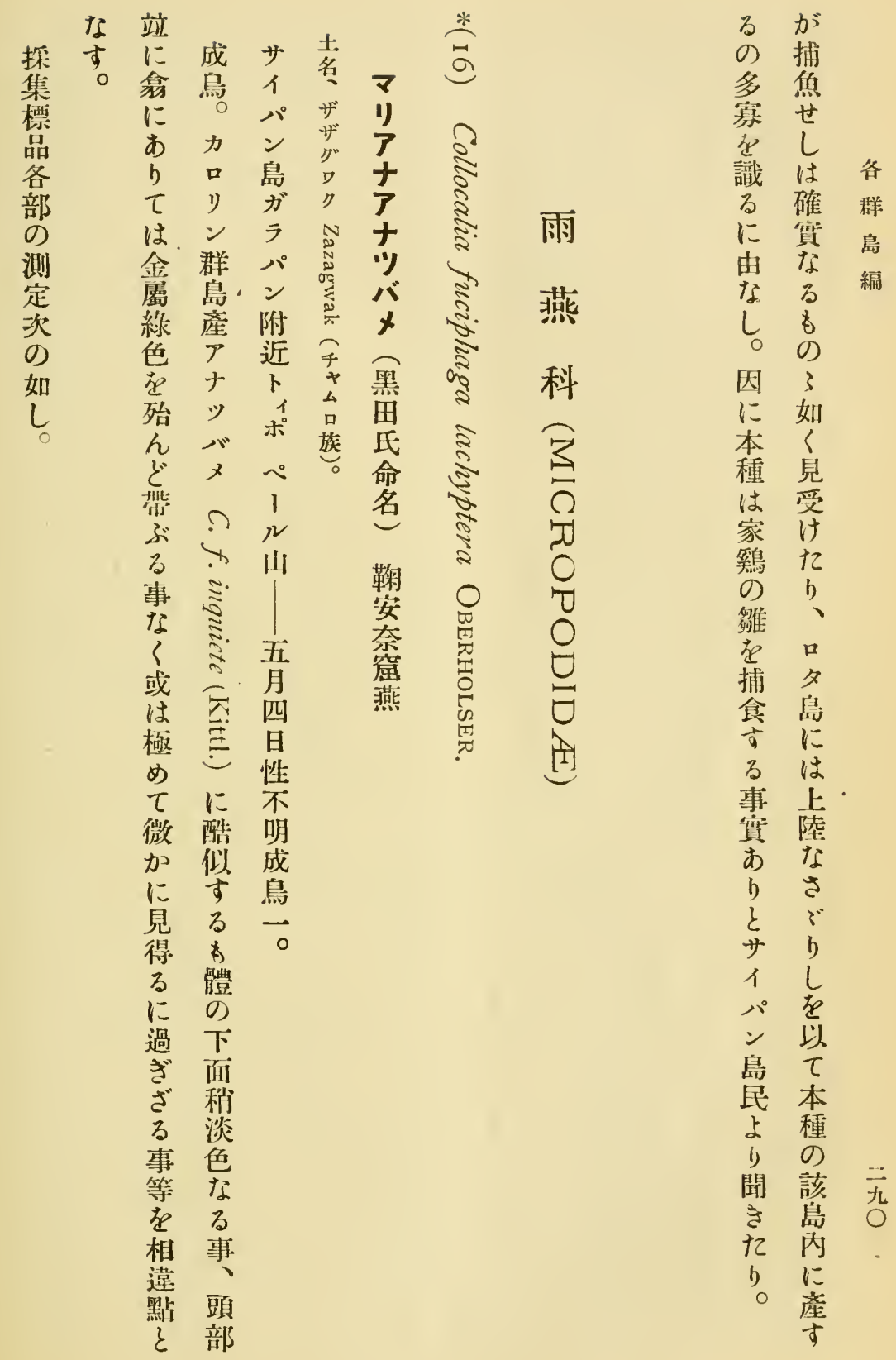




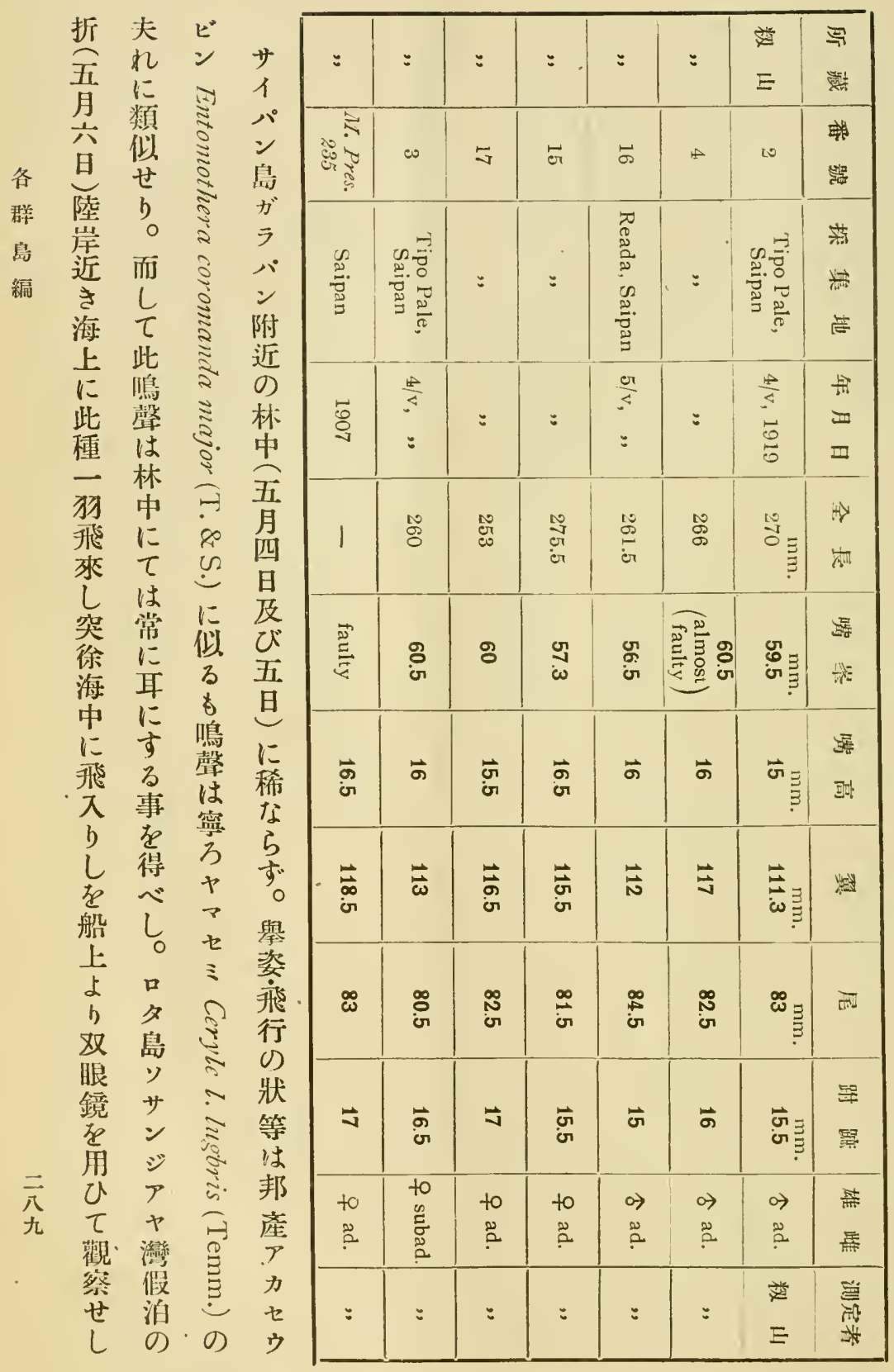


b の

本 0 䕎 幼㭃 種色鳥期

部

の) 紋 需 頂

测芭雅の

定疗方白

左在は色

に る 灰に

表 事台僅

出 等 の 色

すに點に

べ依 あ 淡

りる 綠

て事藍

成色

鳥 上热

墨确 べ

る週吕

ᄂ る 腤

再輪褐

黑に若

田带了

理帶㥙

學 黑 石

士色 板

動 あ色

物事る

學事 班

雜度 紋

誌 頭 混

第 頂 在

世住

学白

曾色

㫐多

上少
し 帶苜同後同少切

ぶ雌は色部色し狍

耳鳥掌不立犲混外

牙。明年軸じ侧

及拿綠億刎黑 但數各

ひは寻なは色但犲群

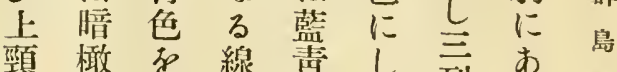

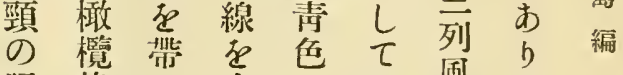

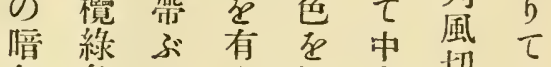

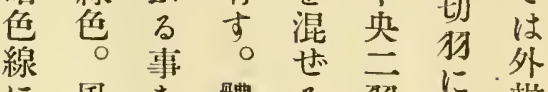

に風あ體る证 ま辨

あ切りの鼠以 以市に

り雅下黑外兄隌

七站又面色口儿褐

もに個は、市共色

茜 尾 體 總 眼 b 基 部

藍訝に七下て部な

色に依白には䕎有

にあり色尚丽褐

乏り事死稍辩色必

して貫呈罡に残に゙

くは上す黑暗餘々

乙雄綠。色色璂

七成色本足緣總他

綠鳥腃種混飞的の

味のち雄蓑”有美諸

勝夫の鳥。すな俨

ちれ

ちよの於 頸 眼 濃犲

りりあけ尔蓝は

、るるる週は白旸

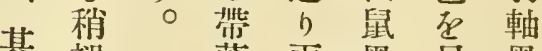

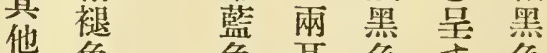

は色色聂色方色

總しは部後上尼內

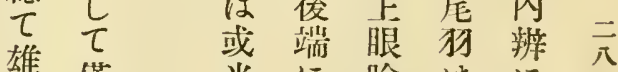

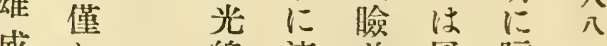

成か 線連前風嗂

烏にに接部切褐

に綠よす支犲色

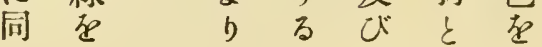




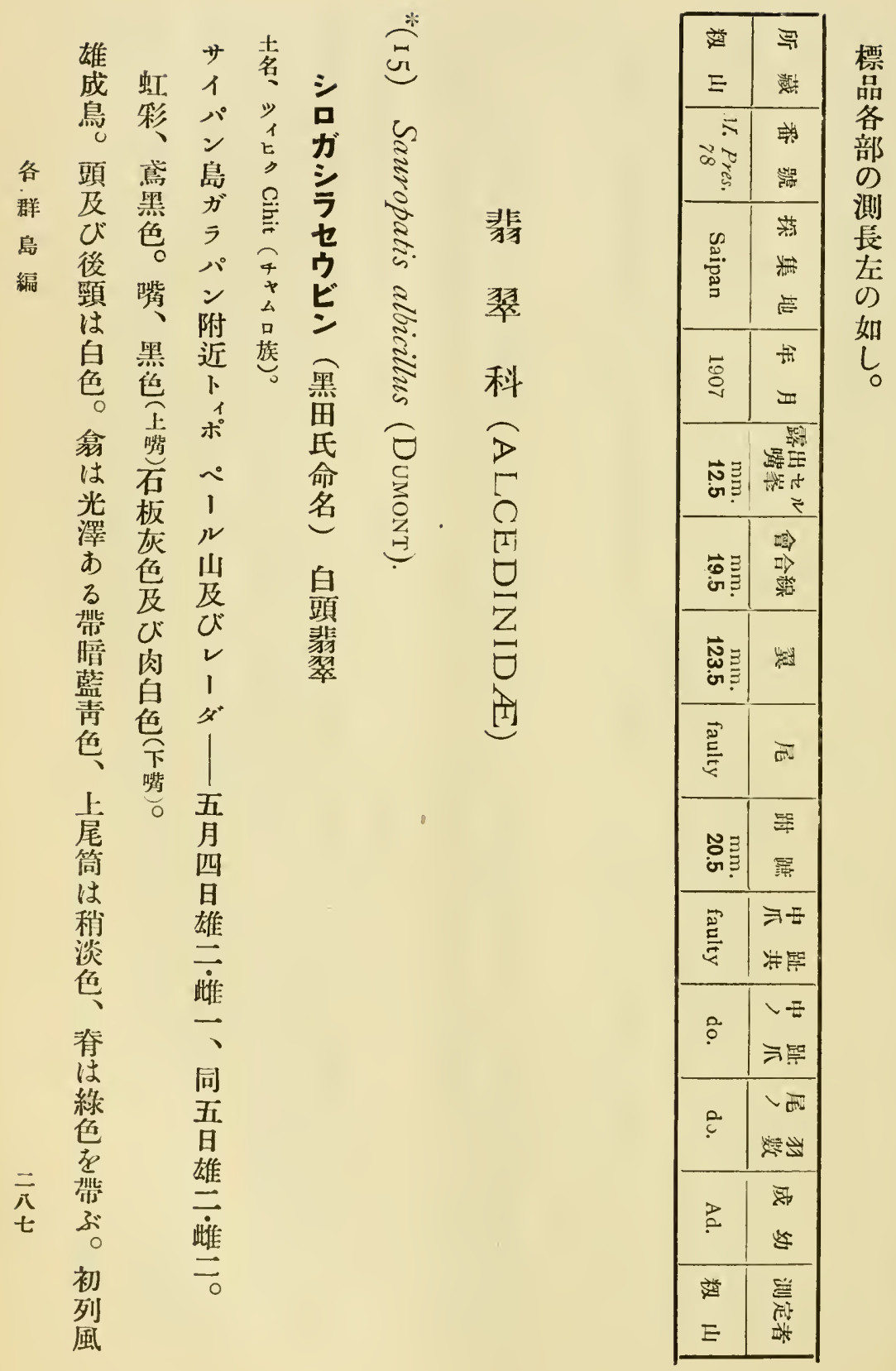




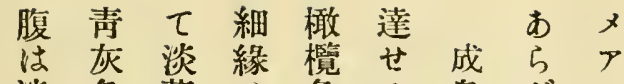

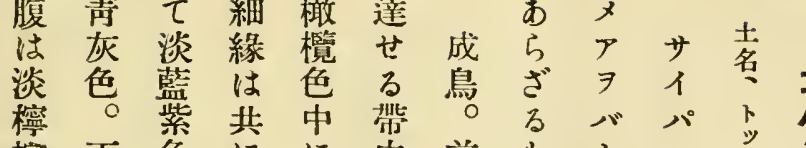

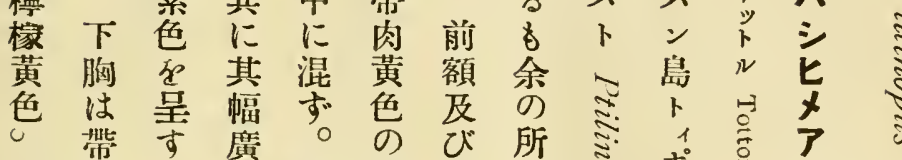

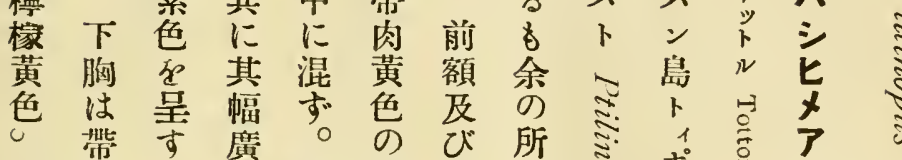
脇暗。翼眉頭荿 は綠尾し要線頂中学へ

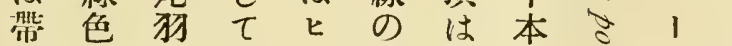
綠中 $中$ 且丈後淡種 色央七淡 $>$ 部䑏

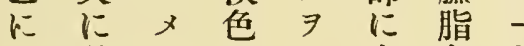
し 稍厂市 バ合色標 $\tau$ 牡 $\exists$ b 1 合稆 है 近 狗丹バ、方後市五 端色卜而同頭部之点

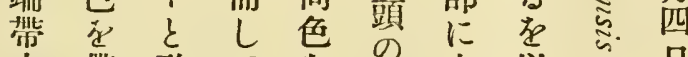
肉帶殆てな殘山怘

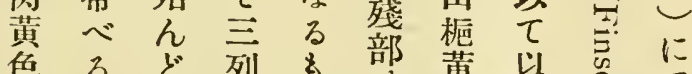

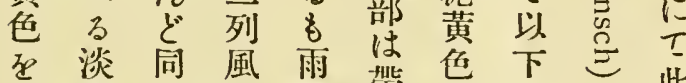

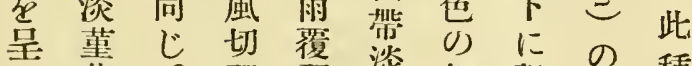
世花。旸旸淡細訅鸣種 り 色腮各各寈緣載騂の ○ 心 は先旸灰等卞音鳴

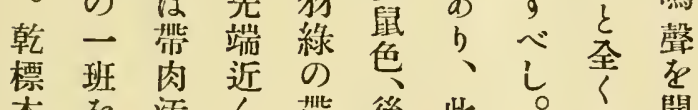
本を污く帶後此。異聞 に構白に黄頭細 あ成色在橄 以緣 り寸、る欖下の $\tau \circ$ 㶊帶色順兩 は上喉紫部次端 嘴腹它色及帶は

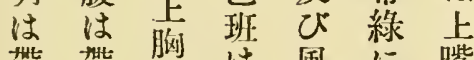
帶帶胸は風に嘴 石淡檪淡切變基 板橙頸藤旸芯部 色肉頸色外拿上 と黄 側な辨の方 な色は的帶眼 る下帶吉黄渵卡品種 


\begin{tabular}{|c|c|c|}
\hline : & $\begin{array}{l}\text { E } \\
\equiv\end{array}$ & 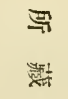 \\
\hline $\begin{array}{l}3 \\
2 \\
2 \\
2\end{array}$ & $\begin{array}{r}3 \\
+2 \\
3\end{array}$ & 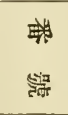 \\
\hline : & 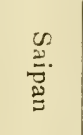 & 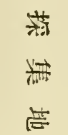 \\
\hline : & $\overrightarrow{8}$ & $\begin{array}{l}+1 \\
=\end{array}$ \\
\hline $\overrightarrow{\text { ir }}$ & $\overrightarrow{0}$ & 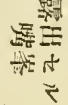 \\
\hline$\stackrel{\sim}{\mathcal{U}}$ & 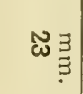 & 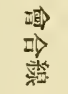 \\
\hline$\vec{\omega}$ & $\stackrel{\vec{\Phi}}{\overrightarrow{3}}$ & 战 \\
\hline జొ & 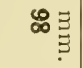 & 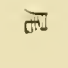 \\
\hline D $_{\text {G }}$ & 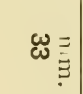 & $\begin{array}{l}\text { 돈 } \\
\text { 䎏 }\end{array}$ \\
\hline$\underset{\omega}{\omega}$ & $\stackrel{\infty}{\infty}$ & $\begin{array}{l}シ \text { シ } \\
\text { 䧊熙 }\end{array}$ \\
\hline$\stackrel{0}{0}$ & ०) & 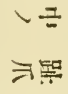 \\
\hline $\begin{array}{l}\vec{\omega} \\
\overrightarrow{.}\end{array}$ & 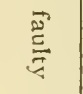 & 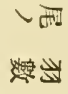 \\
\hline 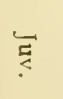 & 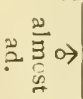 & $\begin{array}{l}\text { 霹 } \\
\text { 亚 }\end{array}$ \\
\hline$:$ & $\begin{array}{l}\text { E } \\
\text { E }\end{array}$ & 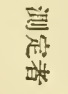 \\
\hline
\end{tabular}

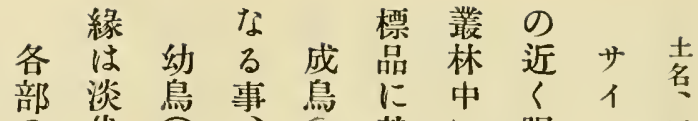
の代 営 雄就に眼パア 测赫當下雄き逸前ンパ 定色生腹。年否白力 左在声部ヤ左遂過ガ

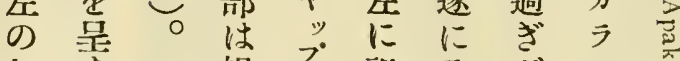
如す么褐 文記 入 し。十色座述手b向 體ジ点公すす附や

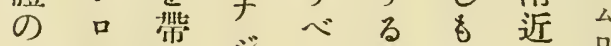
下 バぶ ジ し点探レ族

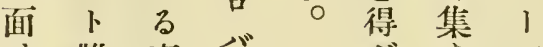
は雌事 バ ざず 稍U) りるの 黄二嘴さ き む林 色年及 文 た中 味息び 品 にに脚き $\approx$ 似 しる 秒至

○長的禁 $\overrightarrow{\text { 日 }}$

二頭大昰喿目芯

辛部广

六U) る

頁票事䈓等

照急褐等 站

○ 淡 相

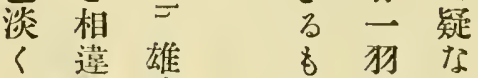
拿器成拙のさ はと鳥藏林此 业なに劣樹種

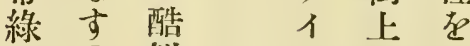
色○似 パに目 栖 三 す ン 見 撃 め 云る 島 る せ 七五 \& 產冴 b

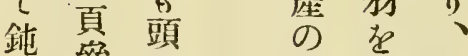

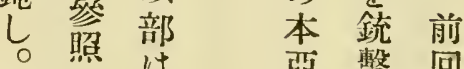
雨篎葄回 社濃 犽色

に寻

あ 雉 ら䧳に ざ各て 


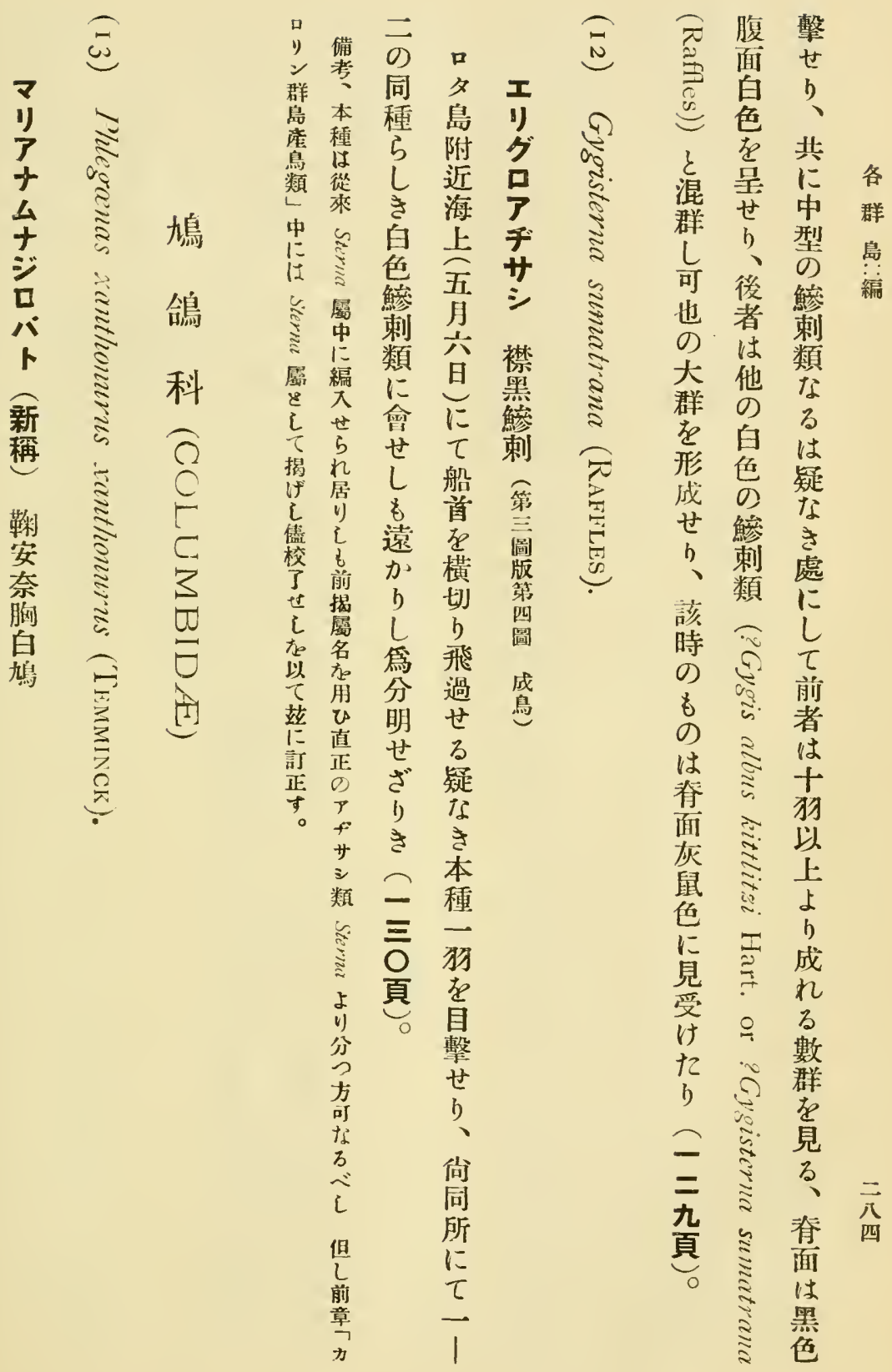




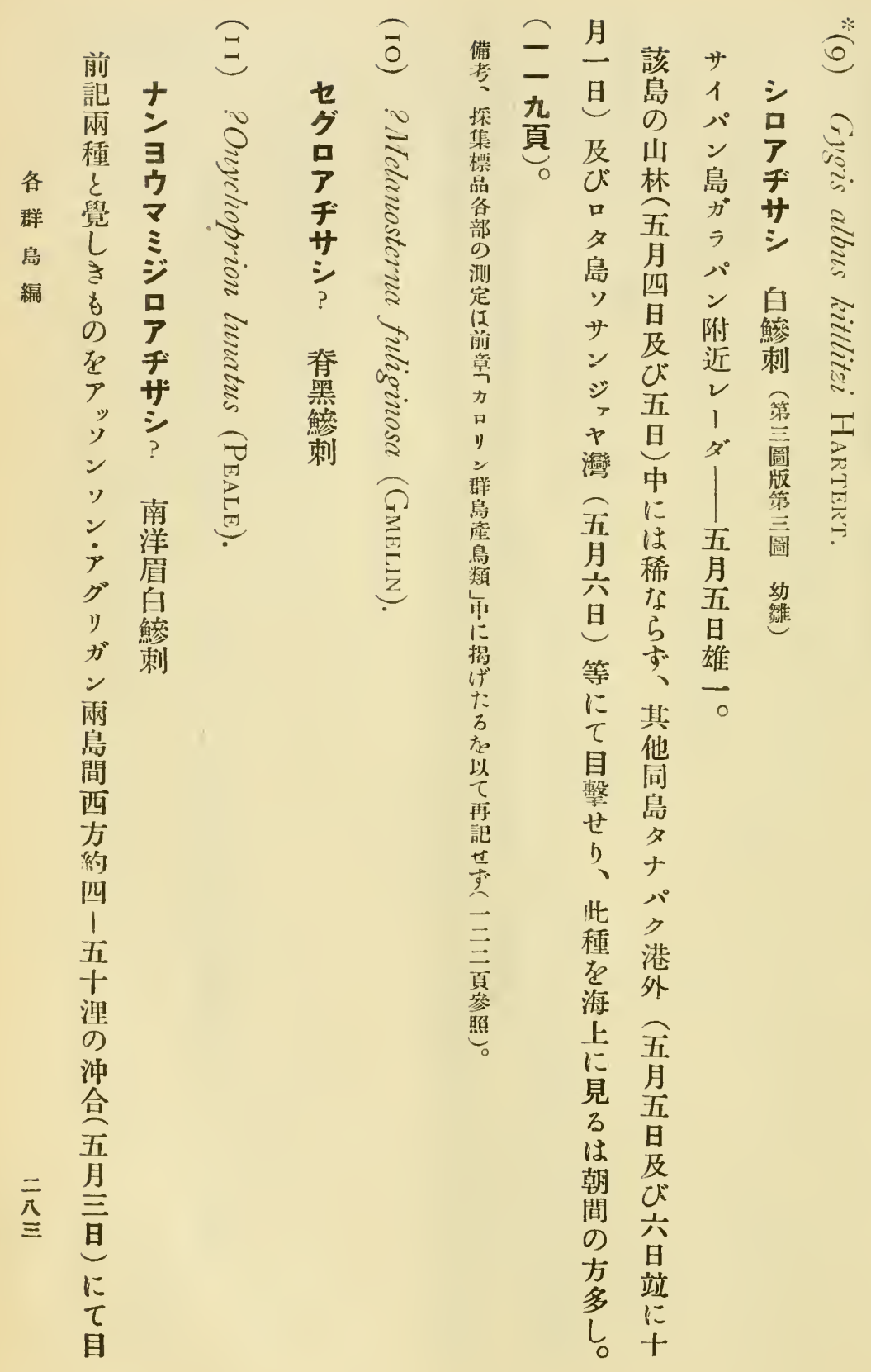




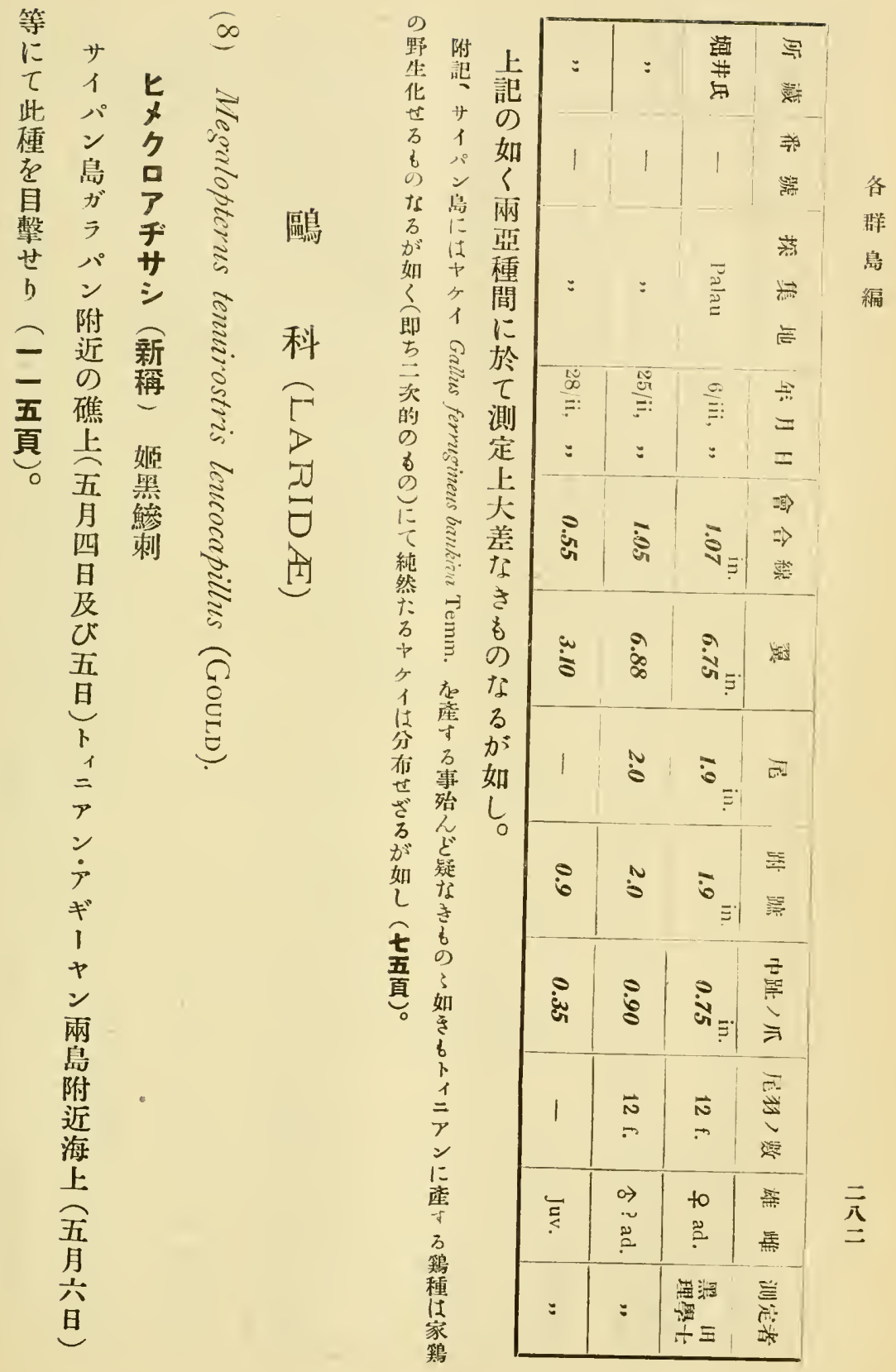




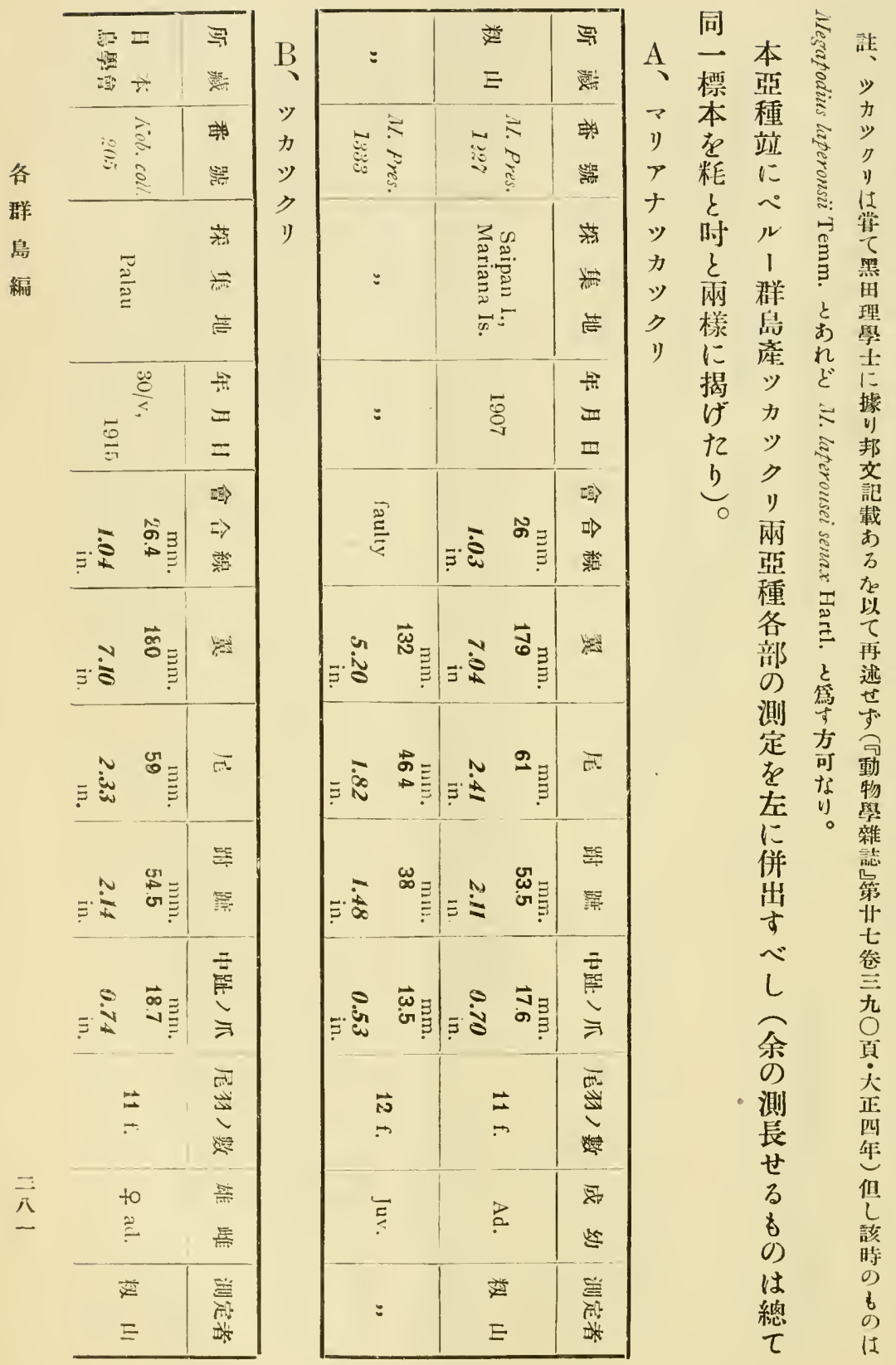


有幼元成 此

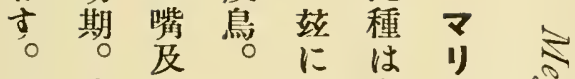

胸成びへ 附今学

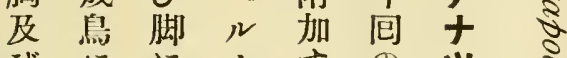

びにに 1 す

腹似 あ群る旅力怘塚

はる b島事中

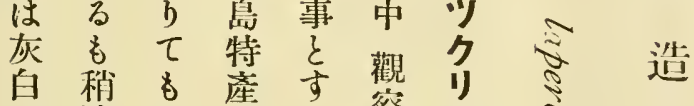

色荡色同なな

を色导䒘

混頭濃 カ

ず部色 ッ

脚 $\begin{array}{ccc}\text { 才才 } & \text { b } & \text { リ }\end{array}$

趾緣 0

は微令

成 か

泉に

に茶

比色

L 死

遙帶

加

に

暗大

色中

灰

呈 雨

せ 㠅

与狗

に

は

幅

狹

に 墨

集垈 命

に附 前

虽 亞

范 㮔

手認各

†离む群

台害ぎ島

族怘き編

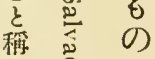

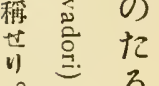




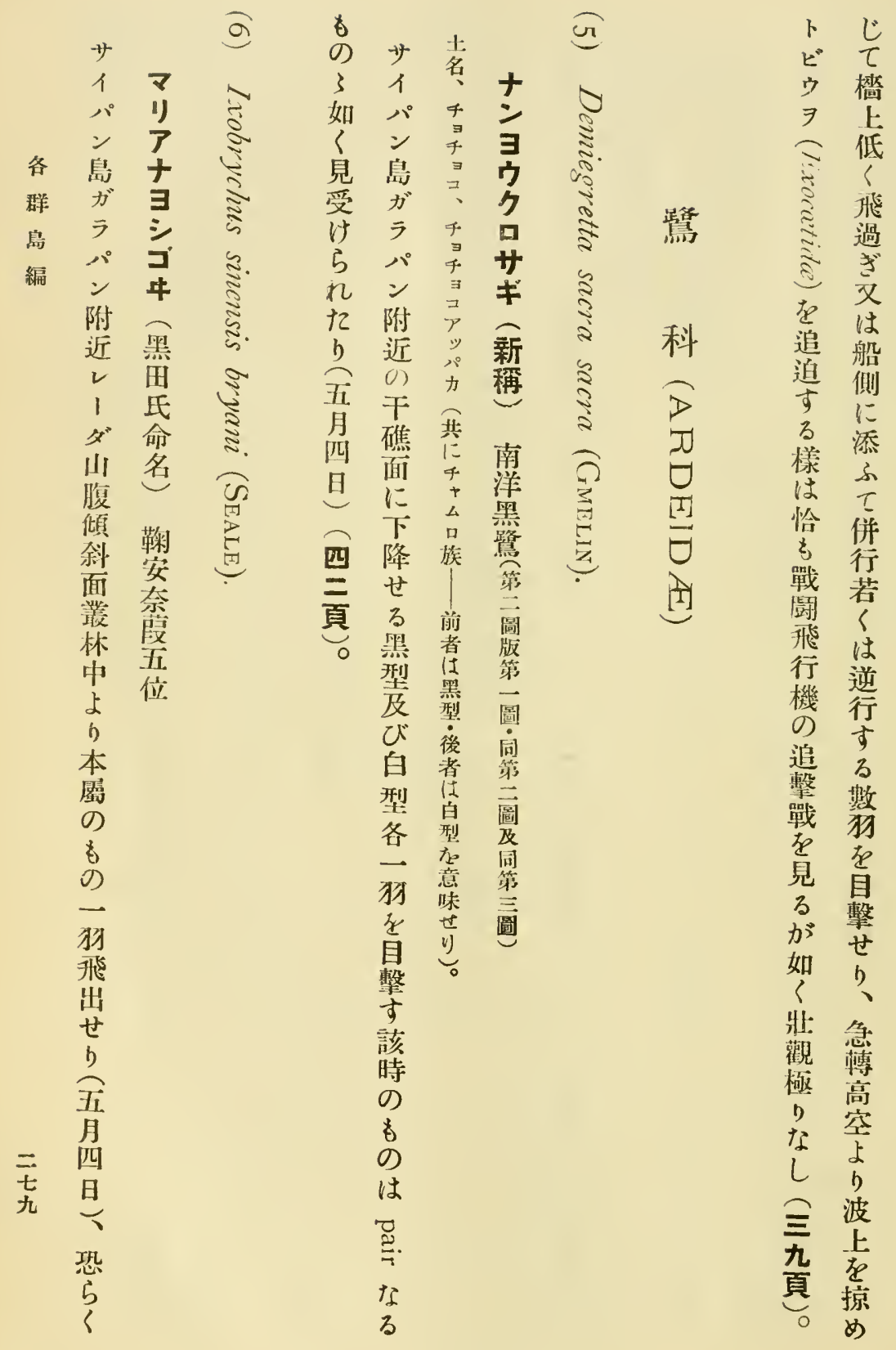




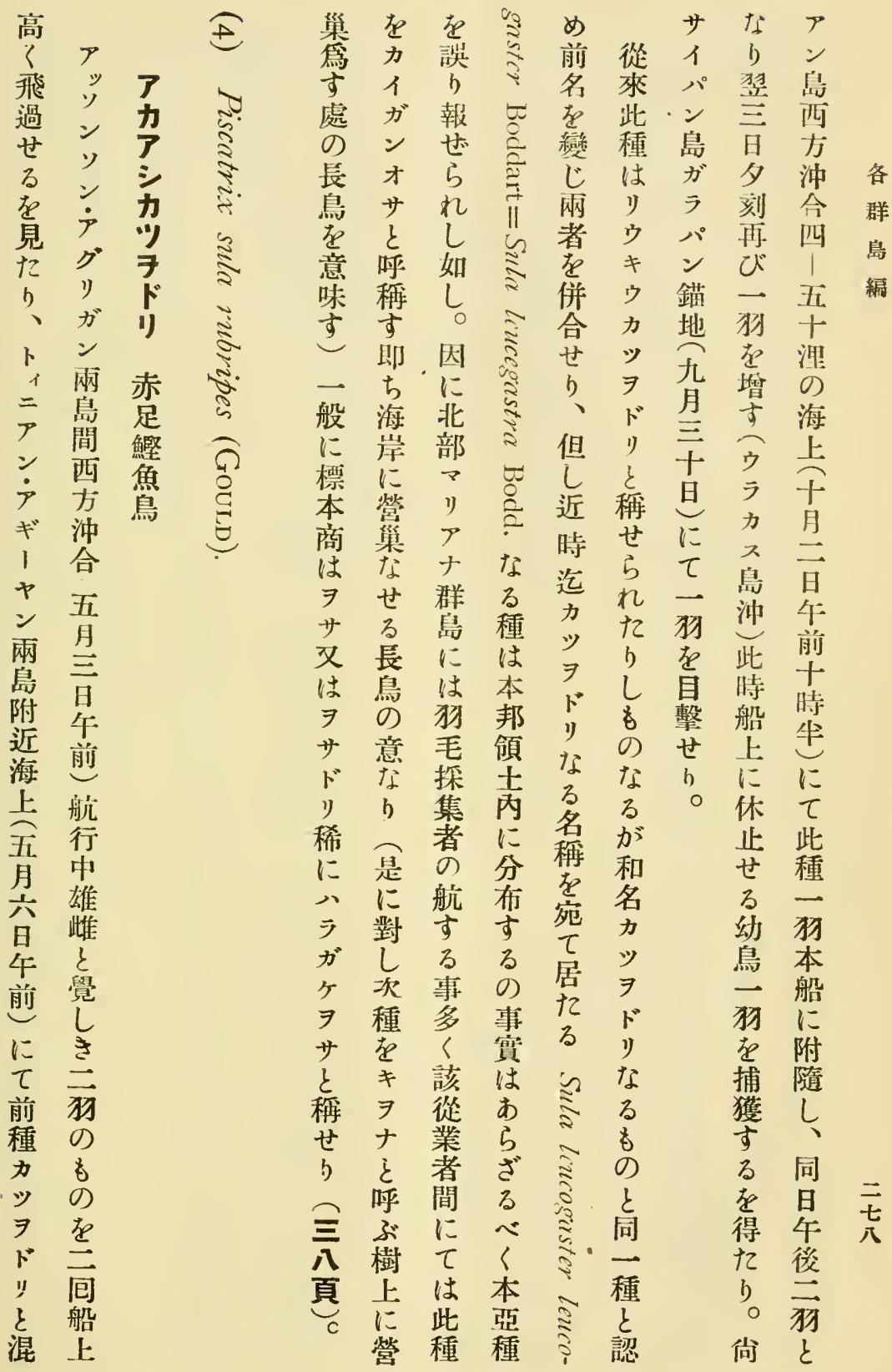




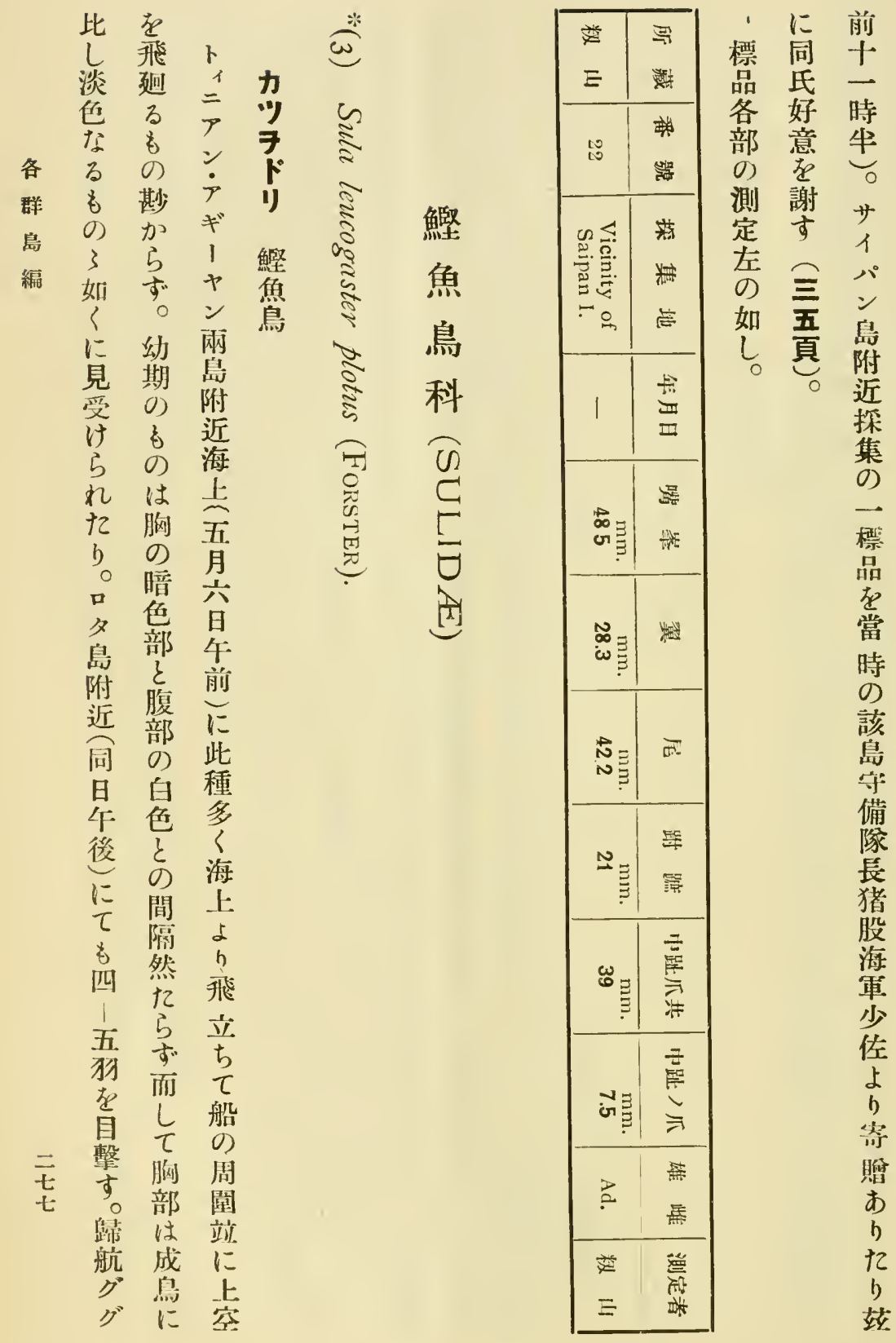




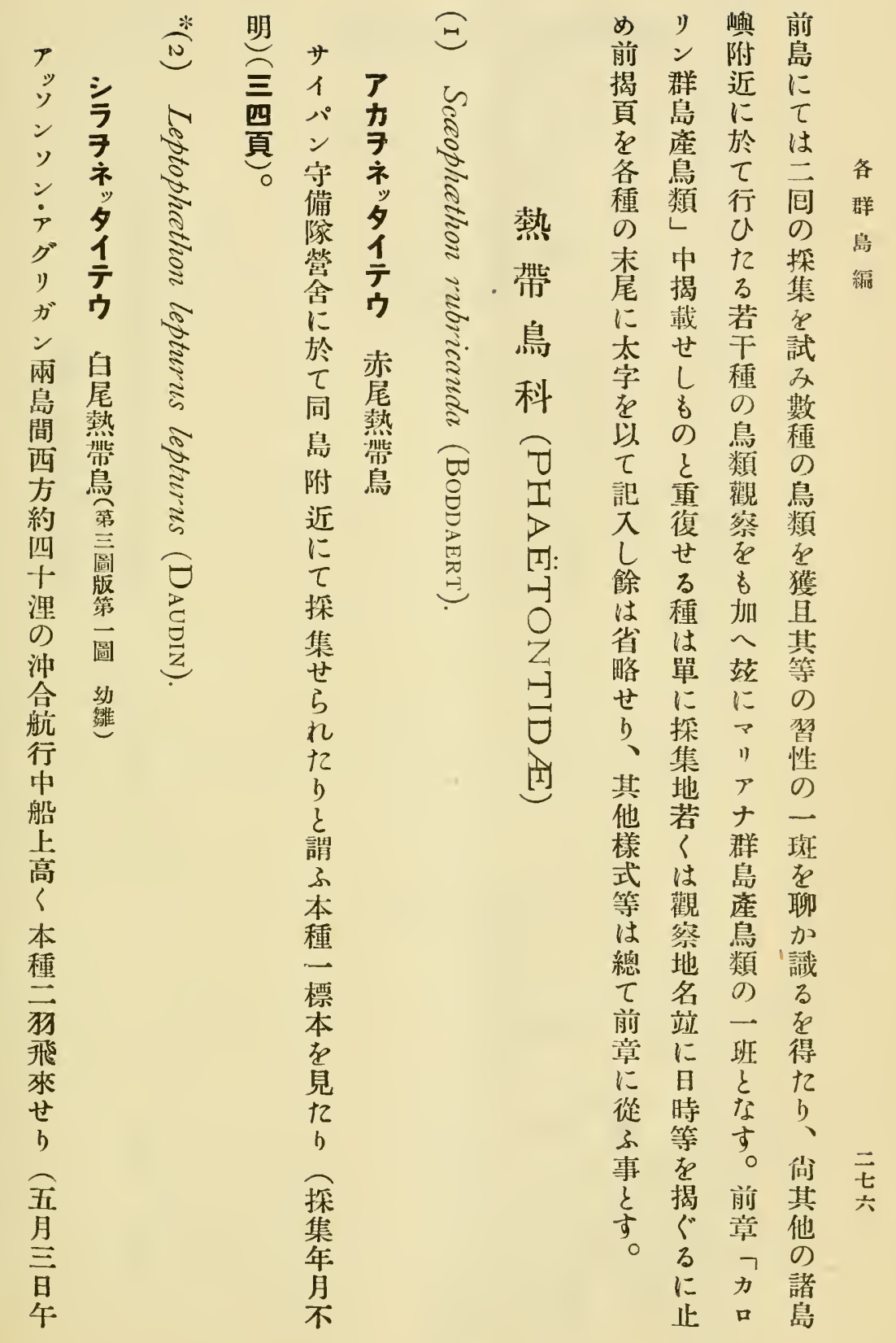




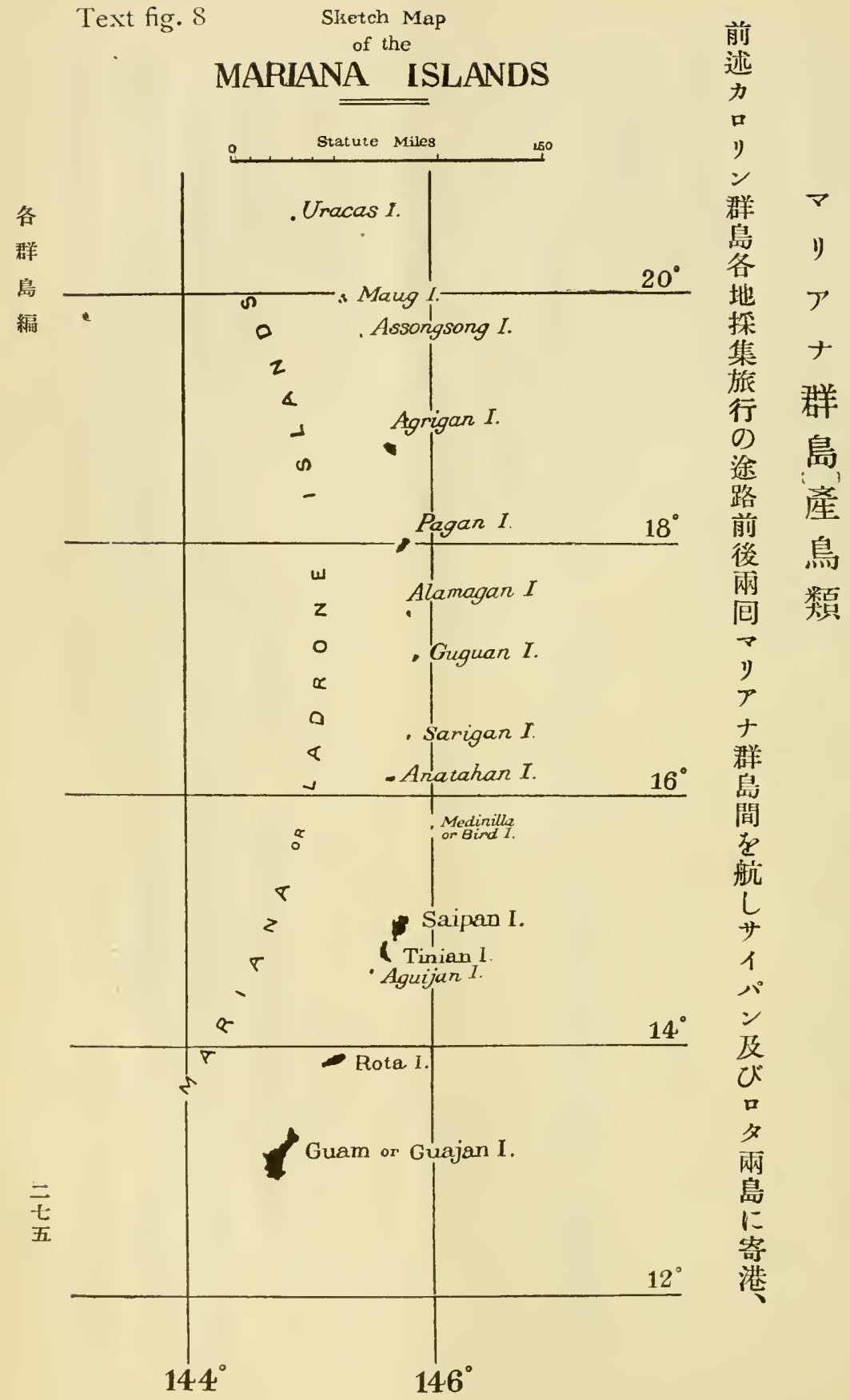




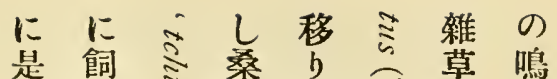

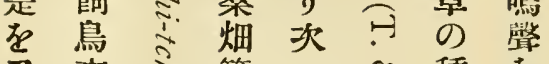

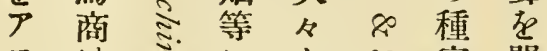
ヨはきにと實聞

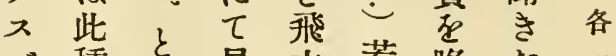
ズ種聞見立若喘れ群

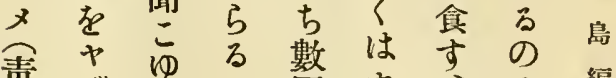
表 省

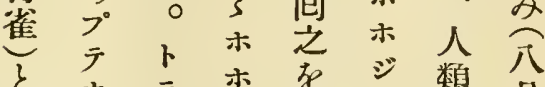

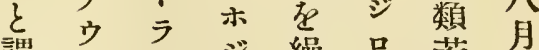

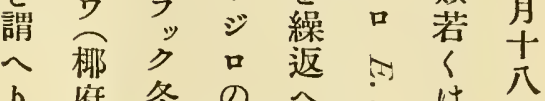

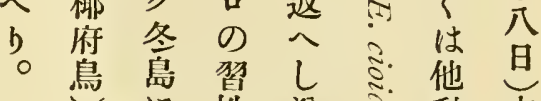
子に性遂灾動本 呼 $\tau$ に物種 雬榴何灾のは

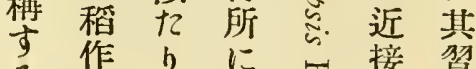
万作 胡に接習

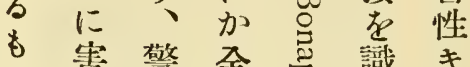
害擎金总識き

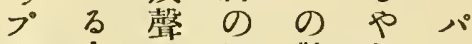
島由は影警邦

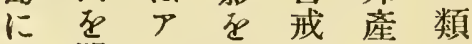

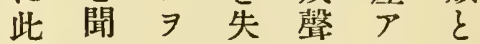
種けジすに 卞问 そどの、似ジ

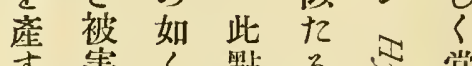
等 万程一は鳴空に 事度韾キ䈉路

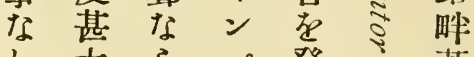
し大ら パ發若

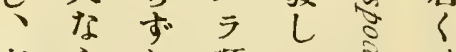

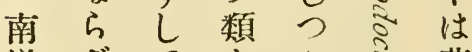
洋ざて そ己草

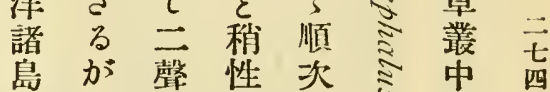

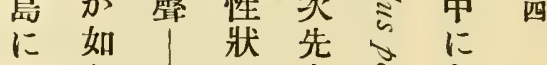

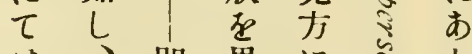

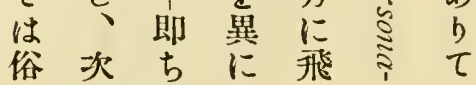




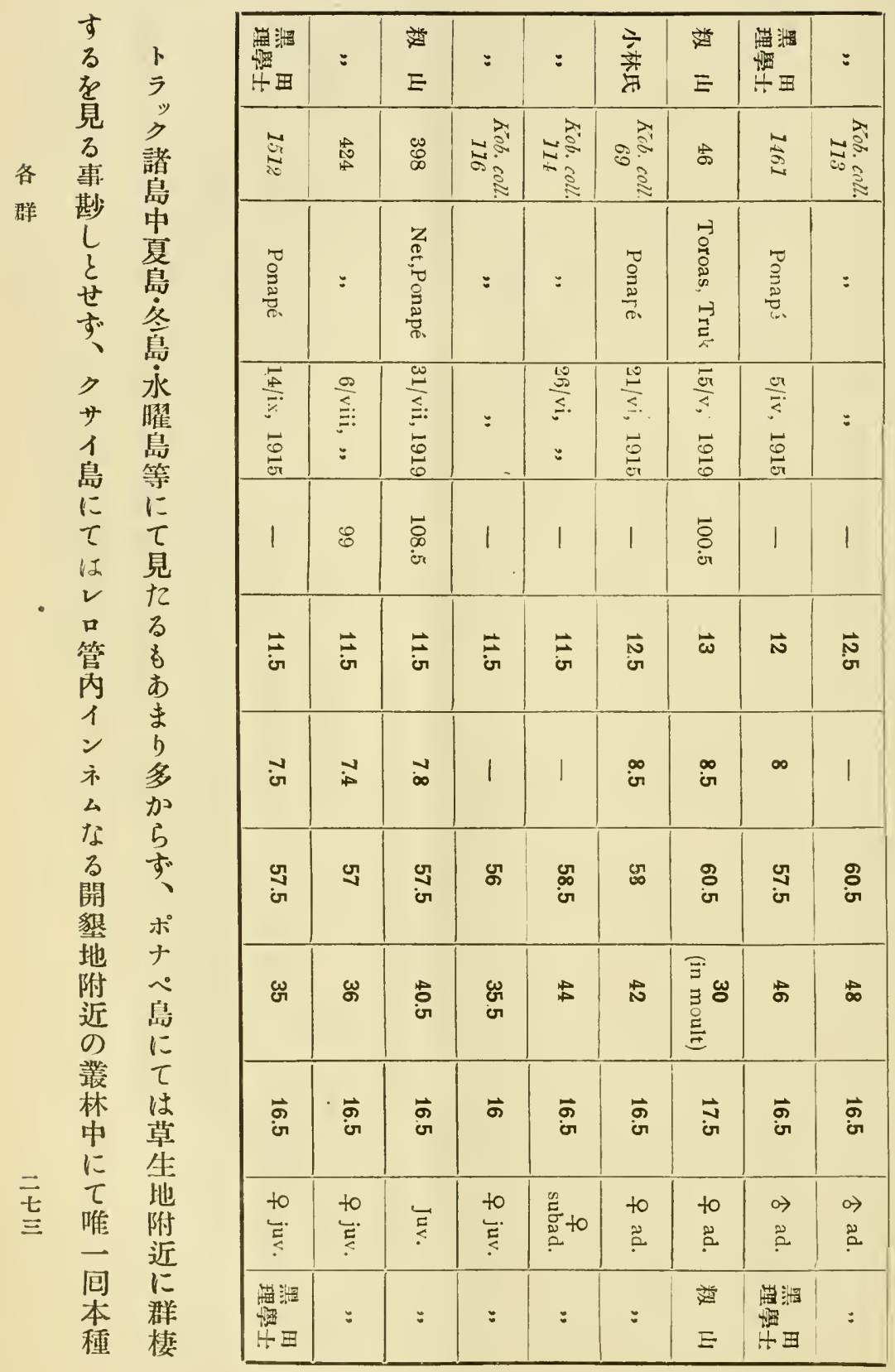




\begin{tabular}{|c|c|c|c|c|c|c|c|}
\hline$\frac{\text { 立 }}{\text { 畜 }}$ & : & $=$ & $=$ & : & $=$ & $\begin{array}{l}\text { 诸 } \\
\equiv\end{array}$ & 汸 \\
\hline $\begin{array}{r}\overrightarrow{2} \\
-13 \\
3 \\
\vdots\end{array}$ & $\stackrel{\vec{P}}{\stackrel{B}{P}}$ & 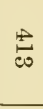 & $\stackrel{\infty}{\mathscr{\rho}}$ & 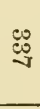 & $\overrightarrow{0}$ & 蛋 & 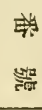 \\
\hline 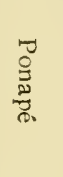 & $=$ & $=$ & 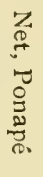 & 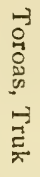 & 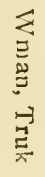 & $\begin{array}{l}\overrightarrow{0} \\
0 \\
\overrightarrow{\mid} \\
\underline{0}\end{array}$ & $\begin{array}{l}\text { 落 } \\
\text { 步 } \\
\text { 些 }\end{array}$ \\
\hline 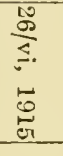 & $=$ & $\begin{array}{l}\stackrel{E}{ \pm} \\
\vdots \\
\vdots \\
\vdots\end{array}$ & $\begin{array}{l}\stackrel{10}{\leftrightarrows} \\
\vdots \\
\vdots\end{array}$ & $\begin{array}{l}\underset{\infty}{\vdots} \\
=\end{array}$ & $\begin{array}{l}\frac{10}{S} \\
=\end{array}$ & $\begin{array}{l}\frac{\infty}{0} \\
\vdots \\
0 \\
0 \\
0\end{array}$ & $\begin{array}{l}\text { III } \\
\text { II }\end{array}$ \\
\hline 1 & $\begin{array}{l}\vec{J} \\
0 \\
0\end{array}$ & Ð & 1 & 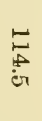 & $\underset{\sim}{\vec{\sigma}}$ & 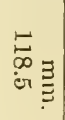 & $\begin{array}{l}\Rightarrow \\
40\end{array}$ \\
\hline$\vec{N}$ & $\begin{array}{l}\vec{N} \\
\dot{\sigma}\end{array}$ & $\vec{\infty}$ & 1 & $\vec{N}$ & $\begin{array}{l}\vec{N} \\
\text { ज }\end{array}$ & $\stackrel{N}{\vec{v}}$ & 蛋 \\
\hline $\begin{array}{l}\infty \\
\dot{G}\end{array}$ & $\infty$ & $\stackrel{\infty}{\omega}$ & 1 & $\begin{array}{l}\infty \\
\dot{\sigma}\end{array}$ & $\begin{array}{l}\infty \\
\dot{G}\end{array}$ & 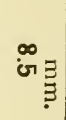 & 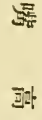 \\
\hline Gु & $\begin{array}{l}\mathscr{G} \\
\text { G }\end{array}$ & G & G్ & G & ఝু & जु & 蛕 \\
\hline $\begin{array}{l}\text { जे } \\
\text { जा }\end{array}$ & $\$$ & 䨨 & $\stackrel{B}{B}$ & ఉ & $\begin{array}{l}\text { के } \\
\text { जे }\end{array}$ & 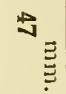 & त्ञ \\
\hline$\vec{v}$ & $\vec{\nabla}$ & $\vec{v}$ & $\vec{\beth}$ & $\vec{\sigma}$ & $\vec{v}$ & के & $\begin{array}{l}5 \\
0\end{array}$ \\
\hline 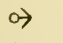 & $\leftrightarrow$ & $0 \rightarrow$ & $\rightarrow$ & 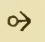 & $0 \rightarrow$ & $\rightarrow$ & 致 \\
\hline 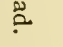 & مٌ & مٌِّ & مِّ & 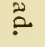 & ְ. & $\stackrel{\text { }}{0}$ & 点 \\
\hline : & : & : & : & : & : & $\begin{array}{l}\text { 产 } \\
\equiv\end{array}$ & 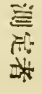 \\
\hline
\end{tabular}

本 黑 せ 近 種學加迄 標士た此 品にり種各 各㨜しは群 部り 光泉 の) 其 ラ 测儿後为編 定 1 の 右群 研二 左帛究 ! にににギ 表產㨜 = 出す b する モ ヘ ह ラ म

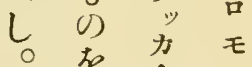
新 二 群

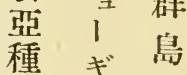
と 䜣 せ兵 b $\therefore$ 力 れ 口 た只

b モ 本群 群 書帛島 後產產 附 は旌 三别 る 七 亞 ह 頁 種の 參照文 照認 總

め て

同

h. -

又

4 है

[回 


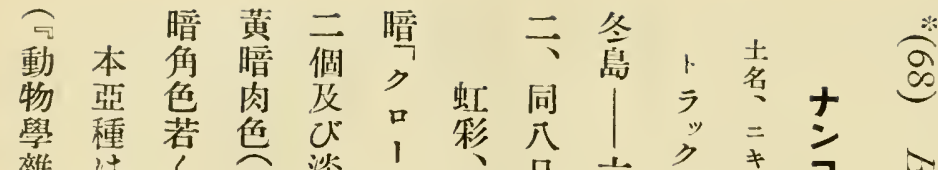

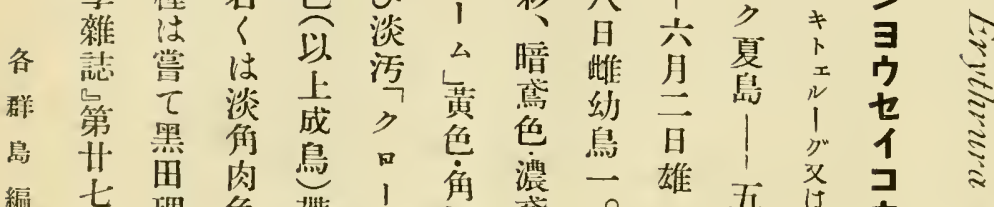

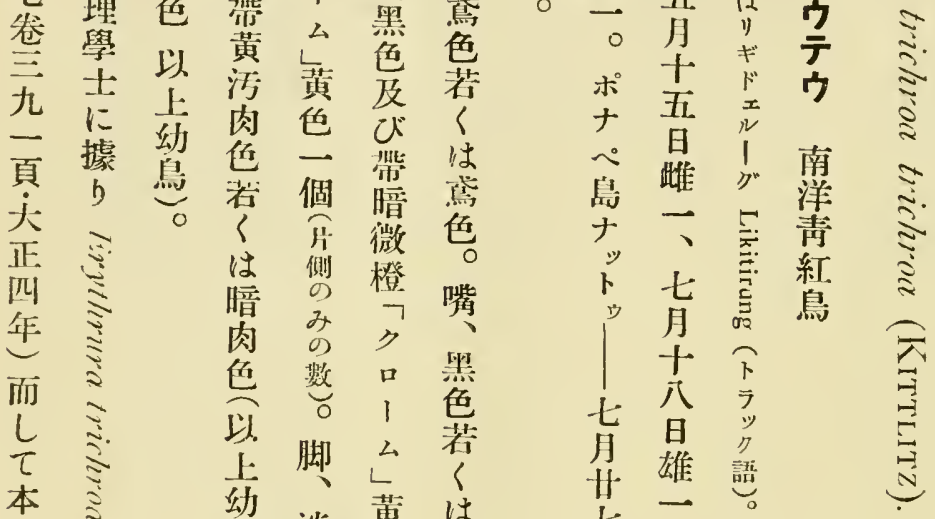
亞乏鳥淡黄は 種 玄些色角

成

鳥

蛙々

彩 $\tau$

は 訅

霖 載

色 せ

小 5

5 $九$

ざ †

3 3

事灰

二 以

七 站 $\tau$

に再

附 述

驾考 せ

爪褐会绝

们带幻以

点紫舀

色暗等成

淡黛幼鳥

伿色鳥黑

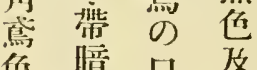

色湢口改

若黄角宕

々茶部石

は焦附板

角暗屬灌

色肉物色

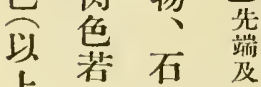

㠿石等

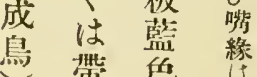

七 0

昆占 1

同水章

州曜

一島

幼 簿

鳥

性 月

否产

日

、 雄

八。

月

四

日 
受る等 見放 入

此けらにざちせ 本 種ら事自るたれ亞 のるあ生な・るた種 亞引らすすきる る

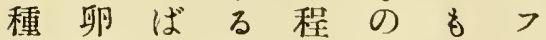
決を小處ななの比 定藏害の歽り にしを草ばと如ビ 就居被實該 誚 L て る 盖子、群 鹰 b事渻產、即岛 司即 理ちら科類今該 ゾ 學六ん? 中に岛 土月はのに帛 に下豫是加は民に

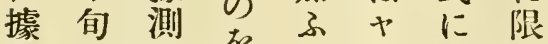

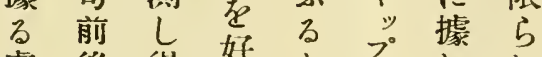
處後得好 尠は岂过岛ば分 し該しを㗬甾此有 と島。潒畐各種せ せに六食は所はら 声於会し市增獨る 、け井農方增領了 立る七作ざ殖時 に本日物る代の 深福箱によ殊他な 謝の集加し草所れ の蕃 0) 害。 草よ

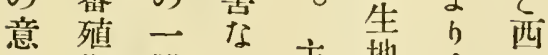
を期雌さ主地多部

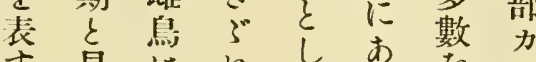

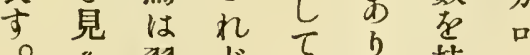
る 翌 ぞ草 し中後原は來 ン

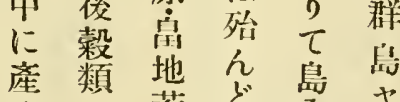
今耕若每 し作蛙回諸㿝 世路是得的 自方畔在に移

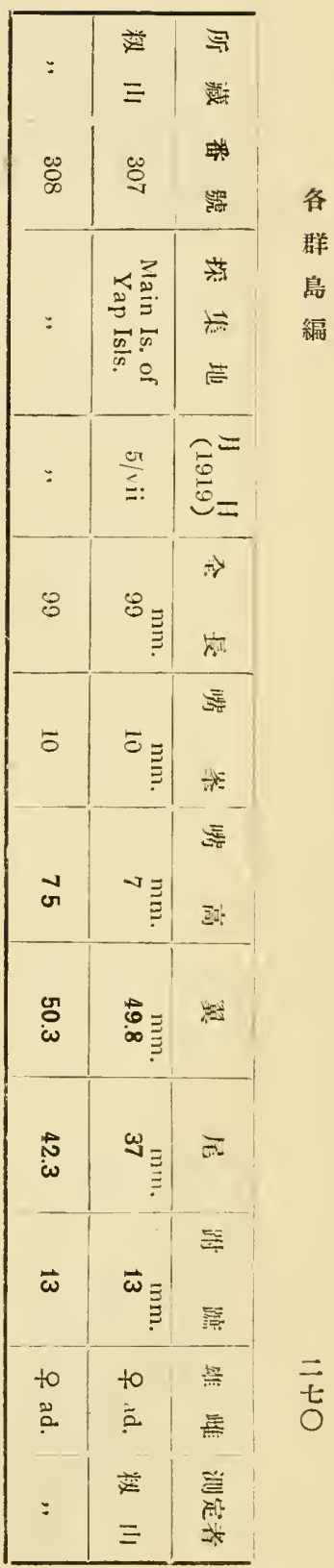




\begin{tabular}{|c|c|c|c|c|c|c|c|c|c|}
\hline$=$ & : & : & : & : & $\begin{array}{l}E \\
E\end{array}$ & 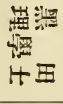 & : & $\begin{array}{l}\text { 艾 } \\
\equiv\end{array}$ & 코 \\
\hline $\mathscr{\&}$ & $\stackrel{10}{\mathscr{N}}$ & $\begin{array}{l}10 \\
\substack{10 \\
c}\end{array}$ & \begin{tabular}{l} 
E \\
\multirow{4}{*}{}
\end{tabular} & $\stackrel{\oplus}{\omega}$ & $\begin{array}{l}10 \\
\infty \\
0\end{array}$ & 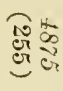 & 点 & $\vec{J}$ & $\begin{array}{l}\text { 氣 } \\
\text { 霹 }\end{array}$ \\
\hline : & : & : & : & $=$ & : & : & : & 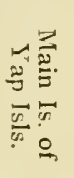 & $\begin{array}{l}\text { 案 } \\
\text { 学 } \\
\text { 范 }\end{array}$ \\
\hline : & $\frac{10}{\leq}$ & $\frac{\mathrm{s}}{\mathrm{e}}$ & $\frac{\stackrel{0}{0}}{\leq}$ & $\frac{\varpi}{\vdots}$ & $\frac{\stackrel{0}{c}}{\leq}$ & $\frac{0}{s}$ & $\frac{\bar{\sigma}}{\leq}$ & $\equiv$ & $\frac{\hat{\sigma}_{0}}{\hat{\theta}^{\prime}}=$ \\
\hline$\overline{8}$ & $\stackrel{+}{\mathscr{D}}$ & $\begin{array}{l}0 \\
0 \\
0 \\
0 \\
0\end{array}$ & $\vec{\omega}$ & $\begin{array}{l}\overrightarrow{0} \\
0 \\
0\end{array}$ & $\frac{\overrightarrow{0}}{\dot{r}}$ & $\begin{array}{l}\mathscr{8} \\
\text { or }\end{array}$ & $\bar{c}$ & $\mathscr{E}_{\Xi}$ & $\begin{array}{l}\Delta y \\
\dot{x}\end{array}$ \\
\hline ' & $\underset{\sigma}{\vec{G}}$ & क्ठ & $\vec{\infty}_{\infty}$ & $\ddot{\Xi}$ & $\Xi$ & ‡ & $\vec{\infty}$ & $\stackrel{*}{\Xi}$ & 踏 \\
\hline जे & or & जे & $\infty$ & $\infty$ & ir & $\infty$ & $\infty$ & $\infty$ & 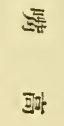 \\
\hline gr & $\stackrel{\sigma}{\stackrel{\omega}{\omega}}$ & 它 & $\begin{array}{l}\text { 苟 } \\
\text { जो }\end{array}$ & 它 & iv & $\begin{array}{l}+\infty \\
\dot{\sigma}\end{array}$ & $\begin{array}{l}\text { \&ै } \\
\text { जा }\end{array}$ & SI & 战 \\
\hline $\begin{array}{l}\omega \\
\sigma \\
\text { G }\end{array}$ & $\begin{array}{l}\text { 屯े } \\
\text { के }\end{array}$ & $\overrightarrow{0}$ & $\underset{\infty}{\omega}$ & 出 & 8 & $\underset{\emptyset}{\omega}$ & $\underset{i}{*}$ & 要 & $\bar{m}$ \\
\hline$\stackrel{\vec{v}}{\mathrm{v}}$ & $\vec{\omega}$ & $\vec{\omega}$ & $\stackrel{\omega}{\omega}$ & $\vec{\omega}$ & $\overrightarrow{\mathrm{v}}$ & $\vec{\omega}$ & ज़ & $\vec{N}$ & 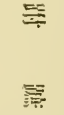 \\
\hline $\begin{array}{l}\text { to } \\
2 \\
2 .\end{array}$ & $\begin{array}{l}\text { to } \\
\text { בै }\end{array}$ & $\begin{array}{l}\text { to } \\
ٌ \\
ٌ\end{array}$ & $\begin{array}{l}\text { to } \\
\stackrel{2}{2}\end{array}$ & $\begin{array}{l}\text { to } \\
\ddot{2}\end{array}$ & $\rightarrow$ & $\begin{array}{l}\stackrel{\rightarrow}{0} \\
\triangleq\end{array}$ & $\begin{array}{l}\rightarrow \rightarrow \\
2 \\
2\end{array}$ & $\begin{array}{l}\stackrel{\rightarrow}{0} \\
\stackrel{0}{0}\end{array}$ & $\begin{array}{l}\text { 黑 } \\
\text { 点 }\end{array}$ \\
\hline : & : & : & : & : & : & 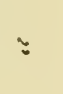 & : & $\begin{array}{l}\text { E } \\
E\end{array}$ & 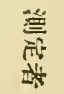 \\
\hline
\end{tabular}


採色事因等的褐成色色带淡色

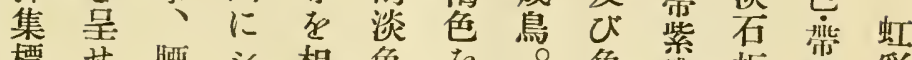

標せ腰 シ 相色を。角濃板黑彩

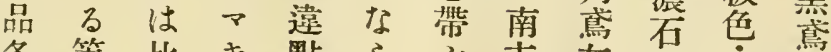

各等比 ₹點 ら ぶ支灰板角色濃各

部の較ンをずる那色色灰淡代群

の諸的 八点卢事海市带色石赫島

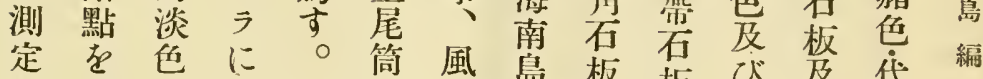

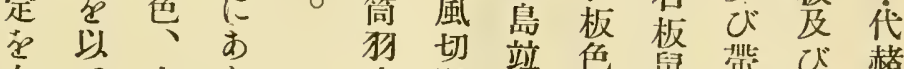

左七上至

に本尼保

揭亞简は

ぐ種狗啺

$\varepsilon$ 先は

區 端 赤

別は褐

得鿷 色

心源帶

し 肉 び

色盾

了切

事 犲

尾 \&

氞緣

は褐

中 赤

点色

二 t

枚呈

及 せ

びる

其 事

他、

の 脇

冬狗

外沖

緣 暗

は褐

灰苗

菒な

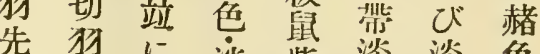

端々喜準紫焱淡色

は緣囊石色石空濃

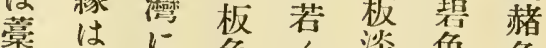

黄喑產色は窗色色

に褐す灰淡碧黑䇶

富色急石色若若

屯な若楚若色々

事る

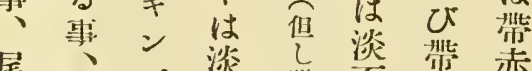

尾、パ淡囉不业赤

旸脇 角踓板空赫

中狗年灰楚琵色

央は心色稳に板嘴

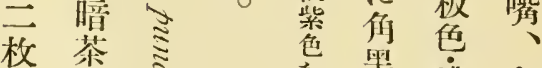

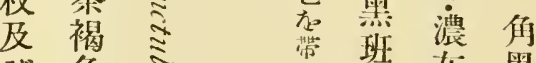

び色ミ城黑

其に文

他 ᄂ s

の $\tau \lesssim$

各暗 ミ

外褐 喁

緣色主

はなる

歶らに

黄ざ 酷

灰る似

色事す

⿸丆了

呈 腰

せは翕

る比は

色 色

爪却范及

、带 亚 淡

淡紫淡石

角石石板

黑板板 監

色色淡色

们最苹们

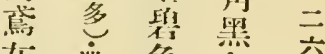

灰器色色六

色淡煙度

淡紫灰 び

石不色 淡

板板及不 


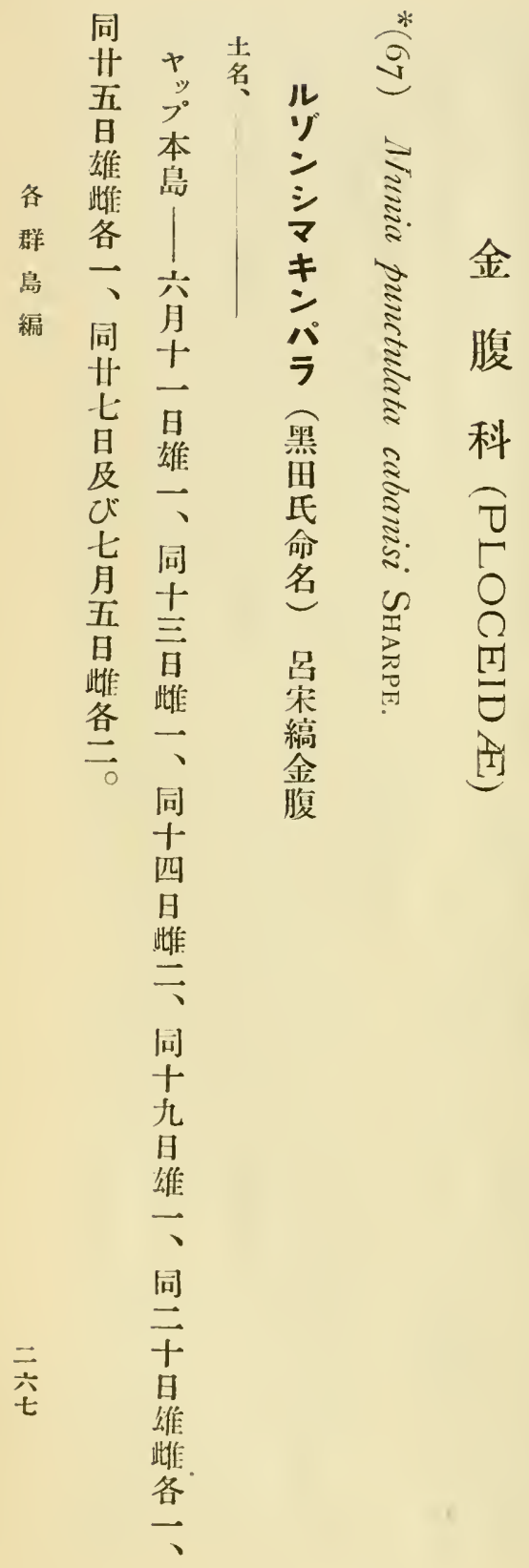

想落 州

考近該月b種 すを帛サしは 、訪香八在卜 如 人少䧕ラ 何る千 下与

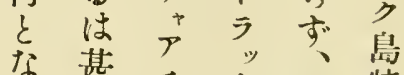
れだ恐特 ば稀 村水恐產 該有落曜々に 島な附島今先 名近, 回稀

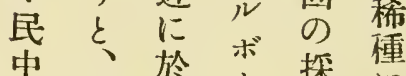
此恐 $\tau$ ! 集 種占学鳥㟔物 識本虚第賞 占種獲㷊㐭嘗 万人然中回 क 50 貝 1 の)岛初相

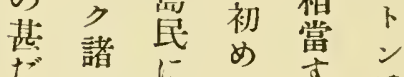
多島依正代

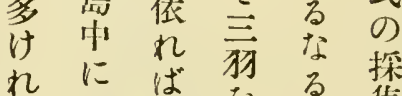
ばて此暂息

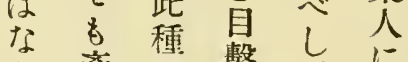

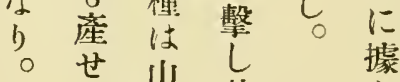
ざ其嵒 当丙视 ○) の 獾 地 三 尠栖対倠 加息难 さ加售 の 3 了施以 心年䍿外 し 村名探 


\begin{tabular}{|c|c|c|c|}
\hline : & $\begin{array}{l}\text { 产 } \\
\equiv\end{array}$ & 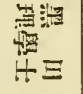 & 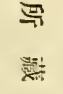 \\
\hline$\vec{c}$ & 寻 & 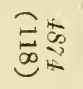 & 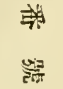 \\
\hline : & : & $\begin{array}{l}\stackrel{-}{0} \\
\overrightarrow{0} \\
\vec{E}\end{array}$ & 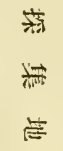 \\
\hline$\stackrel{\mathscr{\rho}}{<}$ & : & $\frac{10}{<}$ & $\begin{array}{l}\stackrel{\vec{\theta}}{0}= \\
\stackrel{\mathscr{e}}{\Theta}=\end{array}$ \\
\hline $\begin{array}{l}50 \\
0 \\
01\end{array}$ & $\begin{array}{l}\vec{\omega} \\
\dot{c} \\
\dot{c}\end{array}$ & $1 \stackrel{\Xi}{\Xi}$ & $\begin{array}{l}\Delta \\
+5\end{array}$ \\
\hline$\vec{\infty}$ & $\vec{v}$ & $\vec{\exists}$ & 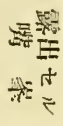 \\
\hline $\begin{array}{l}\text { O० } \\
\text { जे }\end{array}$ & 응 & ثٌ & $\begin{array}{l}\Rightarrow \vec{r} \\
\Rightarrow \\
\Rightarrow \\
\text { 渠 }\end{array}$ \\
\hline హ' & $\begin{array}{l}\text { O } \\
\text { जे }\end{array}$ & ป & 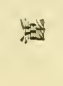 \\
\hline$\underset{\omega}{\stackrel{\circ}{\omega}}$ & $\underset{\infty}{\mathbb{W}}$ & 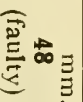 & Fr \\
\hline$\underset{\infty}{N}$ & $\underset{\infty}{\stackrel{\infty}{~}}$ & 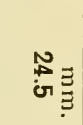 & 哭 \\
\hline $\begin{array}{l}\text { to } \\
2\end{array}$ & $\begin{array}{l}\text { to } \\
\stackrel{2}{*}\end{array}$ & $\begin{array}{l}\text { to } \\
\vdots\end{array}$ & $\begin{array}{l}\text { 啉 } \\
\text { 点 }\end{array}$ \\
\hline : & : & $\begin{array}{l}\text { E } \\
\equiv\end{array}$ & 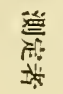 \\
\hline
\end{tabular}

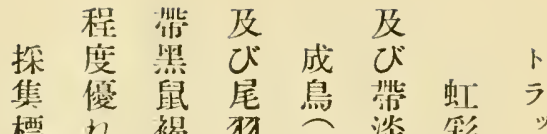

標れ褐旸雌淡柇”

品り㶵は此紅、水

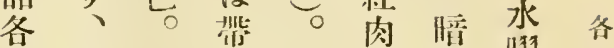

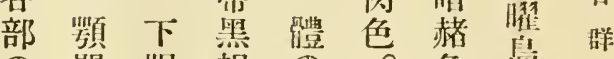

の間腿褐の色品泉

测 部 脸 色上

定にに面

をは添共は

左 極穴に桠

にめ $て$ 外 め

表て 絹 辨て

記微絲に僅

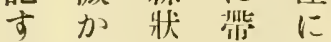

心に絊淡 橄

し 紫白橄 㰖

㫮犲㰖色

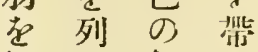

混尘細

寸。 す緣 る

○○線暗

乾下年

標 IIII ○袺

若 編

本は皇色

にに学に

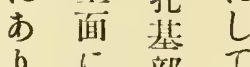

bに部七

$\tau$ 比前

は し 前額

脚秒前は

趾 淡 眼 秒

淡色! ! 装

敬に张味

甲 し 下 布

色艺证紫

る 橄に ぶ

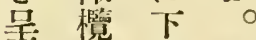

与色嘴暲

○基 の

五

敒 月

㸺 H

淡

膘 日

赫 此任

色 -

踭同

濃王

浱 日

板 此倠

雳 0

色

脚

淡

橙

任

$\pi$

淡

角

嫼

垈

带 部 風

ぶ等 切

るは旸 


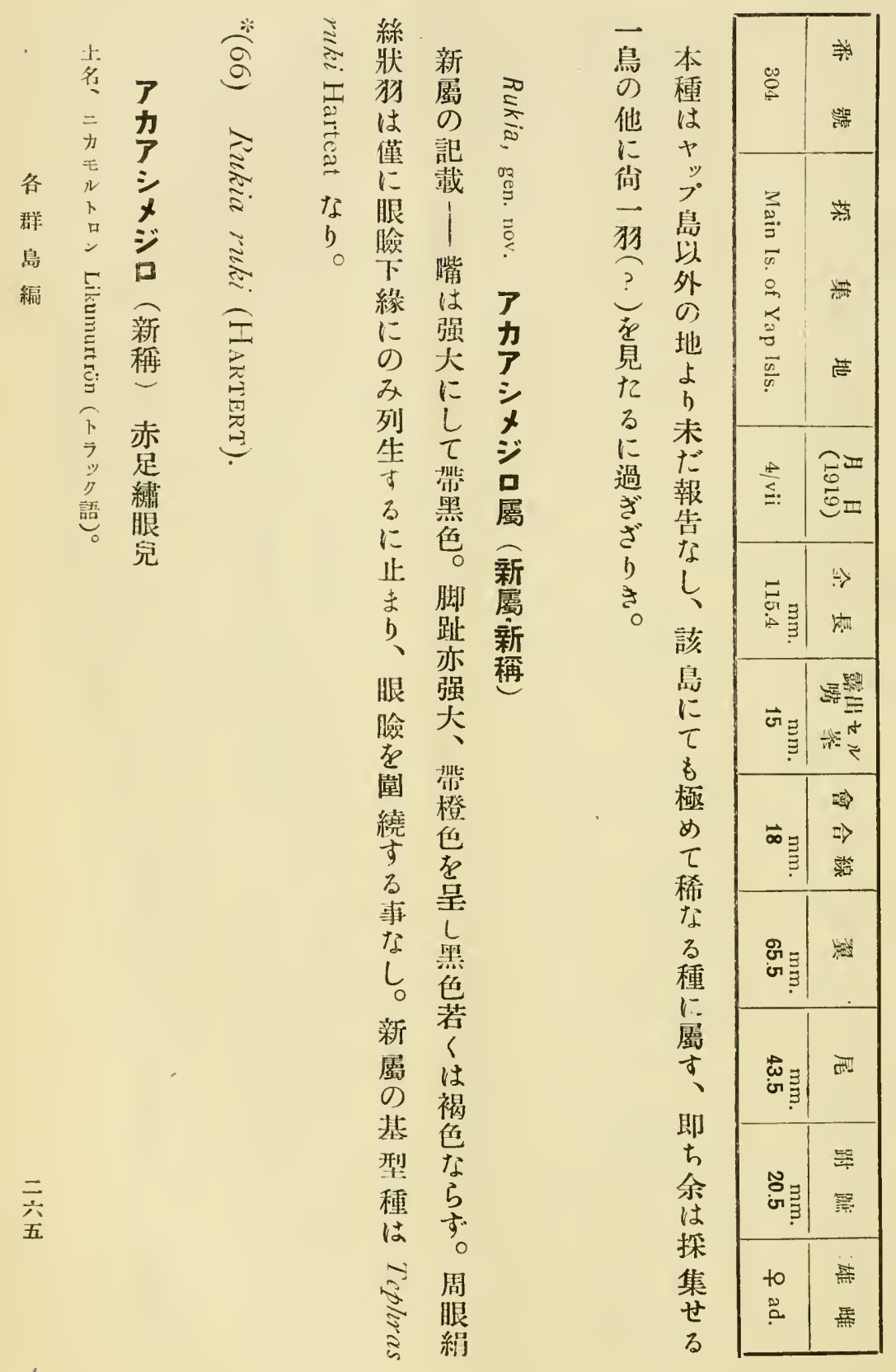


稍下耳に

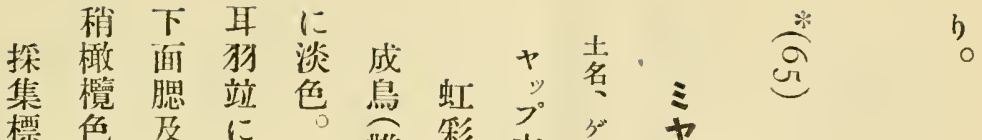

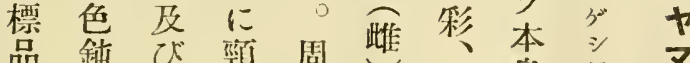

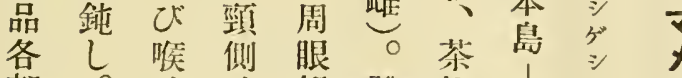

部。は絹體褐|爻

の乾淡脊絲0)色七学

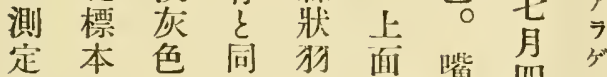

定本色同雅面觜四年

るこに色はは、日

左 あし旦橄帶䧳 シ

にりて翼色㰖 卧此

揭て 各のに褐角鳥䓤

ぐ脚狗風し色灰鳥占

帶先呵吸ち色口語

石端は滕所确

板僅黑な 謂咒

褐に褐り第尔

色淡色口色嘴

范橄、眼居端

呈 欖 尾 䛔呈 范

高色狗よし ひ

をは h 角

帶 襡 腿 前 灰

ふ灰下額色

色眼交

胸 共眼び

以に後頭 紫

は外掛頂 脚

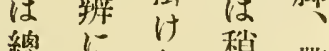

總にた秒业

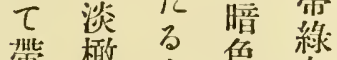

霰㰖 小色灰

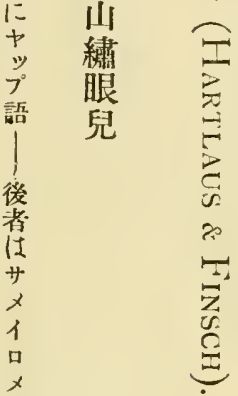

各

群

島

新 20 編

編

欖 褐 部腰色

蕉色忬芨朵

、細觜上此

下緣 罡 尾蓝

尾存色筒角

深 焉

$\frac{2}{2}$

¿.

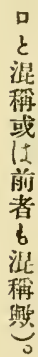

のす褐

みす。䀰僅色 


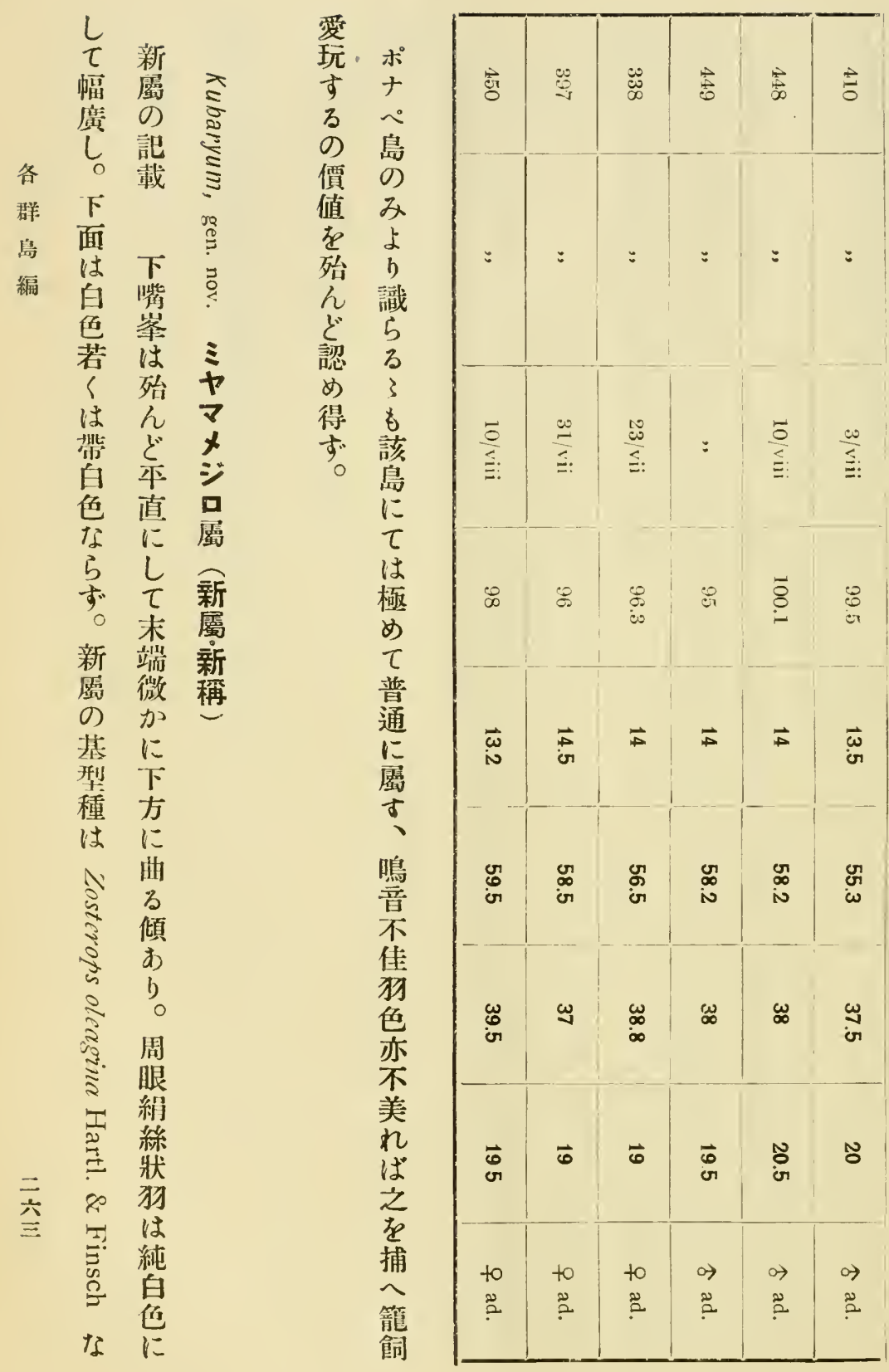




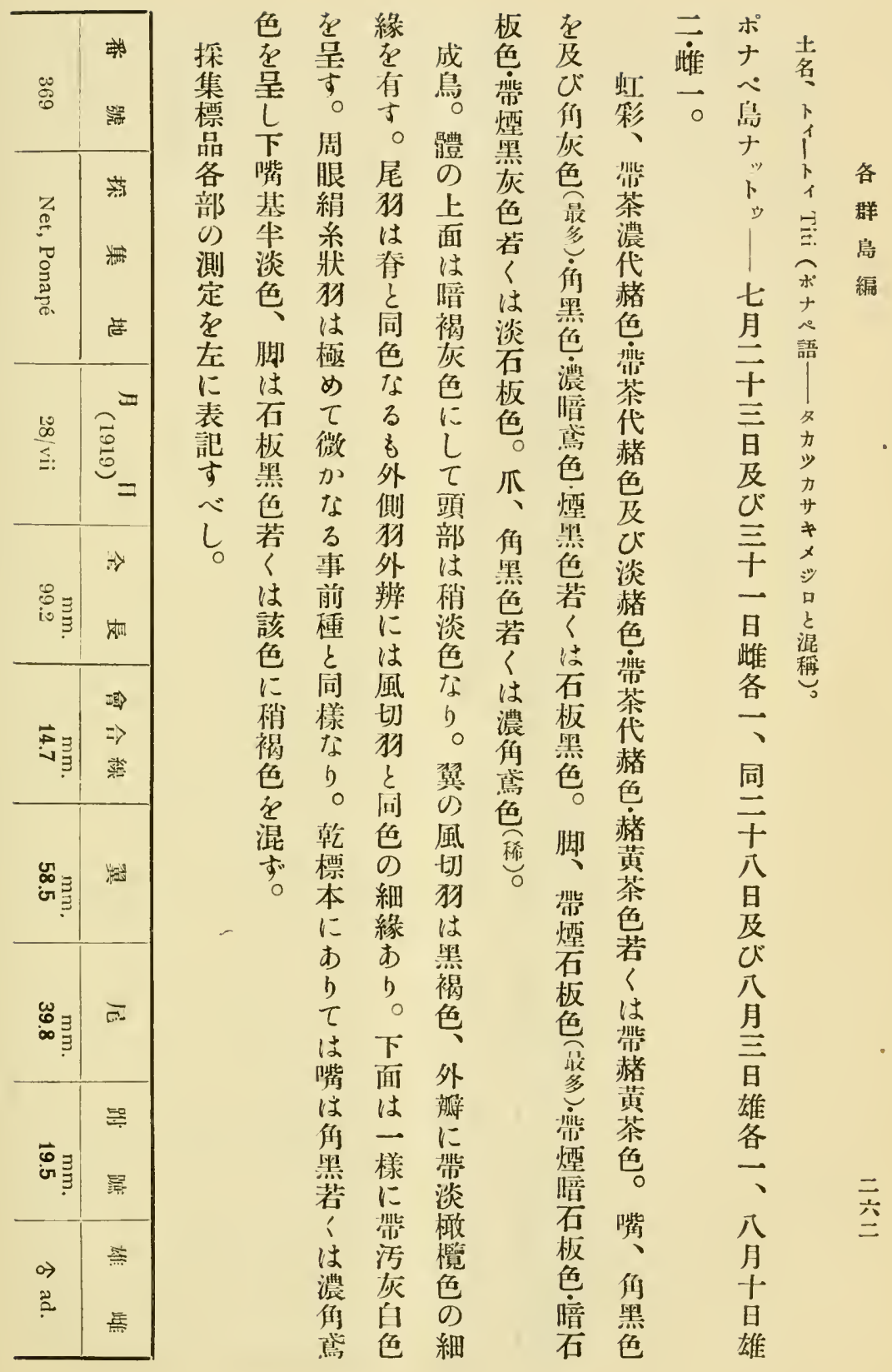




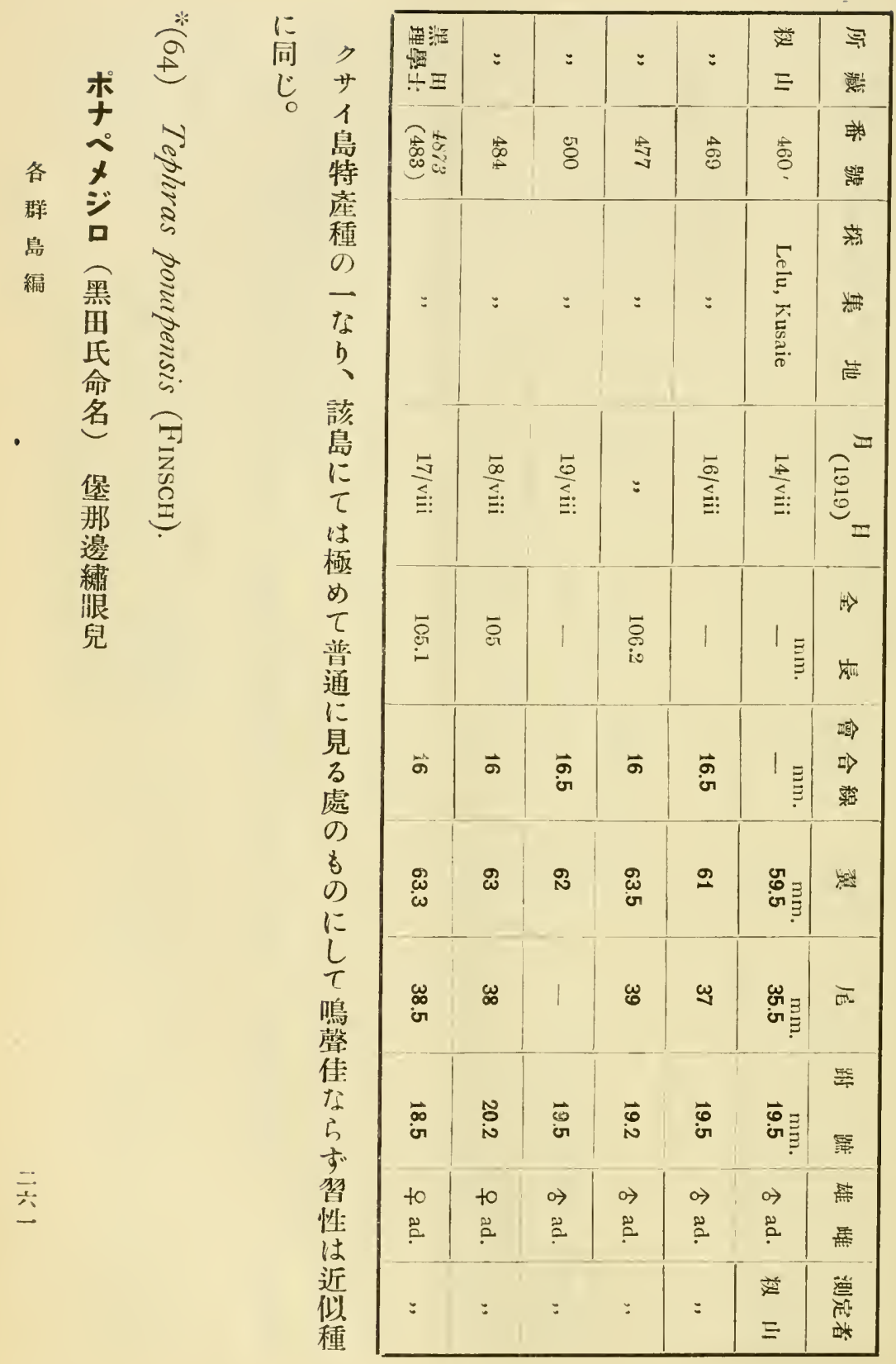


脚邪灰は黄

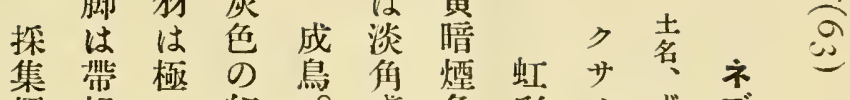
標褐め細。駏色彩人ド

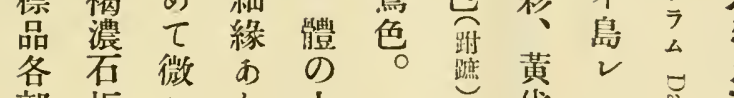
部板加り上 の色に。面 测な見尼は 定 b 得旸帶 を。るは薈 左に風灰 に過切鼠 揭峦狗色 ל"

且略翼

带同の 灰色風 白な切 色口狗 を。は 呈下淡 せ面黑

りは褐

。總色

乾㳊

標器 し

本污 $\tau$

に灰外

内白辨

点色椣

は耳

㗪狗 $\tau$

は山微

角稍 加

黑濃

若䇼綠

管

生周老

蕽眼帶

保絹 次

武絸

色娄

狀淡

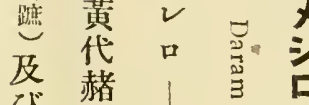

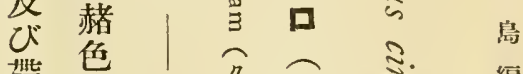

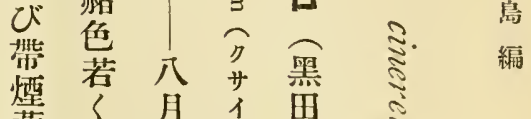

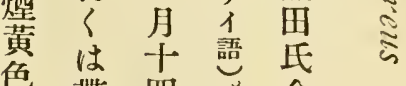

色带四命不

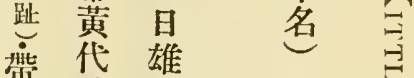

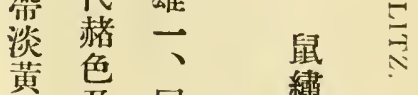

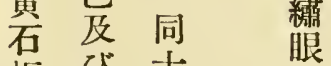

板导兒

黑黄共

忿代旦

若赫雄

人

先嘴同

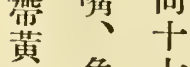

黄角 七

板黑 日

䇼急歪

爪社分

角角

瑟黑 雌

墨色各

角莨

黛㬓同

黑黄十

色符九

你色 日

䳏口堆 


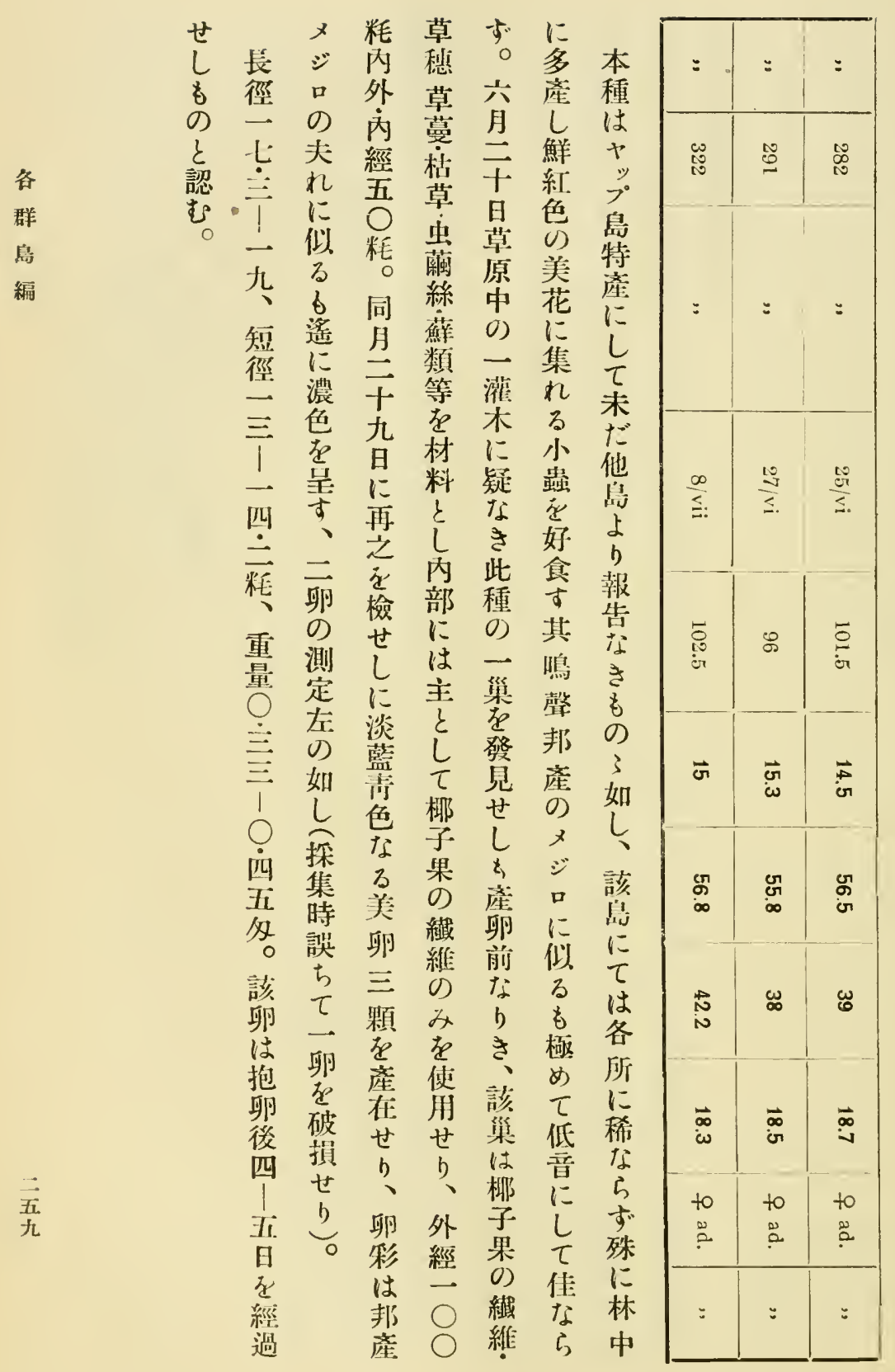




\begin{tabular}{|c|c|c|c|c|c|c|c|c|c|c|}
\hline : & : & $=$ & $=$ & : & $\begin{array}{l}\text { E } \\
\equiv\end{array}$ & 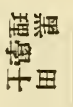 & $=$ & : & $\begin{array}{l}E \\
E\end{array}$ & 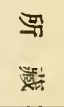 \\
\hline$\frac{\omega 0}{10}$ & $\ddot{\theta}$ & : & $\mathbb{C}_{10}^{0}$ & 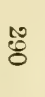 & $\stackrel{\infty}{\infty}$ & 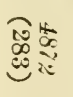 & 商 & 足 & $\begin{array}{l}\mathbb{1} \\
\mathbb{E} \\
\mathbb{E}\end{array}$ & 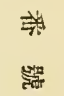 \\
\hline$=$ & : & $=$ & : & $=$ & $=$ & $=$ & $=$ & $=$ & 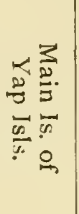 & 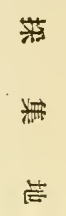 \\
\hline$\frac{\rho}{\dot{=}}$ & $\frac{0}{0}$ & $=$ & $=$ & $\frac{10}{5}$ & $\frac{\stackrel{L}{\circ}}{\leq}$ & $\frac{10}{5}$ & $\frac{8}{5}$ & $\frac{\vec{\sigma}}{\leq}$ & $\frac{\vec{s}}{\leq}$ & $\stackrel{\overrightarrow{0}}{\overrightarrow{0}}_{=}^{=}$ \\
\hline$\stackrel{0}{v}$ & 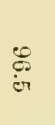 & हi & e् & 隹 & 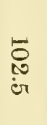 & 灾 & 5 & $\ddot{\infty}$ & $1=$ & $\begin{array}{l}\Rightarrow y \\
\text { 寉 }\end{array}$ \\
\hline$\vec{\sigma}$ & $\underset{\Delta}{\Delta}$ & $\overrightarrow{~ ज ़ ~}$ & जं & $\begin{array}{l}\vec{G} \\
\text { जा }\end{array}$ & $\overrightarrow{\text { जे }}$ & जे & $\underset{+}{\not}$ & $\stackrel{\vec{N}}{\mathrm{~N}}$ & $1 \Xi$ & $\begin{array}{l}\Rightarrow \vec{\gamma} \\
\Rightarrow> \\
\text { 禁 }\end{array}$ \\
\hline$\underset{\infty}{S}$ & ฮু & લુ & $\begin{array}{l}\text { gr } \\
\text { or }\end{array}$ & $\begin{array}{l}\text { धु } \\
\text { ध }\end{array}$ & ' & लू & g্ & or & $\mathbb{G}_{3}$ & 5 \\
\hline $\mathscr{\emptyset}$ & 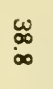 & $\mathscr{\emptyset}$ & $\mathscr{\infty}^{\omega}$ & $\begin{array}{l}\omega \\
\stackrel{\omega}{*} \\
\stackrel{N}{N}\end{array}$ & \pm & $\overrightarrow{0}$ & \pm & ज़ & \pm & $\pi$ \\
\hline$\underset{\infty}{\infty}$ & $\underset{\infty}{\infty}$ & $\vec{\infty}$ & $\underset{\infty}{\infty}$ & $\ddot{\omega}$ & $\underset{\infty}{\infty}$ & $\vec{\infty}$ & $\begin{array}{l}\vec{\infty} \\
\dot{\sigma}\end{array}$ & $\stackrel{\infty}{\infty}$ & $1 \stackrel{\Xi}{\Xi}$ & 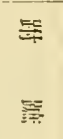 \\
\hline $\begin{array}{l}\stackrel{\rightarrow}{0} \\
ٍ\end{array}$ & 가 & $\begin{array}{l}\text { 일 } \\
\stackrel{2}{2}\end{array}$ & $\begin{array}{l}\stackrel{\rightarrow}{0} \\
\stackrel{2}{0}\end{array}$ & $\begin{array}{l}\rightarrow \\
\stackrel{2}{2}\end{array}$ & $\begin{array}{l}\rightarrow \\
\stackrel{2}{0}\end{array}$ & c) & $\begin{array}{l}0 \rightarrow \\
2 \\
2\end{array}$ & $\begin{array}{l}\rightarrow \\
\stackrel{0}{0}\end{array}$ & $\begin{array}{l}\stackrel{\rightarrow}{2} \\
\stackrel{2}{2}\end{array}$ & $\begin{array}{l}\text { 突 } \\
\text { 熹 }\end{array}$ \\
\hline$=$ & : & $=$ & : & : & $=$ & : & $=$ & $=$ & $\begin{array}{l}\text { E } \\
\text { E }\end{array}$ & 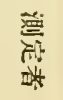 \\
\hline
\end{tabular}




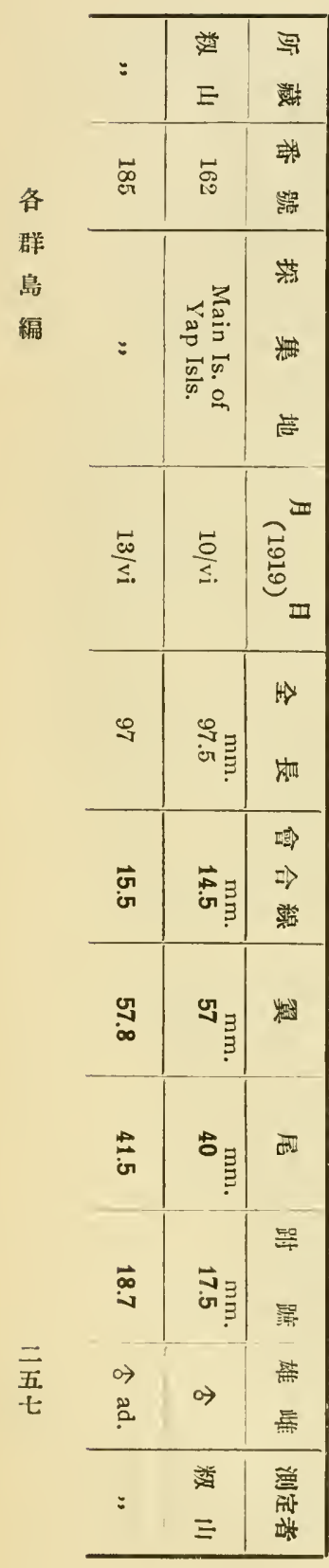

の極䧳色色絹前礼 採極雌 標て鼠嘴卡白には 品僅。は尾て狗達暗 各に雄帶筒るははす褐 部肉成贵は白梅乃色 の色点淡桠色め烧に 测右に褐め佃灰し

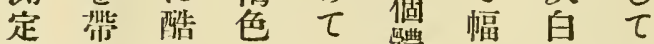
をぶ似。淡脰塽色各 表るし脚き依くの犽 訑事外趾卵依し細の す等 見は黄背線外

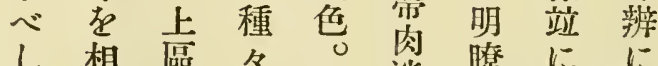
し相區々心淡睹にに

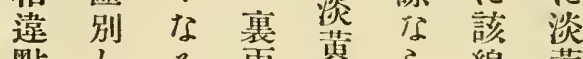
點 ᄂ る 雨曹ら線黄

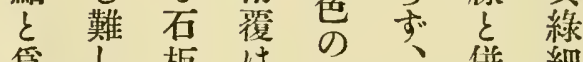
恧し 板は併細 す、色純 の 耳列緣

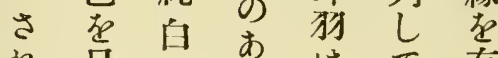
れ呈色占は者 どす色り頭口专 比 0 侧角而 較兴上に部し 上胸比附 $\tau$ 體乾䍃稍近队 下標黄僅 b比 面本色に眼細 はにの黃前き 僅 क度色眼白 か b 多表緣 に $\tau<$ 帶に者 污は胸ぶ到自

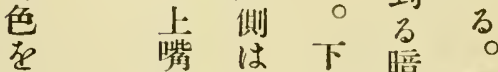
帶们淡面暗鼻 ぶ紫さ線孔 了若灰總 子 色 $\tau$ b 端 下待微步 尾焦兴に周 h

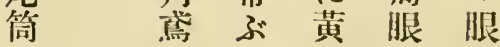




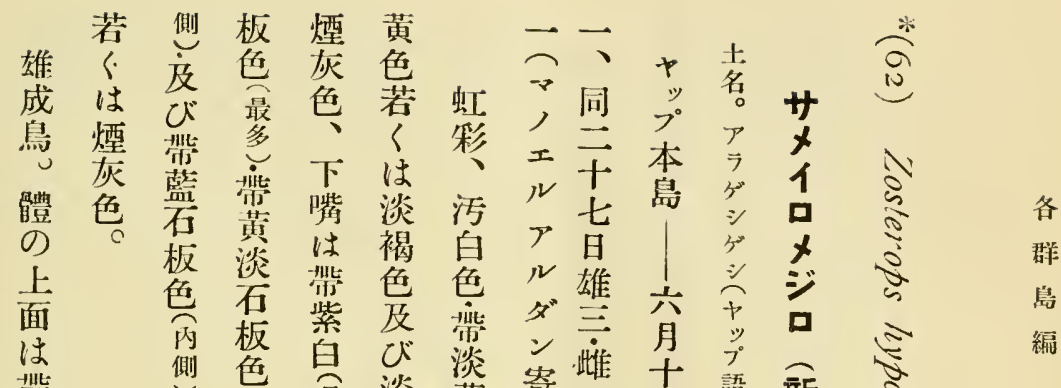

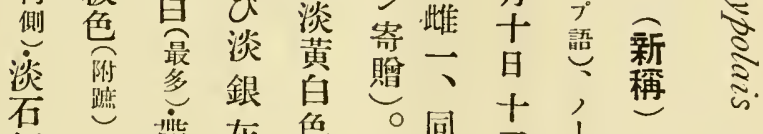

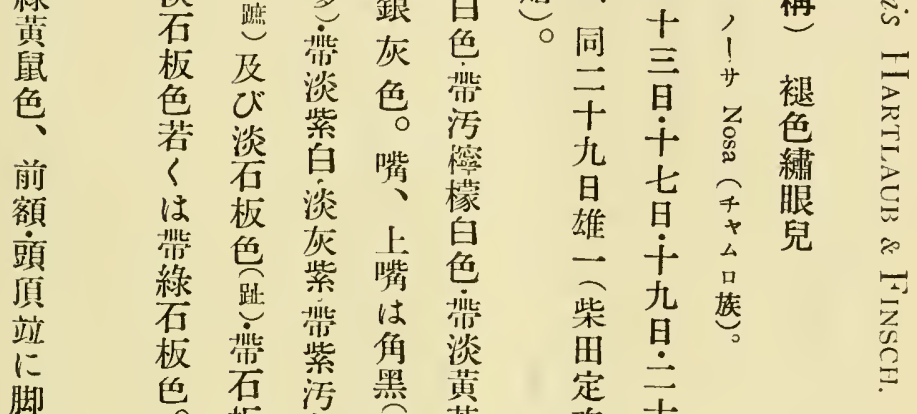

及

ひ

尾

筒

の

諸

部

は

僅

黃

綠

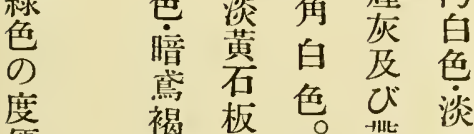

優

わ淡吕脚 紫

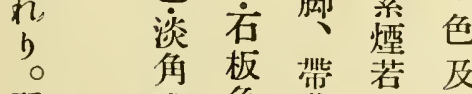

。板白最茶次士

爪黄带筧色郎日

色霖淡及雄

角靕紫角 び 寄各

帒蹠番黑污睮—

色及白濃白的

最び带褐色同同

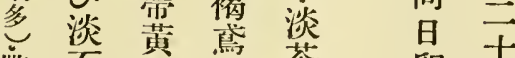

帶石肉角茶卯古

茶板若点色急 日

角色々黑到雄

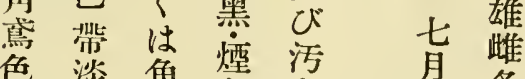

窨黄白灰白六各

褐 板色 び榄

色绝脚零 茶

翼 武色黄要

雄 同

同 市

七六

日旦 


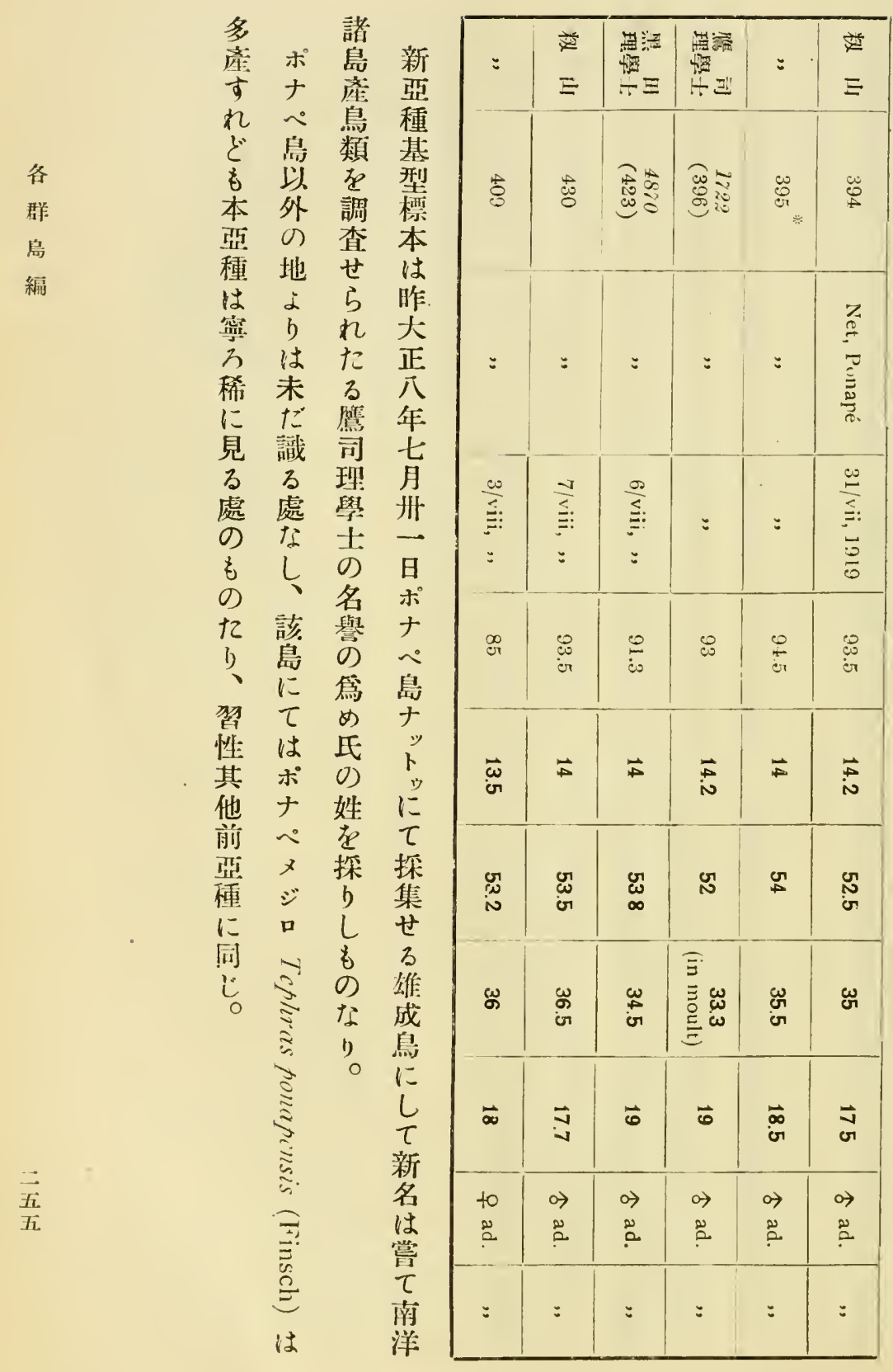




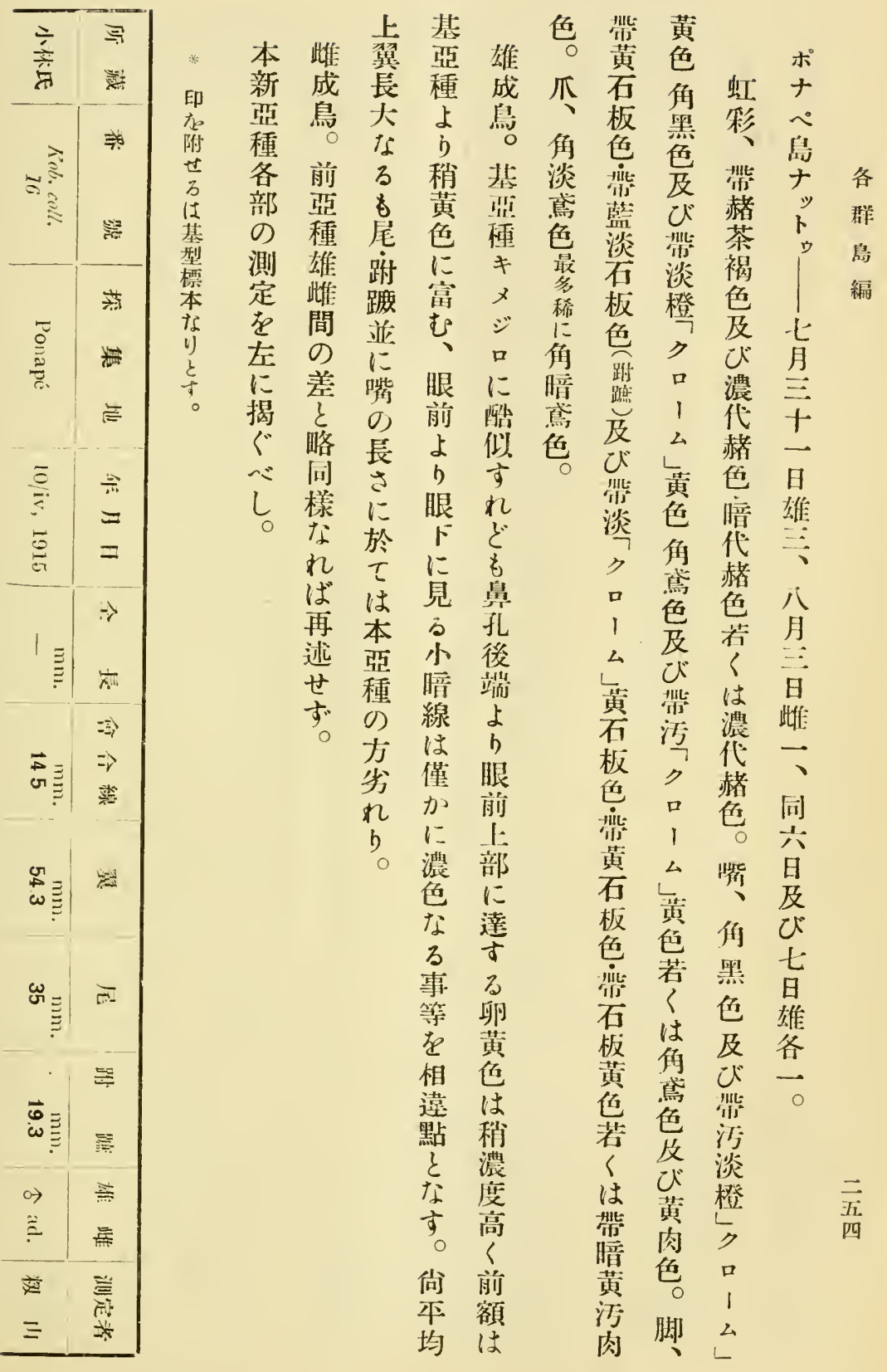




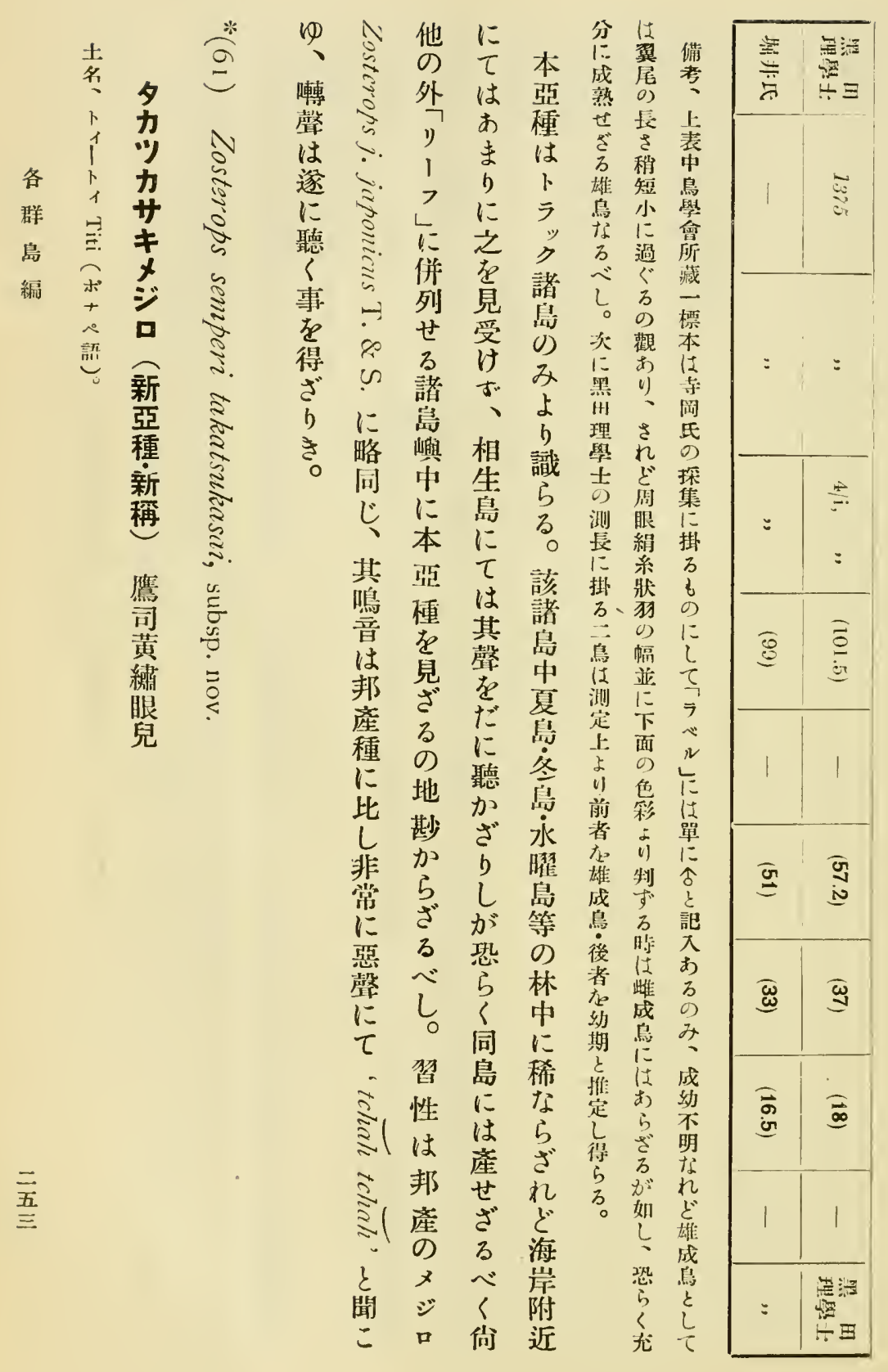




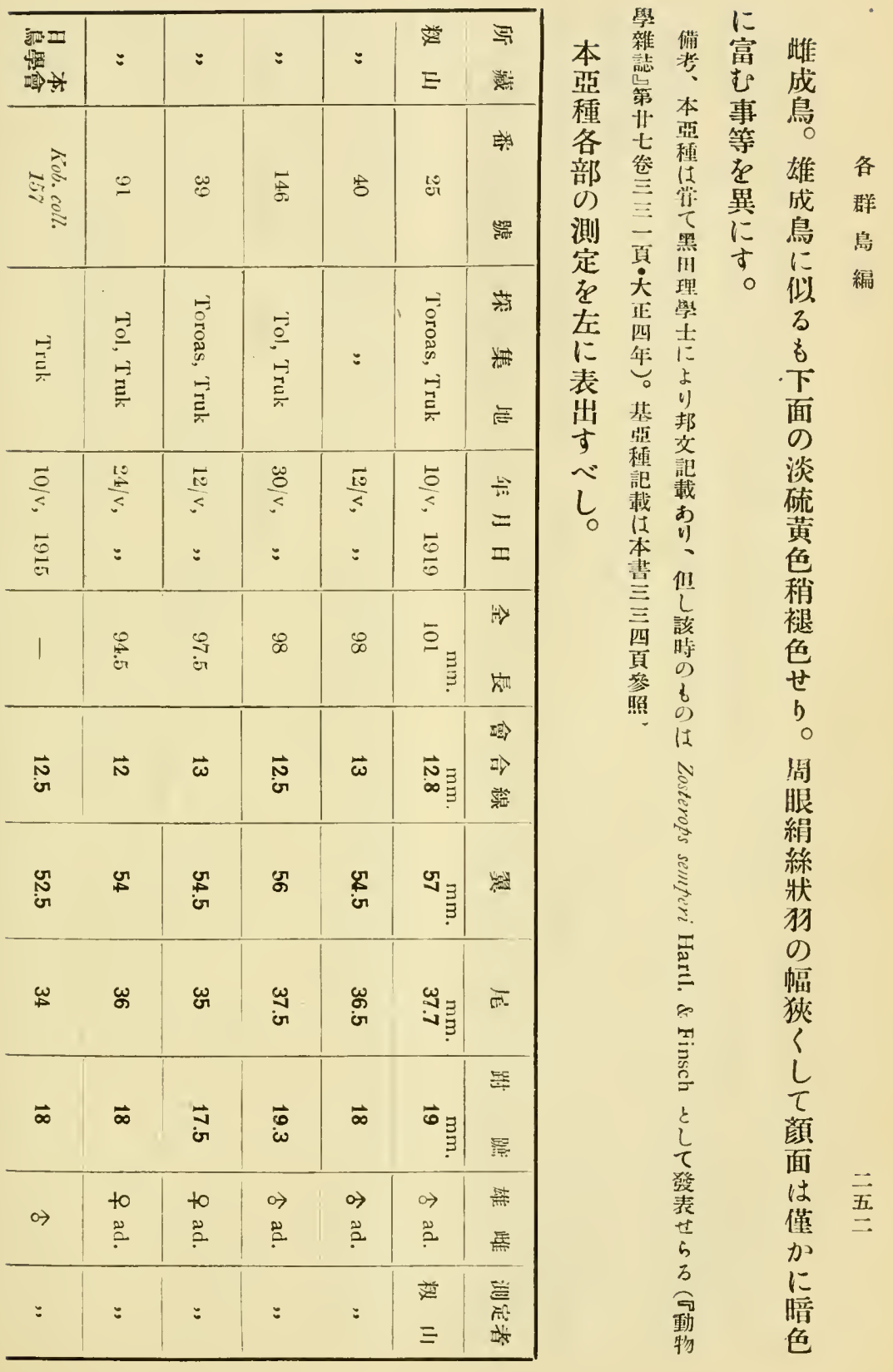




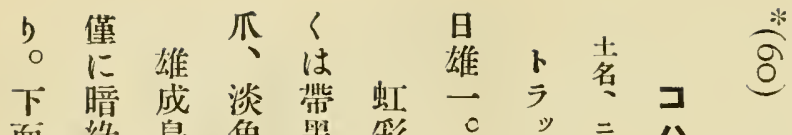

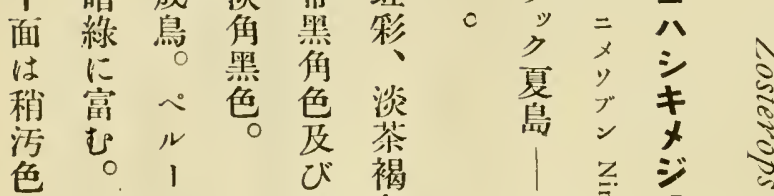

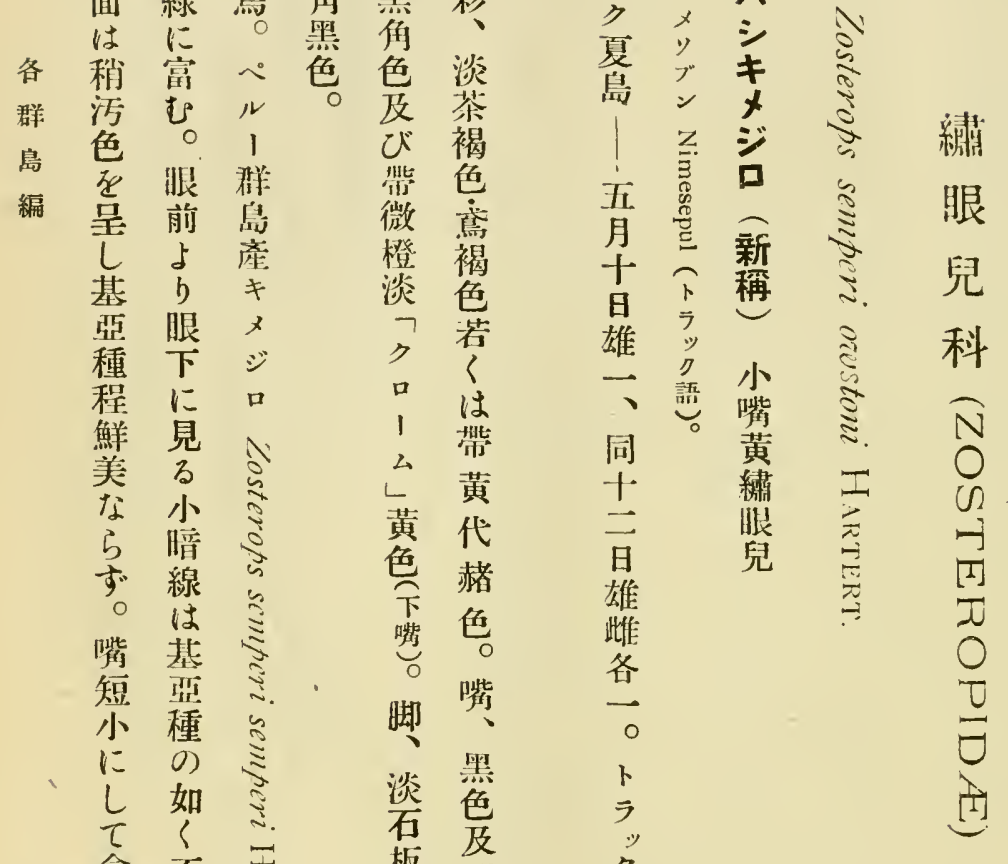

俞不

合 明

線 暸

一小に

三 5 酷

柜吉似

老且守

超濃れ

之度ど

志多多

- ᄂ 面

板 次

色角

帶色

微淡

黄㷋

沰

板色

急若

陲

は白

五谓地

带

䋭色

黑 榇

鼠 極

色 め

板不

色 若

水

嚁

島

五

月

干

[व

此隹

同 


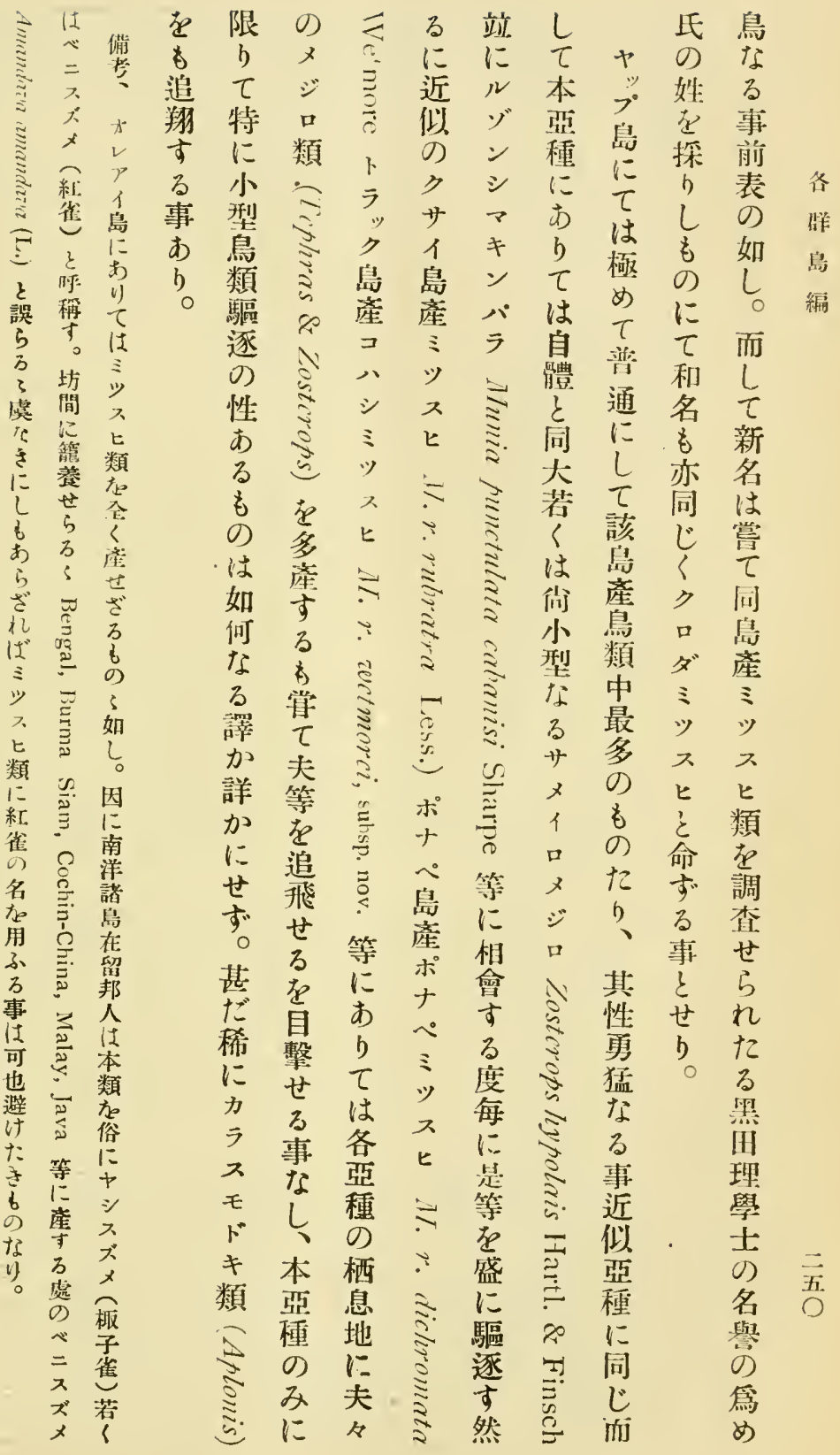




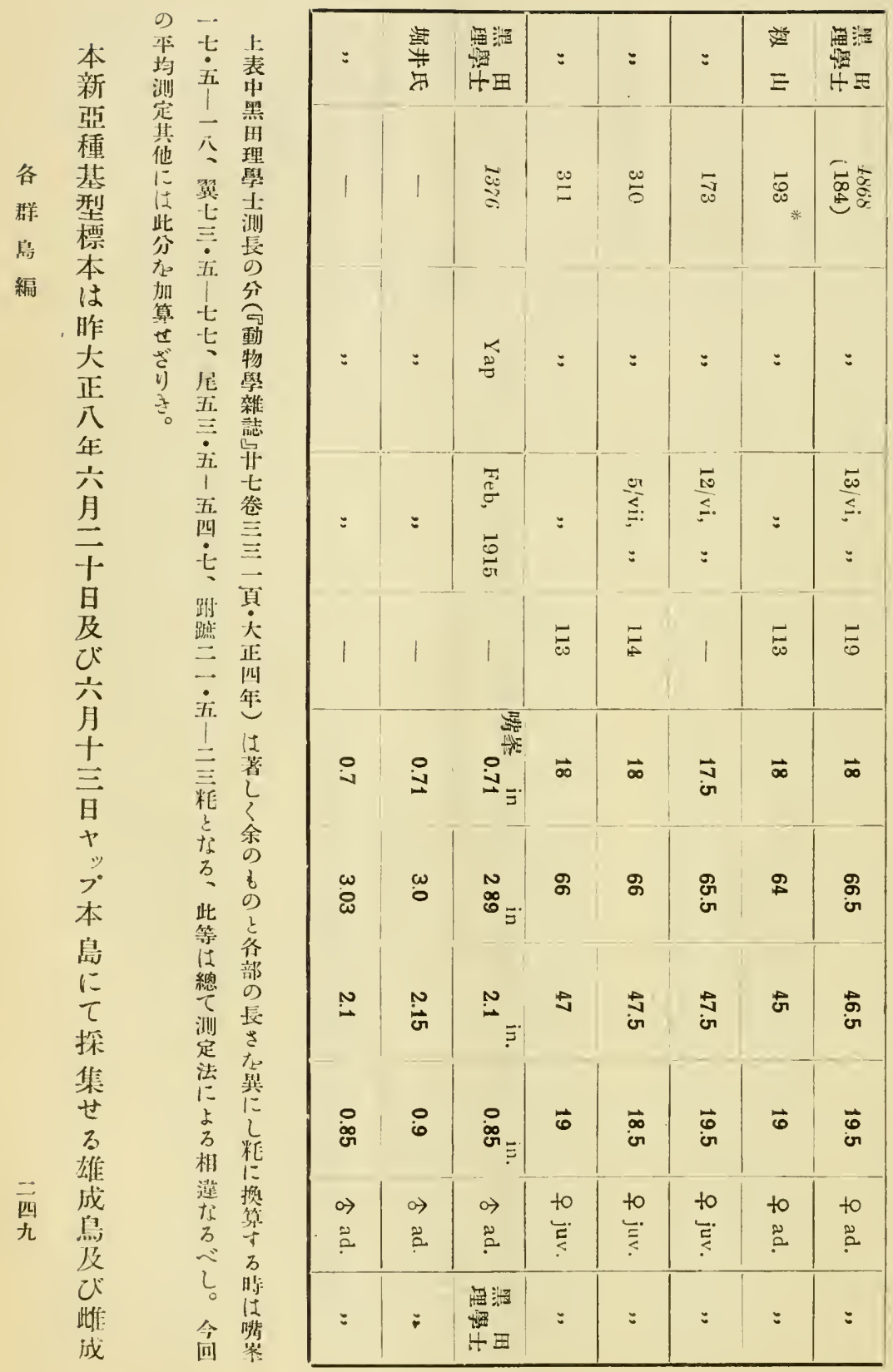




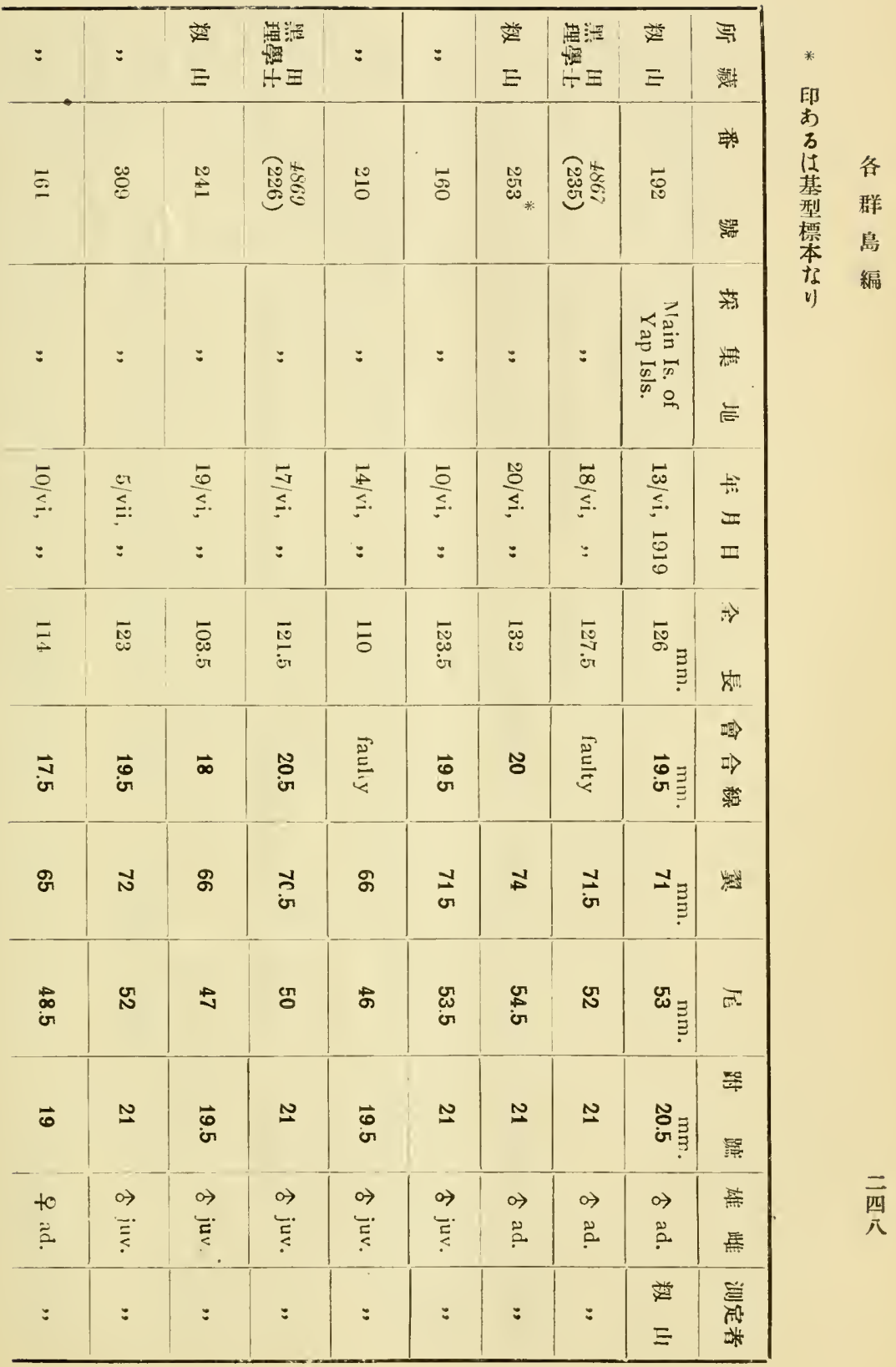


各

群

島

編

本 雌 本䧳 b $の$ は雄外し雌雄於部。

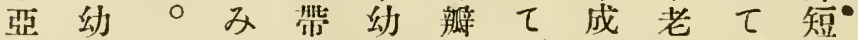
種期風は暗期に頭舀烏は小・ 各及切紅深。は部。略に 部び狗赤紅雌 淡市體 基同し。

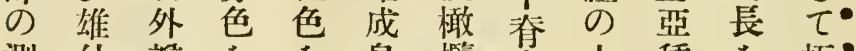

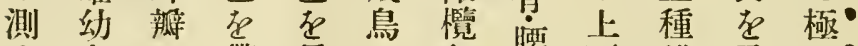
定烏に业呈に色㤎面雄示め。

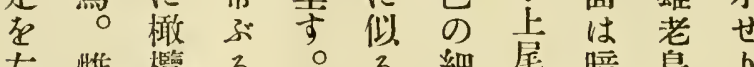
左雌欖乃 300 細尼暗彁 に成色度下緣筒橄に 表烏の 合面前を腮欖亚 出に細䔮は額有喉裀似

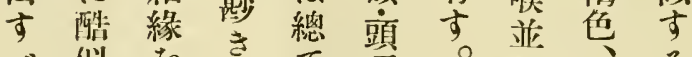
べ似市邑て 頂 し. 寸有 以絓官

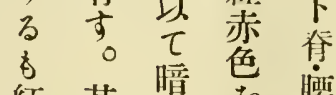
紅 其 暗 色 䑏 赤他 任带 主 色のの ぶ 尾 る 諸 橫 る 筒 州部 带 类等

ぶはを雄の

る 此 顯 成 紅.

に成す烏赤

度息。に色

合に雨比は

僅同蕧す著 かし犽れし によ施く

少緣遥優

3

学 b

微に特 力褪に

に色前

紅な 額

色b度

四 る、び 然而頭

ぶし頂

万てに

6 前 あ

の) 頸 り

に卡当

脑面稍

等 腮 樑

の 喉 紅

各站色

部にの

に前度

紅 頭 合

赤部量

色 8 異

を同に

少色本

下 れ 亞

垈占種

部稍方

最淡暗

多色色

く胸亦

下 部 る

胸以 傾

最上市

淡は b

七

な 带

b黄

灰

题白

町色

$\tau$

僅

加

i。

东。

色。

t?

is

ぶ。

る

等。

の

范皆

琣

䧄

港

5

但

․

シ

ミ

\%

ᄌ

七

衣

制.

種 


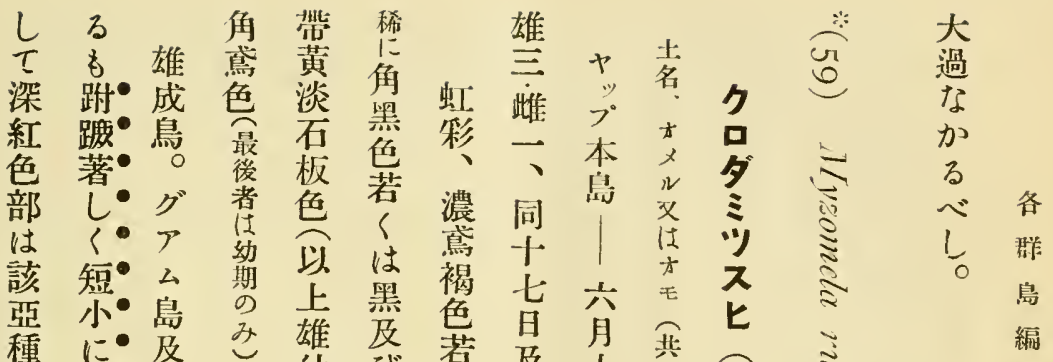

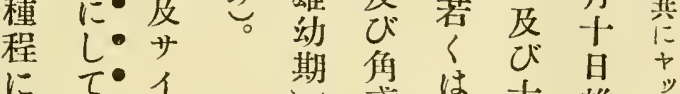

に $\tau^{\bullet} 1$

朱 二・パ

色 二・ン

を 粍島

帶を・に

び超・產

ずゆ・す

○ る・

基 事・

亞な・リ

種し・ア

站 マ ミ

にッッ

ポ ス。

ナナ と

ミ ミ ま

ッ

ス

七 に る

๖

八.

ะ $\tau \stackrel{2}{2}$

ミは 引

ツ 跗 そ.

下. 踒之

七等

等宽粍

比以

吉上酷

似

ば而等

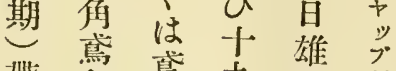

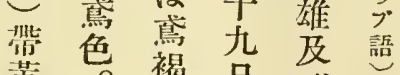

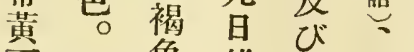

石脚色雄雌堆稱

㭾石占各盛声墨

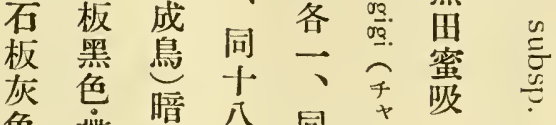

色漹億公同吸

若紫色最士嘅

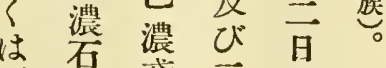

石板盗示雌

栬色急古一

以く雄同

以上は成士

上雄濃鳥三

雌成第各百

成鳥褞 、雄

鳥非色: 成

熛以㫐鳥

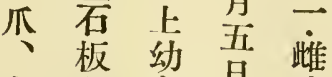

角色鳥星成

黑暗焉雄鳥

色石嘴雌三

色色 缹同

苦䓔色十

品四

西 
にト氐

もラトの新本

島” 今 姓名 新

上諸”をは亞

よ鹪夏附労種

各り島傷せ基

群本圱島し同型

島亞鳥冬類地 標

編㮔中然の方本

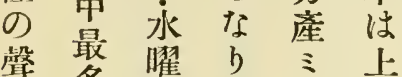

の多息

風の豆告䛌

政宁

吹やは

ᄅ 12 極

邆べめ

b $\succ$

る 秋 普

了秋通

走恶に

に总る

せ 處

b㮯 $\sigma$

、島

恐 $=の$

ら产な

$<$ 苛

該 竹 है

諸 竹 相

岛臯生

各

島息

二船 $\tau$

般のは

に附稍

通近尠

范迪海き

四 1 ह

の 上

子航 3

兒行 如

$\tau$ 時 ᄂ

七 如

類〈

昨

調大

查 正

せ公

ら年

礼公

ウ 㝵

卜

>

1 "

比冬

之皇

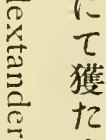

之雄

$\stackrel{0}{\Xi}$ 成

鳥

¿ な

()

名京

譽

の

爲

め

\begin{tabular}{|c|c|c|c|c|c|}
\hline 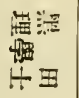 & : & $\begin{array}{l}\text { E } \\
E\end{array}$ & 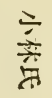 & : & $=$ \\
\hline
\end{tabular}

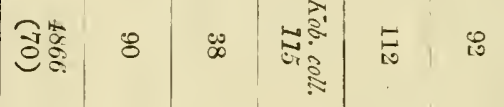

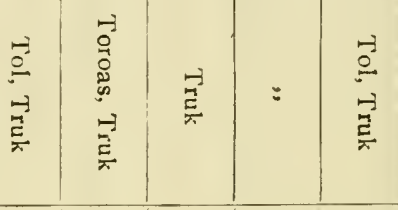

\begin{tabular}{|c|c|c|c|c|c|}
\hline$\frac{10}{6}$ & $\frac{10}{S}$ & 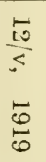 & 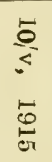 & $\begin{array}{l}\frac{10}{4} \\
=\end{array}$ & $\frac{\stackrel{10}{\pi}}{<}$ \\
\hline 1 & 10 & $\sqrt{5}$ & 1 & 惡 & 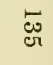 \\
\hline
\end{tabular}

\begin{tabular}{|c|c|c|c|c|}
\hline $\begin{array}{l}\vec{\infty} \\
\dot{0}\end{array}$ & $\vec{\infty}$ & $\begin{array}{l}\bar{\infty} \\
\dot{\sigma}\end{array}$ & $\vec{\varphi}$ & 苧 \\
\hline : & $\approx$ & ฮี & जै & जै \\
\hline
\end{tabular}

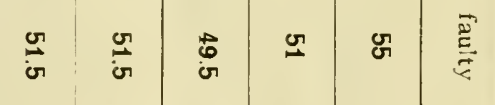

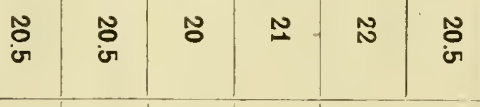

\begin{tabular}{|c|c|c|c|c|c|}
\hline to & to & to & $\rightarrow \rightarrow$ & $\leftrightarrow$ & 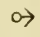 \\
\hline$\stackrel{2}{2}$ & 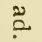 & $\stackrel{2}{2}$ & छે & 亞 & $\overleftrightarrow{\mathrm{E}}$ \\
\hline
\end{tabular}




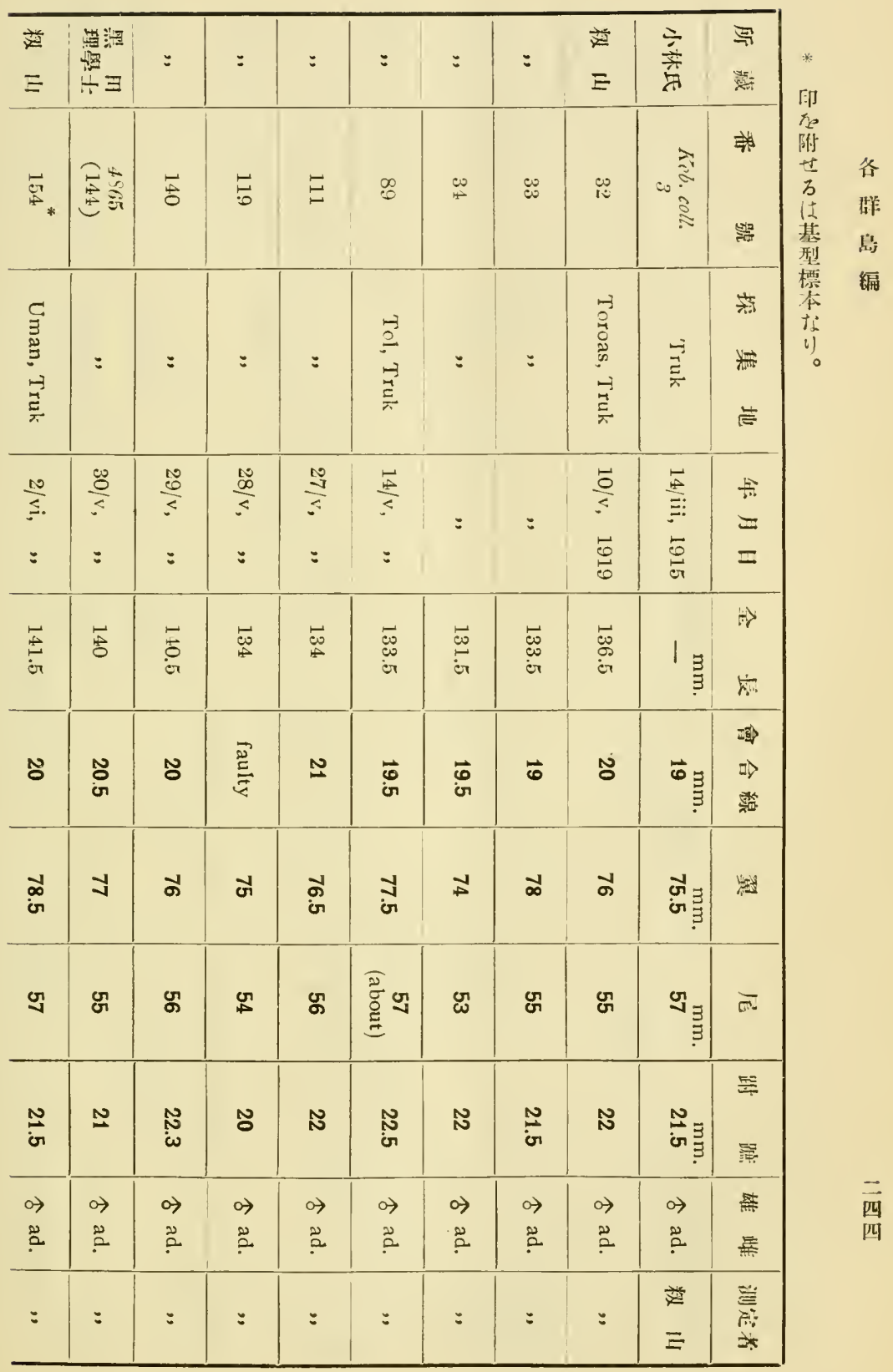


りて 稍は紅板成同 本○幼雌は来稍色雄黑鳥三卜 亞期成全色劣 の成色蛙各十 種 各 各 部 群 の 島 測 編 烏々存れ濃鳥。移、四”

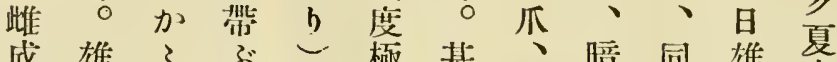

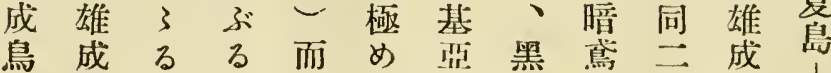
に鳥事のして種色色十鳥 定

左:

に

表

訑

殆にな度占僅ミ゙

ぞる。 鍝紅に ス・

同 8

紅

風 色

切 稍

雅褪

外 せ

辨比

の 較

細 寸

緣る

は時

僅は

美

に 觀

橄 少

欖る

色、

ชe 而

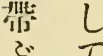

实各

主 部

と著

L

口小

角な

宊

部 b

黃。

色
呈

色劣

丙虫 3 酰。

に微本似。

ポ か 㟧

ナに種

へ 米中

ミ色 の

\%

入器 少。

七濃に。

にる色し。

あ 傾な て。

りある 會。

$\tau$ b 合

は、線。

往さに沖。

↔れて二。

桃 ぞ

色 前热方。

菛 惡 粍。

带種種苍・

びポの 超の

れナ溜超。

るへ度手。

主高。

の ッき狗

あ ス绝

りヒのに

、ににあ

本比比 b

亞 寸 寸

種れる。

にば時深
萑若及

垔人日゙

色 は维此隹月

若濃 成成十

黛鳥鳥 日 色—各雄

焦成

牙嘴森、鳥

小禾小同

黑辨三同

色突主立

脚 頾 日 二

○ 雄 早

黑卜 一成

色 今同 鼠

煙”云一

黑 系-10

色甾七下

带曹|雄紧

板枀成水

黑幼碓

色兰各岛

带白一

黑 维 问

石成二五

板量十月

色二八三

若。日十

及 日

は视

带 三成

淡卉烏

黄旦 


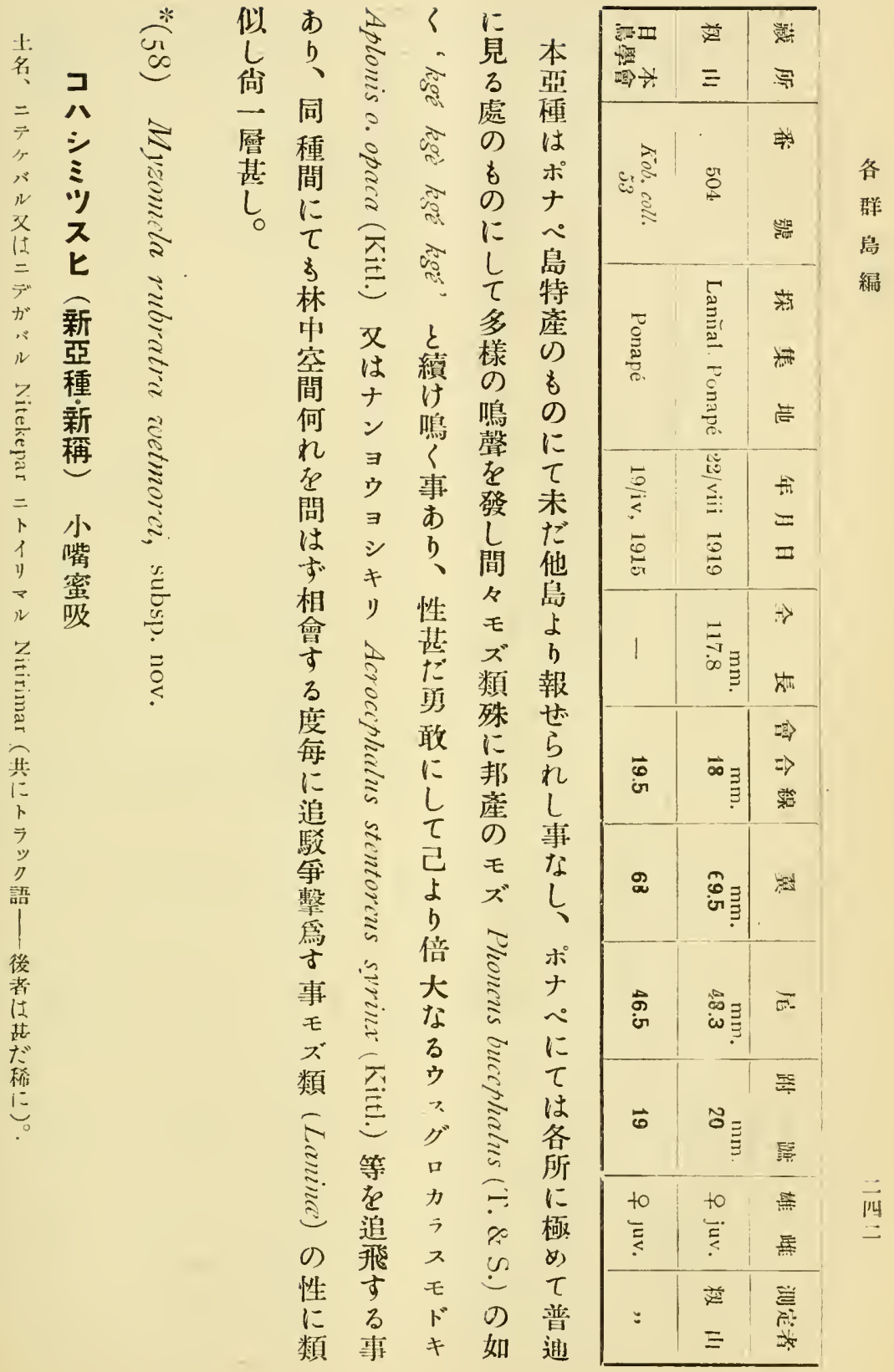




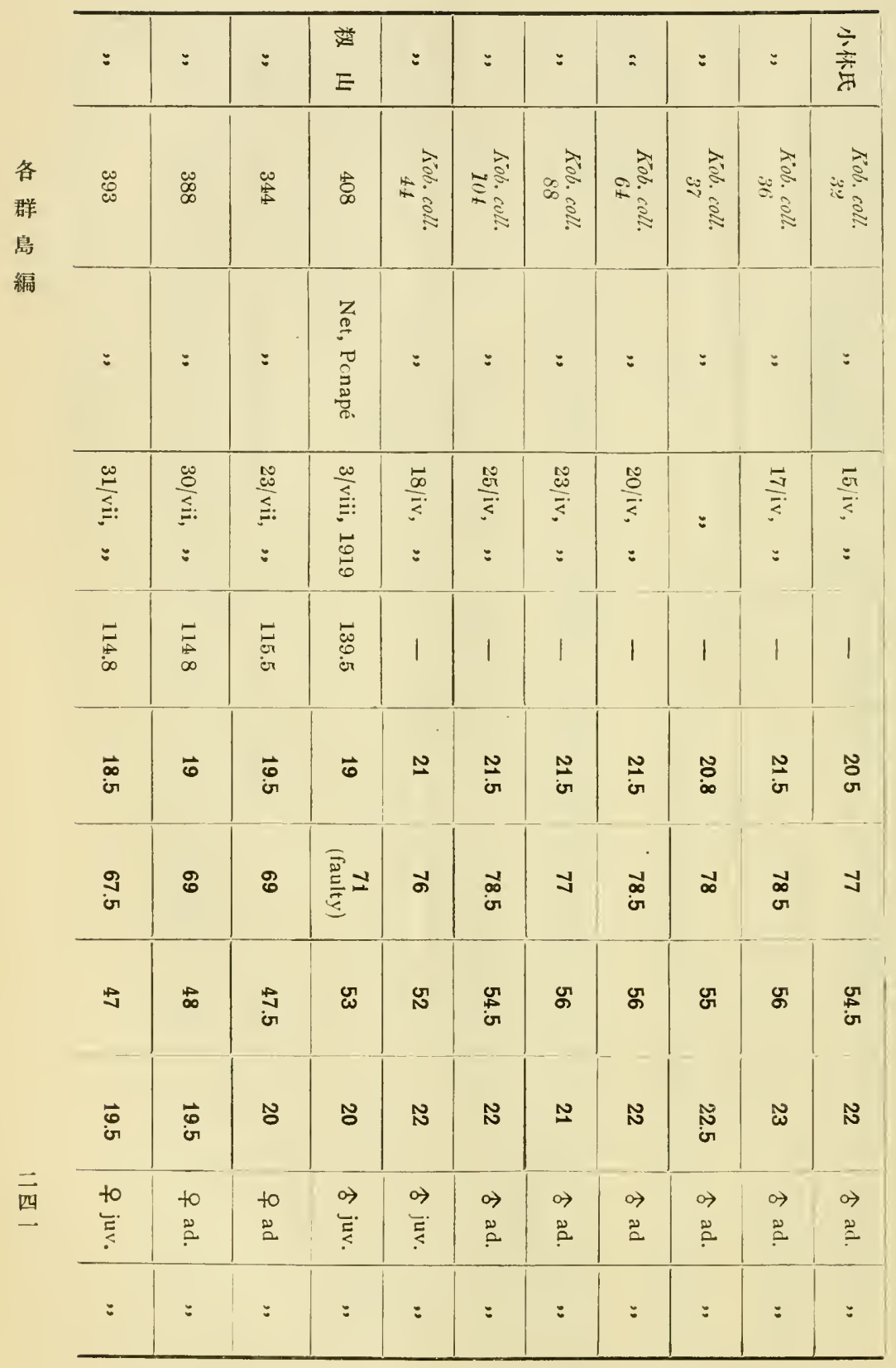




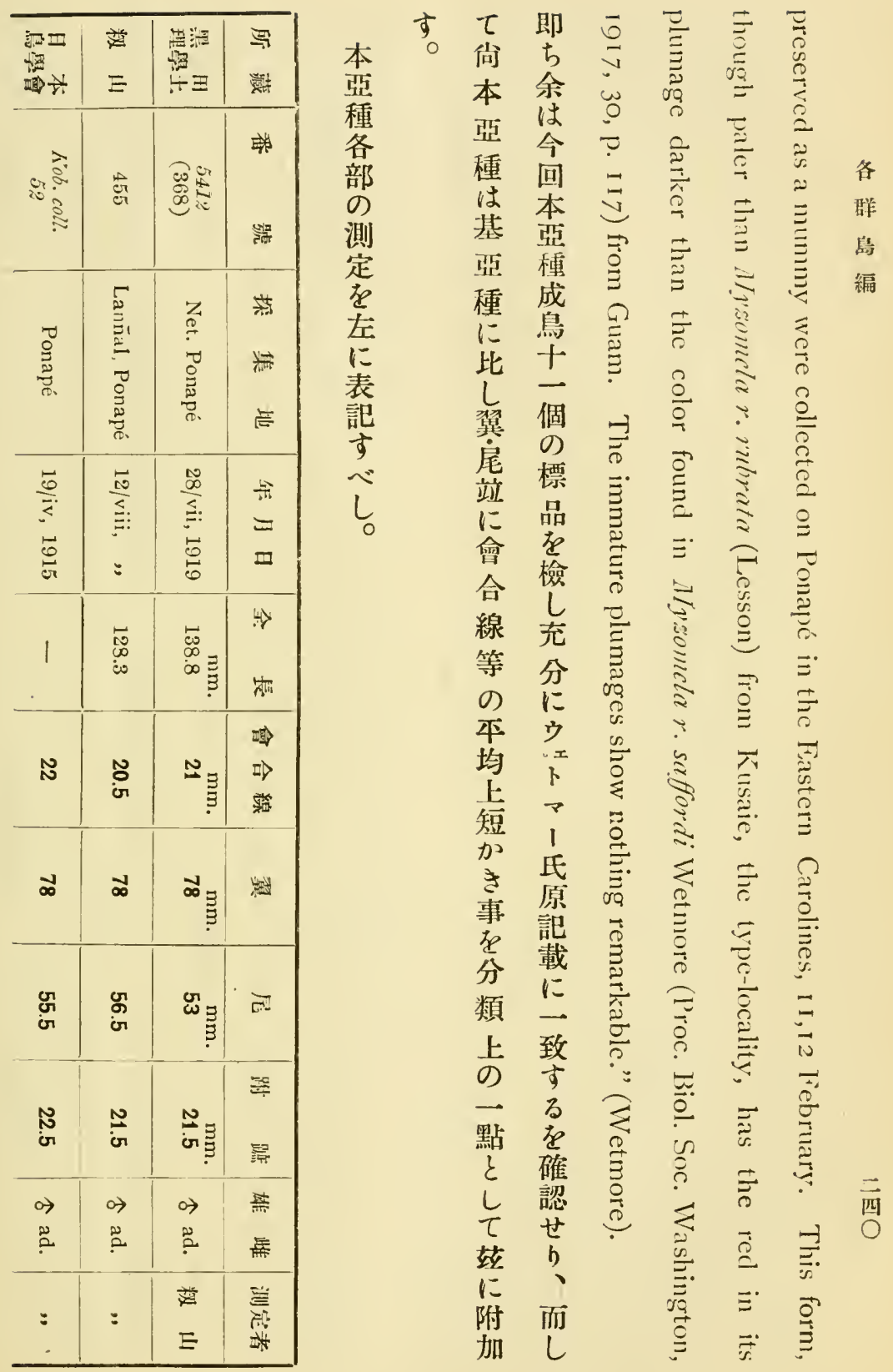




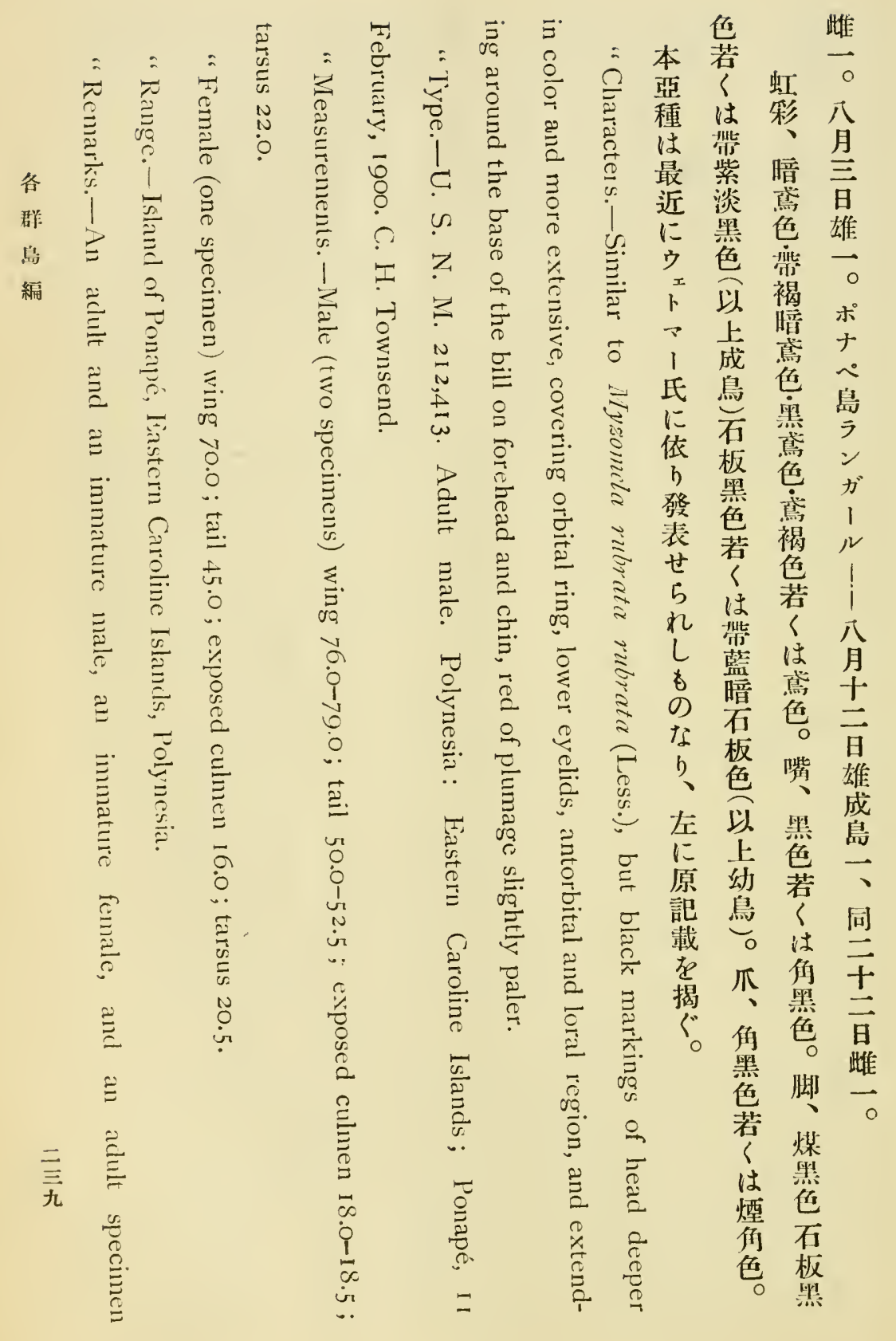




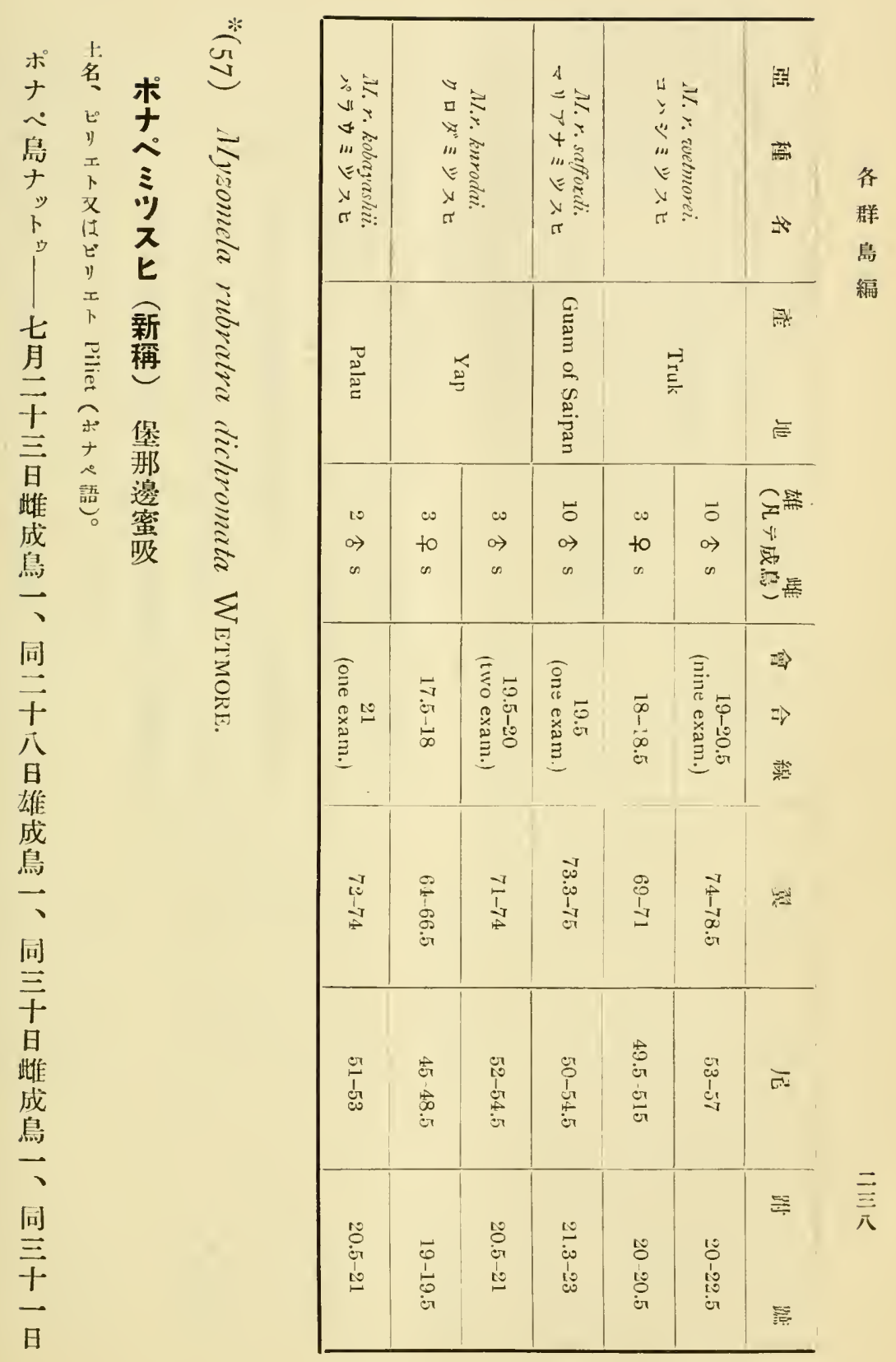




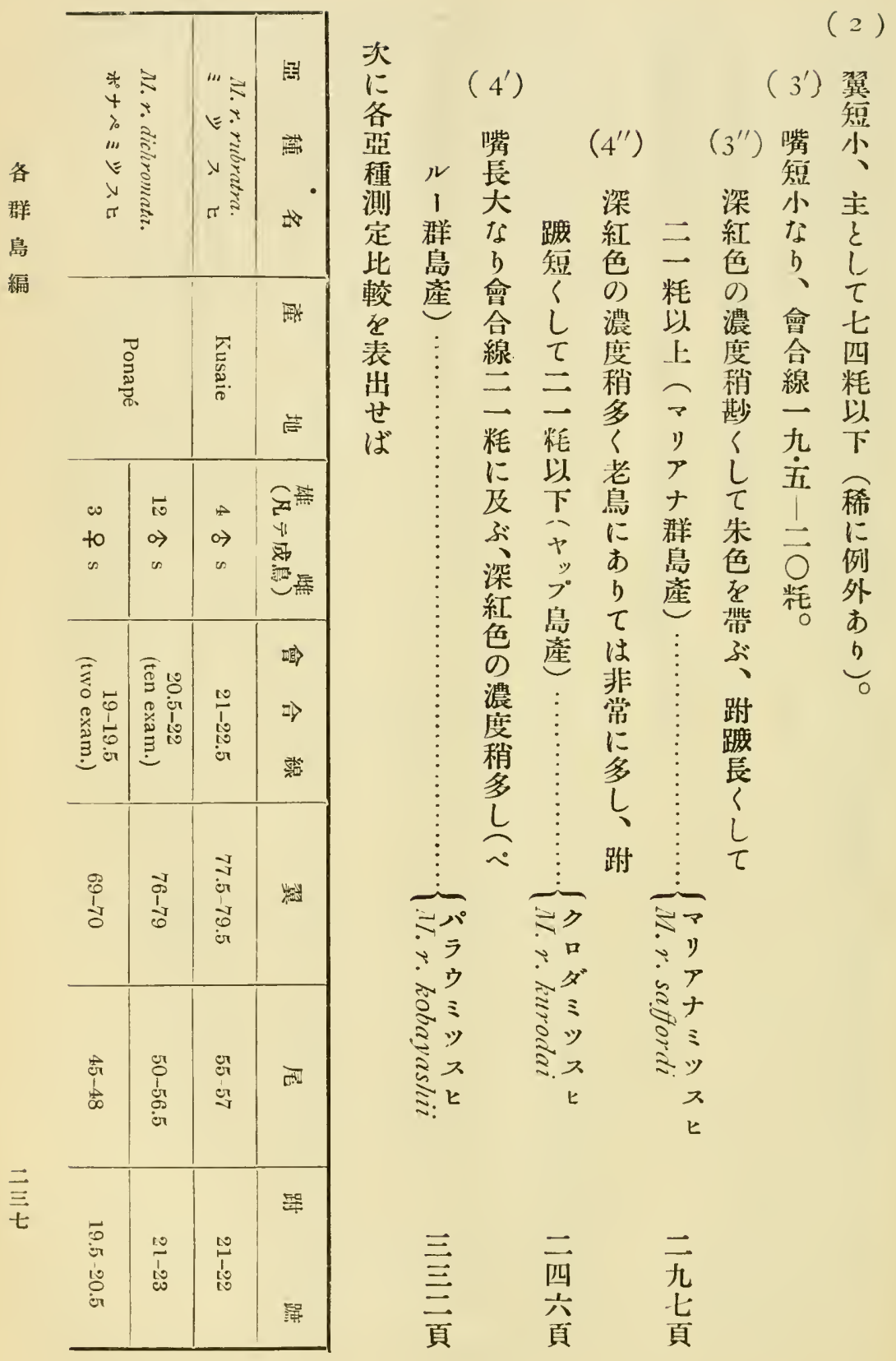


$\left(2^{\prime}\right)$

嘴

短

な聟僅紅し紅 な

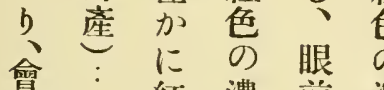

會 $\vdots$ 紅 濃 前 浱

線

線 $\vdots$ 苑

九 $\vdots$ 帶 勘

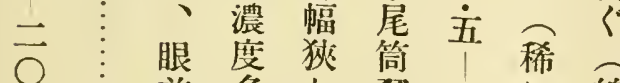

方前多し邪二に總

粍

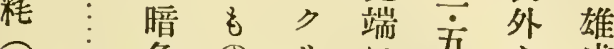

卜

ラ：部は人紅性々鳥

” $\vdots$ 幅下岛色管 の

諸 侲 尾虐

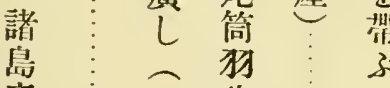

產

ポ 先

ナ 端

ペ・に
带

3

事

な
み

に

就

$\tau$

調

査

せ

b
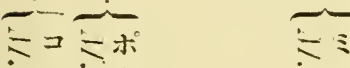

$\therefore \%$

$\therefore$ シ

ई $\leqslant$ ㅊ

ミッ

不

ヒミ

$\vdots$
$\vdots$
$\vdots$
$\vdots$
$\vdots$
$\vdots$

西 三
頁 頁 


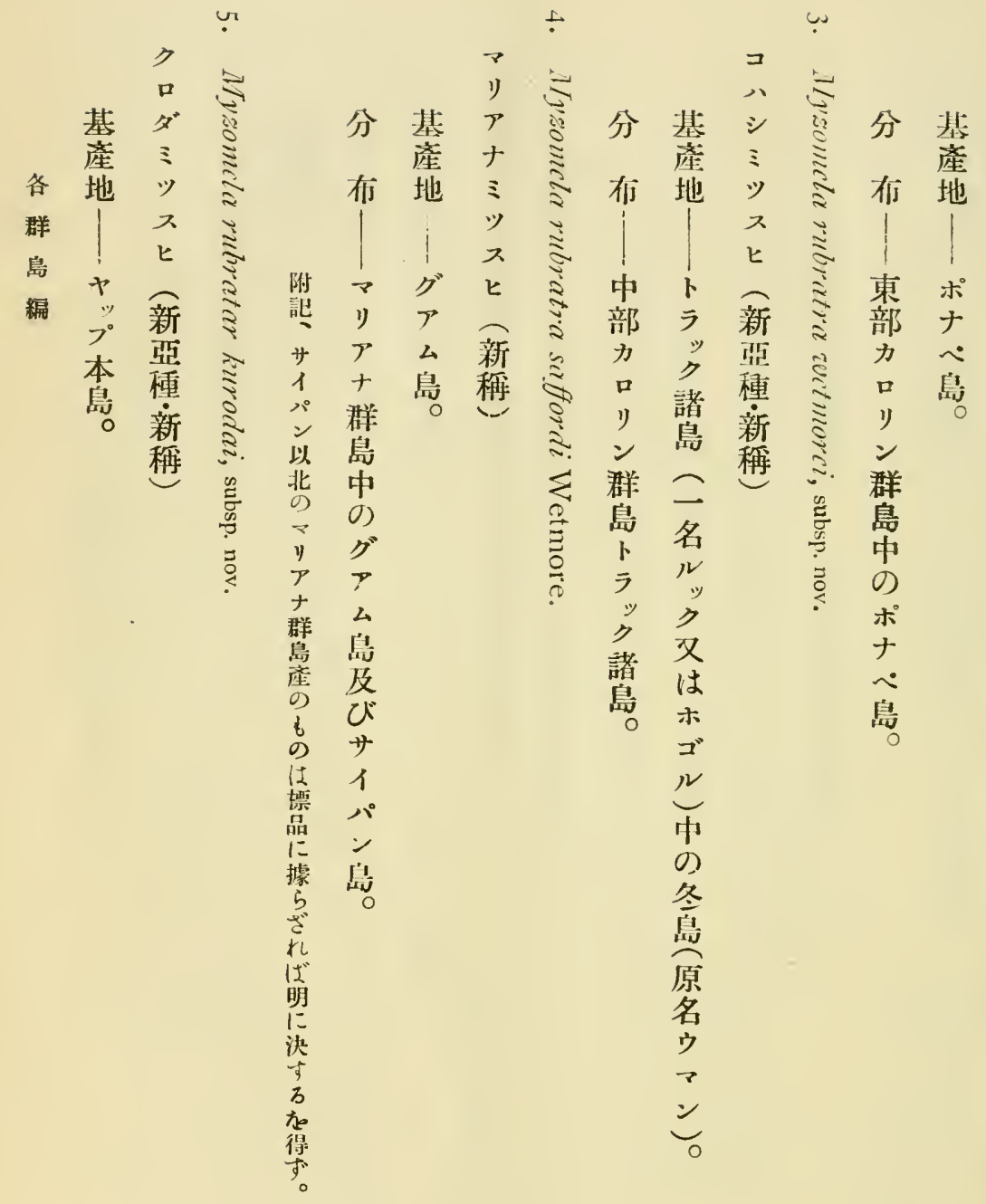

韭 
- 產卜
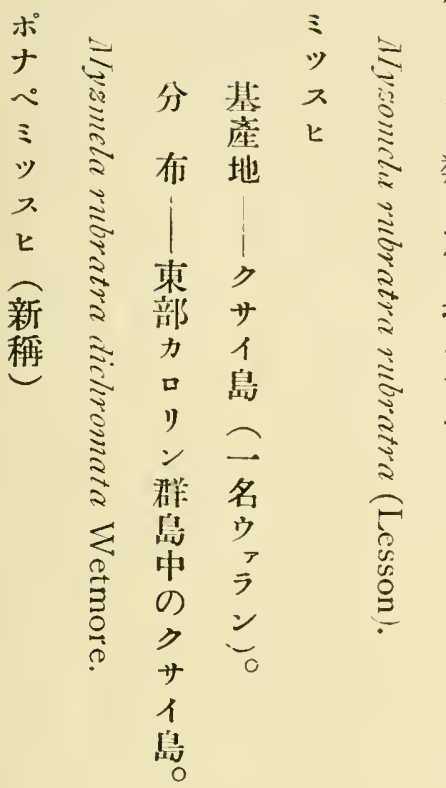

学余

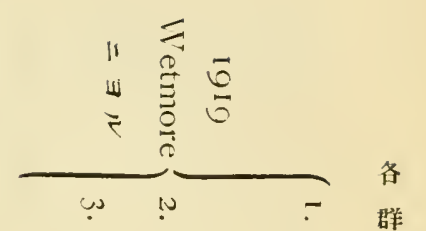

を犁 サ

左の

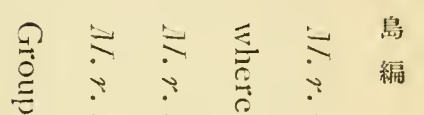

揭にな

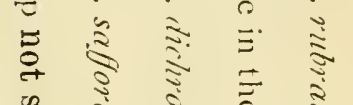

心゙充下

じ允 ラ

に䛧”

足

す プ

事に

得イ

得 イ

じ パ

文

忍

更 び

に パ

菛 ウ

種 各

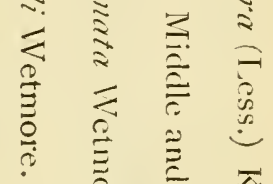

を 岛

新の

設探

せ 集

ん品

微就

す

斯調

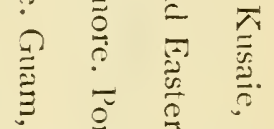

ち査

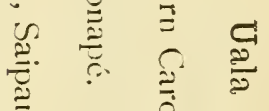

洋に

in

草

$\overrightarrow{0}$

$\stackrel{\circ}{\stackrel{5}{0}}$

吾.

$\stackrel{\overparen{g}}{\Xi}$

$\frac{\vec{\omega}}{\tilde{\Xi}}$

苛

जे

畐

อุด

ลั.

$\frac{2}{3}$ 


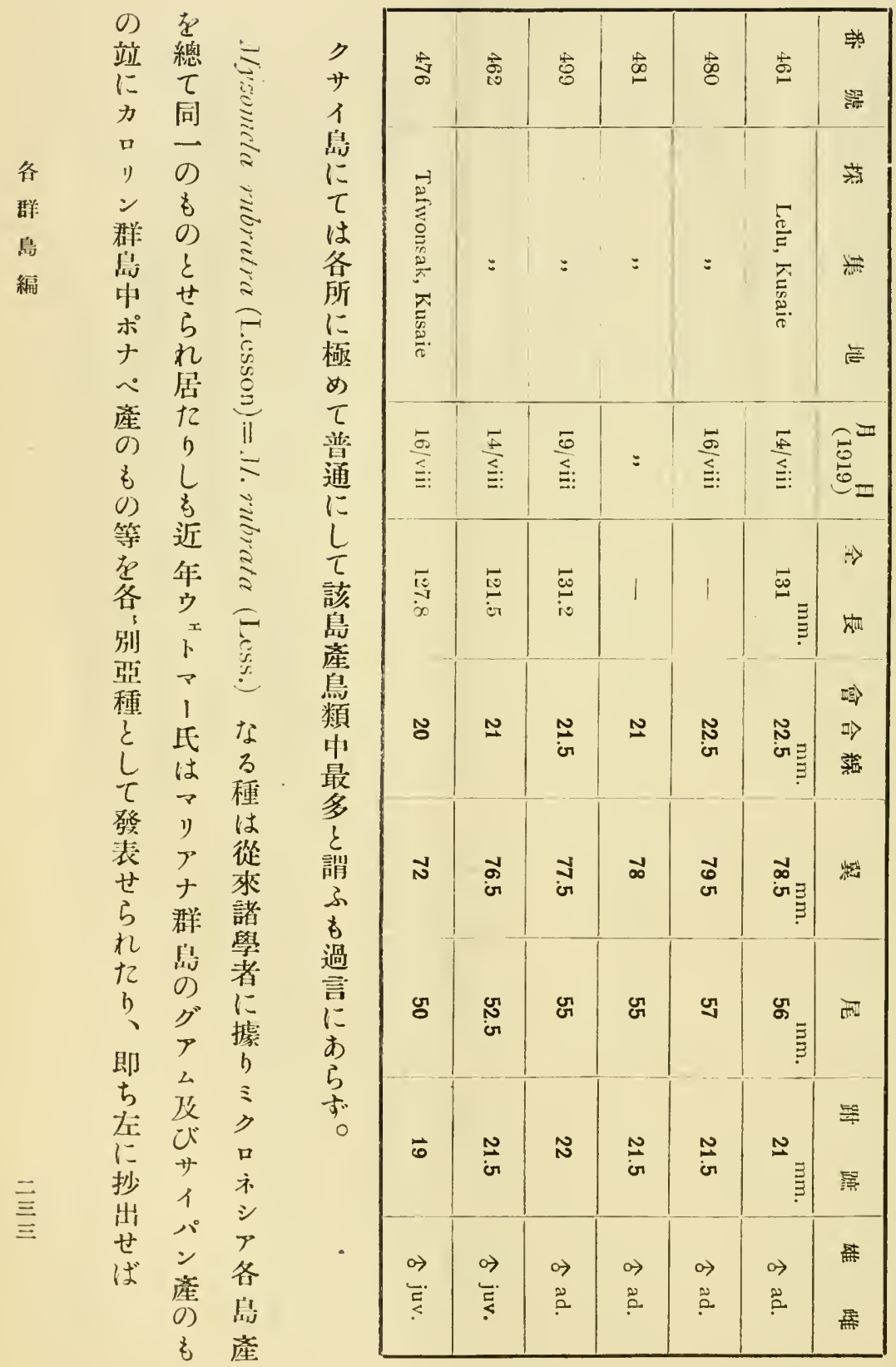




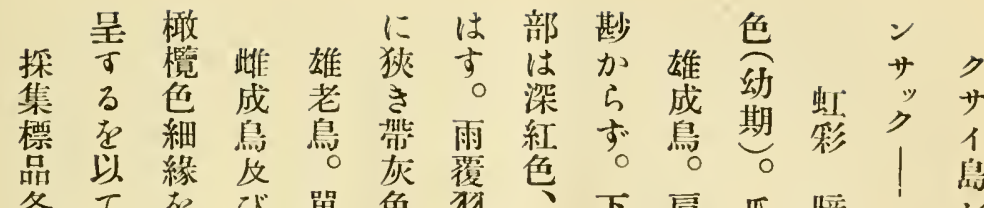

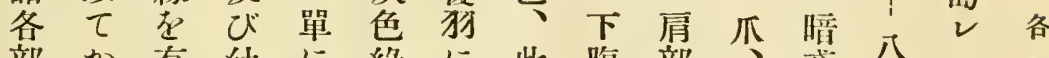
部加有幼に緣に觜腹部、臣公口群

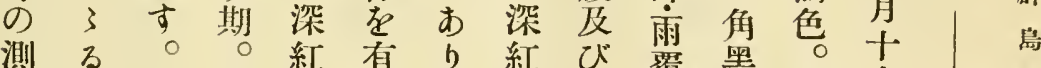

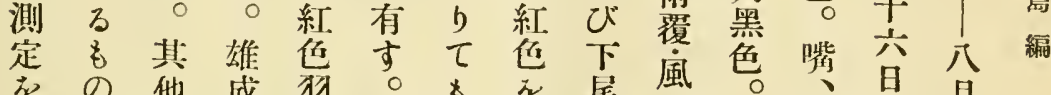
をの他成狗。娄尾風。昆月 左にの点緣先呈简切黑雄一 にあ諸にの端せは色居 表り部酷幅紅了鼠屋若白 出 $\tau$ は似虚色各黑旸 寸は一守增焉狗色站 べ品體る加呈は。に し別にす寸的裹翼 殊 深 雨る に紅覆 の 容色腹 み 易の市な 㠾度 尾 尠简 外 し 向裀上 售層

幼考鮮

期 美

に化 1

क 橄 b

乙 欖

は 灰

多褐

色

其 風

只風

你旸

部外

色辨

る 部雷僬

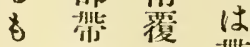

の黑は带

在色灰褐

混に黑墨

吉 し色色

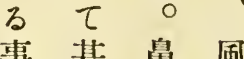

事基鼻 風

क 部孔 切

b灰基旸

。色基及

風な部び

切るよ尾

狗在 多旸

の 以 眼に

大 $\tau$ 前

坐楛眼

は夕臉保

外にはは

辨不帶稍

帶 規 黑 淡

烣黑則色

色 地其呈

色他卞

外表 の

辨現殘事

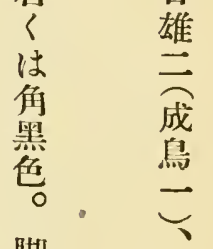

脚 同

黑墨

神禁

淡 雄

黑 成

苦奠鳥

同

は十

石 九

板旦

黑 雄

色 成

以 鳥

上 $\overrightarrow{0}$

盛节恶

紫

黑

量

石

板 


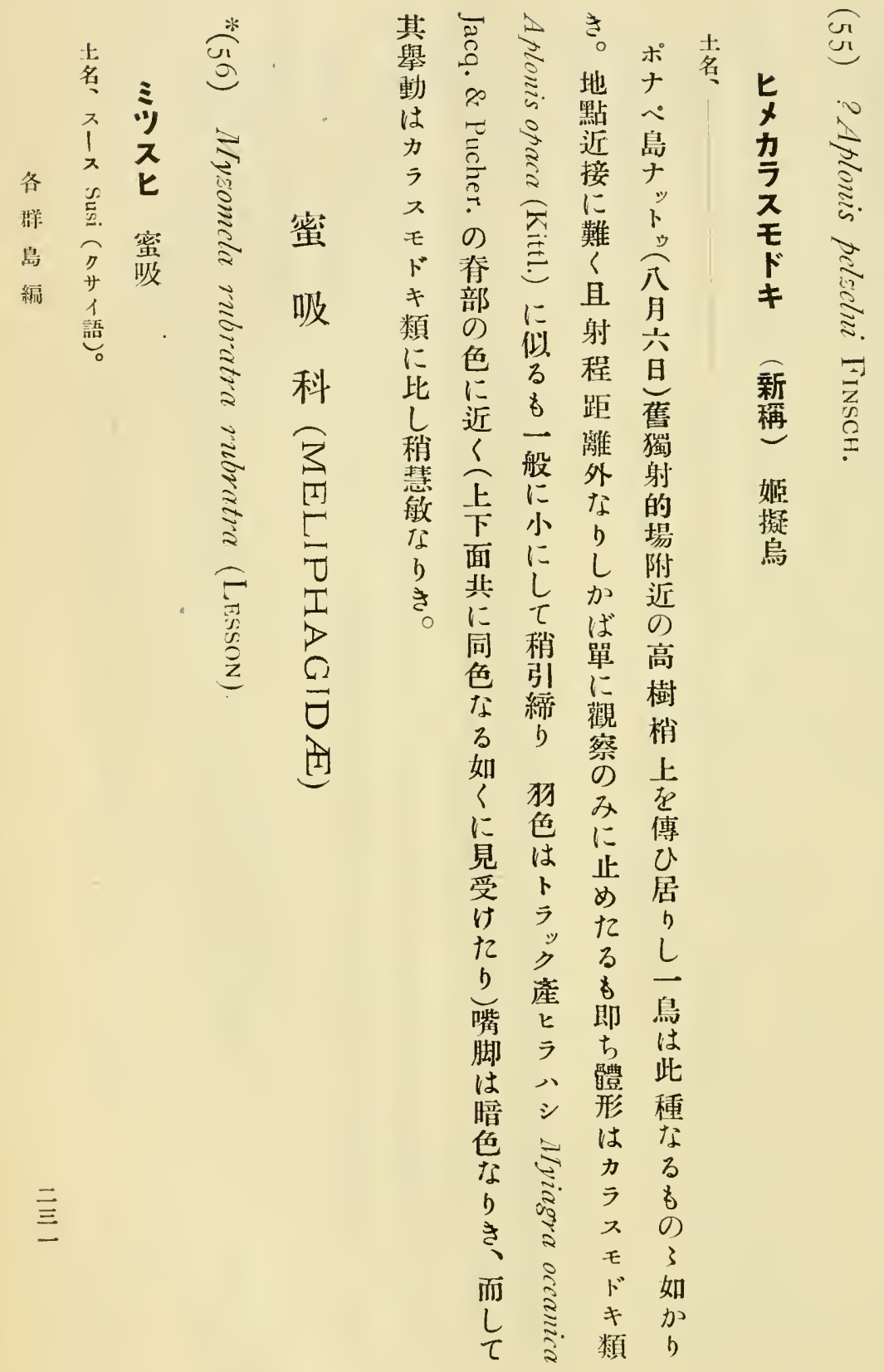




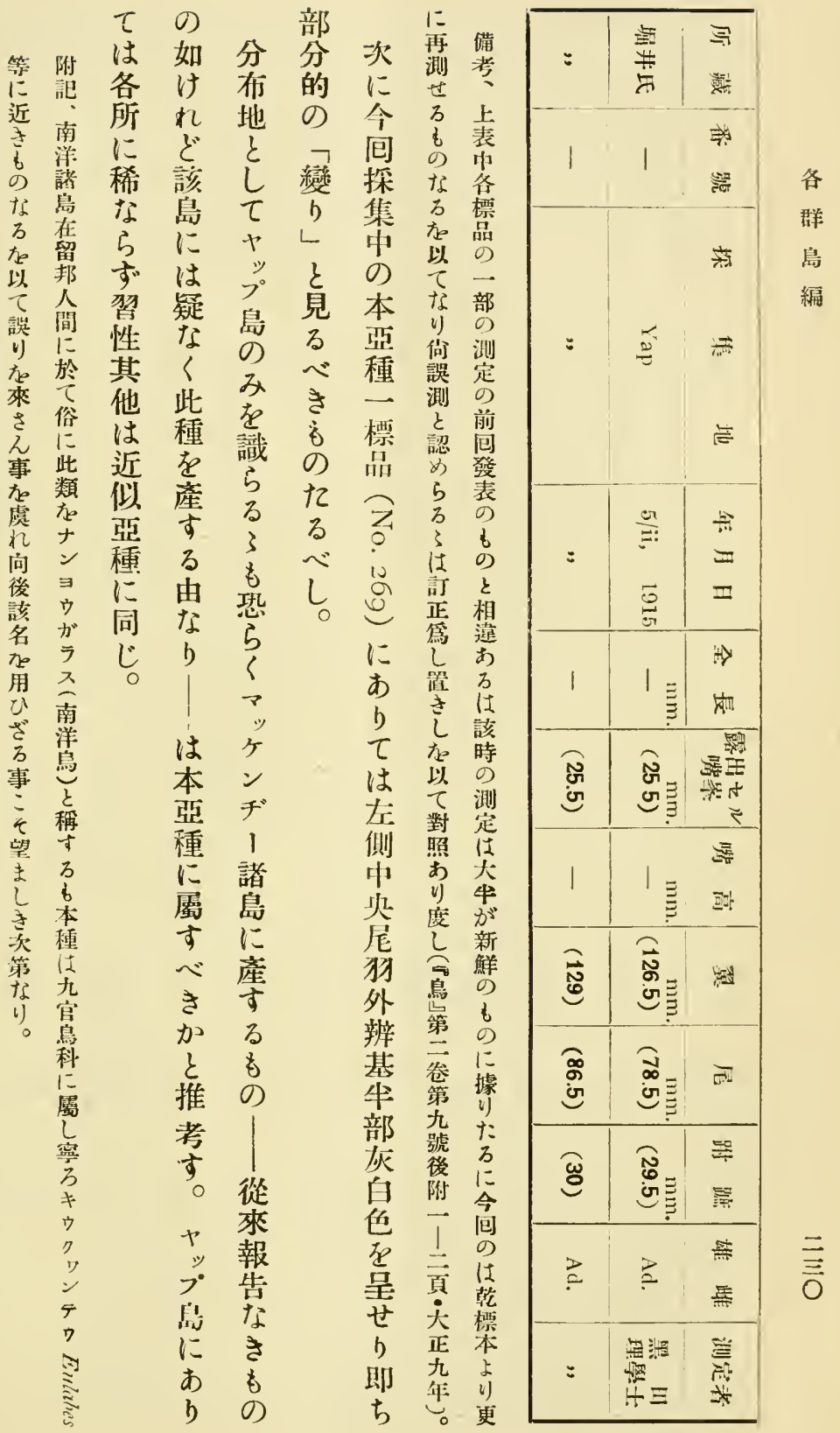




\begin{tabular}{|c|c|c|c|c|c|c|c|c|c|c|c|}
\hline 莬 & 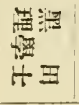 & $\approx$ & $=$ & $=$ & $=$ & : & $=$ & $=$ & $=$ & $\begin{array}{l}\equiv \\
\equiv\end{array}$ & 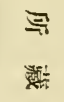 \\
\hline 1 & 㤐密 & 8 & $\overline{1}$ & ᄅ્ટ & $\stackrel{10}{8}$ & 岂 & \&్ర & $\begin{array}{l}10 \\
0 \\
0\end{array}$ & $\mathscr{C}_{\mathscr{H}}^{\mathscr{C}}$ & $\begin{array}{l}10 \\
\infty \\
\infty \\
*\end{array}$ & 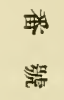 \\
\hline 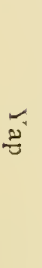 & $=$ & $=$ & $=$ & $=$ & $=$ & $=$ & : & : & : & 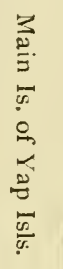 & $\begin{array}{l}\text { 获 } \\
\text { 崖 }\end{array}$ \\
\hline$\stackrel{\mathrm{g}}{\Xi}$ & $\frac{10}{0}$ & $\frac{\omega}{s}$ & $\frac{\sqrt{0}}{\leq}$ & $\frac{5}{3}$ & $\frac{15}{\leq}$ & $\frac{10}{5}$ & $\frac{10}{5}$ & $\underset{5}{-5}$ & $\stackrel{\text { 蛋 }}{\leqq}$ & $\frac{10}{5}$ & 点 \\
\hline$\stackrel{Ð}{\bullet}$ & $=$ & $=$ & $=$ & : & $=$ & $=$ & $=$ & : & $=$ & $\stackrel{6}{0}$ & $=$ \\
\hline 1 & $\underset{⿱ 乛 龰}{5}$ & $\begin{array}{l}\vec{g} \\
\text { er } \\
\text { er }\end{array}$ & $\begin{array}{l}10 \\
\stackrel{10}{0} \\
\dot{c}\end{array}$ & $\stackrel{\circ}{\infty}$ & $\begin{array}{l}10 \\
8 \\
0 \\
0\end{array}$ & 8 & $\stackrel{10}{8}$ & 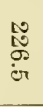 & 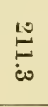 & $\stackrel{10}{5}$ & $\begin{array}{l}\Rightarrow \\
\text { 梅II }\end{array}$ \\
\hline$\widehat{N}$ & 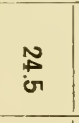 & No & $\stackrel{N}{\perp}$ & $\stackrel{N}{\Perp}$ & $\stackrel{\sim}{\infty}$ & 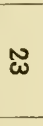 & $\begin{array}{l}\text { जั } \\
\text { जั }\end{array}$ & $\begin{array}{l}\text { के } \\
\text { जे }\end{array}$ & $\begin{array}{l}\text { J } \\
\text { ir }\end{array}$ & $\stackrel{\mathcal{J}}{3}$ & 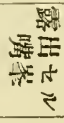 \\
\hline 1 & ठ & $\infty$ & $\begin{array}{l}\infty \\
\dot{\sigma}\end{array}$ & or & 0 & $\omega$ & $\omega$ & $\overrightarrow{0}$ & $\overrightarrow{0}$ & 옴키 & 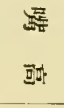 \\
\hline ث્心 & $\overrightarrow{\vec{\varphi}}$ & $\mathscr{\theta}$ & $\overrightarrow{\text { जे }}$ & $\vec{\omega}$ & $\underset{\vec{\sigma}}{\vec{\omega}}$ & $\begin{array}{l}\overrightarrow{\vec{G}} \\
\dot{\sigma}\end{array}$ & $\begin{array}{l}\overrightarrow{0} \\
\text { जे }\end{array}$ & $\begin{array}{l}\vec{w} \\
\text { जu }\end{array}$ & $\begin{array}{l}\vec{N} \\
\text { जे }\end{array}$ & $\vec{\omega}_{\Xi}$ & 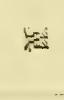 \\
\hline 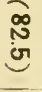 & $\stackrel{\infty}{0}$ & $\begin{array}{l}\mathbb{\infty} \\
\dot{G}\end{array}$ & $\underset{\text { in }}{N}$ & $\stackrel{\infty}{N}$ & N & $\stackrel{\infty}{\circ}$ & $\stackrel{\infty}{\infty}$ & $\stackrel{\infty}{\sim}$ & $\stackrel{\infty}{\mathfrak{G}}$ & \begin{tabular}{l}
$\infty$ \\
$\infty$ \\
\hdashline \\
$\sigma$
\end{tabular} & DW \\
\hline $\begin{array}{l}\widehat{\mathcal{O}} \\
\text { G्व }\end{array}$ & ઼ֻ & $\begin{array}{l}\text { ज } \\
\text { نे }\end{array}$ & 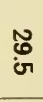 & ज्ञ & o & $\begin{array}{l}\text { ज } \\
\text { G }\end{array}$ & ల & $\begin{array}{l}\infty \\
\dot{\infty} \\
\text { जे }\end{array}$ & $\begin{array}{l}\infty \\
\dot{\sigma} \\
\dot{\sigma}\end{array}$ & $\begin{array}{l}\omega_{0} \\
\text { G }\end{array}$ & $\begin{array}{l}\text { 㗨 } \\
\text { 琶 }\end{array}$ \\
\hline$\stackrel{p}{2}$ & $\begin{array}{l}\text { to } \\
2 \\
?\end{array}$ & $\begin{array}{l}\widetilde{0} \\
\stackrel{5}{5} \\
010\end{array}$ & $\begin{array}{l}\text { to } \\
\stackrel{E}{\vdots}\end{array}$ & $\begin{array}{l}\text { to } \\
\stackrel{\mathrm{E}}{\mathrm{K}}\end{array}$ & 일 & 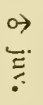 & $\begin{array}{l}\text { to } \\
\stackrel{2}{2}\end{array}$ & $\begin{array}{l}\text { to } \\
\cong \\
2\end{array}$ & $\begin{array}{l}\stackrel{0}{0} \\
\stackrel{0}{2}\end{array}$ & $\begin{array}{l}\stackrel{\rightarrow}{0} \\
\stackrel{2}{2}\end{array}$ & $\begin{array}{l}\text { 箖 } \\
\text { 点 }\end{array}$ \\
\hline : & 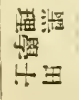 & : & $=$ & : & : & : & $=$ & : & $=$ & $\begin{array}{l}\text { E } \\
\text { E }\end{array}$ & $\begin{array}{l}\text { 关 } \\
\text { 就 } \\
\text { * }\end{array}$ \\
\hline
\end{tabular}


* 本

印 亞

辇種

附 標

点

告各

基 部

型 0

本 测

定

v) b

在

泣

揭

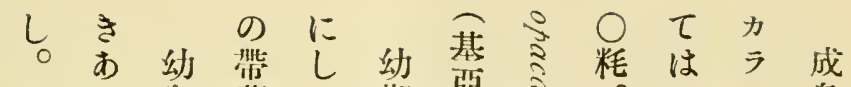

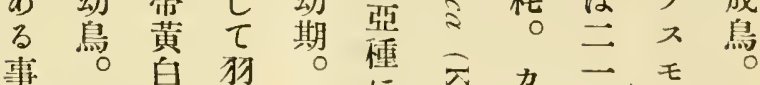

と基色緣 基

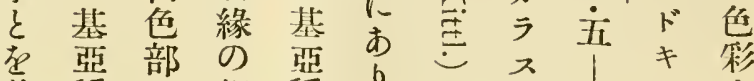

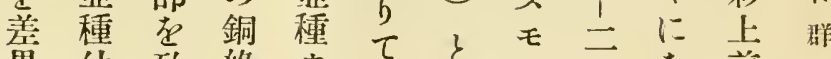

異幼殆綠ウ

點鳥ん色 ス露は粍り政

とにど 光グ出體にに粍て種

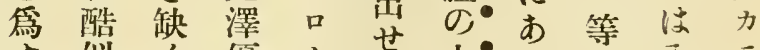

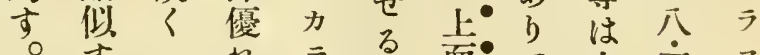

因攼點 る

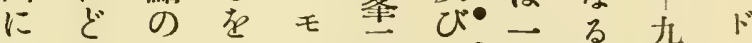

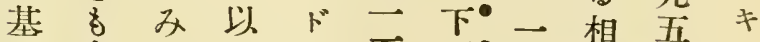

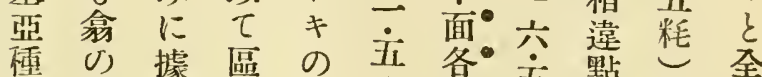

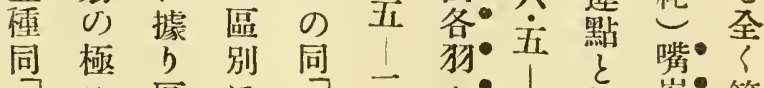

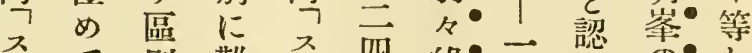

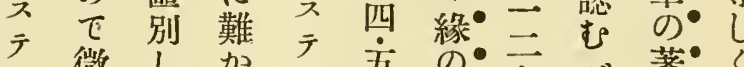

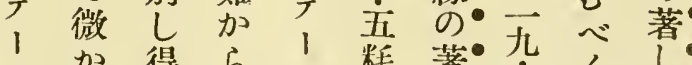

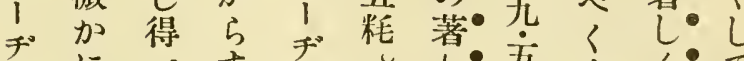

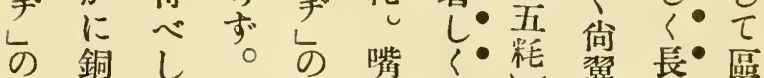

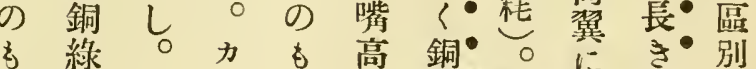

ラの 九 に き・別

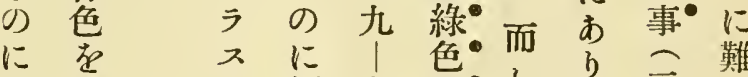

あ 带 モ 類 九 光 ${ }^{\circ}$ て 三 難

b) ऊ゙

$\tau$ ら

は㯨

本字

亞 下

種面

に

比多

L 少

占褐

面色

は学

灰带

鼠

色多傾
ド似主澤して 五

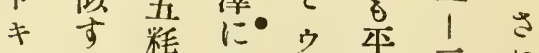

のる富。均二れ

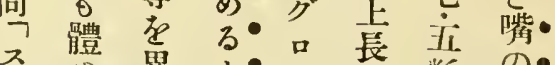

テ り 異と・カ大紝の・

声啙 嘴・ラな

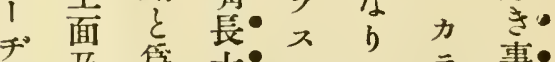

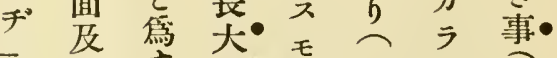

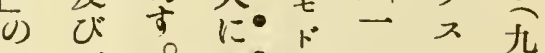

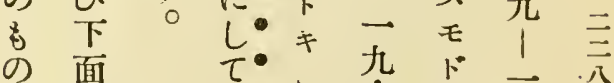

そは

は 稍

下 濃

面 色

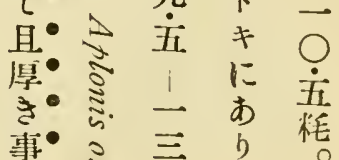

同方等 め。グ卢 ど 


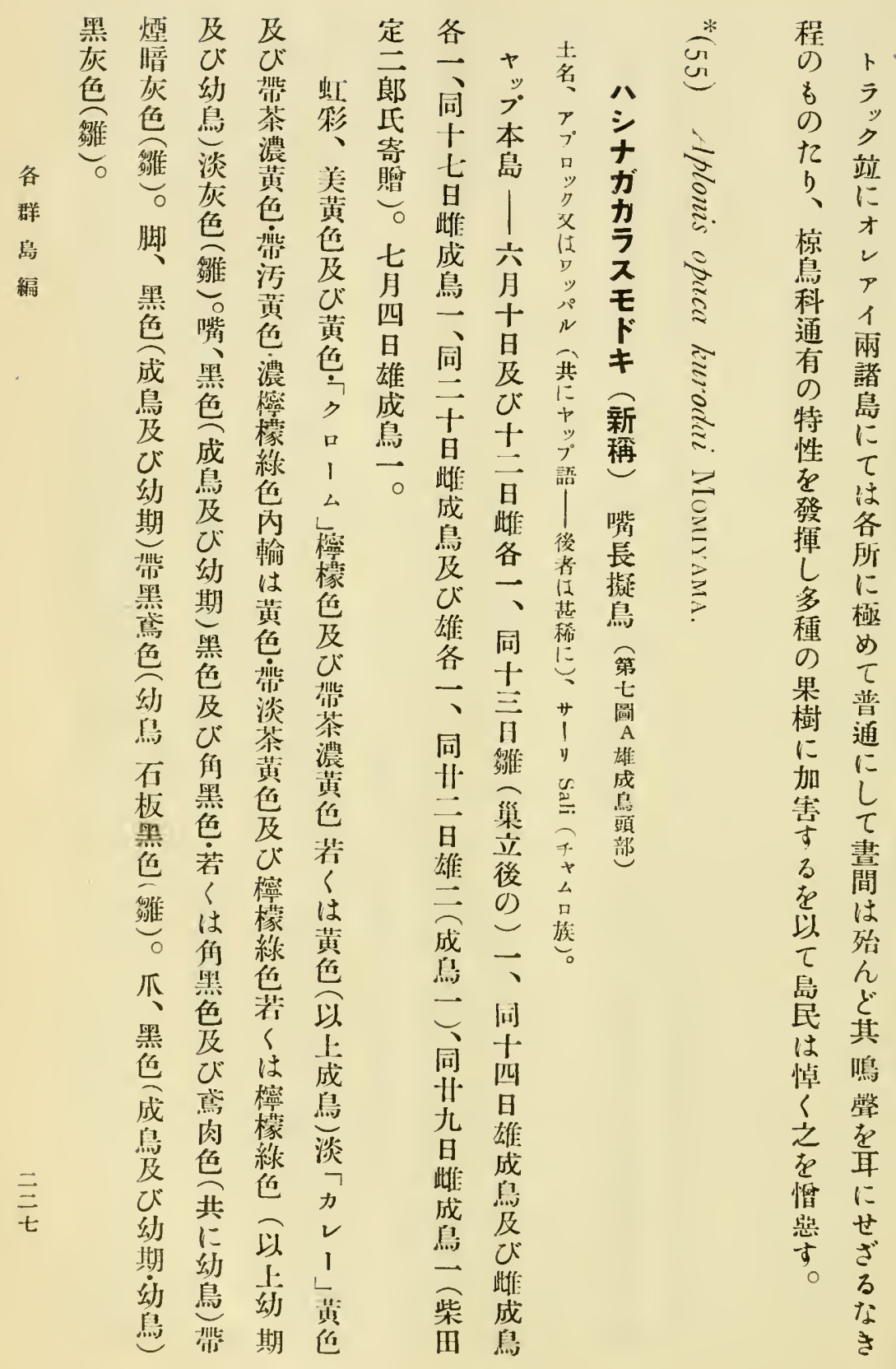




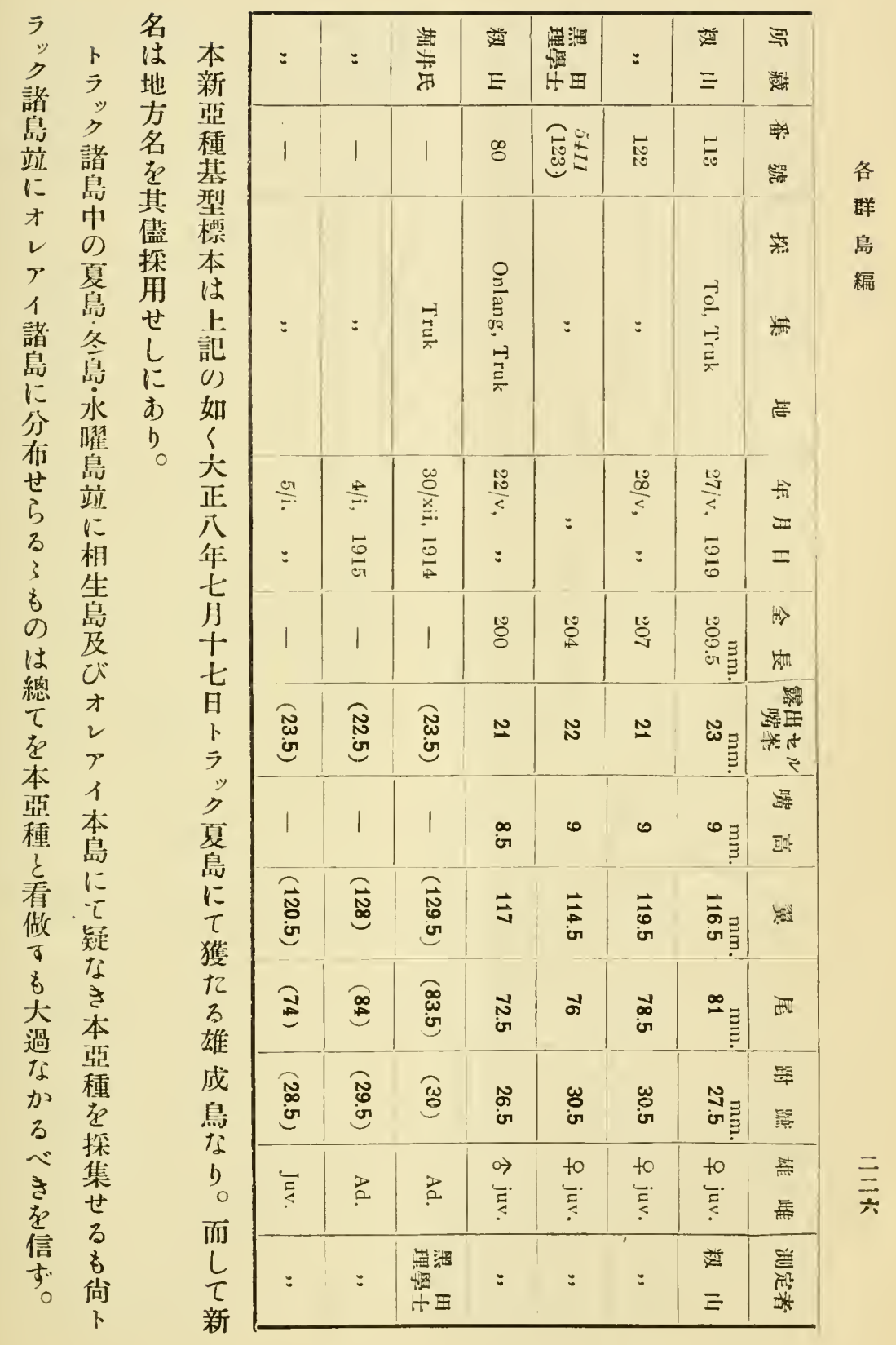




\begin{tabular}{|c|c|c|c|c|c|c|c|c|c|c|c|}
\hline : & : & : & $=$ & : & : & $\begin{array}{l}\text { E } \\
E\end{array}$ & 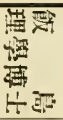 & $=$ & : & $=$ & $=$ \\
\hline 용 & $\underset{\omega}{\stackrel{\omega}{\omega}}$ & $\stackrel{\infty}{\infty}$ & $\stackrel{10}{5}$ & $\stackrel{\circ}{\circ}$ & 总 & Cु & 出 & ֻ & 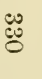 & 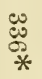 & 苞 \\
\hline $\begin{array}{l}-1 \\
\underline{0} \\
-1 \\
\underline{\underline{E}} \\
\frac{1}{x}\end{array}$ & 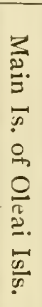 & : & $=$ & 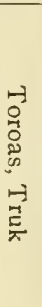 & 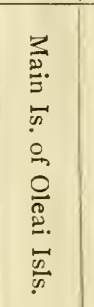 & 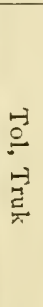 & 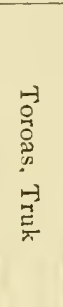 & : & $\begin{array}{l}3 \\
\frac{3}{0} . \\
0 \\
0 \\
0 \\
0 \\
\frac{0}{3} \\
\frac{0}{0 .}\end{array}$ & $\begin{array}{l}= \\
0 \\
0 \\
0 \\
0 \\
0 \\
0\end{array}$ & 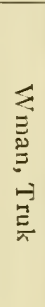 \\
\hline $\begin{array}{l}\frac{v}{<} \\
:\end{array}$ & $\begin{array}{l}\frac{\tilde{\omega}}{\vdots} \\
\underline{\Xi}\end{array}$ & : & : & $\begin{array}{l}\frac{5}{<} \\
=\end{array}$ & $\begin{array}{l}\stackrel{\omega}{\leftrightarrows} \\
: \\
:\end{array}$ & $\begin{array}{l}\frac{\sqrt{0}}{6} \\
=\end{array}$ & $\begin{array}{l}\frac{\text { er }}{<} \\
=\end{array}$ & $=$ & $\begin{array}{l}\underset{\omega}{\omega} \\
:\end{array}$ & $\begin{array}{l}\frac{\bar{J}}{\vdots} \\
\Xi: \\
=\end{array}$ & $\begin{array}{l}\frac{N}{\leq} \\
=\end{array}$ \\
\hline 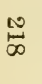 & $\overbrace{C 1}^{\infty}$ & $\frac{10}{10}$ & $\stackrel{\infty}{\infty}$ & 怘 & 莺 & $\stackrel{0}{0}$ & $\begin{array}{l}\frac{10}{\omega} \\
0 \\
0\end{array}$ & $\frac{10}{N}$ & 墨 & $\begin{array}{l}15 \\
10 \\
10\end{array}$ & $\stackrel{10}{\infty}$ \\
\hline $\begin{array}{l}\text { N } \\
\text { v }\end{array}$ & N & $\stackrel{\omega}{\omega}$ & 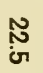 & $\begin{array}{l}\text { N } \\
\dot{G}\end{array}$ & $\begin{array}{l}\text { N } \\
\text { G }\end{array}$ & $\stackrel{N}{\$}$ & $\widehat{\omega}$ & ज & $\widetilde{\omega}$ & 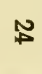 & $\begin{array}{l}\text { N } \\
\text { Un }\end{array}$ \\
\hline$\bullet$ & $\stackrel{\infty}{\sigma}$ & 0 & 0 & $\stackrel{\infty}{\dot{\sigma}}$ & $\begin{array}{l}\infty \\
\dot{0}\end{array}$ & $\begin{array}{l}\infty \\
\dot{\sigma r}\end{array}$ & ज & $\begin{array}{l}\infty \\
0\end{array}$ & ơ & ơ & 0 \\
\hline$\stackrel{N}{\Delta}$ & $\vec{N}$ & $\underset{\text { vi }}{\stackrel{N}{*}}$ & 安 & ज्ञ & $\overrightarrow{\overrightarrow{0}}$ & $\overrightarrow{0}$ & $\overrightarrow{0}$ & $\vec{\omega}$ & $\overrightarrow{\text { సे }}$ & ज़ & $\overrightarrow{\mathrm{G}}$ \\
\hline$y$ & $\underset{\text { iv }}{\vec{F}}$ & రૈ & $\begin{array}{l}\text { ơ } \\
\text { or }\end{array}$ & नै & 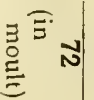 & \& & 1 & $\stackrel{\infty}{\boldsymbol{\sim}}$ & ळొ & ऊँ & $\underset{\text { G }}{\infty}$ \\
\hline$\underline{\omega}$ & $\begin{array}{l}\hat{U} \\
\text { of } \\
\text { or }\end{array}$ & $\stackrel{\omega}{\omega}$ & $\begin{array}{l}\infty \\
\dot{\sigma} \\
\text { G }\end{array}$ & స్ర & $\begin{array}{l}\text { Uै } \\
\text { ज̆ }\end{array}$ & స్ర & 1 & 保 & $\begin{array}{l}\omega_{0} \\
\text { or }\end{array}$ & జ & w \\
\hline $\begin{array}{l}\text { to } \\
\text { E. }\end{array}$ & $\stackrel{\circ}{\stackrel{\square}{\vdots}}$ & $\begin{array}{l}\text { to } \\
\stackrel{\Xi}{\Xi}\end{array}$ & ㅇ & $\begin{array}{l}\stackrel{\rightarrow}{\leftrightarrows} \\
\stackrel{5}{4}\end{array}$ & ᄅ. & $\begin{array}{l}\text { to } \\
\stackrel{2}{0}\end{array}$ & $\begin{array}{l}\text { to } \\
2 \\
2\end{array}$ & 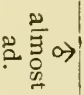 & $\begin{array}{l}\rightarrow \\
\stackrel{2}{0}\end{array}$ & $\begin{array}{l}\stackrel{\leftrightarrow}{0} \\
\vdots\end{array}$ & $\begin{array}{l}\leftrightarrow \\
\stackrel{2}{*}\end{array}$ \\
\hline : & : & : & $=$ & $=$ & $=$ & : & : & : & $=$ & $:$ & $=$ \\
\hline
\end{tabular}




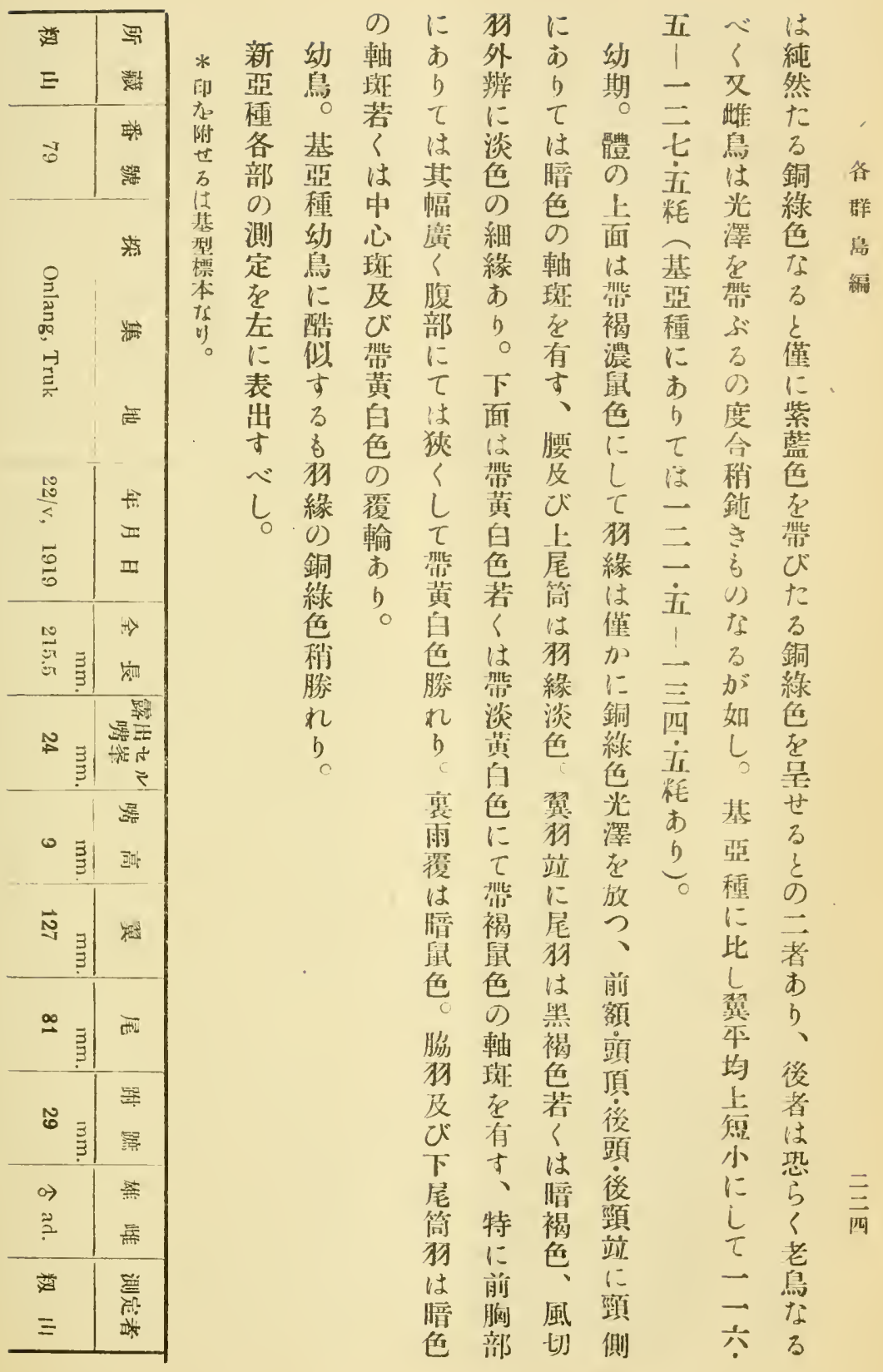




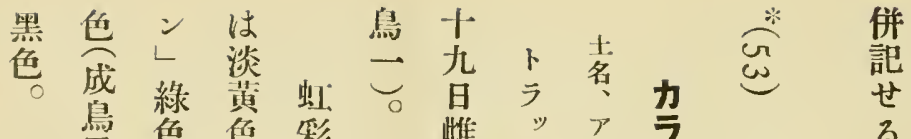

$$
\begin{aligned}
& \text { 基 }
\end{aligned}
$$

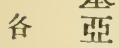

$$
\begin{aligned}
& \text { 群種 } \\
& \text { 岛酷 } \\
& \text { 編 似 } \\
& \text { I } \\
& 3 \\
& 8 \\
& \text { 體。 } \\
& \text { ) }
\end{aligned}
$$

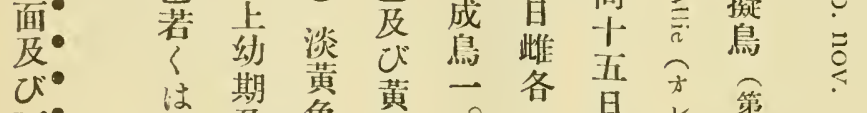

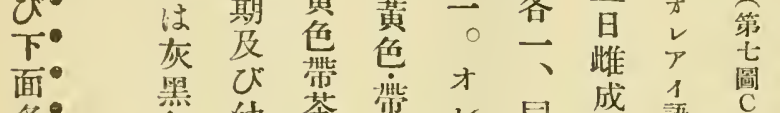

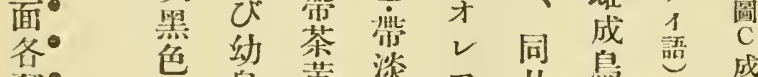

$$
\begin{aligned}
& \text { 犲。 鳥黄淡ア业鳥漹成 }
\end{aligned}
$$

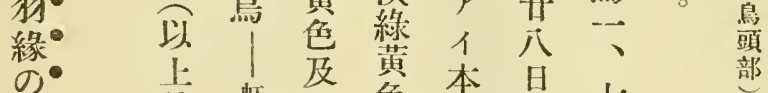

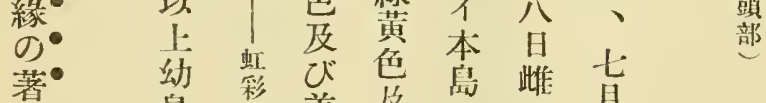

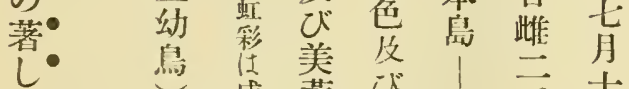

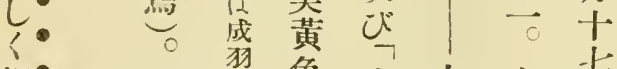

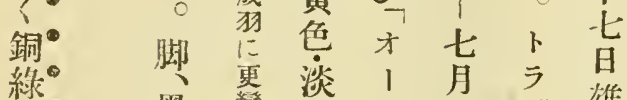

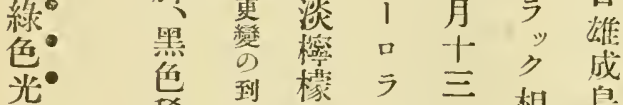

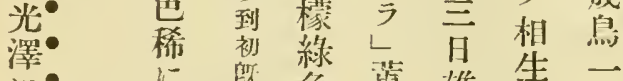

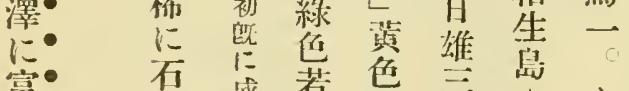

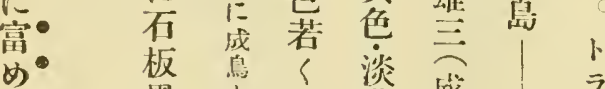

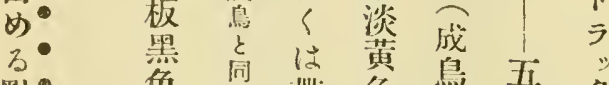

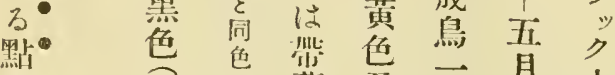

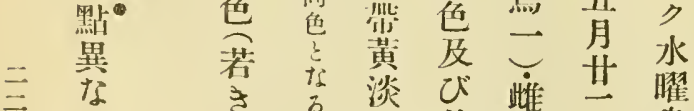

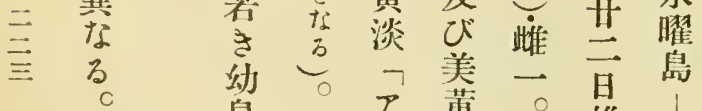

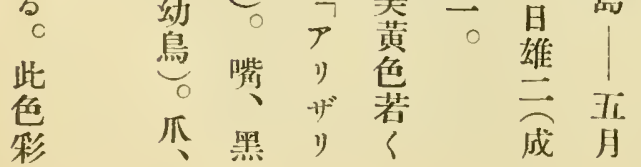




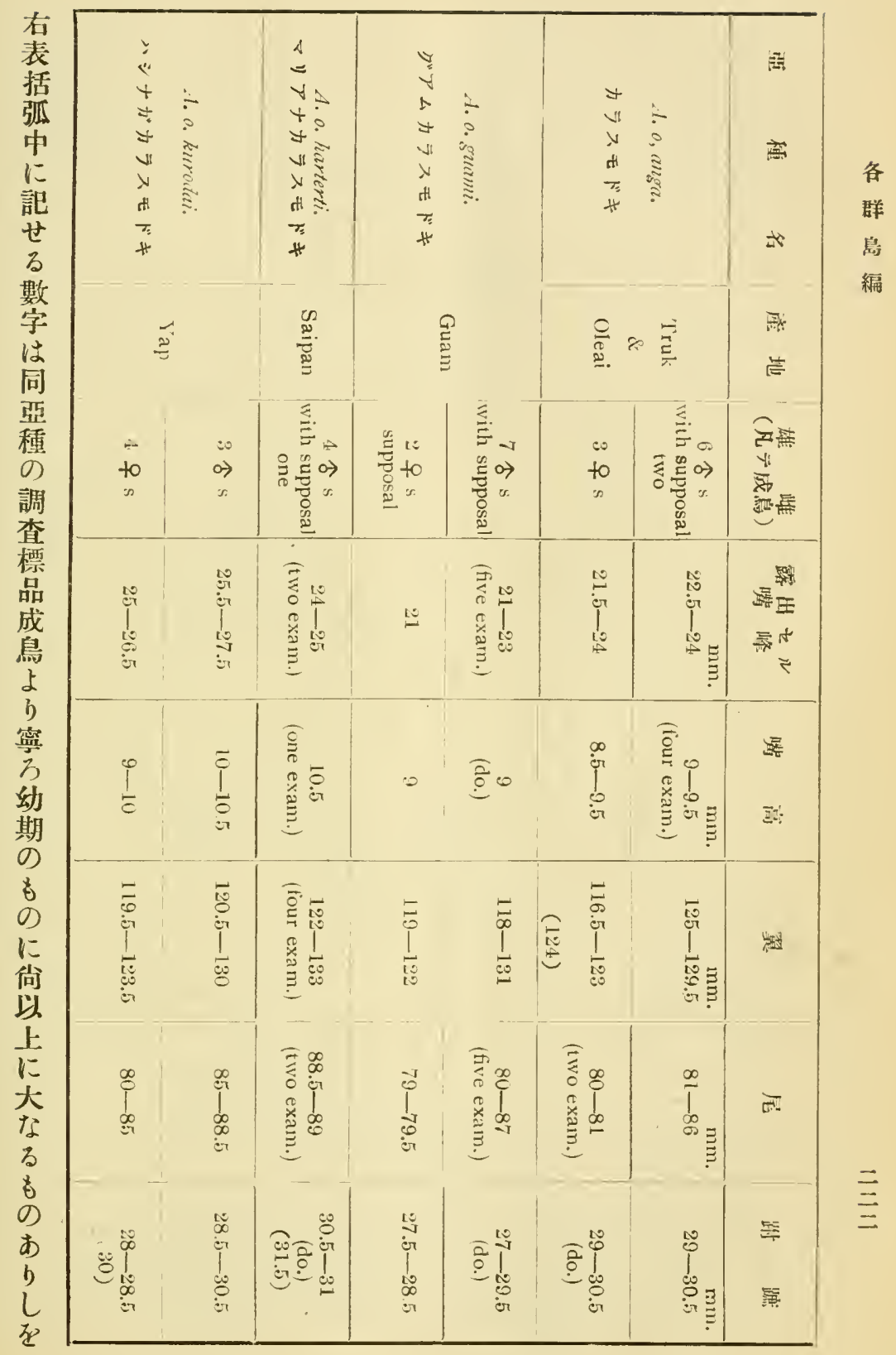




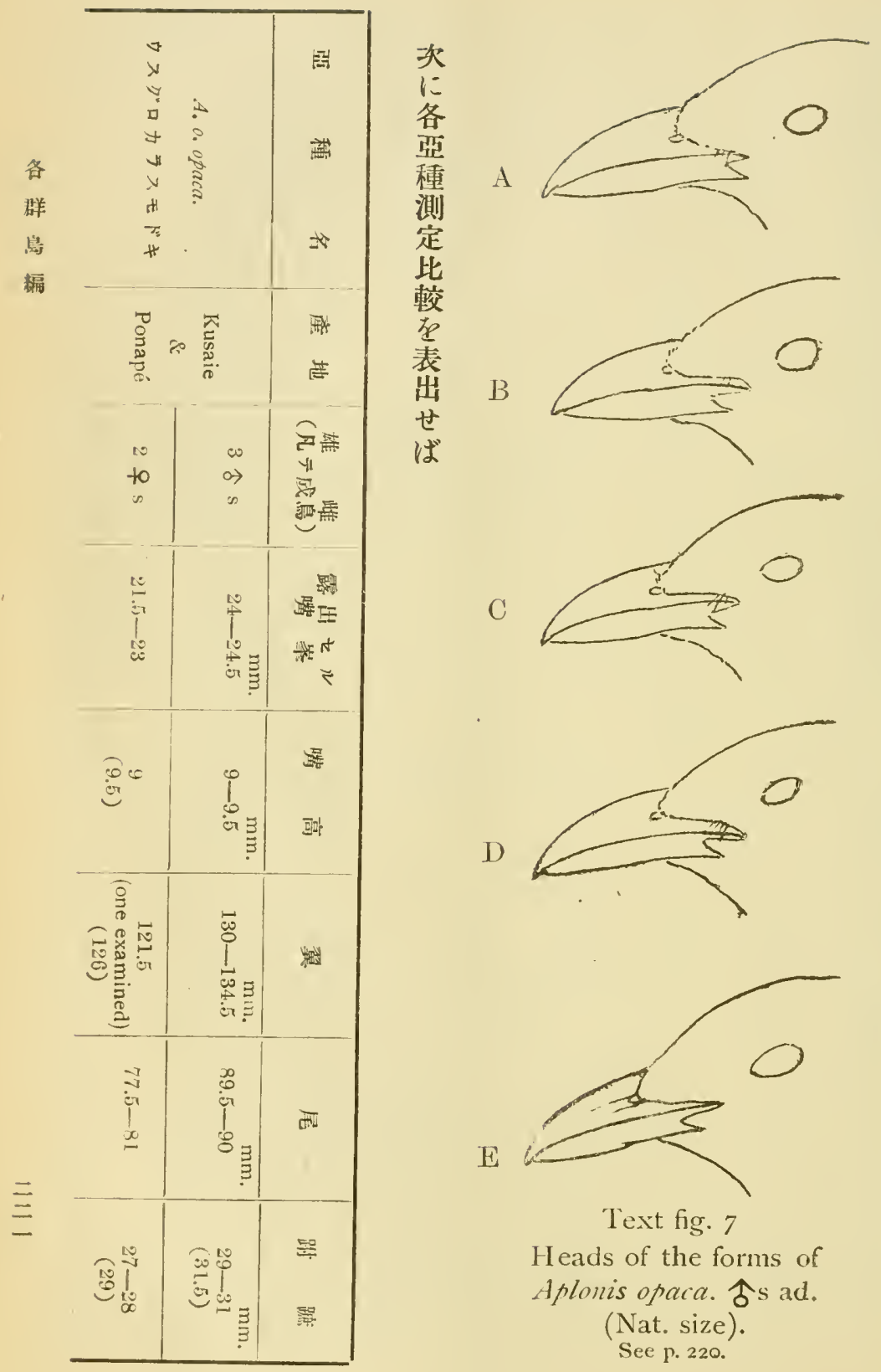




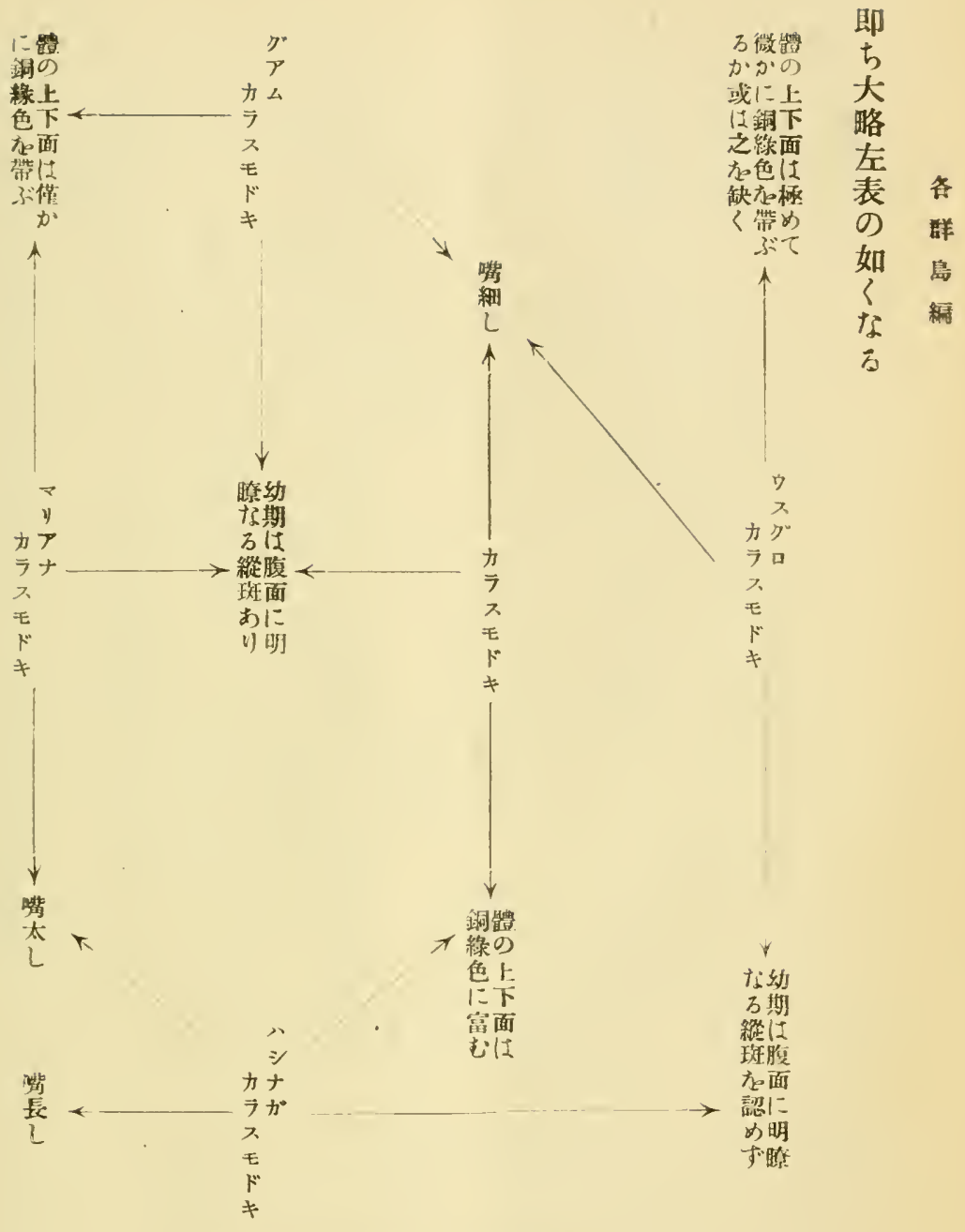

第七 圖 境 明

カラスモドキ類の頭部

A. A. o. kurodez, from Yap. No. 268. (Type specimen).

B. A. o. harterti, from Saipan. No. IS. (Type specimen).

C. A. o. zum, iz, from Truk. No. 336. (Type specimen).

D. A. o. opaca, from Ponapé. No. 503. (not typical!).

E. A. o. gumi, from Guam. No. I309. (Type specimen). 
竞超成

群超了鳥

各岛离去は

群、座、缺體

島

編

㭃 ? 1

期、面
は露各

腹出牙

面せ

にる 䋖

明㗪

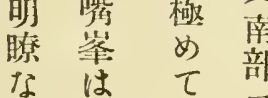

る 堂

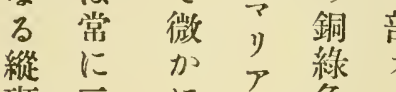

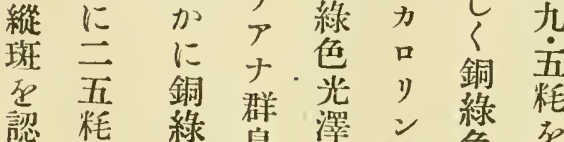

め以

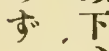

部高 ぶ

カ九 部杂

口㐬或

リ粍は $\left(2^{\prime \prime}\right)$

( $\left(i^{\prime \prime}\right)$ 释 露 斑 出

$\left(z^{\prime}\right)$

$\left(2^{\prime \prime \prime}\right) \quad\left(I^{\prime \prime \prime}\right)$ 嘴 中嘴 あ せ は比部比嘴

罣

は

常

に

五

距

以

高

下

O

粍

死

超

ゆ

了

事

稀

な

ל

幼

期

は

腹

面

明

膫

な

3

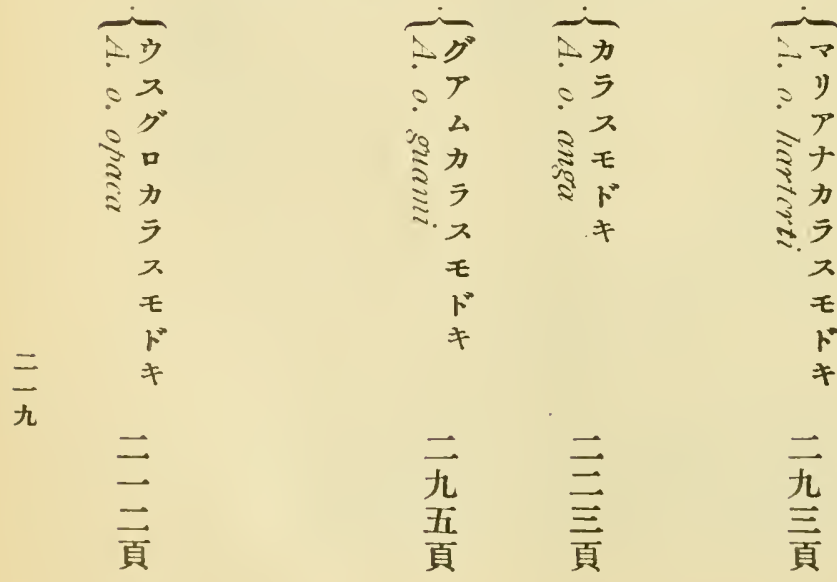




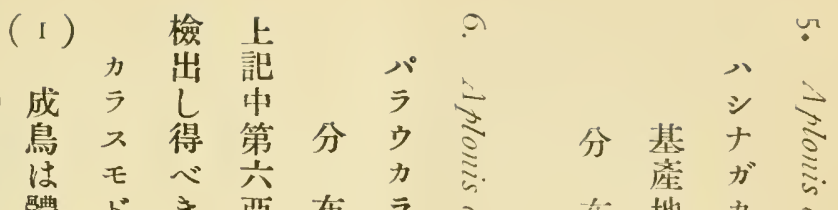

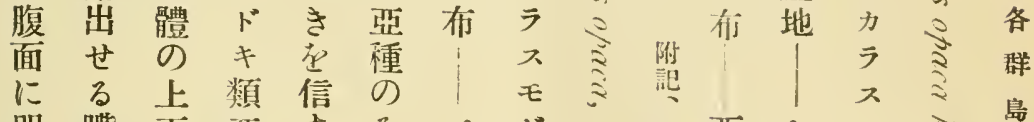

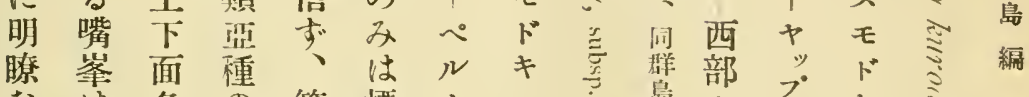

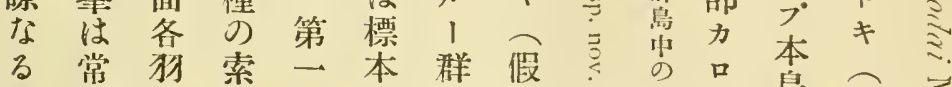

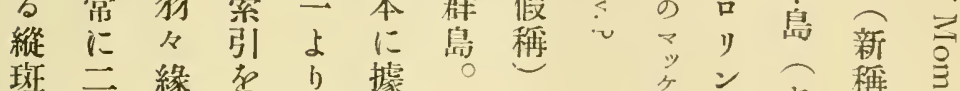

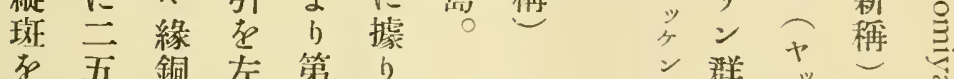

$$
\begin{aligned}
& \text { 㑇吾粕綠左第方 } \\
& \text { め以色揭迄檢 } \\
& \text { ず上をぐのせ } \\
& \text { ○帶 } \\
& \text { 西稀ぶ但種る } \\
& \text { 部にしはき } \\
& \text { 力 例 第總 の } \\
& \text { 口外共てな } \\
& \text { 》あ 亞標る } \\
& \text { ン b種品走 } \\
& \text { 群 ᄂ 存以 } \\
& \text { 茙幼含檢元 } \\
& \text { 这期焉し確 } \\
& \pm \pi \\
& \text { จ }
\end{aligned}
$$

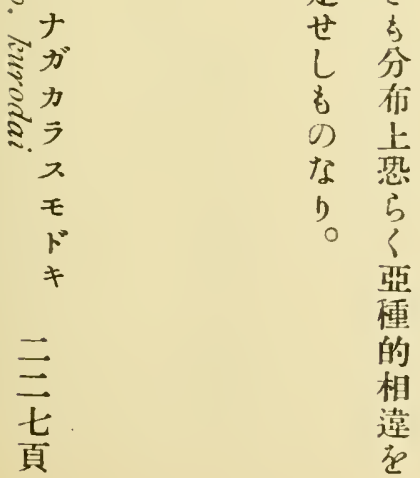

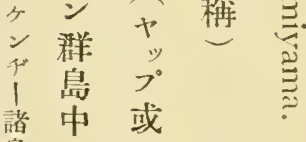

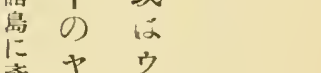

$$
\begin{aligned}
& \text { 虐 } \\
& \text { 方 } 7^{\circ} \text { 島 } \\
& \text { 现 } \\
& \text { 恐 } \\
& \text { 同 } \\
& \text { 亞 } \\
& \text { 種 } \\
& \text { 左確 } \\
& \text { 定き }
\end{aligned}
$$

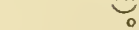

$$
\begin{aligned}
& \frac{\bar{a}}{\pi}
\end{aligned}
$$




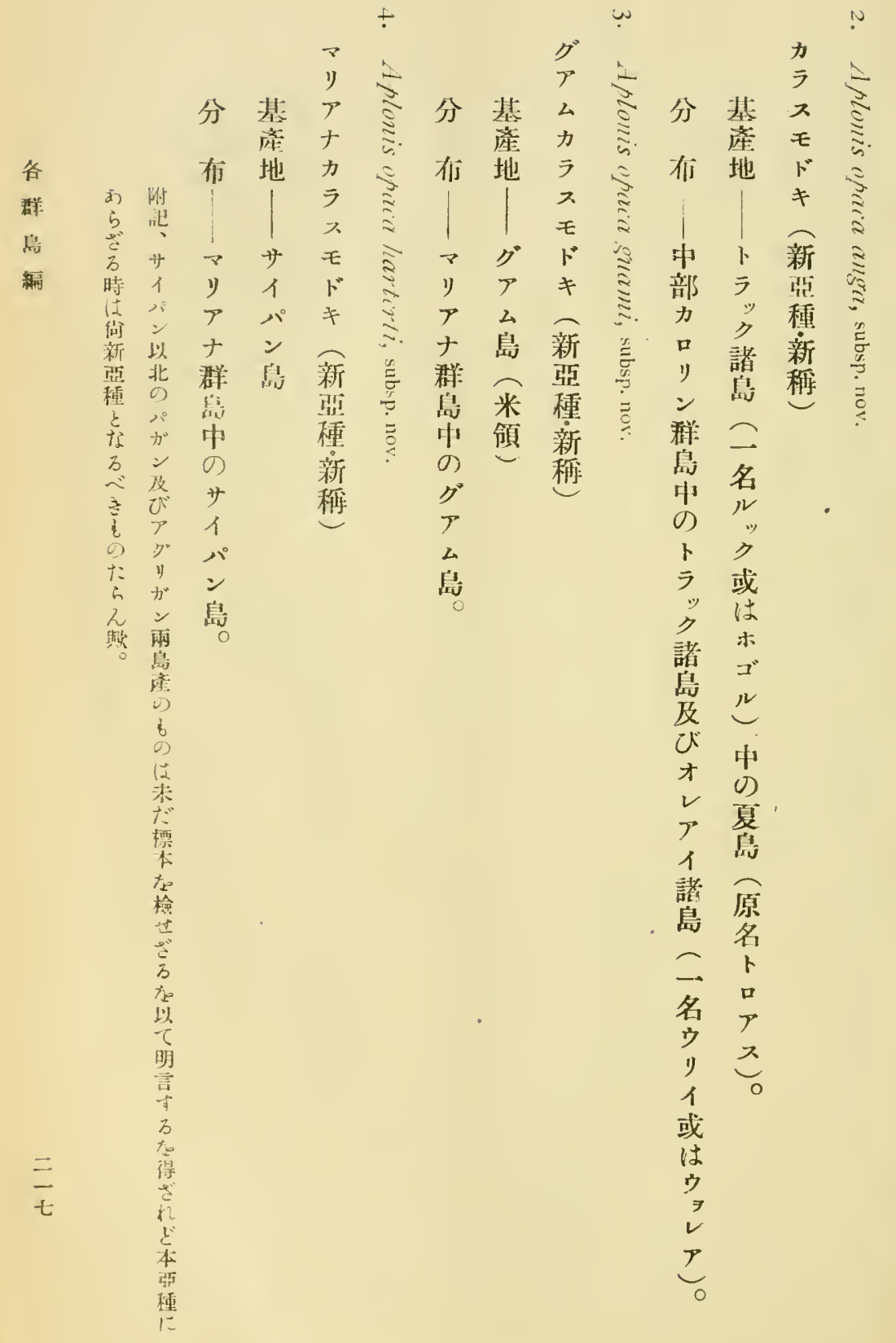


- 增

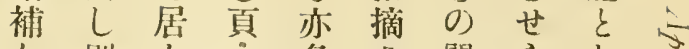

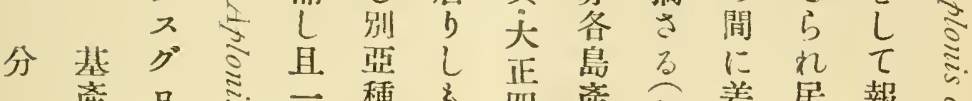

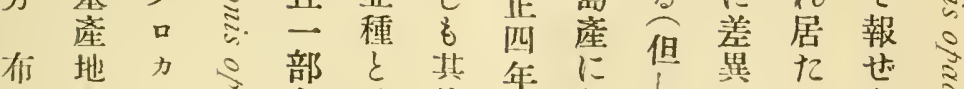

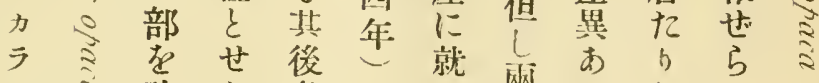

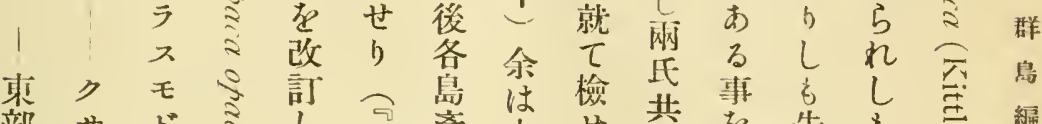
部サドミし鸟產本せ共を先も縒

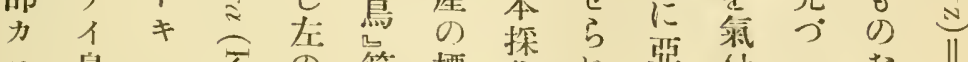

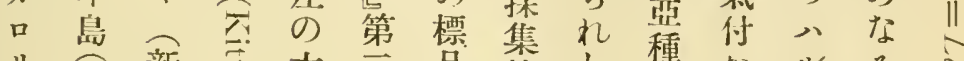

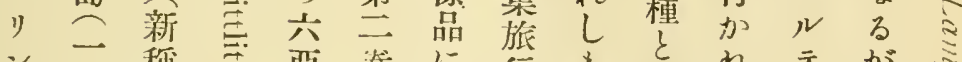

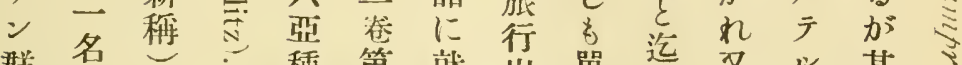

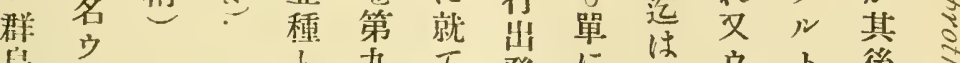

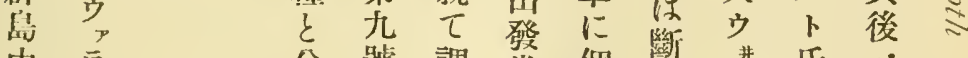

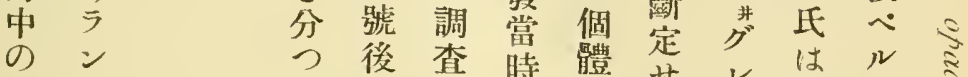

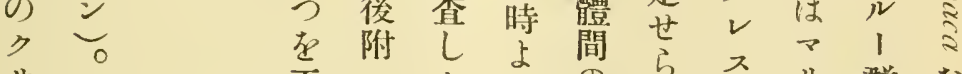
当

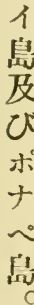

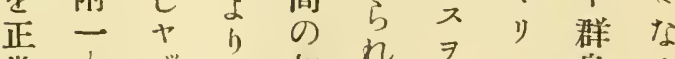

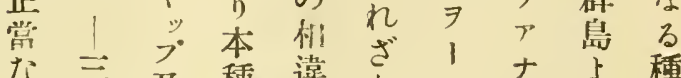

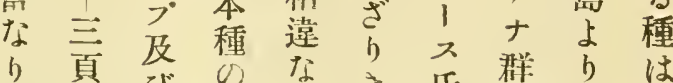

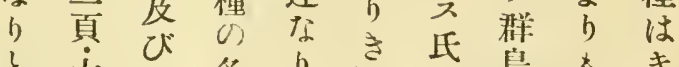

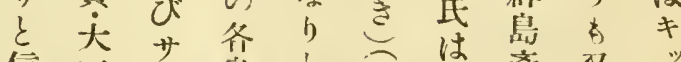

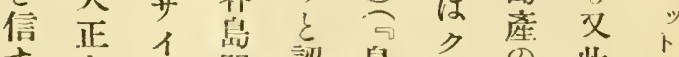

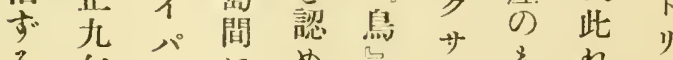
る 年ンにめ第人民币

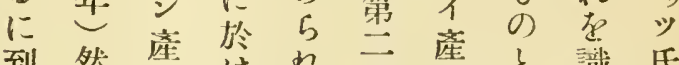

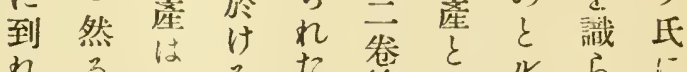

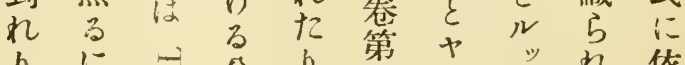

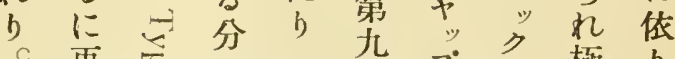

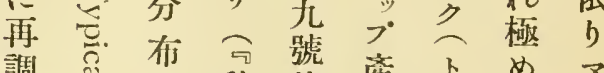

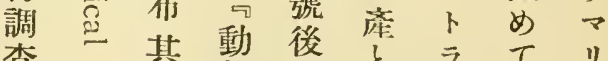
查一其䳯後 のの他物附の”最》

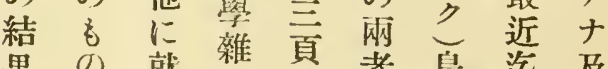

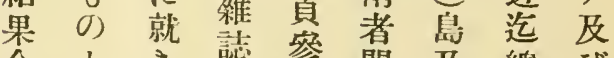
余とき訫笪間及總ひ 小相大第照にび元

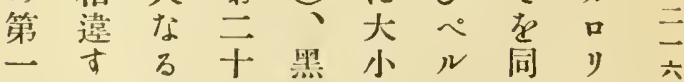
问了期七四市 $1-$ 冫 調點待尜理 万群の雨 查皮疮學點島。群 死見持三士农產の島 


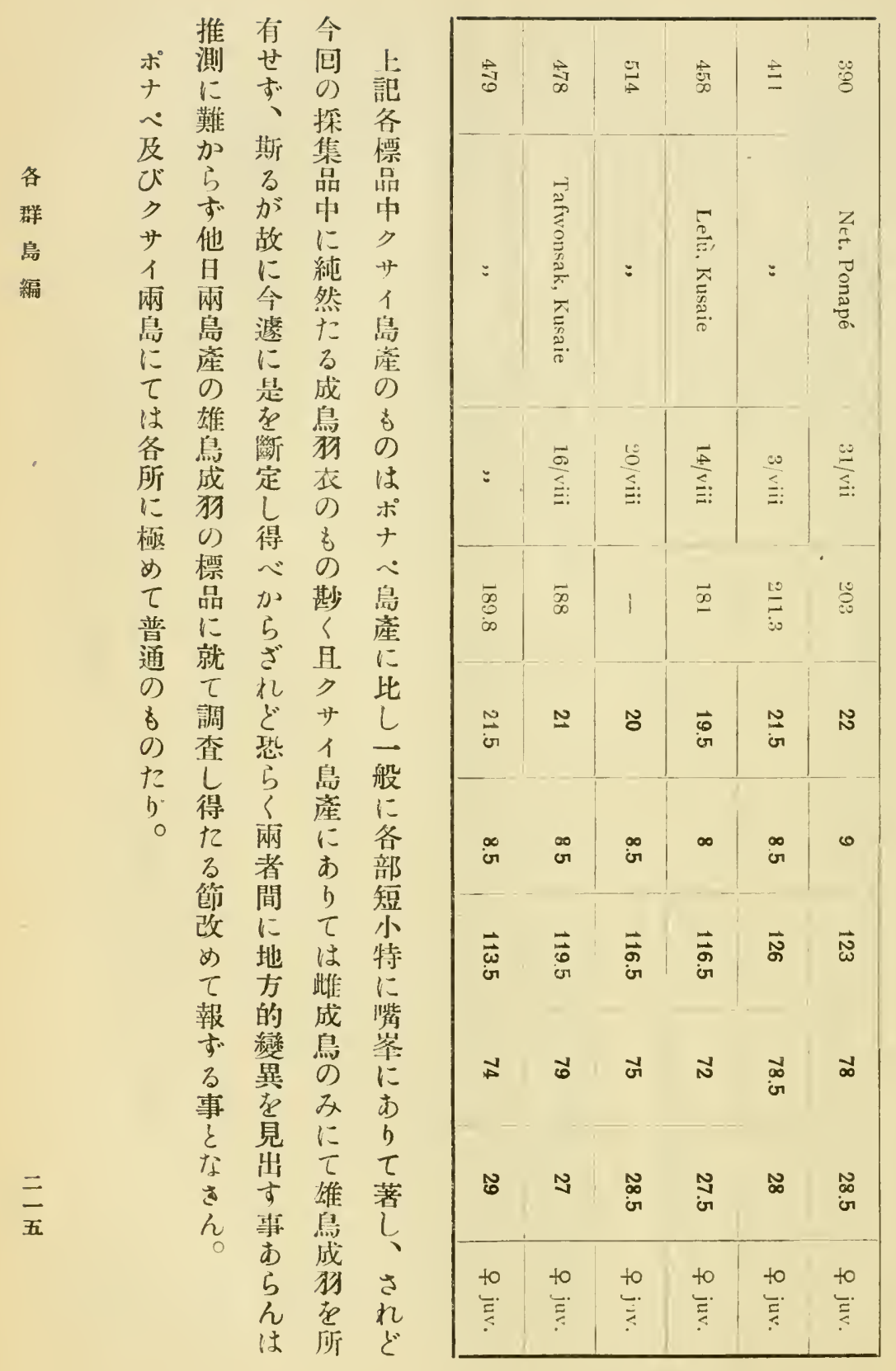




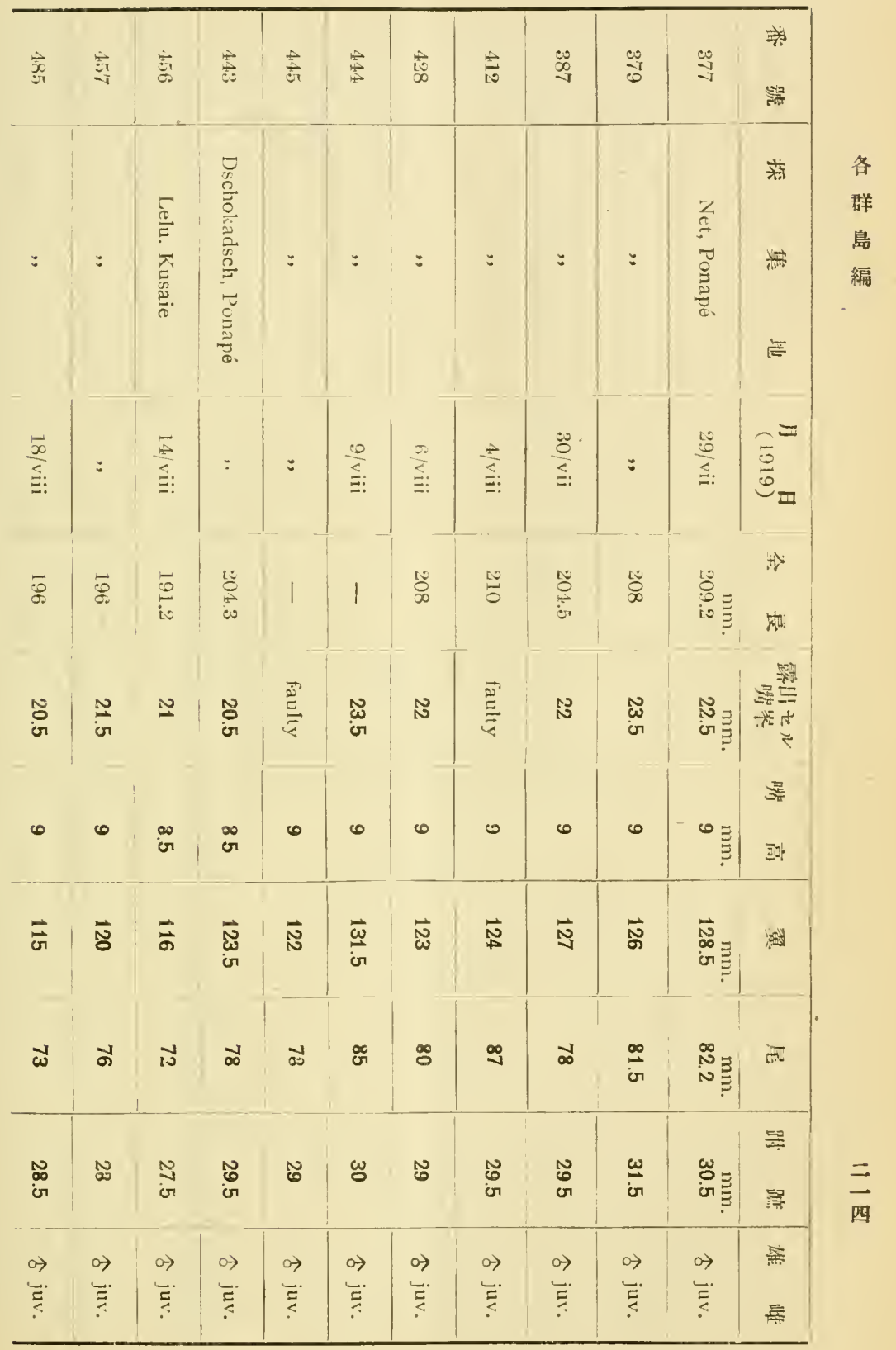




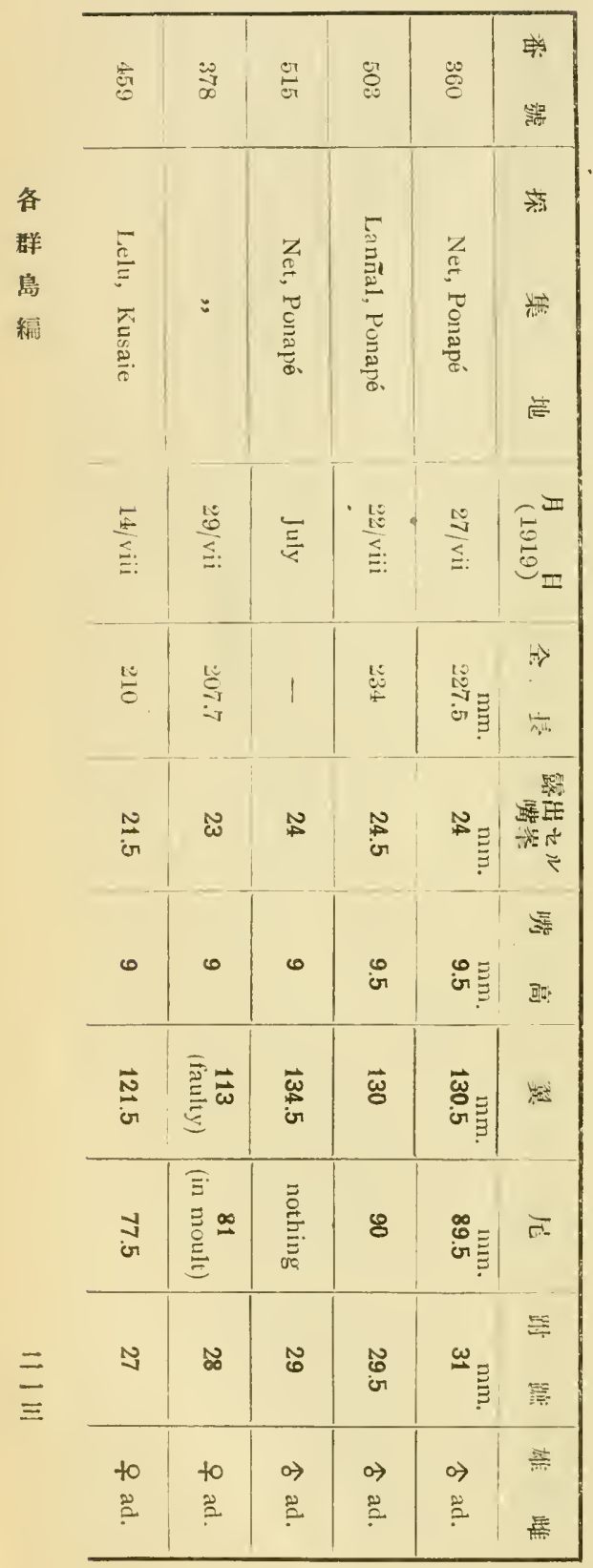

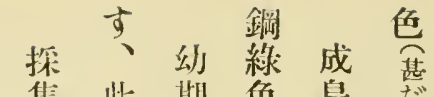
北此期色鼠總 品色成度體巨 各は郘合し 淡 部地に尠上黑 の色此面色 測りし或は牥 定混馀は璚壆 を在 程全 㫮 等 左し淡く色。 に極色是に瓜 表め.、岩し 出 $\tau$ 上缺 $\tau$ 们 方醜面人各黑 べし各。雅色 し。汫緣若 ○翼緣化く はに微は 暗鋼囟 褐線な色 色色的 存鈰 呈带緗 せ ぶ b

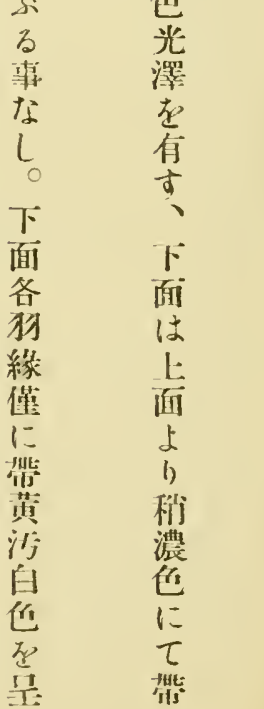




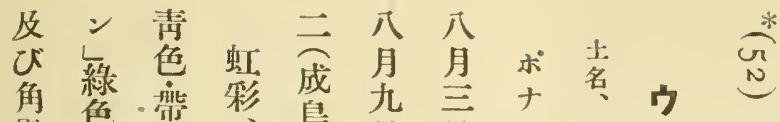

黑色・而綠鳥白

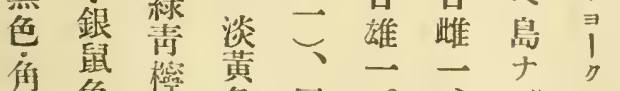

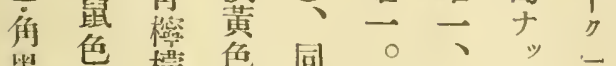

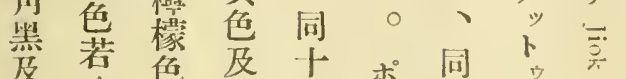

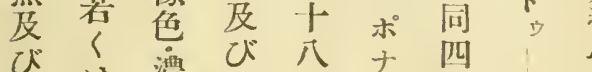

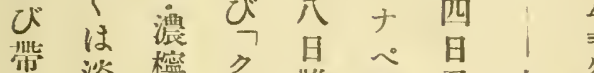

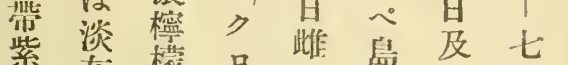

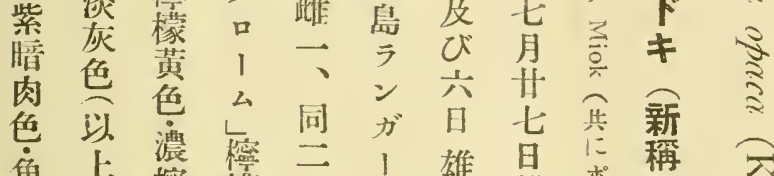

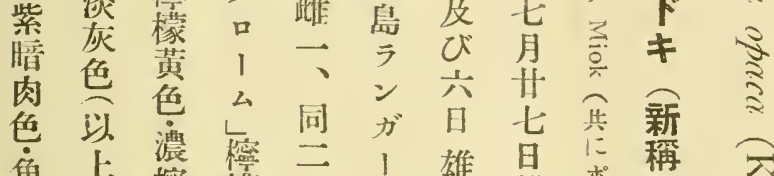

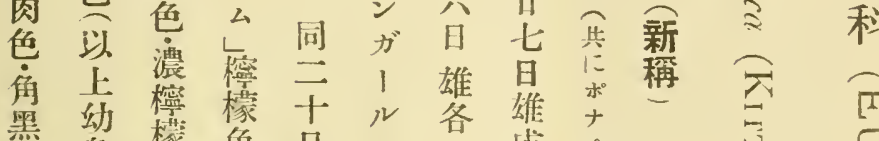

带嘴色檬一公同一、擬氙

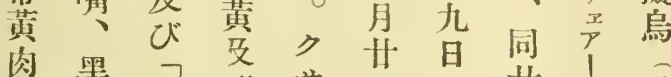

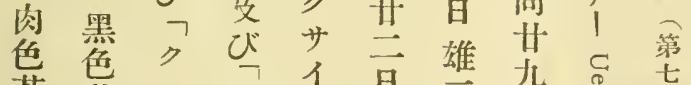

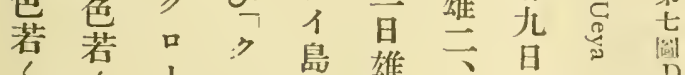

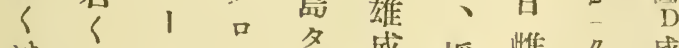

はは厶

各

九

群

官

泉

科

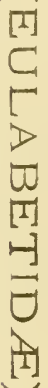

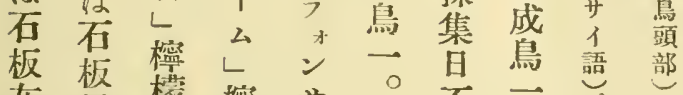

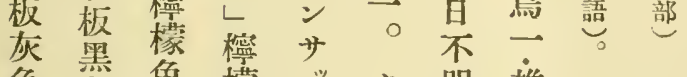

色色色檬単ク明雄

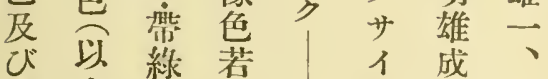

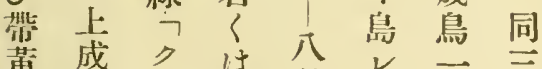

肉鳥口濃月市声

色石 恶亲| ポ日

原板么色公难

上黑黄以雌公帛一

幼色色上至十息同

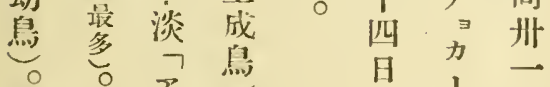

脚

板ザ䎡䍏音雌

黑黑 リ綠雌 


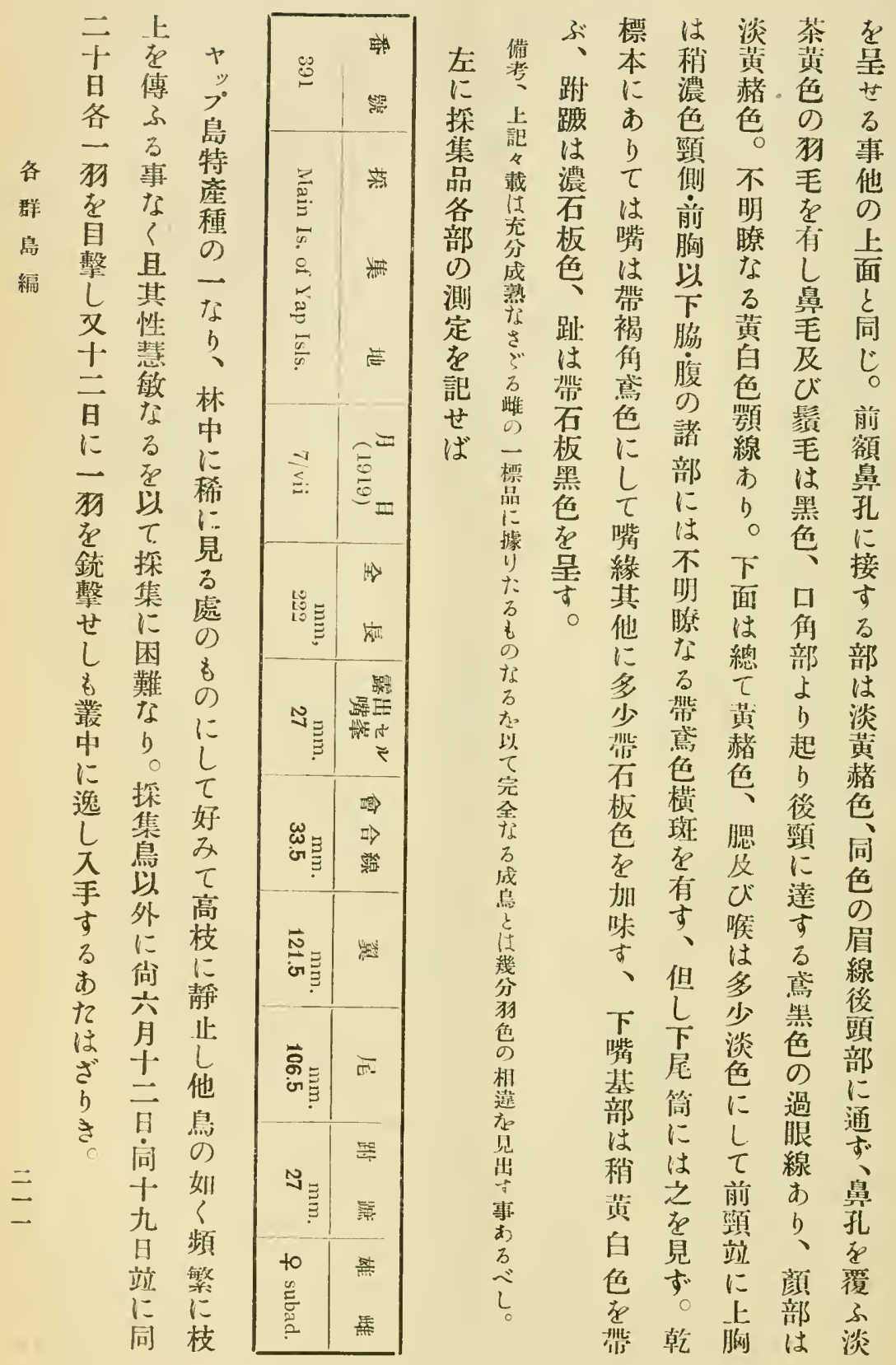




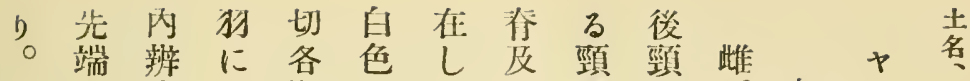
上に先て得下び環は虹 プ

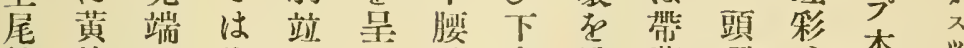
筒赫に此にすは棒黄頂本少 は色当淡大。帶山成淡及暗島令

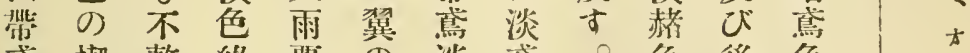

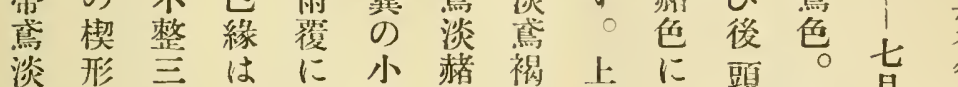

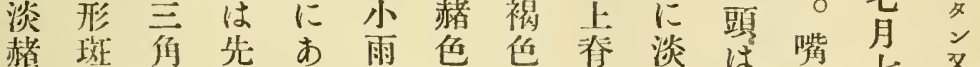

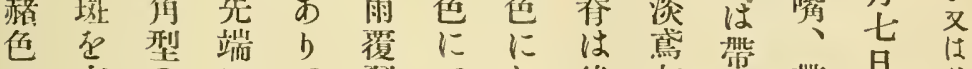

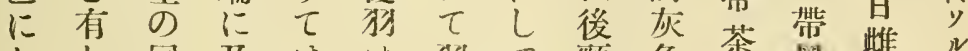
しし同及はは狗て 頸色茶哭雌少 七内色 3 黑淡緣狗に不灰灰一。”

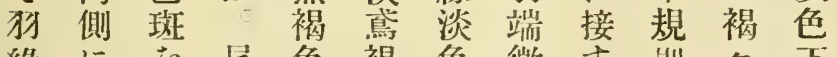
螕上展色褐色微亭賟色下 带到有㹯に色なか子な嘴

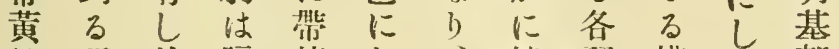

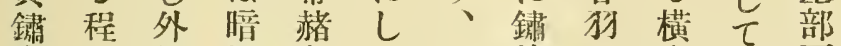

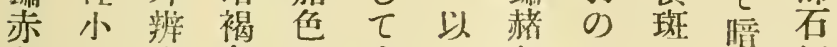
色形中色の先上色及二褐板 疋部中緣端藷在淡门褐白

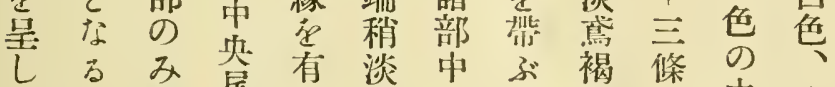

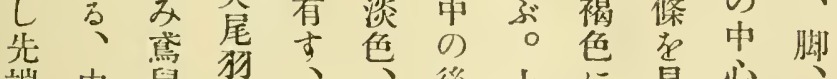

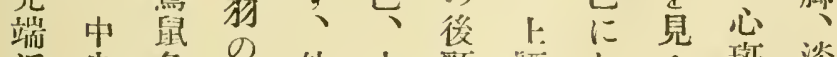

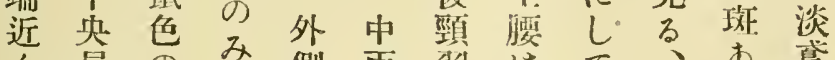

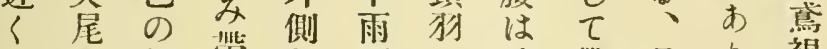

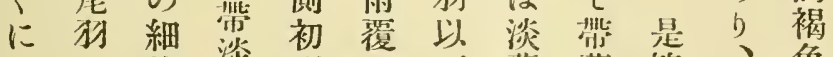

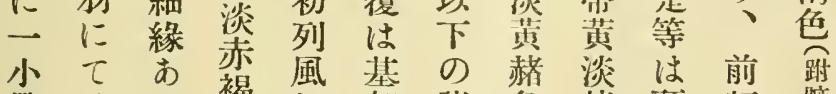

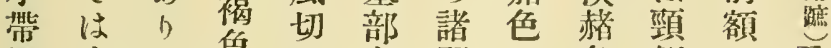

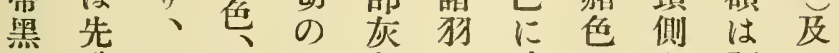
琁端二最三鼠に淡の上頭び कに主外了色市琶中顶淡 $b$ 淡四侧 $三 に b$ 灰心後 $\varepsilon$ 黑 基柿對尾呵して色斑项同色 部色各旸走 はの尾外除先其横有周け告

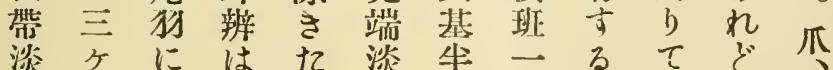

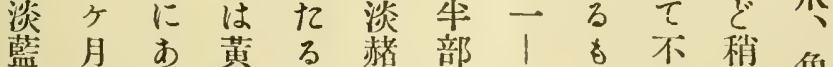

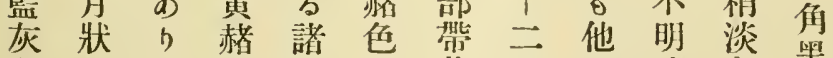

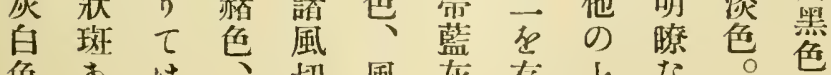

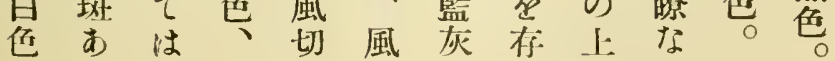




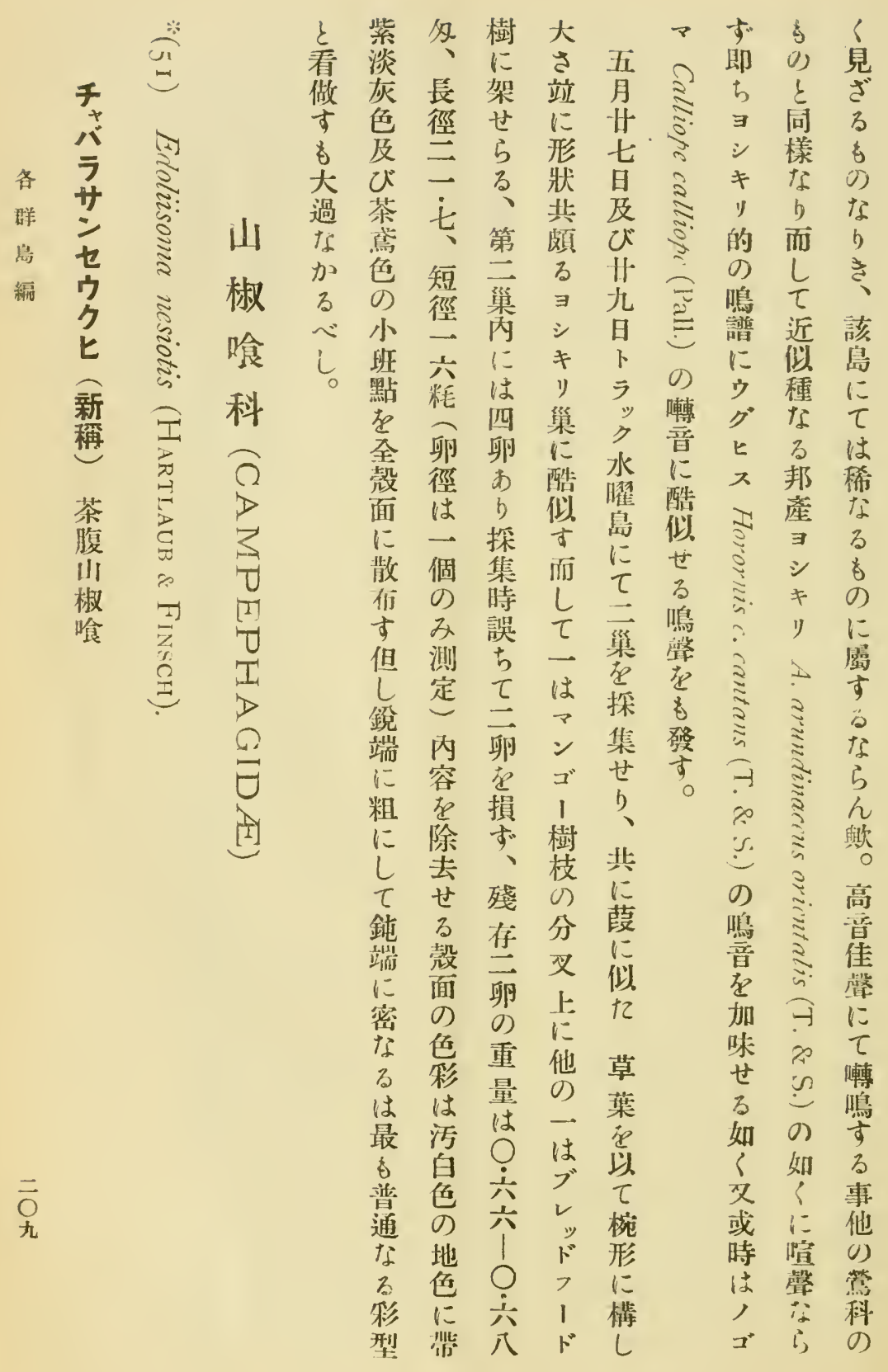


に見少

て 數卜

はbの

殆 栖?

ん相息諸

ぞ自易る 白

るにに中

をは過の

得極 ぎ 夏

ざめ方島

b $\tau 0$

き尠才

人島

唯唯

间葋島 水

目老皇

擊自びに

せ擊ポ

りせナは

しぺ甚

又の島だ

》みに 普

1 求通

島大普自

よ 乞 通見

此年

䄈はすの

草にの

報生屬れ

告地する

る 近

に 今 相

今尔生

回不》帛

は尠にに

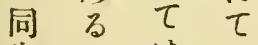

島もはは

に梁各極

$\tau$ 林 所

全中にて

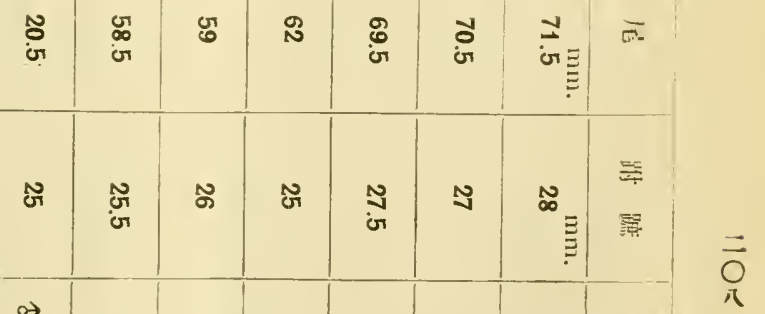

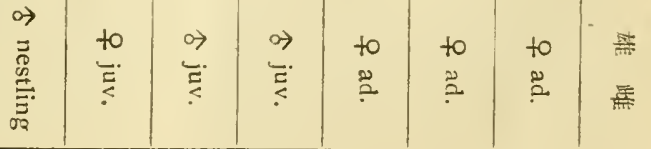




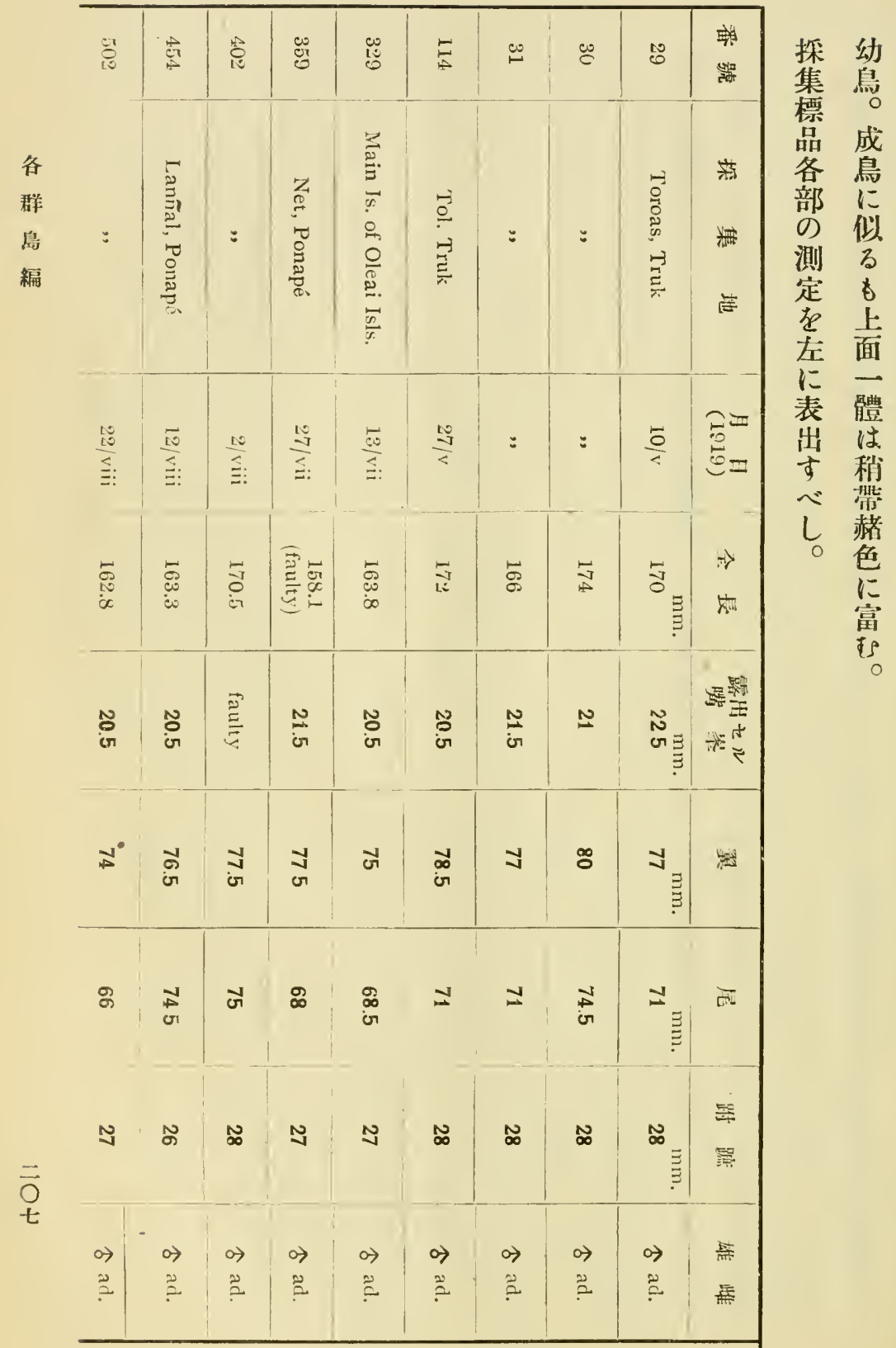




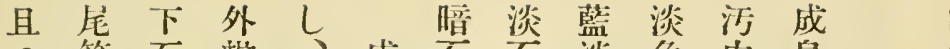

つ筒面粦、成石石淡角肉鳥 最は腮に後鳥板板石武色〕虬 長淡喉淡頭。色空板黑呙暗彩

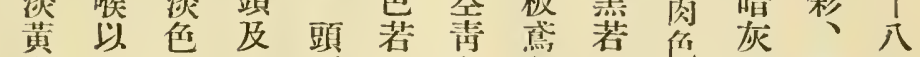
第肉下の殴頂々色色々妾色喑月各

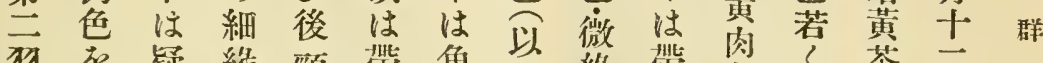

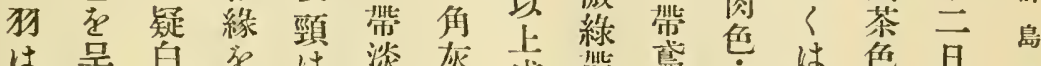

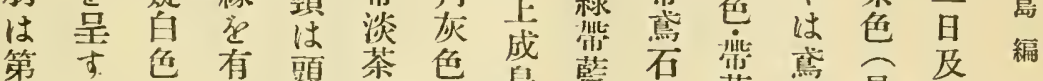

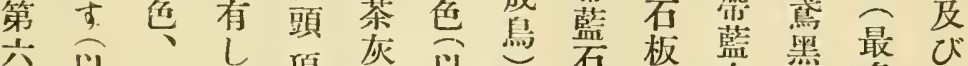

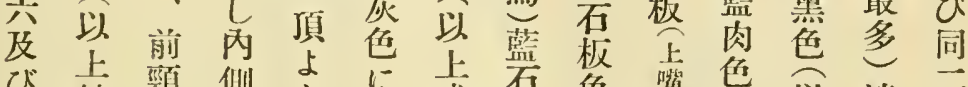
第總 站 風

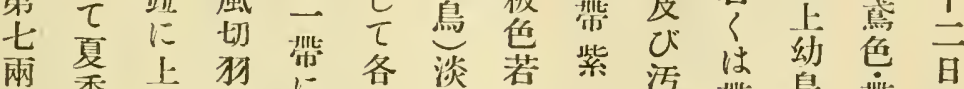

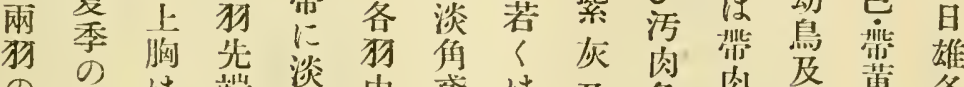

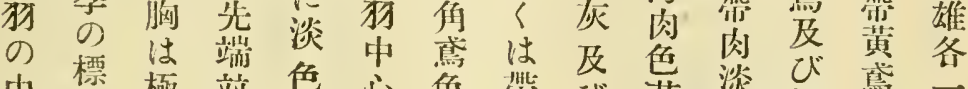

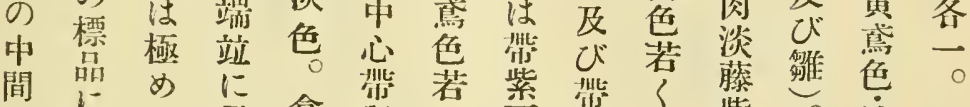

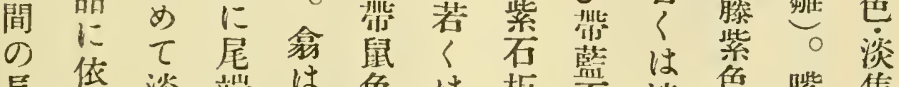
長售淡端は色は板監淡色嘴焦

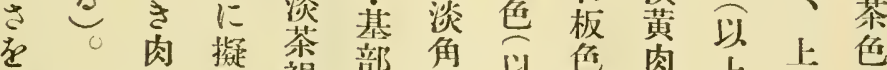

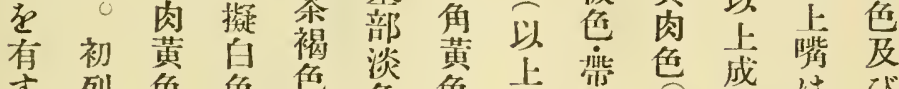

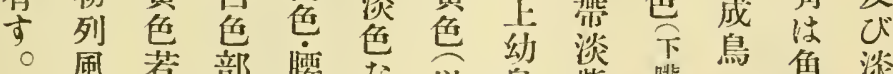
風若部腰な间紫啡鳥角淡

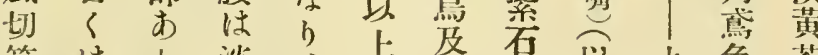
第はb淡、幼び板以占色茶

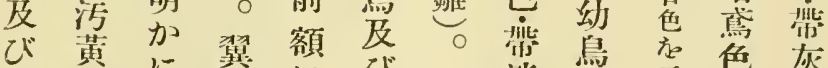
第色に菱にび爪淡点色灰

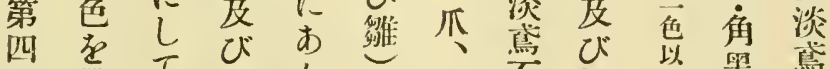

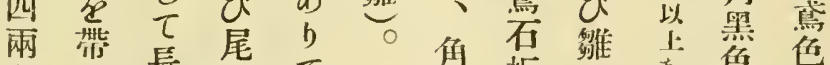

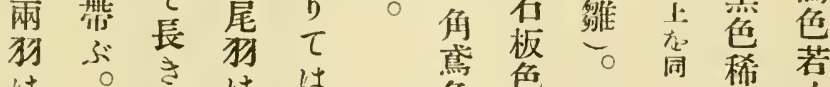
は。忌はは 殆 䏲 擬热 牙

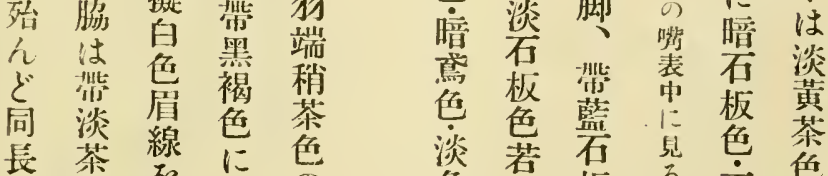

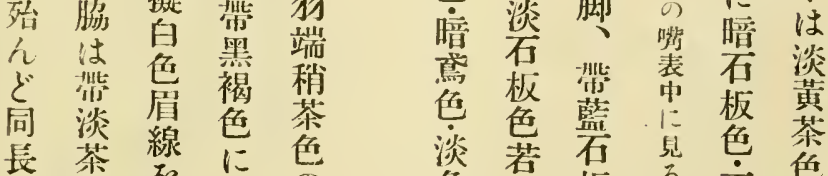

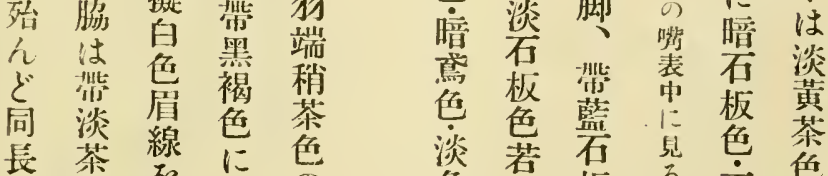
に色看し し 盛は色市嘴以 て下各多色费带可は上 


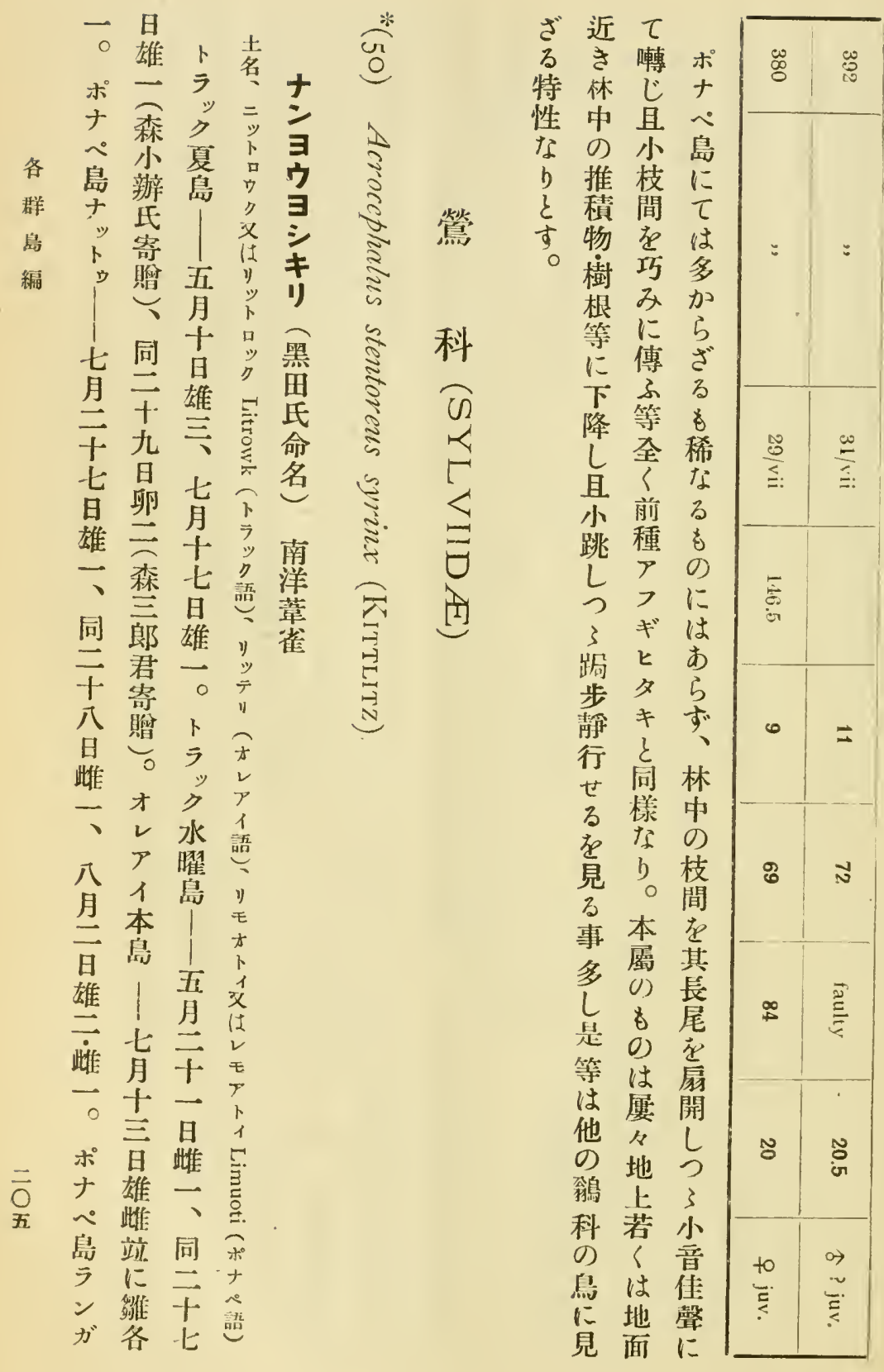




\begin{tabular}{|c|c|c|c|c|c|}
\hline $\overrightarrow{\text { ) }}$ & $\overrightarrow{0}$ & $\begin{array}{l}\mathscr{J} \\
\stackrel{\sigma}{\circ}\end{array}$ & $\stackrel{0}{0}$ & 峞 & $\begin{array}{l}\text { 㔖 } \\
\text { 誉 }\end{array}$ \\
\hline$=$ & $=$ & 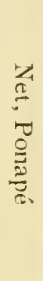 & 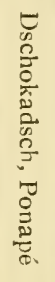 & 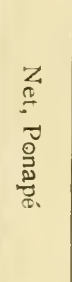 & 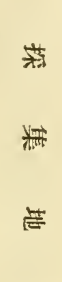 \\
\hline$\sum^{\omega}$ & $\stackrel{\epsilon}{\vdots}$ & $\frac{10}{\leqq}$ & $\frac{\stackrel{10}{*}}{\leq}$ & $\stackrel{\omega}{\vdots}$ & $\stackrel{\overparen{\theta}}{\overrightarrow{0}}=$ \\
\hline जु & 1 & $\overline{\ddot{g}}$ & 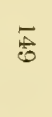 & $\begin{array}{l}\vec{\pi} \\
\dot{\infty} \\
\dot{\infty} \\
\underline{3}\end{array}$ & 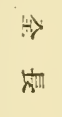 \\
\hline \% & 하 & $\vec{G}$ & $=$ & $\vec{N}_{3}$ & 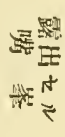 \\
\hline $\begin{array}{l}\infty \\
\text { o } \\
\text { or }\end{array}$ & రั & $\vec{\omega}$ & బు & б' & 12 \\
\hline$\stackrel{\infty}{G}$ & 总 & 8 & 8 & $\stackrel{\infty}{\circledR}$ & ल] \\
\hline 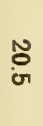 & $\begin{array}{l}\text { No } \\
\text { or }\end{array}$ & 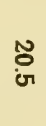 & ํ & ${ }^{N}$ & 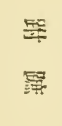 \\
\hline 알 & 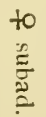 & $\begin{array}{l}\text { to } \\
\stackrel{2}{\dddot{2}}\end{array}$ & $\begin{array}{l}\text { to } \\
\cong\end{array}$ & 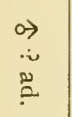 & 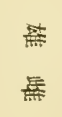 \\
\hline
\end{tabular}

は先 側 b 採幼多端 前後 集烏々白部方 標。淡色にに 品眉色基澾 各線 在部正: せ 各 部不呈灰引 ず群 の 明し 鼠、 、 測 瞭 脚 色喉 眼 定なは前 をる不脇び及 左子板は前び に翼 黑 鼠 钼 腿 揭 の色灰は下 ぐ雨よ色鼠は

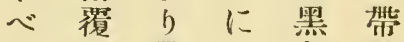
し旸門し色黑 緣 紫充 淡 石 先 前 鈿板端胸耳 赤褐微 の狗 色色 か 各 は 迄に犲鼠 带 の 紫は 黑 ぶ 齐褐间色 事色呈に䍐 等な焉て は をる。白鼠 以。乾色色 $\tau$ 標 成本䨱 狗 鳥に輪 先 と क そ 端 のり有は 相宁白 違點嘴後 $\varepsilon$ 角脑同 隽 黑 以 色 它 下の 顎 嘴 各 緣 基狗は 部は頸 


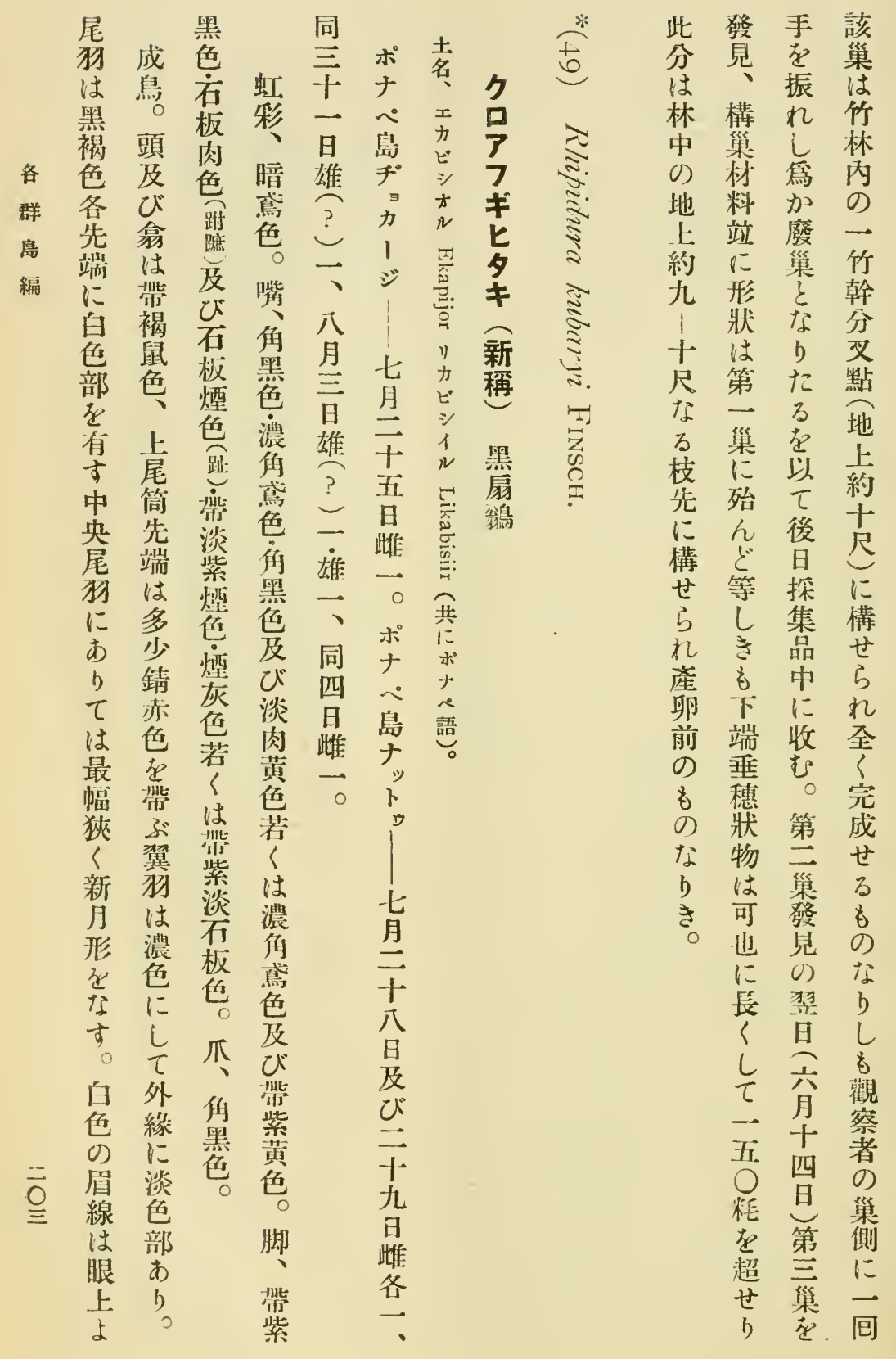


の 該

上 巢

端 探

分 集

の 翌

一

类

除公

き

开

如日

き 發

形 見

狀 せ

にる

$\tau \rightarrow$

巢 策

(1) は

下 其

方 構

に巢

穗 材

狀 料

下は。

垂 前

物 述

なの

ᄂ

内

四差

秏な

、多

外桑

徑 形

亲を

八 異

栫に

क ᄂ

b、球
の非 ちの

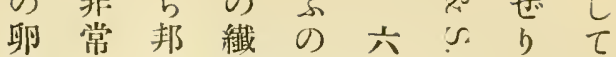

款に產維 餘月枝

の 小才等 地十の其間

色型木尼な如地㕲

夥にヨ集し

はてシめ主には、り群

污內キ棰該卵之文? 島

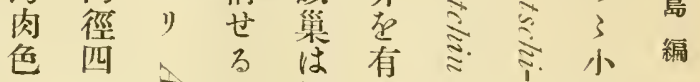

に五々も林せ豆

し 粔 $の$ 中る $を \lesssim$ 佳

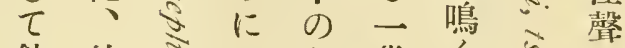

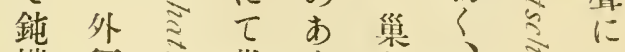

端徑方巢ま在、方元

近共々 の b探共嚩

に公粍怘端南集尔心

三三 㤐

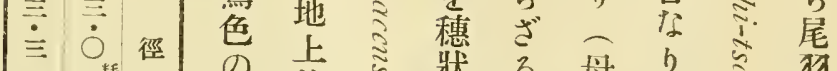

㽗

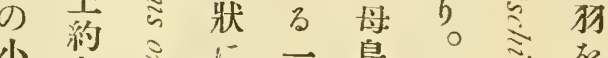

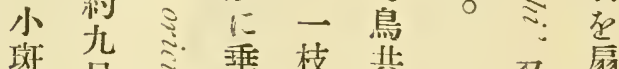

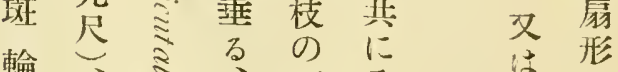

狀、䎡、下

に云 卿其垂手

周卵蒖せ せ ジぐ

はぬ災るしる

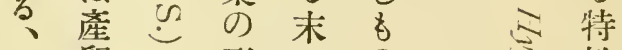

卵卯の形端の 性

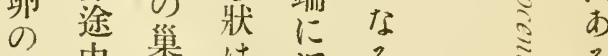

測中果は近る

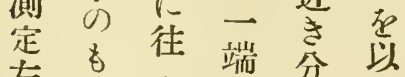

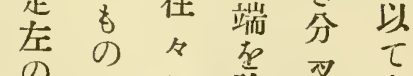

の見除疍本

如る る き

$\begin{array}{cc}\text { L } & \text { 卵 } \\ \text { 得 形 } \\ \text { は } \\ \text { 万 短 }\end{array}$

指 短

數 走

te 以

以 $\tau$

亭

示徑

?.除
心處点竹種

くの る 類 临

內 形球U 卯

容 狀 形 枯な

除江皮る

去 b 近棂事

以但し子は

前し 即䨘疑 $\lesssim る$

ษ表

亏ั $\tau$

新

₹

ล 7

きだ

₹

G 


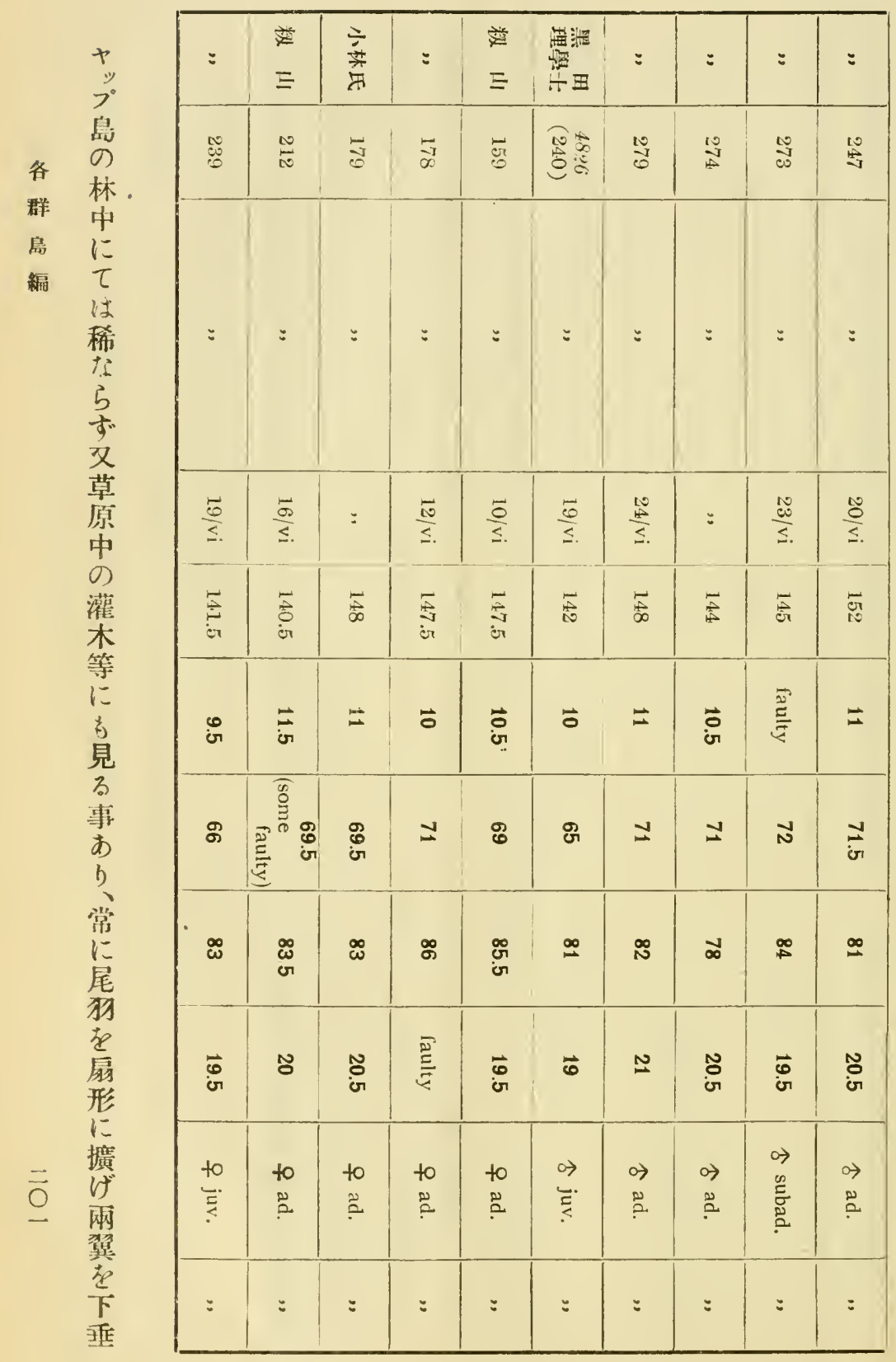




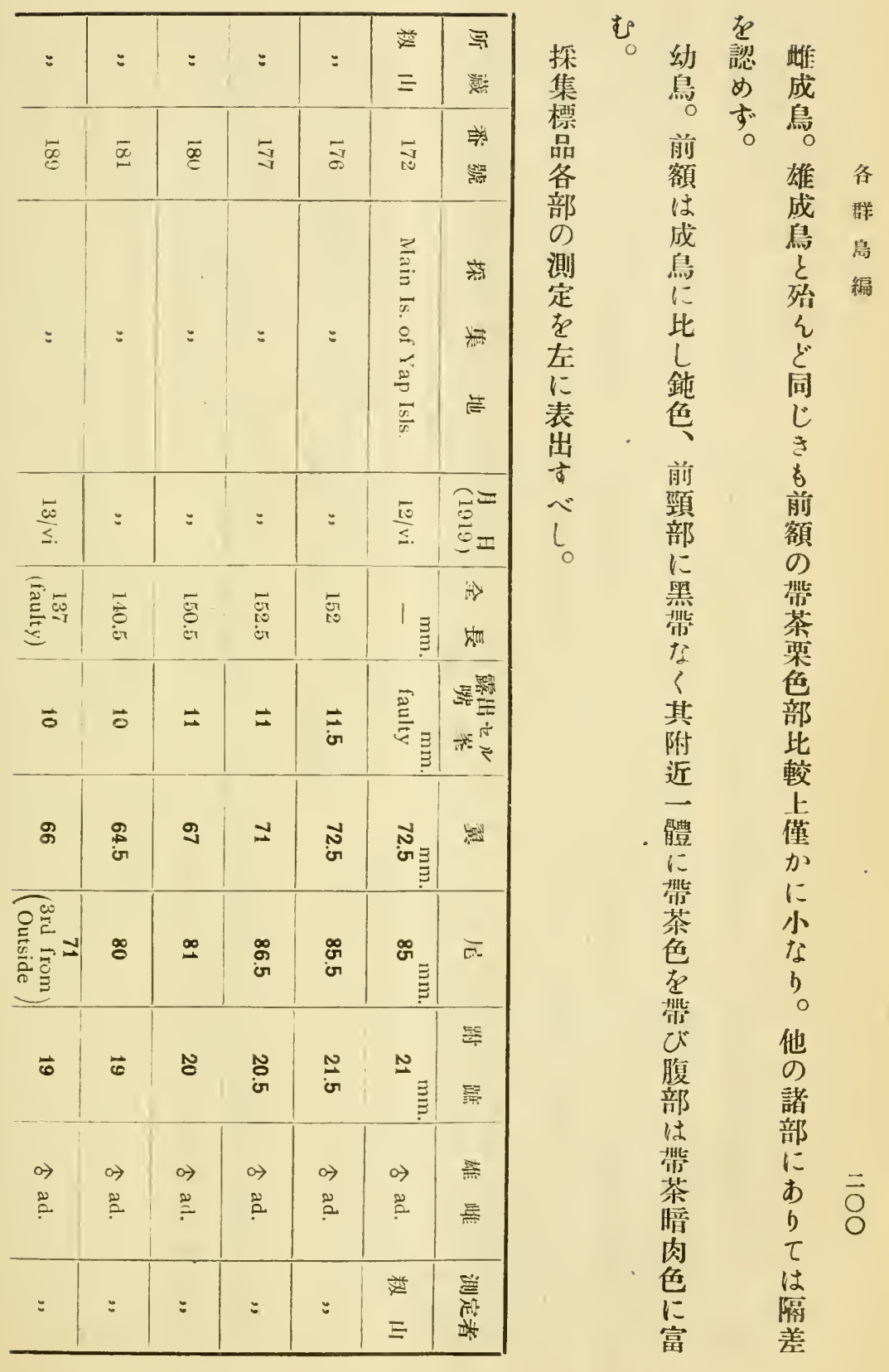




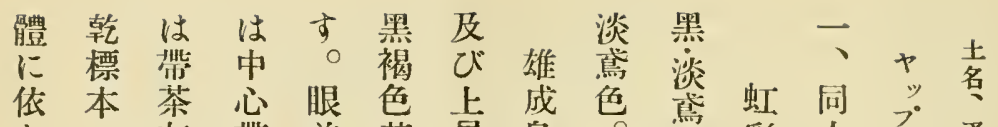

bに灰帶前基尾鳥䙒彩十 70 本

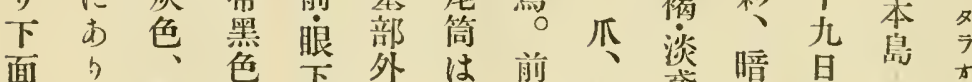

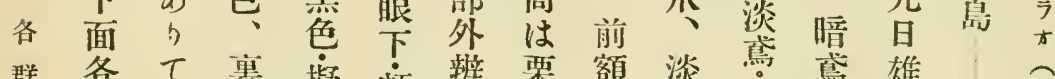

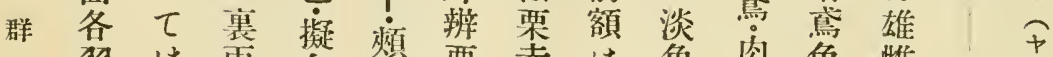
岛狗は雨白端栗赤は角肉色雌市

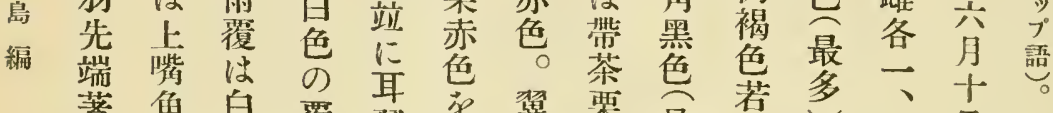
著角白覆犽蛋翼栗最若多、十 々黑色輸 独带 心゙下年有雳中褐同角帶褐十一、 フ嘴基尔色扈色色墨黄色萿同

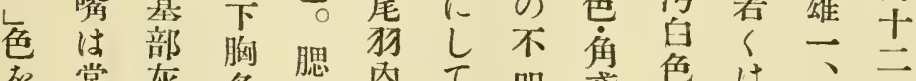

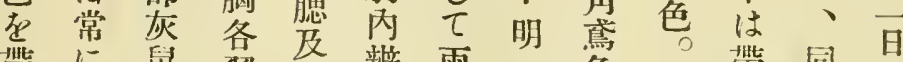

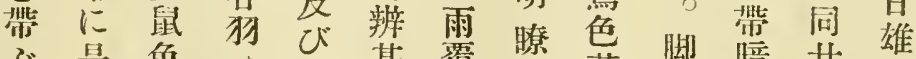
ぶ是色は喉基覆な若脚暗世主

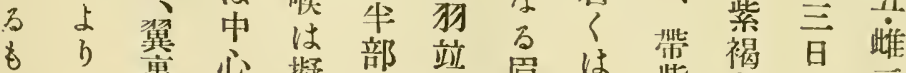

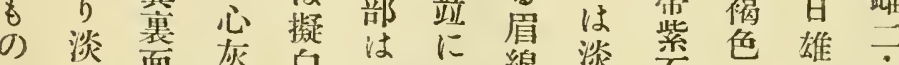

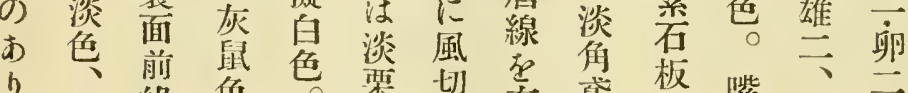

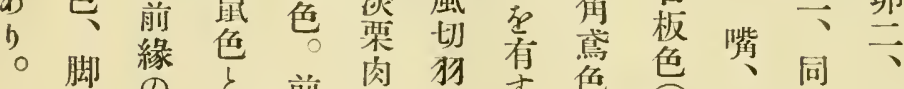
はの前角外方色最上苗同

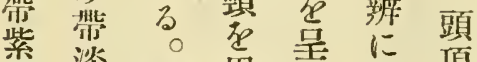
淡膘周至非 頂 色茶狗与而茶後 若檴はてし暗頭

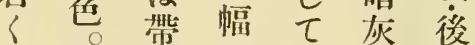
は腿白狭各褐頸 帶然色き尾色端 紫花に黑旸可に

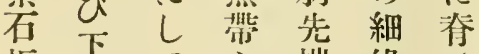
板尾而端緣生

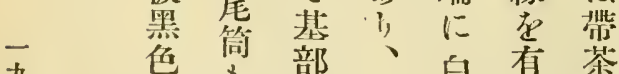

九色部、白有举 等筒色尔淡 呈色鼠胸色。褐 重色色。部尾色 個点脇翅营翟腰 


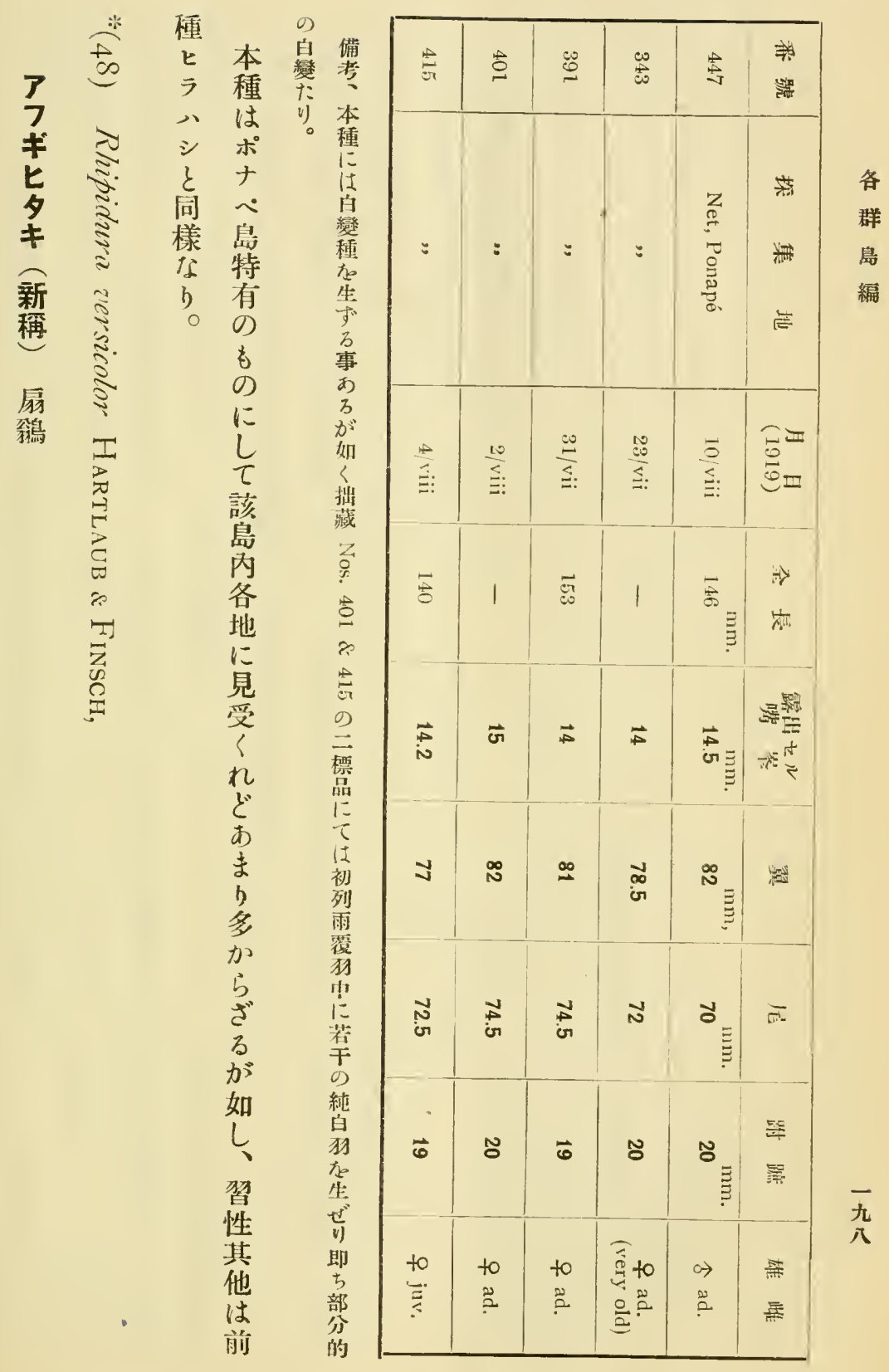




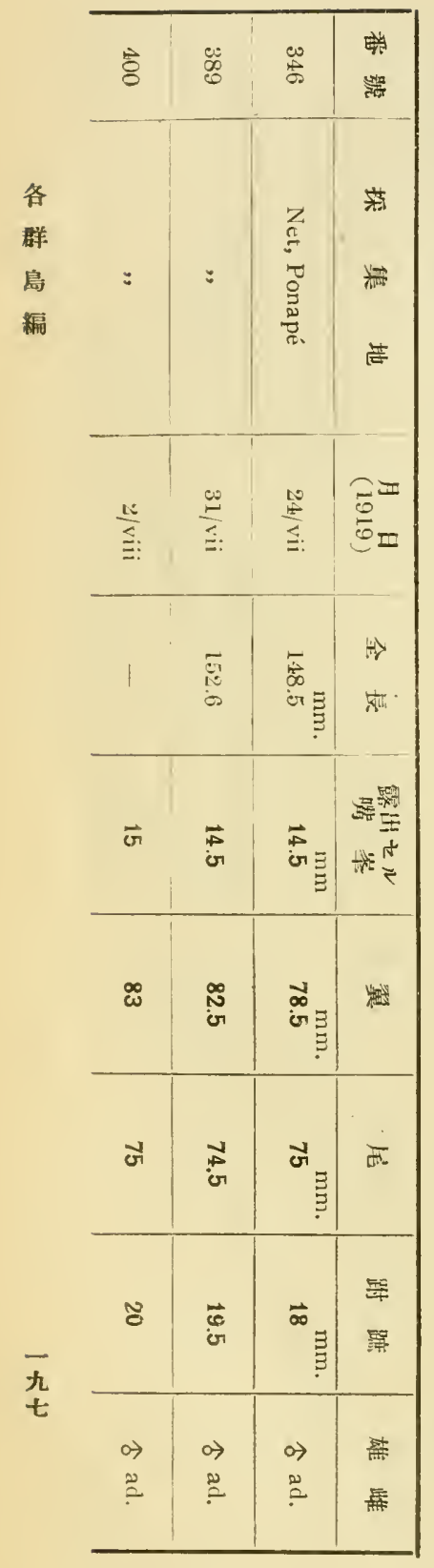

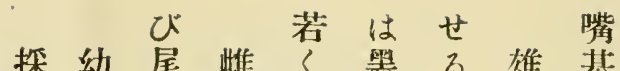
集䳆雅成性褐は成部

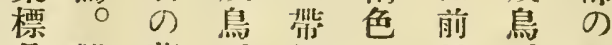
品雌監。褐に種○み 各成色腮灰しに頭岪

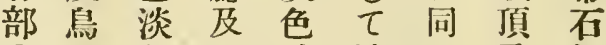
のにしび、淡し及板 测似。喉以藍。び角 定る 但は下灰鿖後黑 古し必の色は頭色

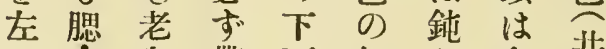

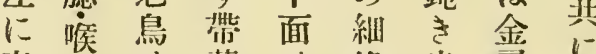
表のは茶は螕光屬雌 出堦翼灰淡 あ 澤光雌 す茶狗色藍 b澤息 べ色站子灰○有あ 。 し濃に呈色顏する 脚 度尾しに注る藍、 以狗且し暗藍鼠黑

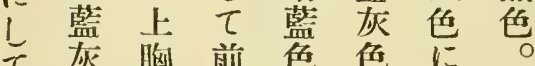

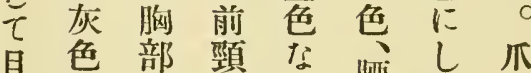

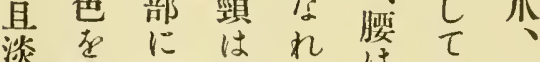
色芘達稍々゙は各伯 なびし濃頡多狗黑 が其留色上淡中色

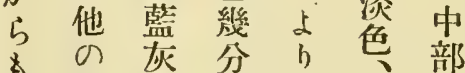
腹犲鼠光僅尾は 部色色涬少㰬鼠

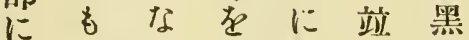
沦一ら保淡に色 及般す”有じ此頭 ○雄風 0 慙简頂 に划芚は雅 近狗び稍 長 らは㘈濃く く暗、は色し

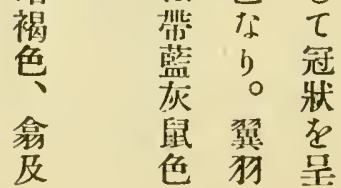




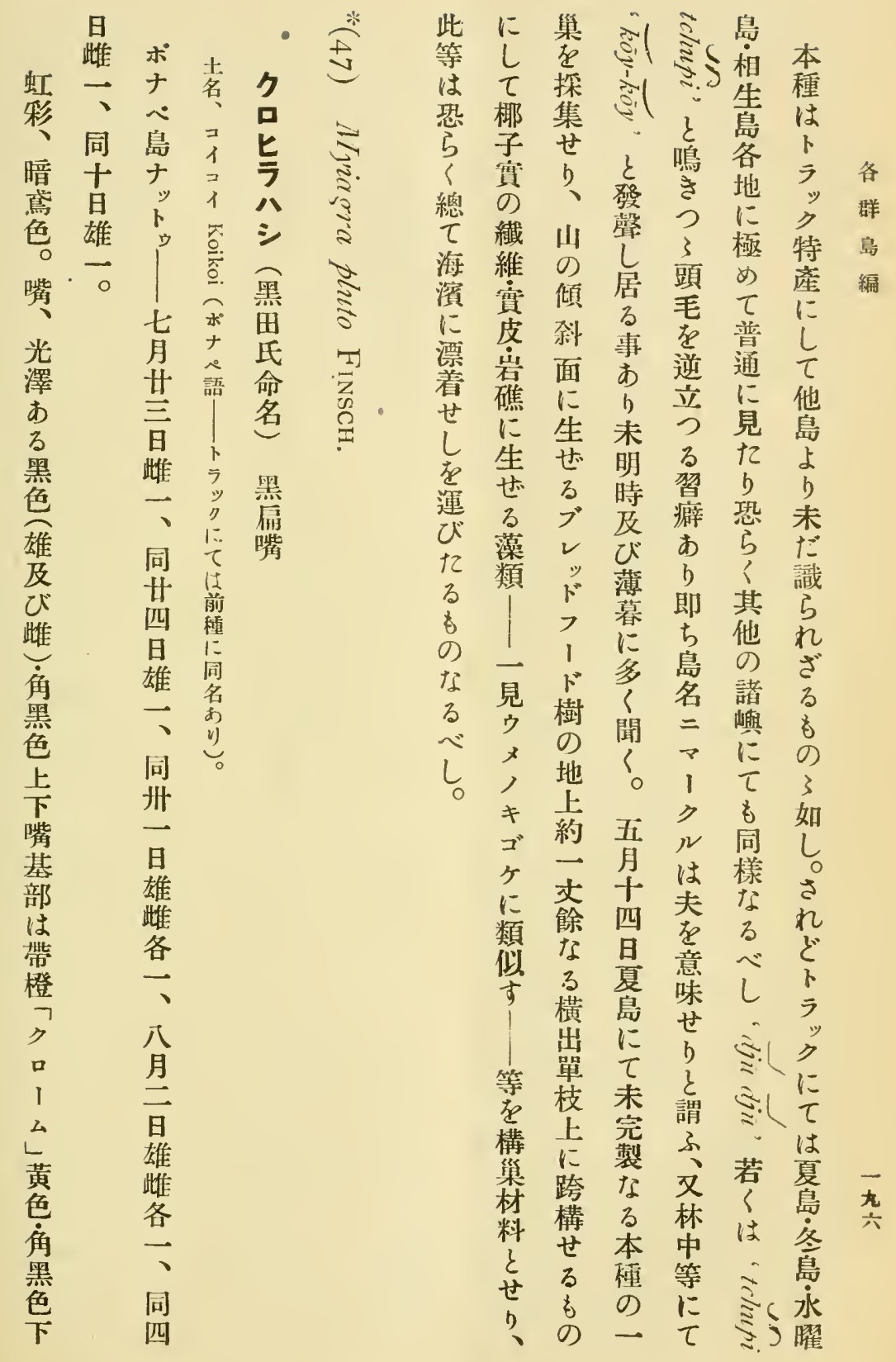




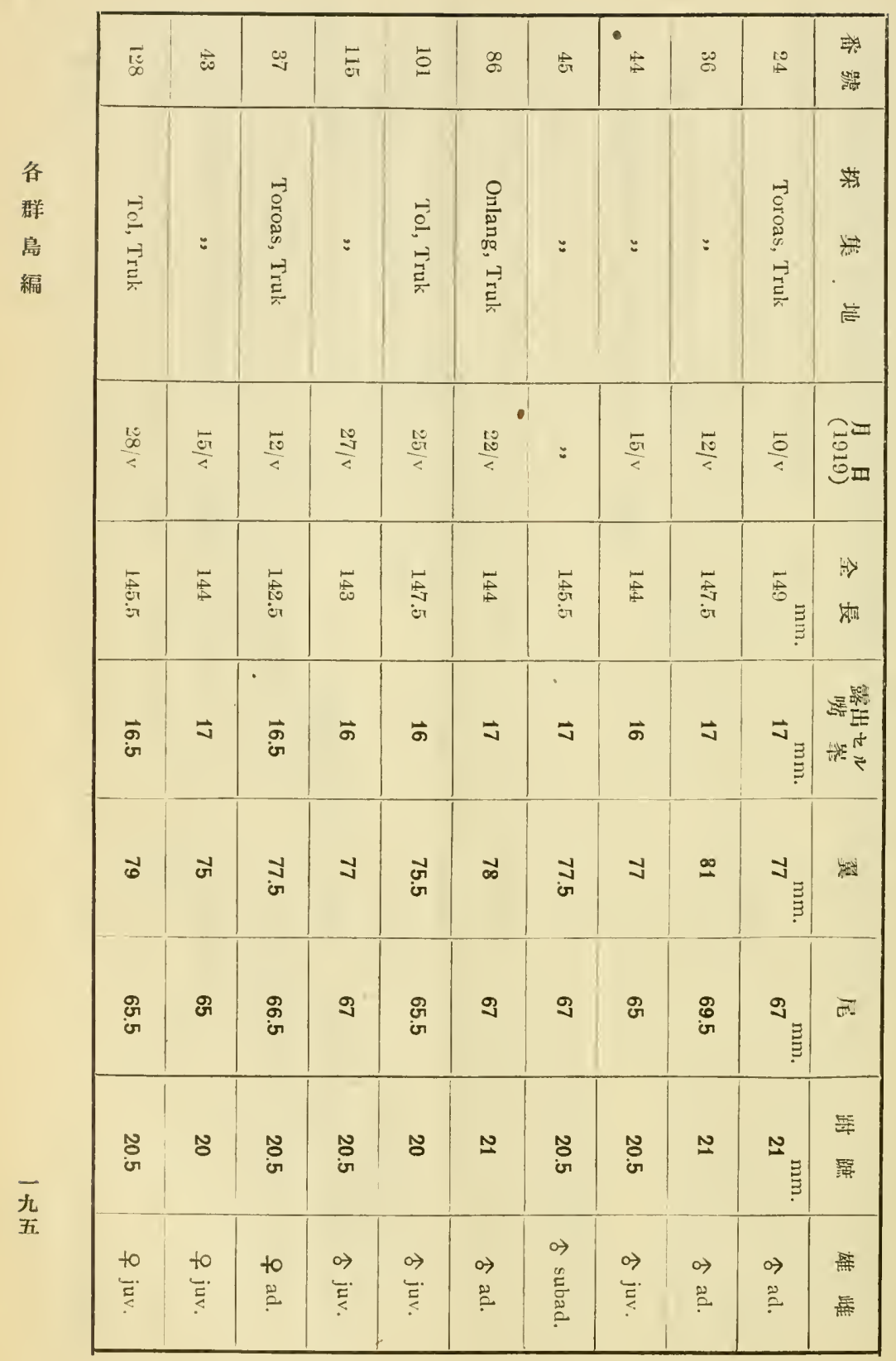


雄上石其 前外外及 探 幼成 雌胸 雄 板 限額 侧 側び雄 集鳥鳥成心老黑界は坊に腰成

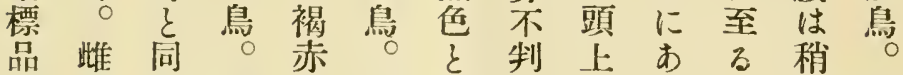
各成色前色頭な明にb淡頭各 部鳥な 頸部旸ら门比從色媔群

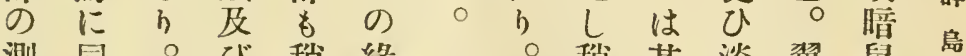
測同○び稍 緣 定じ上濃は

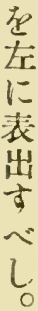

胸色金

褐な光

赤方澤

色口䔰

稍禾篗

淡非

色

る

の

み原

他

は 腰

雄は

成厤

子 淡

異色

な

ず

b

但 灰

雌学

老其主

に

あ

$\tau$

は

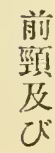

。秒其淡翼罂

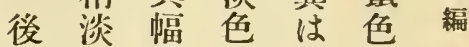

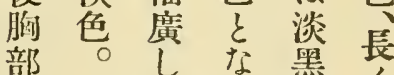

以下先家褐的

下面端色色

は榃端各雨冠

擬芯洼倠狀

息喉新外站皆

各时月辨にな

旸淡形成內专

基吉自帶侧各

部今色震風・狗

灰 ゙部色切に

鼠了市細旸鎑

色色總外色

。品辫

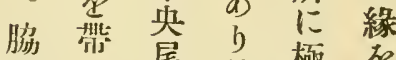

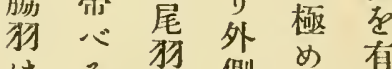

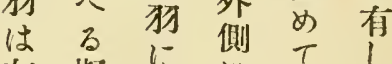

灰擬占卡細後

侦白至至き纈

星色后淡。

前韭從色赤

。攻其罂緣同

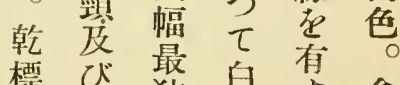

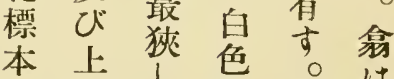

に胸し色。拿

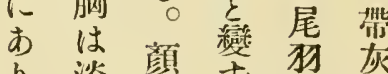

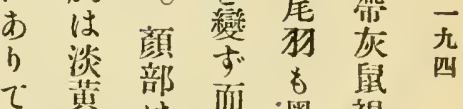

は褐は而墨褐

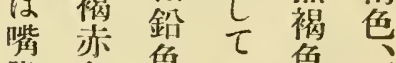

脚色色最色頸 


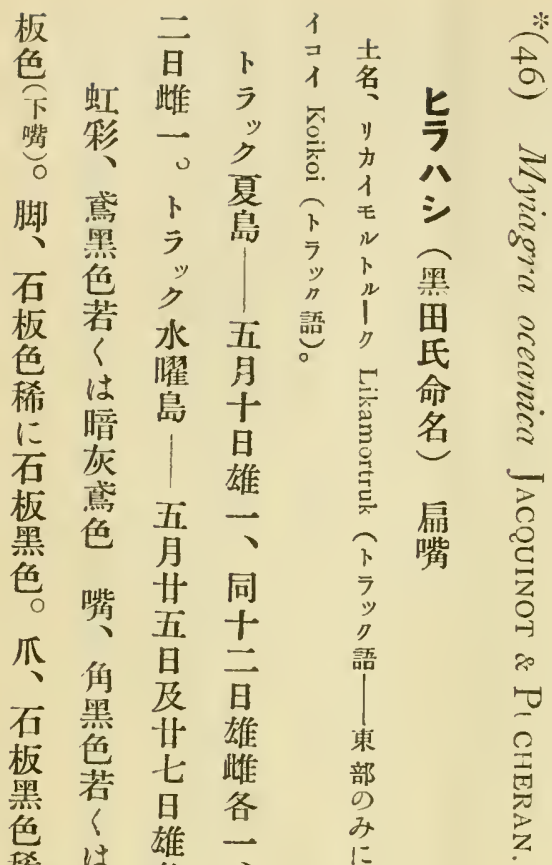

䇥各同咢

像牙、十

牙黑同五

黑色甘日

色步八雄品

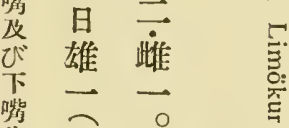

路森不不

及就 $\bar{y}$.

び氏ク語

石 寄 相

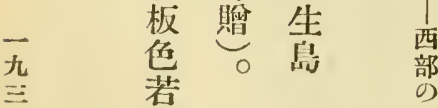

々. अ

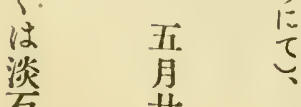

石 \#=

部林殖の事

少中器 ह

量のをのれ

の 地檢 $\xi$ ぞ

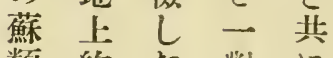

類約た對に

存 $3 \dot{\varepsilon}$ 幼

混間をな旸

于゙ $匚$ 以

其横 $\tau$ 居

形枝誤たの

狀上素了

站にな存一

に構さ見對

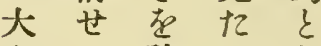

さる確るな

等一證 事れ

は巢串ある

粫探

に集云該喜

於 せ 時

け b- $-の$ 會

万内丙鳥せ

通部名はし

有に二冓事

型卵 合者な

なな基し

约余甚

構少 だ

巢探珍

材集し

料品き

$\varepsilon$ 中 例

$\tau$ 收

織狂

維 得 雌

在老

使且䳆

用自

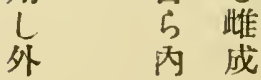


はの ハ此りは 成はり方七心本 邪野七は夕㐫種 の外夕地キ就は 雄 觀 キ 鳴に 它ヤ 祭に な 似 仓 伴時て る た に点唯囀督特

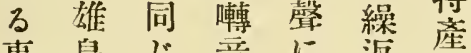

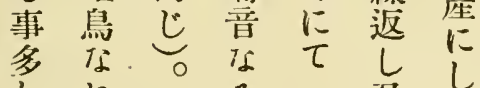

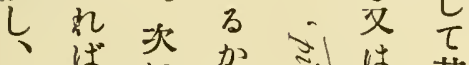

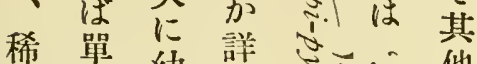

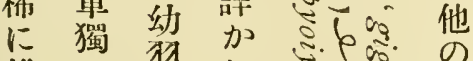

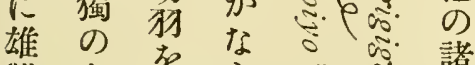
䧳

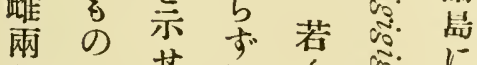
小比即人河に

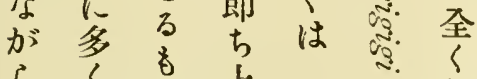
ᄃ

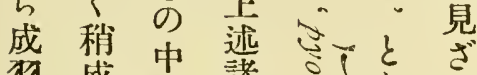

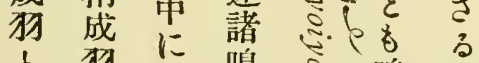

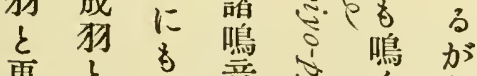

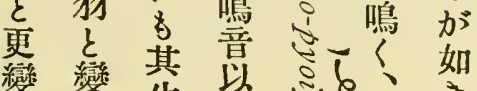
等告岁等:

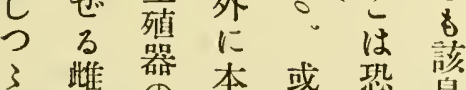
क鳥の㮔惑恐島 ると完梏單々尼 連全㖦に共注

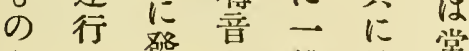
了女警古馨地常

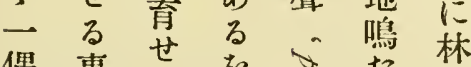
偶事芆农江蚻

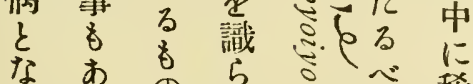

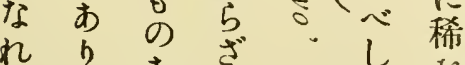

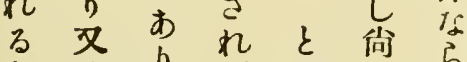

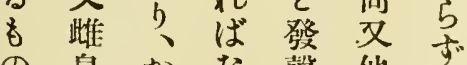
の鳥加な篮他思

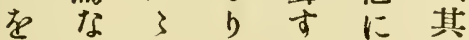

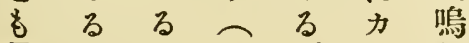

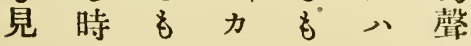

\begin{tabular}{|c|c|c|c|c|}
\hline$=$ & $:$ & : & 茫 & \\
\hline & & & & \\
\hline 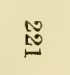 & 总 & ๓ & $\vec{\Phi}$ & 淢 \\
\hline & & & 苞 & \\
\hline$:$ & : & : & 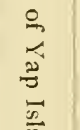 & $=$ \\
\hline$\frac{5}{8}$ & $\stackrel{ \pm}{s}$ & 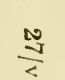 & $\frac{50}{\frac{50}{2}}$ & 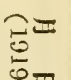 \\
\hline 茄 & 点 & जु & $\overrightarrow{\hat{\sigma}_{0}}=$ & $\Rightarrow$ \\
\hline & & & & 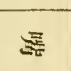 \\
\hline$\vec{\sigma}$ & $\vec{\infty}$ & $\vec{\sigma}$ & $\vec{\Phi}_{\underline{\underline{\Xi}}}$ & $*$ \\
\hline$\Phi$ & ने & 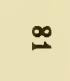 & 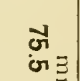 & 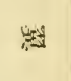 \\
\hline ळे & के & बे & 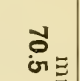 & $\approx$ \\
\hline s & $\approx$ & $\approx$ & 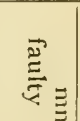 & 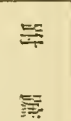 \\
\hline & to & & & 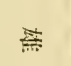 \\
\hline ఢ̆ & $\overleftrightarrow{\mathrm{̣}}$ & 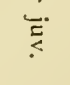 & $\overleftrightarrow{\mathrm{E}}$ & 焉 \\
\hline : & : & : & $\begin{array}{l}\text { 茫 } \\
\equiv\end{array}$ & 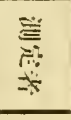 \\
\hline
\end{tabular}




\begin{tabular}{|c|c|c|c|c|c|c|c|c|c|c|c|}
\hline$=$ & : & $=$ & $=$ & $:$ & 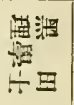 & $=$ & $\begin{array}{l}E \\
E\end{array}$ & $\frac{\div}{\frac{*}{*}}$ & $=$ & $=$ & : \\
\hline 8 & $\begin{array}{l}10 \\
\text { "ूँ }\end{array}$ & $\begin{array}{l}10 \\
\delta\end{array}$ & $\begin{array}{l}\stackrel{N}{\infty} \\
\infty\end{array}$ & $\begin{array}{l}19 \\
\end{array}$ & 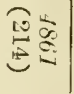 & 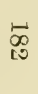 & $\vec{G}$ & $\vec{b}$ & 苂 & హ) & نु \\
\hline
\end{tabular}

群:

島

編

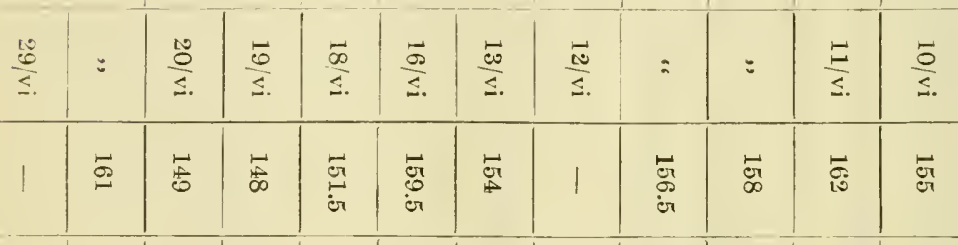

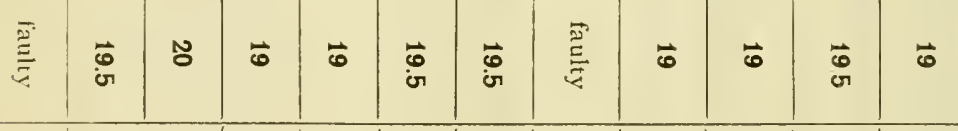

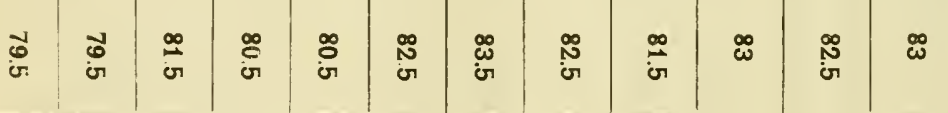

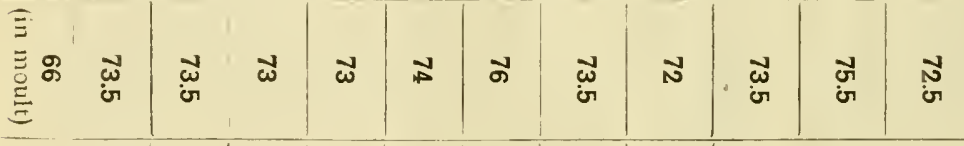

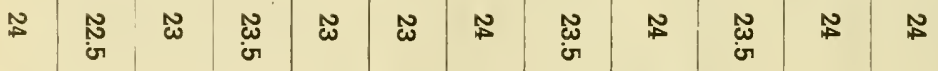

\begin{tabular}{|c|c|c|c|c|c|c|c|c|c|c|c|}
\hline 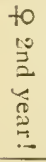 & 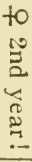 & 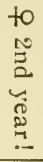 & 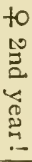 & $\begin{array}{l}\text { to } \\
\stackrel{2}{2}\end{array}$ & $\begin{array}{l}\text { to } \\
2 \\
2\end{array}$ & $\begin{array}{l}\text { to } \\
0\end{array}$ & $\begin{array}{l}\text { to } \\
\text { ?ֶ. }\end{array}$ & $\begin{array}{l}\text { to } \\
\cong\end{array}$ & $\begin{array}{l}\text { to } \\
\text { ¿ }\end{array}$ & 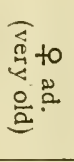 & $\begin{array}{l}\text { to } \\
2 \\
2\end{array}$ \\
\hline : & : & $=$ & : & $=$ & : & $=$ & $=$ & : & : & : & $\because$ \\
\hline
\end{tabular}




\begin{tabular}{|c|c|c|c|c|c|c|c|c|c|c|c|}
\hline$=$ & 三 & $\frac{خ}{\frac{\pi}{*}}$ & $=$ & $=$ & $=$ & $=$ & $=$ & $=$ & $\begin{array}{l}\text { E } \\
\equiv\end{array}$ & 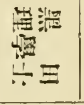 & 푝 \\
\hline 勇 & $\begin{array}{l}\stackrel{10}{\infty} \\
\stackrel{\infty}{\circ}\end{array}$ & $\stackrel{10}{\mathscr{L}^{\circ}}$ & $\begin{array}{l}10 \\
\text { 足 }\end{array}$ & $\begin{array}{l}\infty \\
\stackrel{\infty}{\infty} \\
-1\end{array}$ & $\begin{array}{l}\text { D. } \\
\text { S: }\end{array}$ & 总 & $\frac{10}{\omega 0}$ & $\underset{\sim}{\stackrel{D}{*}}$ & $\vec{\infty}$ & $\stackrel{\overrightarrow{8}}{\mathscr{B}}$ & 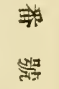 \\
\hline : & : & $=$ & : & $=$ & $=$ & $=$ & $=$ & $=$ & $=$ & 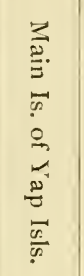 & 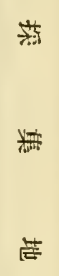 \\
\hline 岕 & $=$ & $\frac{\stackrel{10}{f}}{\leq}$ & $\frac{8}{5}$ & $\frac{\overrightarrow{0}}{\leq}$ & $=$ & $\frac{\triangleright \infty}{\leq}$ & $\frac{\sigma}{\leq}$ & $=$ & $\frac{\vec{\omega}}{\leq}$ & $\frac{\Xi}{\vdots}$ & $\frac{\sigma}{6}=$ \\
\hline 1 & $\begin{array}{l}\vec{c} \\
\stackrel{\vec{\omega}}{\mathrm{c}}\end{array}$ & $\stackrel{\vec{\sigma}}{\sim}$ & $\begin{array}{l}\overrightarrow{9} \\
\stackrel{5}{0} \\
\text { or }\end{array}$ & $\vec{\sigma}$ & 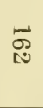 & 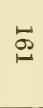 & హ్ & 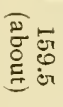 & $\begin{array}{l}\text { हु } \\
\text { है }\end{array}$ & 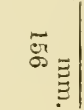 & $\begin{array}{l}4 \Delta \\
4 \times m\end{array}$ \\
\hline $\overrightarrow{0}$ & 응 & 웅 & $\begin{array}{l}\overrightarrow{0} \\
\text { जे }\end{array}$ & $\overrightarrow{0}$ & 응 & $\vec{\omega}$ & $\vec{\bullet}$ & $\frac{\vec{\Xi}}{\vec{E}}$ & $\stackrel{\vec{\Xi}}{\stackrel{\Xi}{\varepsilon}}$ & ${ }^{\vec{\varphi}}$ & 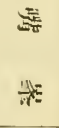 \\
\hline oै & $\stackrel{\infty}{\infty}$ & $\stackrel{\infty}{\circ}$ & $\begin{array}{l}\infty \\
\text { ज̆ } \\
\text { v }\end{array}$ & $\stackrel{\infty}{\sigma}$ & 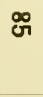 & $\stackrel{\infty}{్}$ & $\begin{array}{l}\infty \\
\underset{\cup}{0} \\
0\end{array}$ & $\begin{array}{l}\text { 心 } \\
\text { G }\end{array}$ & $\underset{⿱ 乛}{\infty}$ & 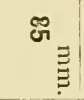 & 㯊 \\
\hline$\infty$ & N & $\begin{array}{l}\text { के } \\
\text { जे }\end{array}$ & in & $\begin{array}{l}\text { के } \\
\text { जा }\end{array}$ & $\begin{array}{l}\text { v } \\
\text { or }\end{array}$ & ฮै & iv & 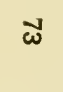 & $\begin{array}{l}\vec{\omega} \\
\text { v }\end{array}$ & कै & Fid \\
\hline $\begin{array}{l}\tilde{\omega} \\
v\end{array}$ & $\underset{\Xi}{\stackrel{\Xi}{\Xi}}$ & $\stackrel{N}{\sim}$ & $\stackrel{N}{\oplus}$ & $\approx$ & ڤ్ & $\stackrel{\vec{\Xi}}{\vec{\Xi}}$ & $\stackrel{N}{\sim}$ & $\stackrel{N}{\Delta}$ & $\stackrel{N}{\perp}$ & $\begin{array}{c}\tilde{\omega} \\
\mathcal{G}\end{array}$ & $\begin{array}{l}\text { 等 } \\
\text { 箈 }\end{array}$ \\
\hline 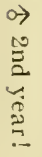 & $\begin{array}{l}\rightarrow> \\
\sum_{0}^{\infty} \\
\vdots \\
0\end{array}$ & $\begin{array}{l}0 \\
\text { Qै }\end{array}$ & $\begin{array}{l}0 \rightarrow \\
20\end{array}$ & 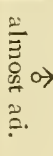 & $\begin{array}{l}\stackrel{\rightarrow}{0} \\
\stackrel{2}{2}\end{array}$ & $\begin{array}{l}\rightarrow \rightarrow \\
\stackrel{0}{0}\end{array}$ & 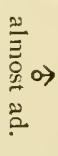 & $\begin{array}{l}\stackrel{\rightarrow}{0} \\
\stackrel{0}{0}\end{array}$ & $\begin{array}{l}\text { के } \\
\stackrel{2}{?}\end{array}$ & $\begin{array}{l}\stackrel{\leftrightarrow}{0} \\
\stackrel{2}{0}\end{array}$ & 臹 \\
\hline : & $=$ & $=$ & $=$ & : & : & $=$ & $\Xi$ & $=$ & $=$ & $\begin{array}{l}\text { } \\
\equiv\end{array}$ & 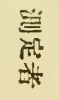 \\
\hline
\end{tabular}




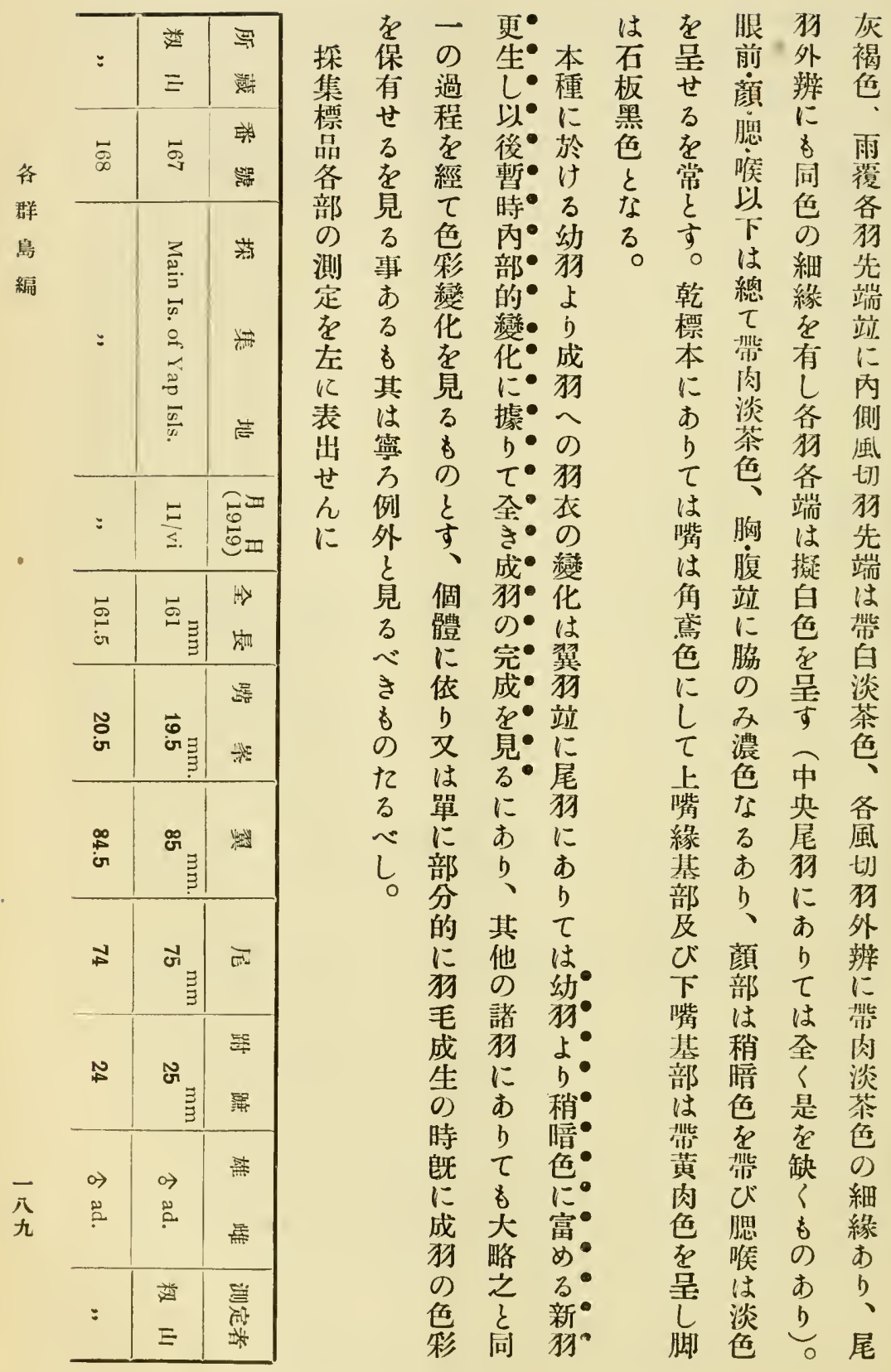




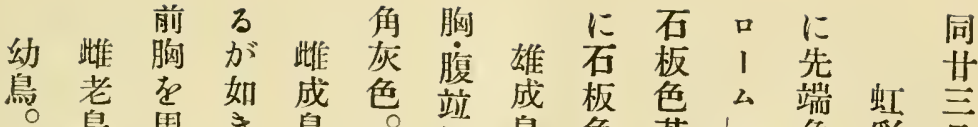

前鳥周き鳥脚脇鳥色若黄 焦彩 豆

額雄了上頸は妿頭色は色色武幼各

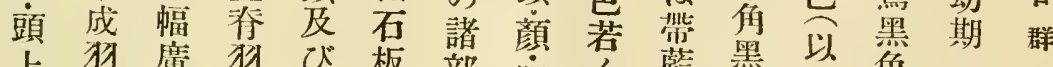

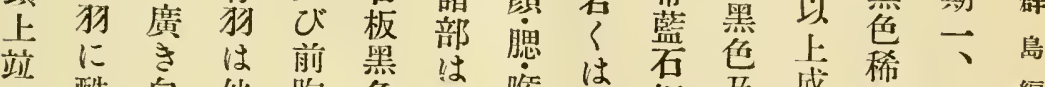
に酷白他胸色純喉角板莨成に同編

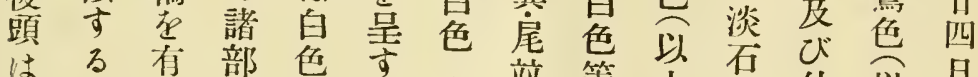

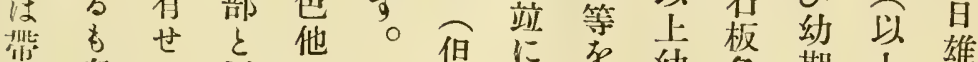
褐隹る 同の但に存幼色期上雄 灰部色諸各泼混狗若占成成 鼠赔 りに部雅榙 色腹 导 拿部白皆

はに

茶黑

鼠旸

色戈㡲

喓 分師後

及 殘方 项

ひ存

1.

尾 る

简总

は 以

﨓 $\tau$

灰制光復

淡别は外

茶外恰

褐 得

色 心

翼

项

尾

才才

は

觀 है

上

後 部

点色

站呈

兩部

辨はb鲜黑黑同

の带 $\underbrace{3}_{0}$ 角黑色色 サ

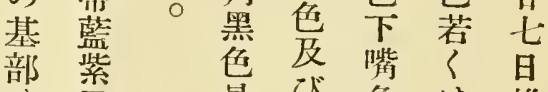

は 黑

灰 色

鼠 特

色頭

畭 部

標に

本 क

に

क

当 金

保蜀

は觜光

は 澤

不に

板葍

黑 0

色 钲

䟰春

緣 惯

最び㢈は雄

多淡第带幼

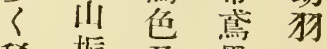

稀㱬蔗墨

石色滥立同

板橙增

黑墨趞去

色幼色㬎曷

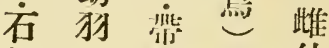

板 。黑㗪幼

色脚角期

若石灰淡一

生板色石柴

は焦整田

沰色筬悲先定

板或砲端郎元

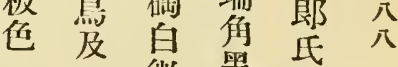

別微黑榇

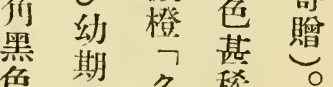




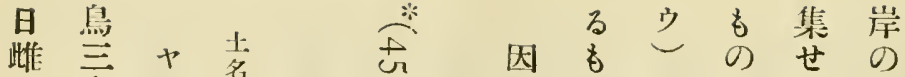

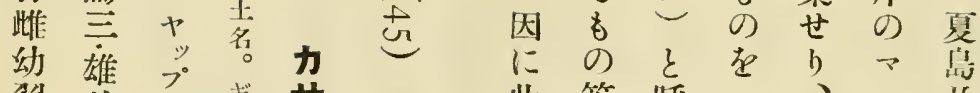

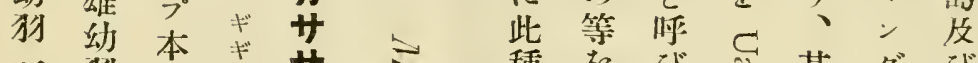

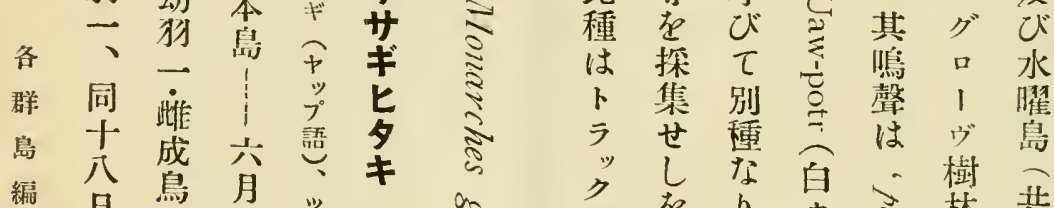

$$
\begin{aligned}
& \text { 日鳥尔 } \\
& \text { 雄 一十古唯 } \\
& \text { 成同雌加 } \\
& \text { 新 } \stackrel{\infty}{3} \\
& \text { 岛存古白主林共 }
\end{aligned}
$$

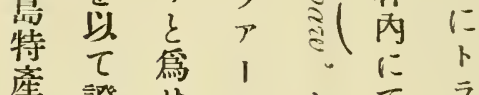

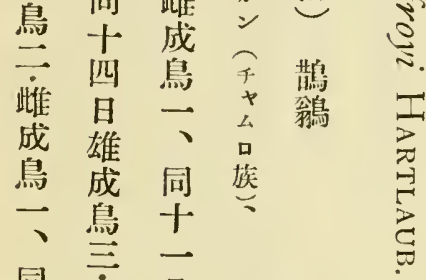

$$
\begin{aligned}
& \text { 同雌 日 } \\
& \text { 九 成 雄 } \\
& \text { 日量成 } \\
& \text { 雄 } \overrightarrow{\text { 雌 }} \\
& \text { 鳥 幼 雌 } \\
& \text { 一狗成 } \\
& \text { 雌、壆的 } \\
& \text { 縕同同 } \\
& \text { 兵士 } \\
& \text { 同 日 } \\
& \text { 首维 日 } \\
& \text { 古草雌 } \\
& \text { 雄此鳥 } \\
& \text { 成咸一 } \\
& \text { 入鳥忞同 } \\
& \text { 七雌 、素 } \\
& \text { 幼间百 } \\
& \text { 期十雄 }
\end{aligned}
$$




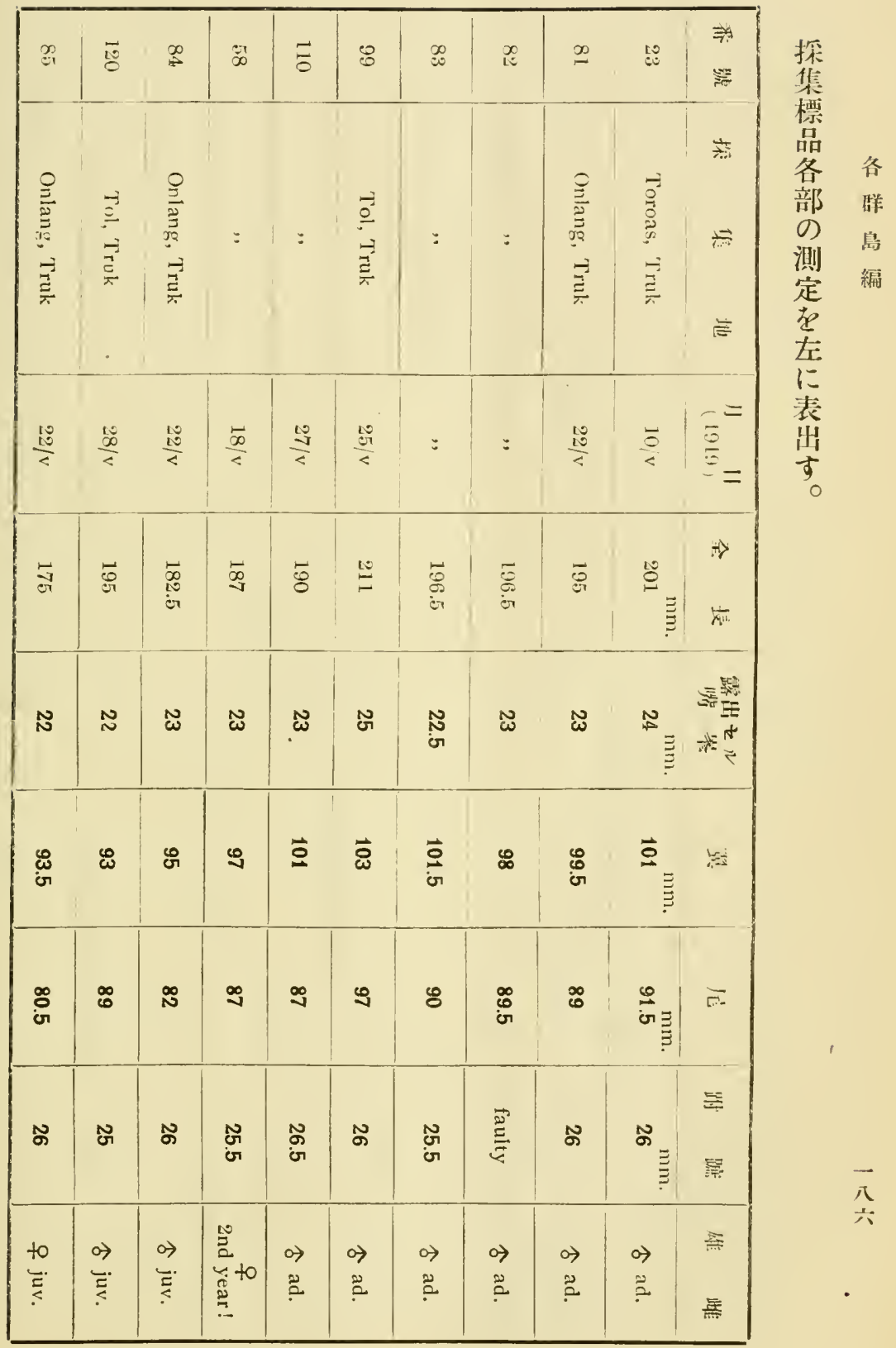




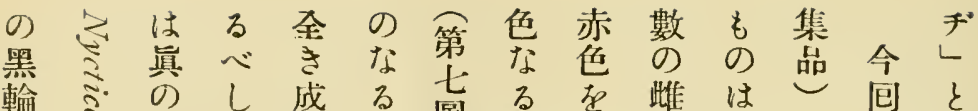

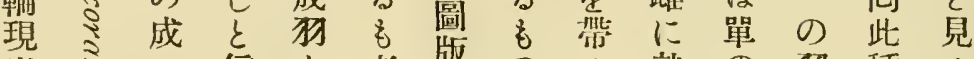
出 各にミにずな鳥第尔るて成色の心 群就さはのりに圖雌も調烏の全き

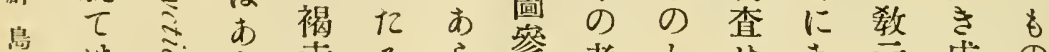
編は らら赤る ら照老々 せ あ 示成の

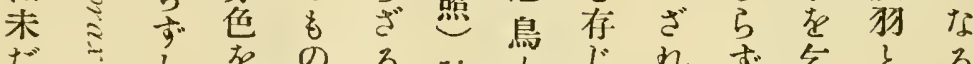
だ亡し皇 の る

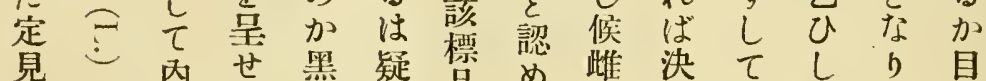
に内焉疑品め雌決 なに部る彎点はら成し恐にた下

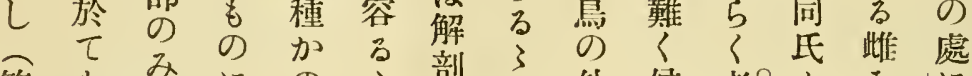

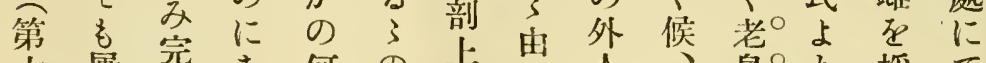

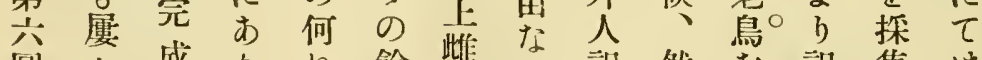

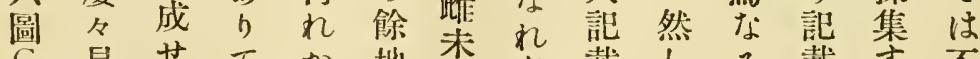

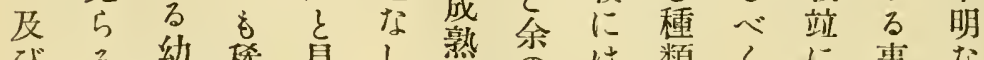

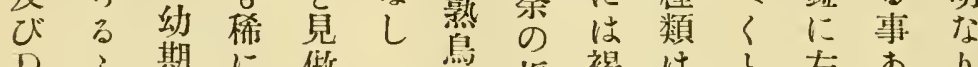

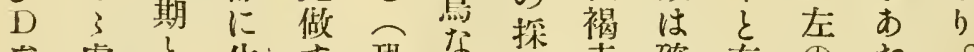

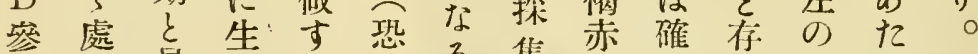
照な見殖心゙学集焦か心交は

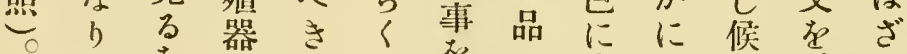

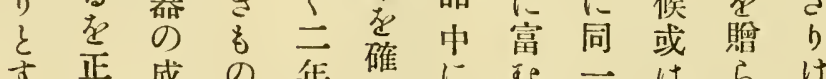

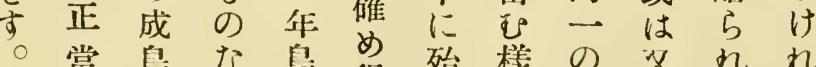

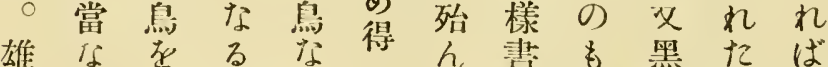

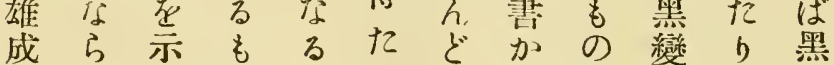

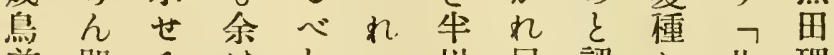
前即了生し以居認加此理

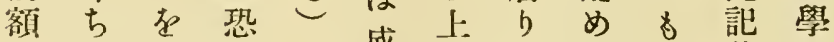
の近見点即成黑侯申知载圭

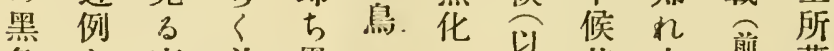
色々事前黑にせ潶若申㮍藏

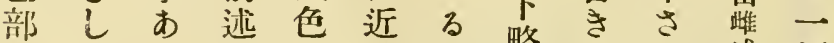

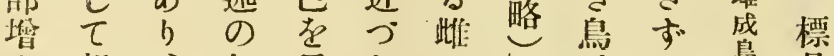

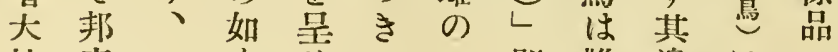

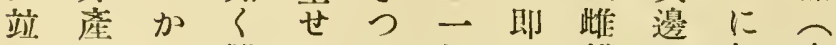

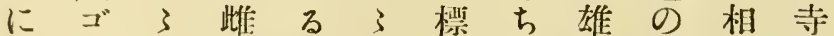
後中了成雌市嵒氏其處當岡 頍 部ギのな泩る可黑褐多る探 

Birds of Micronesia. Pl. VIl.

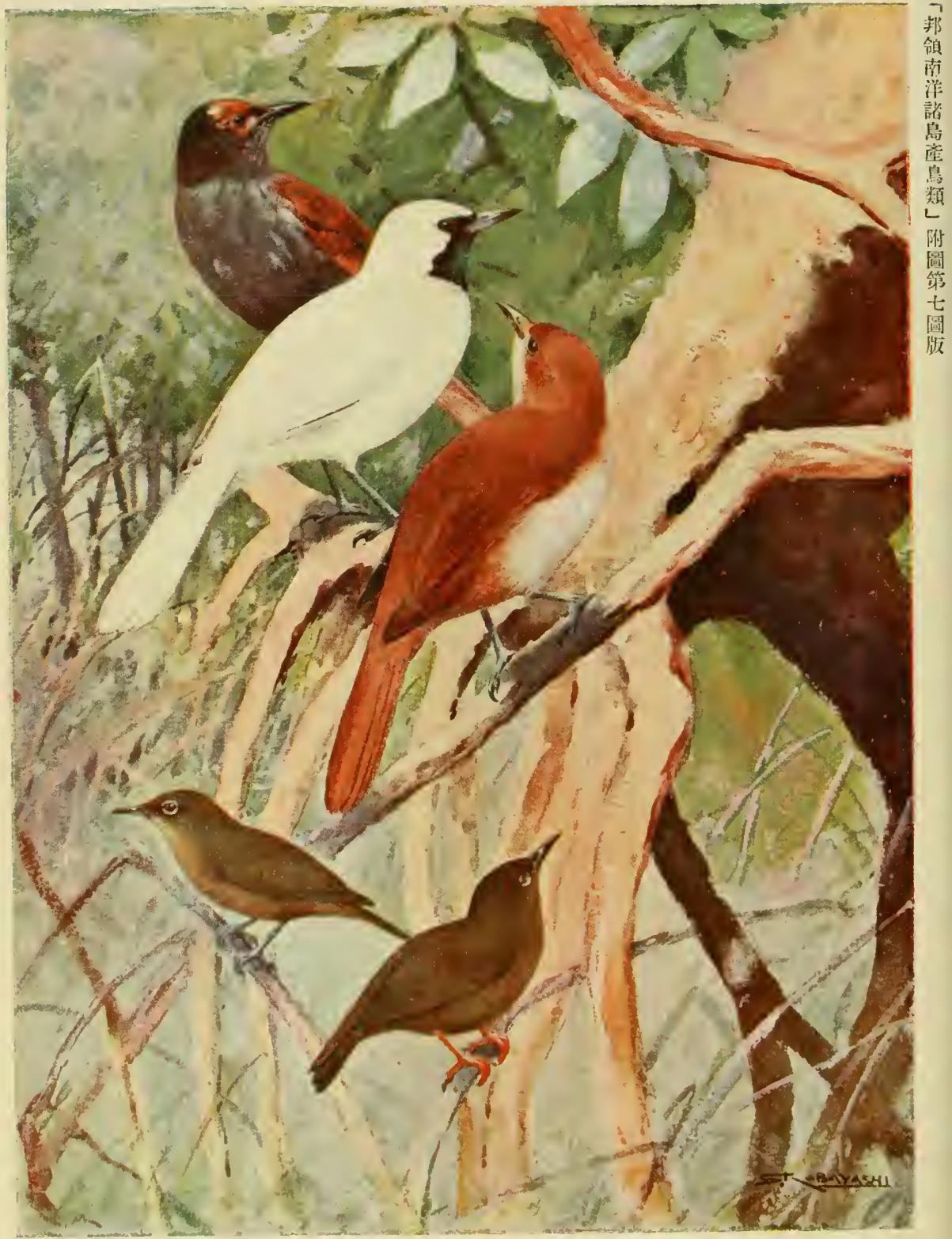



Birds of Micromesia. Pl. VII.

Metabolus rugensis: p. 182 .

力八 $、$ 七 \& $\neq$

Fig. I. 오 subad.

Tol J., Kuk group. I8/v, Ig. (No. 58 ).

Fig. 2. $\hat{\delta}$ ad.

Toroas I., Ruk group. ro/v. 19. (No. 23).

Fig. 3. $\hat{\delta}$ juv.

Tol. I., Ruk group. 28/v, 19. (No. 120).

Kubaryum oleagimum: Pp. 246 \& i (Fing. text).

$$
\text { ミ十マメジ口 }
$$

Fig. 4. 오 ad.

Yap I., Yap Is. 4/vii Ig. (No. 304).

Rukiu ruki: pp. $265 \& 2$ (Eng. text).

アカアシメジロ

Fig. 5 . 오 ad.

T'ol. I., Ruk group. 30/v, I9. (No. I $\$ 3$ ). 


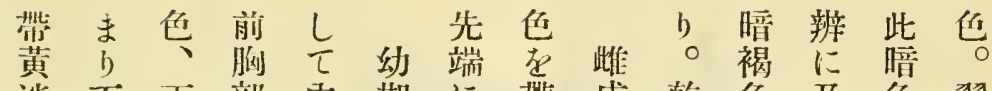
淡下下部内期に燕成乾色及色翼 㬨腹㗪に侧。小ぶ鳥標をぶ部初 色范基隐に上白。本呈事は列 そび部れ到面斑下命にせ市個風

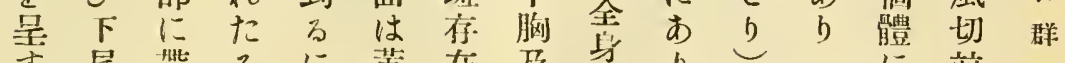

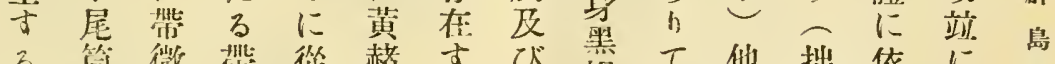

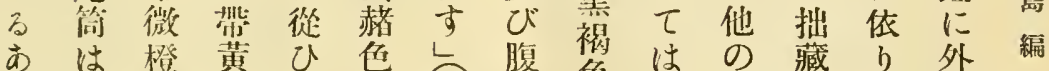

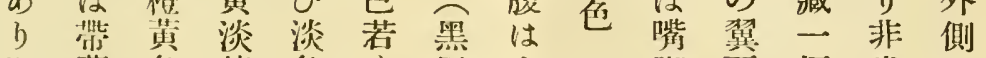
即黄色赫色? 思上歌脚面標常次

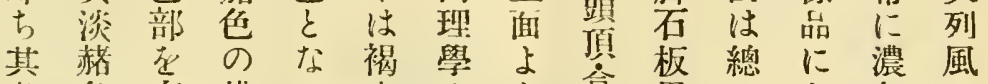

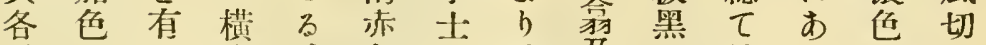

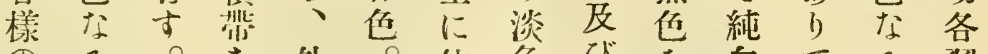

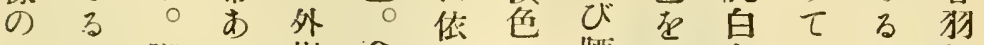
を脚り辦鿖子に腰呈色は当軸 のりは○ははこしは寺。初の铜 は、石裹總稍。濃。尼列 性胭板雨 $\tau$ 濃狗色狗風 b 色

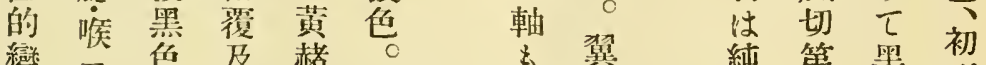

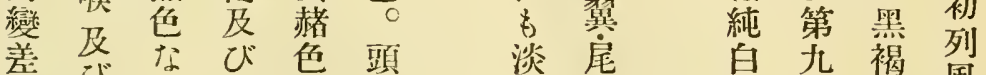

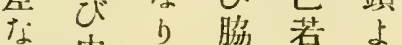

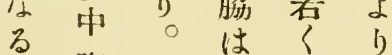

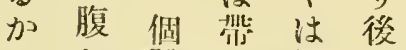
又部體 黄 褐 頸 はのに泟は 單 に殆 b 赫。少

子 下色腿淡

フど 面。 前色

白

又色擬標喉翼

々な向本㔍の

なる色に年風

る あ 部 あ 下 切

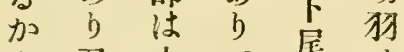
或父中展生

は下腹注简縕

一面迄觜㧉暗

ス一には擬褐

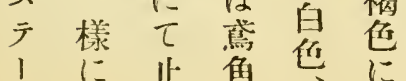

色度色狗色風

なび、外不切

b下先辨整第

下面端告角哥

尾多除端斑

简少け存を數

の燊 3 除形數

或色第虫成の

の 照 U) 軸 た

緣喉 及内甚辨

は以喑侧だ先

白下褐中稀端

<上色軸に

又臘

最迄

外 は

側 僅

狗に

の 灰

喜添曋色甾

る 守色部

總蔀有

क $\tau$ 外吉 


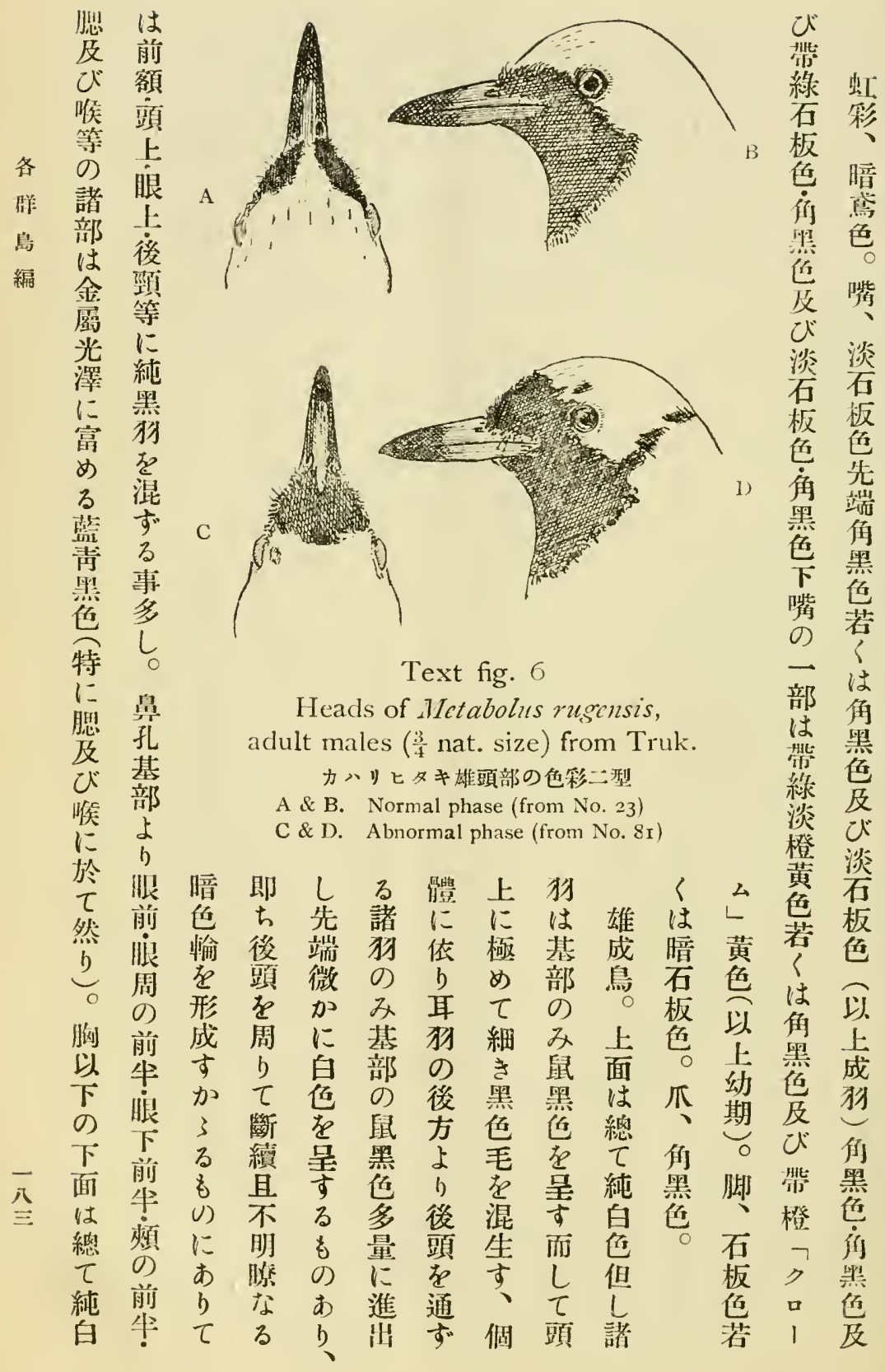




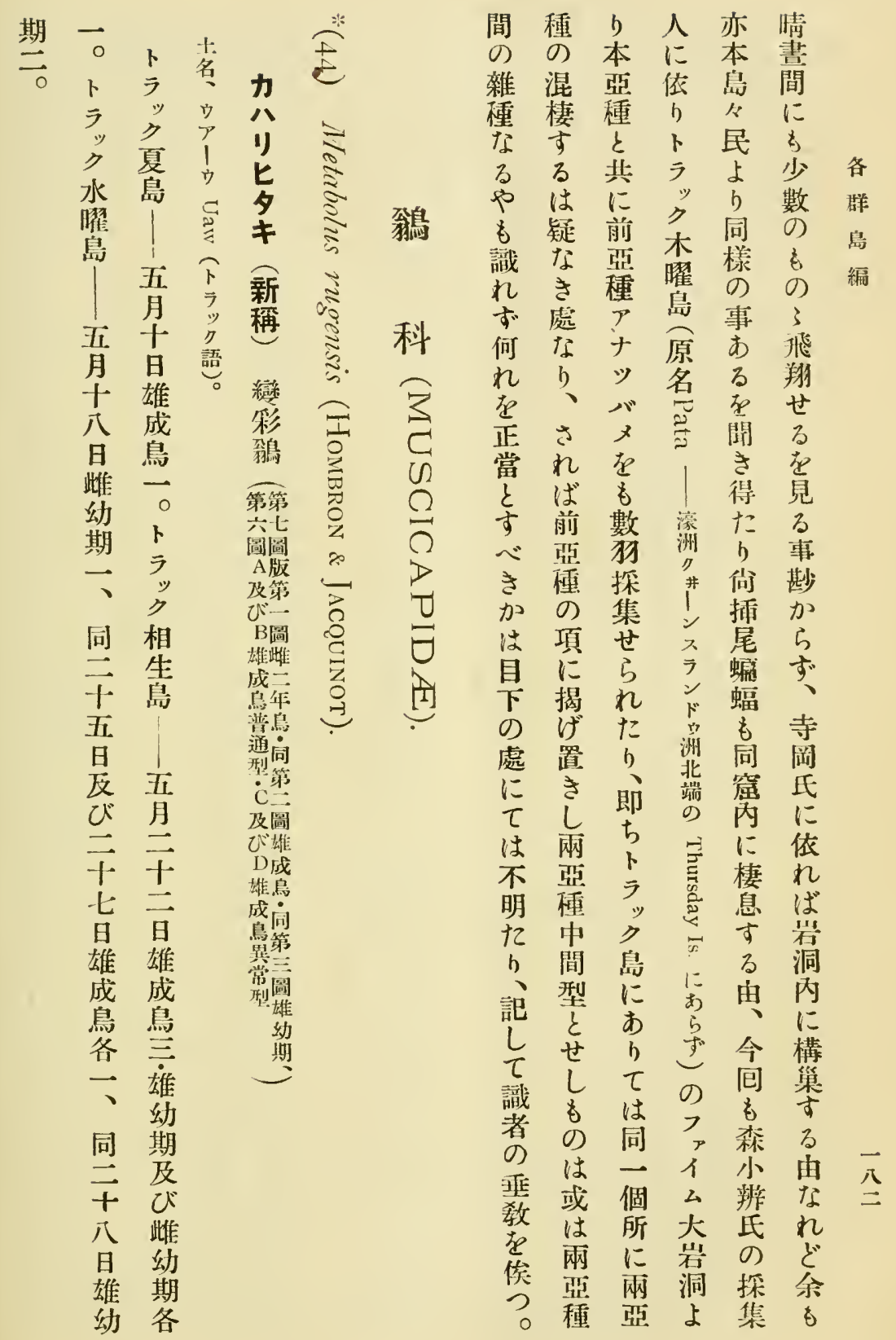




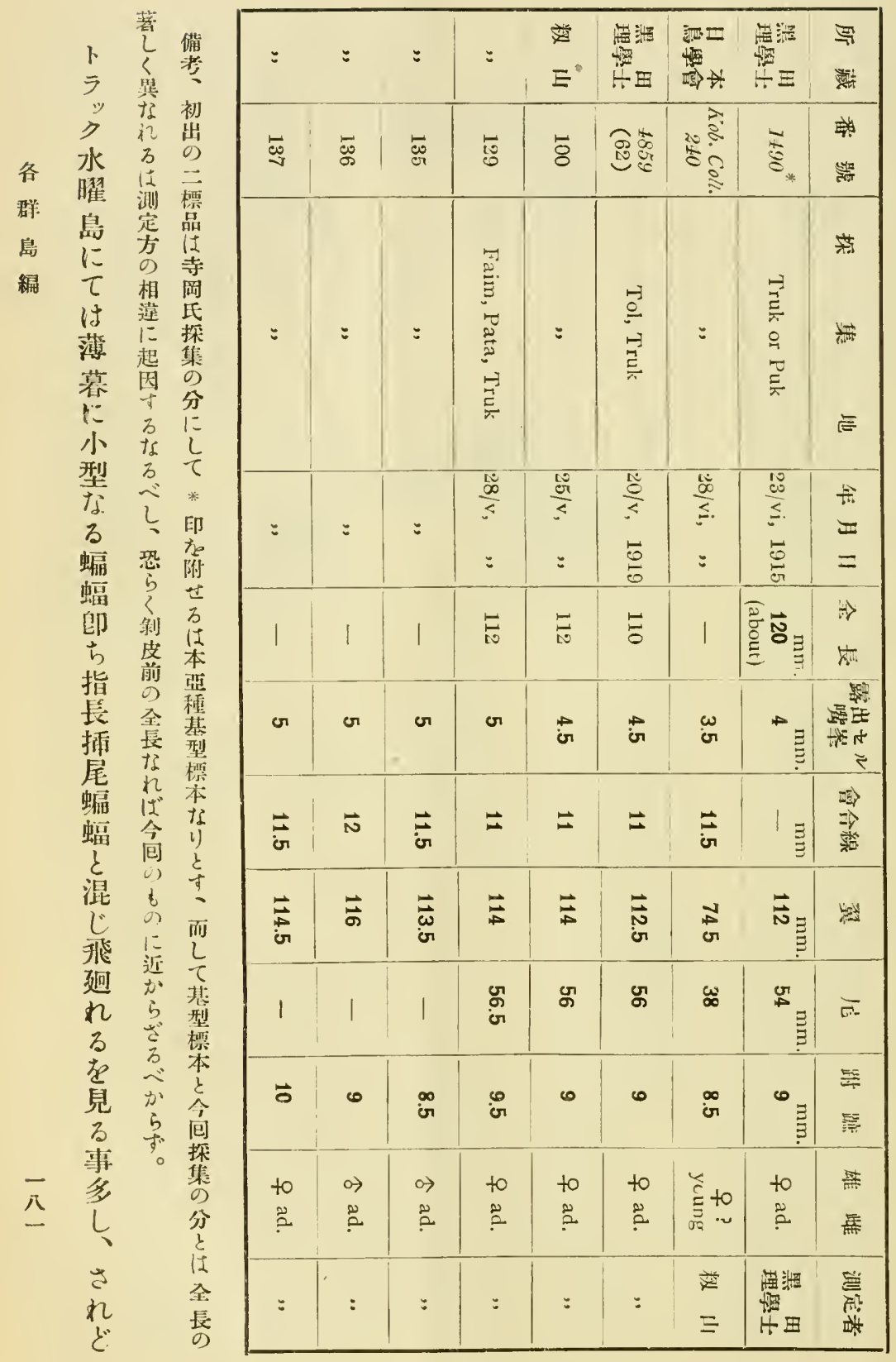




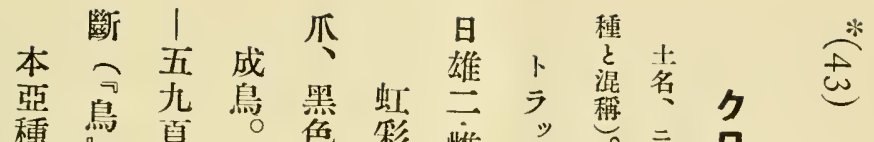

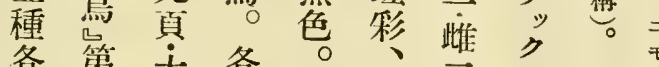

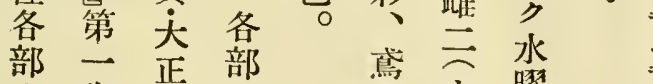

の䉥四の 定第年色 驾圖但壮 左版 し 黑 に第同田 表一詀理 出圖 9 學 潂本士 心゙に亞の し 第種 原 三 謻 圖色载 ó 圖に 殆 秒 薄 ぞ 角致 多

先

に以

過 $\tau$

〈゙再

る 揭

の せ

觀 禾

क)

与 $\overparen{9}$

前

留 第

種 -

に 卷

あ 第

b

$\tau$ 號

同公
墨觉䧳

脚森 禁

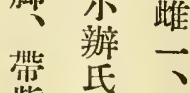

紫害同

墨 贈

䇼口克

舞

煙

若

辇

趾

住

煙

黑

色

若

?

生

慆

煙

色。
日

雌

$\rightarrow$

1

亏

")

木

雌

岛

7

1

么

洞

筮

五
各。

群

編 
もす於に地の少洞にあり どり

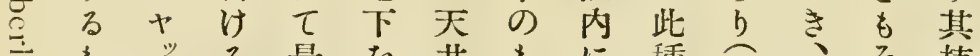

它 プる最を井当に種但、を楼

の品綿深通にの出表但故は所

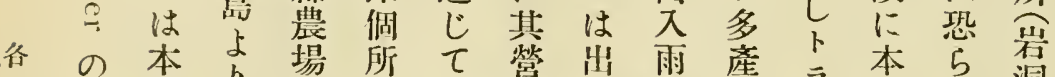

群 誤 留 b に

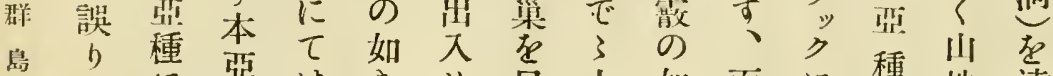

編にに丝はきせ貝上如而に敇地遠

はは常はる 臈下しして み附く

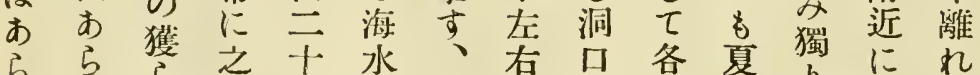

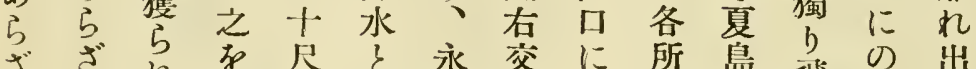

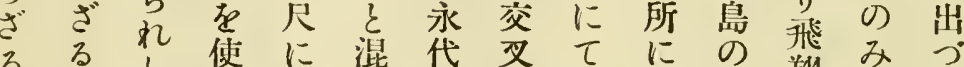

るるし使に混代必てにの翔みう

か心報用餘じ本迴人尠如翔限了

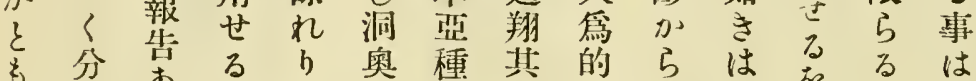

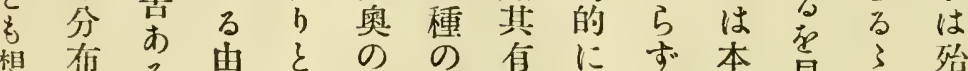

の有にす本見了烈

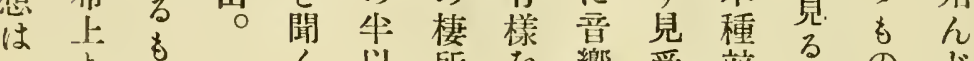

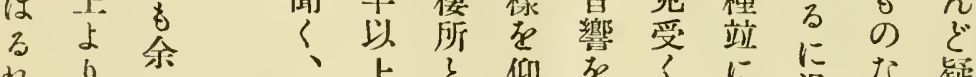

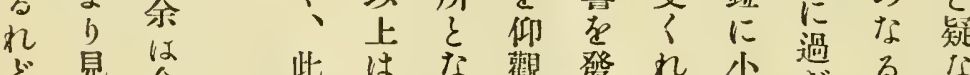

ぞ見今此はな觀發れ小過る゙な

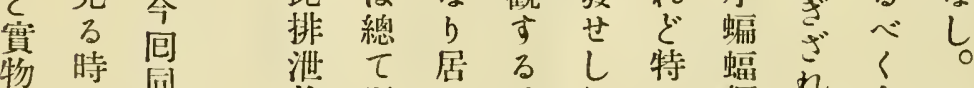

は间

接寧息

せ方豆

ざパ此

り ラ 類

ᄂ 少

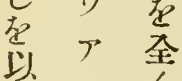

テナ自

碓 少

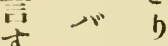

了メき

事 ○恐

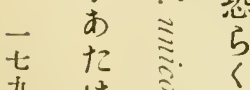

は ミ同

息

物泥て時さに類

は樣るはる夕をば余す

農々它時了多に同へ

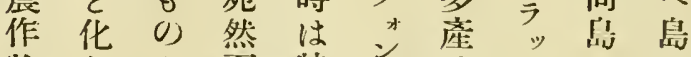

物し了夏 特者せ にに

の其如多に芕多滯

施深くの其々一藻在小

肥さ洞蚊出な引の型

と優底桂入る 空十な

しににを頻岩イ間餘る

$\tau$ 人其望繁洞岛に日螎

良體排む $\varepsilon$ 附に比中蝠 好を 䛧にな近 品潜物似 hにb秋间を た沟のた洞はて風方產 り 世堆 b外芘は落見す 即し積、のだボ莫るる ちめ、該上多ナたあ由 同得外洞空くべ 血了海窟に具以のは聞 に程と内大其上威ざけ 


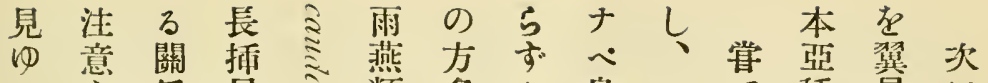
れ范尾交類多夕岛ル艺種尾に ぞ拂上蝙ミ數 サ產紧寺と長本 事ふ勢蝠气! の

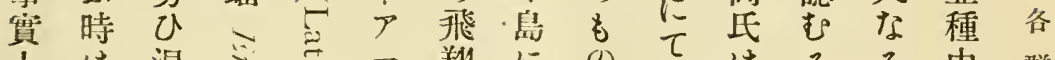

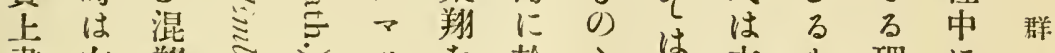

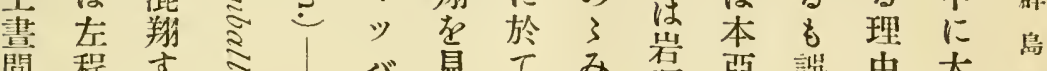

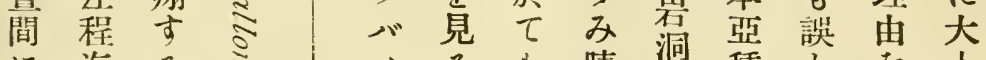

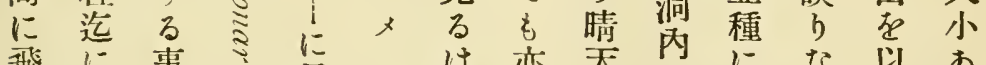
飛に事息さは亦芺内にな以あ

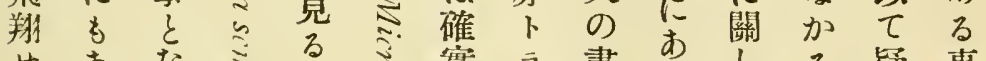

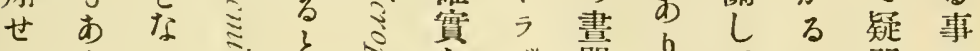

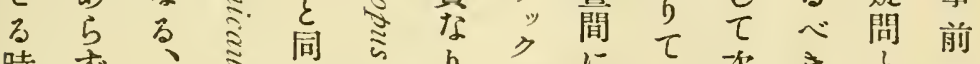

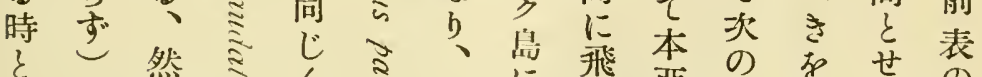

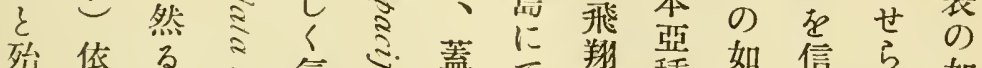

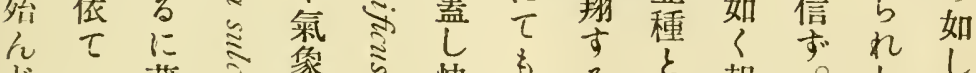

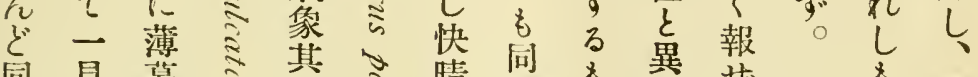

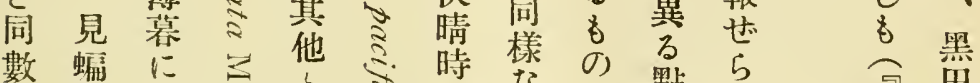

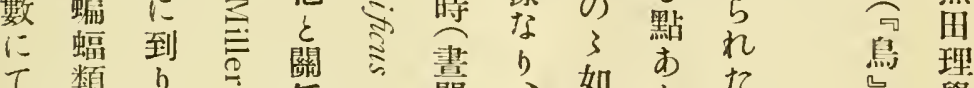

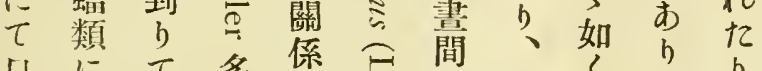

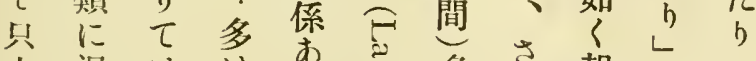

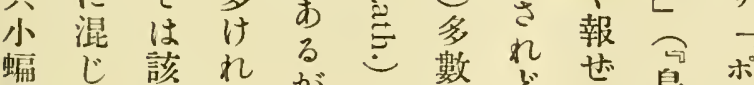

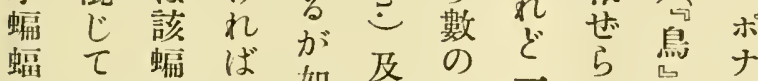
類本蝠多如仗专般れ第へ の種 と刻 ᄂ 子多本に, 增亦種到卢为盛は畫第生 加桠とれ 世め生ばクマ群萻飛號蕳 して識其にッ飛筒翔五表

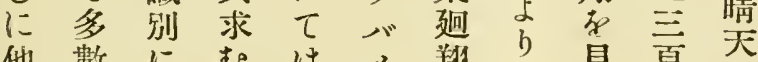

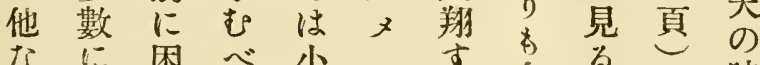

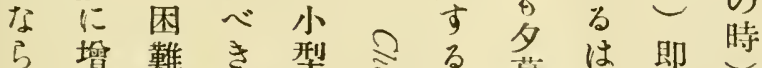

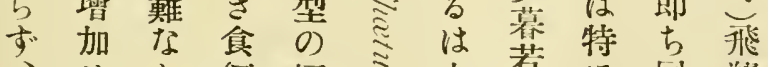

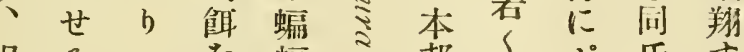
但る 在蝠之邦任氏主

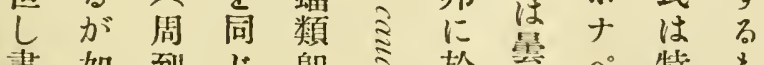

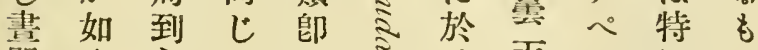

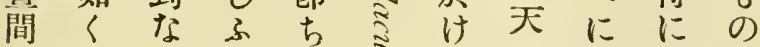
上に方李指名時限术多

學

第

在

聕寺

第 岡

號 氏

五

頞

及

ש̋

九 探

頁 集 犬 世

正

四社

年元

C. 3

疑 -

小 慗

き 品 
$\begin{array}{llll}\text { み } & \text { 同 } & \\ \text { 分 } & \text { 種 } & \text { ム } \\ \text { 布 } & \text { 至 } \\ \text { せ } & \text { 型 } & \text { 中 } \\ \text { ら } & \text { る } & \text { † }\end{array}$ 各学看事印 群了做を尼 島をす示附 綟 べせ 七 り る 從当。は 來 の次次 のなに臬 儘る當種 に か 然 從々起名 山 た疑 べ りな き れ 問 ぞ 題 メ 本は 亞ク 種 はつき 分 布 ッ

非 バ

常 メ

は 度 里下 贸 果面 に 對 别 色 し 亞 $\tau$ 種 次尔兩 亞 b 亞 種や種 $\vec{t}$

\begin{tabular}{|c|c|c|c|c|c|c|c|}
\hline 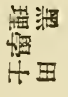 & 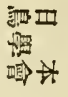 & 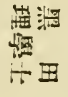 & $=$ & $=$ & $:$ & : & $=$ \\
\hline$\frac{\pi}{6}$ & $\begin{array}{l}\text { ह } \\
0 \\
0 \\
\vdots\end{array}$ & 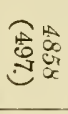 & 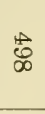 & 它 & 苞 & $\underset{\sim}{\infty}$ & $\stackrel{\text { 空 }}{\mathrm{c}}$ \\
\hline 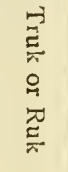 & 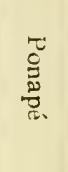 & $:$ & : & : & : & 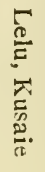 & : \\
\hline $\begin{array}{l}\frac{\infty}{\vdots} \\
=\end{array}$ & 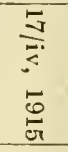 & : & $=$ & : & $\begin{array}{l}\frac{\omega}{\vdots} \\
\vdots \\
\vdots\end{array}$ & $\begin{array}{l}\frac{\infty}{\vdots} \\
\vdots \\
=\end{array}$ & $=$ \\
\hline 1 & 1 & 巨点 & ছ゙ & 巨 & $\overrightarrow{8}$ & $\begin{array}{l}\text { E } \\
\text { is }\end{array}$ & 范 \\
\hline 1 & $\stackrel{p}{\text { or }}$ & $\stackrel{p}{c}$ & $\vec{G}$ & $\stackrel{\circ}{\circ}$ & $\vec{G}$ & in & 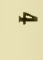 \\
\hline 1 & $\vec{\rightleftharpoons}$ & N & $\underset{\dot{r}}{\rightleftarrows}$ & $\stackrel{\vec{\sigma}}{\leftrightarrows}$ & $\vec{N}$ & $\underset{\sigma}{\sigma}$ & $=$ \\
\hline$\underset{\sigma}{*}$ & 용 & $\vec{\infty}$ & $\underset{\dot{\sigma}}{\overrightarrow{0}}$ & $\overrightarrow{\mathrm{N}}$ & $\overrightarrow{0}$ & 它 & $\underset{\omega}{\vec{\omega}}$ \\
\hline জু & S & $\underset{\text { G }}{G}$ & $\begin{array}{l}\text { S } \\
\text { i }\end{array}$ & $\mathcal{G}$ & క్ర & $\begin{array}{l}\text { @ } \\
\text { in }\end{array}$ & G \\
\hline 1 & $\omega$ & $\bullet$ & $\stackrel{\infty}{\circ}$ & $\begin{array}{l}c 0 \\
\text { or }\end{array}$ & 0 & $\omega$ & $\infty$ \\
\hline 2 & $0 \rightarrow$ & $\begin{array}{l}\text { to } \\
\stackrel{2}{2}\end{array}$ & $\begin{array}{l}\text { to } \\
\stackrel{2}{2}\end{array}$ & $\begin{array}{l}\text { to } \\
2 \\
0\end{array}$ & $\begin{array}{l}0 \\
0 \\
0\end{array}$ & $\begin{array}{l}\stackrel{0}{0} \\
\stackrel{2}{0}\end{array}$ & to \\
\hline 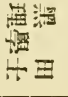 & $=$ & $=$ & $=$ & : & : & : & $=$ \\
\hline
\end{tabular}




\begin{tabular}{|c|c|c|c|c|c|c|c|c|c|c|}
\hline : & : & : & $=$ & : & : & : & : & $=$ & $\begin{array}{l}\text { 䒚 } \\
\equiv\end{array}$ & 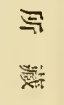 \\
\hline ज्ञ & $\vec{\infty}$ & $\stackrel{\vec{\Delta}}{\vec{v}}$ & $\stackrel{\infty}{\infty}$ & $\stackrel{\infty}{=}$ & $\sqrt{7}$ & $\overrightarrow{\omega_{0}}$ & $\begin{array}{l}\tilde{c}_{5} \\
+\end{array}$ & $\overrightarrow{\underset{10}{0}}$ & $\vec{\omega}$ & 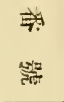 \\
\hline 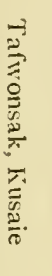 & : & 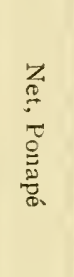 & $=$ & 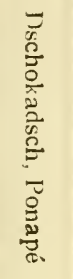 & 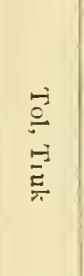 & : & : & : & 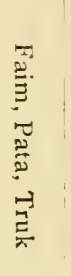 & $\begin{array}{l}\text { 获 } \\
\frac{1}{1} \\
\text { 点 }\end{array}$ \\
\hline $\begin{array}{l}\vec{\sigma} \\
\vdots \vdots \\
\vdots \\
\vdots\end{array}$ & : & $\begin{array}{l}\frac{1}{\leq} \\
\vdots \\
\vdots\end{array}$ & : & $\begin{array}{l}\frac{\tilde{g}}{\vdots} \\
\vdots \\
:\end{array}$ & $\begin{array}{l}\frac{\infty}{0} \\
\vdots \\
=\end{array}$ & : & : & : & $\begin{array}{l}\frac{\tilde{\infty}}{\vdots} \\
\vdots \\
\frac{0}{0}\end{array}$ & $\begin{array}{l}\therefore \\
= \\
=\end{array}$ \\
\hline${ }_{i}$ & 尽 & $\begin{array}{l}\vec{D} \\
\stackrel{5}{c} \\
\text { co }\end{array}$ & 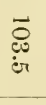 & i & हु & 1 & 1 & 1 & $\stackrel{5}{-9}_{3}$ & $\begin{array}{l}\Rightarrow \\
\qquad S^{H}\end{array}$ \\
\hline$\vec{\omega}$ & $\rightarrow$ & $\Leftrightarrow$ & in & $\vec{\infty}$ & Gr & $\overrightarrow{\text { जे }}$ & G & G & G & 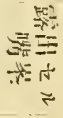 \\
\hline हं & $=$ & $\Rightarrow$ & $\overline{\text { जे }}$ & एं & 宊 & $\vec{N}$ & \# & ప & ज㯊 & $\begin{array}{l}\Rightarrow \vec{p} \\
\Rightarrow> \\
\Rightarrow x\end{array}$ \\
\hline$\underset{\text { er }}{\overrightarrow{\vec{b}}}$ & $\overline{\bar{N}}$ & 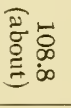 & $\overrightarrow{0}$ & 胥完 & อे & $\overline{0}$ & $\overrightarrow{\vec{N}}$ & 호 & $\overrightarrow{\vec{\omega}} \bar{\Xi}$ & 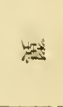 \\
\hline $\mathbb{\infty}_{\infty}$ & G & N & or & जু & 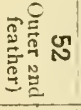 & $\stackrel{\vec{E}}{\stackrel{\vec{E}}{\xi}}$ & $\stackrel{\vec{\Xi}}{\Xi}$ & $\stackrel{\vec{\Xi}}{\stackrel{\Xi}{\rightleftarrows}}$ & भु & $\bar{\pi}$ \\
\hline$\bullet$ & ᄒ & $\boldsymbol{\omega}$ & 0 & $\stackrel{\infty}{\dot{\sigma}}$ & or & $\bullet$ & 0 & $\infty$ & $\begin{array}{r}\overrightarrow{0}_{z} \\
\underline{\Xi}\end{array}$ & $\begin{array}{l}\leftrightarrows \\
\leftrightarrows \\
5\end{array}$ \\
\hline $\begin{array}{l}\leftrightarrow \\
\ddot{0}\end{array}$ & to & to & $\begin{array}{l}0 \\
\ddot{0}\end{array}$ & 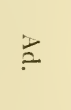 & $\begin{array}{l}\rightarrow \\
\stackrel{2}{2}\end{array}$ & $\begin{array}{l}\text { to } \\
\ddot{\vec{\theta}}\end{array}$ & $\begin{array}{l}\text { to } \\
\triangleq\end{array}$ & $\begin{array}{l}\stackrel{\leftrightarrow}{2} \\
\stackrel{2}{2}\end{array}$ & $\begin{array}{l}\leftrightarrow \\
\stackrel{2}{2}\end{array}$ & 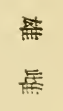 \\
\hline : & : & : & : & : & : & : & : & : & $\begin{array}{l}\text { E } \\
\equiv\end{array}$ & $\begin{array}{l}\text { 竧 } \\
\text { du }\end{array}$ \\
\hline
\end{tabular}




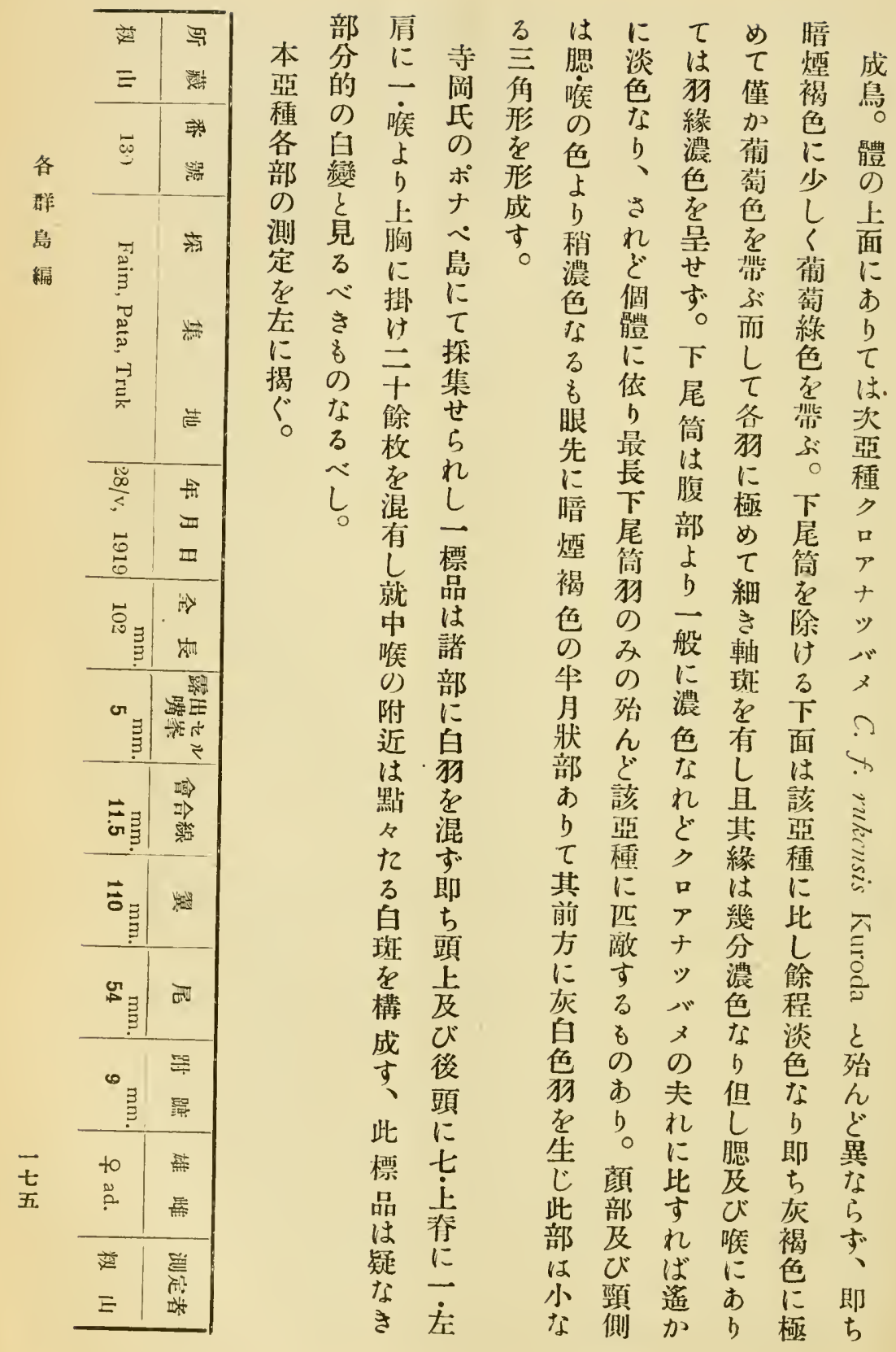




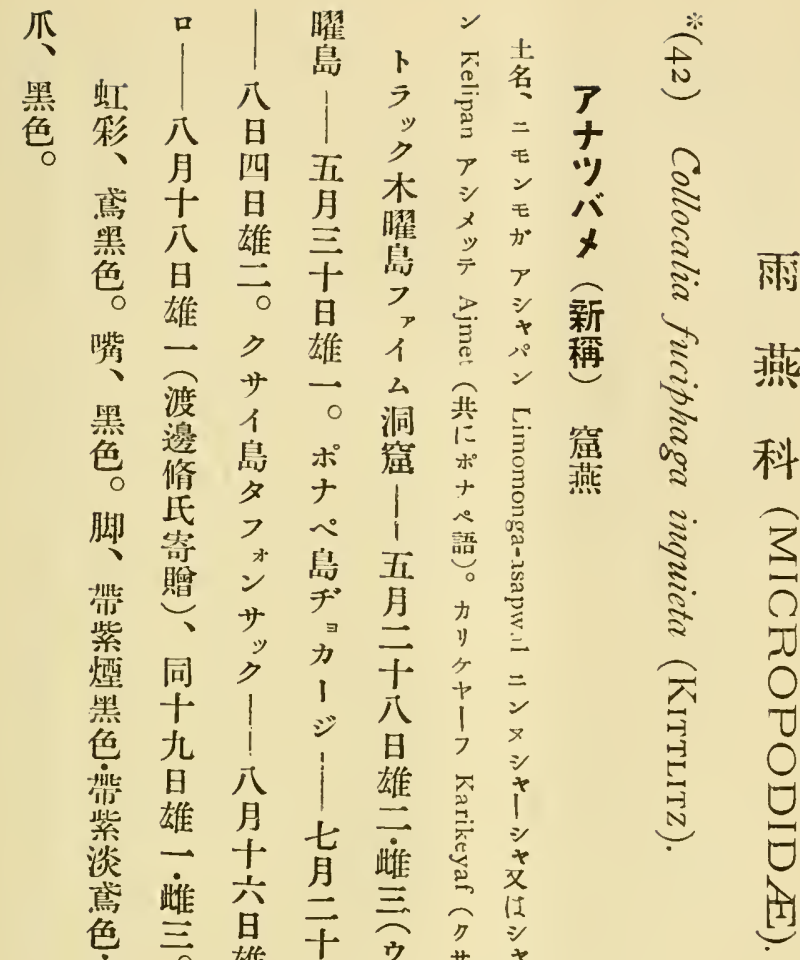

地

附 該

近䜿

には

$\tau$ 書

は間各

葆睡群

間突島

其雨編

模

装㯟

をに

聞

々 備

事榢

あ の

b 䳽

而 舍

L 附

$\tau$ 近

此に

穆 飛

は來

鼠 せ

を る

好斿

食の

すな

る る

ह 由

雛岛

に 民

被に

管 依

あ 几

り ば

ᄂ

老 ト 七

諟的四

5 基

す。他

$\varepsilon$ J 


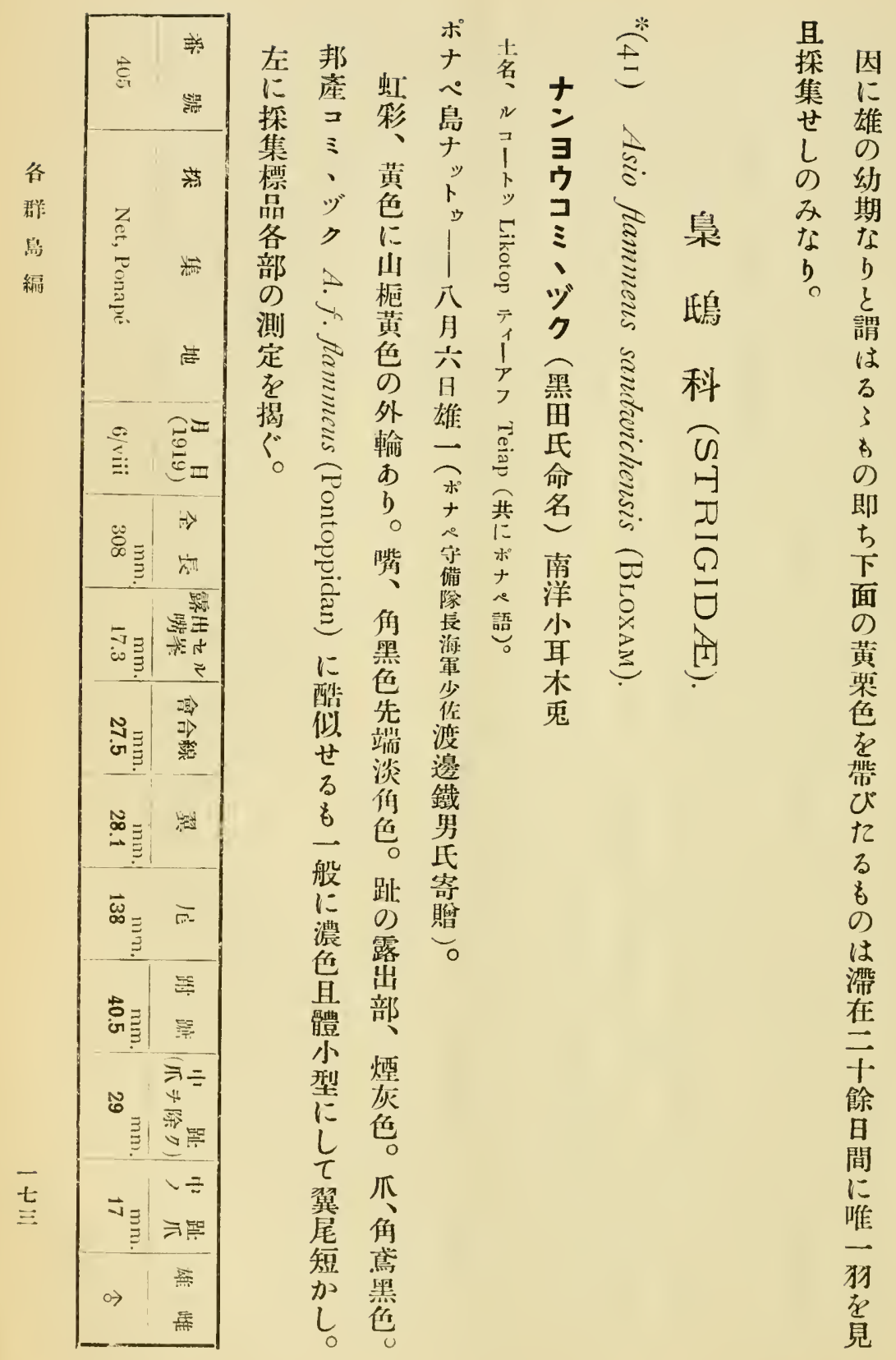




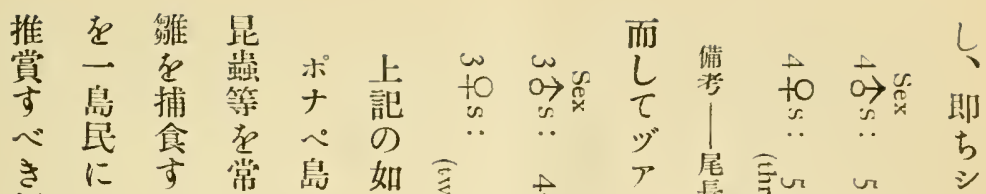

價依る 食內

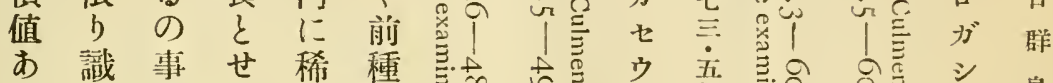

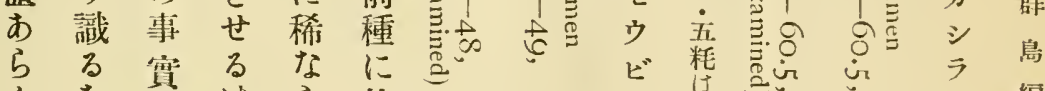

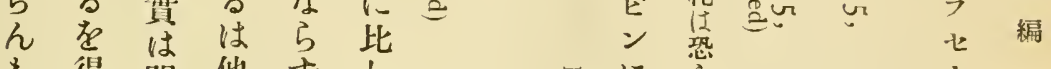
当得聞他声し 倘け加の 多各 其 り ざ近方 部 度該き種中程 は蟲佾にに短 来誃此同見小

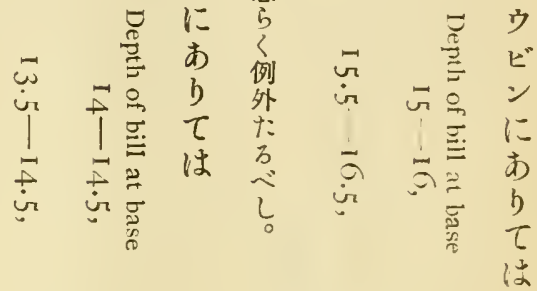
數食 は、處特

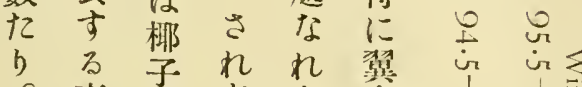

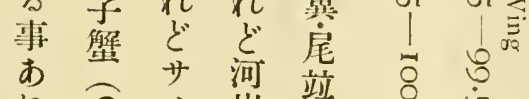
れ 1 岸前 ばるパ若嘴 此五ンく留 種壱岛は長 が 它に農 さ

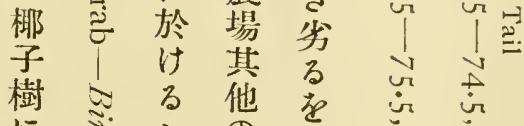

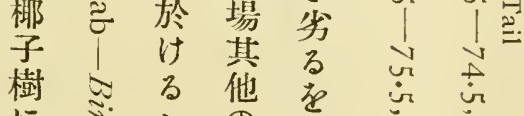

に

對灾品平

しの ガ 地 制

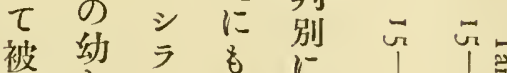

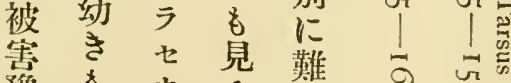

豫

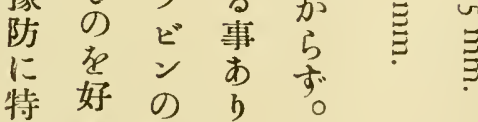

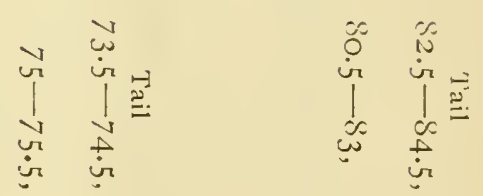

効 全 如、

あ す く 蚚

るるに蝎

や由鷄類 


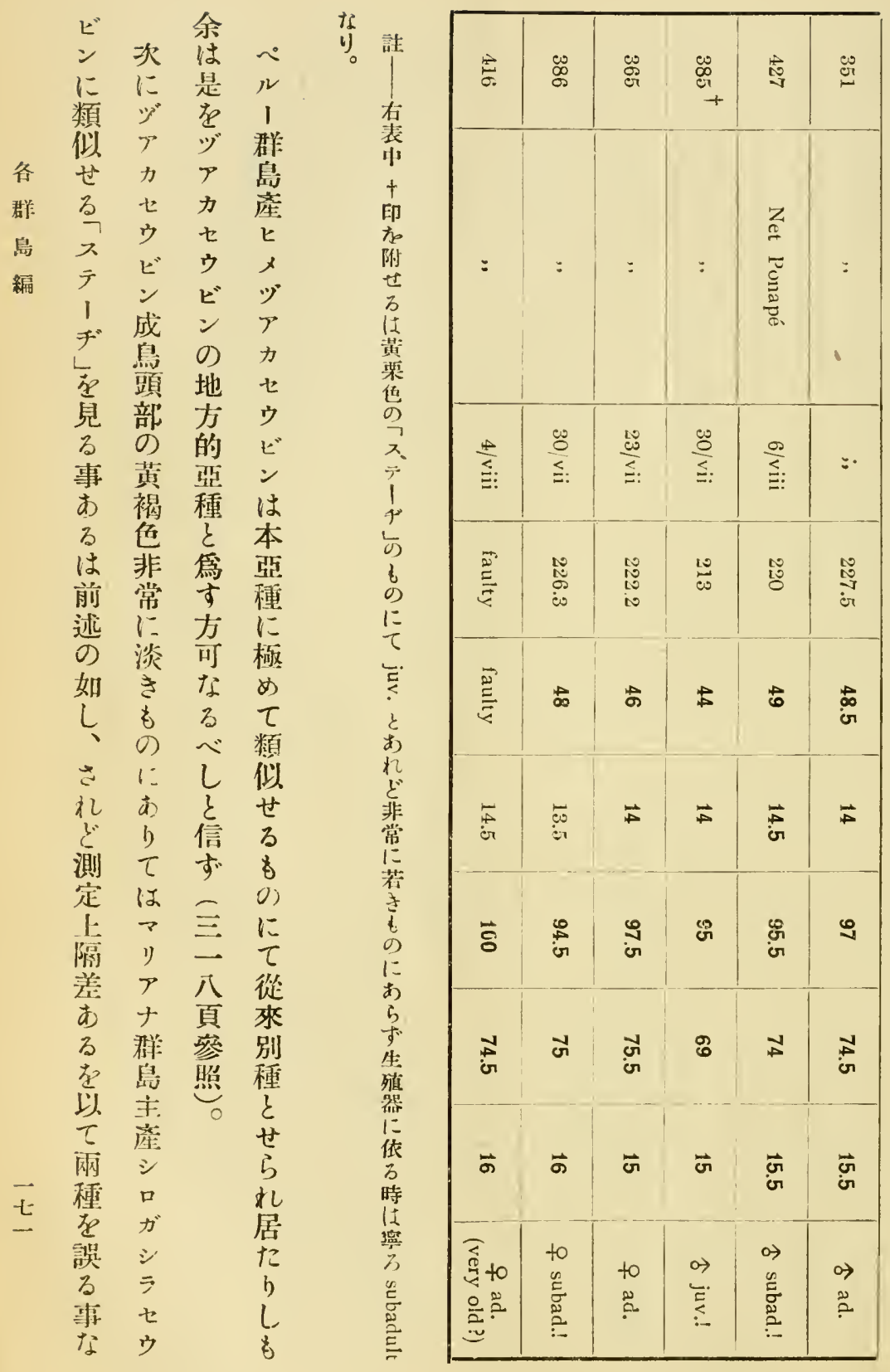




\begin{tabular}{|c|c|}
\hline i̊g & 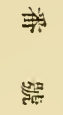 \\
\hline 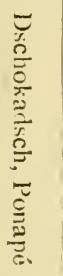 & 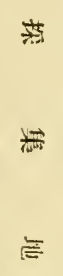 \\
\hline$\frac{10}{30}$ & $\frac{c}{\frac{c}{c}}=$ \\
\hline$\stackrel{10}{\Xi}$ & $\begin{array}{l}\rightarrow \\
\frac{1}{n m_{2}}\end{array}$ \\
\hline$\stackrel{\infty}{\sigma}$ & $\begin{array}{l}\text { 佘 } \\
\text { 标 }\end{array}$ \\
\hline$\vec{E}$ & 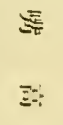 \\
\hline $\begin{array}{l}\mathscr{E} \\
\text { ज. }\end{array}$ & 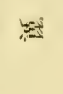 \\
\hline $\begin{array}{l}\omega \\
\omega \\
\text { जै }\end{array}$ & $\bar{\sigma}=$ \\
\hline ज़ & $\begin{array}{l}5 \\
5 \\
5\end{array}$ \\
\hline $\begin{array}{l}\stackrel{\rightarrow}{0} \\
ٍ\end{array}$ & 弄 \\
\hline
\end{tabular}

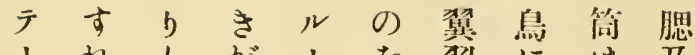

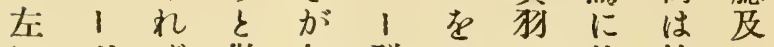
にデば做如群さに比餘び

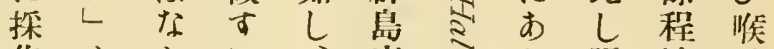
集をbに、產念り暗淡は 槽は、は依七空色色擬 品見如倘てメきたな白

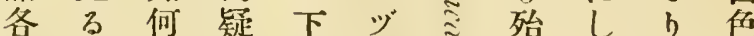

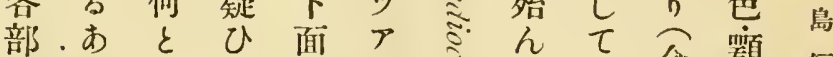
のたな的な旗

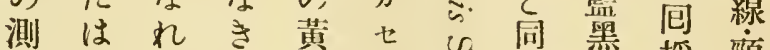

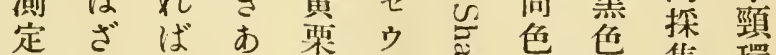
をる他て色ビ恕心に雀環

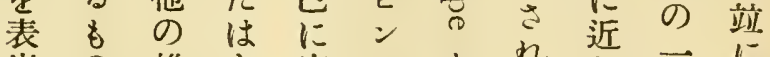

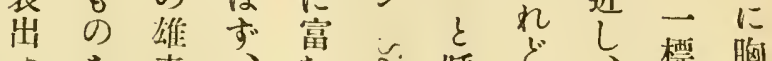

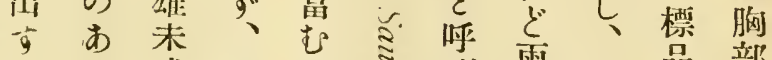
ヘ る 成即事壱ば雨さ品部

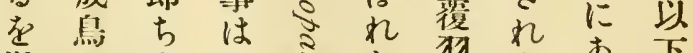

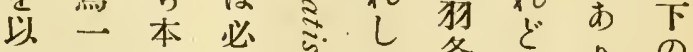

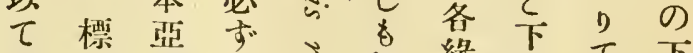

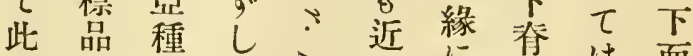
一に焳名ミく革腰朐面

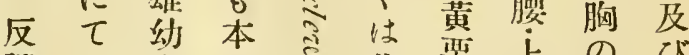
證は期 亞ミ此染上のび

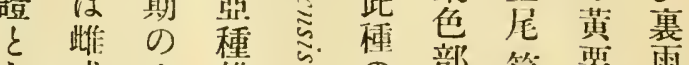
な成 及雄 $の$ 部简萊雨 す点に牥 雄

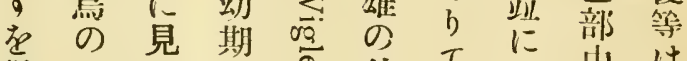

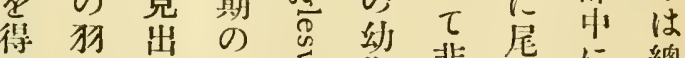

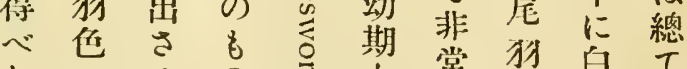

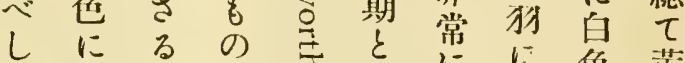

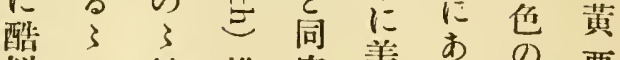
似一總 雄定美少の栗 し種て 牥せ 黄のが期ら方蛙手点

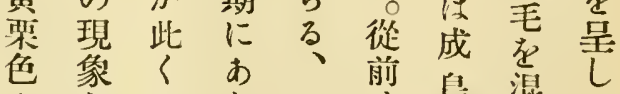

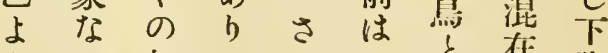
bる 如てれ加要在腹 進がきは岕 み如任加近る 七く柇了似色點上及 るに起惡彩點䄃ひ ᄀ想呈事種ひ市な

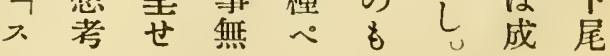




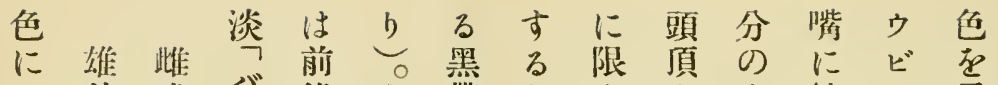

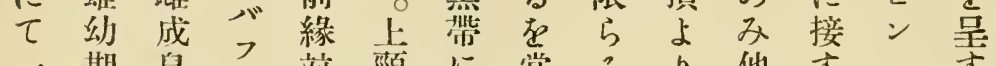
一期鳥

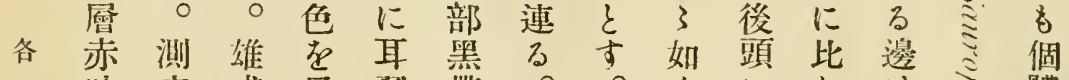
群味定成呈旸乖。軆

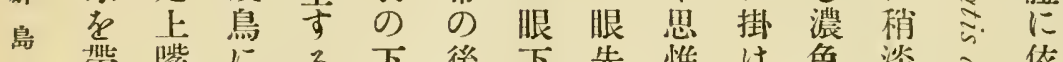

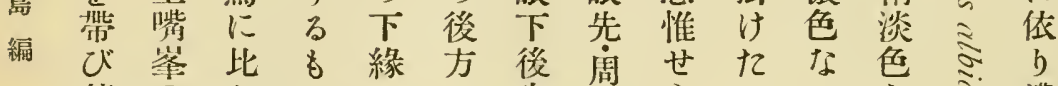

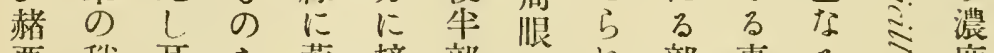
栗秒耳更接部部れ部事る度 色短狗り褐しに吕て分古在在

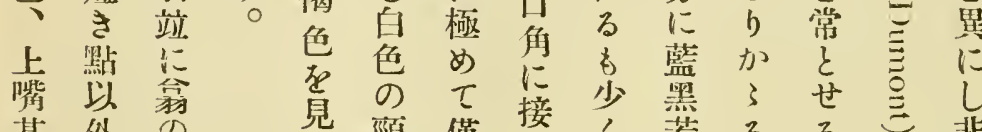
基 外 $\sigma$

部に色 上大稍 り 差 暗 後な綠

颚きに

にを富

到色 め

る 彩る

部はの

分大み

にに。

は 相

藍 違

墨

の 見

軸別

斑 種

を の

尠 感

か あ

5 b

亲吉 即

艽混 万

在 頭

せ 部

$\begin{array}{ll}\text { b } & \text { は } \\ \text { 濃 }\end{array}$

己 頸僅 接

事環が

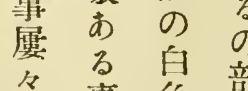

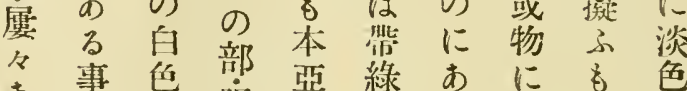

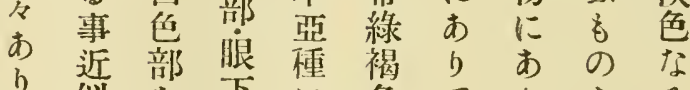

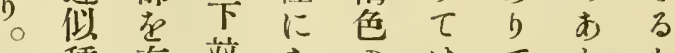

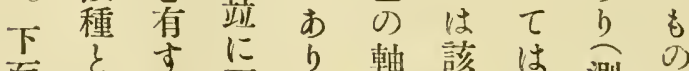

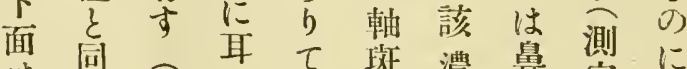

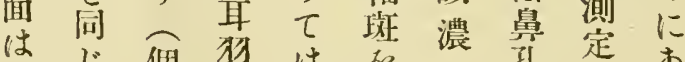
總し個旸は尼色孔走才

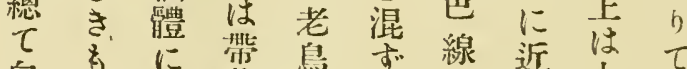

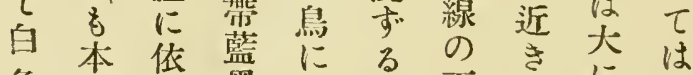
色種嚜あ事下部に? 小殆色占市部異り れあんにざ

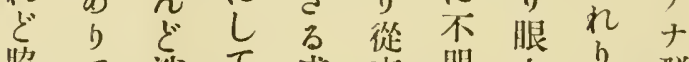
脇 $\tau$ 渻 $\tau$ 成來朋上

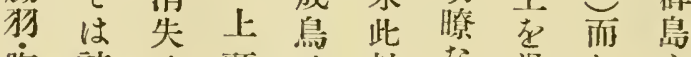
腹該せ㶪は軸な過し主 侧頸るの嚾斑るぎて産 若環か黄小存眉寽此の 〈中褐つ混線後黄 シ はの如色了吉在方裪口 兼前き，後是る構に色ガ 雨緣を部をは成到部シ 蕧若のに殘幼吉了は亏 の々 


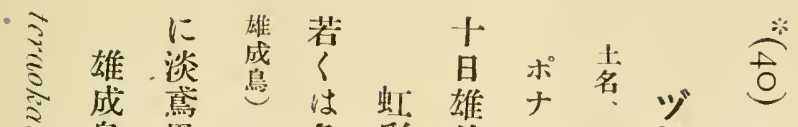

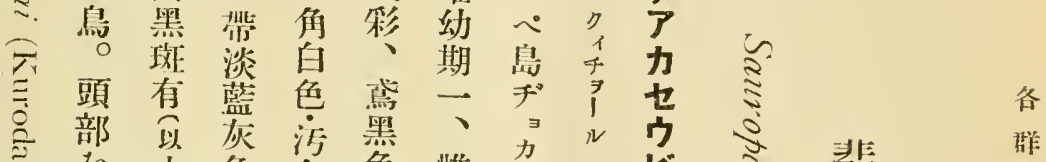

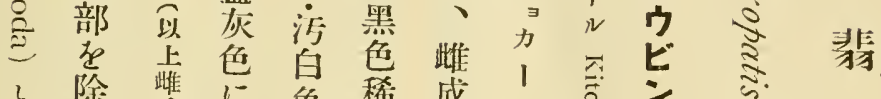

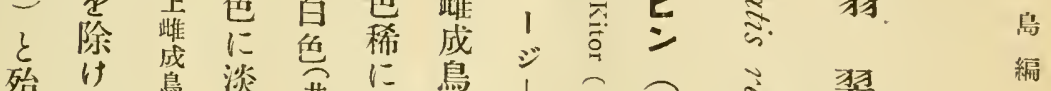

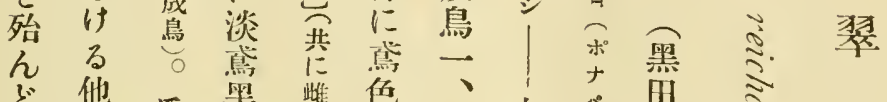

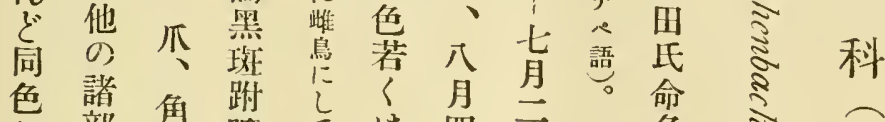

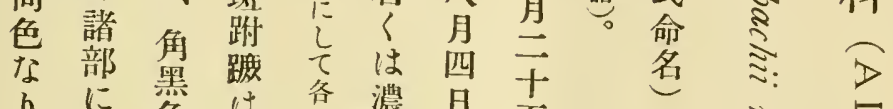

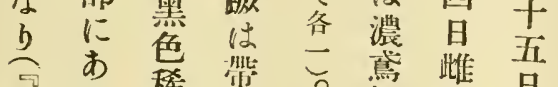

第快角筍脚色鼠堆

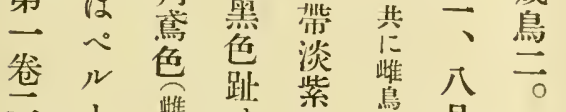

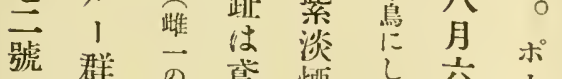

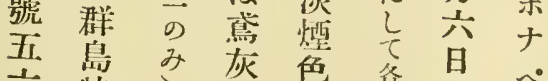

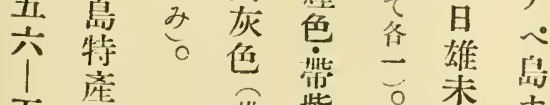

頭 今.

帟藋田

翠

五な

八る

頁 天

犬

正 7

四力

年 セ

$\checkmark$ ウ

頭 ビ

頂

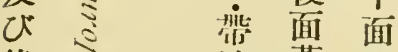

後淡黄 の

頭 紫肉み

はミ石色肉

黄豆板正白

褐施

色占色 


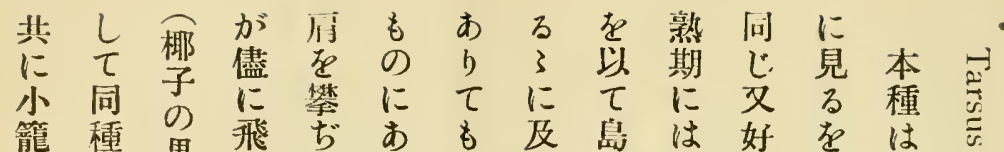

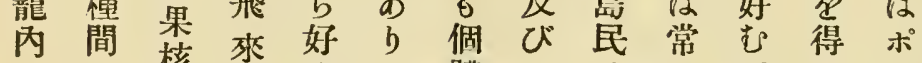

各にに核すめ體てはにで心゙ナ

群飼 あ 及るるはに籠高該楖くへ

鳥養りは等人饲依よき樹子極以文

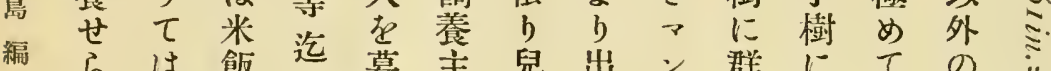

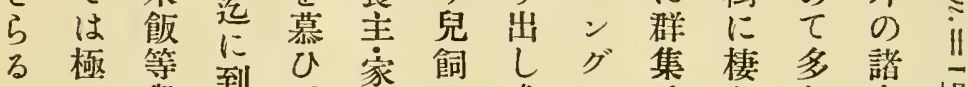

了め興到家暨或口婪多諸茕

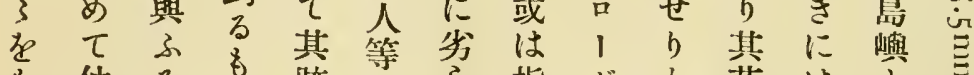

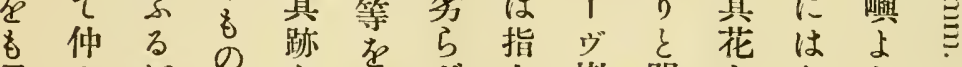

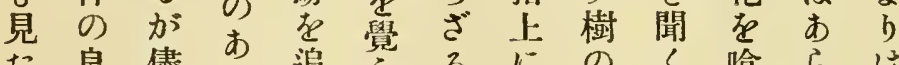

た良儘古追豭るにのく喰らは

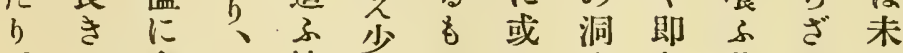

も食飼等數の恃內ち蓋れだ

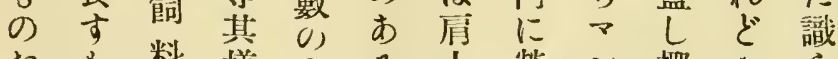

た料樣人弓上營

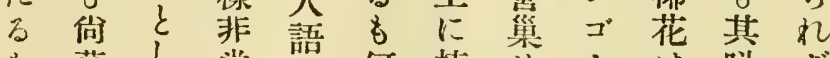

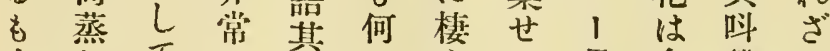

小してに他れらる果多䠛る

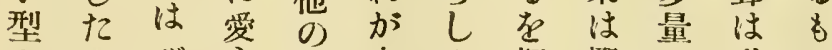

のる心゙ら物良め探楖の殆の

鳩甘妾し直好愛知花花九な

類藷さく其な玩し蜜蜜どる

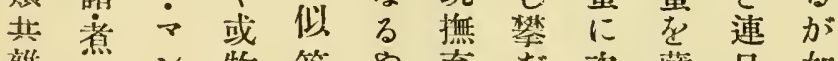

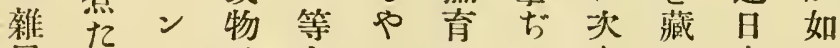

居飼

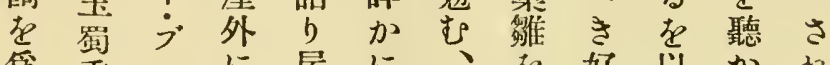

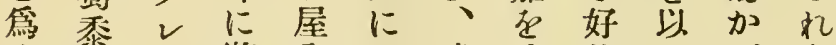

す等 娄遊内成生物てざど

をにド飛に省熟掘々なる該

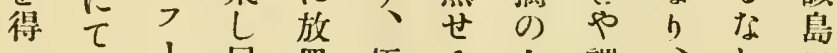

心゙!居置極る卡謂、しに

く飼等り

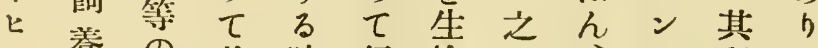

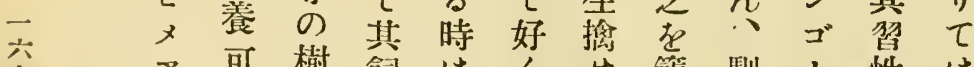

$>$ 可樹飼はく世篰馿、性は

$\exists$ 能果主廊, 潟し 飼致樹近常

バなコのをれ るしし果似に

卜b プ呼步け白其易の類各

と而ラぶしるに㖪さ成に所。 


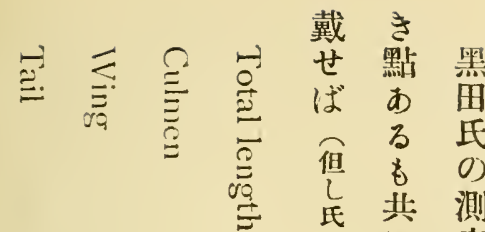

世 $0 \%$ \%

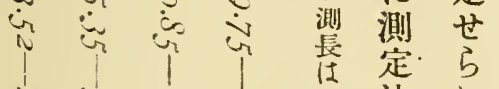

$\therefore \quad 0$ 留 法狄

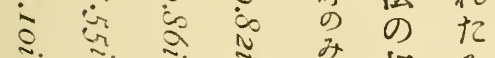

ミ ミ ※ み 相る

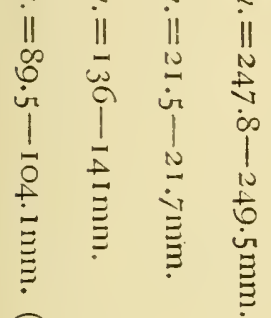

¿

迨 ह

にの

起 合

可動

万 學

な 雜

べ 誌

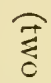

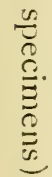

\begin{tabular}{|c|c|c|c|c|}
\hline$\underset{\omega}{\stackrel{\overbrace{}}{\omega}}$ & 尺̊요 & $\begin{array}{c}\text { है } \\
1\end{array}$ & त्ञ & 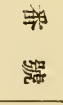 \\
\hline 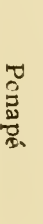 & $=$ & $=$ & 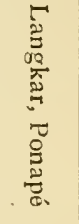 & 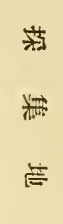 \\
\hline $1^{\circ}$ & $\begin{array}{l}\frac{10}{1} \\
\frac{1}{5} \\
\vdots\end{array}$ & : & $\frac{10}{5}$ & 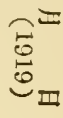 \\
\hline $\begin{array}{l}\overrightarrow{0} \\
\stackrel{0}{c} \\
\text { co }\end{array}$ & $\stackrel{10}{E}$ & 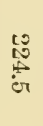 & $\stackrel{100}{8}$ & $\begin{array}{l}4 \\
\text { Hin }\end{array}$ \\
\hline$\vec{\infty}$ & $\begin{array}{l}\vec{\infty} \\
\dot{0}\end{array}$ & वै & के & 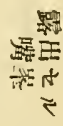 \\
\hline $\begin{array}{l}\hookleftarrow \\
\infty \\
\infty\end{array}$ & $\begin{array}{l}\vec{T} \\
\dot{\omega}\end{array}$ & $\stackrel{\vec{\infty}}{\vec{s}}$ & $\begin{array}{l}5 \\
\text { iv } 3\end{array}$ & 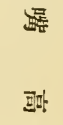 \\
\hline के & $\begin{array}{l}\vec{G} \\
\text { ज }\end{array}$ & $\vec{\infty}$ & $\bar{\sigma}^{3}$ & 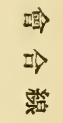 \\
\hline $\begin{array}{l}\vec{N} \\
\text { ov }\end{array}$ & $\begin{array}{l}\vec{\omega} \\
\dot{G}\end{array}$ & 虫 & $\stackrel{\omega}{\omega}^{\vec{\omega}_{3}}$ & 龄 \\
\hline ज़ & $\begin{array}{l}\mathscr{G} \\
\dot{G}\end{array}$ & $\vec{\infty}$ & 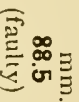 & ता \\
\hline$\vec{\omega}$ & ज़ & $\vec{v}$ & कै & 籍 \\
\hline ᄋ & $\begin{array}{l}\text { to } \\
2 \\
2\end{array}$ & $\begin{array}{l}\text { ?े } \\
\text { ?ैं }\end{array}$ & $\begin{array}{l}\text { to } \\
\stackrel{2}{?}\end{array}$ & 要 \\
\hline
\end{tabular}




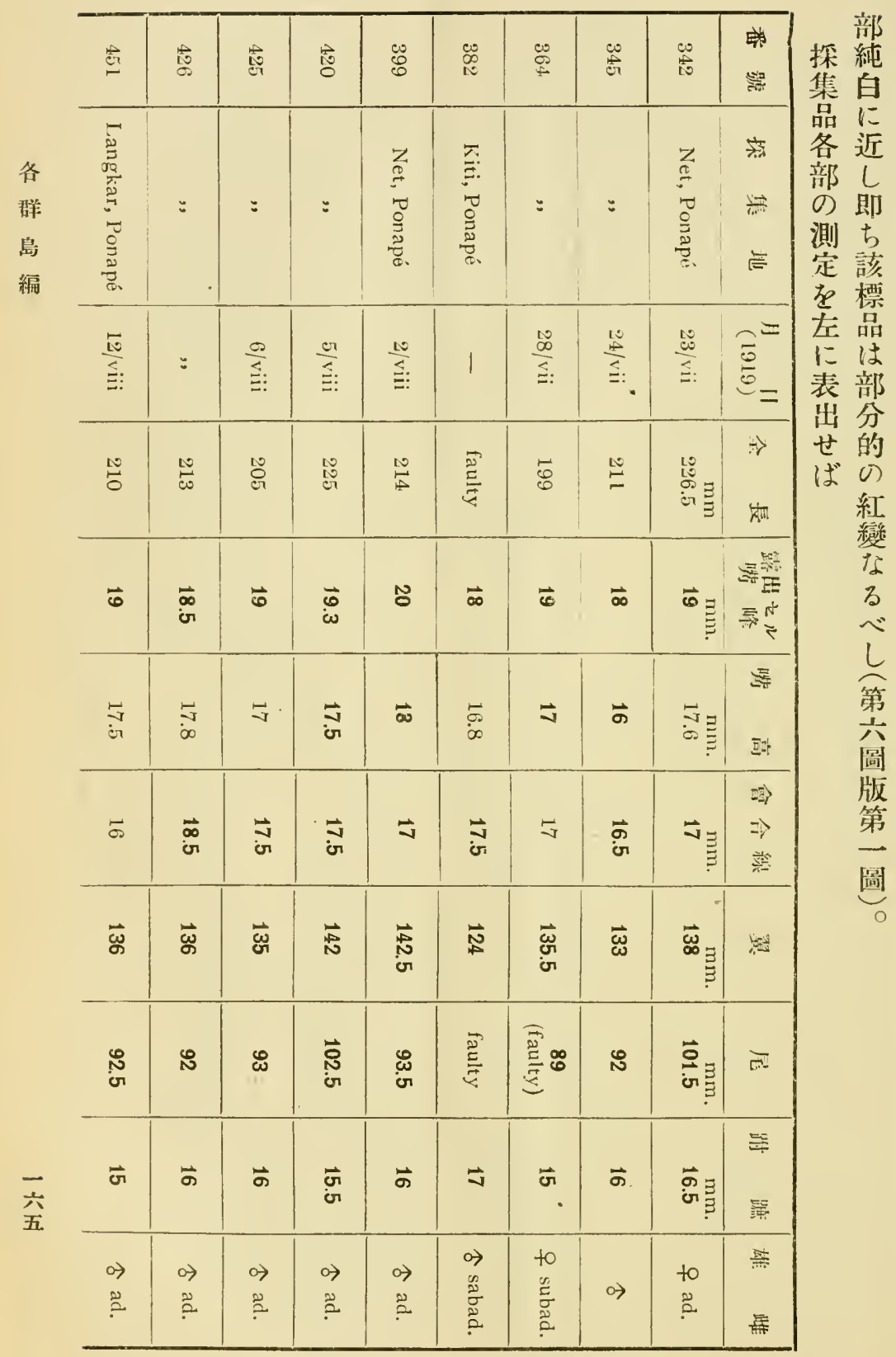


に帶 橙三帶年黑帶 赤

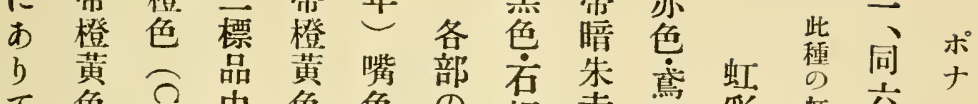

七色 中色色の板赤褐彩虹六。

は幼吉带にの色黑色色点等昆島

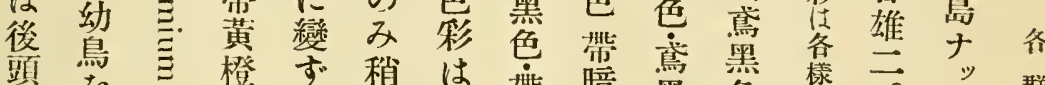

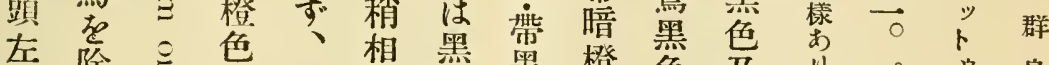

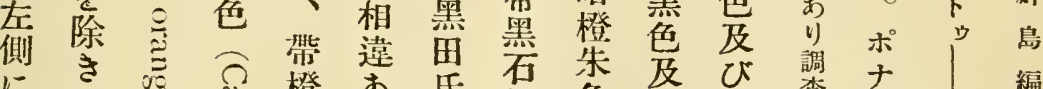

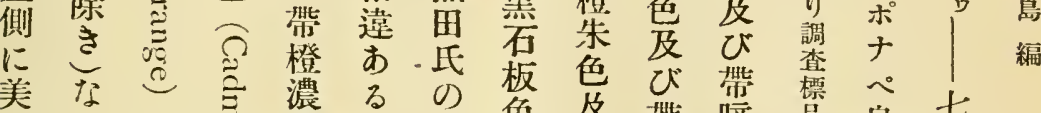

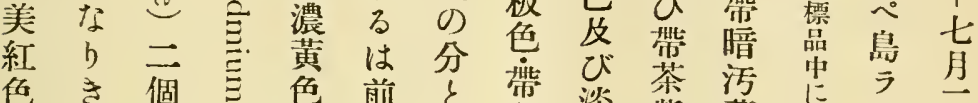

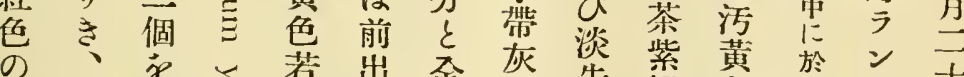

二次檢气若出至黑朱 褐色管 ガ士

狗に出五は如二色赤色後同 1 豆

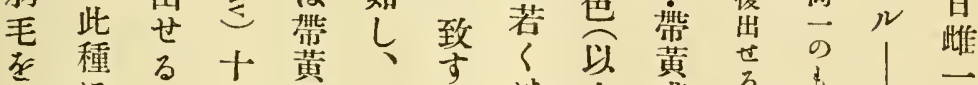

生にの個橙而るは上晸

せ はみ色しを帶此褐吉㱠八同

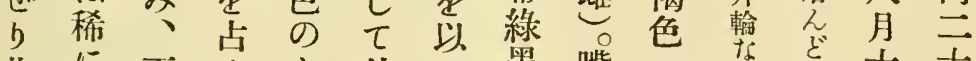

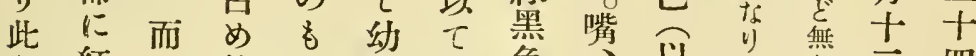

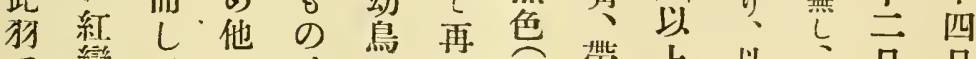

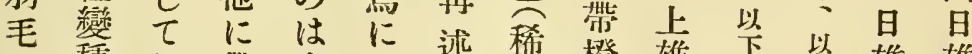

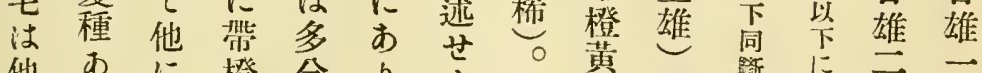

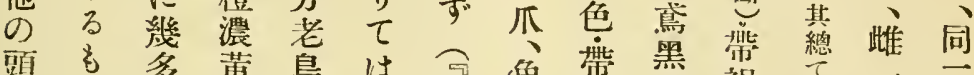

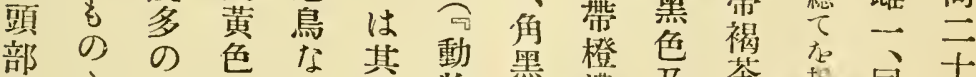

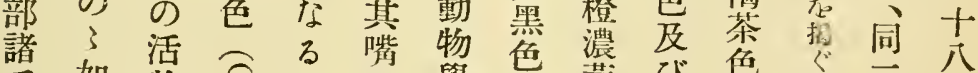

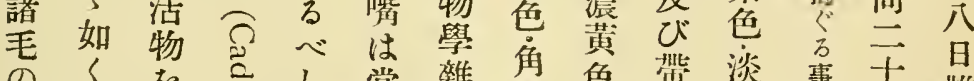

のくを主し常雜角色带淡事士 雌

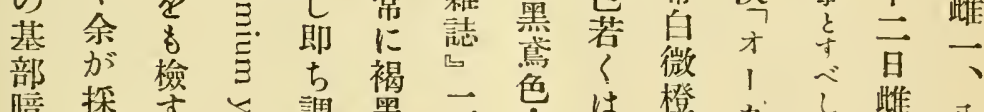

暗探梦它調黑二色は橙刃 し 雌八

烣集方

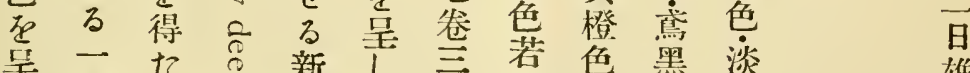

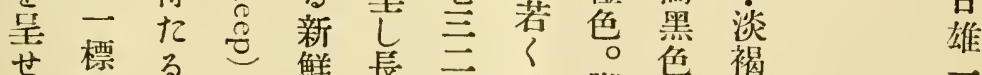

る 標る゙

に其個る る 頁石光び色

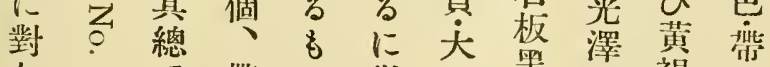

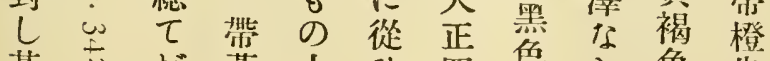

基志が黄十苗色き色来

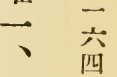

同

五 

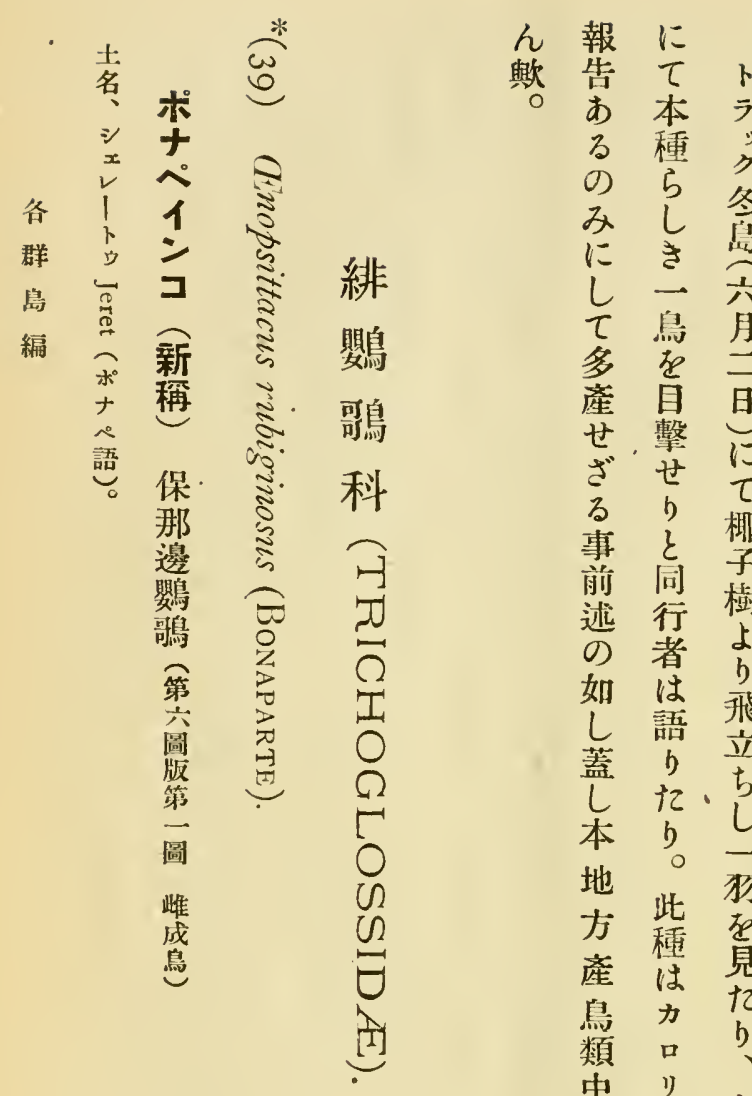

\begin{tabular}{|c|c|c|}
\hline \multicolumn{2}{|c|}{ 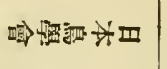 } & 舆 \\
\hline 恳 & & 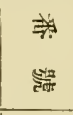 \\
\hline 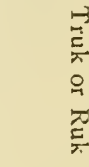 & & $\begin{array}{l}\text { 荡 } \\
y \\
y\end{array}$ \\
\hline $\begin{array}{l}\frac{\sigma}{<} \\
\text { है } \\
\text { है }\end{array}$ & & $\underset{\text { III }}{=}$ \\
\hline$\dot{\dot{s}} \overrightarrow{.}$ & बू. & 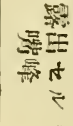 \\
\hline$\stackrel{5}{5}$ & $\underbrace{\omega}_{\text {ن }}$ & $\begin{array}{l}\Rightarrow \\
\Rightarrow \\
\Rightarrow \\
y\end{array}$ \\
\hline$\ddot{H}$ & ${ }^{\infty} \underset{\Xi}{\Xi}$ & $b=$ \\
\hline$\stackrel{s}{i}$ & $\begin{array}{l}\stackrel{N}{\mathrm{~N}} \\
\text { G }\end{array}$ & 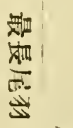 \\
\hline$\vec{b}$ & $\begin{array}{l}\vec{\omega} \\
\text { जा } \\
\vdots\end{array}$ & 沗 \\
\hline$\stackrel{+}{\mathcal{H}} \equiv$ & $\stackrel{\omega_{3}}{3}$ & 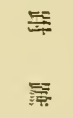 \\
\hline$\rightarrow$ & & $\begin{array}{l}\text { 箖 } \\
\text { 点 }\end{array}$ \\
\hline 诺 & & $\begin{array}{l}\text { 总 } \\
\text { 的 } \\
\text { du }\end{array}$ \\
\hline
\end{tabular}


す褐り腹なお明到て斑切

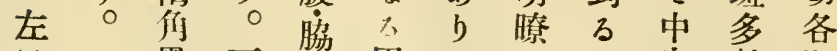
に黑下立眉てなに央數狗 各色尾汇線はb從尾をは 部、筒腿站殆正 $\tau$ 狗有先 の下狗のにん不にし端各

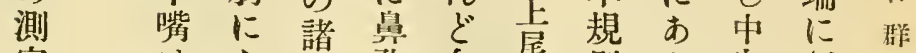
定は中 部孔泉筒則 b莫新帛

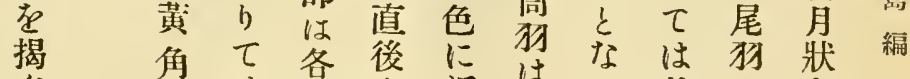
ぐ色は旸近は其其の白

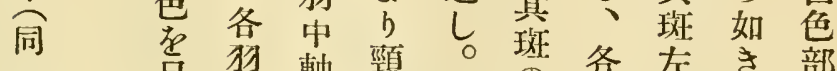

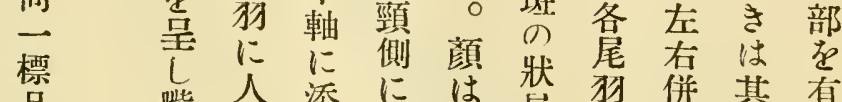
品嘴人添に衤尾旸併其有

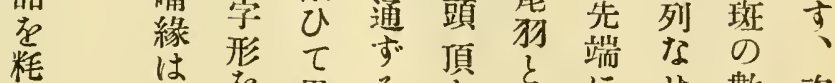

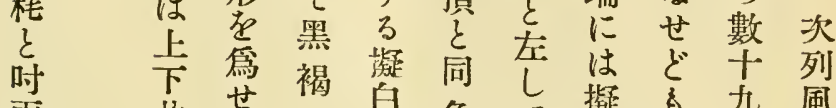
雨共色色色七擬名九風 樣治黑黑色に異泉外声切 に蠟黑縱䫅しな色侧算赔

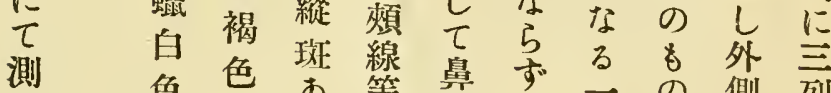
れ色斑 क等但二の 側

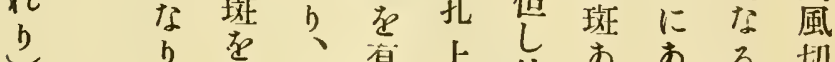

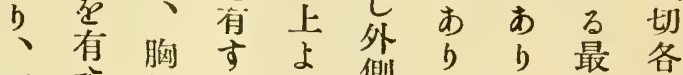

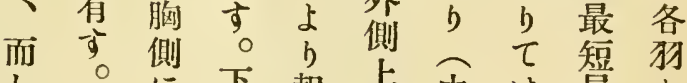
て 乾あ面起虐中は尾す 脚き

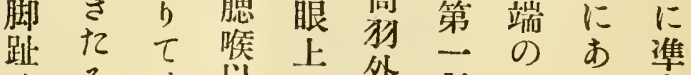

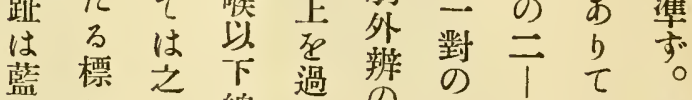
黑品占總感斑

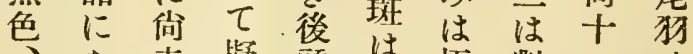
क赤擬頭淡極對二は 爪夕錆泉に淡め生個雨

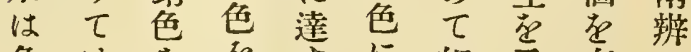

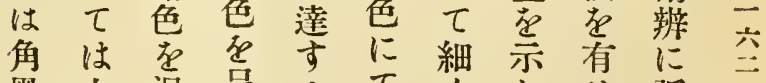
黑上混呈るて胧 色嘴吉” $L$ 擬或 $L$ 其 $b$ 形 をは胸白物て部而の 呈帶可侧色に不㳻儿横 


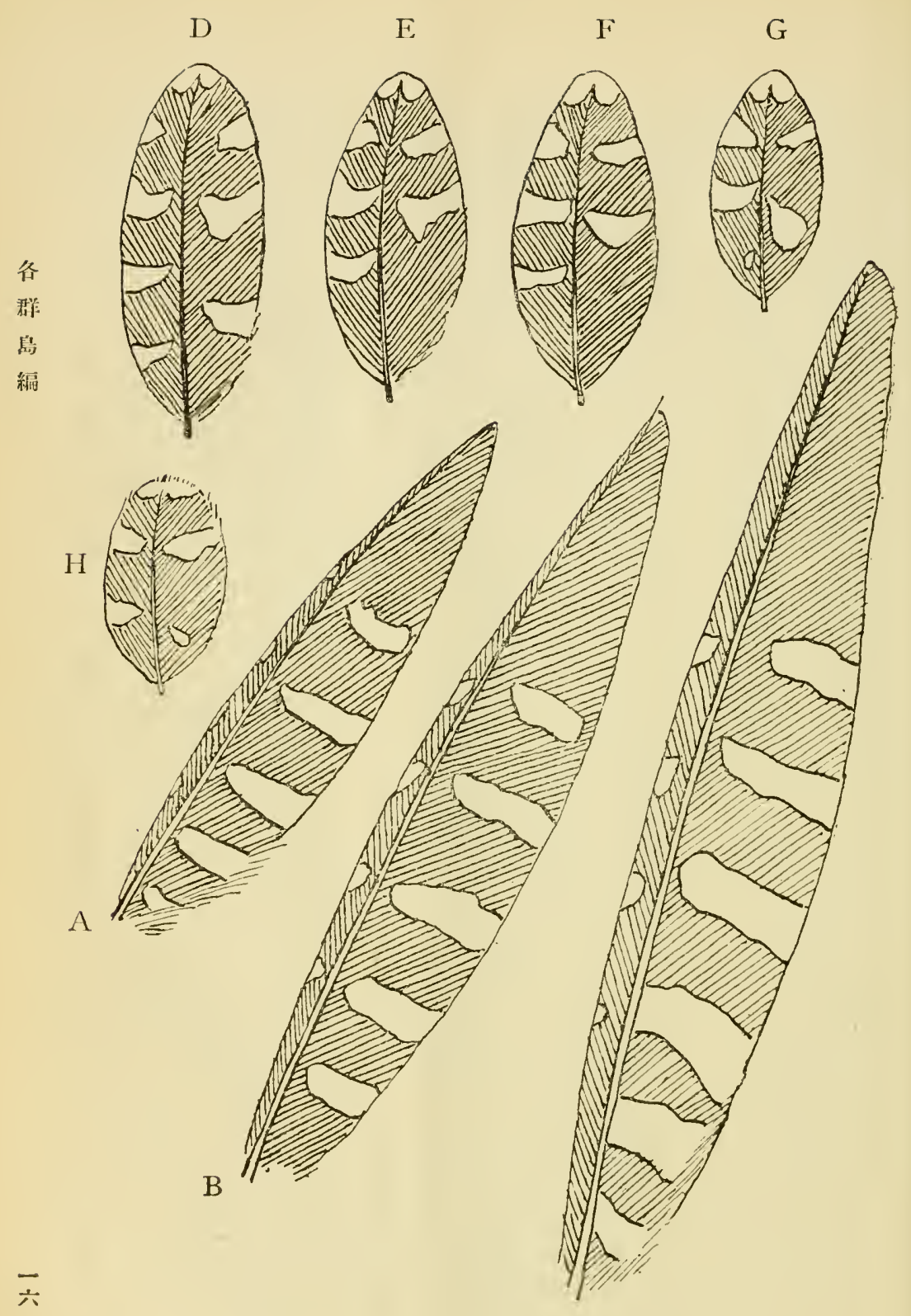

\section{'Text fig. $5 \quad \mathrm{C}$}

The spots on primaries and wing-coverts of Urodylnamis taiticnsis, subsp. from Truk (about $\frac{11}{12}$ nat. size) キジクックコウの翼狗站に雨㠅狗に於けっ坆紋

A. Ist outer-prim., B. 2nd outer-prim., C. 3rd outer-prim.,

D. Greater-coverts, E-F. Mediar-coverts, G-H. Lesser-coverts. 


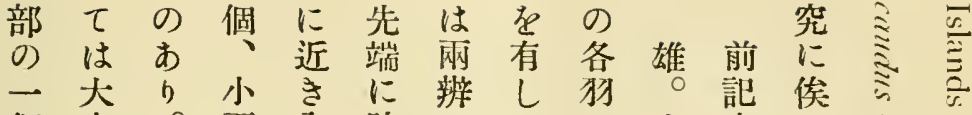

個坐。雨內跨に に上寺つ引中

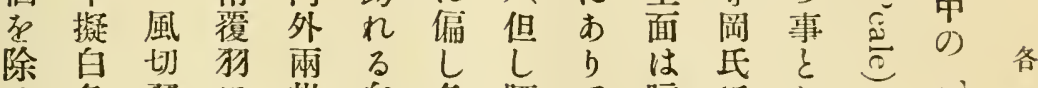

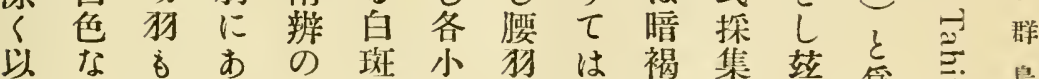

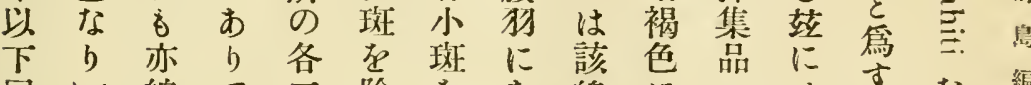

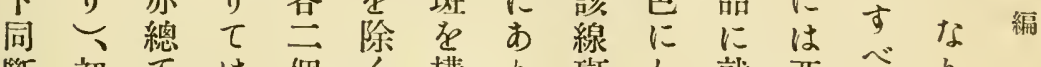

斷初て は個く構り斑し就亞べり

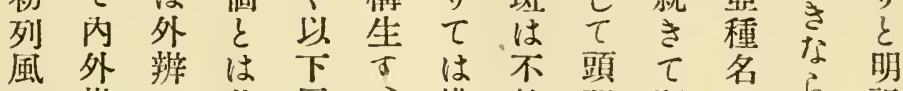

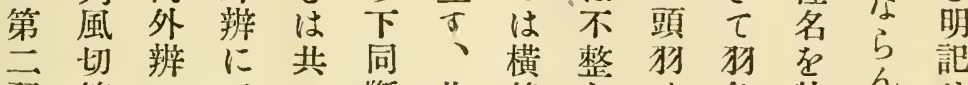

牙第に三に斷此線なは色特ん訑

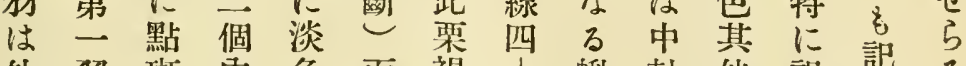

外狗斑內色而褐! 蚪軸他訅傤方

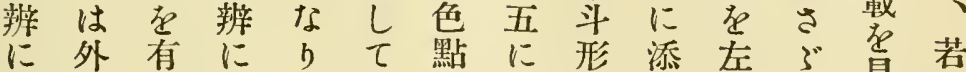

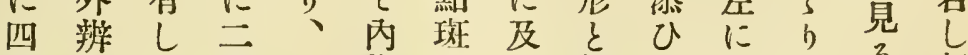

個に䧃中辨は篎栗詳き邦

内極此!雨基大褐述。得領

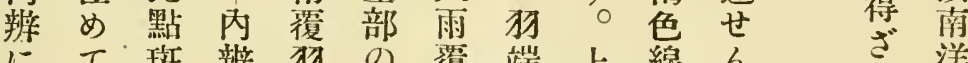

にて 斑辨旸の覆端上線ん

五不は基に一旸擬奉市に

個 明雨部 あ個に白以り

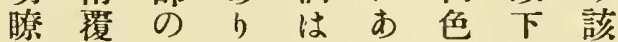

第な旸一兀殆

严るの個はん $\tau$ b 旸 斑

牙微专は外どは。には

以斑の不辨白外翼到末

下至に明に色辨のる端

は個比暸三同に雨各污

第若しな個じ四覆旸白

三人淡るく個狗は色

狗は色か甚中内に栗起

に四、又稀央辨市褐呈

同㑬內はにのにb色专

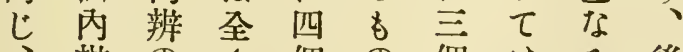

辨のく個の個はる後

內にも之端

侧四の在內に但々斑及

初個に缺辨最內此一匹

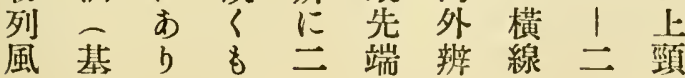

方產

क

以

$\tau$ の

決

基

क 型

た相

は違

守 क

即?

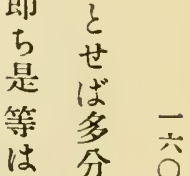

向

後引

䂰 


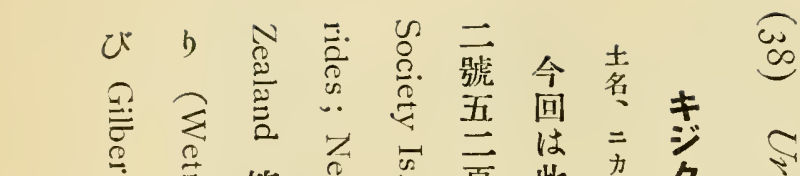

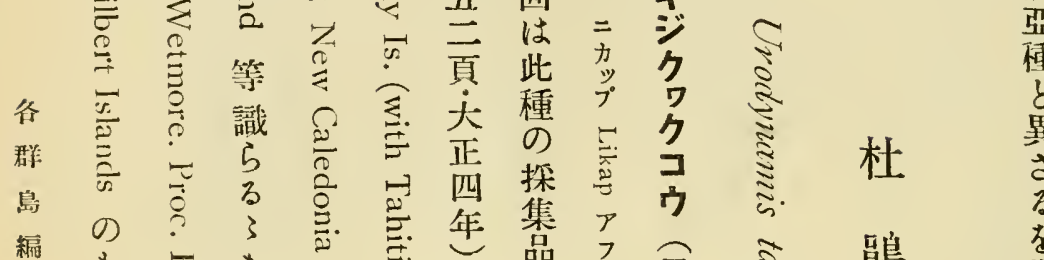

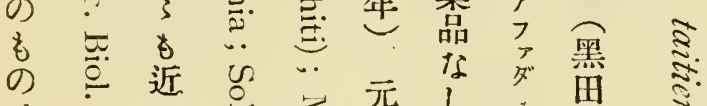

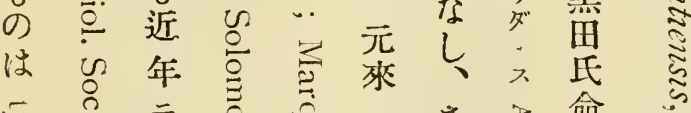

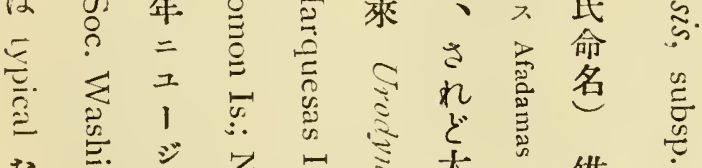

$$
\begin{aligned}
& \text { 小 }
\end{aligned}
$$

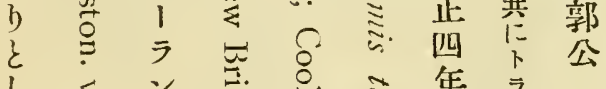

$$
\begin{aligned}
& \text { し } \\
& \therefore \quad y \quad \text { 産 } \\
& \text { - }
\end{aligned}
$$

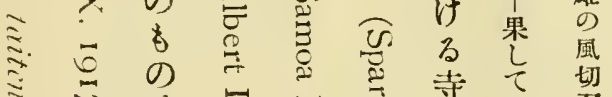

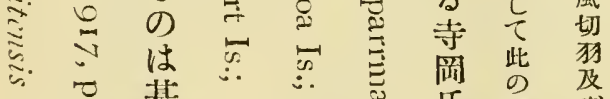

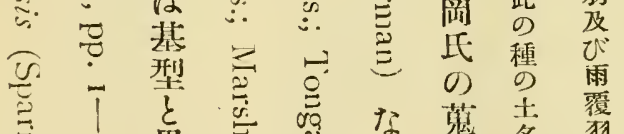

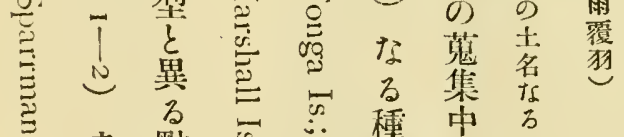

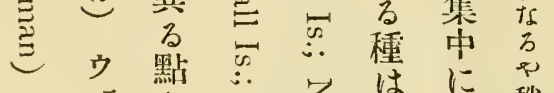

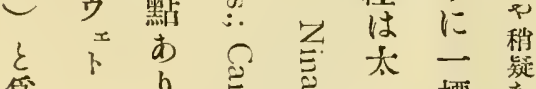

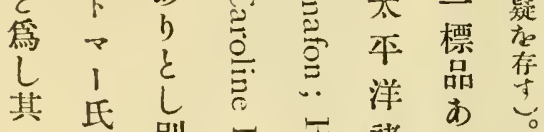

$$
\begin{aligned}
& \text { 基に別 }
\end{aligned}
$$

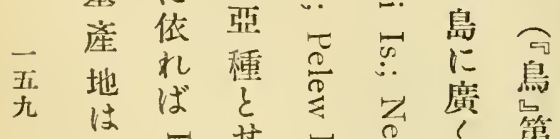

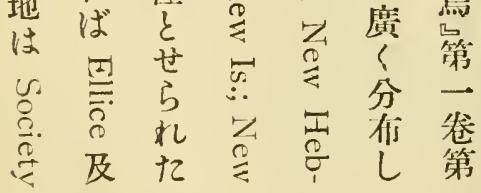


Birds of Micronesia. PI. VI.

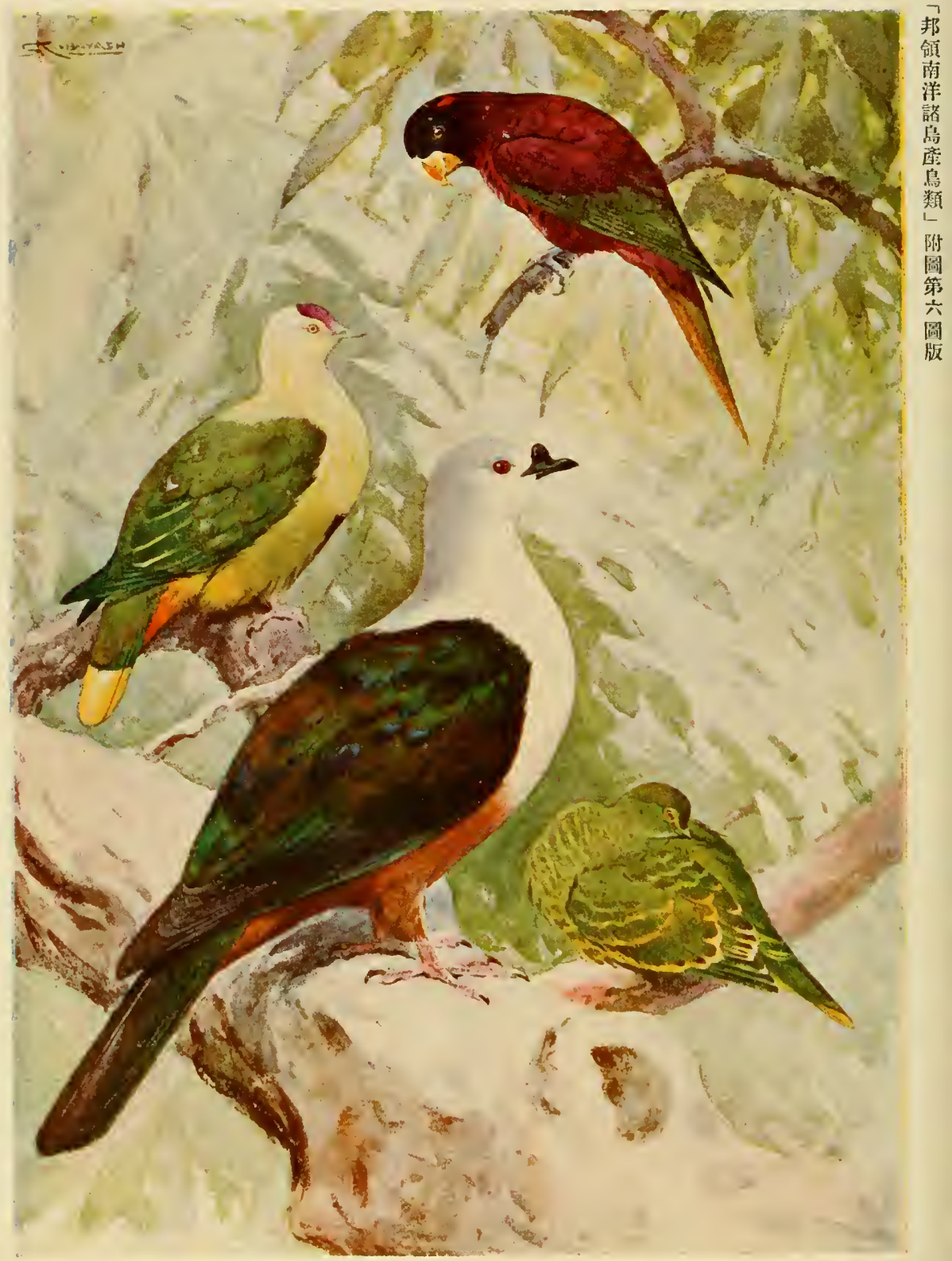



Birds of Miuronesia. Pl. VI.

$$
\begin{gathered}
\text { Eropsittacus rubiginosus: p. } 163 . \\
\text { ポナトイン }
\end{gathered}
$$

Fig. 1. 우 ad.

(A partial Rubious).

Ponapé I., Seniavina group. 23/vii, 19. (No. 342).

Ptilinopus p. ponapensis: p. 153.

$$
\text { 七 }>\neq \cdots+
$$

Fig. 2. 合 ad.

Tol I., Ruk group. 20/v. I9. (No. 69).

Globicera ocermica monacha: $\mathrm{PP}, \mathbf{I}_{4} 9 \& 4$ (Eng text).

$$
\text { ハイがシラコブパト }
$$

Fig. 3. 今 ad. (Type).

Yap I., Yap Is. $24 / \mathrm{v}$, 19. (No. 278).

Ptilinopus p. hermsheimi: p. 157.

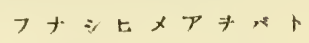

Fig. 4. 오 juv.

Kusaie I. r6/viii, 19. (No. 473). 


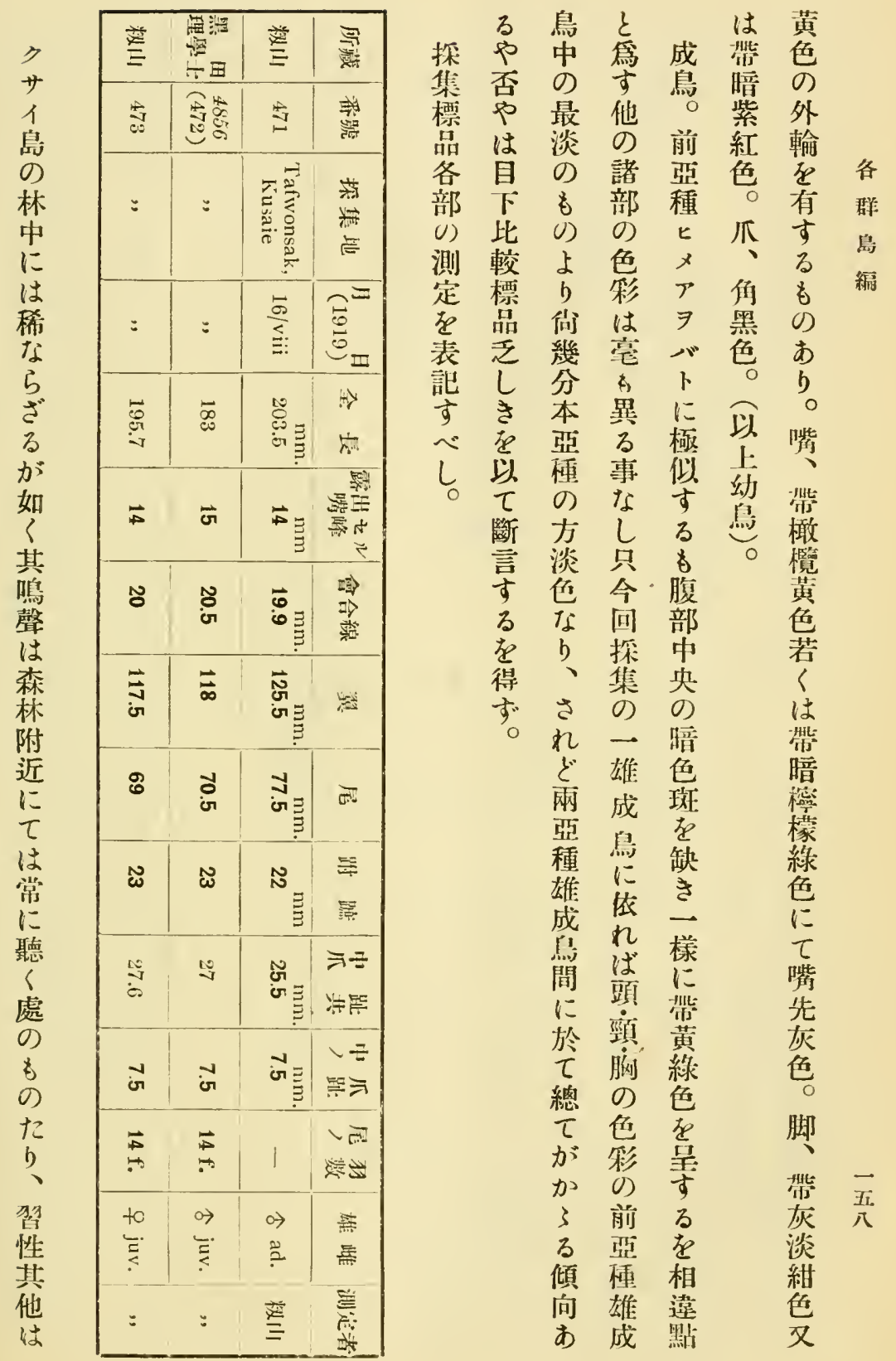




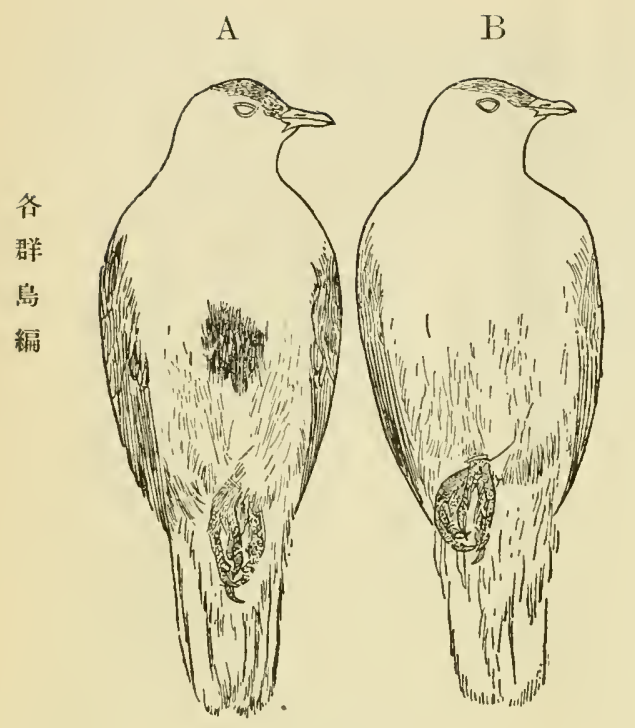

Text fig. 4

Two forms of Ptilinopus ponapensis, (about $\frac{1}{6}$ nat size).

カロリン群島產七メアキパト類 二亞福の腹面比輘

A. P. f. ponatensis, from Truk, No. $65, \hat{\text { ad. }}$ 鳥四

B. P. p. hernsheim, from Kusaie, No. $47 \mathrm{I}$, 今ad. 風圖

炏卡旸

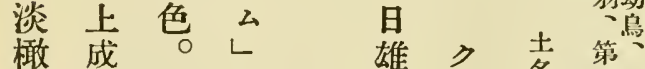

欖鳥脚黄虹成省名茴

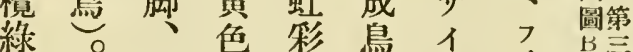

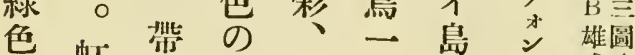

老蛅哣外帶、出、成A

呈彩紫輪活雄 7 鳥成

行

し 緂

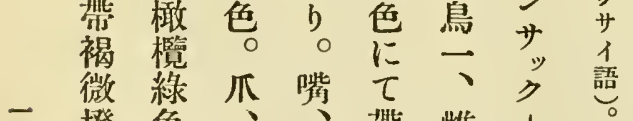

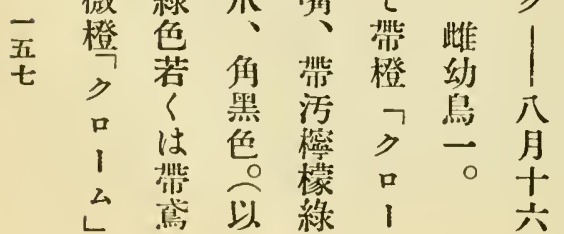

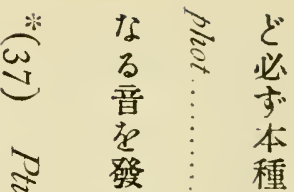

す : U

る $\vdots$ 嘿

- $\vdots$ 聲

鳴と蔦

獘 終 聞

にb<

あを事

万者

す。早 得

LV 0

$\tau$ 間 其

初苑鳴

列約 臀

風めは

切 長 優

第き雅

$\rightarrow \rightarrow$ -

狗 節

の

細了况

屠 嵒

夫繰

に尔

依し心

$\tau$ 鳴

此<

の 、

如 佾

き 飛

意 翔

時

出

出 ₹

12 5

他

小

5! ! 


\begin{tabular}{|c|c|c|c|c|c|c|c|c|c|}
\hline 窟 & $\underset{\infty}{\infty}$ & $\stackrel{\mathscr{d}}{\mathscr{U}}$ & 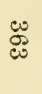 & 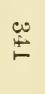 & $\begin{array}{l}\mathscr{0} \\
\end{array}$ & हี & దె & ఠ̊ & 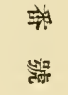 \\
\hline$=$ & : & : & : & : & 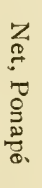 & 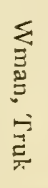 & 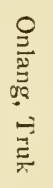 & $\begin{array}{l}\vec{c} \\
\underline{-} \\
\vec{c} \\
\frac{\vec{n}}{\lambda}\end{array}$ & 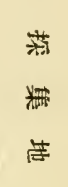 \\
\hline $\begin{array}{l}\overline{0} \\
\vdots \\
\Xi\end{array}$ & : & $\frac{\stackrel{c}{\ominus}}{\leq}$ & $\frac{10}{\infty}$ & : & $\frac{\stackrel{10}{\omega}}{\vdots}$ & $\frac{10}{\leq}$ & $\frac{10}{4}$ & $\frac{0}{4}$ & 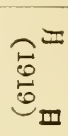 \\
\hline 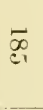 & 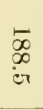 & $\underset{\omega}{\tilde{e}}$ & $\begin{array}{l}\stackrel{\leftrightarrow}{\varnothing} \\
\dot{\infty}\end{array}$ & $\bar{\infty}$ & $\begin{array}{l}\overrightarrow{8} \\
\dot{0}\end{array}$ & $\stackrel{0}{\tilde{\sigma}}$ & 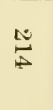 & 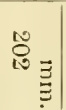 & $\begin{array}{l}\Rightarrow> \\
\text { प्राण }\end{array}$ \\
\hline के & के & $\vec{\sigma}$ & ज़ & $\begin{array}{l}\vec{G} \\
\text { ज़ }\end{array}$ & ज़ & $\begin{array}{l}\vec{\sigma} \\
\text { जे }\end{array}$ & $\ddot{v}$ & $\overrightarrow{\mathrm{v}}$ & 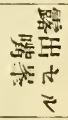 \\
\hline$\underset{\text { G }}{\stackrel{N}{0}}$ & $\underset{\text { G }}{\stackrel{N}{0}}$ & ơ & $\begin{array}{c}\hat{N} \\
\omega\end{array}$ & ธै & $N$ & $\stackrel{\sim}{N}$ & $\vec{\omega}$ & ज़ & 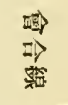 \\
\hline N & $\overrightarrow{\mathrm{N}}$ & $\begin{array}{l}\vec{N} \\
\text { ज. }\end{array}$ & $\begin{array}{l}\vec{\Phi} \\
\dot{\sigma}\end{array}$ & $\vec{N}$ & $\overrightarrow{\mathrm{N}}$ & $\overrightarrow{\boldsymbol{\varphi}}$ & $\begin{array}{l}\vec{\omega} \\
\underset{\omega}{\omega} \\
\sigma\end{array}$ & $\begin{array}{l}\vec{\omega} \\
\infty \\
\text { Gँ } \\
\Xi \\
\Xi\end{array}$ & $\geqslant x$ \\
\hline \& & $\begin{array}{l}\text { जे } \\
\text { जr }\end{array}$ & $\frac{1}{\text { vi }}$ & హै & $\stackrel{8}{\circ}$ & जै & जै & $\begin{array}{l}\omega \\
\omega\end{array}$ & ${ }^{\circ} \mathrm{\Xi}$ & 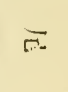 \\
\hline$\widetilde{\omega}$ & $\underset{\text { G }}{\stackrel{N}{*}}$ & $\stackrel{N}{\simeq}$ & $\stackrel{\Delta}{\sim}$ & $\stackrel{\omega}{\omega}$ & ఓ & $\stackrel{N}{N}$ & $\stackrel{\sim}{\sim}$ & 占 & 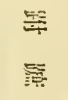 \\
\hline 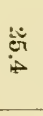 & $\begin{array}{l}\text { Oू } \\
\text { er }\end{array}$ & ๙ै & $\underbrace{\infty}_{i=0}$ & $\stackrel{10}{\circ}$ & ๙ै & జै & $\stackrel{\infty}{0}$ & $\begin{array}{c}\text { जू } \\
\text { जँ } \\
\Xi\end{array}$ & $\begin{array}{l}\text { シ } \\
\text { 淑紫 }\end{array}$ \\
\hline$\infty$ & $\infty$ & $\checkmark$ & $\infty$ & $v$ & जे & 0 & $\begin{array}{l}\infty \\
\text { o }\end{array}$ & ${ }^{\infty} \bar{\Xi}$ & $\begin{array}{l}\downarrow \bar{~} \\
\text { 哭 }\end{array}$ \\
\hline 1 & $\underset{+\infty}{\overrightarrow{+}}$ & $\vec{\phi}$ & 1 & $\stackrel{\infty}{\rightarrow}$ & $\underset{\mathbb{A}}{\overrightarrow{+}}$ & $\vec{t}$ & $\begin{array}{l}\vec{\omega} \\
\vec{c}\end{array}$ & $\vec{N}$ & 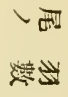 \\
\hline to & $\leftrightarrow \rightarrow$ & to & $\leftrightarrow \rightarrow$ & to & to & $\rightarrow \rightarrow$ & $\leftrightarrow$ & $\leftrightarrow \rightarrow$ & 椋 \\
\hline $\bar{\Xi}$ & ؛્ટ & 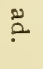 & 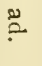 & 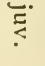 & مُّ & . & $\stackrel{2}{2}$ & مٌِّ & 点 \\
\hline
\end{tabular}




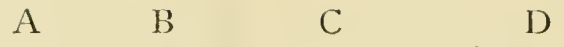

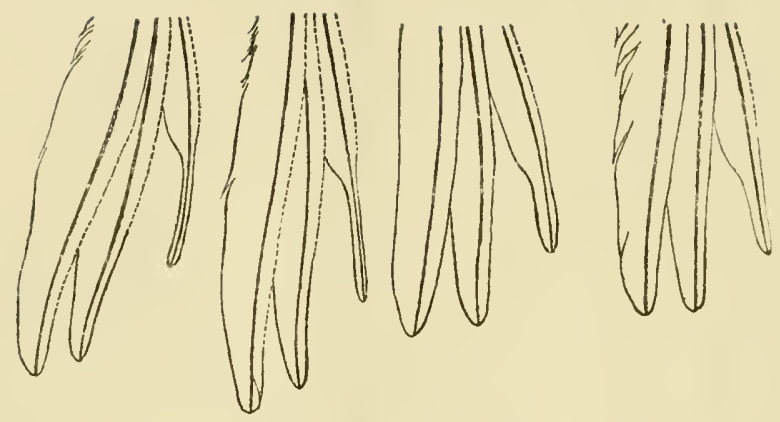

Text fig. 3

Three outer primaries of adult and young of Ptilinopus, ( $\frac{1}{2}$ nat. size)

ヒメアキバト類の初列風切第一犲乃至策三狗に於ける成幼間の變照

B \& C. P.t.ponapensis, from Truk, Nos. 69 \& 34 I (Ad. \& Juv.)

A \& D. P. f. heminheimi, from Kusaie, Nos. 47I \& 473 (Ad. \& Jur.)

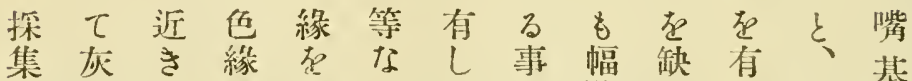

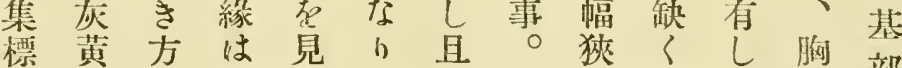

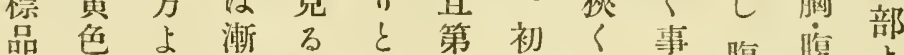
各部り時事す例且、腹复よ 部走順消 の侵次失 b個列切色腹の 站腿 測す發し 體風各に方草に上 定口生胸幼に切旸しび黄脚に を吉部鳥依犲先七下色旸到 表而淡のb先端各尾縁はる 訅し色稍頭牛に狗筒の維極 せ灭長及は細末来の幅色め ば尾なすひ成き端黄廣にて 犽りる 頸鳥鸹近色 末前にの程ヶくは且各き 端頭及各其月に淡腹犽黄 ののび旸幅形灰く部先色 黄桃楛に狹の黄尾中端の

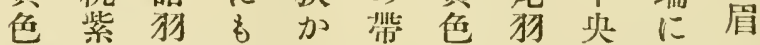
緣色末狹ら白部の黄線 彍の端きざ色を黄暗色 あ が額の黄る部有色色細る りに黄色事を专带斑緣こ 


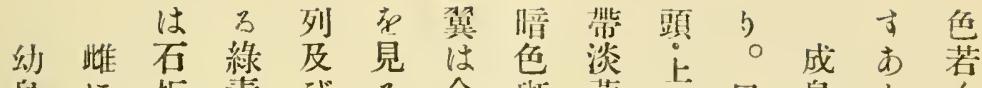

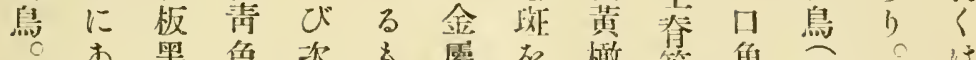

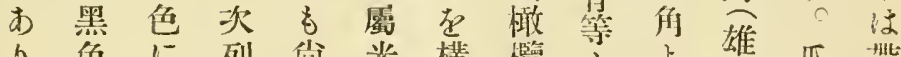

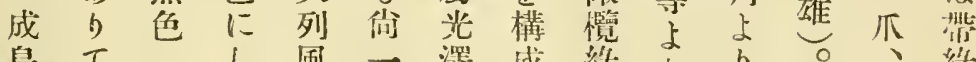

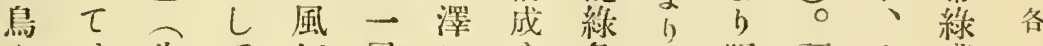

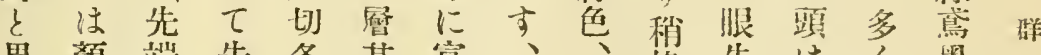
異顏 端先各其當、箓先はく黑岛

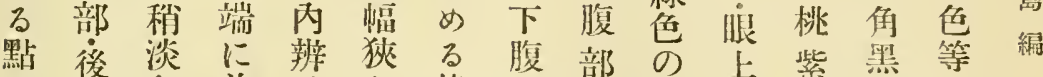

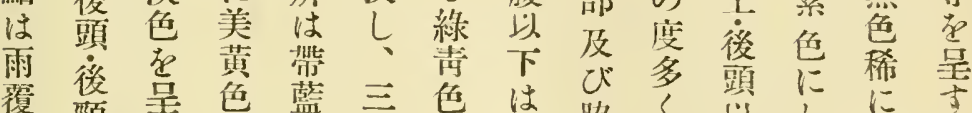

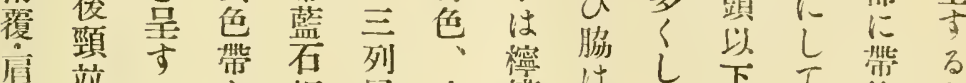

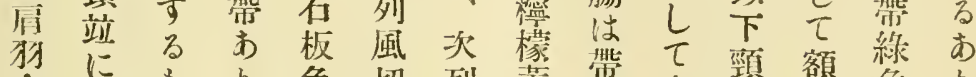

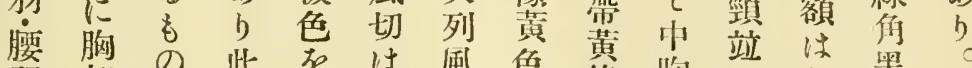

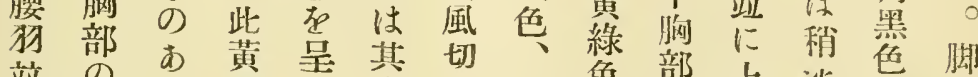
站の b 色毛先狗下色部占淡

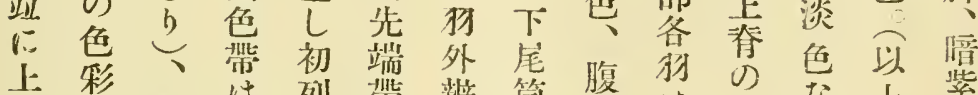

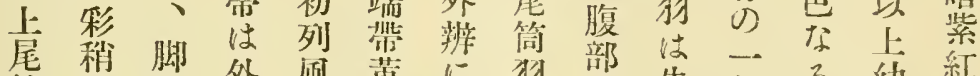
简、湢趾外風黄に狗中先部了幼紅

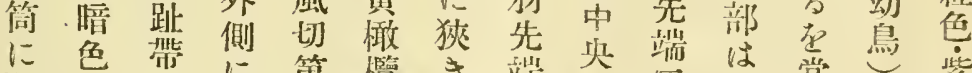

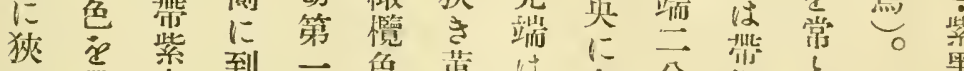

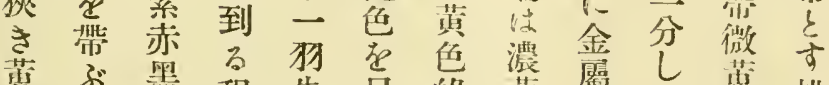

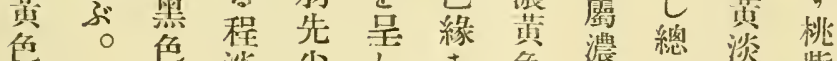

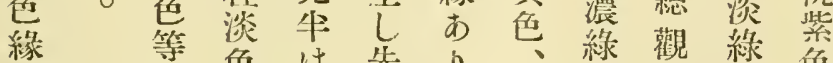

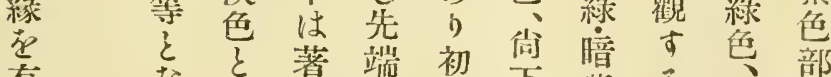

有

I

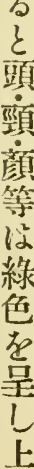

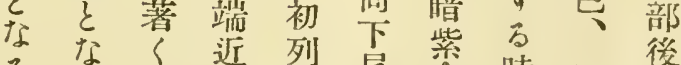

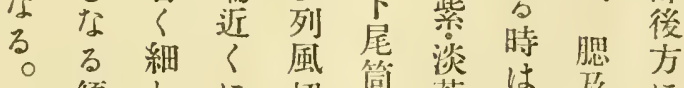
傾Lに切简粱蛸范に

क。淡狗対等稍 ひ極

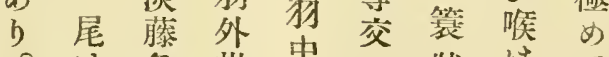

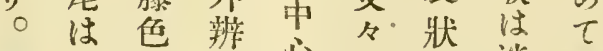

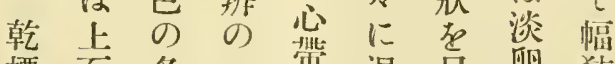

標面各一霍混毫㧮唙

本金一部淡热守黄き

に蜀斑江奖方。色黄

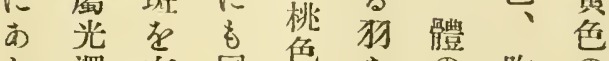

澤有同色あの胸 の

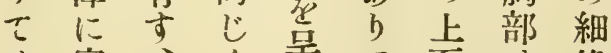

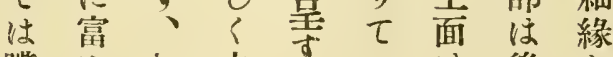

嘴め初之手一性後第

黑

色

あ

b

躈

䠎

D)

部

に

ब

み

帶

紅

暗 $\overline{\text { 五 }}$

鳇

t?

現 
の 色 プ 㬓 檬 を

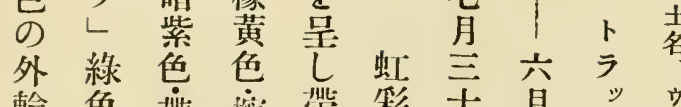

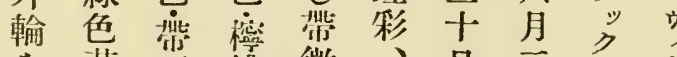

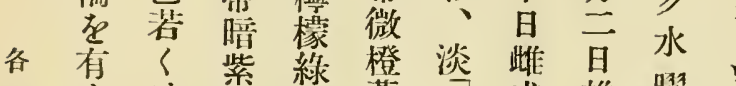

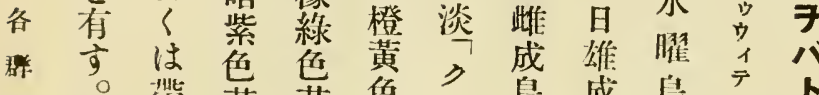

島㗪活若若色口悬成昆

編

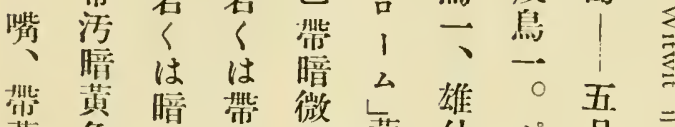

黄色紫槚橙黄幼ポ月

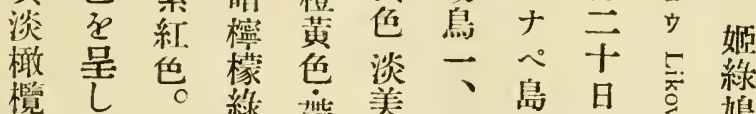

欖し

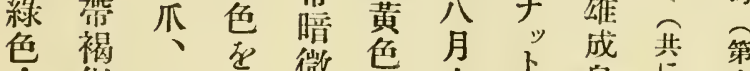

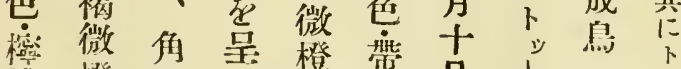

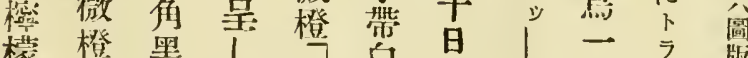

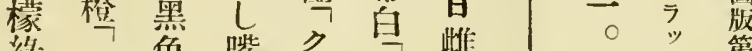

綠》色㗪ク旦雌

色口稀先口品幼 七上語高

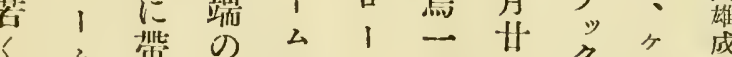

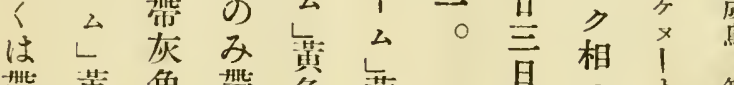

带黄角帶色黄

晤色黑綠若色

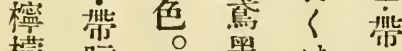

檬暗 合黑は暗

絊 微以色 带

色橙上又䐘》

表云成憕口

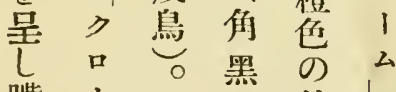

嘴公虹色外黃

先么彩ひ 輪色

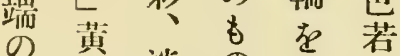

み色淡の有く

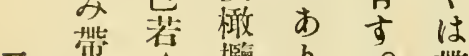

五蕉

等は緑○嘴暗

サ 带色 脚、復

プ 污 淡 瞢檬

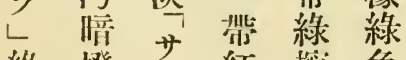

雌 生 第

成島 写 圆

鳥

、五和風

此倠 月十切

仂 正 狗

鼠 望

一日

、雄風

七成 旸

月 息第

\#- 四

公 0 圖

日 卜婎

雄 ラ成

成少舅

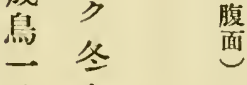

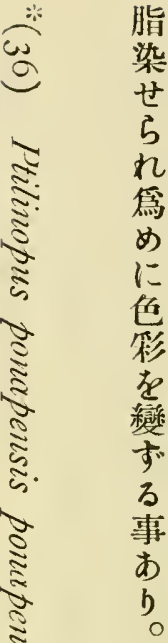

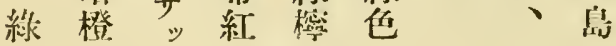


ン事彩な以て軟め以續㗪稍樹

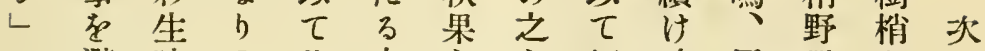

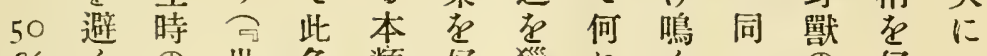

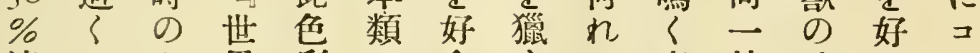
液るき界彩の食卞か事枝呻

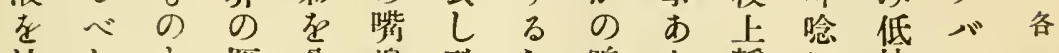

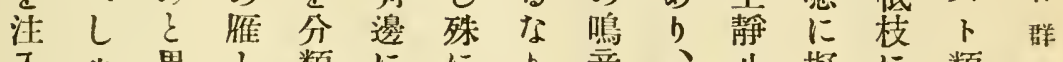

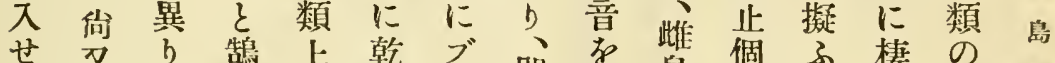

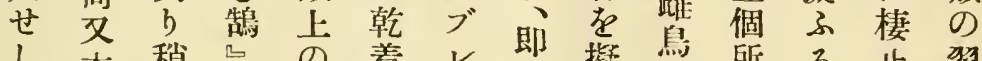
し本稍已の着 め種䕎 ざ色尔點るド各第雄戀音るは

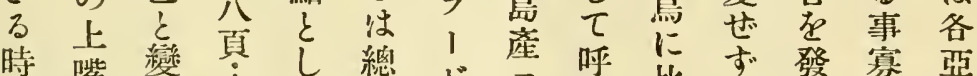

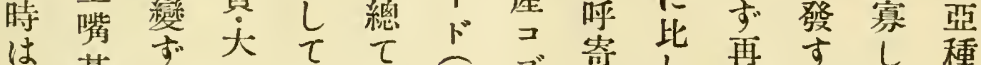
及基る正誤該 パブ䆑し再高し種

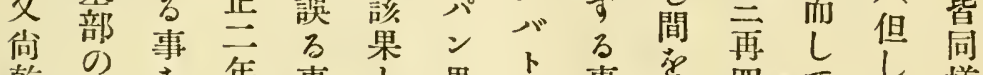

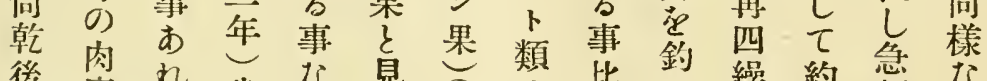
後瘤れ佾な見の類比鈎繰約急な 該大甼唯さる結地較れ返牛斜る

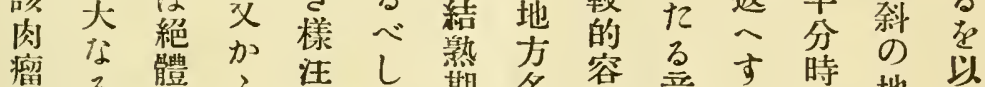

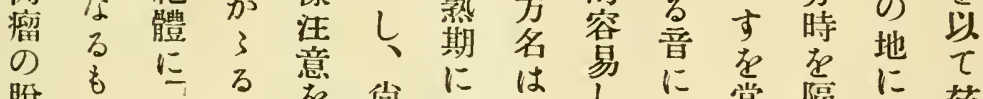

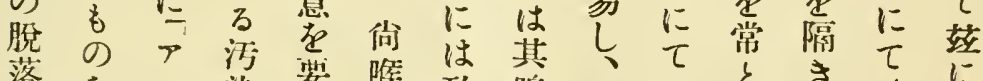

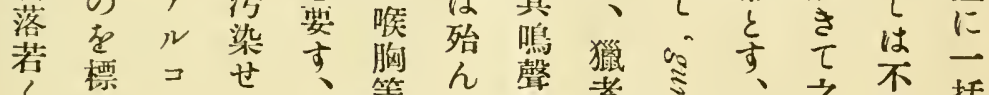

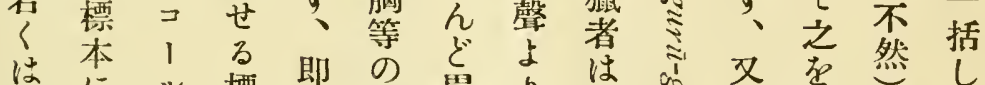
脂に製

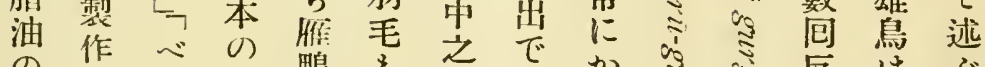

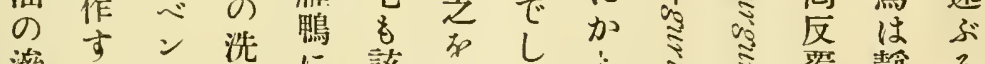

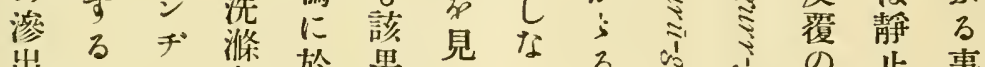

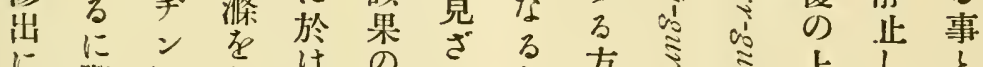

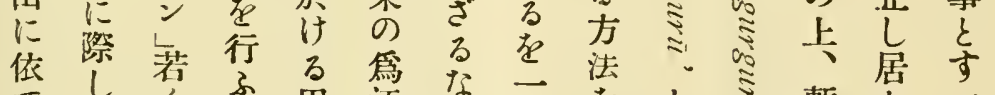

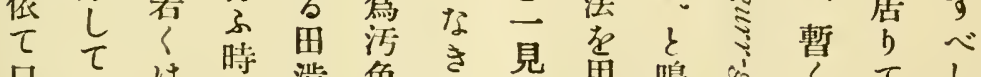

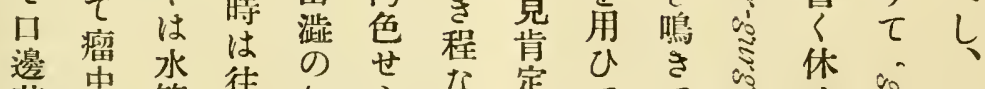
若 中等徍如 ら定元宁

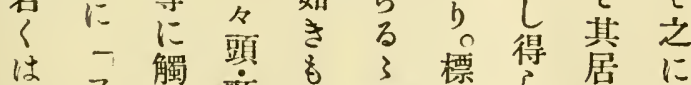

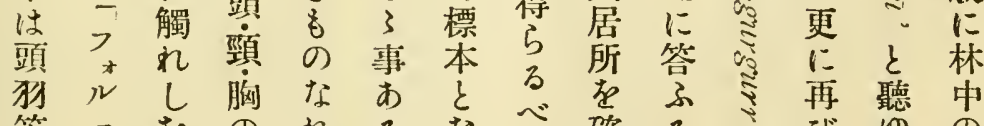

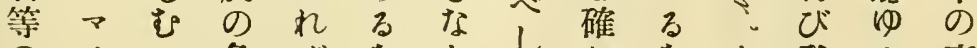
のりる色ば在り合加を考る高 
$<\varepsilon$ 成

ヤ見從泉本作

ブ る 來及新考

品 息

各に特きブ此種壁

群 あ 產 の

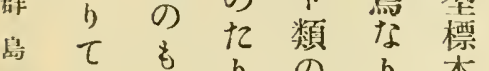

蹁は $\begin{array}{llllll}\text { の } & b & 0 & b & \text { 本 } & \text { は }\end{array}$

多齐看而

ぜ做して 島

ざし 該 よ

己火馜報

の 過外告

3 小 外 世

如加地 5

くる地に

余心枇斿

はし范る

該。丵 事

岛、㮔少

の ब है

林分 布

= す

七 $\quad$ の 如

少

數

友貫 即

憼

祭

せ

L

O)

z)

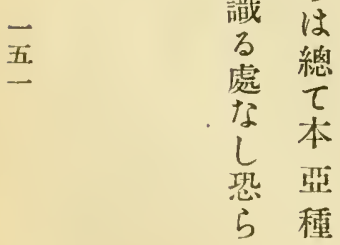

訑颌

如 9

र

昨

大

证 15

八 至

年整

月 保

H 计

四枚

日 の

及 雨

び ま

同方

月 $\frac{1}{0}$

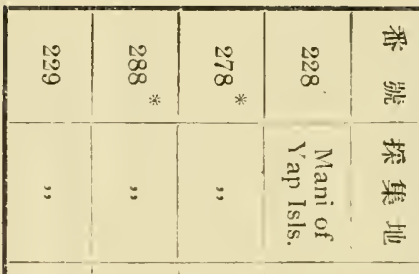

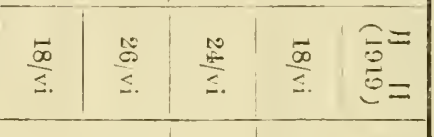

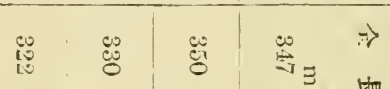

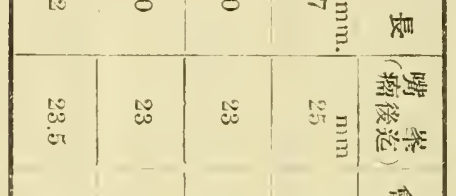

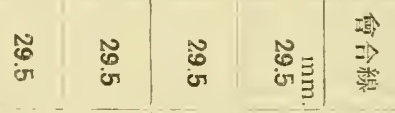
放山

ir 1 कि

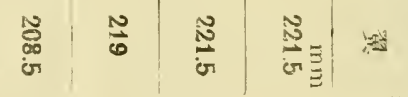

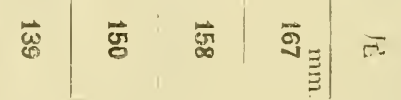

少 9

六㚾

關該

$\uparrow$

\%

本

島

に

於

$\tau$

探

集

世

3

雄

\begin{tabular}{|c|c|c|c|c|}
\hline 密 & $\underline{\omega}$ & $\underline{\omega}$ & $\vec{\omega}$ & 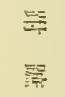 \\
\hline $\overrightarrow{0}$ & $\omega$ & $\stackrel{\omega}{\omega}$ & 总寻 & 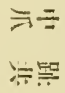 \\
\hline$\vec{G}$ & $\overrightarrow{\vec{v}}$ & $\overrightarrow{\hat{v}}$ & $\vec{w}_{\mathrm{B}}$ & $\begin{array}{l}= \\
\Rightarrow\end{array}$ \\
\hline$\stackrel{N}{N}$ & $\stackrel{\vec{N}}{\mathbb{C}^{2}}$ & $\underset{\bullet}{\vec{\omega}}$ & $\stackrel{\vec{N}}{\stackrel{0}{0}}$ & \\
\hline $\begin{array}{l}\text { to } \\
=\end{array}$ & to & $\stackrel{\Rightarrow}{ }$ & $\leftrightarrow$ & s \\
\hline $\bar{\vdots}$ & $\stackrel{2}{ٍ ~}$ & $\stackrel{2}{\stackrel{2}{2}}$ & בְ. & 点 \\
\hline
\end{tabular}




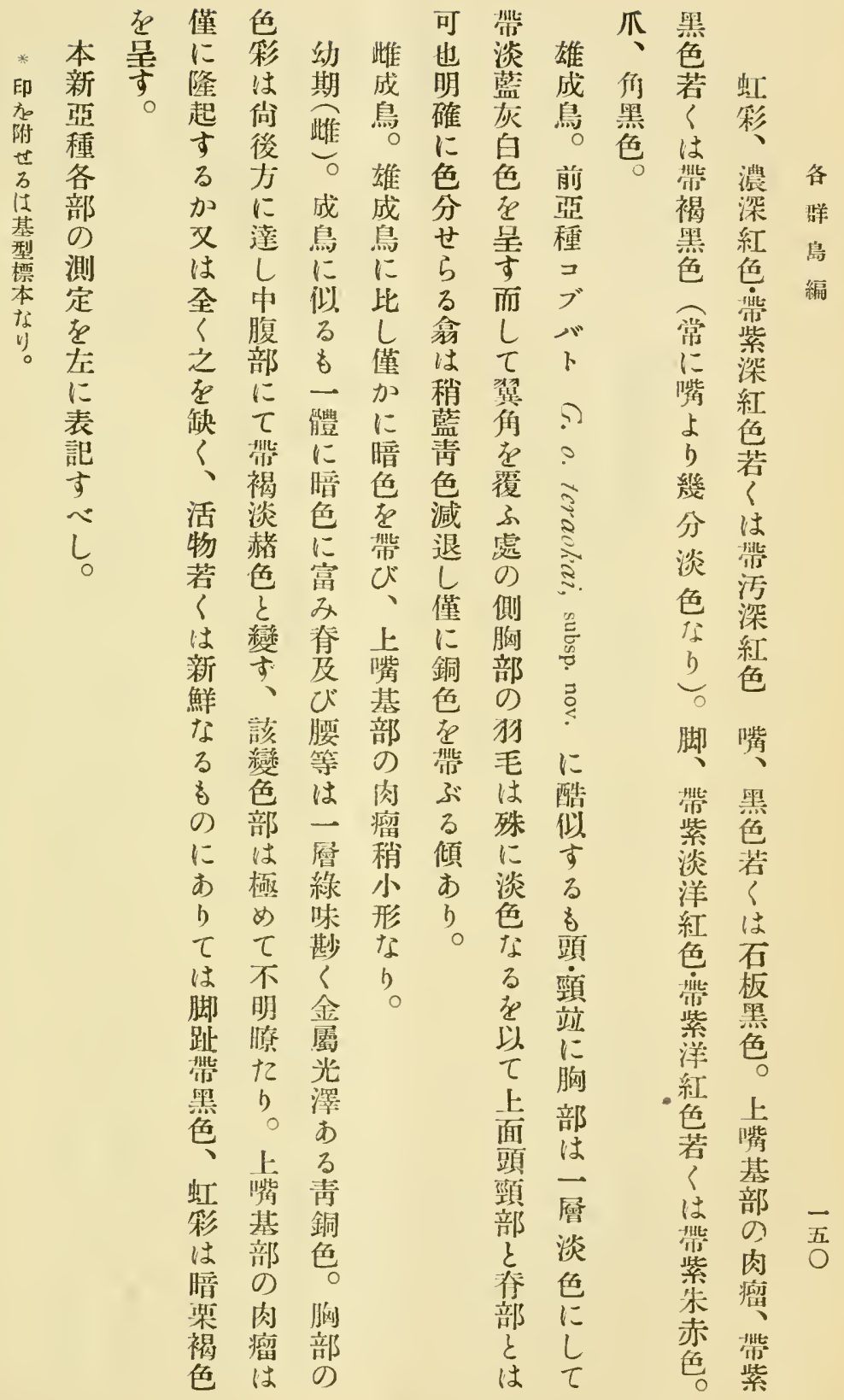




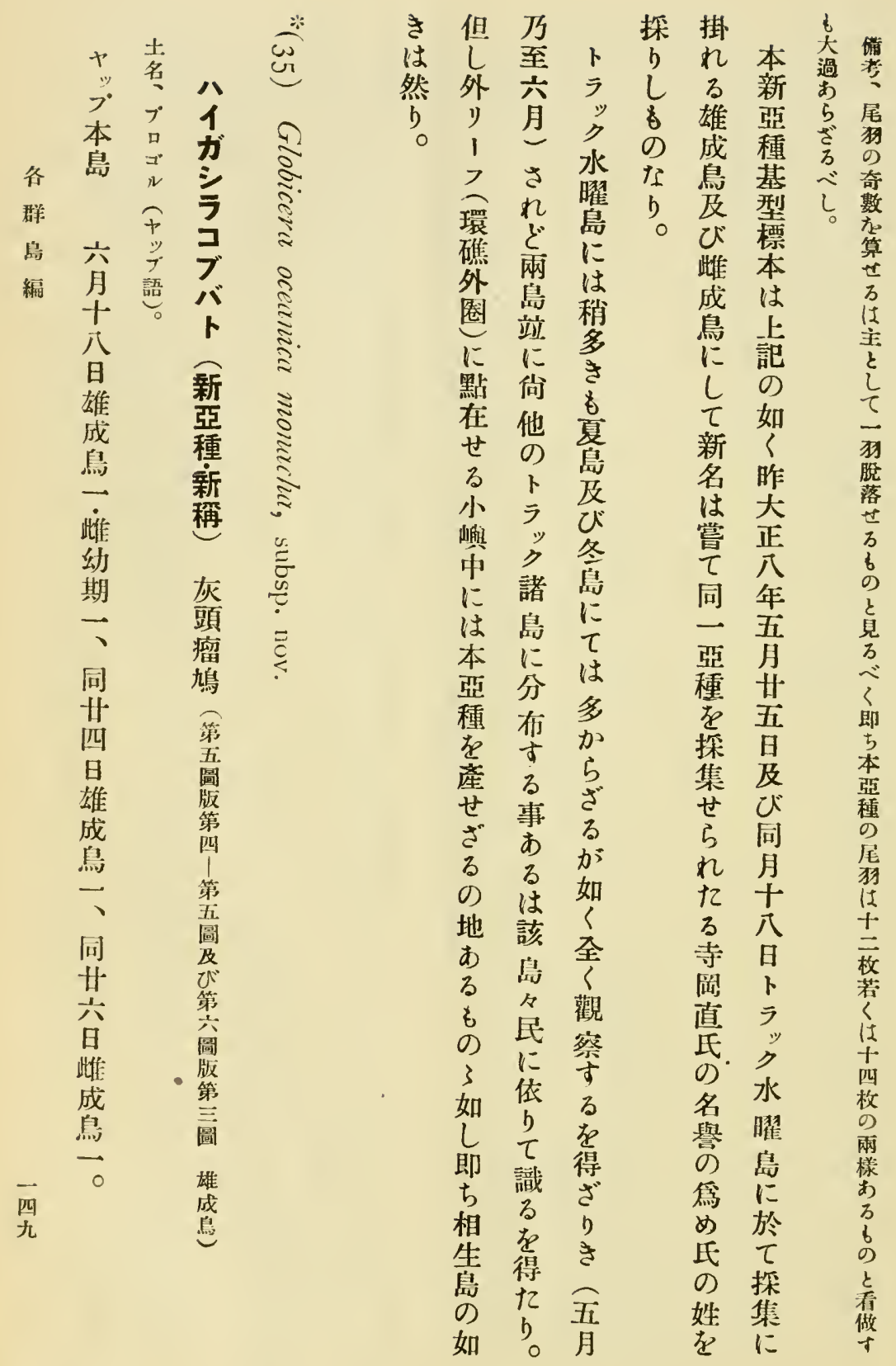




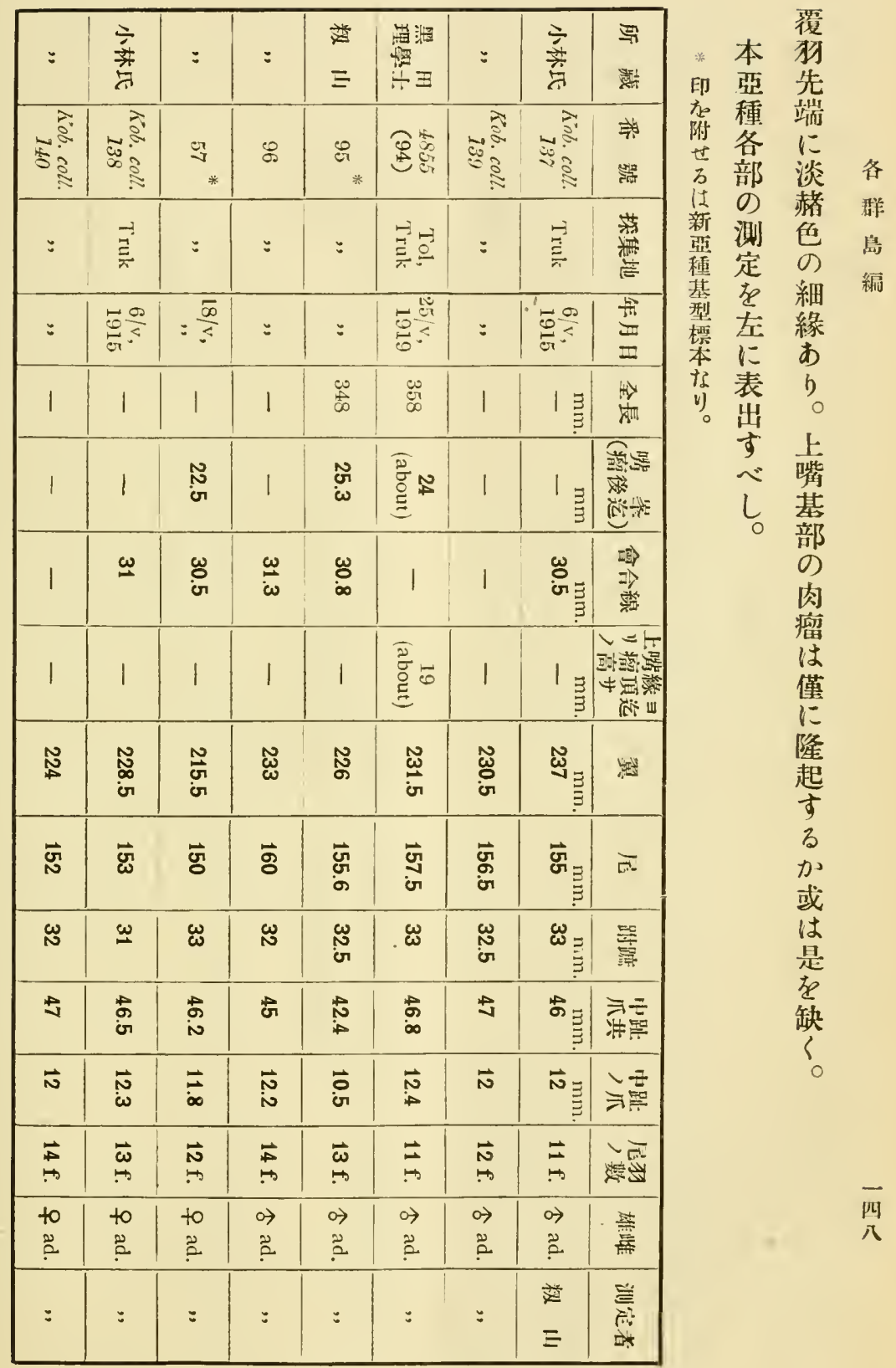


幼 胸 雌赫後 雄 洋

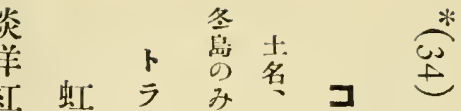

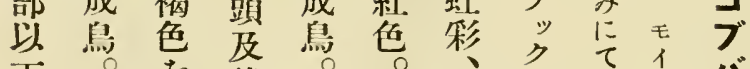

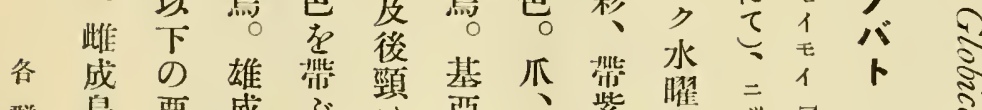

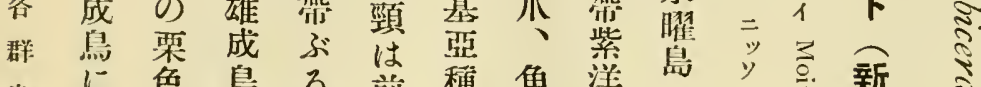

島に色鳥る 前種角洋鼠么亥新 ミ

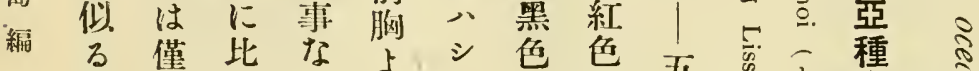

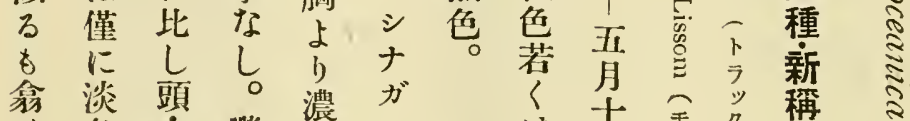

は色頸鲬色コ

秒。端の色な゙

綠上に長り ぶ

味嘴胸さ陵

之基は著下に

乙部僅し胸 陪

胸肉暗劣部守

腹瘤色れ下る

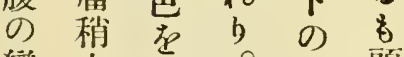

戀小帶○栗頭

色形び任锁

部な 低は 垃

不り個本に

明○體

膫滰

に依

L b

亞 胸

種は

の 稍

$\tau$

方 淡

は土王名稱

暗八!語

深早品| 瘤

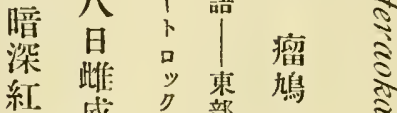

色涉 語部 第 స.

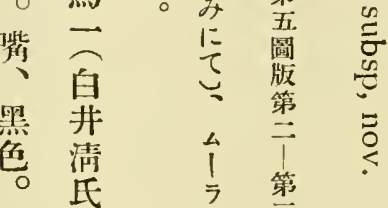

樣

僅 色

に

ら 濃し

整高

色留

は

淡

色

色

四

应

牙

及

丽
外淡

殆

ん

同

侧 藍

第 灰

對 色

甡呈

先端
1. 容

嘴 㹕

基

部同

肉干立

溜 五

明而

㳖 雄部

紫成白

黑茂

若息点号 

Bircls of Micronesia. Pl. V.

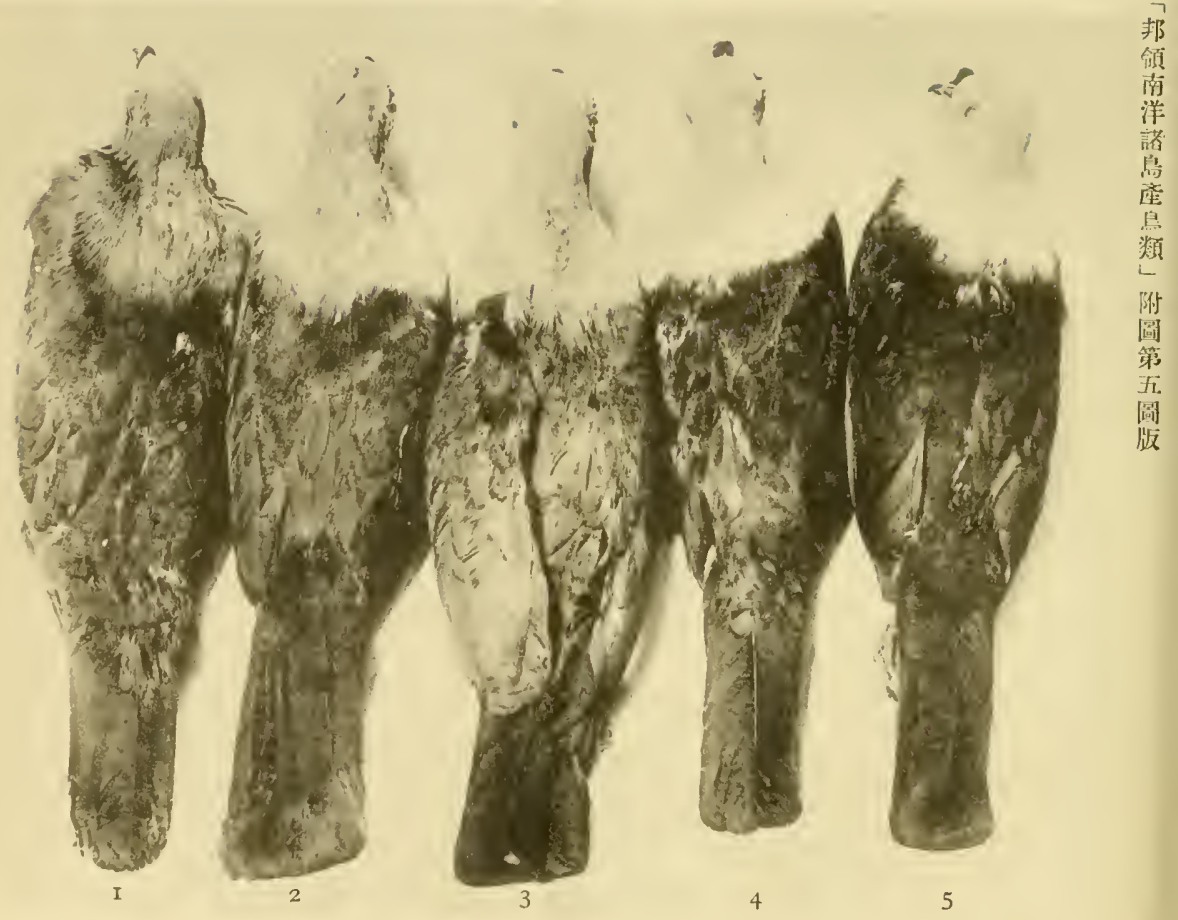

I. Globicera o. oceanica: P. If 1 .

ハシナがコブバト

今 ad. Kusaie I. I6/viii, I9 (No, 470).

$2 \& 3$. Globicert o. temakit: pp. I47\& 2 (Eng text).

$$
\text { ユプバト }
$$

$\hat{o}$ ad. Tol I., Ruk group. 25/v, I9. (No. 95=Type).

今 ad. do. do. (No. 96).

$4 \& 5$. Globicera o. monacha: pp. I $49 \& 4$ (ting. text)

ハイがシラコブバト

$\delta$ ad. Yap I., Yap Is. $24 / v i$, I9. (No. $278=$ Type).

ô ad. do. I8/vi, Ig. (No. 228). 


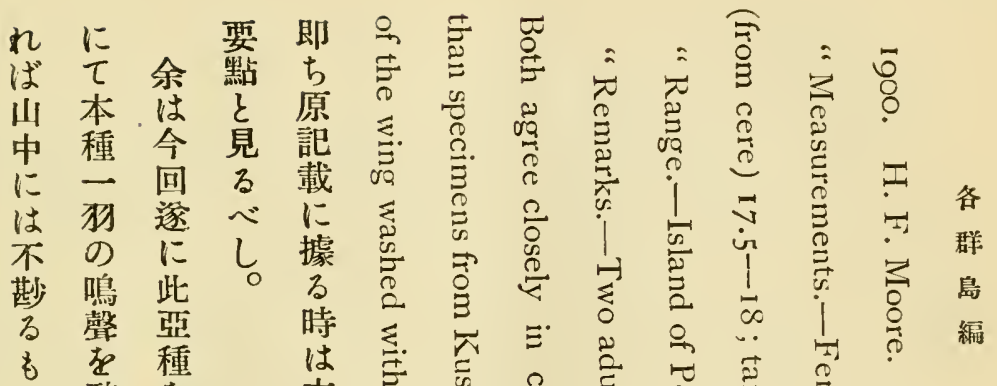

の 聽 存

なき探

b 佔 集

子少守

聞しる

く隔た

ちは

ᄂ

- b

樹 ᄂ

梢

に該

一 旅

牙行

te

百

擊ナ

せ

b)

无

月

干空

旦舊

、獨

因 射

に罊

該場

島 附

s 近

民の

に林

依中 


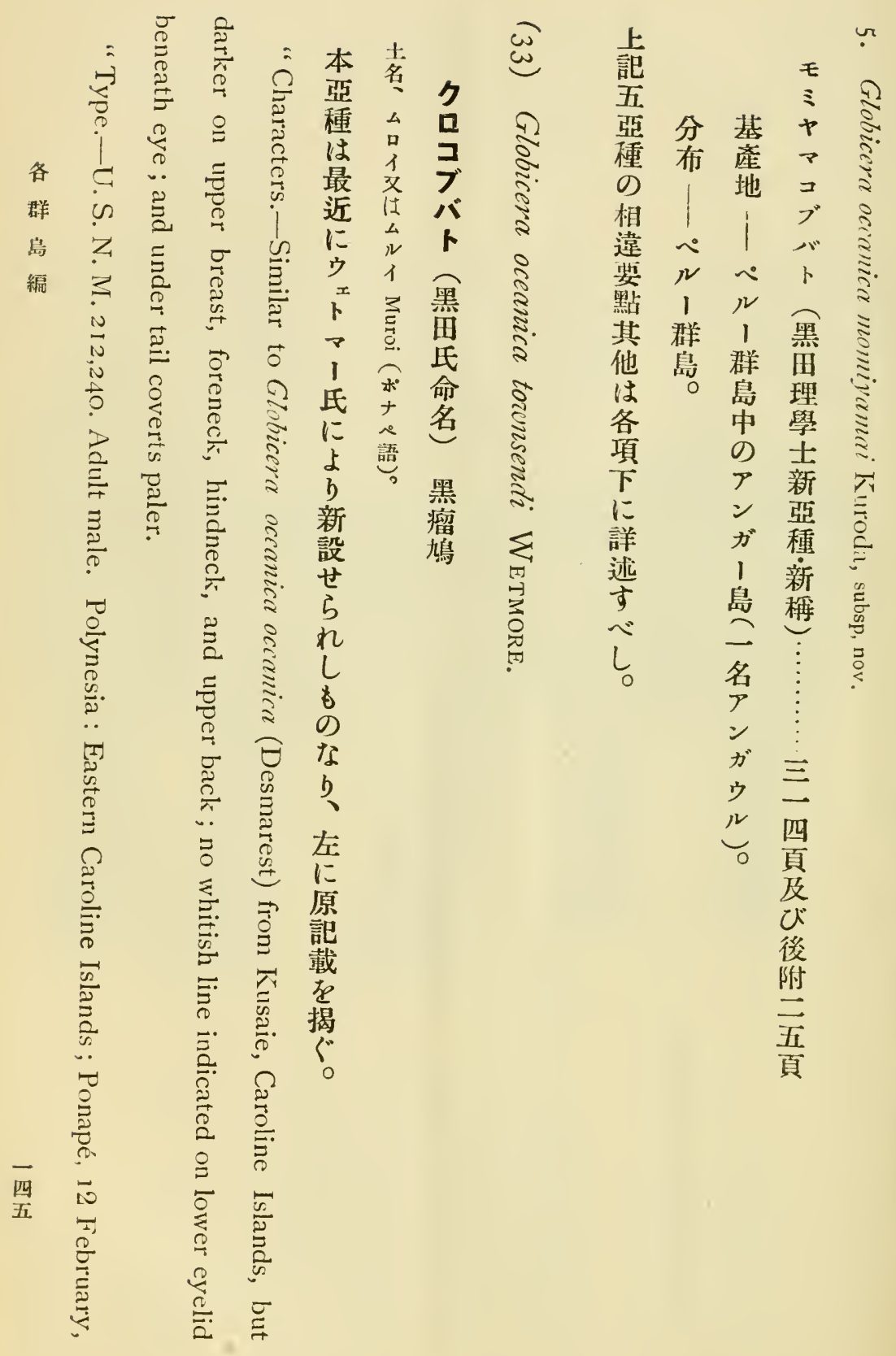




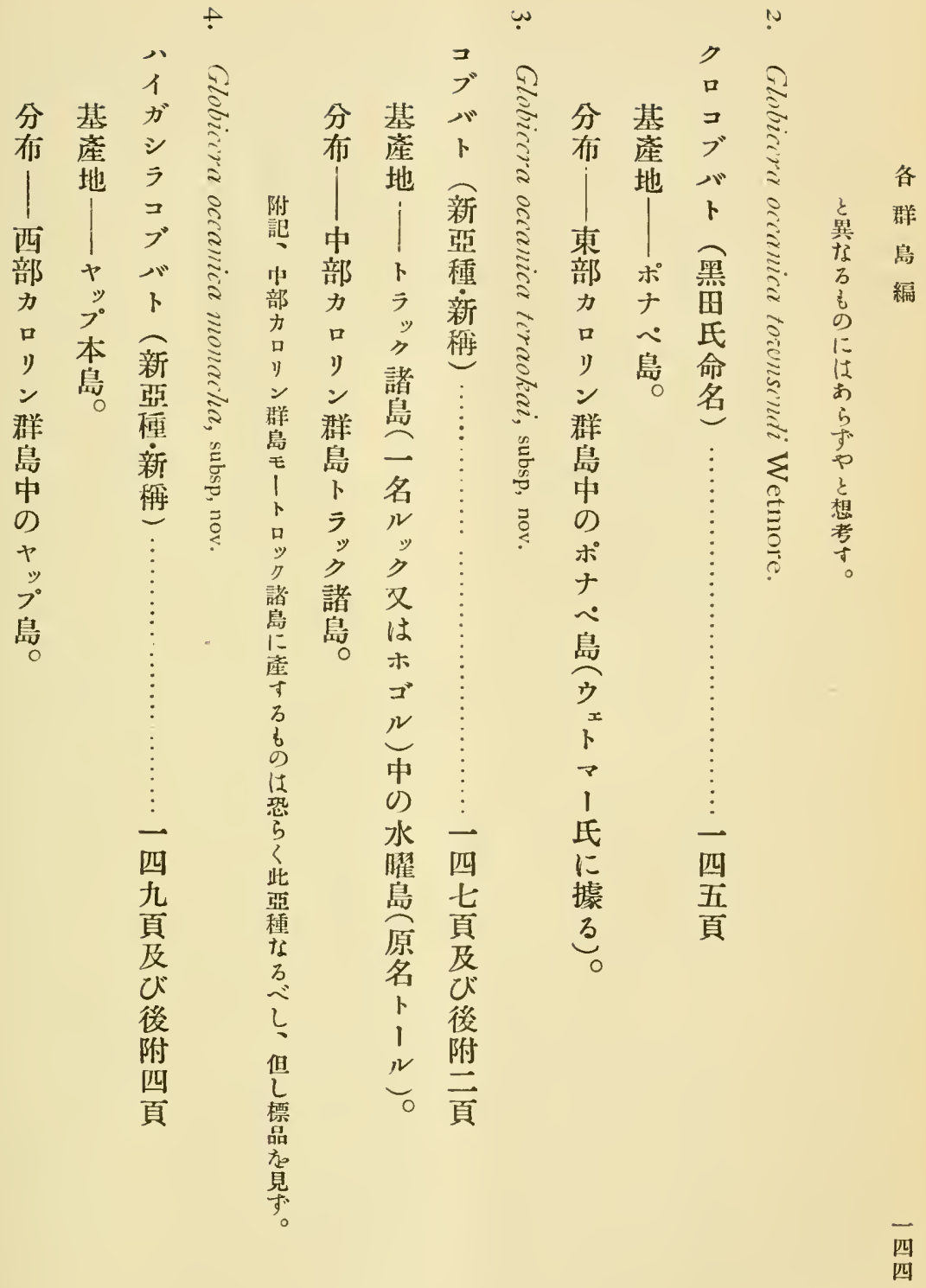




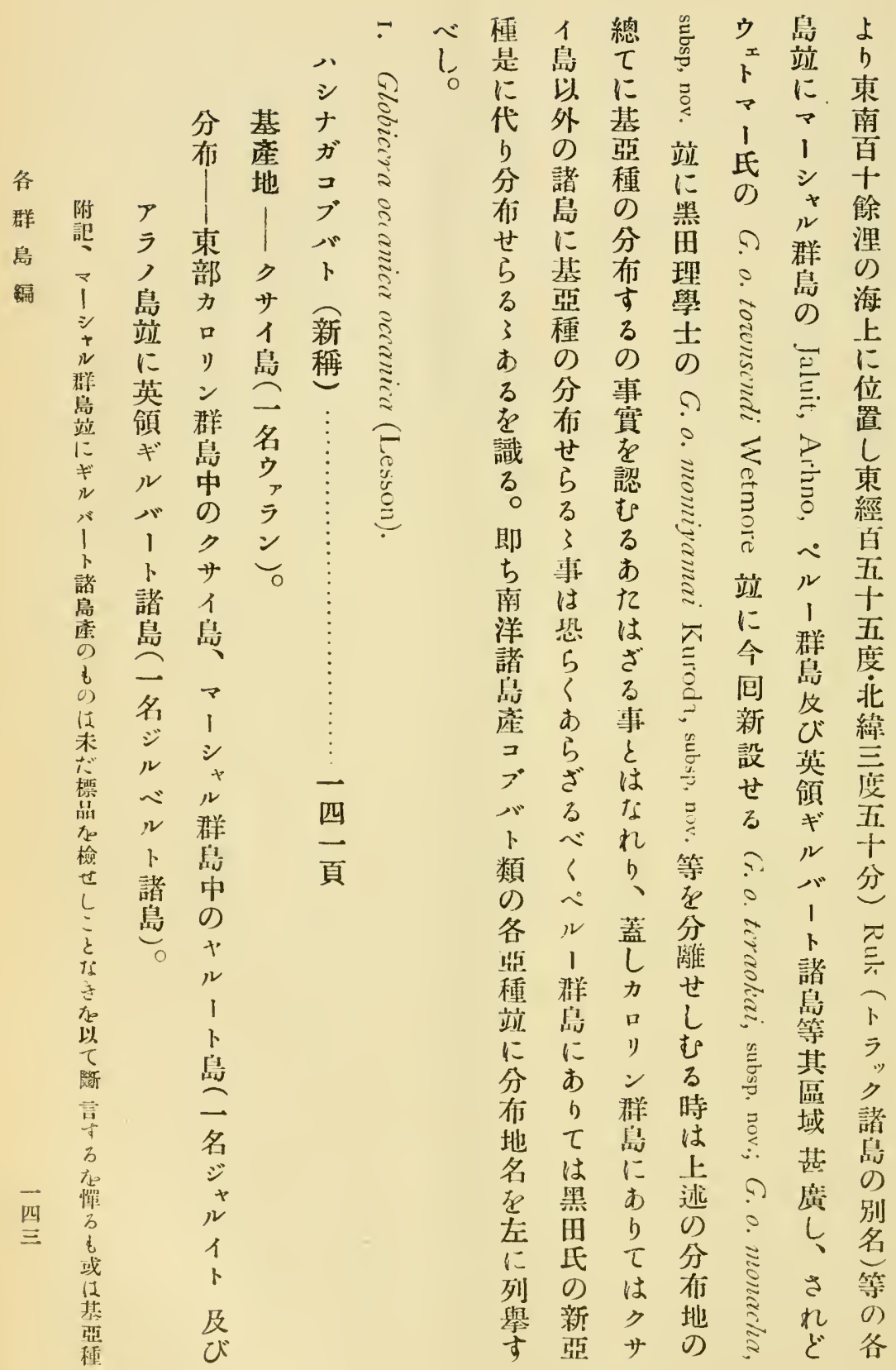


別可雨棠 シ 畣 名從本な樣咳る ナ因畣備 只凤種べに日コ本依榦 总济し充余ブ亞方相 こっと分に バ種正に

ト サ 想發如トにしお

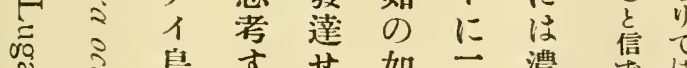

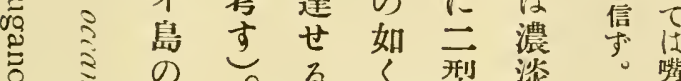

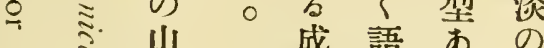

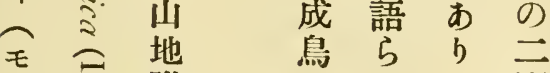

モ 附 党 れ

卜 貝た近方

口受り事る

ッの稀々 ᄀ䆓 ह

万分な

諸布 ら

岛地

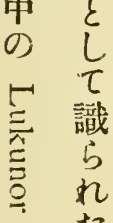

の 12

别政

名力

? 口

○ y

离 群

$\subsetneq$ 晻

镕中

該の

島

は邑

る該はの

苑亞該了

以種昆如

七中に

幼 淡 年 前

の 二居 揭

美 型 任 せ

๘ あ せ

看りらは

做でる暗

寸脚了色

存 趾 野 型

得の田 $\varepsilon$

す色秀自

ᄂ 㩐保る

ह ह 氏

聊にき

即方從 当

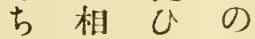

余違纪

はせるす

氏 b ह

の 而 のク

言しに サ

をててイ

信 解 同岛

じ剖 代產

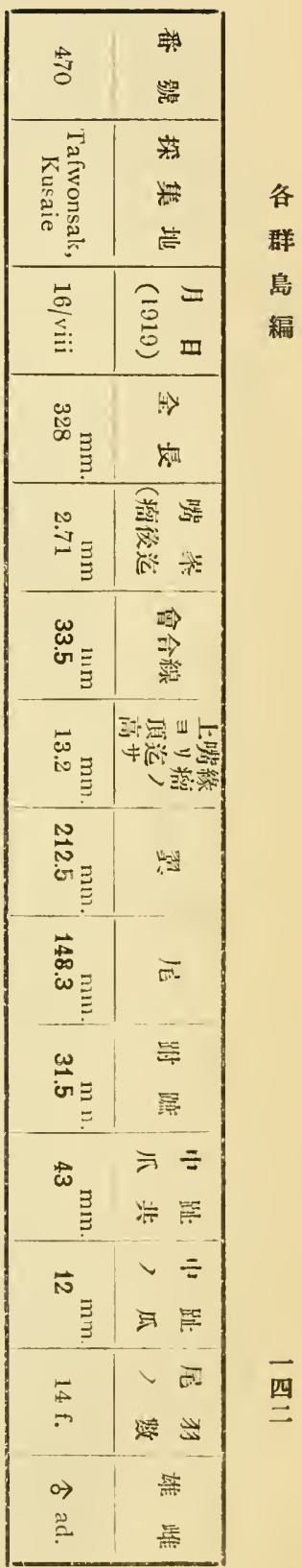




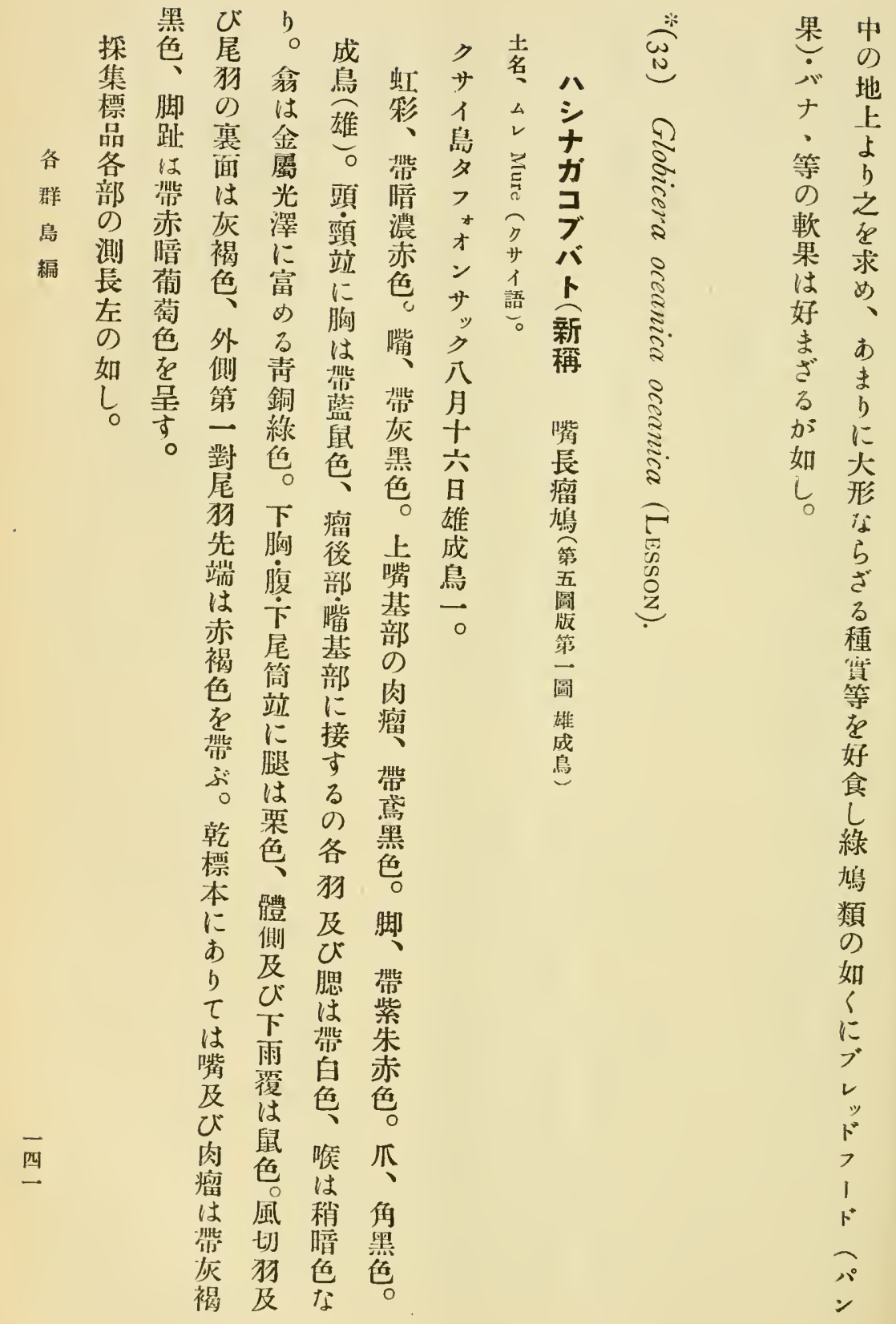




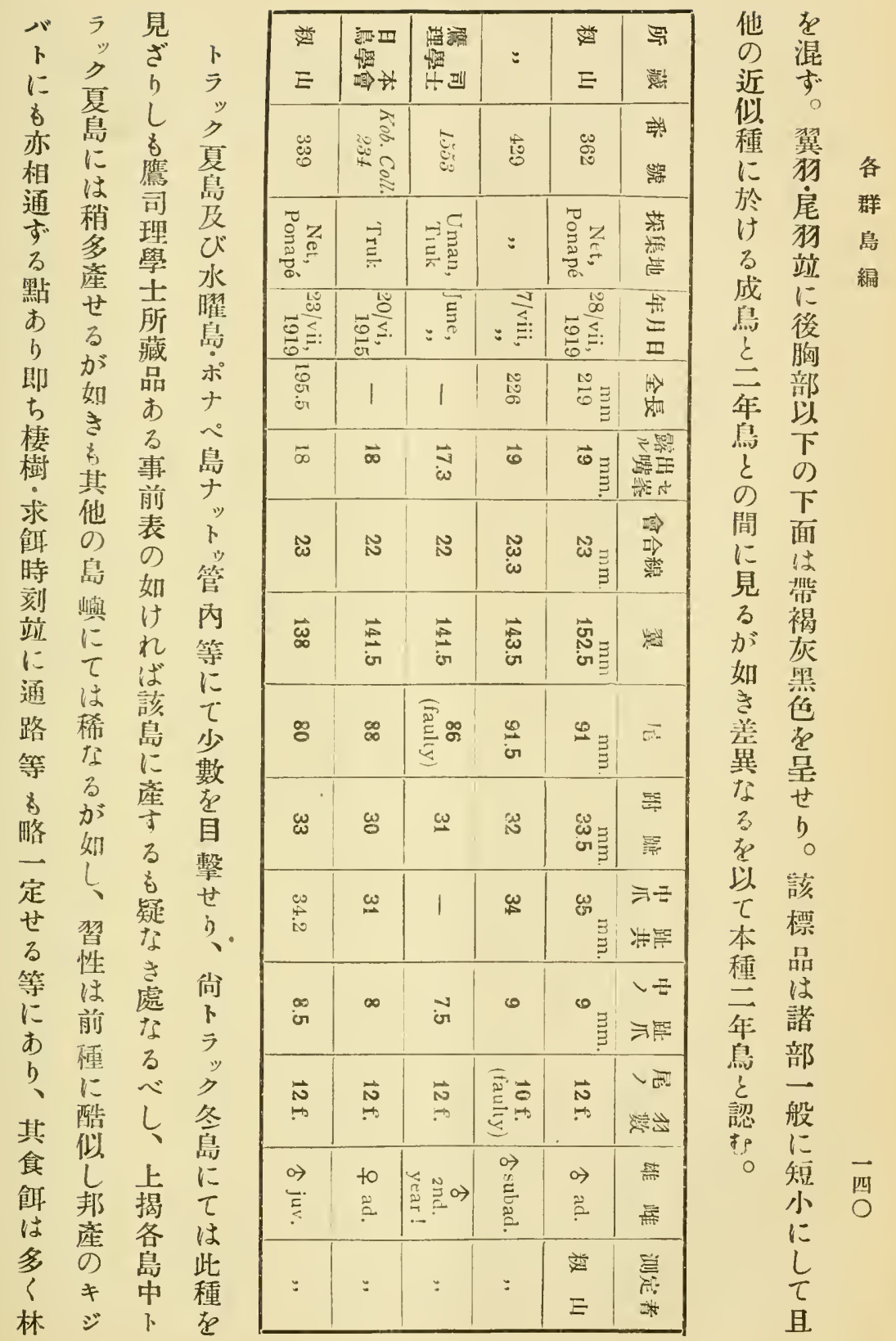




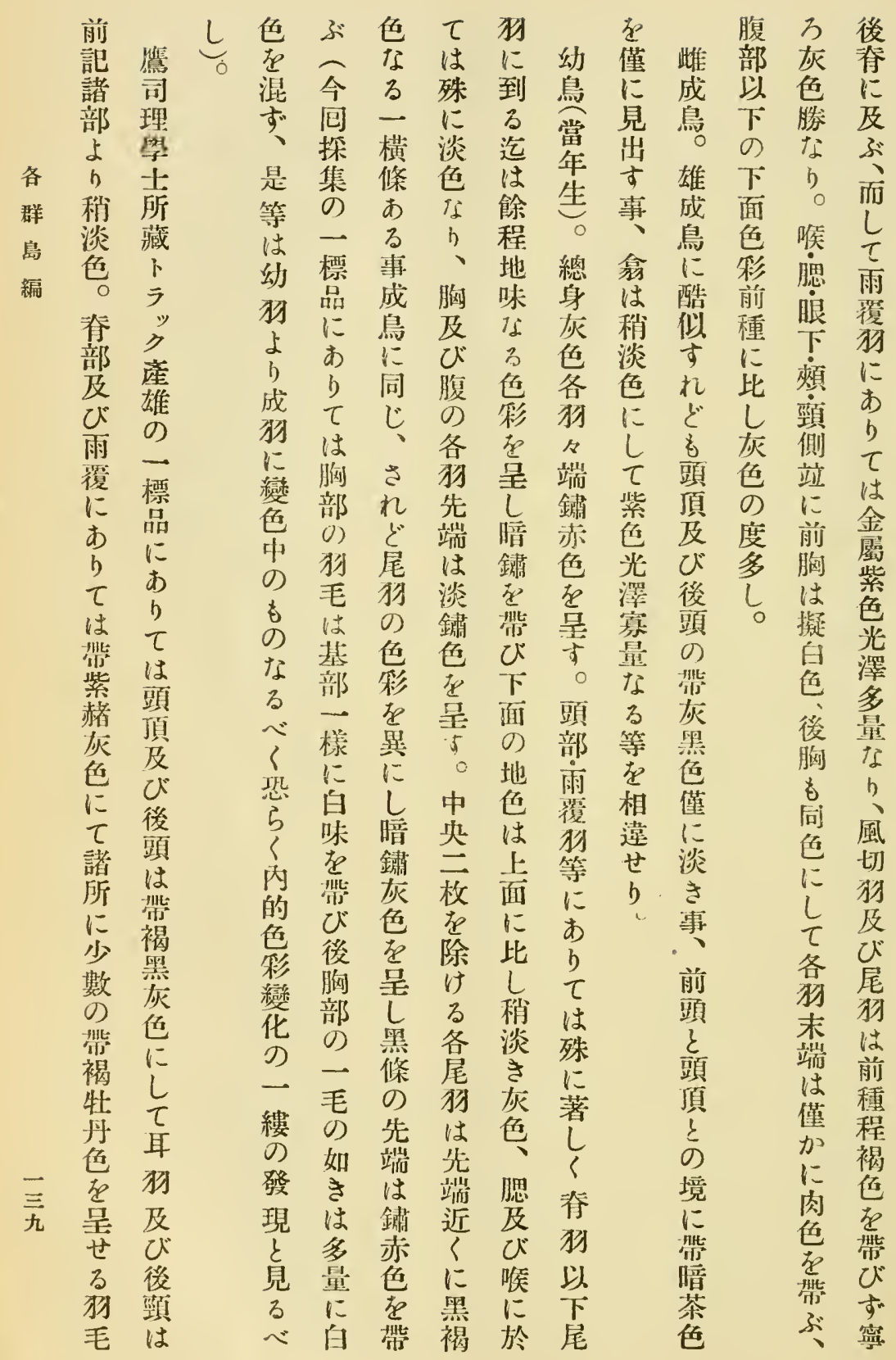


色雄色色虹名、羔

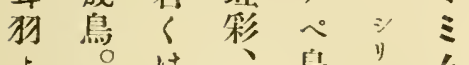
b 額淡黑䎡

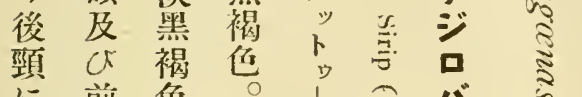

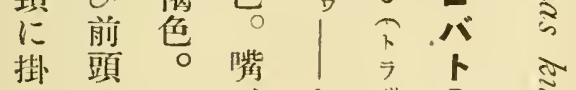
けは 黑 擬 灰白 色 色 壁 哇 分

食 後

及 副

雨 部

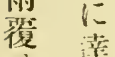

は迹

前

種 幅

頪膺

類 き

可居

子線

专形

- 成

層 す

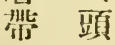

褐 頂

牡及

丹 び

色 後

强頭

度は

江 此

ᄂ 灰

$\tau$ 㫮

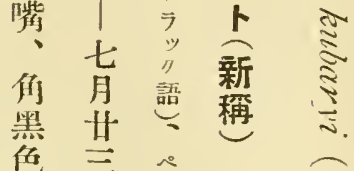

若草点眉导

灰一管

黑同束阅

色同先㸝

墨 日圆

色雄㱔雄

脚鳥腎或

紫: 宗

褐八種

色贺

若七意

日

は雄焉

帶 未 些

紫成兄

濃鳥?

紅 - 桑

色口管

爪

乖

淡

紫
は雄学胸至

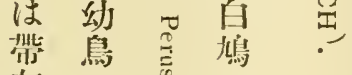

端分䇺第

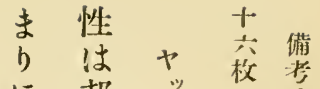

に邦 プ枚考

多產帛需尾

か キ岗市 の

ら シ 林万数 各

ざ バ 中殆五群

る

如 地磪算 編

L 方

モ下べは

降而恐

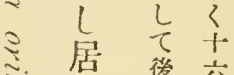

るる者枚

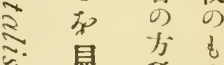

見 稀

万

ई事 万人

ミ多べ狗

占 $l, 0$ 落

$\supseteqq$ 县方

地点

楛落

略くな告

似樹亦

せ自等

万等 雑

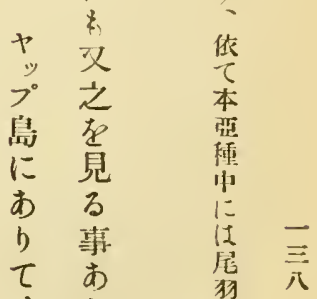

は b 索

其、四

數 其 筸
あ 


\begin{tabular}{|c|c|c|c|c|c|c|}
\hline : & : & : & $\begin{array}{l}\text { E } \\
\text { E }\end{array}$ & 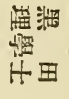 & $\begin{array}{l}\text { E } \\
E^{\prime}\end{array}$ & 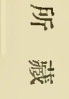 \\
\hline 20 & $\stackrel{10}{10}$ & $\begin{array}{l}1 \\
15 \\
15 \\
10\end{array}$ & $\begin{array}{l}10 \\
\text { t: } \\
10 \\
10\end{array}$ & $\stackrel{\overparen{E}}{\stackrel{\Xi}{\rightleftarrows}}$ & $\overrightarrow{\mathscr{\omega}}$ & 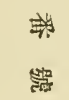 \\
\hline : & : & : & : & : & 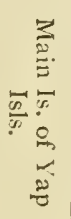 & 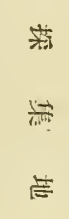 \\
\hline$\frac{\vec{\infty}}{\vdots}$ & $=$ & : & $\frac{\vec{a}}{\leq}$ & $\frac{\vec{E}}{\leq}$ & $\stackrel{E}{\vdots}$ & $\begin{array}{l}\tilde{6} \\
\stackrel{0}{6} \pi\end{array}$ \\
\hline $\begin{array}{l}10 \\
0 \\
0 \\
0\end{array}$ & $\begin{array}{l}10 \\
\stackrel{0}{0}\end{array}$ & $\stackrel{10}{0}$ & $\begin{array}{l}10 \\
\text { in } \\
\text { er }\end{array}$ & $\begin{array}{l}10 \\
\text { D } \\
\text { ci }\end{array}$ & 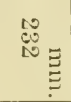 & $\begin{array}{l}\Rightarrow \\
\Delta\end{array}$ \\
\hline $\begin{array}{l}\vec{v} \\
\text { نे }\end{array}$ & है & $\begin{array}{l}\vec{N} \\
\text { in }\end{array}$ & $\underset{\infty}{\vec{N}}$ & $\begin{array}{l}\text { iv } \\
\text { نr }\end{array}$ & $\vec{\infty}$ & 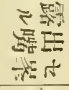 \\
\hline $\begin{array}{l}0 \\
0 \\
0\end{array}$ & $\stackrel{N}{\mathrm{G}}$ & N & $\stackrel{N}{\sim}$ & N & 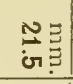 & 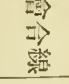 \\
\hline$\vec{\omega}$ & $\begin{array}{l}\vec{\omega} \\
\dot{\omega}\end{array}$ & 虰 & 宓 & 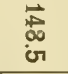 & 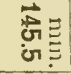 & 烟 \\
\hline $\mathscr{8}$ & $\begin{array}{l}\mathscr{G} \\
\text { ज़ }\end{array}$ & $\begin{array}{l}9 \\
\text { ir }\end{array}$ & ஃ̊ & 홍 & 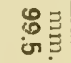 & 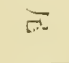 \\
\hline న & $\stackrel{\omega}{\omega}$ & $\stackrel{\omega}{\omega}$ & $\underset{\omega}{\omega}$ & $\underset{N}{\omega}$ & $\begin{array}{l}\omega \\
\dot{\sigma} \\
\vec{\sigma}\end{array}$ & 鴜 \\
\hline w & $\frac{\omega}{\sigma}$ & $\begin{array}{l}\underset{\omega}{\omega} \\
\dot{\sigma}\end{array}$ & $\stackrel{\omega}{\infty}$ & $\stackrel{\mathscr{c}}{\infty}$ & $\stackrel{\omega}{W}$ & 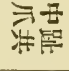 \\
\hline$\infty$ & $\infty$ & $\varphi$ & $\bullet$ & $\stackrel{\infty}{\text { iv }}$ & 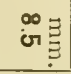 & $\begin{array}{l}v 5 \\
\text { 晏 }\end{array}$ \\
\hline$\stackrel{5}{\Rightarrow}$ & $\vec{s}$ & 索 & $\stackrel{\mathrm{cm}}{-\rightarrow}$ & $\vec{\omega}$ & $\underset{0}{\overrightarrow{5}}$ & 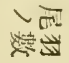 \\
\hline 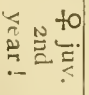 & 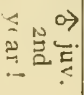 & $\begin{array}{l}\stackrel{\rightarrow}{2} \\
2 \\
2\end{array}$ & $\begin{array}{l}\stackrel{9}{?} \\
\stackrel{0}{2}\end{array}$ & $\begin{array}{l}0 \rightarrow \\
\stackrel{2}{?}\end{array}$ & $\begin{array}{l}\stackrel{0}{0} \\
\stackrel{0}{2}\end{array}$ & $\begin{array}{l}\text { 蕉 } \\
\text { 点 }\end{array}$ \\
\hline : & $=$ & $=$ & : & : & $\begin{array}{l}\text { E } \\
\text { E }\end{array}$ & 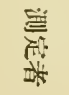 \\
\hline
\end{tabular}

初先喉光 探 列端莸一 集蛗挛び 廣 標 切灰 愢條 品犲淡は后 各內代幣有 部緣 赫䐺 し の色淡中 測び存茶学 定外呈褐 三 侧守色 枚 左次。眼梳 列脇下此 表風㞹及㭬 訅切先び條

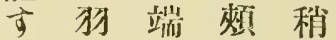
へ内はは淡 し 緣稍稍色 中赤䫒贺 尖褟 部 呈 に色のす 見に色而 る富柇し 淡みにて 代裏近褐 赫雨し灰 色覆胸色 部雅以の はは下極 翼 何下 め の - 尾て 裏 層 筒 不 面赤吩明 に味に睹 一多到な 淡くるる 恋装 各 䖪 色襡犲萦 玟E 赤は斑 色灰范 現々褐見 は㐫芯る す 315 ○郆 側元面 


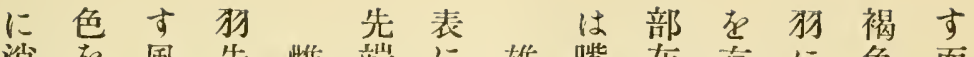
渻盾先雌端に雄嘴灰菅に色而 失見切端三の現三色黑墨あ若し する狗の年带る 年先等 る 腰 外黑 紫鳥喑 一鳥端下 あ

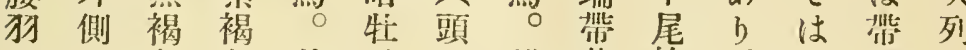
当次色色前丹頂雄茶筒。注黑及群

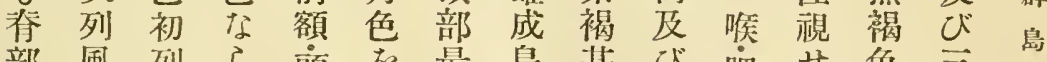

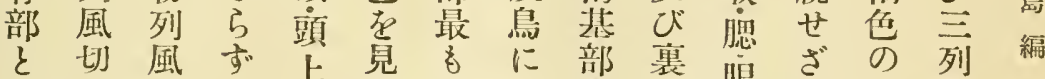

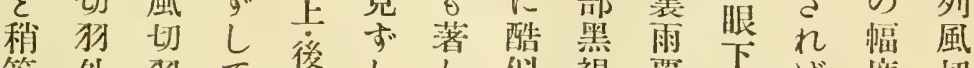

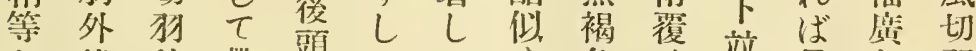

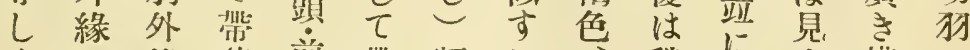
くに緣茶前带額れ、稍䫪出橫に

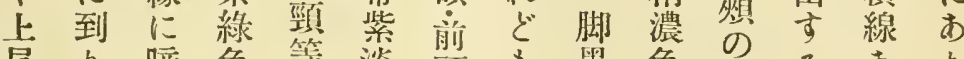

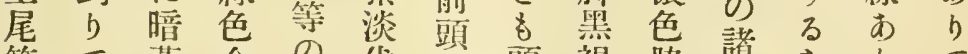

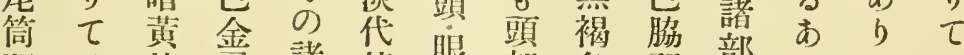

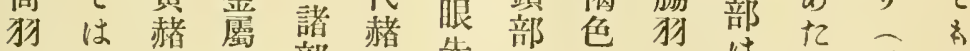

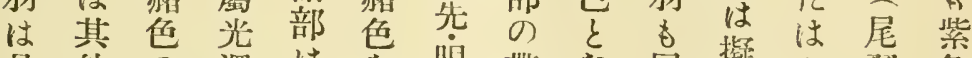

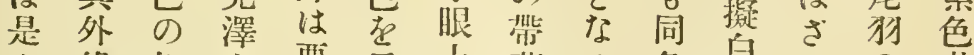

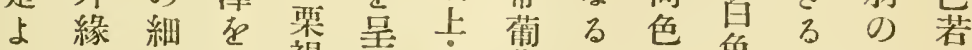

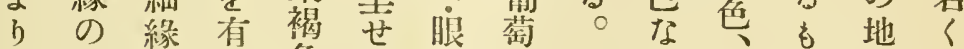
一淡あす寸色b後茶的前の色は

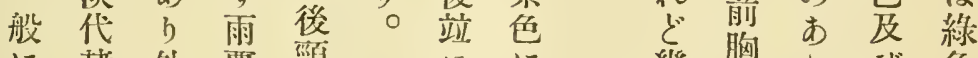
に赫外蕧頸にに幾胸りび色

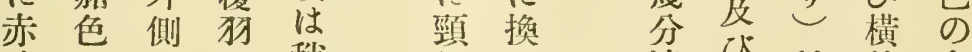
味の初に稍 に幅列む膘はる 富稍虫 b黑、热に

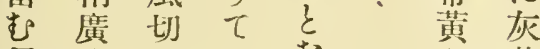
尾く犲 当な白茶

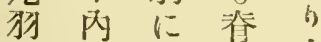
住 侧 褐に肯青 赤到 $\tau$ 色 色数先熛 先永端綠 端從葋色 近 外黄中

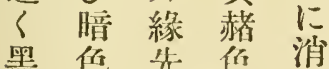

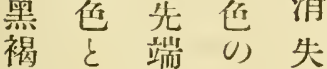
色な管緣夺 幅 b骂上 鹿逐此有奉

色色 胸蛋

部会

は

成地

鳥色

ह क

同带

色䈐

雨色

覆 幾

狗 分

は上
淡稀線金

色摞点心屬

に怔尾色光

$\tau$ 峝狗は澤

金色中齐蛋

光任見

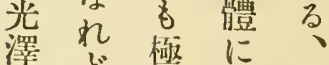

老羿め依尾

有狗 $\tau$ b 旸

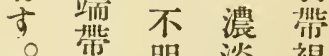

明淡褐

畭息膫嵒灰

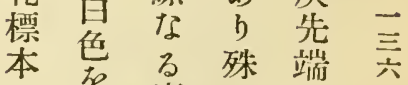

に售鹰に近

あ等斑中?

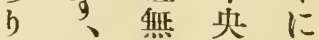

$\tau$ 腹數尾黑 


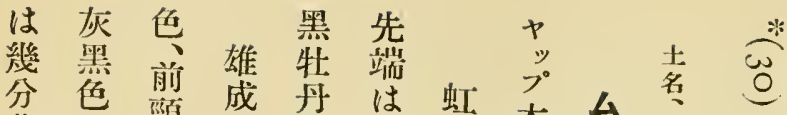
紫先頸鳥色稍箖本台

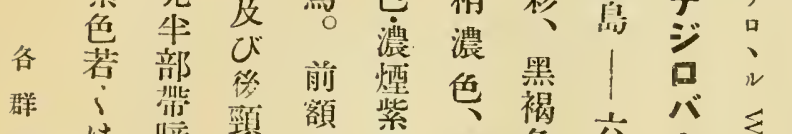

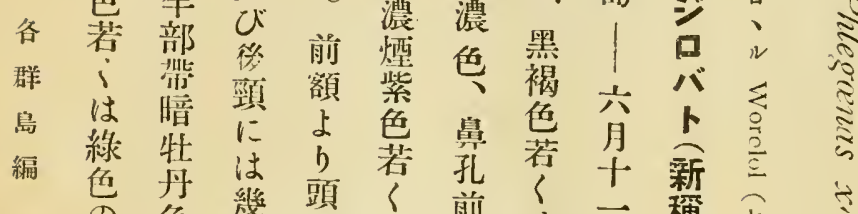

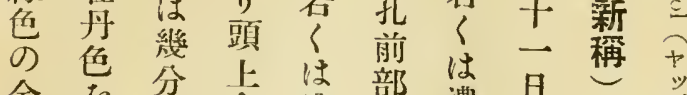

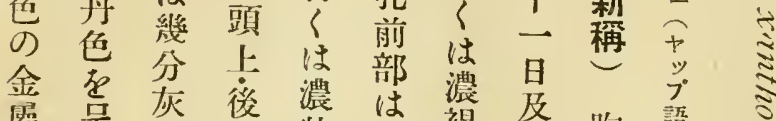

煞呈黑頭特

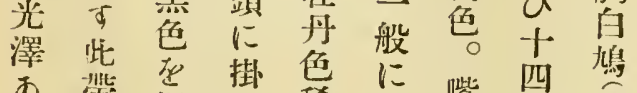

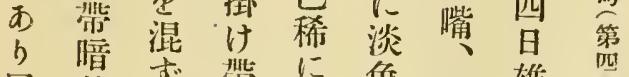

風牡ず帶に色角雄圆

切丹上蒲源に珑版

狗色秦萄紅梁色烏第

はは狗秀色带带各阅

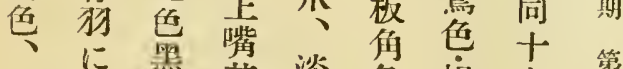

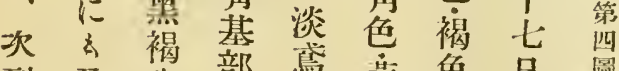

列及先部雼意色日间

鳩

鴿

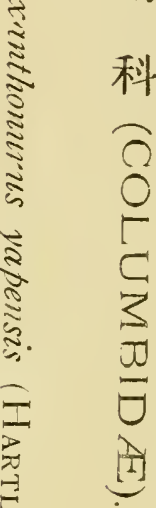

風心端接角褐莀雄管

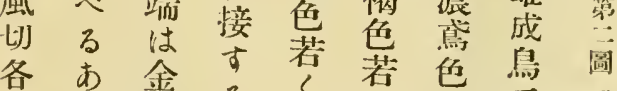

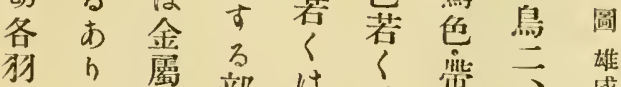

に、光部はは带下成

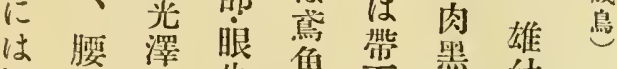

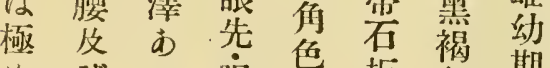

めび 眼色板色期

$\tau$ 上紫後黑若

不尾褐部

吸筒色站

まな嘹雨钼

五る褐蕧側

鷹 灰 狗等

琵色基は

を先生秒

有 端 部淡

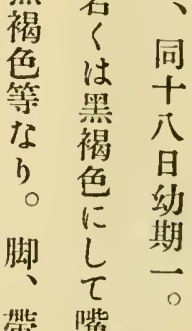



Birds of Mieronesia. Pl. IV.

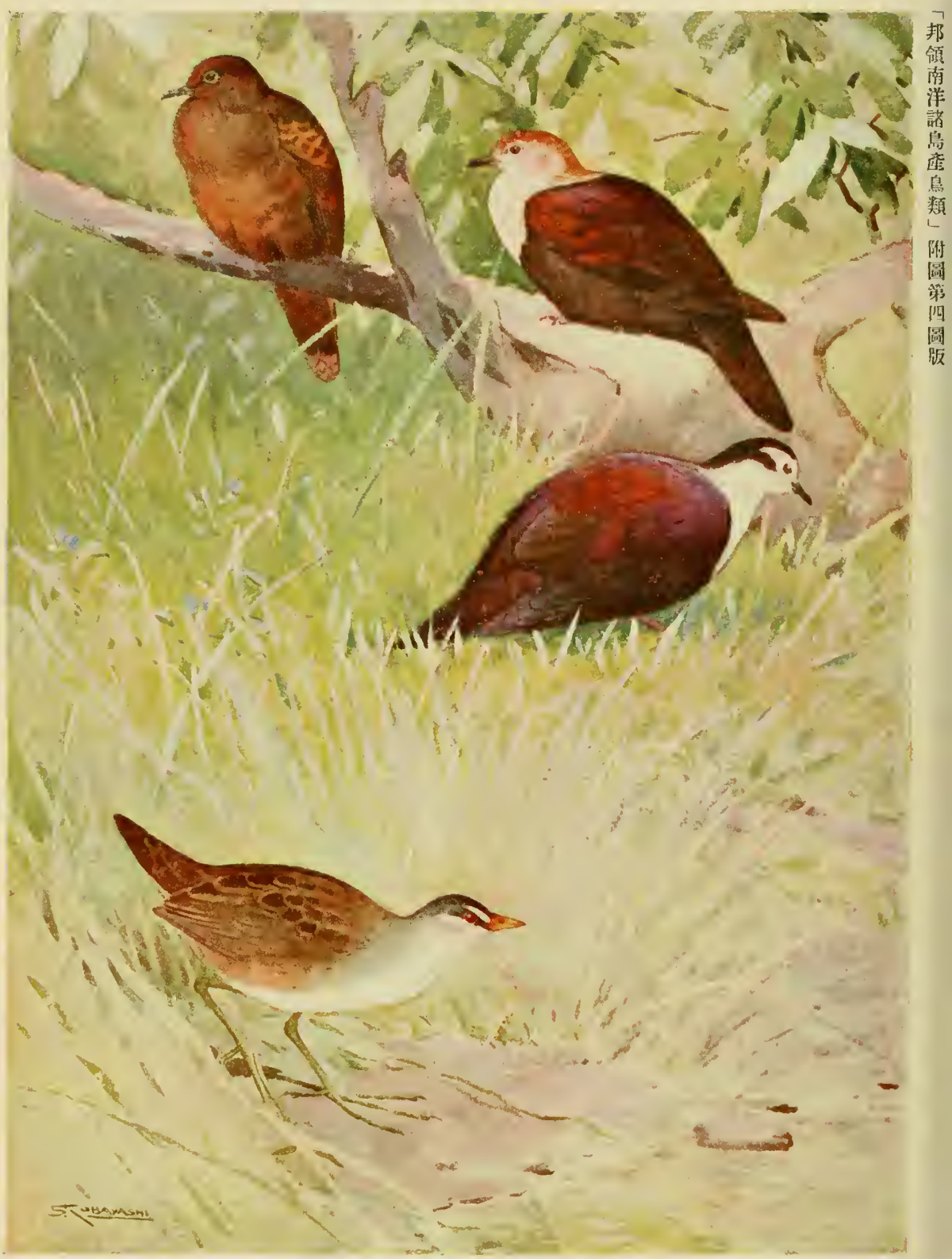



'hlegonus diuthunurus yafensis: p. 135.

$$
\text { ムナジロパト }
$$

Fig. I. 오 subad.

Yap I., Yap Is.

เ8/vi, โ9. (No. 234).
Iin. 2. $\hat{\mathrm{s}} \mathrm{ad}$,

Yap I., Yap Is.

11/vi, Ig. (No. 16.3).

Phleganus labaryi: p. 138.

マミムナジロバト

Fig. 3. 5 ad.

Ponapé I., Seniavina group. $28 /$ vii, 19. (No. 362).

Polimrinmes cimerew, subsp. : p. 77 .

ナンョウマミジクトナ

Fig. 4. 5 ad.

Yap I., Yap Is.

19/vi, 10. (No. 236). 
上るにる淺類あ日

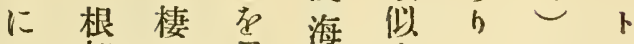

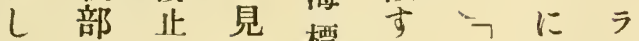
てかする 標る り光

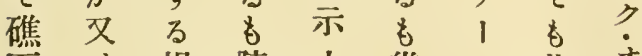
面洼場陸木幽〉此才 全下合岸㳖分府種 部方生の栖之脽一个

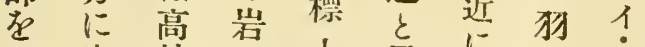

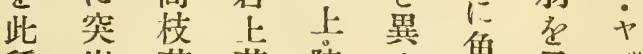
種出若若陸当魚首。” の世纪岸點群整 ?

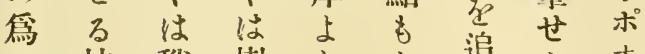

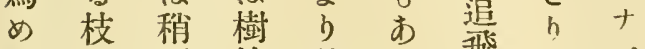

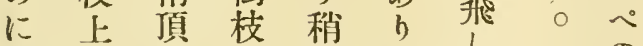
覆に在上隔、居時 の

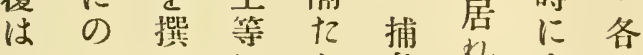

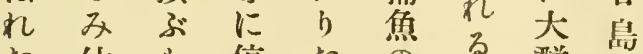

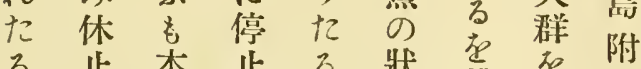

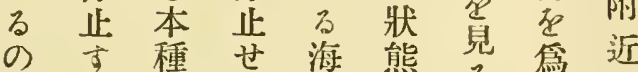

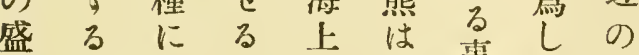
觀性あはに該事二海

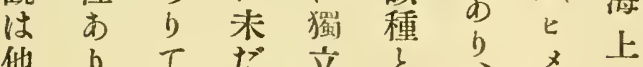

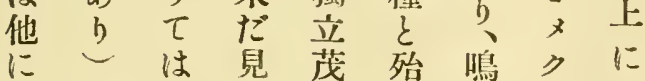
比最常ざ生ん䉪口稀 類るとるぜはアな な大沛處る同アデら

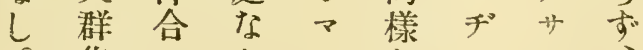
集点占

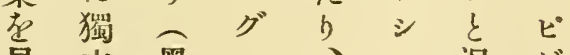
見立黑口、湿唯

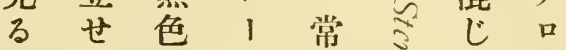

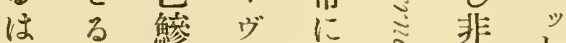
海小刺樹海常卜 上林類林中气常島

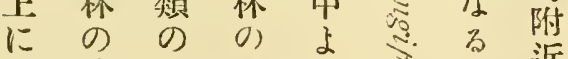
個枝? 根 立翰之部突气群海 世学等出的上

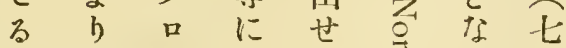

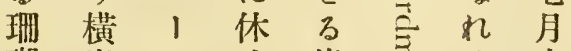
瑚出占止岩了万十 礁せ樹世上に事四

\begin{tabular}{|c|c|c|}
\hline : & $\begin{array}{l}\text { 说 } \\
-\end{array}$ & 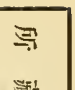 \\
\hline$=$ & 菎 & 粬 \\
\hline ॐ & 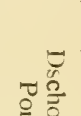 & \\
\hline F & 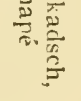 & 禁 \\
\hline 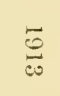 & : & $\begin{array}{l}= \\
=\end{array}$ \\
\hline 1 & 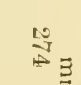 & $\Rightarrow$ \\
\hline & & 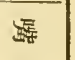 \\
\hline 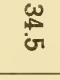 & 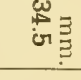 & \# \\
\hline 㩊 & 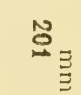 & 蚘 \\
\hline 苞 & $\overrightarrow{\mathrm{s}}_{\overline{\mathrm{z}}}$ & $\Rightarrow$ \\
\hline$\vec{\omega}$ & & 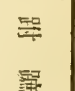 \\
\hline 䔍 & N & 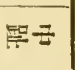 \\
\hline & 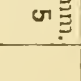 & \\
\hline 党 & ${ }^{\infty} \overline{\underline{\underline{E}}}$ & $\Rightarrow$ \\
\hline 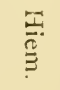 & 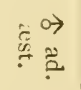 & 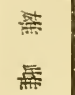 \\
\hline$=$ & $\begin{array}{l}\text { 蓝 }\end{array}$ & 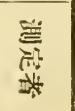 \\
\hline
\end{tabular}




\begin{tabular}{|c|c|c|c|c|c|c|c|c|c|c|}
\hline : & : & : & : & : & : & $=$ & $\begin{array}{l}E \\
E\end{array}$ & : & 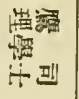 & 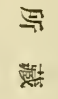 \\
\hline 里 & 虫 & $\begin{array}{l}\stackrel{\infty}{\infty} \\
\stackrel{\infty}{⺊}\end{array}$ & 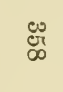 & $\stackrel{\mathscr{c}}{\mathrm{g}}$ & ङू & ङ્ & 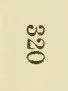 & $\begin{array}{l}\mathrm{J}_{\mathrm{g}} \\
\mathrm{d}\end{array}$ & $\stackrel{\vec{c}}{\vec{g}}$ & 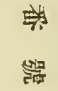 \\
\hline 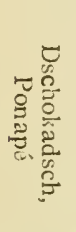 & $\begin{array}{l}z \\
\vdots \\
\vdots \\
0 \\
0 \\
\vdots \\
0 \\
0\end{array}$ & : & $=$ & : & $=$ & 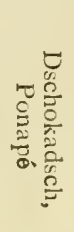 & 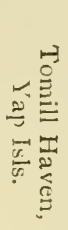 & : & 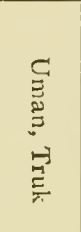 & 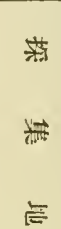 \\
\hline$=$ & $\begin{array}{l}\frac{\varphi}{\vdots} \\
\vdots \\
\vdots\end{array}$ & $\begin{array}{l}\bar{y} \\
\vdots \\
\vdots \\
\vdots \\
\vdots\end{array}$ & : & : & $=$ & $\begin{array}{l}\frac{5}{0} \\
\vdots \\
\vdots \\
\vdots\end{array}$ & $\begin{array}{l} \pm \\
\leq \\
=\end{array}$ & : & $\begin{array}{c}\bar{\Xi} \\
\vdots \\
0 \\
0\end{array}$ & $\begin{array}{l}= \\
=\end{array}$ \\
\hline$\stackrel{10}{\mathscr{E}}$ & $\begin{array}{l}10 \\
0 \\
0\end{array}$ & $\begin{array}{l}10 \\
\mathscr{D} \\
\infty \\
\infty\end{array}$ & $\begin{array}{l}10 \\
\stackrel{10}{10}\end{array}$ & - & 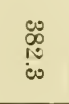 & \begin{tabular}{l}
10 \\
$\infty$ \\
\hdashline
\end{tabular} & $\begin{array}{l}19 \\
\varnothing 0 \\
0 \\
\text { eे }\end{array}$ & 1 & $1 \Xi$ & $\begin{array}{l}y \\
4\end{array}$ \\
\hline$\omega$ & $\underset{\omega}{\omega}$ & $\begin{array}{l}\underset{\mathscr{W}}{\sigma} \\
\dot{\sigma}\end{array}$ & $\begin{array}{l}\omega \\
\text { Gr }\end{array}$ & 苑 & $\underline{\omega}$ & $\mathscr{\omega}$ & $\begin{array}{l}\omega \\
\text { or }\end{array}$ & $\underset{\varkappa}{\omega}$ & 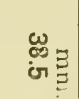 & $\begin{array}{l}\text { 退 } \\
\text { 些 }\end{array}$ \\
\hline$\stackrel{N}{0}$ & 气̆ & $\sum_{\vec{*}}^{\stackrel{\leftrightarrow}{*}}$ & 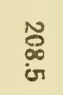 & $\stackrel{N}{\stackrel{N}{*}}$ & 号 & $\begin{array}{l}\text { No } \\
\text { के } \\
\text { जा }\end{array}$ & $\stackrel{N}{O}$ & 兽 & $\stackrel{N}{\vec{N}} \Xi$ & 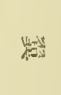 \\
\hline $\begin{array}{l}\text { N } \\
\text { G }\end{array}$ & $\overrightarrow{\underline{N}}$ & $\begin{array}{l}\vec{G} \\
\text { जा }\end{array}$ & 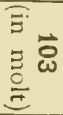 & $\underset{\text { G }}{\stackrel{N}{S}}$ & $\underset{\infty}{\vec{N}}$ & N & $\underset{\omega}{\omega}$ & $\underset{\text { G }}{\stackrel{N}{. ~}}$ & $\begin{array}{l}\vec{N} \\
\text { ơ } \\
\vdots\end{array}$ & tr. \\
\hline$\vec{\infty}$ & $\vec{\varphi}$ & $\vec{\forall}$ & $\vec{\infty}$ & $\overrightarrow{\text { G }}$ & जे & $\vec{\oplus}$ & $\Rightarrow$ & ज্ & 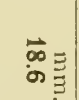 & 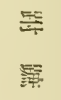 \\
\hline$\stackrel{\sim}{\$}$ & $\stackrel{\sim}{\sim}$ & స్ & N & $\stackrel{N}{N}$ & $\tilde{\omega}$ & స్ట & స్ట & 墕 & $\begin{array}{l}\text { ज. } \\
\text { No }\end{array}$ & $\begin{array}{l}\text { 孯二 } \\
\text { 决 }\end{array}$ \\
\hline$\omega$ & $\stackrel{\infty}{\sigma}$ & $\stackrel{\infty}{\dot{\sigma}}$ & $c 0$ & $\stackrel{\infty}{\infty}$ & 0 & $\stackrel{\infty}{\dot{\theta}}$ & $\stackrel{\infty}{\dot{\sigma}}$ & जै & $\stackrel{0}{\sim} \underset{3}{3}$ & $\begin{array}{l}\text { 哭 } \\
\text { ॠレ }\end{array}$ \\
\hline 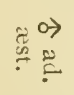 & $\ddot{0}$ & tֶ to & 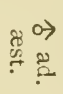 & $\begin{array}{l}\overbrace{\text { to }}^{\text {to }} \\
\stackrel{n}{*} \text { है }\end{array}$ & 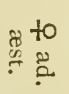 & 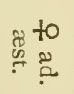 & 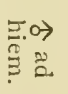 & 궁 & 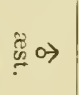 & $\begin{array}{l}\text { 帛 } \\
\text { 要 }\end{array}$ \\
\hline : & $=$ & $=$ & : & $=$ & : & : & : & : & $\begin{array}{l}\text { E } \\
E\end{array}$ & 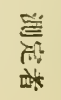 \\
\hline
\end{tabular}




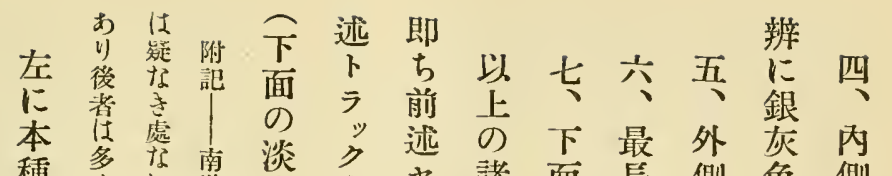
種多れ洋朱産学諸面長侧色侧

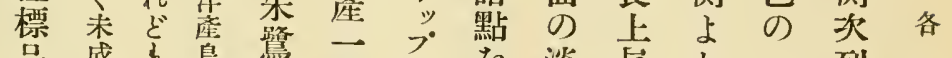

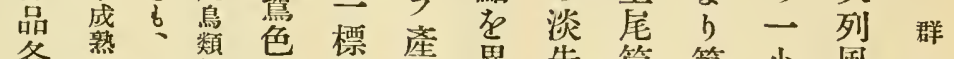

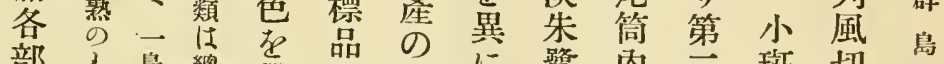

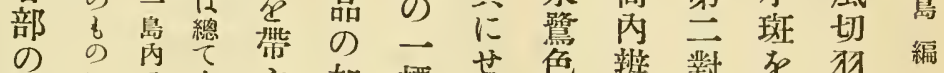
测に年ぶ如標せ色辨對を犽編 定多同帮るき竞る はに自有外

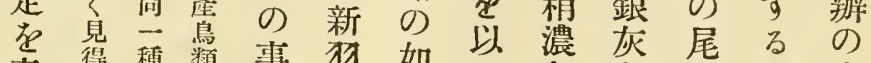
表得種霓事雅如色色旸事大

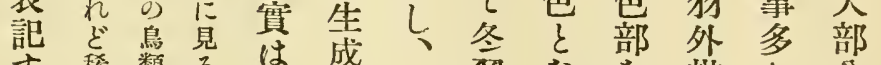

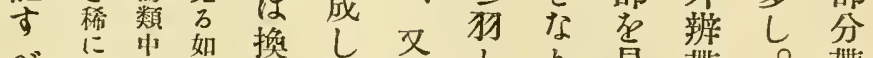
べ老に々 狗更夏 し点二条にに冴は稀る黑灰 之早士依內 备夏 5 的見頸の色 色

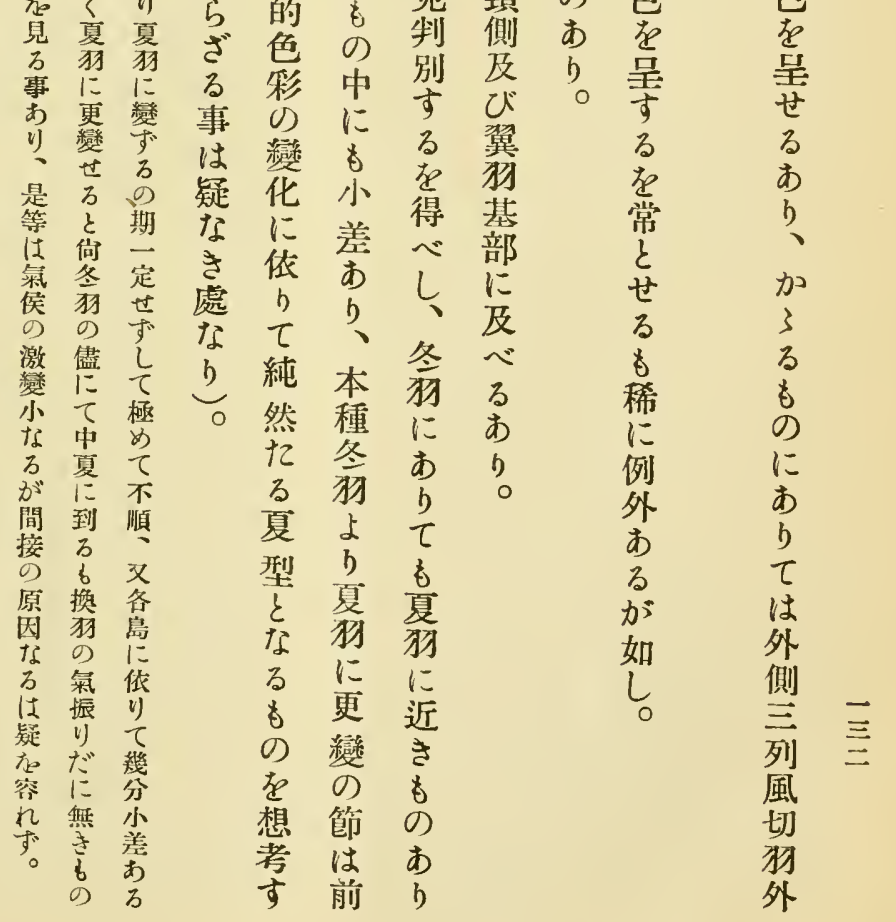




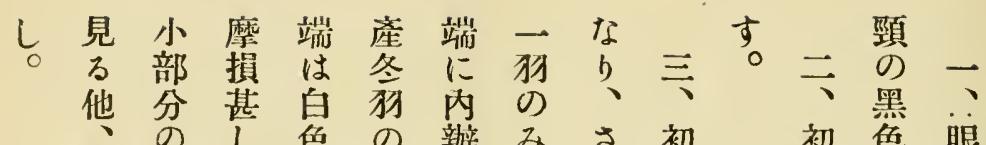
兩銀さ乵にれ䘞副部先 各辦灰舊卜標侧て ぞ風 群內色狗亏本自第此切 荡 緣第

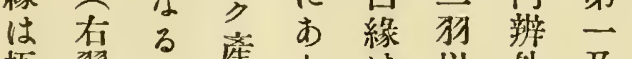

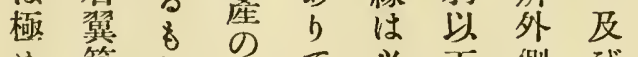
め第他 - て 必下側 び て一卧標は吉はの第 淡狗禁初蕉外白兰 きに本列出辨色の 銀 $\tau$ 換 鹰風 灰は碔筍切具匹゙は狗 色注狗司第各內常は

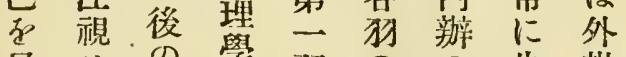
呈せ學旸の靠辨 ず新声外着内端黑 るれ狗藏辦色侧に色 すばな藏慰はの達、 初見b み内銀寺狗 列落而留方灰る軸 風吉し心灰江色事白 切虞て 会黑到蛋子色 中何第に色学亭し内 れb 第七 而從る間辨 の左三はし內

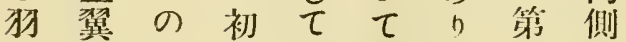
辨第兩列先徐、兰は

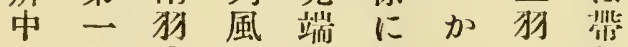

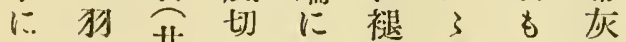
の基第到色る 同黑 带专新音当せ点色

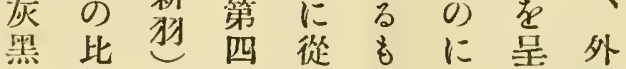
色較外のひ市 部的辦爾淡飞占るは 尼先旸色重的幅 見な端の主。は考 るりにみな爷备、き 事已各旸口品旸又白 な在一端末

雨に上 覆及 呵 ぶ 後 外頸 辨留に に同連 \begin{tabular}{lll} 
滞 & $L_{0}$ & $\vdots$ \\
黑 & 0 & 黑 \\
\hline
\end{tabular} 灰色 菓眼 呈線 せ 中 る に 狗白 毛色 角 尠 か 若 b す は 混白 李色 依湿 七 世 糞当 の 狗 前毛 䋑 


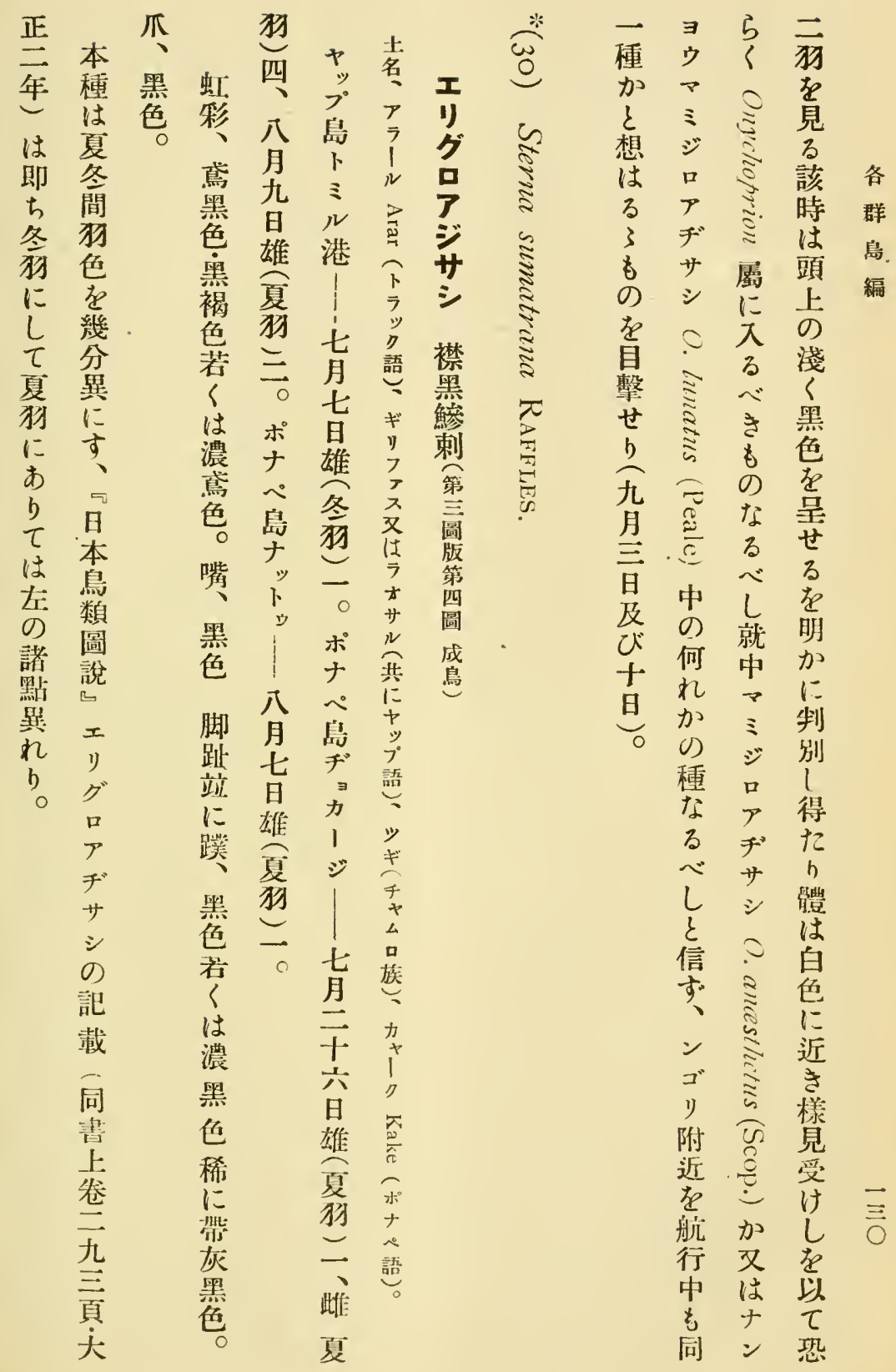




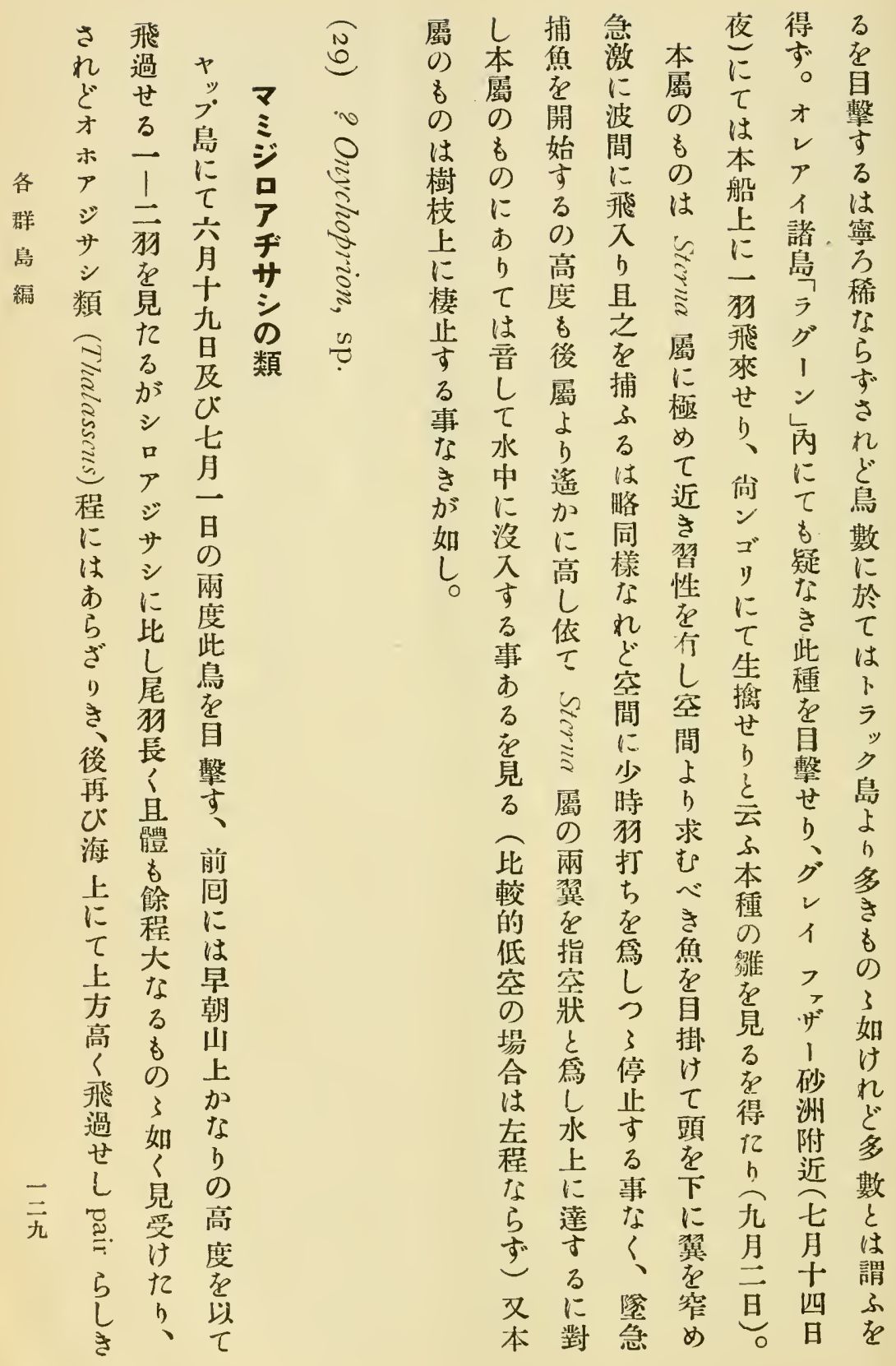




\begin{tabular}{|c|c|c|c|c|c|c|c|c|c|}
\hline $\begin{array}{l}\text { ト } \\
\text { ラ }\end{array}$ & : & : & : & $=$ & $\begin{array}{l}\text { 三 } \\
\equiv\end{array}$ & 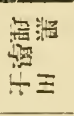 & $\begin{array}{l}\text { 这 } \\
\equiv\end{array}$ & 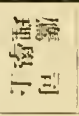 & 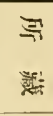 \\
\hline 夏 & $\stackrel{\Xi}{\Xi}$ & $\stackrel{5}{5}$ & $\grave{\vdots}$ & 产 & $\begin{array}{c}0 \\
\text { o' } \\
\text { o }\end{array}$ & ن & 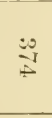 & 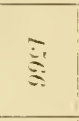 & 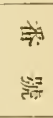 \\
\hline $\begin{array}{l}\text { 及 } \\
\text { び } \\
\text { 水 } \\
\mathrm{B}_{11}^{1}\end{array}$ & : & $\begin{array}{l}\vec{E} \\
\vec{E}\end{array}$ & $=$ & : & : & : & 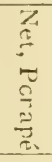 & 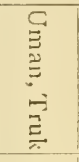 & 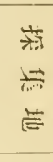 \\
\hline $\begin{array}{l}\frac{15}{n j} \\
\frac{15}{5}\end{array}$ & : & $\frac{t 5}{\bar{k}}$ & $=$ & $\begin{array}{l}=7 \\
\equiv \\
\equiv\end{array}$ & : & : & $\begin{array}{l}10 \\
: \\
=1\end{array}$ & $\bar{\Xi}$ & $\begin{array}{l}5= \\
5=\end{array}$ \\
\hline $\begin{array}{l}\text { 华 } \\
\text { 等 } \\
\text { 足 }\end{array}$ & 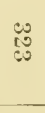 & 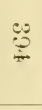 & $\ddot{\mathscr{g}}$ & :30 & $\underset{+}{\infty}$ & 家 & 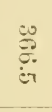 & 1 & $\begin{array}{l}-\overrightarrow{0} \\
\dot{\Delta}\end{array}$ \\
\hline $\begin{array}{l}\text { あ } \\
ま \\
b\end{array}$ & $\vec{\omega}$ & जু & I & $\frac{g}{a}$ & $\frac{\text { or }}{\text { or }}$ & G & $\begin{array}{l}\text { D } \\
\text { on }\end{array}$ & ๙ & 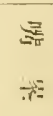 \\
\hline $\begin{array}{l}\text { 隔 } \\
5 \\
5\end{array}$ & $\exists$ & $\overrightarrow{\mathrm{v}}$ & के & $\vec{\sigma}$ & $\vec{v}$ & न & $\overrightarrow{\mathrm{G}}$ & $1 \bar{\Xi}$ & $\begin{array}{l}\text { 롱 } \\
\Xi \\
\Xi\end{array}$ \\
\hline $\begin{array}{l}\text { d } \\
\text { 交 } \\
\text { 游: }\end{array}$ & $\underset{\rho}{\omega}$ & $\begin{array}{l}\text { W } \\
\text { ज़ }\end{array}$ & $\underset{v}{w}$ & 㤎 & $\stackrel{\triangleq}{\varrho}$ & 产 $\omega$ & 记 & 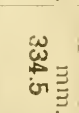 & $=1$ \\
\hline$\frac{上}{\frac{1}{x^{4}}}$ & ज̆ & $\vec{~}$ & స్ & $\begin{array}{l}\vec{\sigma} \\
\text { in }\end{array}$ & $\overrightarrow{\mathrm{N}}$ & 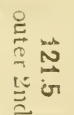 & $\overrightarrow{\underline{\Xi}}$ & $\overrightarrow{\mathrm{c}}_{\overrightarrow{\mathrm{c}}}$ & $E$ \\
\hline $\begin{array}{l}\text { び } \\
\text { 過 } \\
\text { ぐ }\end{array}$ & $\stackrel{\sim}{\sim}$ & $\vec{y}$ & $\mathrm{~N}$ & $\mathrm{~N}$ & $\stackrel{N}{\circ}$ & जै & जิ & जै & 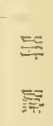 \\
\hline $\begin{array}{l}3 \\
\text { 总 } \\
\text { 間 } \\
\text { 々 }\end{array}$ & $\begin{array}{l}\omega \\
\text { or }\end{array}$ & $\omega$ & $\begin{array}{l}\mathcal{N}^{\prime} \\
\text { or }\end{array}$ & $\begin{array}{l}W_{N} \\
\text { טיר }\end{array}$ & $\begin{array}{l}\omega \\
\text { or }\end{array}$ & $\underset{\dot{\sigma}}{\omega}$ & $\stackrel{\leftrightarrow \Delta}{\phi}$ & $1 \equiv$ & 言 \\
\hline $\begin{array}{l}\text { 目 } \\
\text { 慗 } \\
\text { せ }\end{array}$ & $\stackrel{\infty}{\infty}$ & $\overrightarrow{0}$ & $\infty$ & $\overrightarrow{0}$ & or & or & 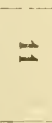 & $\stackrel{\infty}{\sigma \equiv}$ & $\begin{array}{l}\bar{\vdots} \\
\overline{5}\end{array}$ \\
\hline L & $\begin{array}{l}\text { to } \\
\text { : }\end{array}$ & $\begin{array}{l}\text { to } \\
ٍ \\
\varrho\end{array}$ & 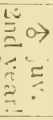 & 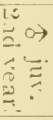 & $\begin{array}{l}5 \\
\vdots \\
0 \\
\vdots \\
\vdots\end{array}$ & 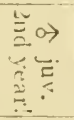 & 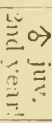 & 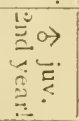 & $\begin{array}{l}\text { 늘 } \\
\text { 올 }\end{array}$ \\
\hline $\begin{array}{l}\text { 數 } \\
\text { 住 } \\
\text { 多 }\end{array}$ & : & : & : & : & : & : & : & $\begin{array}{l}\text { 范 } \\
\equiv\end{array}$ & 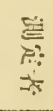 \\
\hline
\end{tabular}




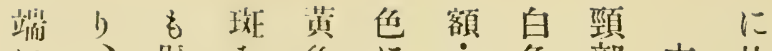
本に、趾在色に䡩色部本此 亞

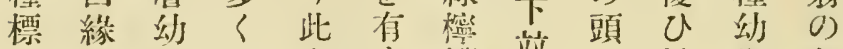

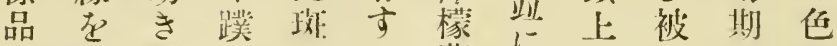

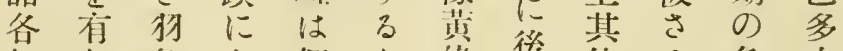

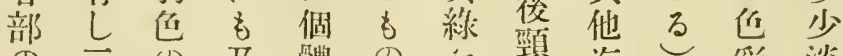

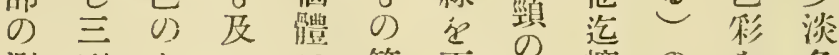

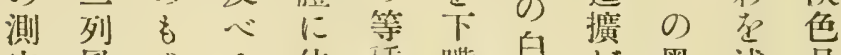

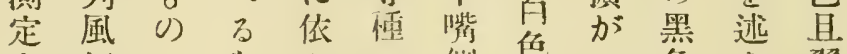
表划に起的部几色ぶ翼

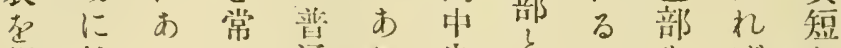

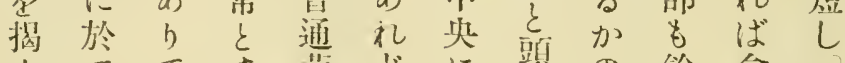

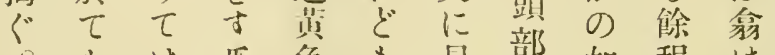

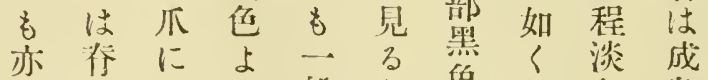
同面於占般市色見色点

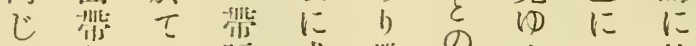

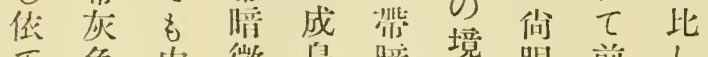
上な 目橙に微刵下䫑稍

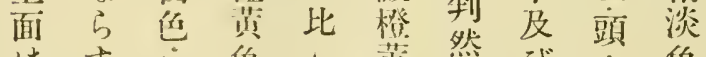

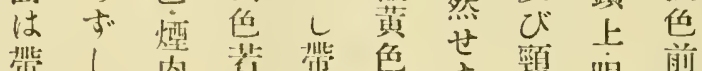

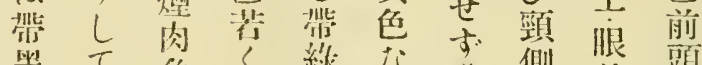

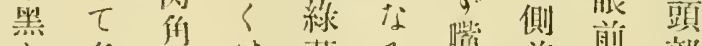

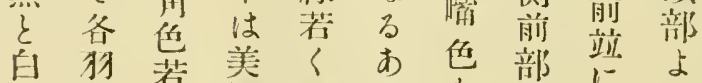

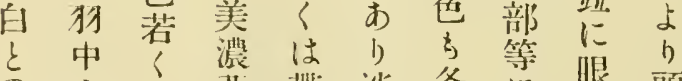

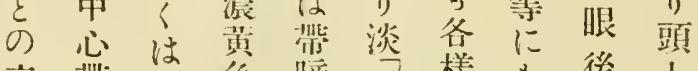

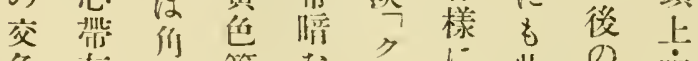

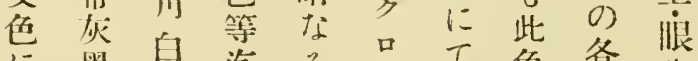

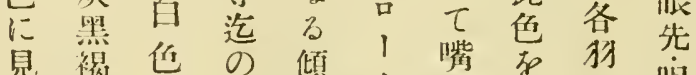

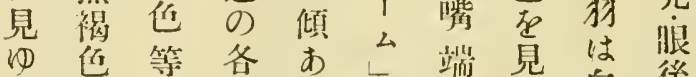

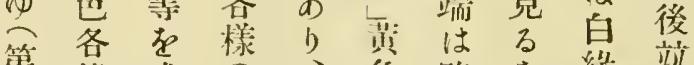

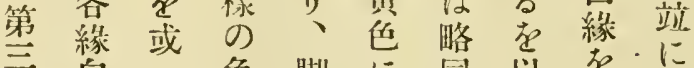

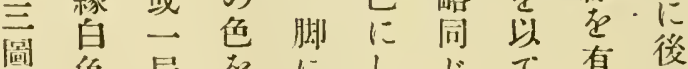
版白局尼にしして有後 右在部現はてけ成し頭

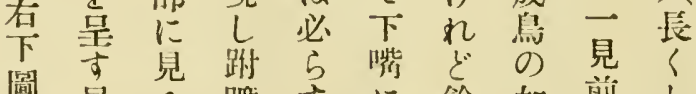

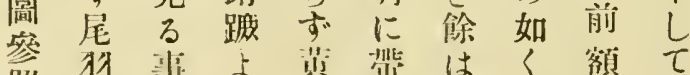

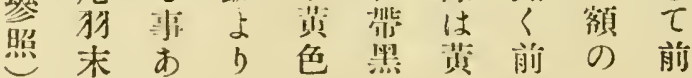




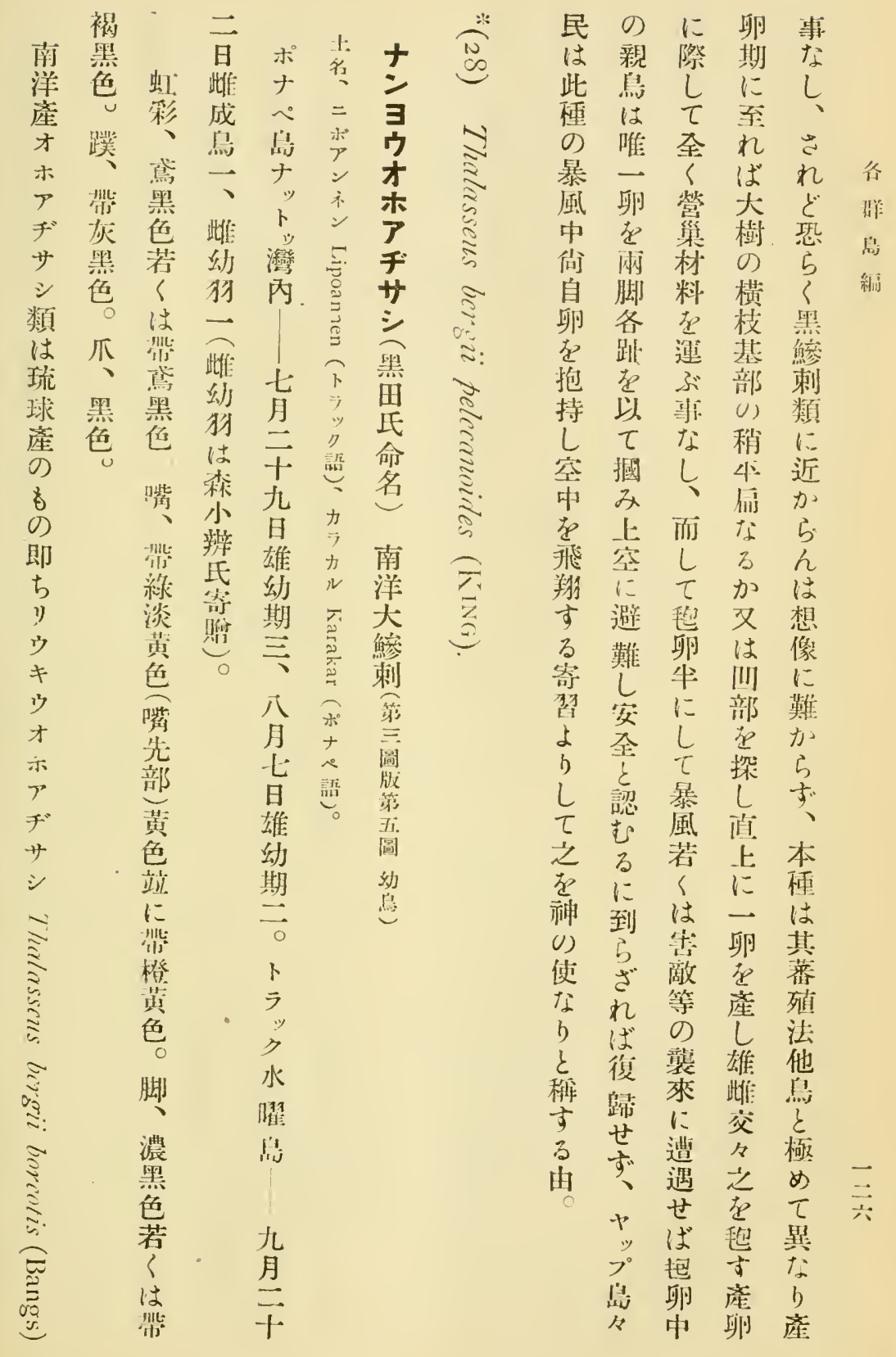




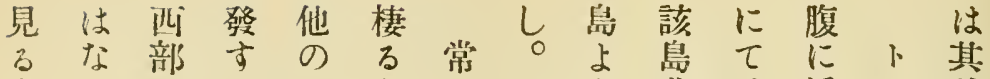

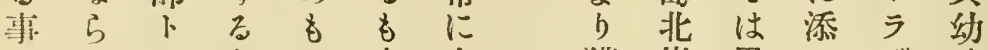
あ九弓在の亦山獲岸黑々”時 れ、”以に楖地 价飞求气王子若 㖓气㙁き前枝樹々

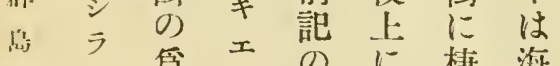
緛 7 破 $\neq$ のに棲海 ネに 如棲 れ岸 海 オ き 夕上 $上 \pm h$ 林

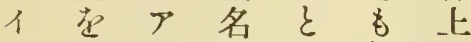
广見 亿尼見在

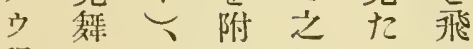
程ふキせにる迴 高了十占近事越

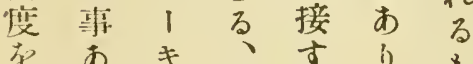

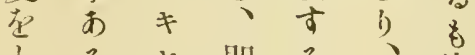
子

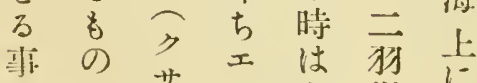

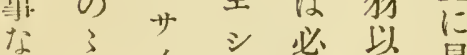
之如今工官上見 米了滗 シ 吉數当 来海の人、狗は

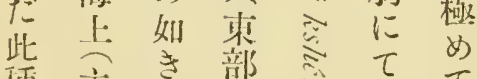

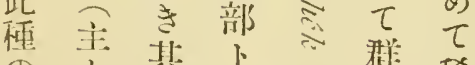

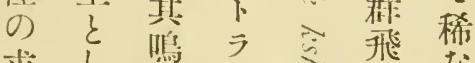

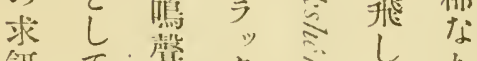

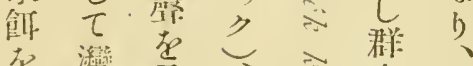
な㜻最、令中好

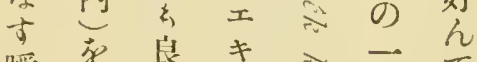

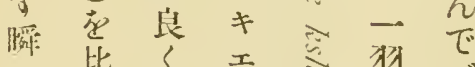

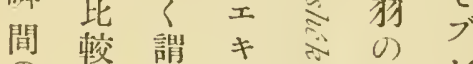
の的 U 、赫 $v$ 姿高琴工と枝ド

三㤰〈はキ炎上〉 五琶飛世的しに 目行るクき漤ド 整せ例 せる照其鎐る上

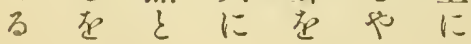

5 附 鯵 $\tau ?$. 0

记近刺飛 生 しに類行 プ 活

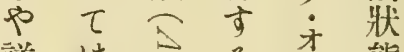
詳はきるオ態

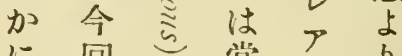
に回常常 せ此混に藏 ず種混見墸せ 即全飛處易 る ちく翔なに現 此見せれて到 種さざるどはな のり点海非る 具崖党事 該揧附票殆

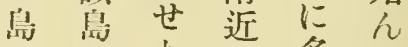
によりに多ど

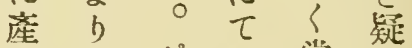
手のポ常な る報ナおにき 事啙 语ま目

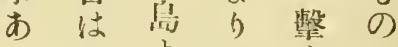
b果よに李了 子 L h 多了姆 る。

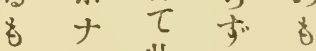
夫へ此さ の は島”褈れた 極に獲 ह゙ ? め $\tau$ 獲 $\checkmark$ $\tau$ 獲 5 ○ 尠られグ サ きれし 。 ᄂ 報 I 易 のか告ヴに た果 お樹法 る其れ林は 心屬ど中川 

Birls of Micronesia. Pl. 111.
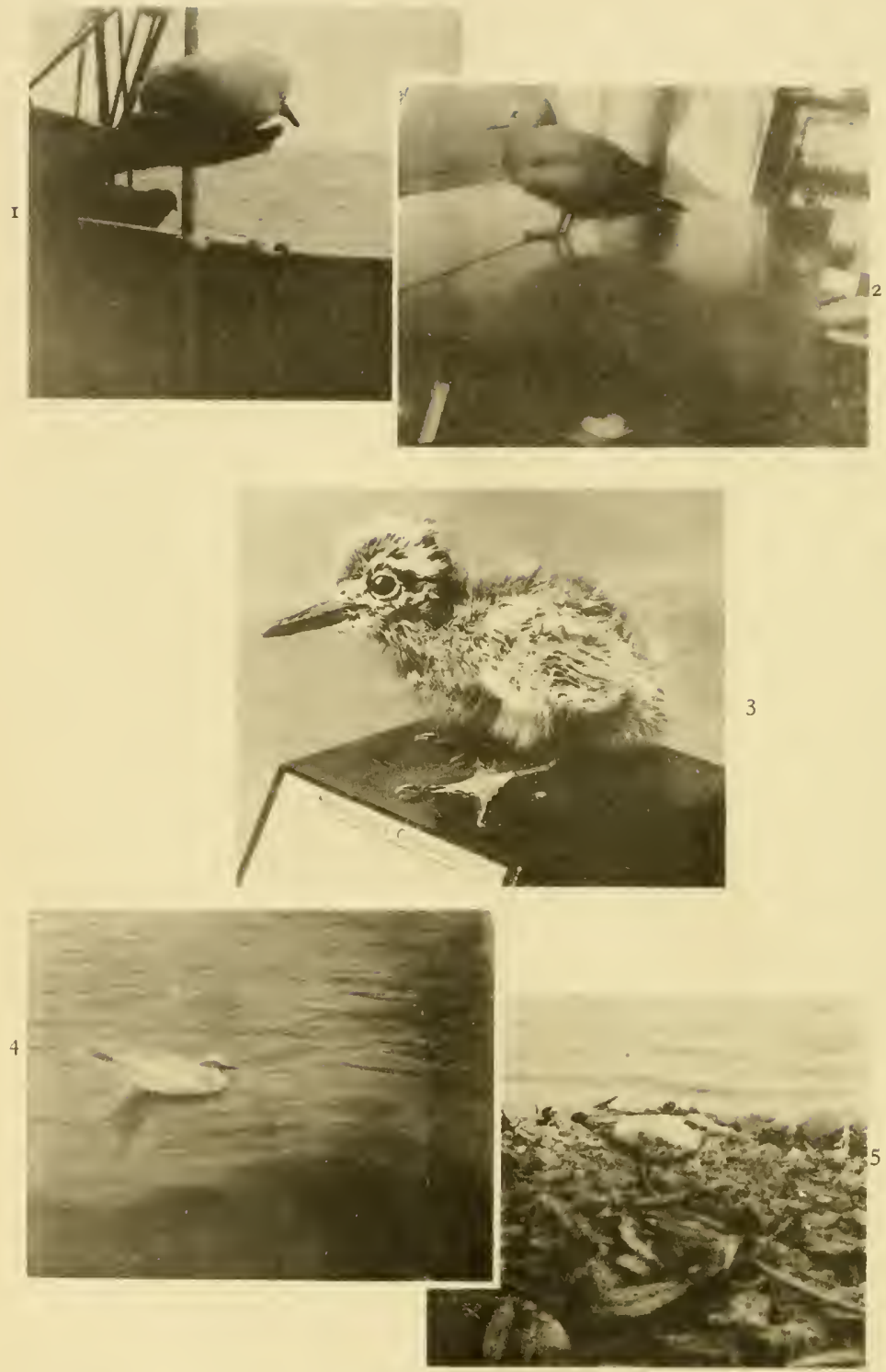

筙 圆 シラキホッタイテウ残維

第二閻 シロピタヘクロアイ゙サシ约照

筜三㬝 シロ

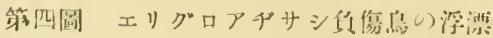

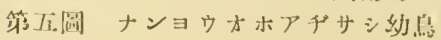




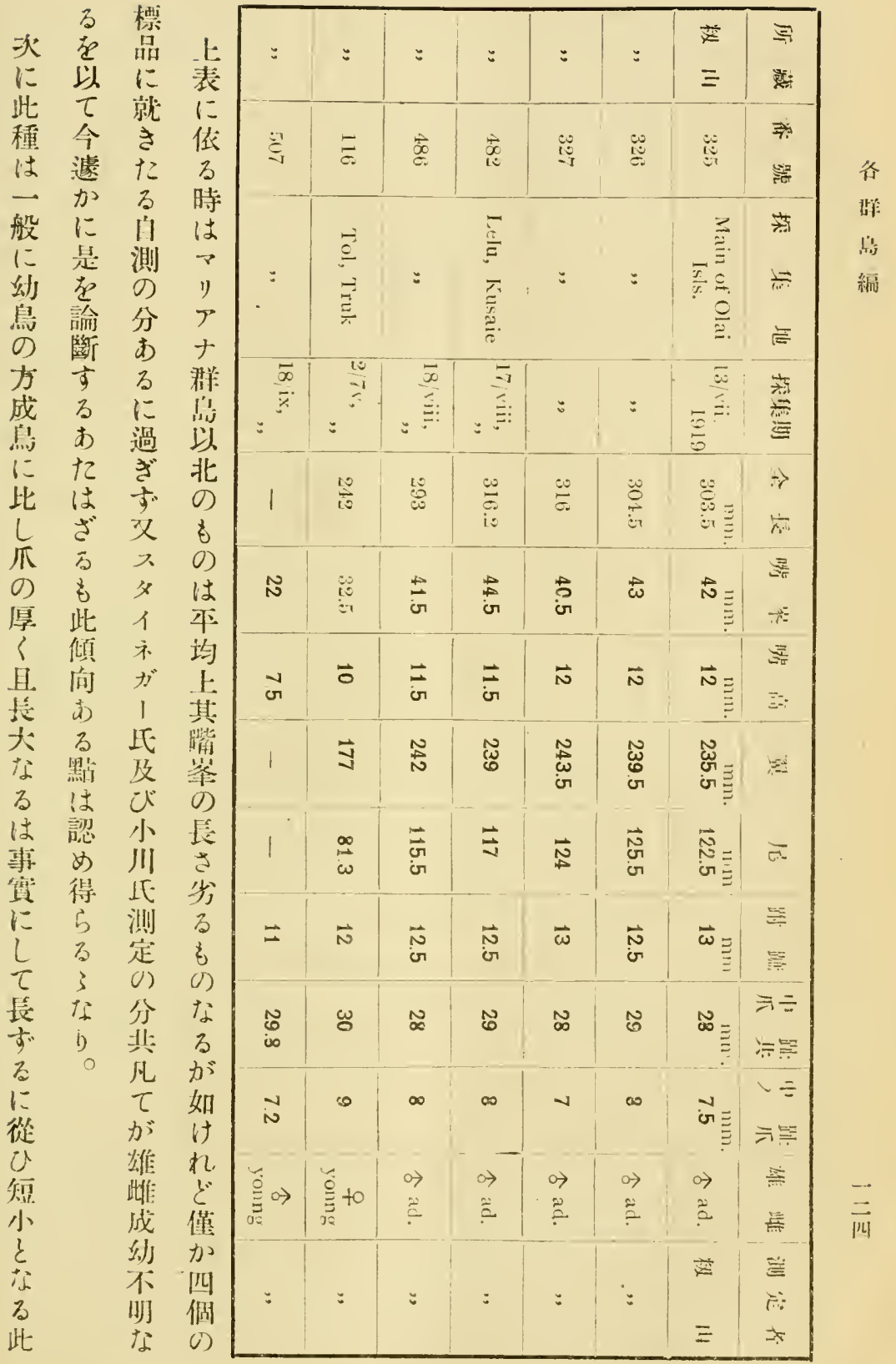




\begin{tabular}{|c|c|c|c|c|c|c|c|c|c|c|}
\hline$=$ & : & : & : & $=$ & $\Sigma$ & : & : & : & : & : \\
\hline $\begin{array}{l}10 \\
20 \\
-7\end{array}$ & $\begin{array}{l}10 \\
y \\
y\end{array}$ & $\stackrel{10}{\mathscr{S}_{0}}$ & $\stackrel{10}{\sigma}$ & 总 & $\begin{array}{l}\frac{19}{10} \\
\stackrel{10}{2}\end{array}$ & $\stackrel{\infty}{\infty}$ & $\overrightarrow{5}$ & $\overline{8}$ & $\overline{\check{\not}}$ & $\overline{3}$ \\
\hline$=$ & $=$ & $=$ & $=$ & $=$ & : & 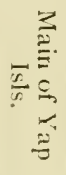 & $=$ & $:$ & $=$ & : \\
\hline $\begin{array}{l}\breve{s} \\
\Xi \\
\Xi \\
\vdots\end{array}$ & $\begin{array}{l}\stackrel{L}{L} \\
\stackrel{+0}{\leq} \\
\vdots\end{array}$ & $\Xi$ & $\frac{15}{5}$ & $\frac{\stackrel{10}{5}}{\vdots}$ & $\begin{array}{l}\frac{5}{5} \\
\vdots \\
\vdots\end{array}$ & $\begin{array}{l}\text { 更 } \\
\vdots \\
\vdots\end{array}$ & $\frac{1}{\infty}$ & $=$ & $=$ & $\begin{array}{l}\stackrel{0}{v} \\
< \\
:\end{array}$ \\
\hline 雚 & $\stackrel{g}{\mathscr{g}}$ & $\stackrel{g}{\rightleftarrows}$ & $\begin{array}{l}10 \\
\stackrel{10}{\infty} \\
:=0\end{array}$ & 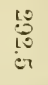 & 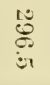 & ب. & $\ddot{\infty}$ & "ٌّ & ఝ్ & $\frac{\omega 0}{\omega 0}$ \\
\hline$\hat{N}$ & $\vec{N}$ & $\vec{\omega}$ & \pm & $\vec{\omega}$ & \pm & 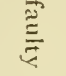 & $\underset{\text { is }}{\vec{S}}$ & $\begin{array}{l}\text { के } \\
\text { or }\end{array}$ & $\underset{\infty}{+}$ & $\underset{\text { G }}{\vec{H}}$ \\
\hline $\overrightarrow{\vec{v}}$ & $\vec{\sigma}$ & $=$ & $=$ & $\Xi$ & $\vec{N}$ & $\overrightarrow{i r}$ & $\overrightarrow{\mathrm{v}}$ & $\overrightarrow{\vec{v}}$ & $\Xi$ & $\vec{\sigma}$ \\
\hline$\tilde{\mathbb{0}}$ & $\underset{0}{N}$ & $\underset{\infty}{\infty}$ & $\begin{array}{l}\text { W } \\
\text { जu }\end{array}$ & జ్ల్ర & $\stackrel{N}{N}$ & $\underset{\$}{\mathbb{N}}$ & $\stackrel{\vec{\omega}}{\omega}$ & $\begin{array}{l}\text { W } \\
\dot{\infty} \\
\text { G }\end{array}$ & స్ట్ర & 菅 \\
\hline $\begin{array}{l}\overrightarrow{\vec{\sigma}} \\
\vec{v}\end{array}$ & $\vec{N}$ & $\underset{\text { i }}{\stackrel{N}{(}}$ & 三 & $\begin{array}{l}\vec{ज} \\
\text { ज़ }\end{array}$ & $\vec{\Xi}$ & $\overrightarrow{\vec{G}}$ & $\vec{\infty}$ & $\vec{N}$ & $\begin{array}{l}\vec{\circ} \\
\text { ज़ }\end{array}$ & $\vec{\omega}$ \\
\hline $\begin{array}{l}\vec{N} \\
\text { जr }\end{array}$ & $\vec{N}$ & $\vec{v}$ & $\vec{N}$ & $\Xi$ & $\vec{\omega}$ & $\vec{\omega}$ & $\vec{\omega}$ & $\vec{\omega}$ & $\vec{N}$ & $\vec{\omega}$ \\
\hline $\begin{array}{l}\text { ज़ } \\
\text { ज़ }\end{array}$ & $\begin{array}{l}\text { I } \\
\text { or }\end{array}$ & $N$ & ల్ర & $\underset{\text { G }}{N}$ & $N$ & $\underline{\omega}$ & $\begin{array}{l}\text { N } \\
\text { or }\end{array}$ & $\underset{\sigma}{\omega}$ & 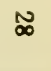 & N \\
\hline जे & or & जे & $\infty$ & $\checkmark$ & $\checkmark$ & $\begin{array}{l}\infty \\
\dot{\sigma}\end{array}$ & जे & $\stackrel{\infty}{\mathfrak{G}}$ & $\checkmark$ & $\infty$ \\
\hline 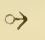 & $\rightarrow$ & to & $\leftrightarrow \rightarrow$ & $0 \rightarrow$ & $0 \rightarrow$ & to & @) & to & $\rightarrow$ & o) \\
\hline$\stackrel{2}{2}$ & $\cong$ & 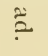 & $\stackrel{n}{2}$ & 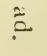 & $\ddot{\Xi}$ & 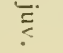 & $\overleftrightarrow{\varrho}$ & 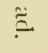 & 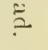 & $\stackrel{\triangleq}{\Xi}$ \\
\hline : & : & $=$ & : & $=$ & $=$ & : & $=$ & : & : & : \\
\hline
\end{tabular}




\begin{tabular}{|c|c|c|c|c|c|c|c|c|c|c|}
\hline : & : & : & : & $\begin{array}{l}\vec{Y} \\
\equiv\end{array}$ & & : & $=$ & $\begin{array}{l}\equiv \\
\equiv\end{array}$ & 1 & $\begin{array}{l}\Xi \\
\exists \\
\text { se }\end{array}$ \\
\hline S. & i & $\stackrel{\mathrm{c}}{\leftrightarrows}$ & $\doteq$ & 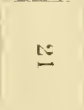 & 1 & 5 & $\stackrel{2}{2}$ & $=0$ & 1 & $\begin{array}{l}\text { \# } \\
\text { 端 }\end{array}$ \\
\hline : & : & $\begin{array}{l}\overrightarrow{0} \\
\vec{\Xi} \\
\vec{E}\end{array}$ & 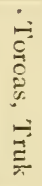 & 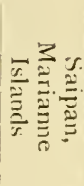 & 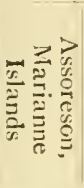 & : & $\begin{array}{l}5 \\
3 \\
0\end{array}$ & 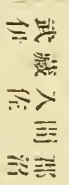 & $\bar{\sigma}$ & $\begin{array}{l}\text { 荡 } \\
\vdots \\
\vdots\end{array}$ \\
\hline $\begin{array}{l}\frac{n}{0} \\
\vdots \\
\vdots\end{array}$ & $=$ & $\begin{array}{l}\bar{x} \\
\vdots \\
\vdots\end{array}$ & $\begin{array}{l}\frac{E}{E} \\
\vdots\end{array}$ & $\begin{array}{l}\frac{1}{5} \\
5 \\
5 \\
0\end{array}$ & 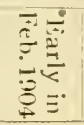 & $:$ & $\bar{v}$ & 产 & 1 & 音 \\
\hline$\ddot{Q}$ & $\stackrel{\mathscr{e}}{\stackrel{\omega}{\oplus}}$ & $\underset{10}{\stackrel{q}{*}}$ & 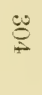 & ?ב: & 1 & 1 & 1 & & $1 \equiv$ & $\begin{array}{l}-\vec{r} \\
x^{m}\end{array}$ \\
\hline $\begin{array}{l}\vec{\omega} \\
\text { ज }\end{array}$ & $\vec{N}$ & $\vec{\omega}$ & $\underset{\text { Gr }}{\stackrel{\theta}{*}}$ & of & $\underset{\text { G }}{\omega}$ & $\overrightarrow{0}$ & $\stackrel{\vec{\Xi}}{\Xi}$ & $\underset{\infty}{\omega}$ & $\stackrel{\omega}{\omega} \equiv$ & $\begin{array}{l}\text { 亲 } \\
\text { F }\end{array}$ \\
\hline जi & $\overrightarrow{0}$ & $\overline{\vec{G}}$ & $=$ & ज़ & 1 & $=$ & $=$ & ơ & $1 \equiv$ & 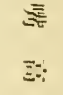 \\
\hline W్ & $\begin{array}{l}\tilde{O} \\
\text { or }\end{array}$ & 点 & $\begin{array}{l}\text { N } \\
\text { G }\end{array}$ & $\stackrel{\tilde{\omega}}{\omega}^{\tilde{\omega}}$ & 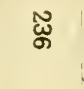 & జ్ట్ర & $\underset{్}{\mathbb{N}}$ & జّ & $\stackrel{\stackrel{N}{S}}{\equiv}$ & 낭 \\
\hline$\vec{\omega}$ & $\vec{\nabla}$ & $\overline{\text { s̆ }}$ & $\underset{\text { जे }}{\overrightarrow{\vec{N}}}$ & $\overrightarrow{0}$ & 1 & $\begin{array}{l}\bar{\sigma} \\
\text { ज. }\end{array}$ & $\overrightarrow{\overrightarrow{0}}$ & $\begin{array}{l}\overrightarrow{\vec{N}} \\
\text { vi }\end{array}$ & $\stackrel{\mathscr{9}}{\Xi}$ & 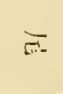 \\
\hline$\vec{N}$ & $\vec{\omega}$ & $\vec{\omega}$ & $\vec{N}$ & $\vec{\Delta}$ & $\overrightarrow{\text { जा }}$ & $\bar{\omega}$ & $\overrightarrow{\vec{G}}$ & $\vec{N}$ & $1 \equiv$ & $\begin{array}{l}\text { 믈 } \\
\text { 籜: }\end{array}$ \\
\hline $\begin{array}{l}\text { ज } \\
\text { ज }\end{array}$ & $\begin{array}{l}\omega \\
\text { or }\end{array}$ & N & जo & $\begin{array}{l}\text { ज } \\
\text { G }\end{array}$ & 1 & $\infty$ & $\begin{array}{l}\text { N } \\
\text { जे }\end{array}$ & $\begin{array}{l}\text { ज } \\
\text { or }\end{array}$ & $1 \equiv$ & $\begin{array}{l}シ \doteqdot \\
\cdots\end{array}$ \\
\hline$\checkmark$ & $\omega$ & iv & $\checkmark$ & $\checkmark$ & 1 & $\vec{v}$ & जे & $\dot{N}$ & $1 \equiv$ & $\begin{array}{l}\checkmark \doteqdot \\
\text { 亏器 }\end{array}$ \\
\hline $\begin{array}{l}\stackrel{\rightarrow}{0} \\
\vdots\end{array}$ & $\begin{array}{l}\text { to } \\
\triangleq\end{array}$ & $\begin{array}{l}\rightarrow \\
\vdots\end{array}$ & $\begin{array}{l}\text { to } \\
\hat{ٍ}\end{array}$ & $\begin{array}{l}\rightarrow \rightarrow \\
\stackrel{0}{?}\end{array}$ & $i$ & $\geqq$ & 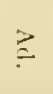 & $\geqq$ & & $\begin{array}{l}\text { 촐 } \\
\text { 点 }\end{array}$ \\
\hline$=$ & : & $=$ & $=$ & $=$ & 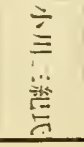 & : & $=$ & $\begin{array}{l}\equiv \\
\equiv\end{array}$ & & $\begin{array}{l}\text { 政 } \\
\times\end{array}$ \\
\hline
\end{tabular}




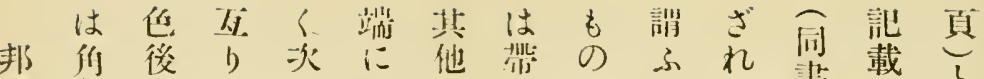

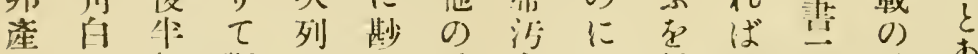

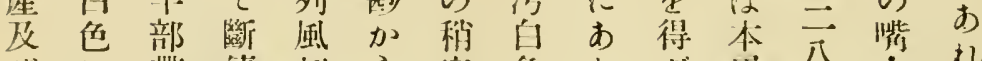

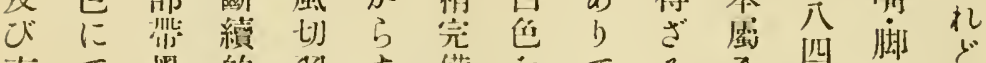

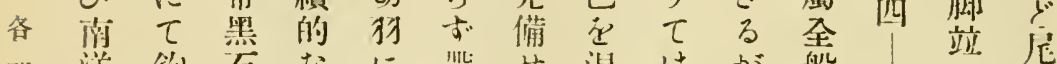

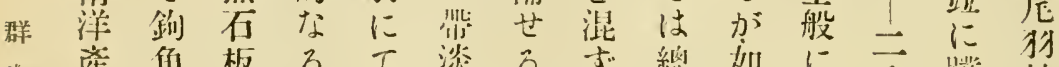

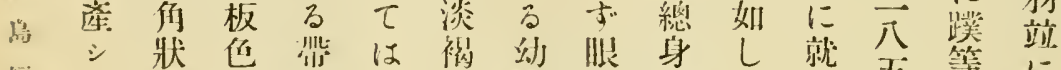

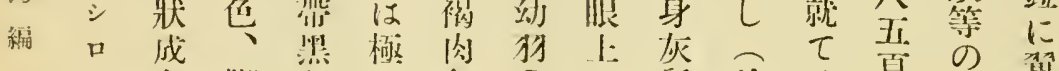

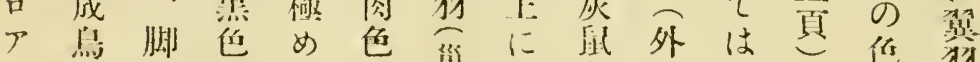

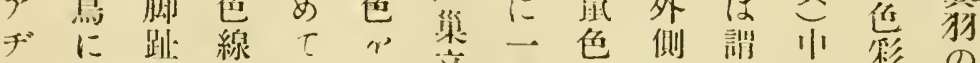

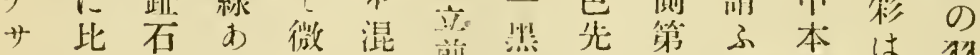

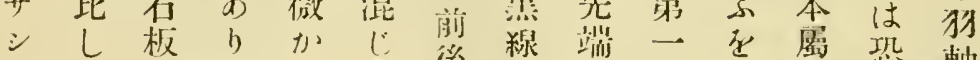

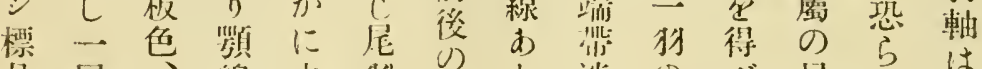

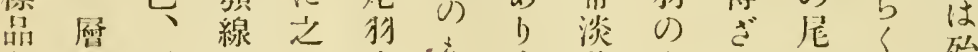

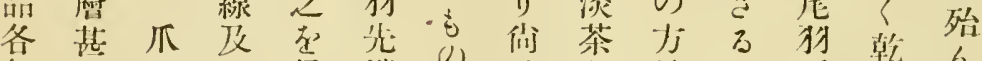

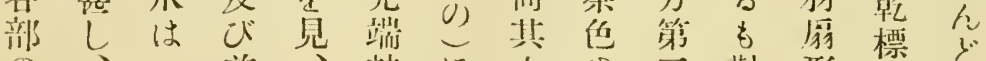

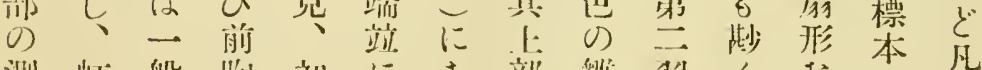

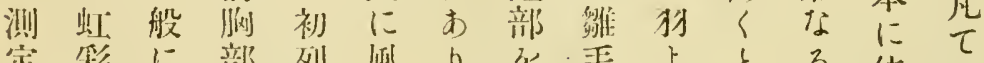

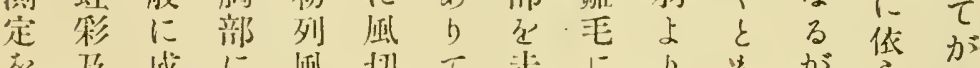

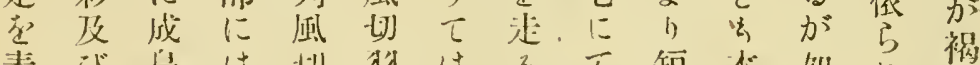

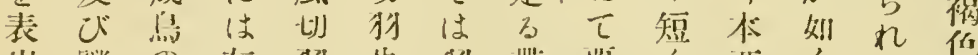

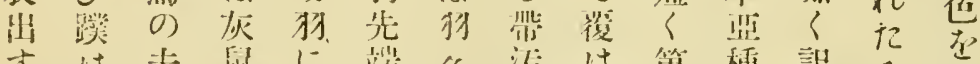

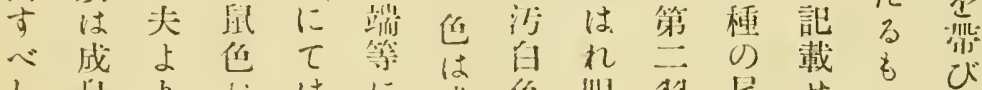
L 1930 小

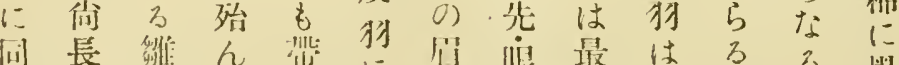

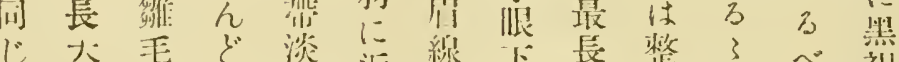

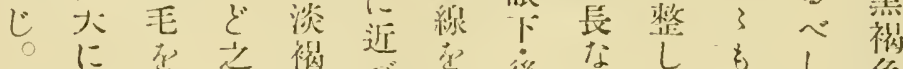

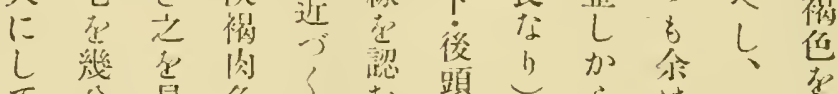

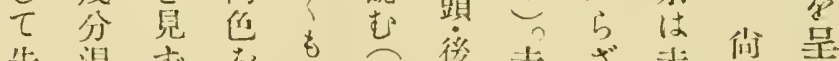

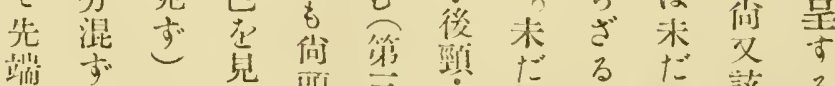

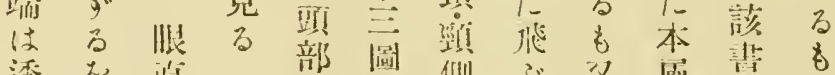

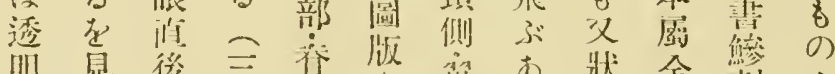

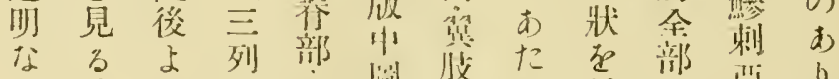

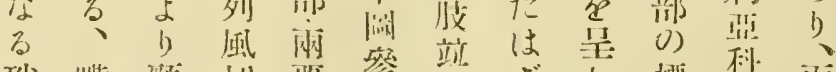

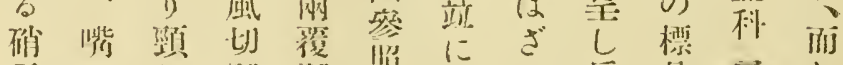

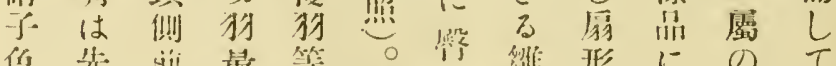
仍 先

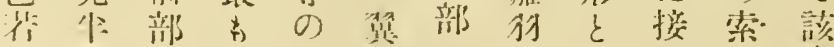

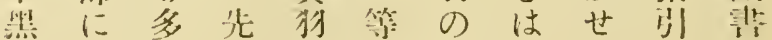




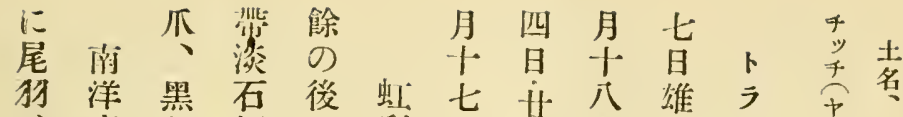

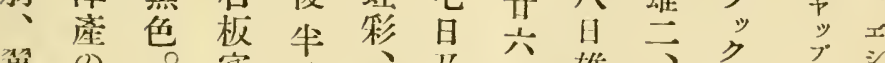
翼 0) 空は、公雄、クプシ

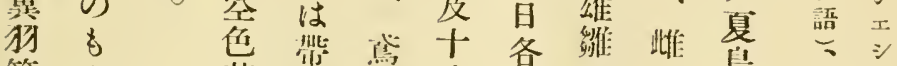

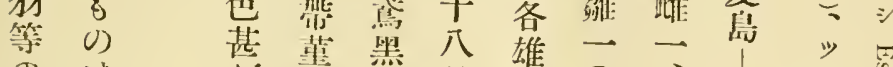
の は 狗 邦 軸 產 褐占

他同

な -

る 留

娄種

๑) $\varepsilon$

あ せ

b 5

궁

溜

は 日

黑 本

色 占

に類

L 圆

$\tau$ 說

脚口

: 1

腷 告

黑

色正

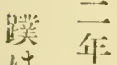

は

㘳本

色 艒

に種

L 0

$\tau$ 訅

ᄂ 截

該 小

葓

亲位

公将

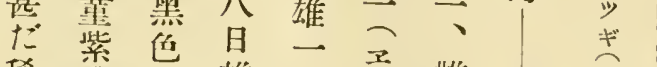

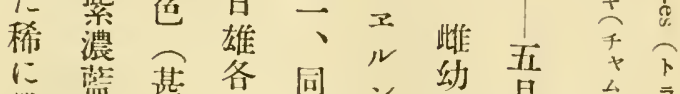

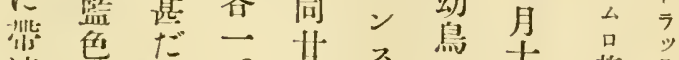

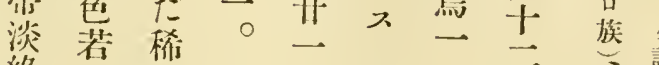

日 乎百語第

淡海

石叟浱

整筑焦

爬紫覆

蹼籃

洲色 淡

肉。啙

白 脚 黑

色蕉色

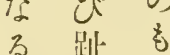

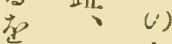

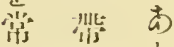

篮

漰

染甭嘴

稀他

衣妾

清板 篎

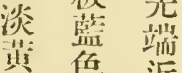

苪色近

自悲要

色碄品

空先

急性

क)

は色

雄

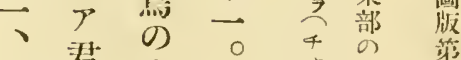

雌君及一等

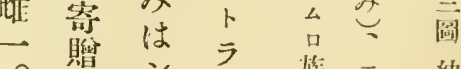

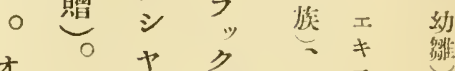

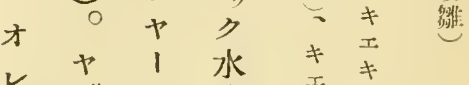

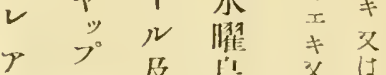

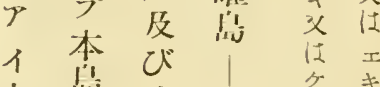

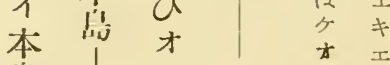

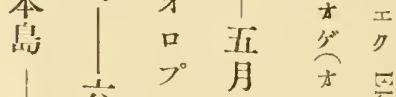

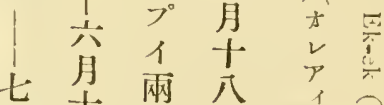

南公公素下

十盟雄

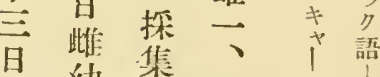

雄維管陫声

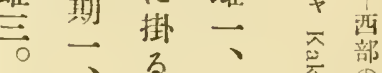

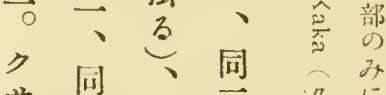

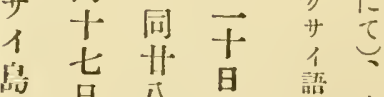

$\checkmark$ 旦公雄橆么

示雄下

分早间落 


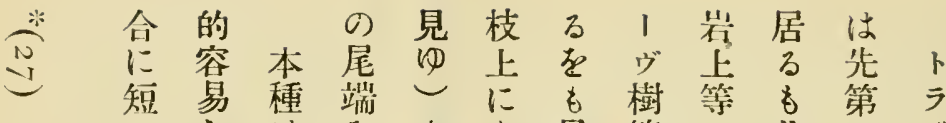

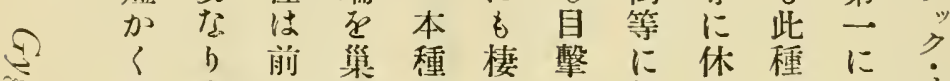

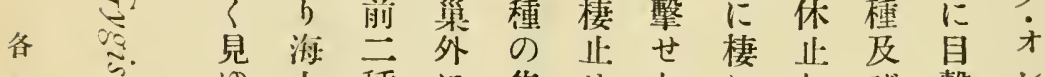
群にゆ上種に集せしれしび擊と

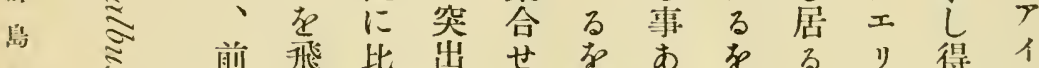
楄

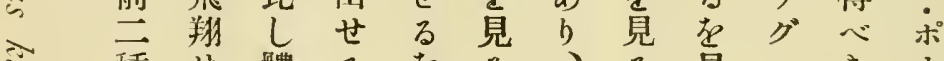

種せ體る在る、る見口きナ はる型を見事即のるヂ種ぺ

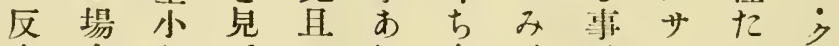
一合小受三れ本、殆 シ る 少

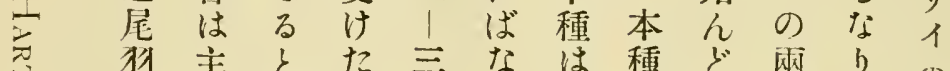

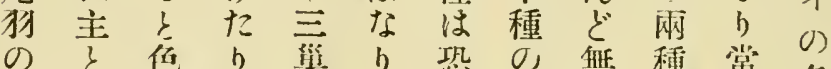

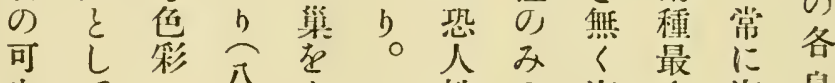

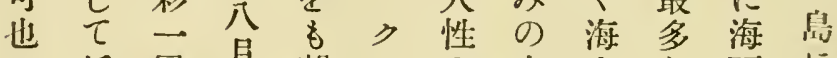
に低層含望サの大上儿面に 長空檍古見イ䑤群ににに杫

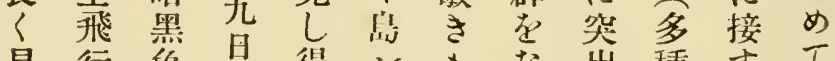

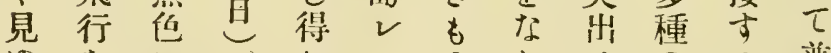
ゆをにひた吹ししせのる普 るな富名海な元る鲹程通 もしめ災灌る海若刺のな の 万市の心梁礁類低 可 な波々に一当近萑は飛、 b上老大畔きく大行前 卵薣と地は群を述 の上考后海热な各

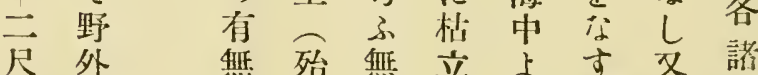

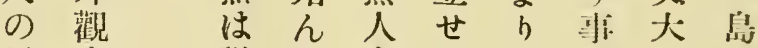
低察詳ど阅る倜尠群の さ時恕禁に死立し站附 事於占 $L \tau$ 樹生而し近 あてざ葉はの成して敏 b 当數比枝 せ $\tau$ 魚上 其:

且 判

尾 別

は比

割 較

し 非較上る 其群に を常的等 、にを近 其に低にン陸追う 漞粗き篦 グ岸飛く 鳥に樹れ口のし時 


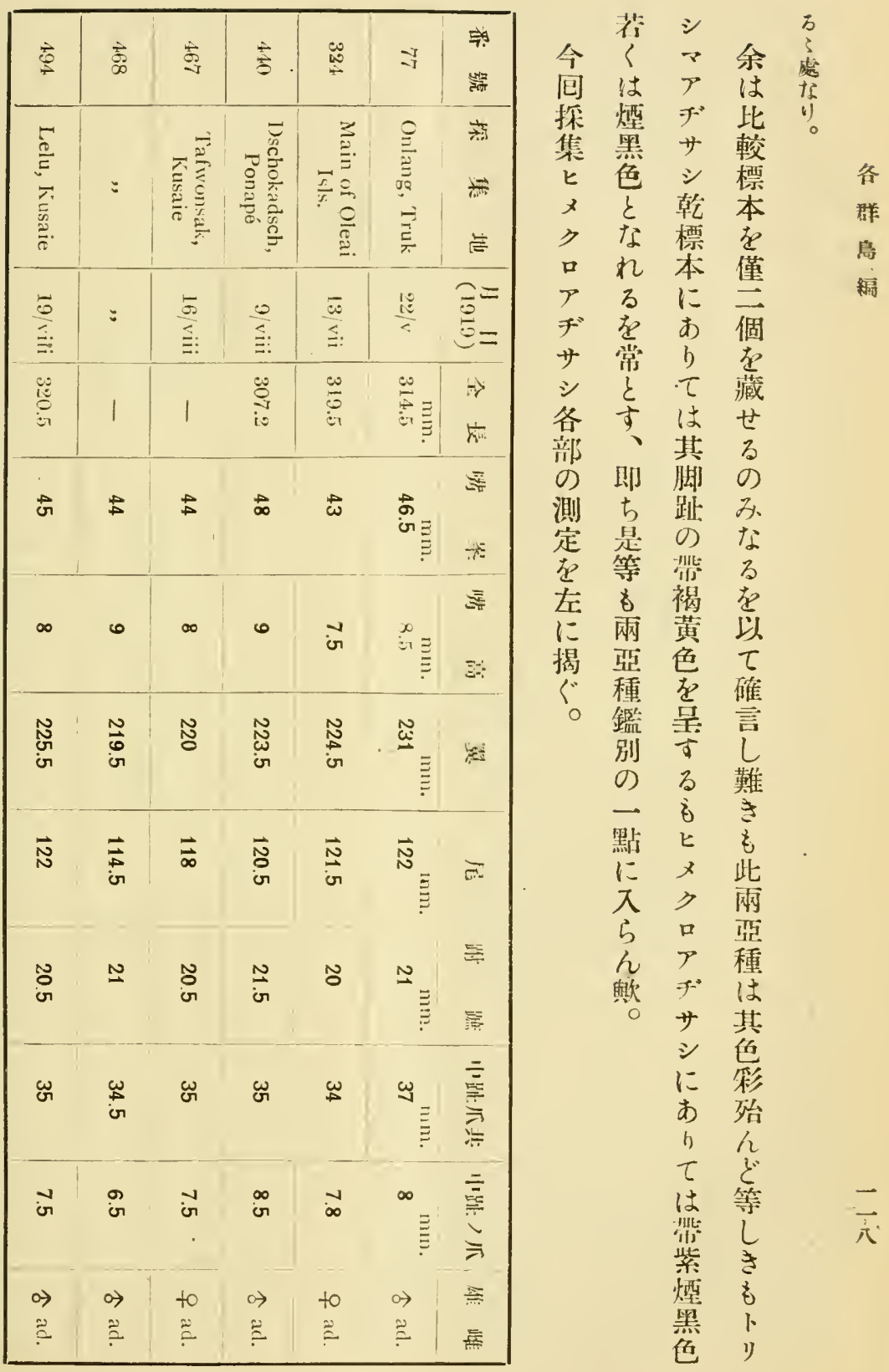




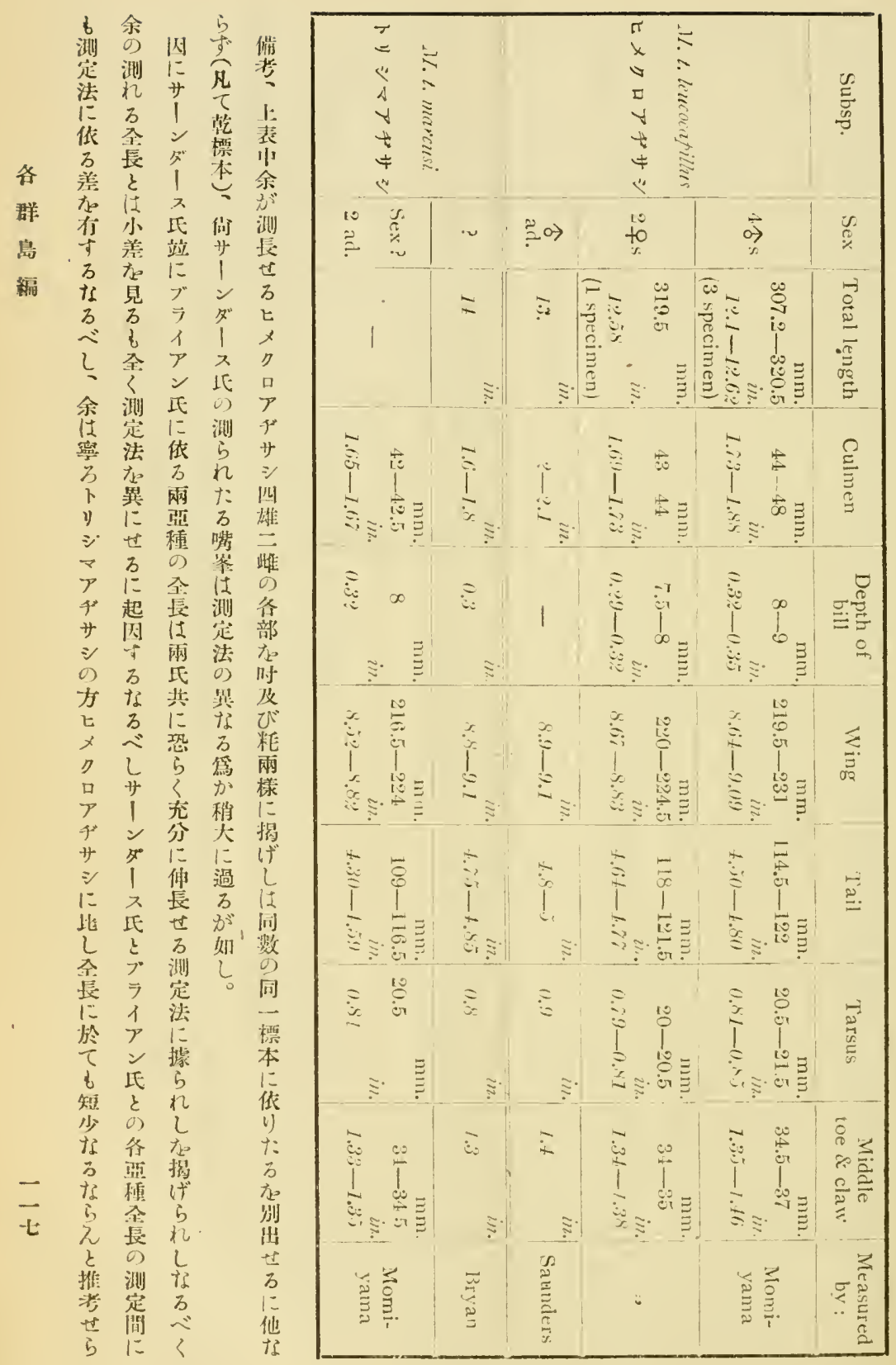


左於ど本若悲䙓 にてブ亞は淡若虹九杂卆公名

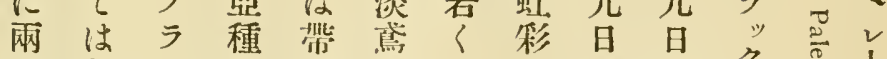
亞却イは暗黑は、雄雄ク豆!

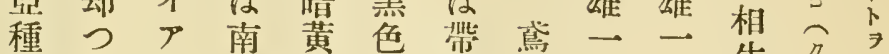

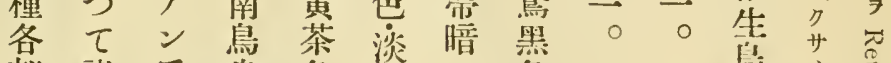
部諸 氏䓝绝淡 の部の產等茶褐才若 测に原下

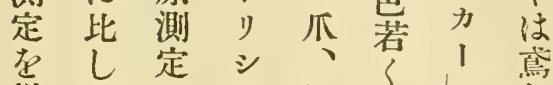
併長に黑は黄色 訅大依ア色亚色稀 ばし時サ

$\tau$ は シ 本該。

留 亞 種種

多然

几 が

ぞ平?

同均 三

長上 ミ

齐

せ短き

り少

○ な 引

る

事 酷

礁 似

要

る $\overrightarrow{\text { 見 }}$

が 見

如 類

ᄂ

但韄

苝

長 さ

污 等

荣占㗪

䲗趾 黑

范何䇼

学机脚

跳

黑踱 䤖

色尘跡

な 熛

る腤橙

あ色色

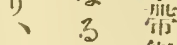

蹼步 微

常 憕

摼と暗

橙要

煙淡口

墨点 |

色黑 1

带色色

璌 溄黄

帜 橙色

淡 淡需

武黛污

黑 墨 淡

色任茶

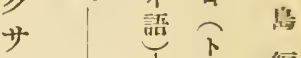

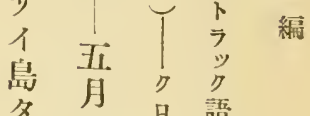

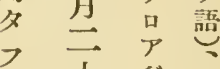

$\Rightarrow$ 十千 ?

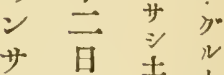

”雄名名

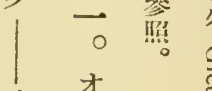

八才 产

月亦

六 1 年

分本高

雄

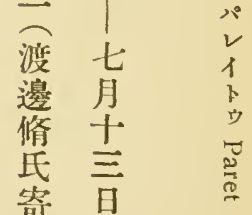

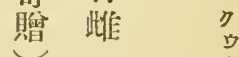

雌 $\overrightarrow{0}=$

一我名

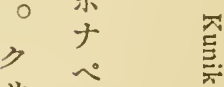

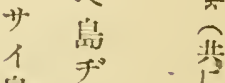

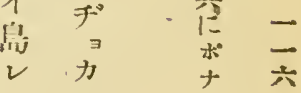

口 I 諳

八 た 


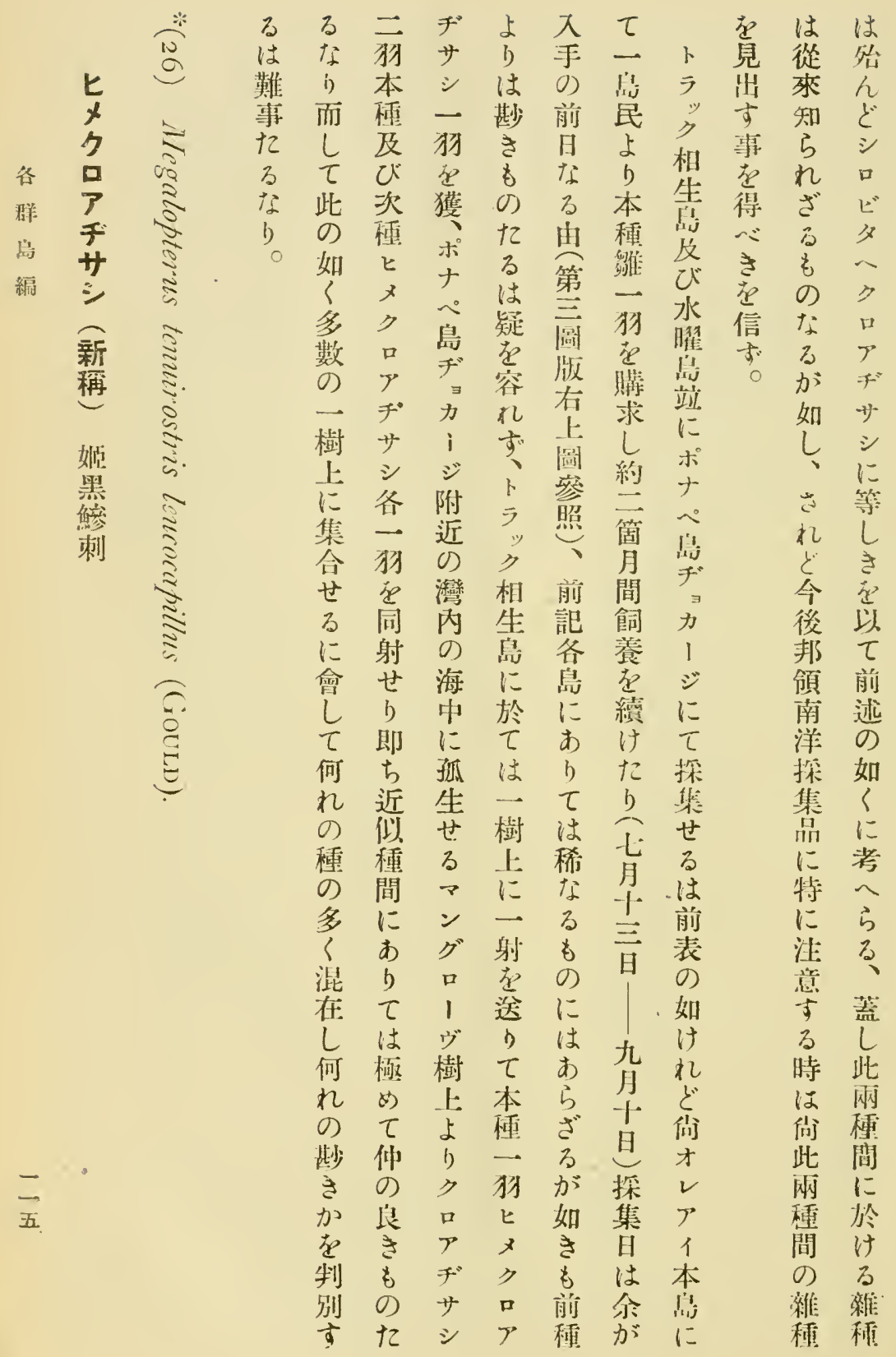




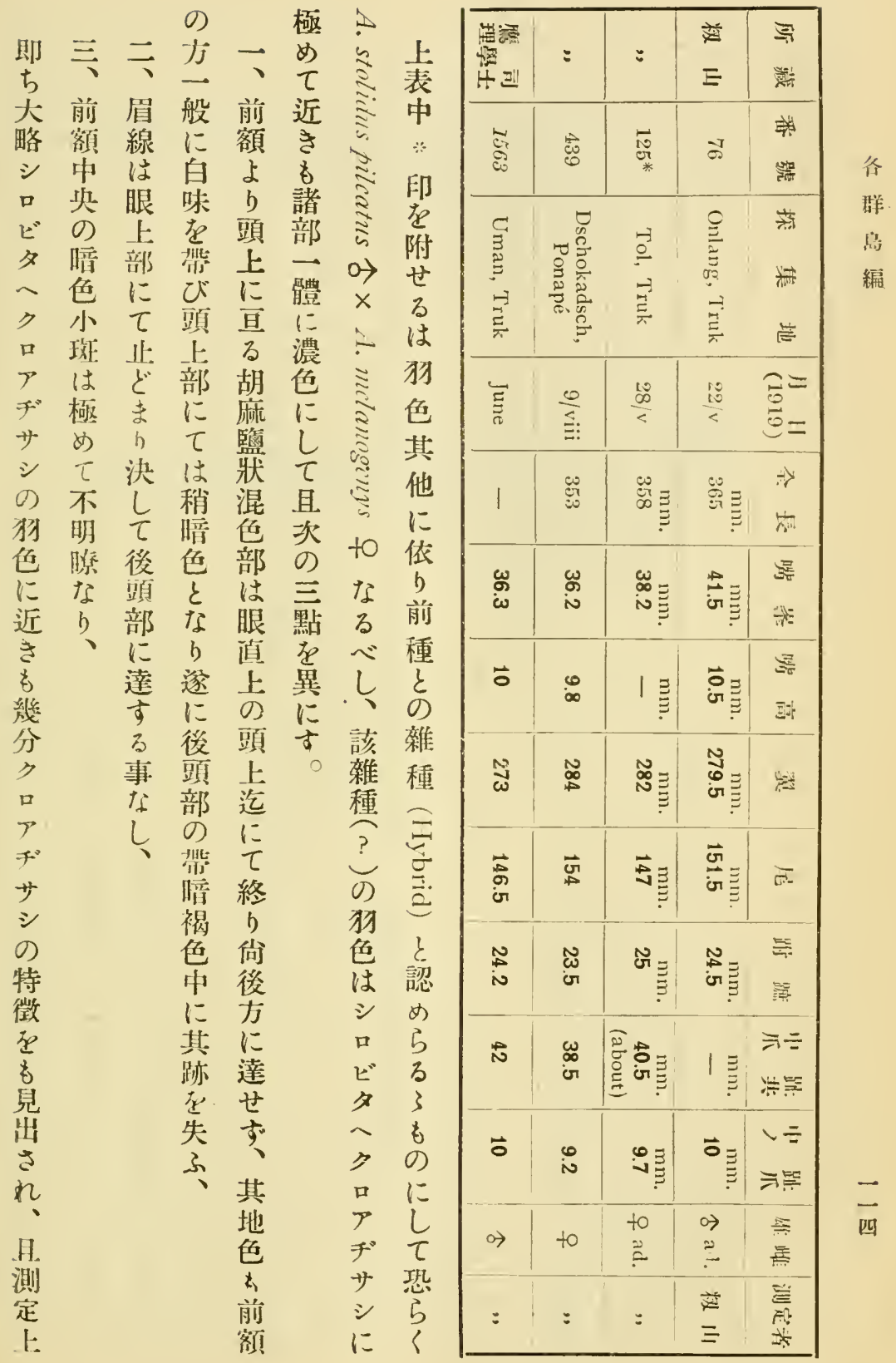




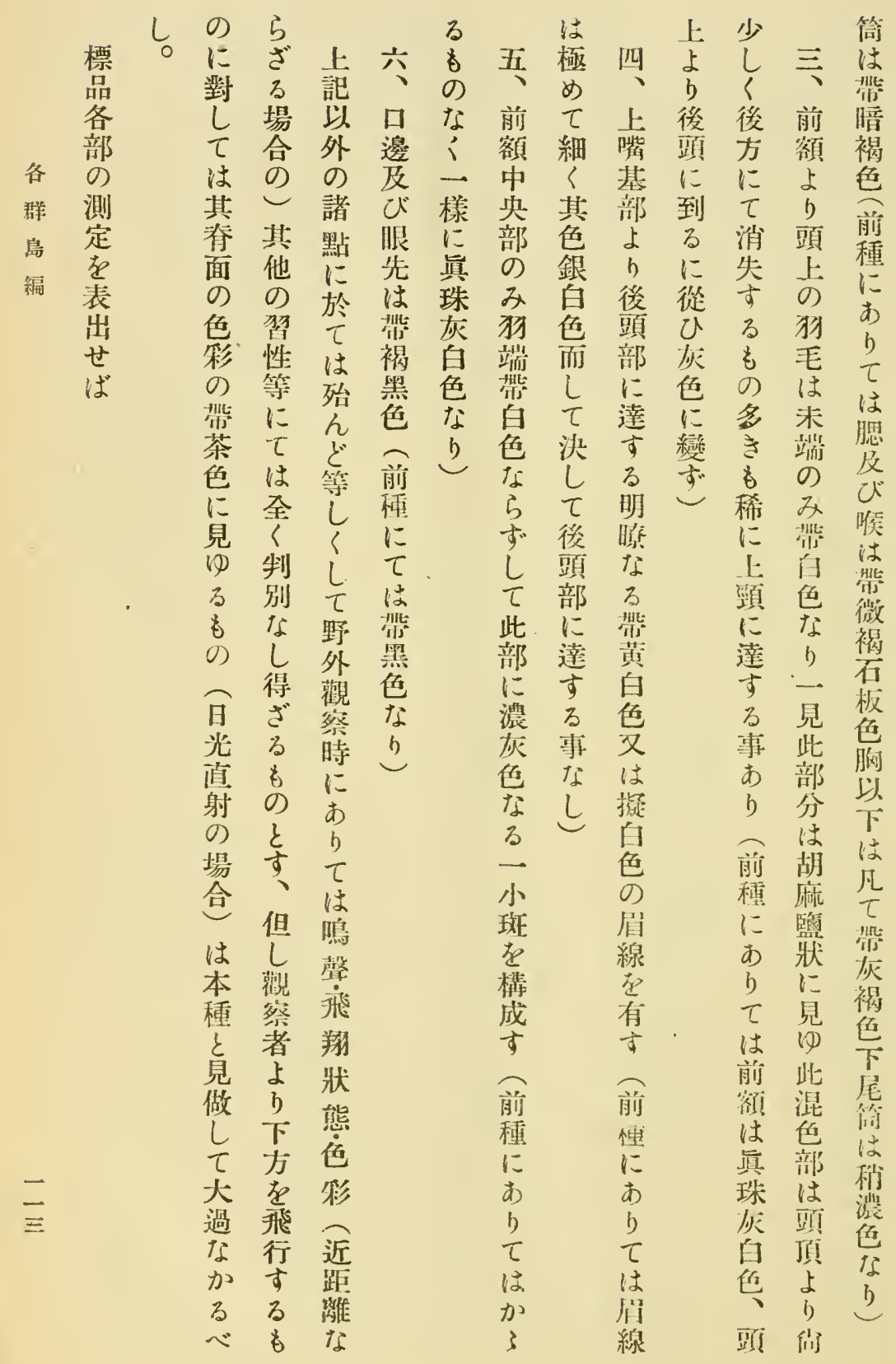



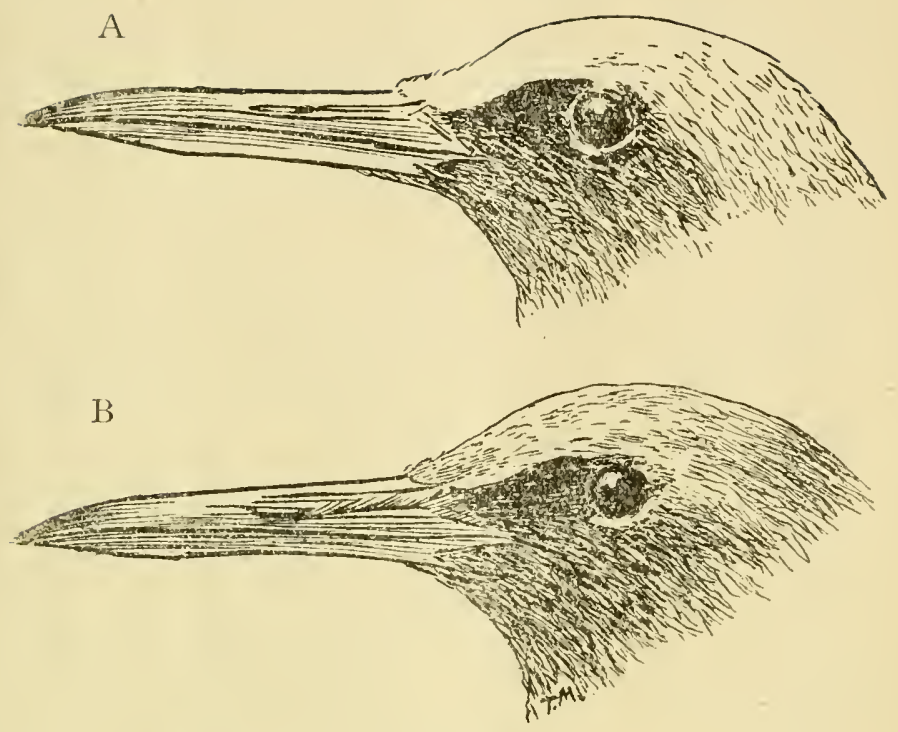

Text fig. 2.

Heads of two species of Anous from Micronesia.

(About nat. size).

南洋產クロアヂサシ類の顕部
A. A. s. pileztus, from Truk, No. 98 , 우 (?) ad.
B. A. melanogenys, from Truk. No. 76 , 令 ad.

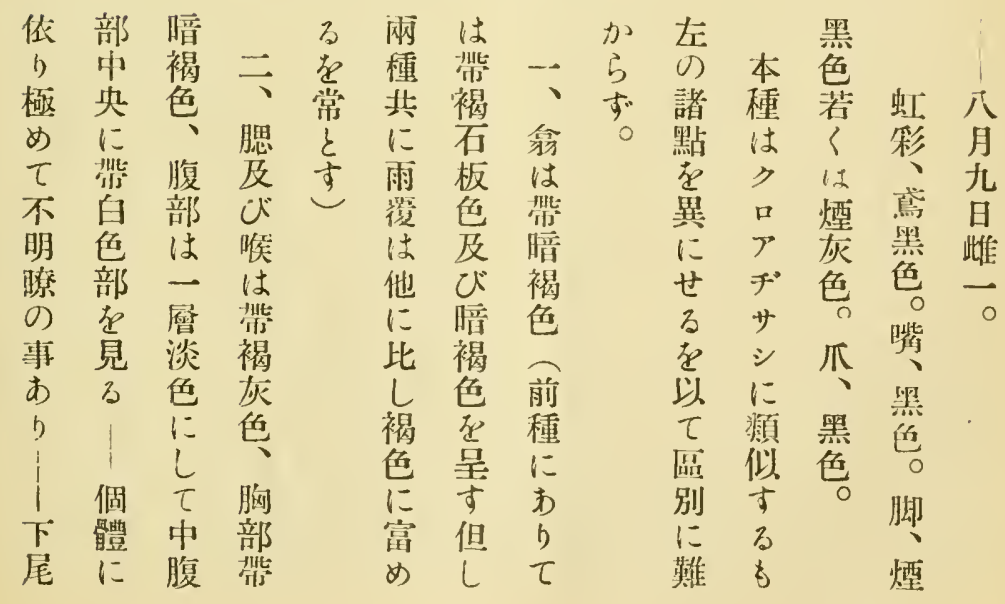




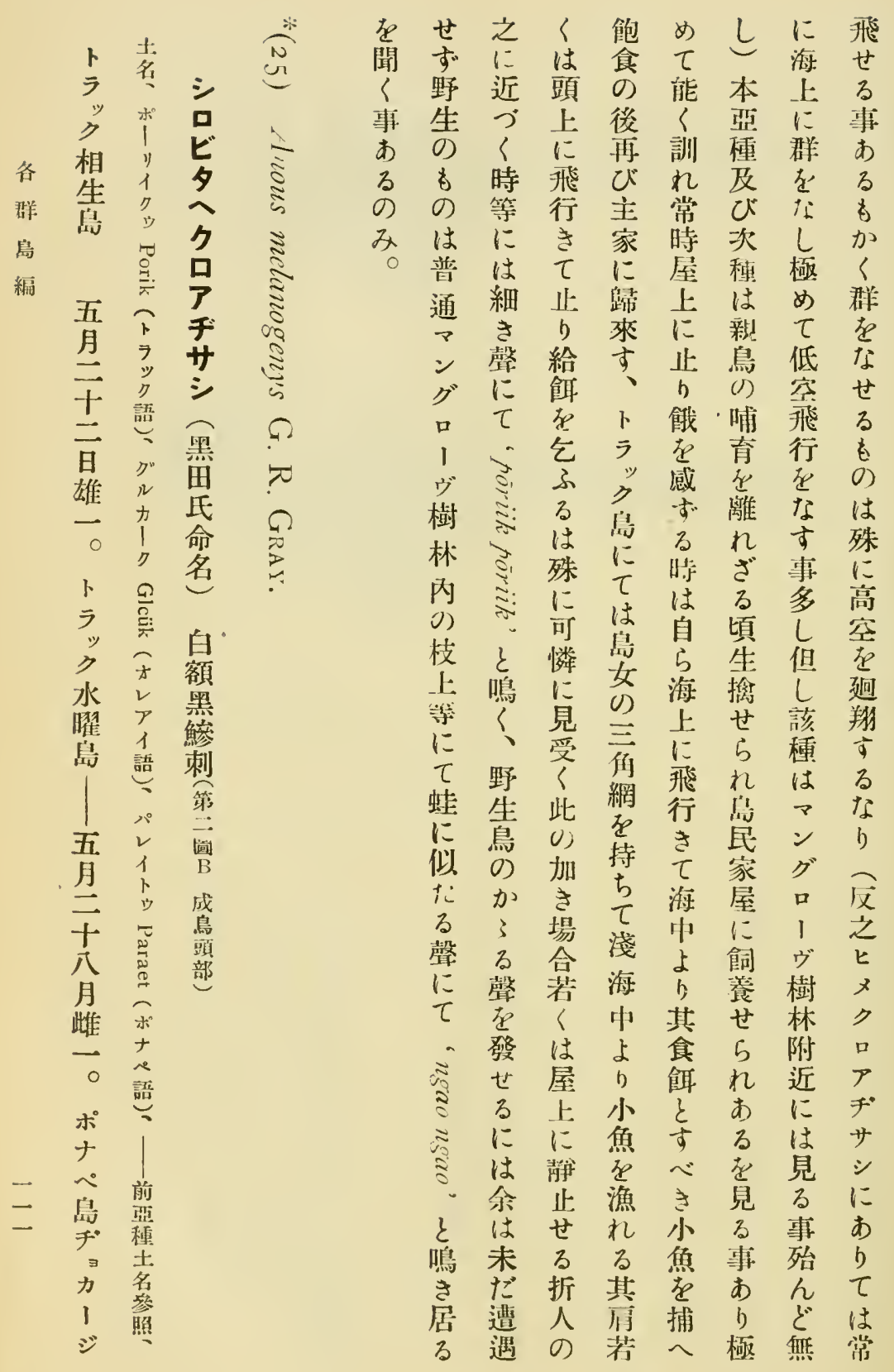


父上く黑せ及

群にク色しび卜 飛群 サ䱵 主島 せ采侧本の る婜虫類種上? 事吉に学空术 殆をは全り 尼ナ

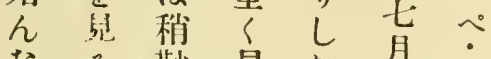
な己尠見か方 ど事しざ次四サ 稀け而き種旦方 にれしにに 單どて 本や多文 聺本常種明数イ

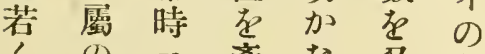

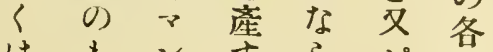
はもンすら ピ 各 少のグるざゲ 諸 數 口 前り 岛 の! 1 訅きッに

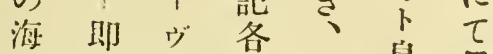
上ち 樹岛 高本林中 $\%$ 附且 惡附に曷海探 飛種近て医集 朔业見何於同せ

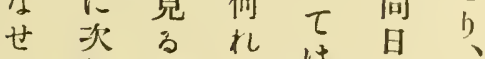

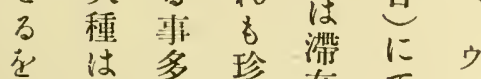

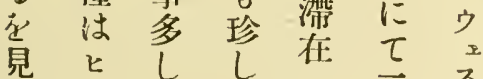
万 小 のク次筒 $\overrightarrow{1}$ 卜

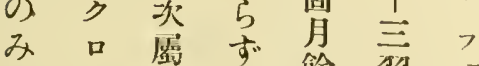

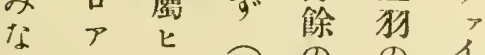
hヂメ特の の 甚サクに中本当

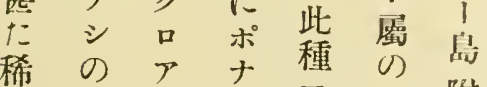
に如手成文附 海くサにひ汇 上にシ近をの に海生化似自海 群上海多繁上 


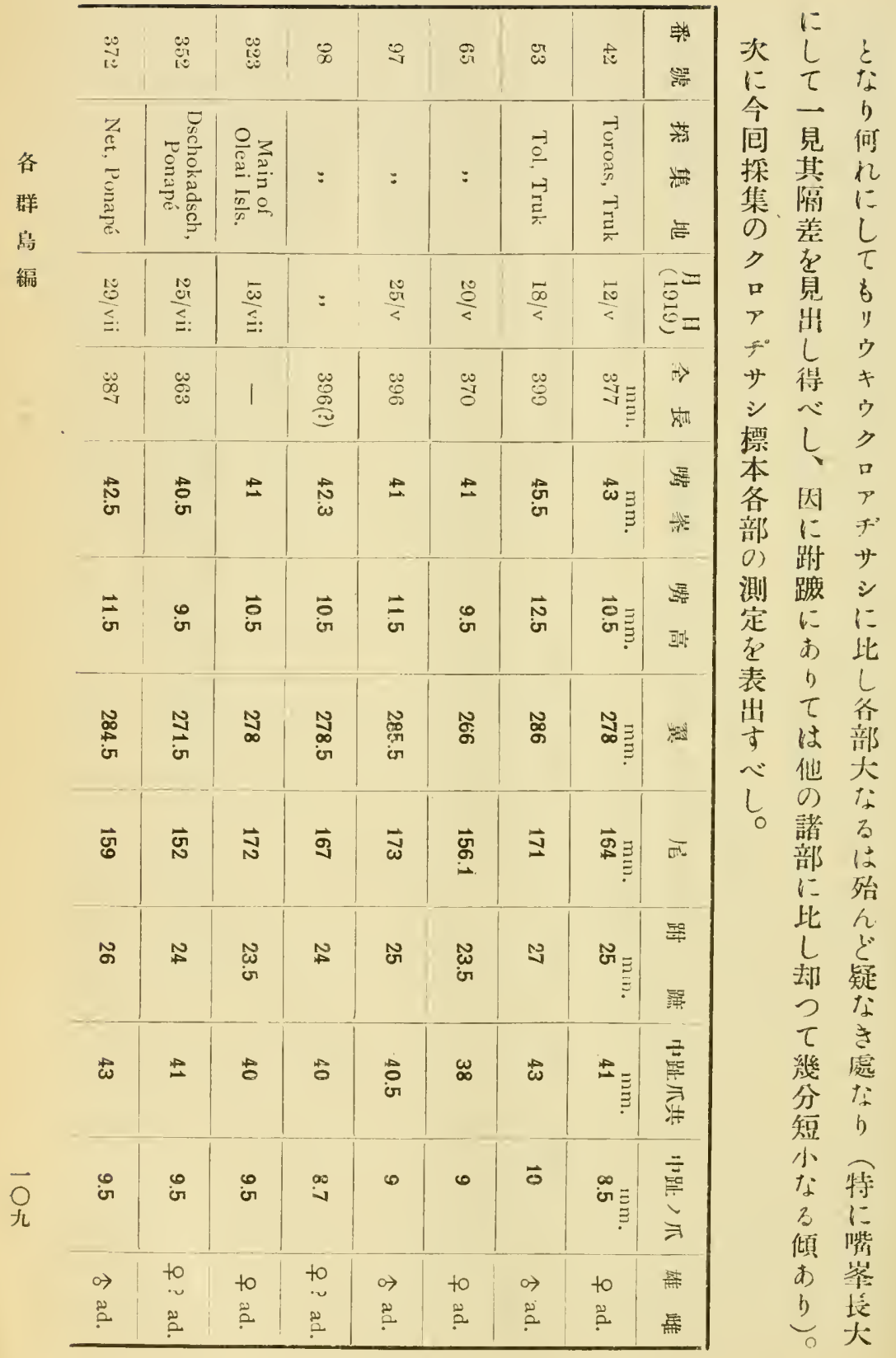


焂

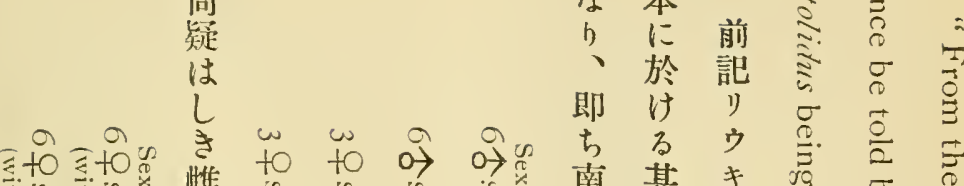

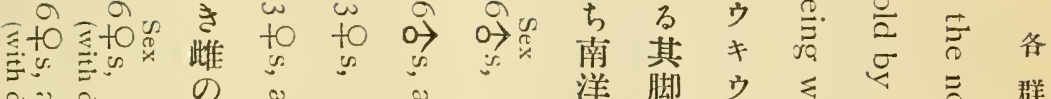

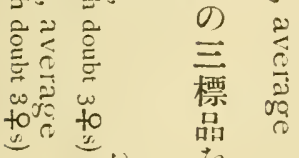

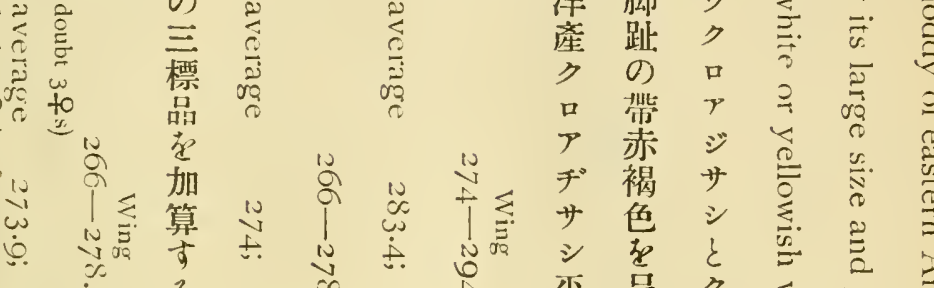

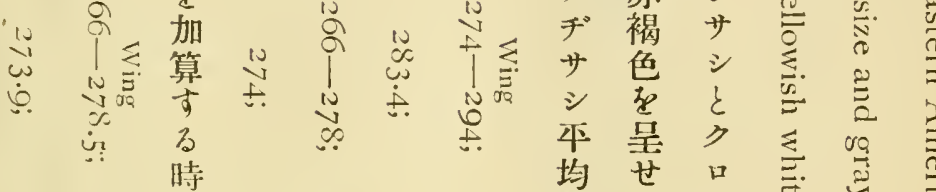

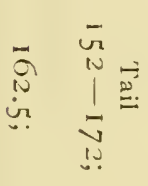

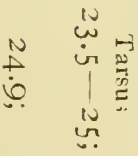

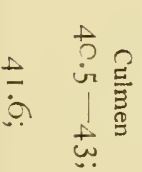

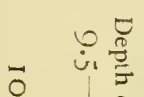

$\stackrel{0}{2} \frac{0}{2}$

草 焉蓄

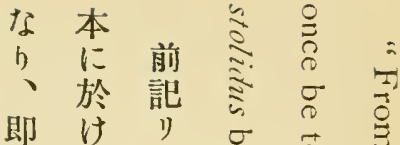

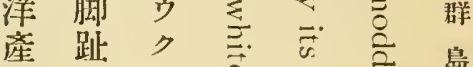

ク の

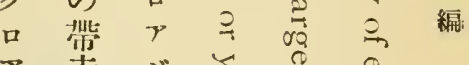

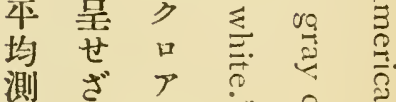

は

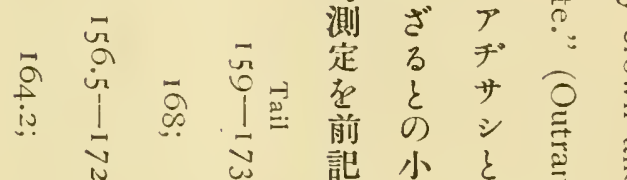

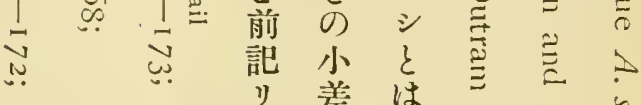

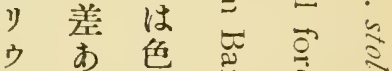

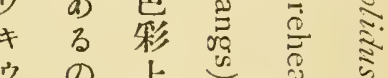

है

द.

而 後

$\rightarrow \stackrel{5}{\circ}$

$\stackrel{2}{3}$

气.

品占均方

比》

$0 \quad-\quad$ 离 較 口 -

の $>$ 懕

1 号䍃 ヂ 暗

豆左サ色

莺总揭

げすめめ

几各る

に部主

長畭

大 標 $-\overrightarrow{0}$

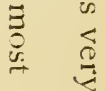

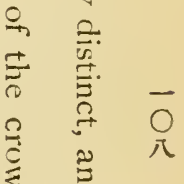

$\stackrel{\Xi}{\Xi}$

इ.

$>\cong$ 


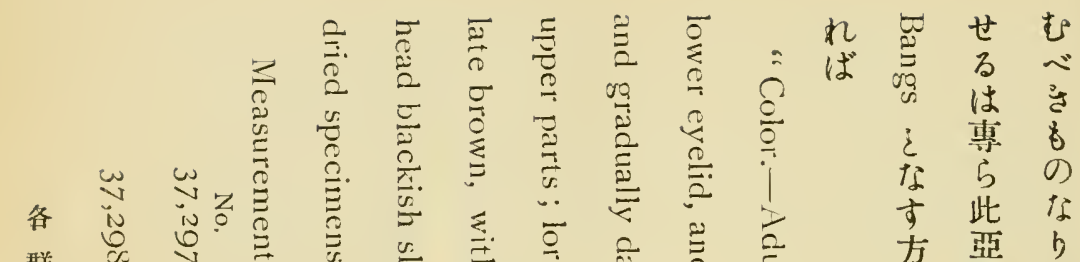

$$
\begin{aligned}
& \text { 群 } \\
& \text { 編 }
\end{aligned}
$$

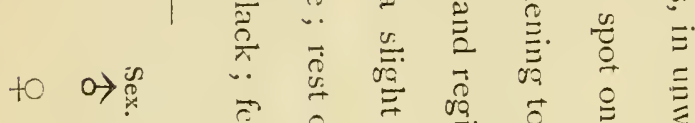

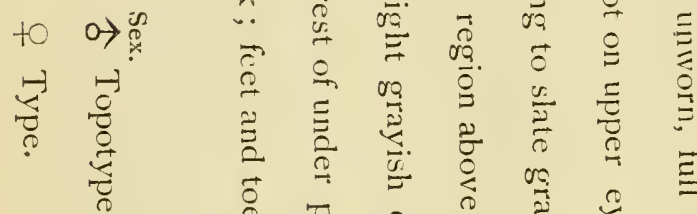

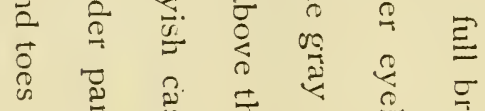

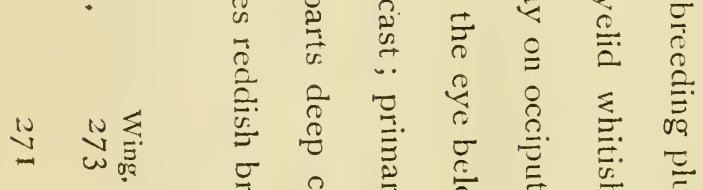

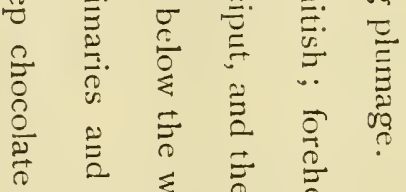

$$
\begin{aligned}
& \text { ज़ }
\end{aligned}
$$

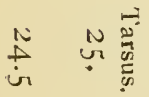

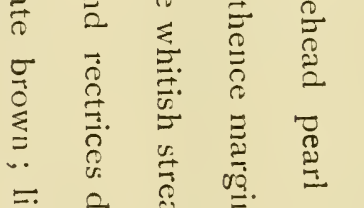

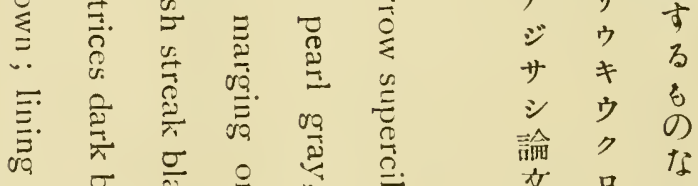

$$
\begin{aligned}
& \text { 品总 }
\end{aligned}
$$

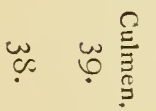

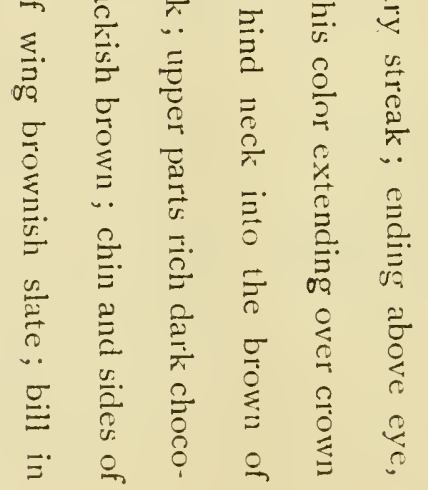

$$
\begin{aligned}
& \text { バめ本 } \\
& \text { グ 球種 } \\
& \text { 不 近 } \\
& \text { 0) 笠 } \\
& \text { ウ拳島 } \\
& \text { ₹ } 3 \text { 附 } \\
& \text { म } 6 \text { 近 } \\
& \text { ク U 迄 } \\
& \text { アリ䒚 } \\
& \text { 訅チ等 } \\
& \text { 截 } \\
& \text { 及新從 } \\
& \text { 其齐來 } \\
& \text { 抄空口 } \\
& \text { 錄 } 7
\end{aligned}
$$

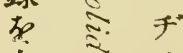

$$
\begin{aligned}
& \text { 左芯少 } \\
& \text { 揭念 } \\
& \text { 热空稱 }
\end{aligned}
$$




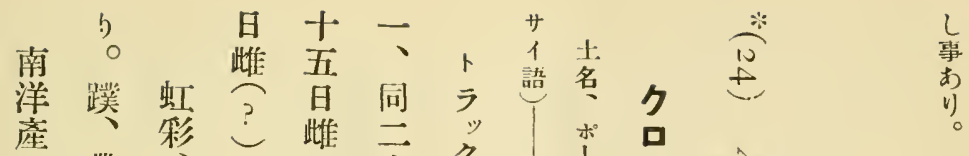

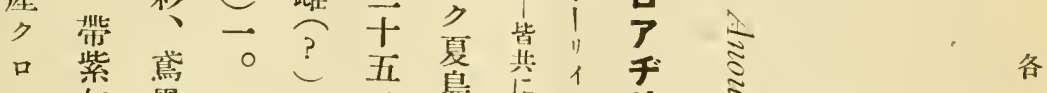

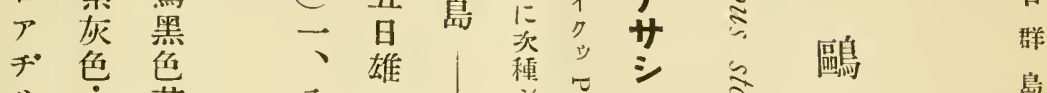

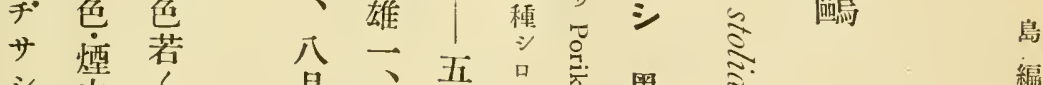

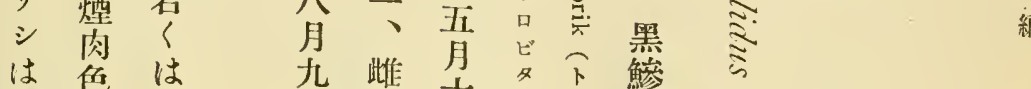

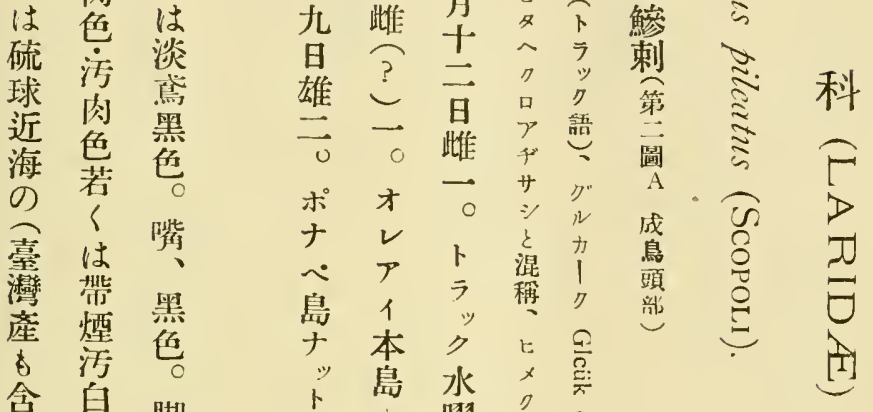

含 白 脚

等 煙

の 般 黑

に船惹

し 脚名

本色 は

均学煙

妾 餘 紫

各程 黑

部淡色

大瓷

型な殊

万马曻

必紫

以爪䇼

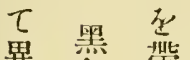

墨色溍

種了

証事

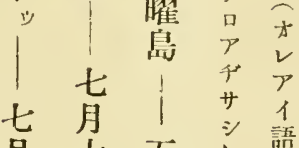

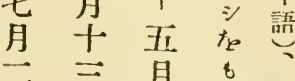

干豆等等

九雌公名

日一百家

雄只雄勫等

○十 方

》帛地禾

サ島菁永

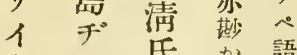

島 $\exists$ 氐加語

上䉕点。

口 1 顨。先

옹

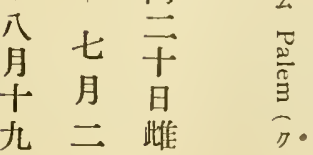




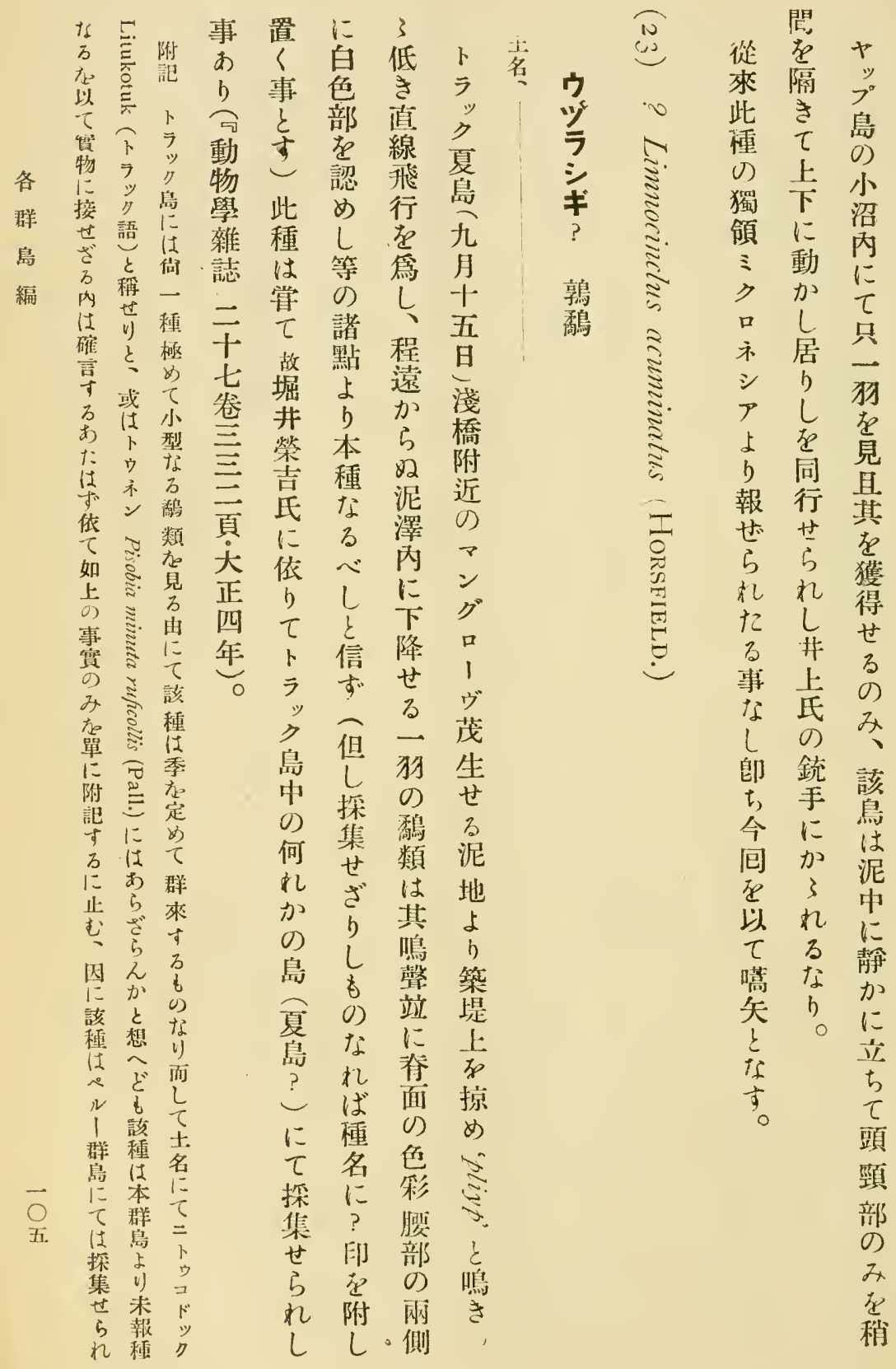




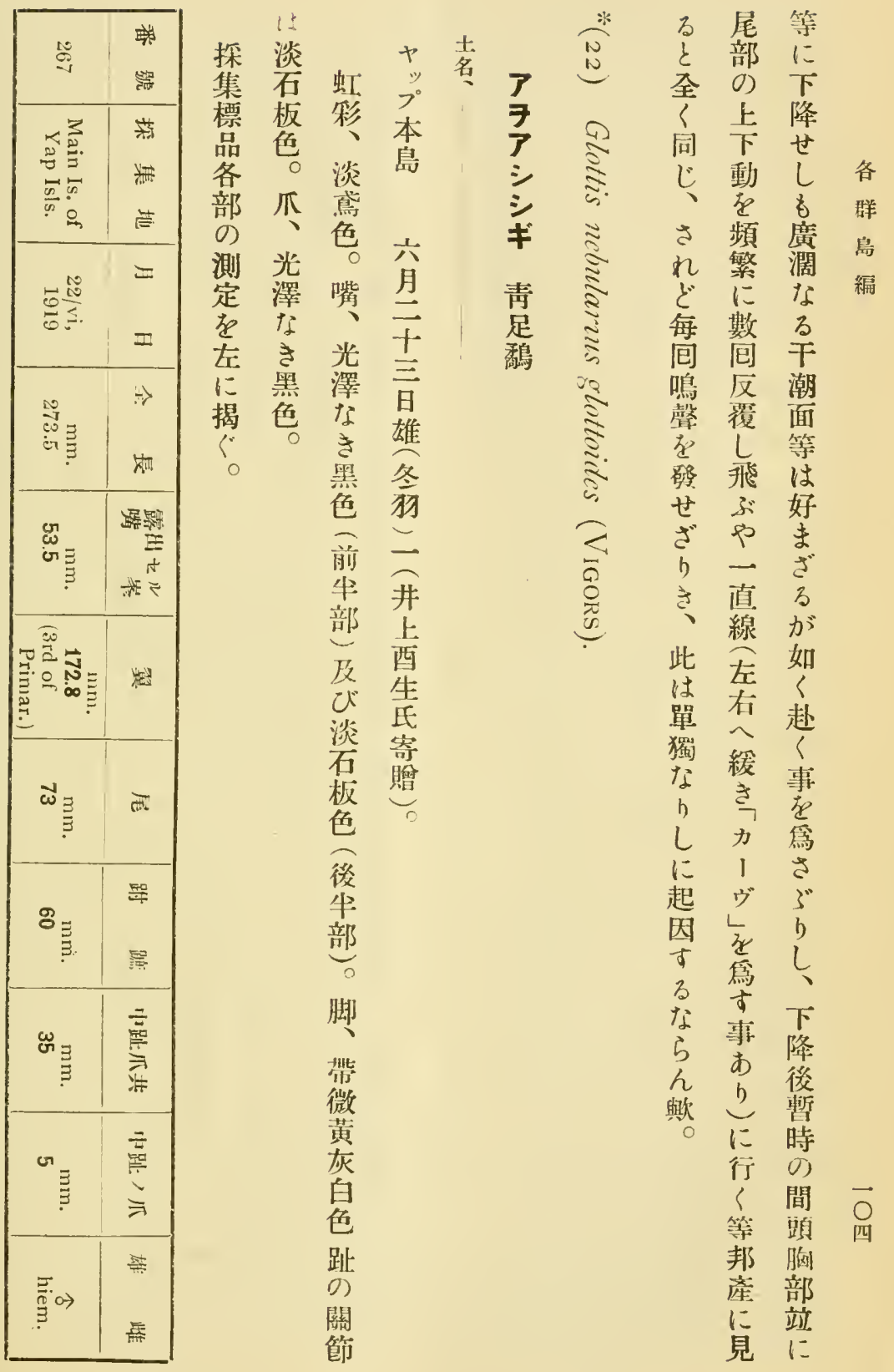




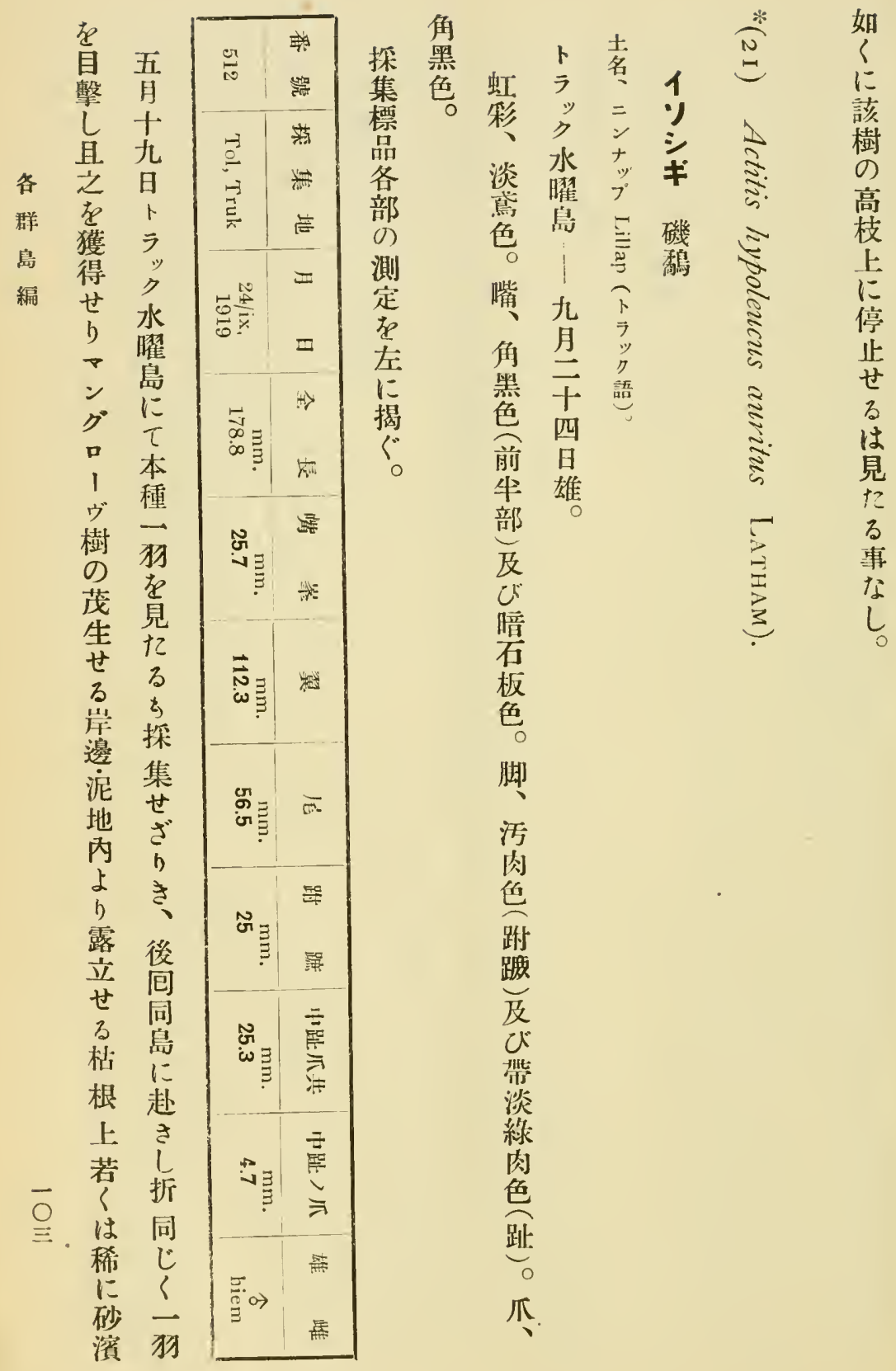


事干 プ 本

あ潮キ島亞上

り時 アに種 ラ

、の

マ珊シ は者諸

グ㗅ギ本を諸

口面 類亞含 中

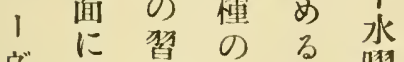

下性みは曜

樹降は它疑帛

水居殆採等

上居ん集ききて

枝る等 り虎只

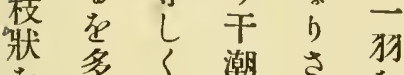

多く潮され面れ

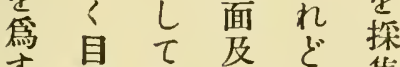

す罊相び本集

處等違小亞せ

のす違小亞し

根る點照種の

部古自等方

ン出に尠な

傳 グ古極 れ

步口 あ め है है

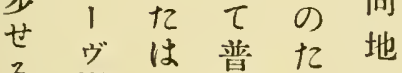

る事樹吉通る方

實の、にはに

鿓茂通見探見

क 生常る 集る

り世海の集手

る 岸種數 $>$

れ梁のた施

ぞ罯紧h h

チ樣礁。敀 ギ

ウ に推類

シ 濕棲 吂

ク る

シ8か方種

ギ見 久

のるは

\begin{tabular}{|c|c|c|c|c|c|}
\hline$\stackrel{\mathscr{E}}{\mathscr{E}}$ & $\begin{array}{l}10 \\
\infty\end{array}$ & $\stackrel{10}{8}$ & 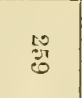 & $\overline{8}$ & $\begin{array}{l}\text { 为 } \\
\text { 筑 }\end{array}$ \\
\hline : & : & : & 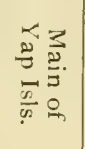 & $\begin{array}{l}\overrightarrow{0} \\
-1 \\
\vec{\nabla}\end{array}$ & 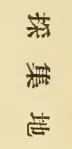 \\
\hline$\frac{\omega}{\vdots}$ & $\frac{10}{3}$ & : & $\frac{10}{\leq}$ & $\frac{10}{<}$ & 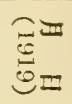 \\
\hline $\begin{array}{ll}100 \\
100 \\
c\end{array}$ & 10.0 & 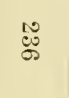 & 递 & $\stackrel{10}{10} \Xi$ & $\begin{array}{l}\text { Hy } \\
\text { 始 }\end{array}$ \\
\hline ఱ & $\omega$ & $\vec{N}$ & $\begin{array}{l}\text { W } \\
\text { or }\end{array}$ & $\mathscr{E}_{\bar{E}}^{\mathscr{E}^{\prime}}$ & 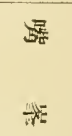 \\
\hline ज़ & $\underset{\text { cr }}{\vec{\sigma}}$ & $\stackrel{N}{\dot{\omega}}$ & $\begin{array}{l}\vec{\infty} \\
\text { जr }\end{array}$ & $\begin{array}{l}\vec{\sigma} \\
\text { जे } \\
\vdots\end{array}$ & 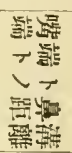 \\
\hline जু & ज्ञ & ज़ & जু & $\mathrm{G}_{\mathrm{J}}$ & 崔 \\
\hline$\infty$ & $\mathscr{8}$ & పૈ & g & 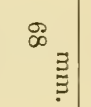 & 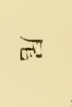 \\
\hline 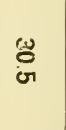 & $\begin{array}{l}\omega \\
\text { ज्ञ } \\
\text { जे }\end{array}$ & $\stackrel{\omega}{\omega}$ & $\stackrel{\omega}{\omega}$ & 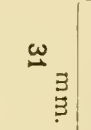 & 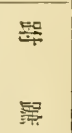 \\
\hline$\omega$ & 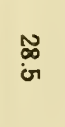 & $\tilde{\bullet}$ & ชี & $\stackrel{\mathscr{O}_{\Xi}}{\Xi}$ & 言 \\
\hline or & or & $\sigma$ & Gr & 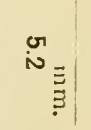 & 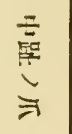 \\
\hline 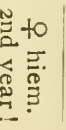 & 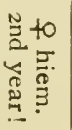 & $\begin{array}{l}N \\
\bar{z} \\
0\end{array}$ & 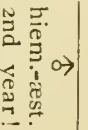 & 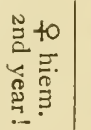 & $\begin{array}{l}\text { 墨 } \\
\text { 墨 }\end{array}$ \\
\hline
\end{tabular}




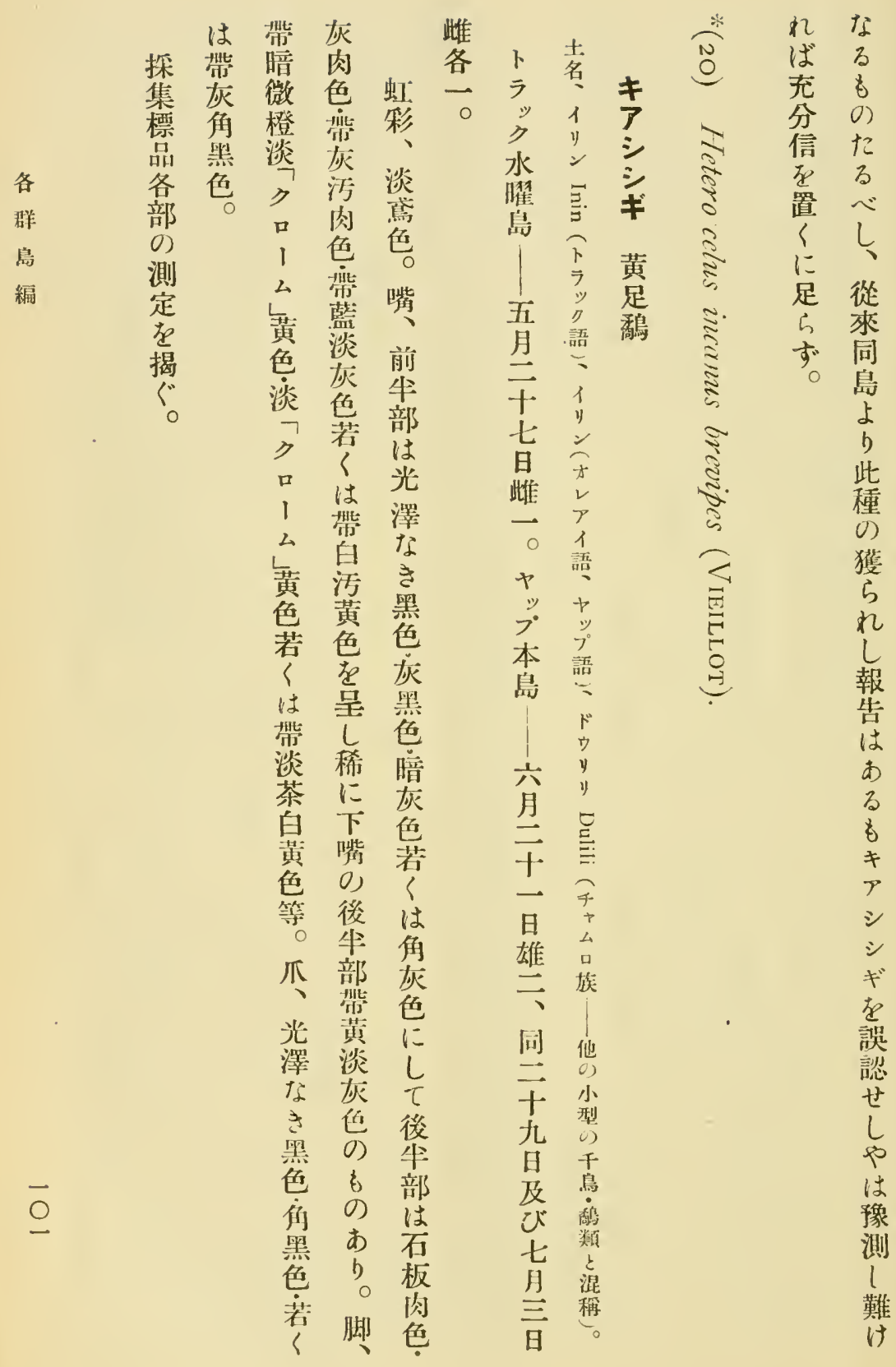


り探せの東方に 推集、士 しせ且如にくは留 $\tau 5$ 本し分乞極種 †れ亞、有キめは惊 \%し種々方厂不 プ 事と ラ るシ 普邦種

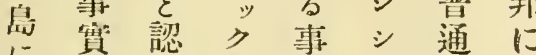

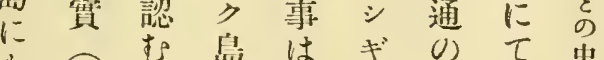
ह $\approx \approx$

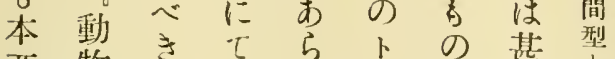

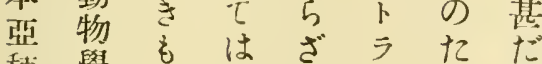

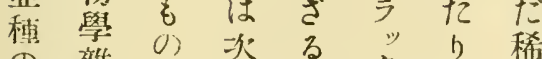

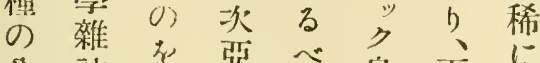

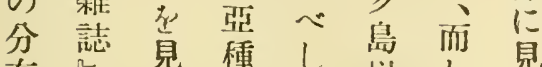
布等見種し岕し見

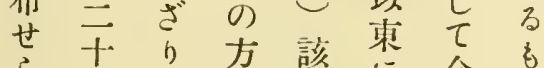
公し尠䉆的今

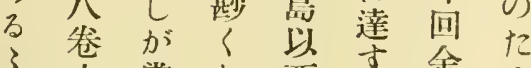
事宍堂し西李余居

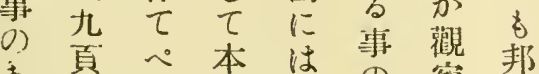
ま頁的本は祭邦 了大儿亞次有祭领 べ正，種亞热篮南 き五群の種は處洋 年島方尹具永諸

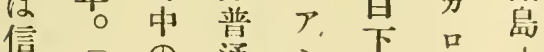

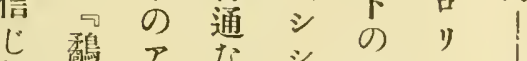

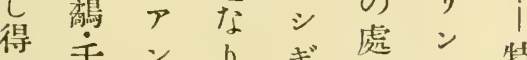

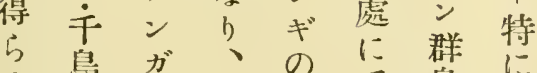

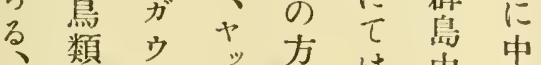

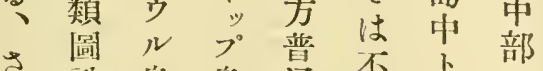
說島鼠通不卜力

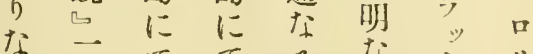

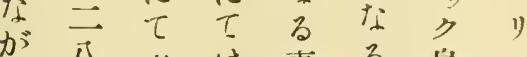
分故生事了鼠。 资面堀今殆方以以 次頁井回九恐東東

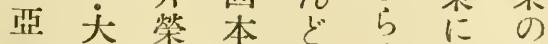
種正吉亞確々は楛 に七民種筫該本㤩

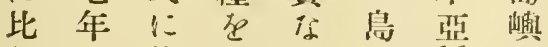
し二依探万よ種 稀上等 


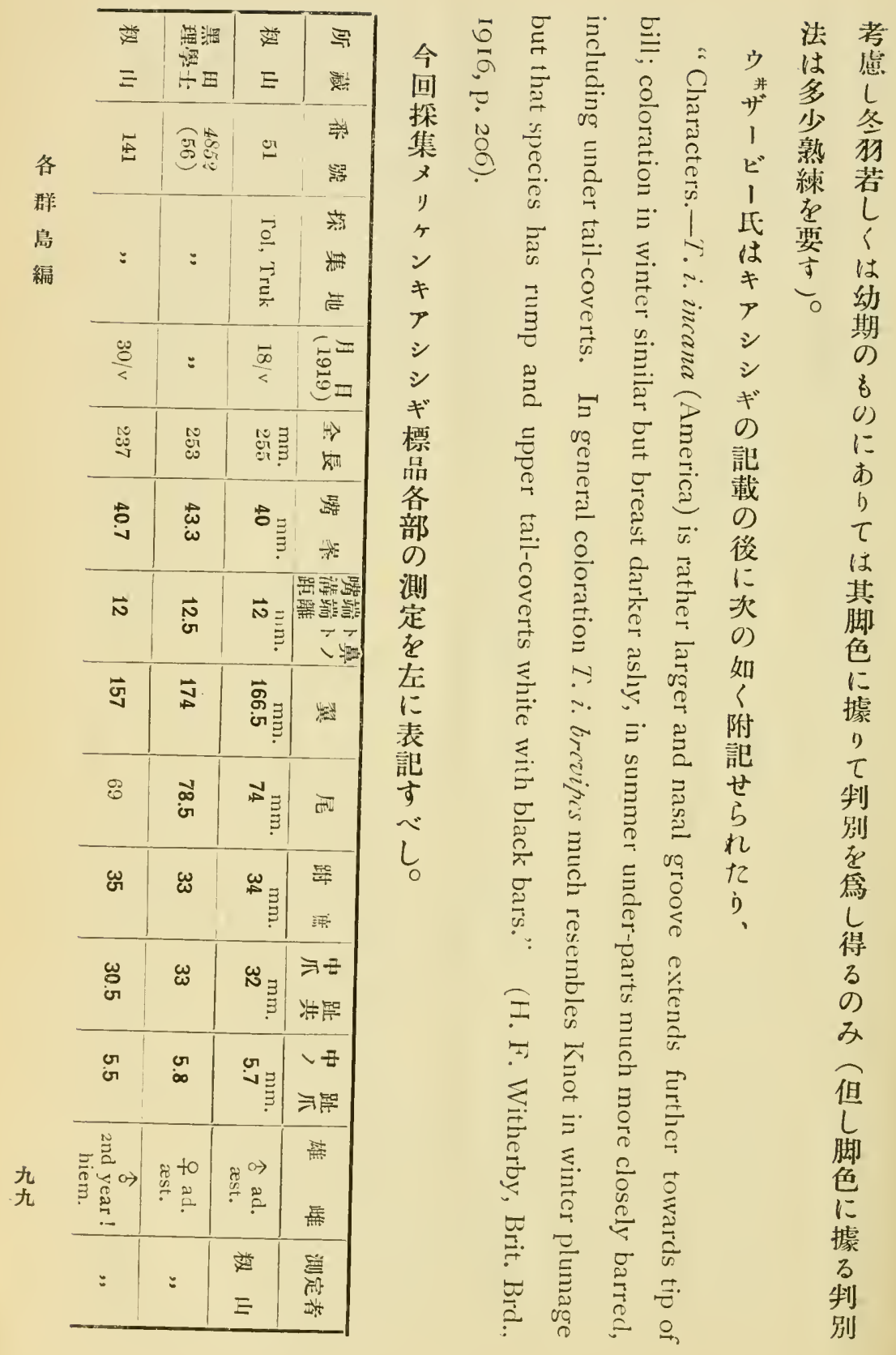


別にシ帶肉て方曋 シギの上

す因無ギ藍色は褐シ の量記e

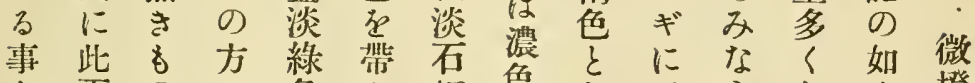
飞兩の—色ぶ板色な橙

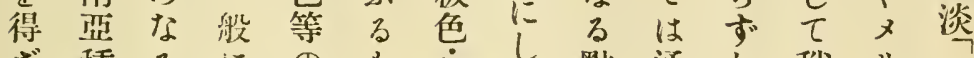
ざ種るにのも帶蒂點通し稍りク群

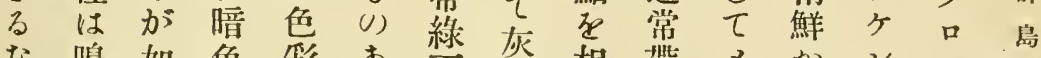

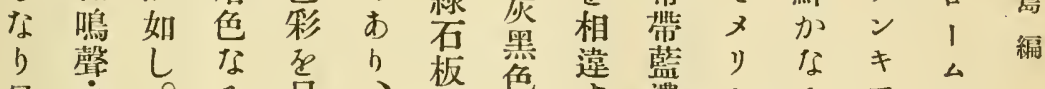

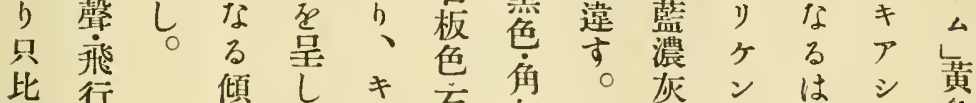

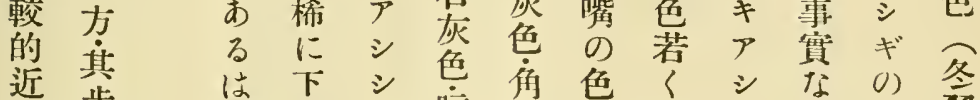
距 步

時

の $の$

場 動

の 作

み 等

双 殆

眼

鏡 ど

を等

使的

夏 ᄂ

讶遠

小距

ば離

胸 の

腹 野

部 外

の 觀

横 察

斑 に

0) $\tau$

柾 は

密 全

存余

0)

確嘴ギ誩黑烸はシ方

筫後に石色は帶ギ而暗雌

な坐部は色若同紫に

、淡其等 は說灰見趾く

さ黄後迄光の色出のは

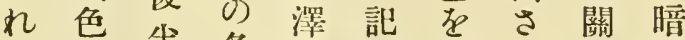

ぞ芭本各な載呈る 節綠

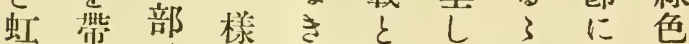

箖心は墨少キ處暗在

はる帶色色しな色裝

兩あ河䇙をくシ りをび

亞る淡茥異シ ○帶キ

種を黄呈しらギ乾心ア

其自色し 後兩にきる

にる 座下坐亞

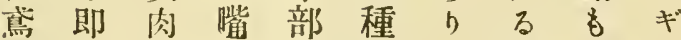

色ち色的共て標肯に

に嘴淡後メには本定あ

しに灰坐り前帶にせり

七於・色部ヶ坐紫 あらて

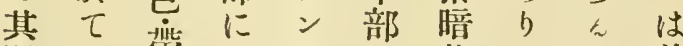

間も霑はキつ茶て 前

にメ綠淡 $>$ 即褐は堅

些y污肉シ ち色 メこ種

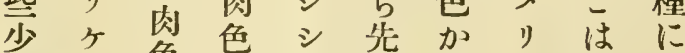

のン色若ギ端又ケキ比

異キ綠くににはンアし

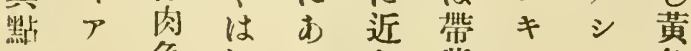

だ色泒りき紫アシ 色 


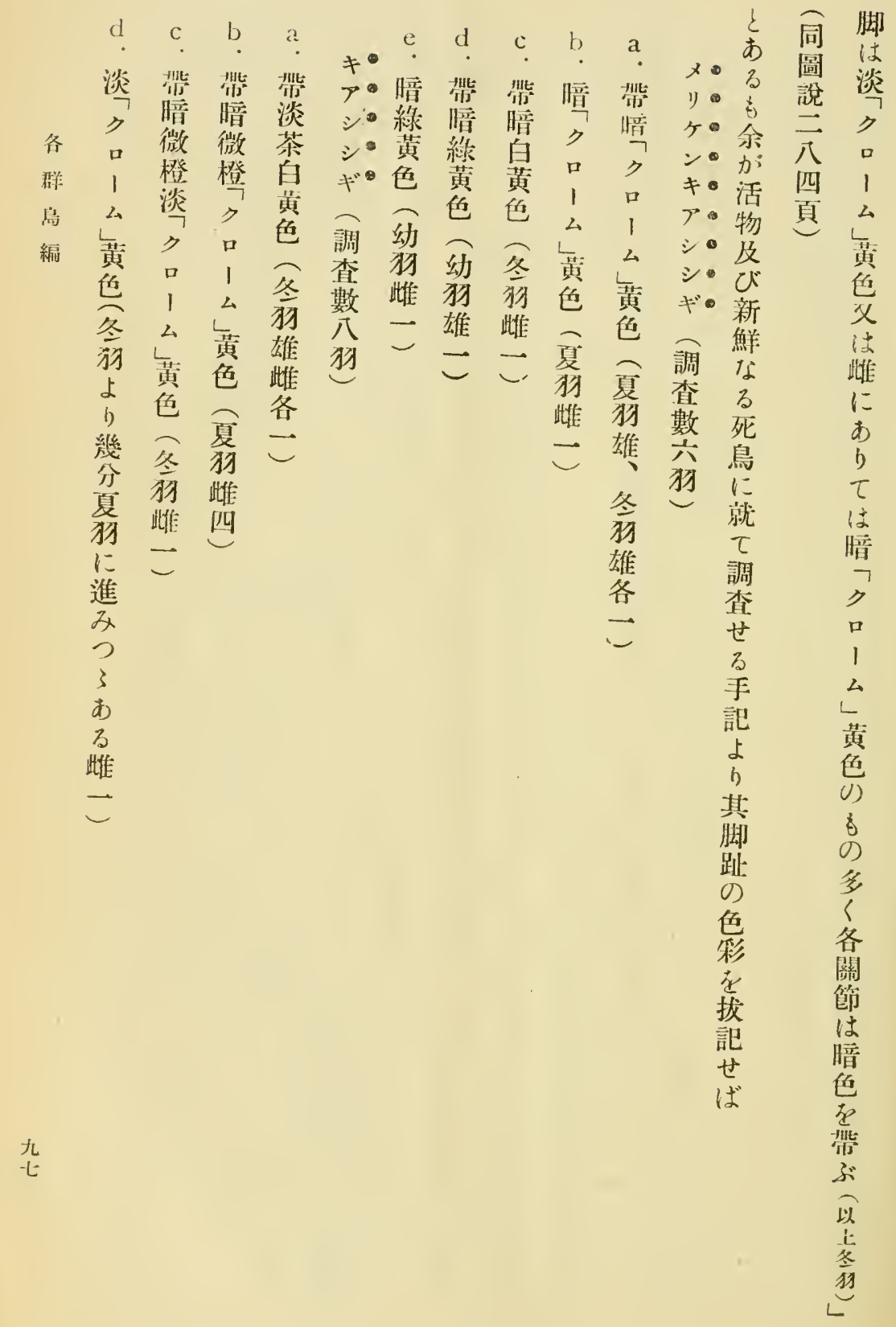




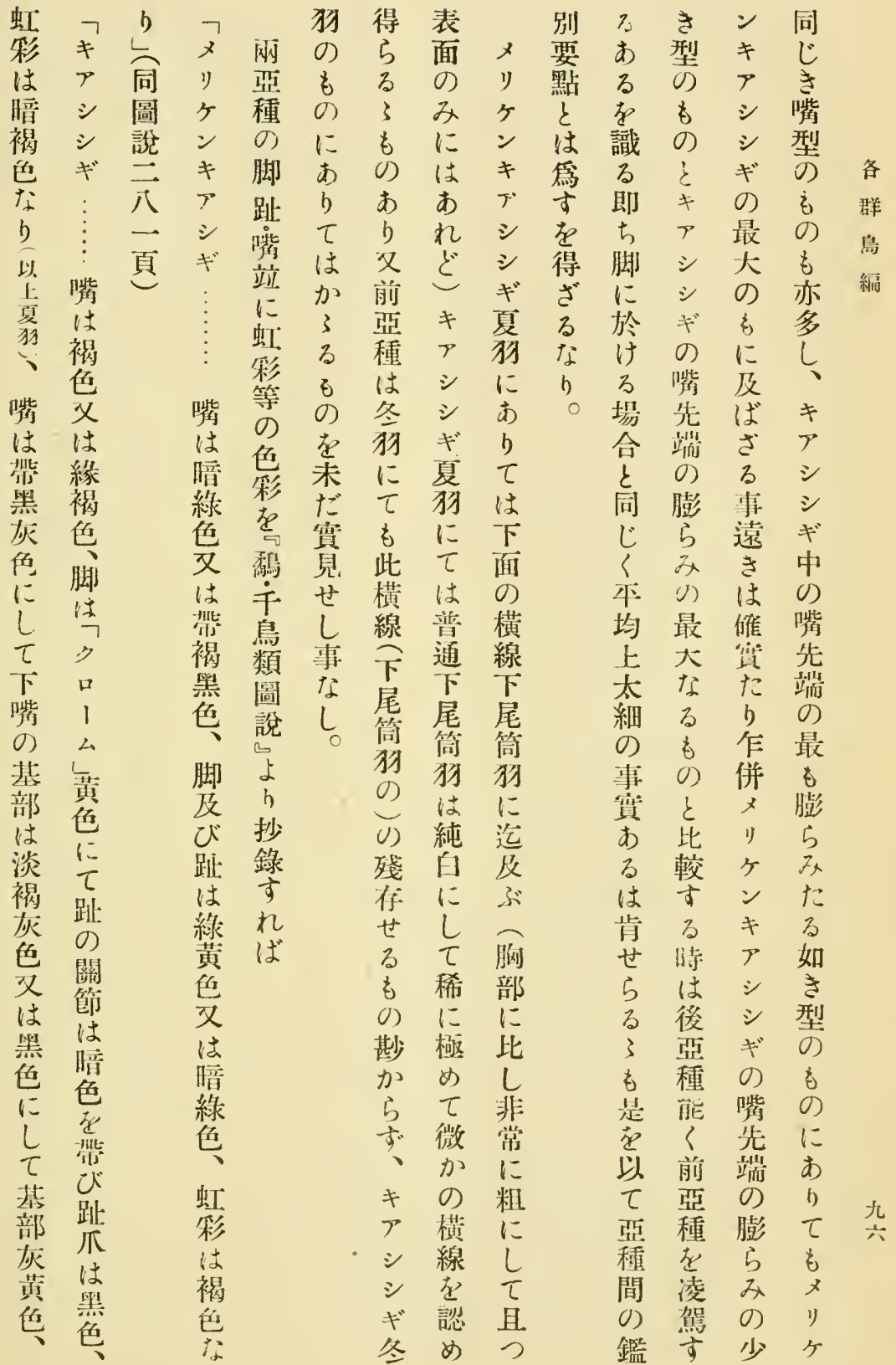




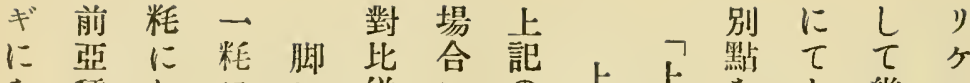

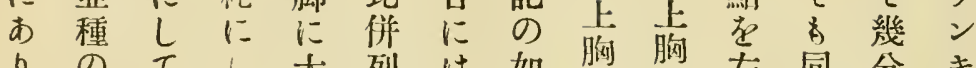
bの $＼mathrm{~ ～ 太 列 は 如 胸 胸 左 同 分 ~} \neq$

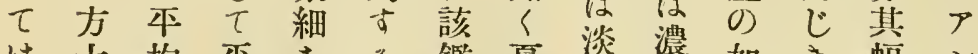
群嘴

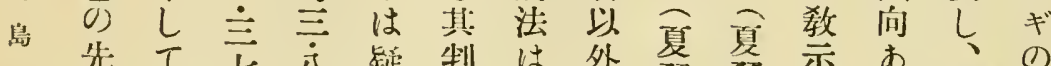

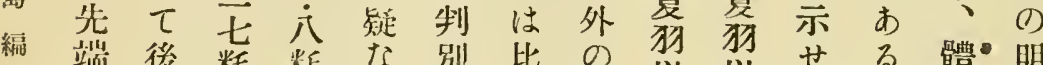
の後粍粔な别比の悡以 る 體。明

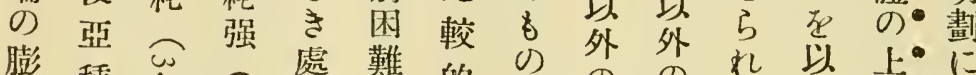

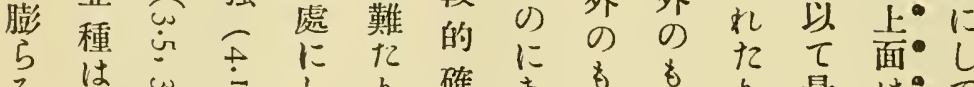

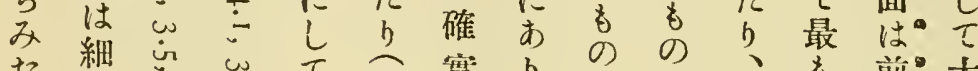
れ き 如事

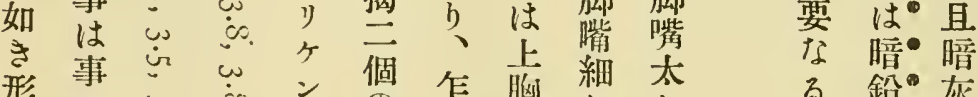

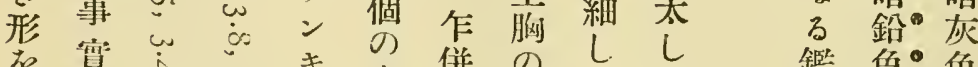

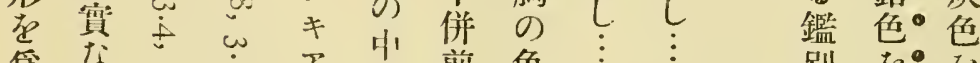
䉆な せ 、 $\doteq \dot{c}$ 型述彩 b u i

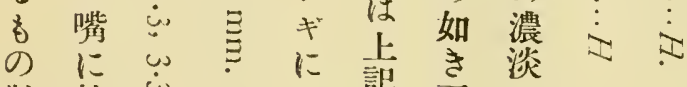

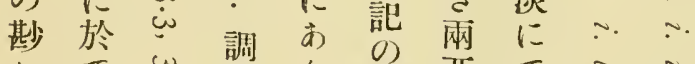

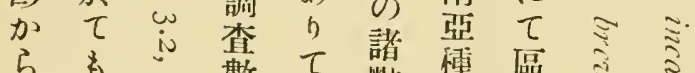

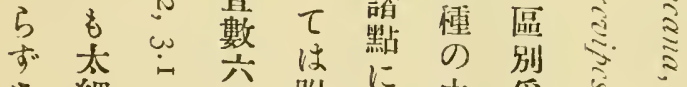

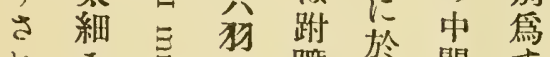

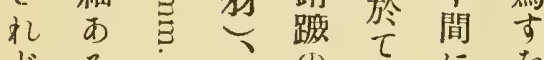

どる調キひ前にを 然は調 毛最前近得 占確查繁 ざか數シ部近型ど るに十ギ部近の爾

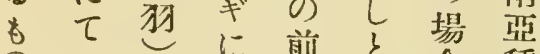
の はり あて後認にを

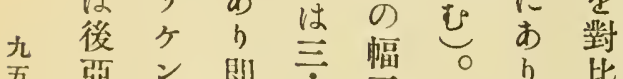
亞 $ン$ 即 $\doteqdot$ 首 0 b 此

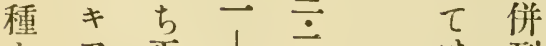
子小库 $\frac{1}{\equiv}$ は 列

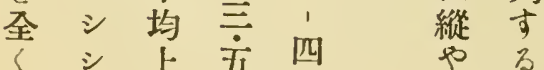
點 呈・呈 なす・せ b) $3^{\bullet} る$ 范に 黑 後 對 田者し 理 學 带恶 士 褐・種 は灰・の 此鼠” 兩色 0 亞 な・は 種 $b^{\bullet}$ 稍 冬 不 牙冬明

の 旸 膫

ह 並な

のにる

に幼淡

於 期 黑 けの褐

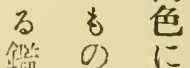


シ腹純に蛇志ら別の・ば

ギ部純 正腹 、ざ跗営は・其・此を借

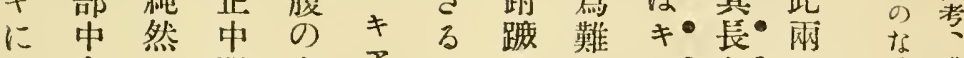

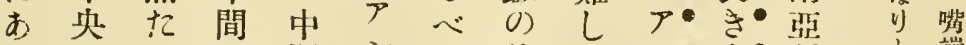

b並るの間 シ $し$ 後

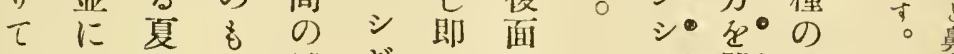

は下旸し鱗ギちの

上尾の存列にメ鳞

胸筒 $x$ 戛存於少烈

部にリる 見てケに

及めケ事方はン從 びりンンあ事大斗子 體て 側はア $\underbrace{}_{0}$ る 數 シ は に横シ は蛇シ 頗

の線 シ

み淡 ギ

横色に

線な あ

子る b

認 か $\tau$

む事は

子は上

そ極 胸

下め部

胸 $匚$ 以

部不下

以 明 O

下瞭下

はと面

白な 全

な色全

b同に

而じ横

しき線

七 老

上元

胸 テる

部 チ 後

橫尗胸

線 キ 部

は学中

的

前腹ギる

揭牀に危

の排七 險

如列は

し点網し

中 思䚬县

間 ぞ排不

の 列 正

排稀 の確

列に方な

繲多る

篇貝きは

す 鱗 が 前

るな如表

のきけに

は虔れ據

多保 ぞり

せ 蛇 て

何す，腹 ह

九面牀

加 L 政

- $\tau$ 亯 $\overrightarrow{\text { 般 }^{2}}$

方雨势

溜名制

編種高杰

共亦后

るに尠に

網加難

稀具方妿

ギ・單・重

・位 妿

認・と・鑑

链 し・别

る・ $\bigcirc$ 點

を・市はは

得・吋っ 鼻

へ・滗

L・約 端

但 \#。 $^{\infty}$

し一精 嘴

中 以 先

間 以“端

型下:

各

群.

क है 距

b 離

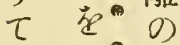

は メ 長

此 り短

點 ケ・に

の ン・お

み キ。 h

に ア・即

於

於 其”

はギ・距。

キと・踓。

$>$ 鶕・离。

し・故

シ 左。

シ 右 距

ギ ○等・赔

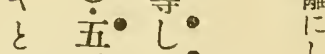

茴

同 吋

样 以“ 强

に上さざ・出

$\tau \sigma^{\bullet}$

區 ह 時 


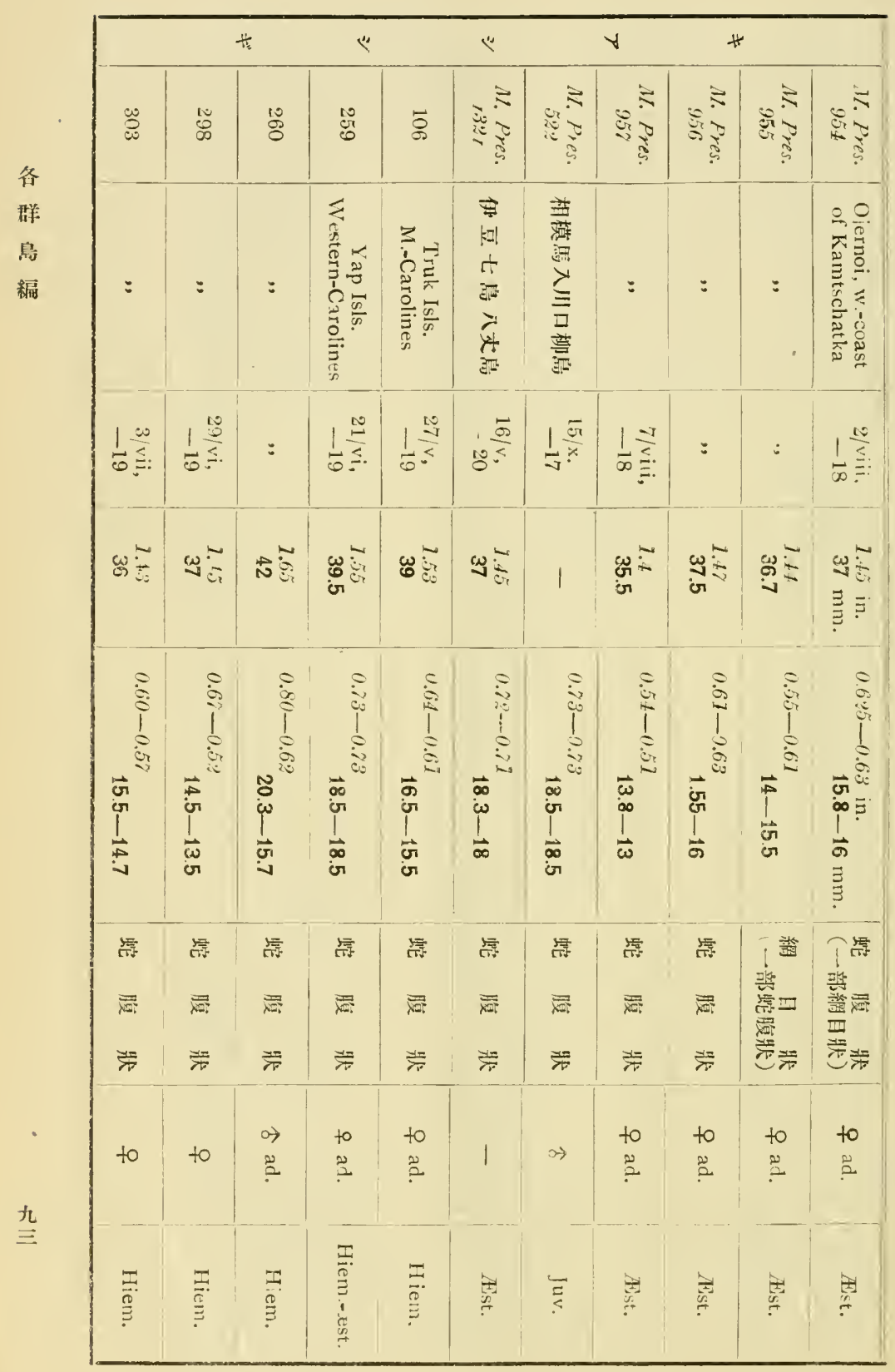




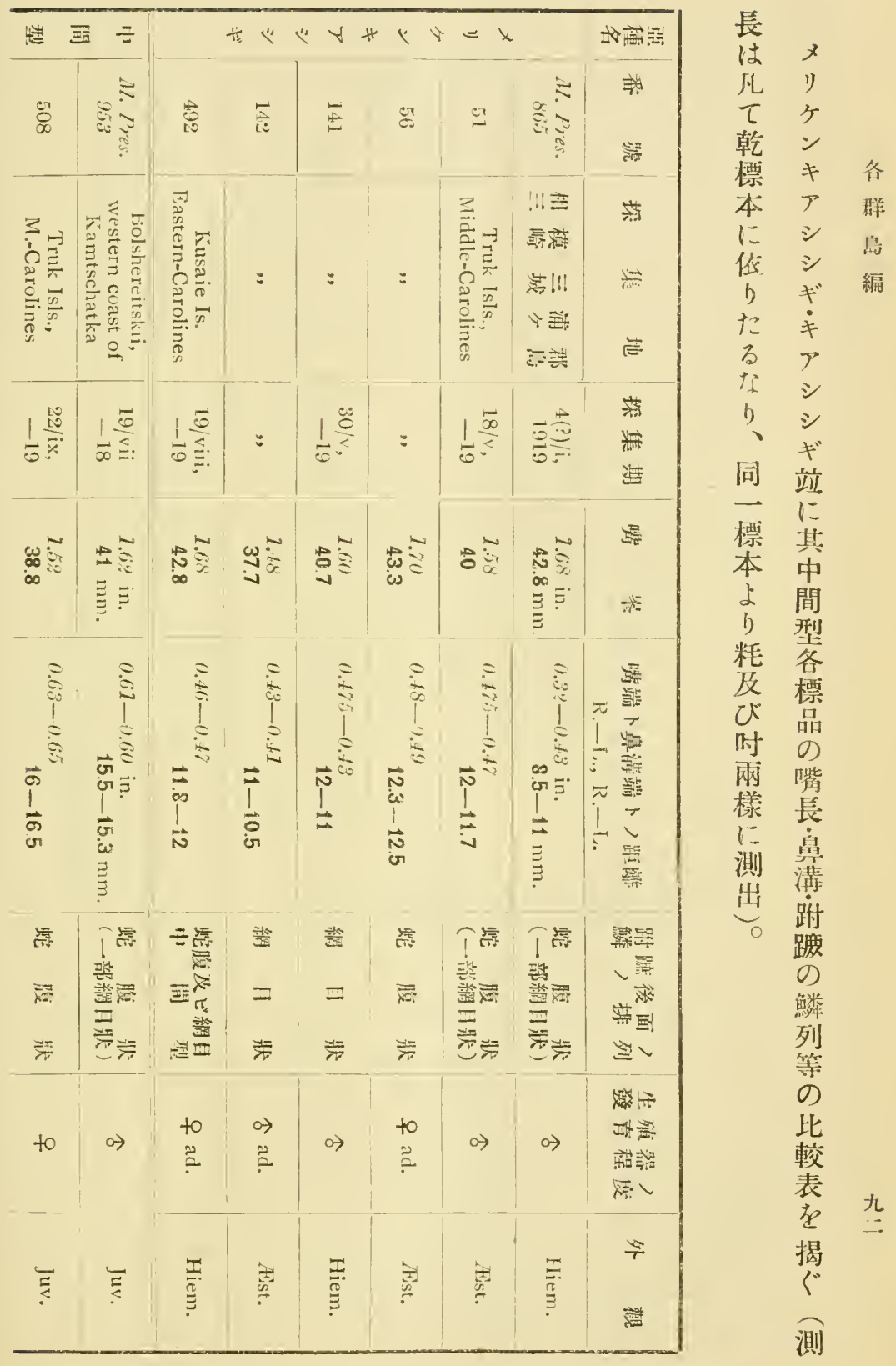




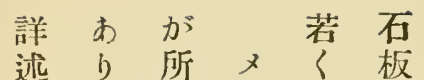

寸 早卜年

るは藏りケは色虹 冬ラッ棓

事從に二綠綠沙水他

行子爽名 $>$ 黄石淡—水他

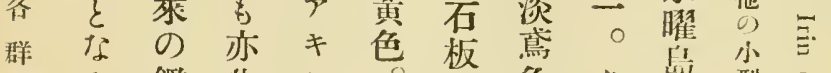

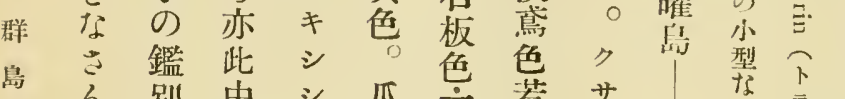

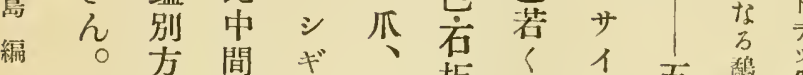

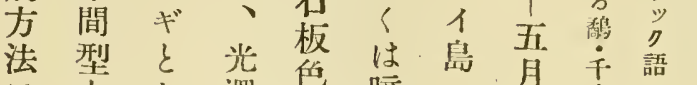

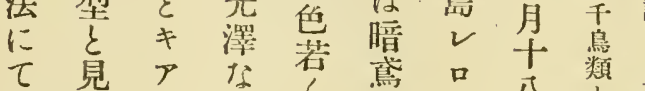

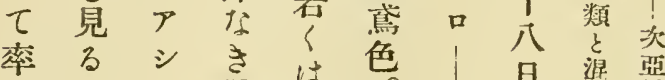

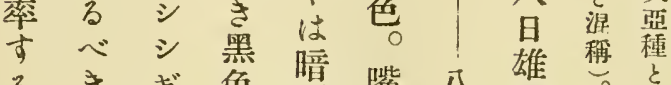

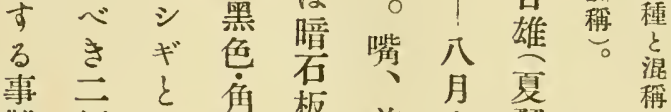

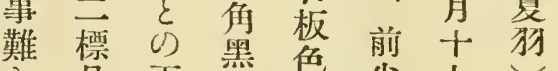

き品兩色等尘部光二

のり種に脚は雌雌

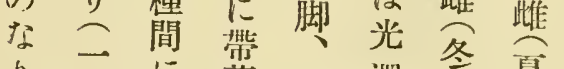

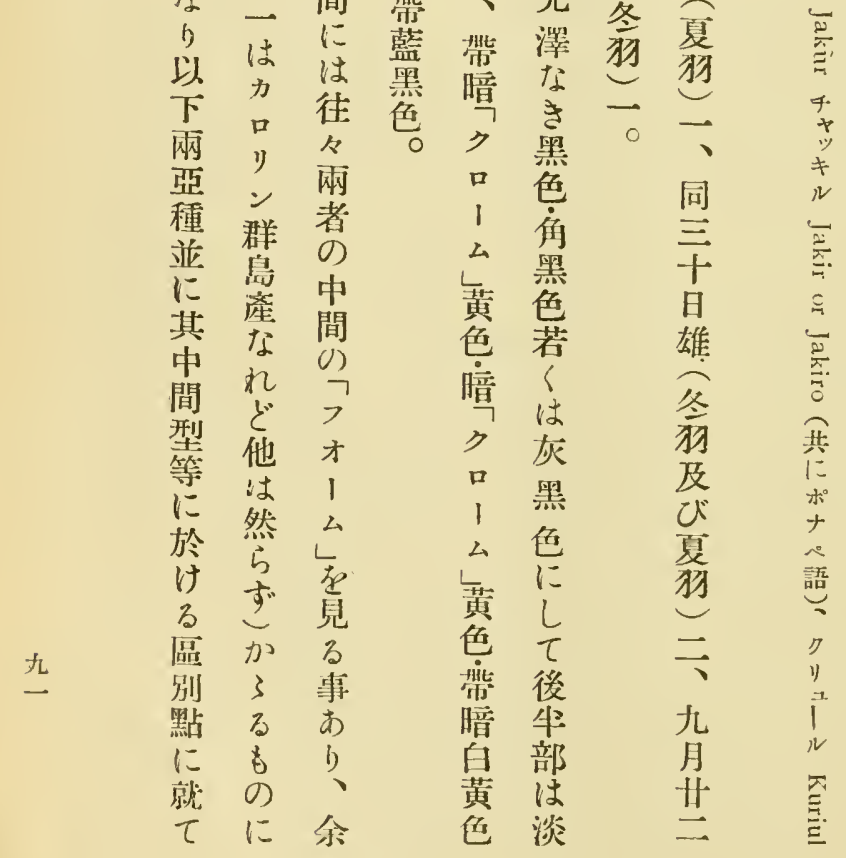

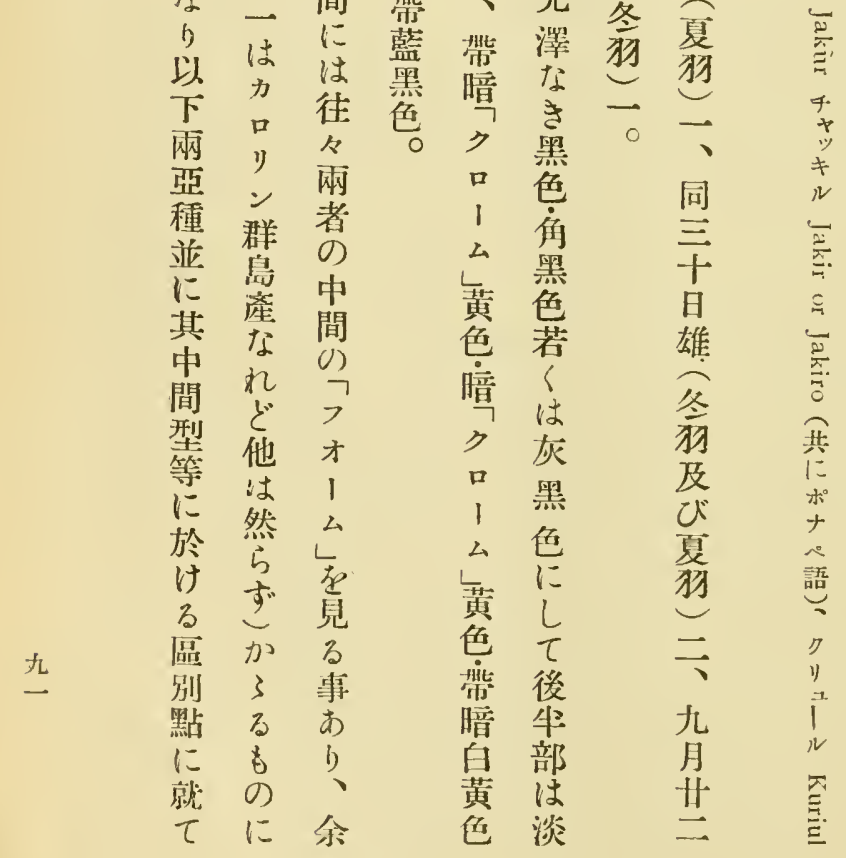

稱足空

产 
るは、島樹ずははグ 因に尗に林該六愿品或て 本めは聞海に目ヴッ 地て八き水公同擊樹?

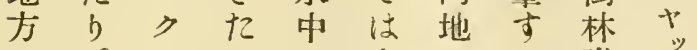
にモるに中とる附 プ

七 モは构口處近兩 はチ疑り鵤㿝な若諸 中。ウなて 類に 构 シく所死七》注に

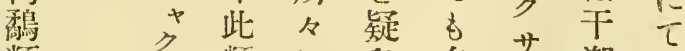
類

の

震

々

$\checkmark$

ע

グ

口

I

ヴ

樹

の

高

枝

上.

椿

㠿

3

存

る

事

$$
\text { 類にな夕夕潮は }
$$
$\beth$ 泥々刻本時多

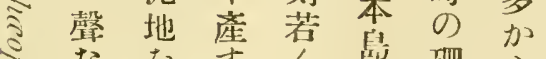
な老李く昰珊占 b見るは楜ざ

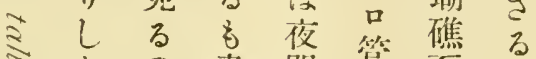

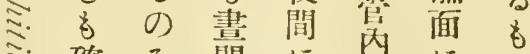
ミ確み間に内にの

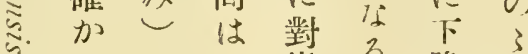
にに一岸崖降如 ఏ該在 ン こ時りグダかるれ なの吕吊皇 り告潮省少、見其 しの潮学クヴる他 やが面樹附樹事の 子于等 林近林多各 知员内呙员地 れシ出交其に圣に

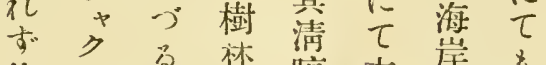

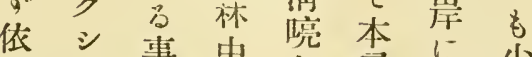
て 代事中眇蜀添少 以な 尠 $\frac{c}{3}$ の 添數

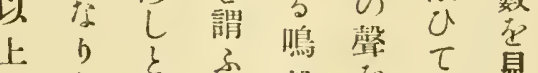
のと聞京督等鳴自 事は地荡聞鴽る る 貫明、上閶き?得 の言今にくらり

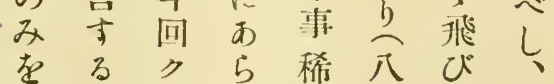

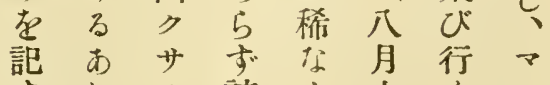

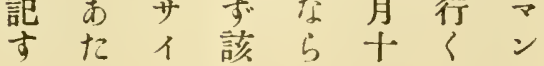

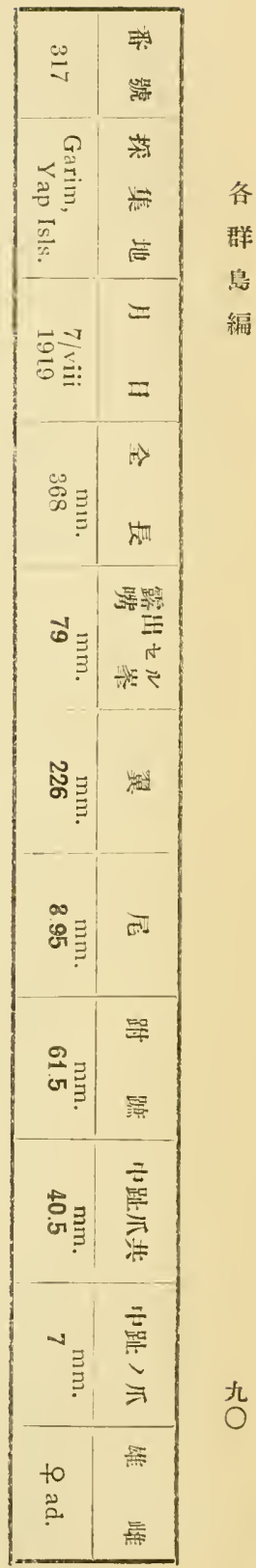




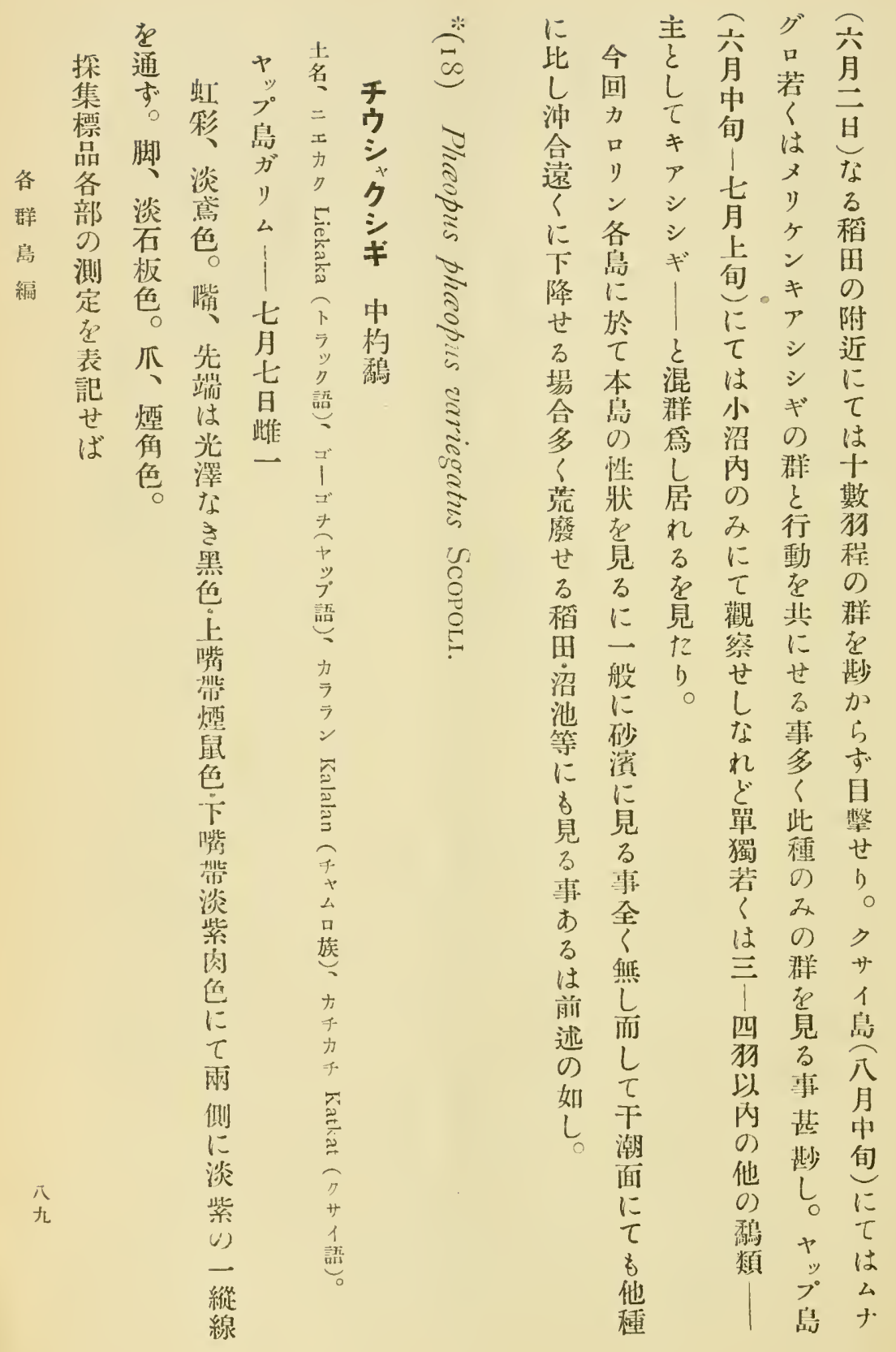




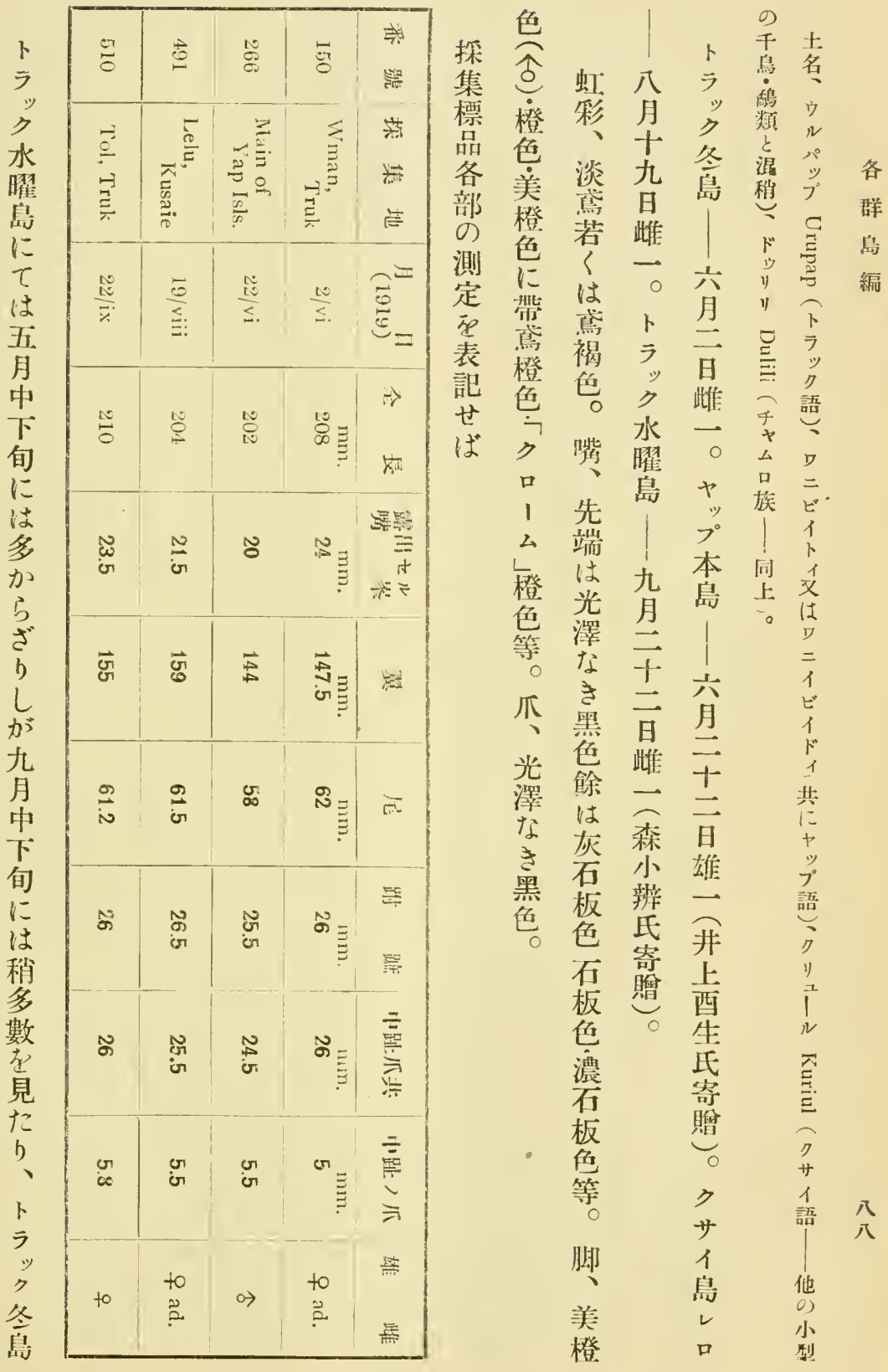




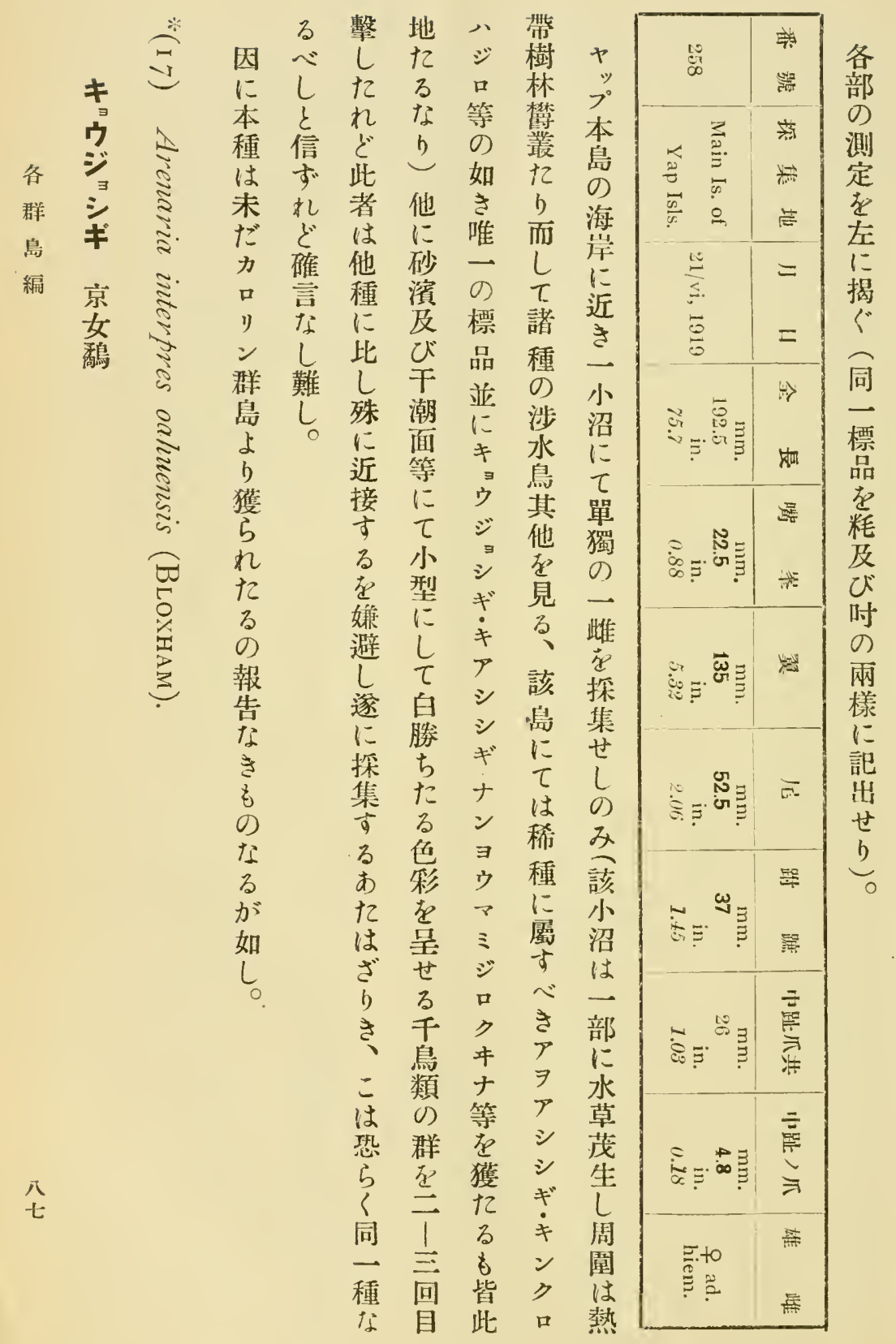




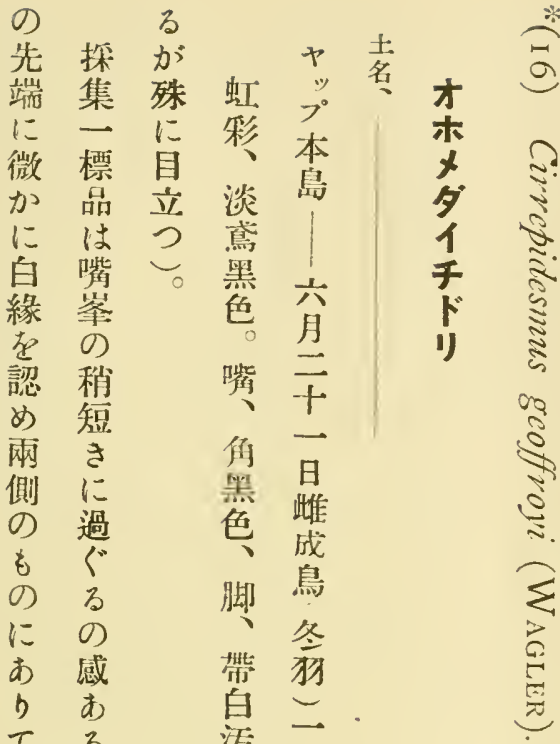

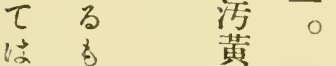

其 此

色

外 種

侧 認

蹀

白起

緣 3

の k

幅 正

廣賞

L

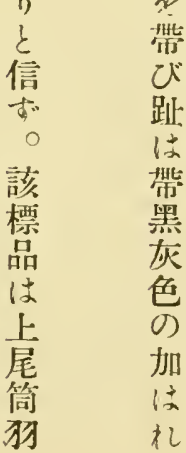

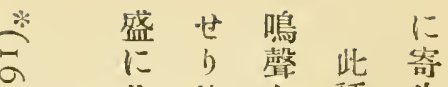

此依存種生

鳥て發は虽

在之夺下の

捕を步降發各

食喰步静生群

せ窃時步せ島

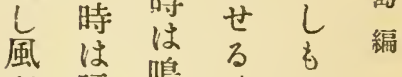

習暗鳴時の

0)夜架かに

今志若

佾 物 暗 く

殘走夜は号

存視に飛ざ

しるて翔る

現をものべ

時得倘際け

の 之之记

卜ををりば

亏傳聞 飛 か

, $2<$ 行 3

島謂、中る

名文に会

民徍”快

此時島短食

種条岛々性

丞㠗县有

好住告銳盆

喰皆此き鳥

間鳥。节

りのは之有

。爭夜 害

䦥 緭 ह

のに

折名文

に倘 ह 3

㿽其“省

せ視离 b

九力閥。

七无㳭る 


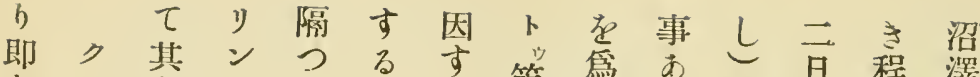

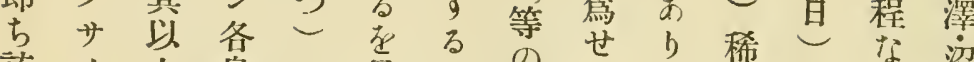

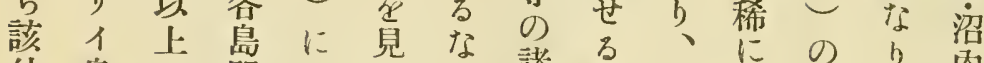

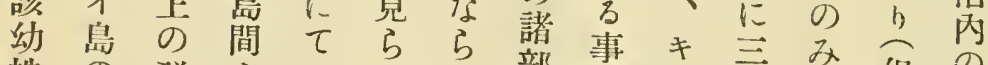

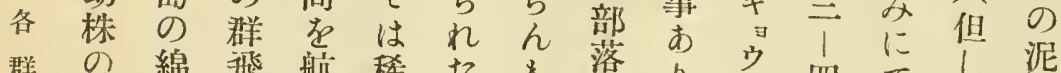
群の綿飛航稀て子落り ウ四てし 泥 島根試に行版或附つジ雅他ポ地

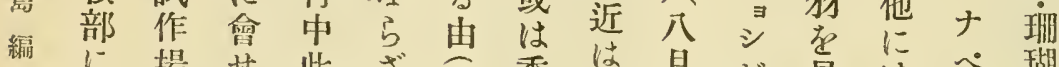
に場せ此ざ季は月ギ見は心辞

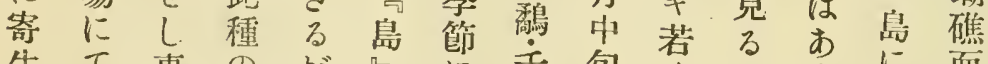
生て事のが第に宁旬若にまに面

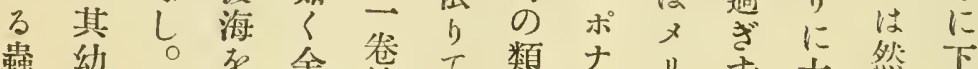

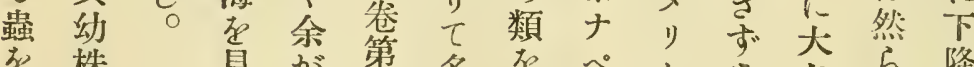

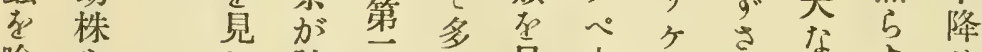

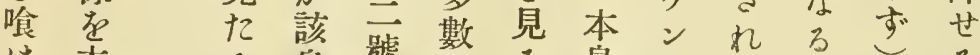

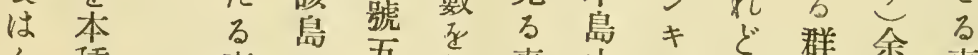
几 種 子 $\tau$ 営 第江

せ 引

拔

結 加

果 几

が困

加 却

害 せ

犎事

な あ

b) b

t2

2 $\varepsilon$

小同

ら場

几擔

賞

八全著

五農よ

場 b

の)聞

線き

株 た

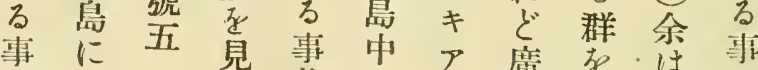

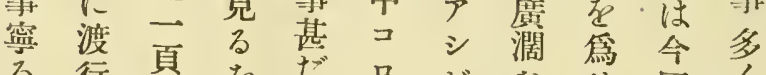

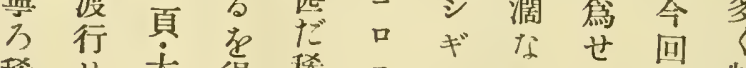

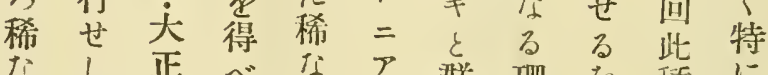

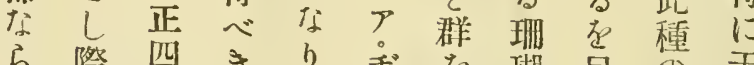
5 際四き

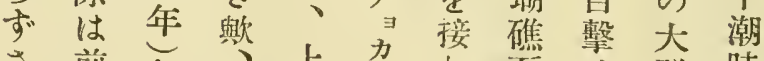
子前但、去力八面世群時

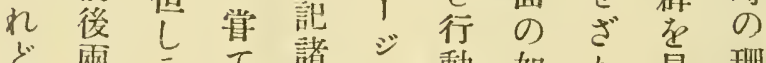

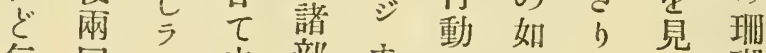
每回之寺部な差ききれ瑚

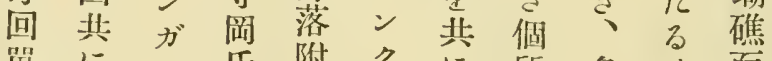

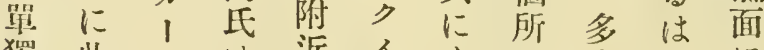
獨此儿は近个者に多にに

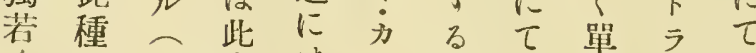

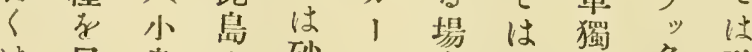
蛙目島砂》合此畧”殆

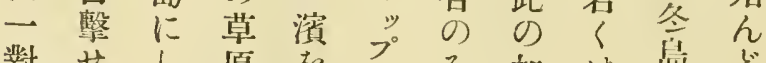

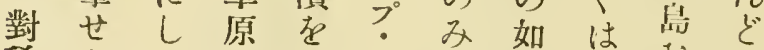

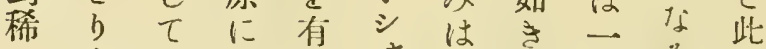

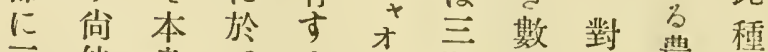

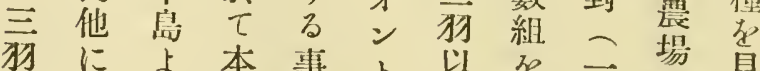

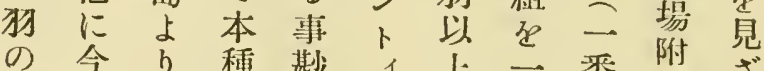

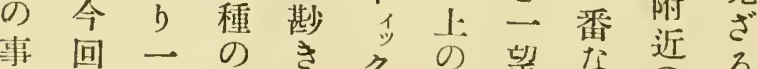

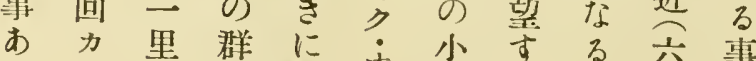

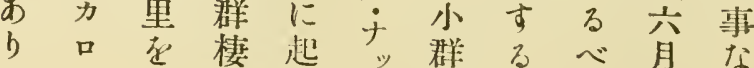




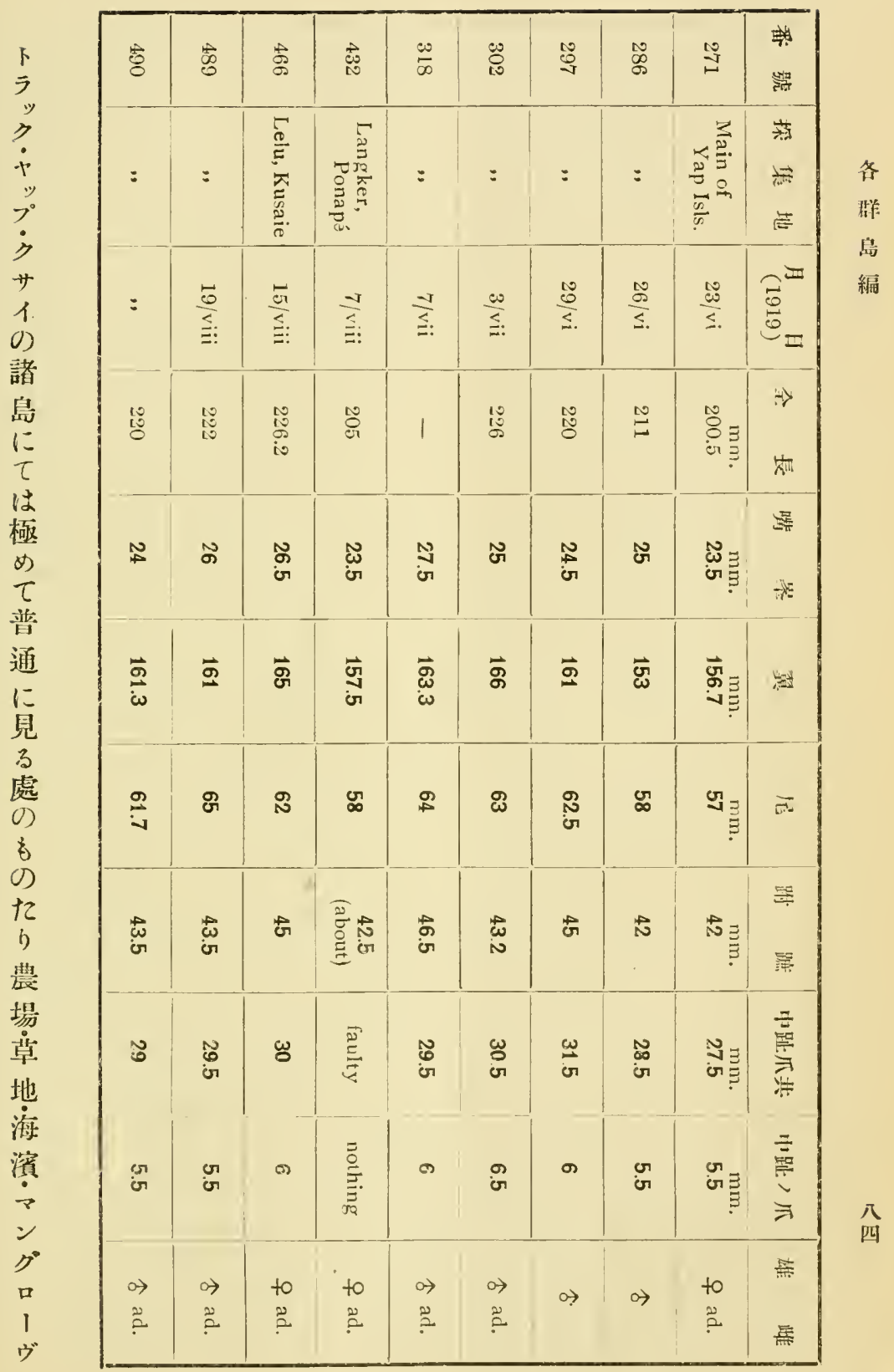




\begin{tabular}{|c|c|c|c|c|c|c|c|c|c|}
\hline$\frac{10}{6}$ & $\stackrel{10}{\infty}$ & $\stackrel{10}{=}$ & 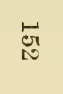 & 芯 & చే & હै & जै & ثे & $\begin{array}{l}\text { 패 } \\
\text { 绩 }\end{array}$ \\
\hline$=$ & : & 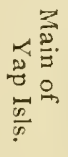 & 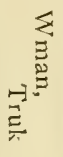 & $=$ & $=$ & $=$ & $\begin{array}{l}\underline{-1} \\
\underline{0} \\
\vec{E} \\
\underline{n}\end{array}$ & 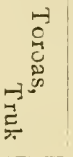 & $\begin{array}{l}\text { 荡 } \\
\text { 崖 } \\
\text { 落 }\end{array}$ \\
\hline$=$ & $=$ & $\frac{\tilde{\sigma}}{\Xi}$ & $\frac{10}{s}$ & $\stackrel{\omega}{<}$ & $\stackrel{\leftrightarrow}{\stackrel{\leftrightarrow}{\circ}}$ & : & $\frac{10}{4}$ & $\frac{\vec{r}}{<}$ & $\begin{array}{c}\tilde{\omega}_{0} \\
\stackrel{0}{0}_{=}\end{array}$ \\
\hline$\stackrel{\stackrel{N}{e}}{e}$ & 茎 & $\begin{array}{l}10 \\
10 \\
10\end{array}$ & 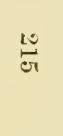 & $\stackrel{10}{10}$ & $\begin{array}{l}\stackrel{10}{0} \\
\mathscr{E}^{\circ}\end{array}$ & $\begin{array}{l}195 \\
15 \\
150\end{array}$ & 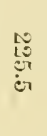 & $\stackrel{10}{0}$ & $\begin{array}{l}\Rightarrow \\
\Delta\end{array}$ \\
\hline$\stackrel{N}{\Delta}$ & G & ผै & ตั & 心 & G & స్ & E & $\mathcal{G}$ & 退 \\
\hline$\vec{g}$ & న & & $\begin{array}{l}\vec{g} \\
\stackrel{N}{c}\end{array}$ & $\begin{array}{l}\vec{\Phi} \\
\dot{\sigma}\end{array}$ & $\begin{array}{l}\overrightarrow{\mathrm{g}} \\
\text { i }\end{array}$ & $\vec{\Phi}$ & $\begin{array}{l}\vec{G} \\
\stackrel{\infty}{*}\end{array}$ & $\overrightarrow{\bar{\omega}}$ & 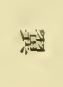 \\
\hline $\begin{array}{l}0 \\
\infty \\
\dot{G}\end{array}$ & $\begin{array}{l}\text { g } \\
\text { نे }\end{array}$ & $\underset{P}{\stackrel{P}{0}}$ & $\begin{array}{l}\text { जे } \\
\text { जा }\end{array}$ & ని & S & 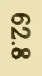 & $\begin{array}{c}\infty \\
\omega \\
\omega\end{array}$ & \begin{tabular}{c}
0 \\
$\infty$ \\
\hdashline \\
$\rightarrow \vdots$
\end{tabular} & $\bar{\pi}$ \\
\hline 忠 & $\begin{array}{l}\mathbb{N} \\
\text { G }\end{array}$ & E & E & 忠 & \& & N & $\stackrel{\vec{E}}{\Xi}$ & 㤐 & 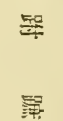 \\
\hline $\begin{array}{l}\text { So } \\
\text { ט1 }\end{array}$ & ज्ञ & $\underset{\text { N }}{\omega}$ & & $\begin{array}{l}N \\
\infty \\
0\end{array}$ & 1 & $\mathbb{\infty}$ & $\begin{array}{l}\text { जै } \\
\text { ज़ }\end{array}$ & $\begin{array}{l}3 \\
3 \\
\vdots\end{array}$ & 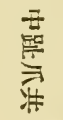 \\
\hline$\sigma$ & $\sigma$ & 0 & G & $\underset{v}{G}$ & a & G & N & is & 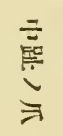 \\
\hline $\begin{array}{l}\text { to } \\
\stackrel{2}{?}\end{array}$ & $\begin{array}{l}\text { to } \\
\text { :ै. }\end{array}$ & 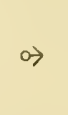 & $\begin{array}{l}\stackrel{\rightarrow}{ } \\
\stackrel{2}{0}\end{array}$ & $\begin{array}{l}\text { to } \\
2 \\
0\end{array}$ & $\begin{array}{l}\text { to } \\
\stackrel{2}{2}\end{array}$ & ๑) & $\begin{array}{l}\text { to } \\
\stackrel{2}{2}\end{array}$ & $\begin{array}{l}\text { to } \\
\stackrel{2}{6}\end{array}$ & 熹 \\
\hline
\end{tabular}




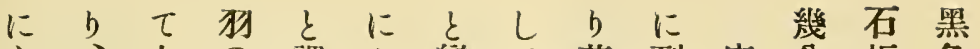
主、七の謂 あ 變て 著到廣分板色

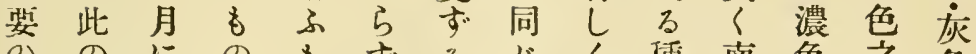
ののにのも方るじく種南色之色 原如殆芭乞色 はき黄々洋なに淡

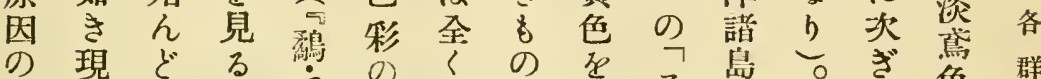
の罳夏 事市 の く

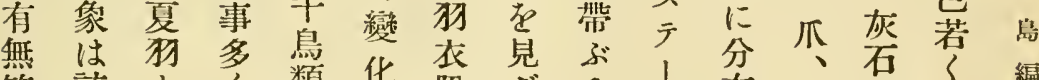
等該子々 類化脫ざる和布、石々 編

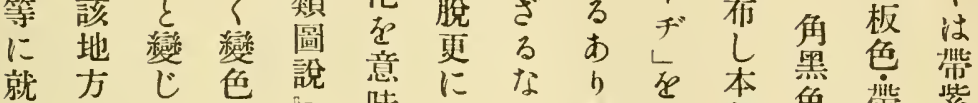
就方 目溫了与六す方、斑集產黑淡石 下度を了頁学す其承す包篮板

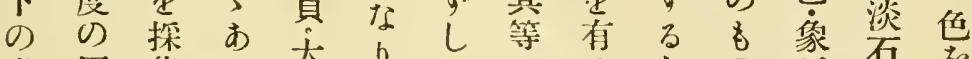

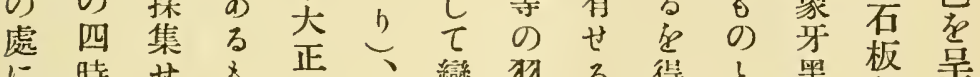

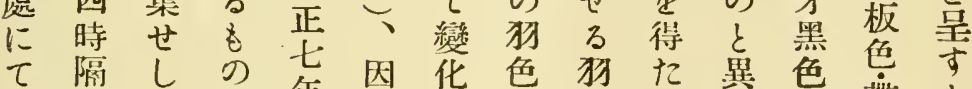
は差即年に守の在り落带 不著此ち力本る黑萃而るく淡間

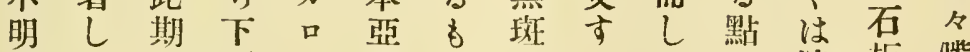
たかに面り種の质るてな淡板嘴 りら見にンのな併あ探し像空の ざる 黑 諸 全る 視り集、牙色 全 鳥斑島き事考及諸今黑若般

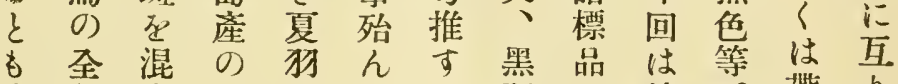
多部ずすとどる邪に純。帶り 少がるの變疑に步就然白て の夏もに艺方本混き们灰黑 關呵のあ終の種ずて 係子はbる 餘情る 檢冬 は少ては地冬あ古弱 有り數注本な呵りるよ b終死五邦し付てにり 得炾自月にこ色嚴其純 心 る得に あ更彩密下然

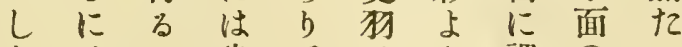
とはに少てせり謂のる 想的過純

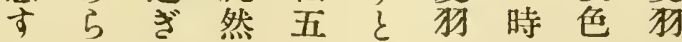
るざ秀䎲月在のはなに

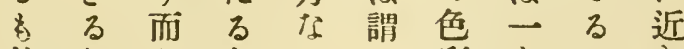
他な $L$ 冬b方彩 $\varepsilon$ क

色 色 な 呈 3 すे る b

あ 0

b 脚

般沰 に 板 趾 色 の 最 方多 


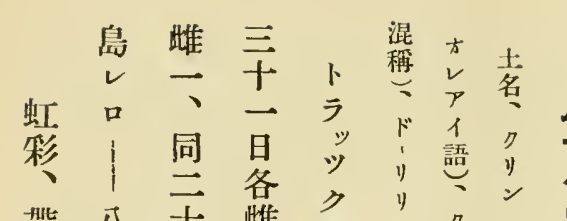

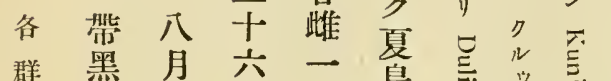

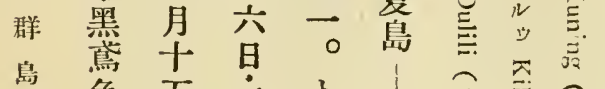

編色票白

は 崔九只品

地、日冬十族語語

褐同㫐兒五語

臨十量|旦同

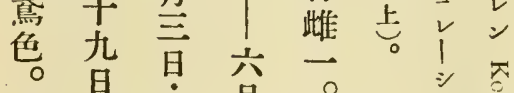

嘴雉闹合。盯

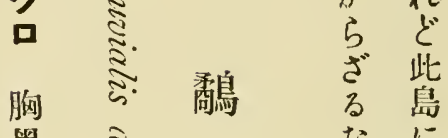

先等

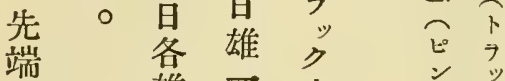

は 雄

角

黑

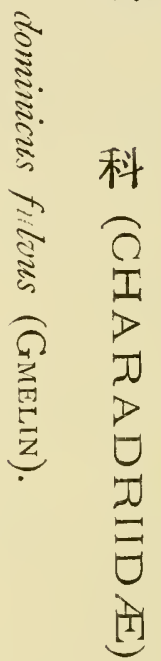

事 疑

蓋な

L

尠さ

加

なに

5 比

几 較

黑

色 ナ本 兵星

○ 島

語 東

ก岛五品

は

像

牙

黑

色

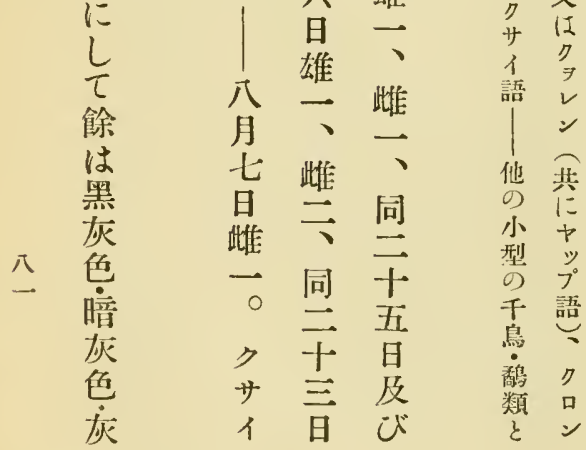

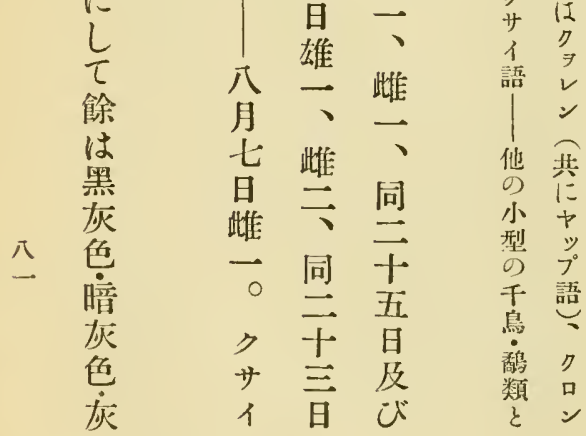

$\varepsilon$ 的

推 多

考 產

すす

る

大

蚚

蝪

は

本

亞

種

の

常

棲

地

に

常

1

出

沒

夺

る

点

$\tau$

其

卵

嗮隹

に

加

害 
る擬 の强て 知に整は あ

事鶴みきはる害種全卜ら

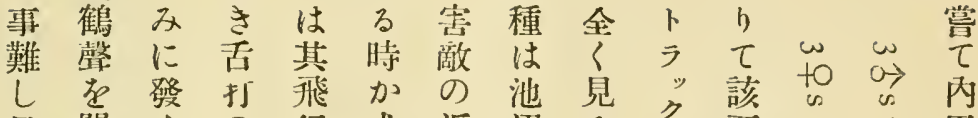

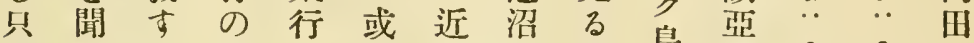

池くる 如のは接畔を島種气き氏 各

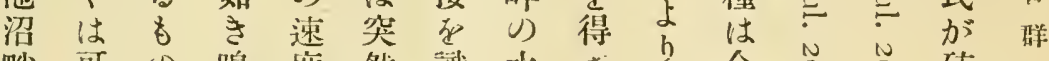

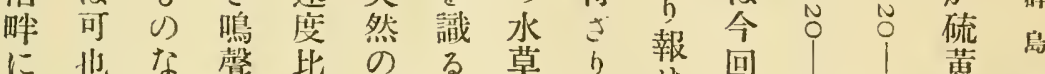

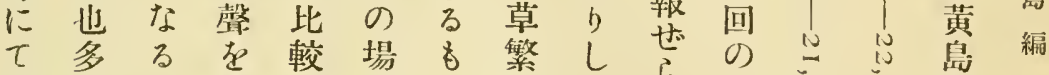

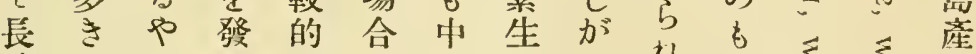

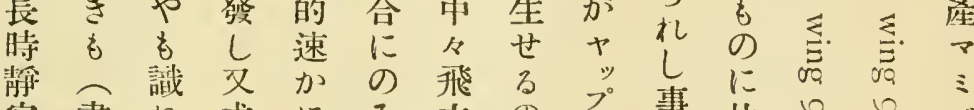

察晝れ或にみ立のプ事比只方

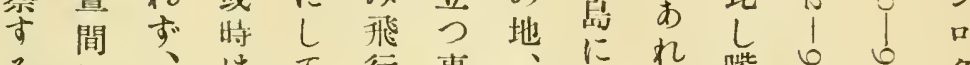

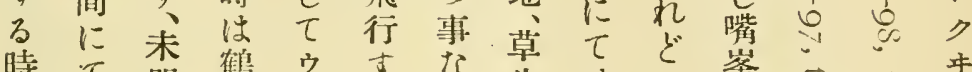

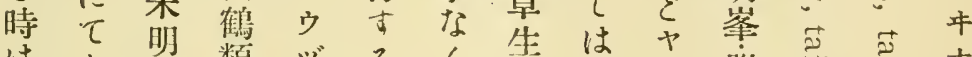

はるに類ヅるく地數ッ跗导芯+

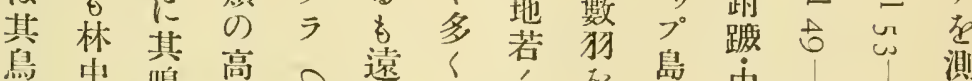

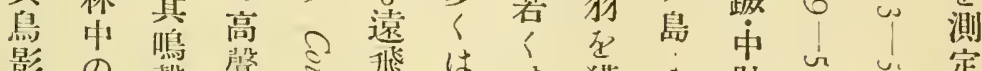

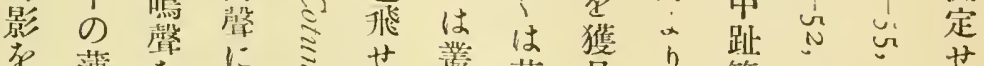

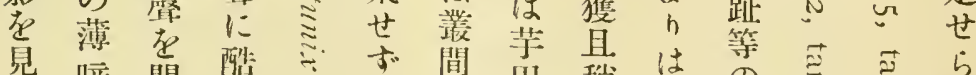

る暗聞似

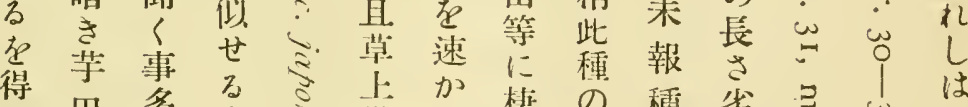

へ田多大劣僅に楼の種劣导出は

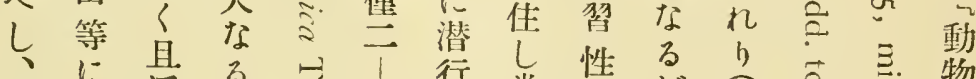

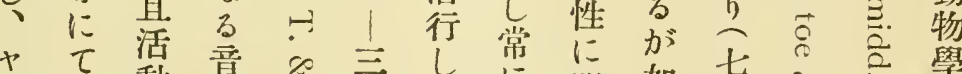

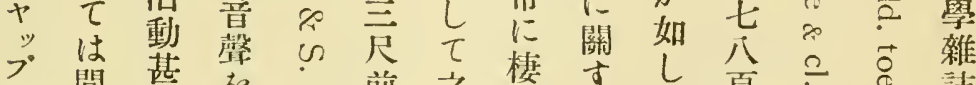

島間 し 望

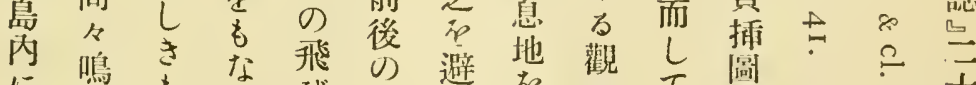

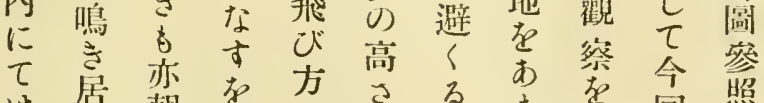

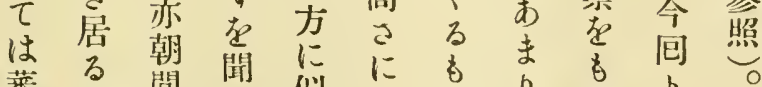

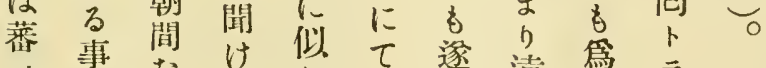

殖あ事な げた

す b る 後

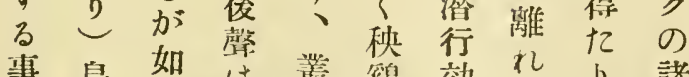

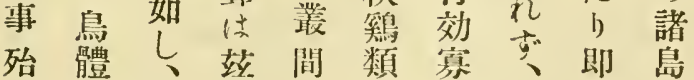
ん齐所尾に主し身ちに と見謂期 $と と$ 邊本元

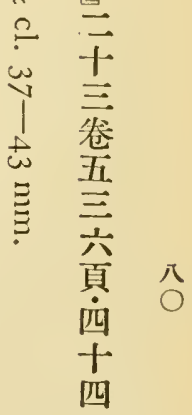




\begin{tabular}{|c|c|c|c|c|c|}
\hline : & : & $=$ & $\begin{array}{l}\text { 三 } \\
\equiv\end{array}$ & 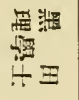 & $\begin{array}{l}\Xi \\
\text { ङ }\end{array}$ \\
\hline$\stackrel{10}{0}$ & $\underset{\mathrm{i}}{\mathrm{i}}$ & 苋 & 党 & 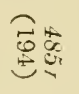 & $\begin{array}{l}\text { 为 } \\
\text { 䈃 }\end{array}$ \\
\hline : & : & : & : & 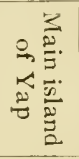 & 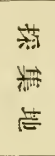 \\
\hline$\frac{\sqrt[\omega]{\omega}}{\Xi .}$ & $\frac{10}{\leq}$ & $\frac{\vec{\varphi}}{\leq}$ & $\frac{\sigma}{\varsigma}$ & $\frac{\vec{T}}{\leq}$ & $\begin{array}{l}\stackrel{6}{0}= \\
\stackrel{6}{0}=\end{array}$ \\
\hline$\underset{\infty}{\infty}$ & कू & $\underset{⿱ 宀 \infty}{\stackrel{\infty}{e r}}$ & $\begin{array}{l}\bar{\infty} \\
\stackrel{\sigma}{\sigma} \\
\text { or }\end{array}$ & $\vec{\infty}^{\infty} \Xi$ & 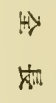 \\
\hline N & N & $\vec{\omega}$ & స్ర & $\stackrel{\omega}{\omega}$ & $\begin{array}{l}\text { 몬 } \\
\text { 잠 }\end{array}$ \\
\hline $\overrightarrow{0}$ & 5 & $\overrightarrow{0}$ & 0 & ठ & 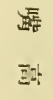 \\
\hline G & \& & 9 & $\begin{array}{l}0 \\
\text { a } \\
\sigma\end{array}$ & $\stackrel{\mathscr{E}}{3}$ & s \\
\hline $\begin{array}{l}\text { G } \\
\text { G }\end{array}$ & $\stackrel{G r}{\leftrightarrows}$ & G & $\begin{array}{l}\text { N } \\
\text { G }\end{array}$ & $\begin{array}{l}\text { G } \\
\text { G } \\
\text { G }\end{array}$ & $\bar{\sigma}$ \\
\hline 8 & 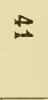 & $\begin{array}{l}\text { a) } \\
\text { o. }\end{array}$ & $\begin{array}{l}\omega \\
\infty \\
\dot{\sigma}\end{array}$ & $\begin{array}{l}\omega \\
\infty \\
\dot{\sigma} \Xi\end{array}$ & 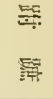 \\
\hline $\begin{array}{l}\text { g } \\
\text { or }\end{array}$ & $\stackrel{\mathcal{G}}{\sigma}$ & g & 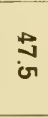 & 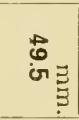 & 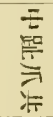 \\
\hline$\stackrel{\infty}{G}$ & $\begin{array}{l}\infty \\
\dot{\sigma}\end{array}$ & $\infty$ & $\infty$ & 0 & 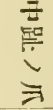 \\
\hline$\rightarrow \rightarrow$ & 가 & $\rightarrow$ & to & $\leftrightarrow \rightarrow$ & 量 \\
\hline$\stackrel{2}{2}$ & مِّ & مै & 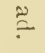 & $\stackrel{0}{0.0}$ & 乓 \\
\hline$=$ & : & : & : & $\begin{array}{l}\text { E } \\
E\end{array}$ & $\begin{array}{l}\text { 毵 } \\
\text { * }\end{array}$ \\
\hline
\end{tabular}

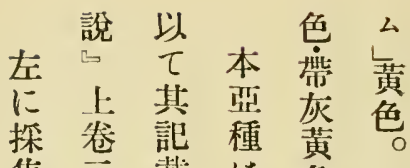
集爷載 は硫角脚 鳥三少黄若堦 の頁略島く暗 测參す特は樒 定照 $\subsetneq$ 產角檬 老但ミな肉緂 表但脑る色色

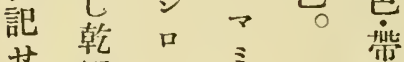
せ䌘ク ミ 綠 几本年 にナ口 あ 午 り訅 方 はは一帶 橴綠 の 動 之灰 管物 焉 暗學文吕

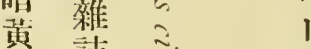
褐誌主文 色立志黄 脚毐 $ミ$ 色 は悉若

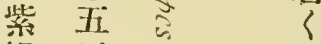
褐三三梳三 色五要緮 に 1 灰 變 五 五色 る 亲極留 事頁極会

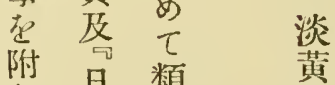

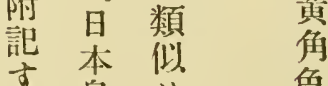
。烏せ 類 る 訚有 


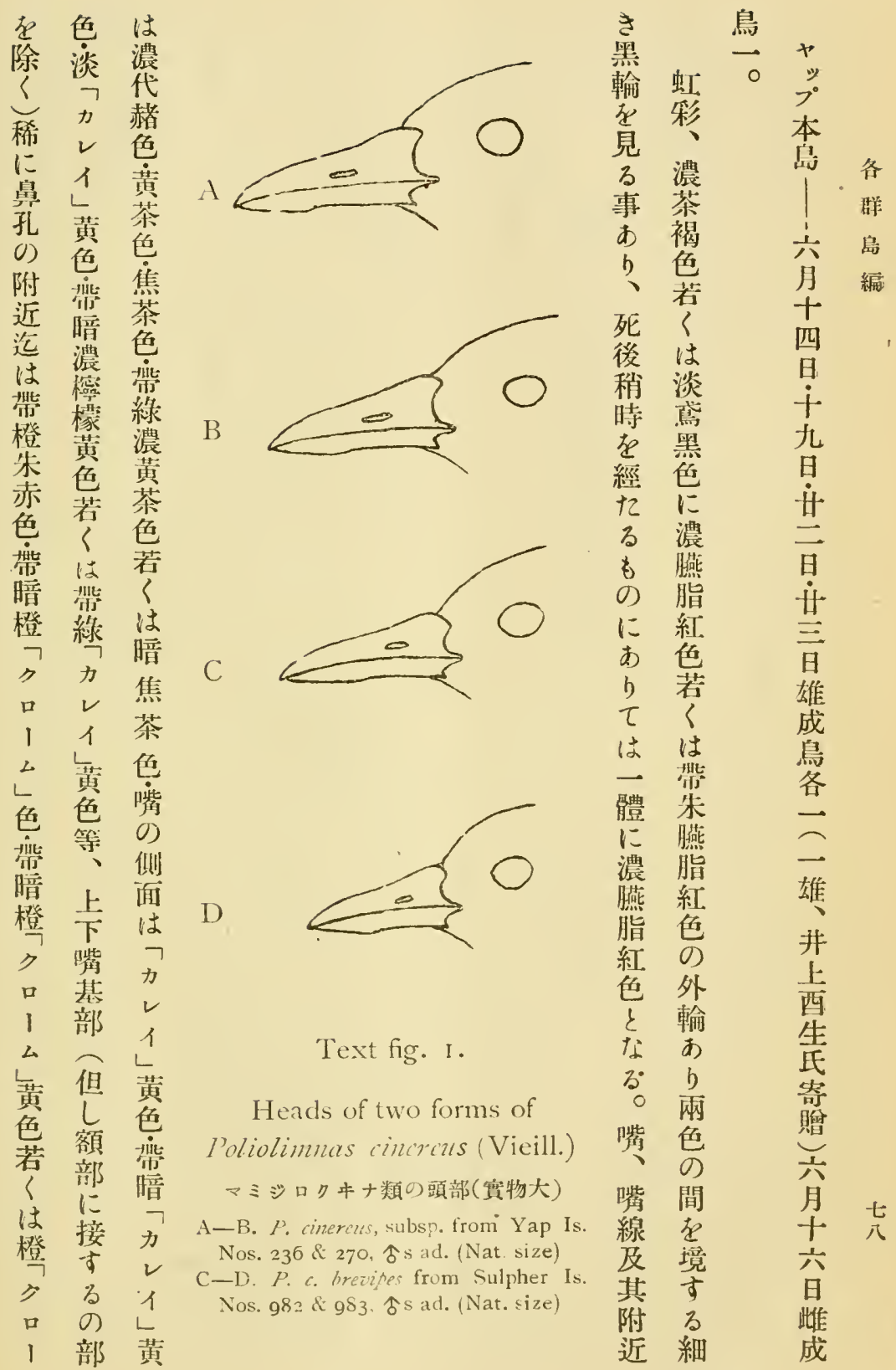




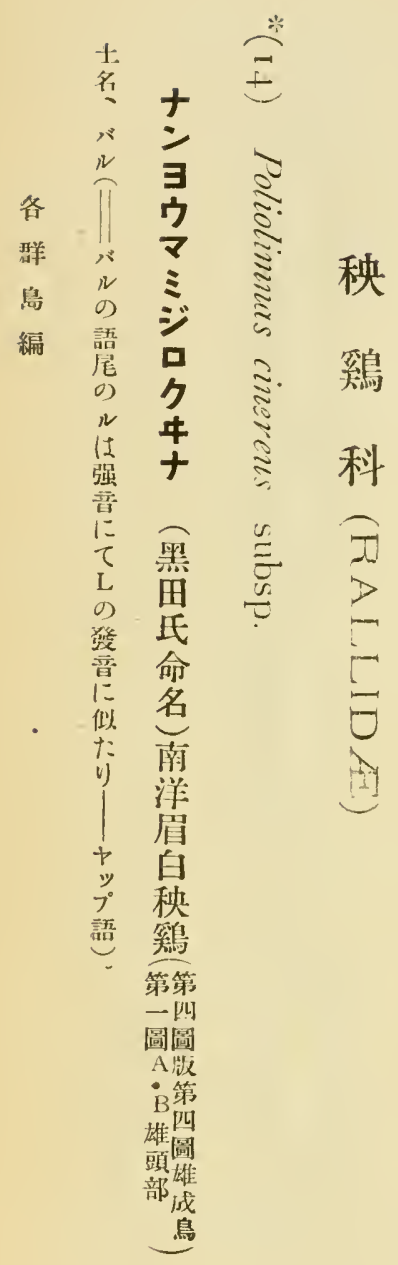

きと等しし聲朝の

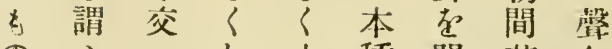
のふ名し小種聞若占

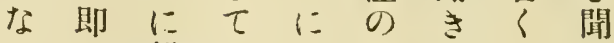
りち 雜可し形てはき 子家 b出て態 b夕得 信鷄胸深昆立公刻た ま。腹け旸に公にり は部れ全站箖士部公 にに頭鵄等 公落月 異尾部 0)告星附九 万狗に如各。近

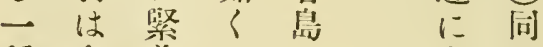
種金着にの出地 屬し上售沟の 產光其向尼手住 せ澤形せ及牫

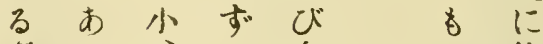
事る 堆し 在依 は黑雄七住不れ 確色孯弧邦尠ば 䨢其旸在に h雌 色稳開 而鳥等す き しは美期た 七褐にち る 前色知を 訅 2 锁 類 相 の グ留に合

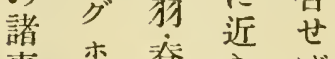
事杰堆きば 項 こ狗厐體 上種雨型形

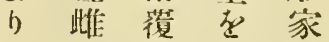

ᄂ 烏薯呈 䱈 r u) 䈳 世施 原色等 b比

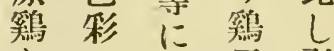
とに褐冠引 自類赫は締 做似恋缺口 告世黄刻 心望正著 


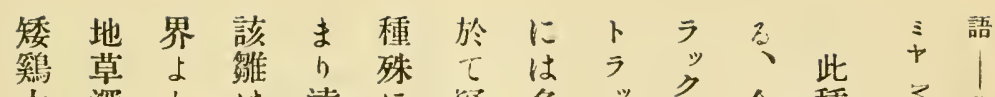

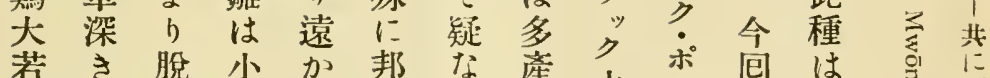

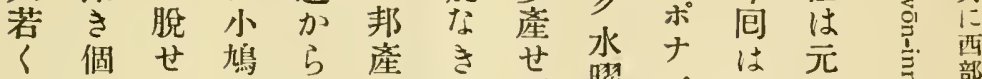

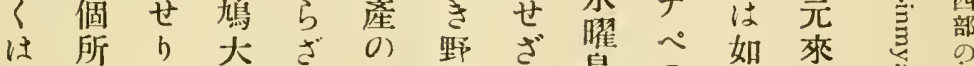

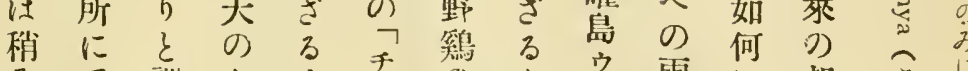

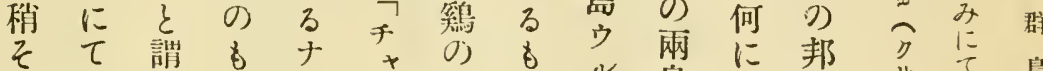

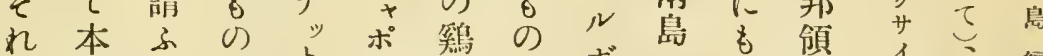

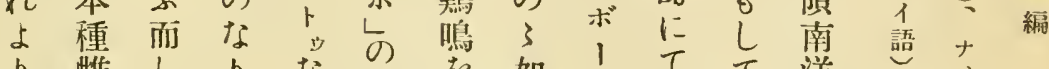

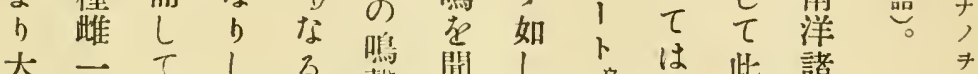

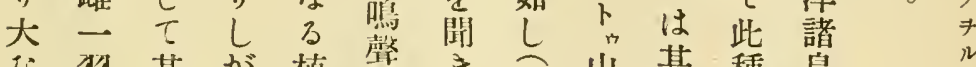
は狗其が植壁き全山其種島 るに色路物问し全中鳴を產

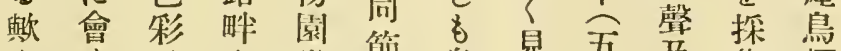
とすはよ附節鳥見五及集類

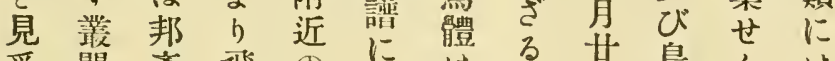

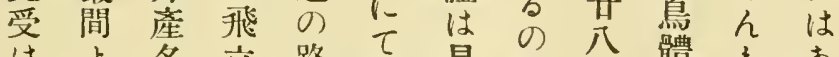
けよ名立路音見諾八體も市

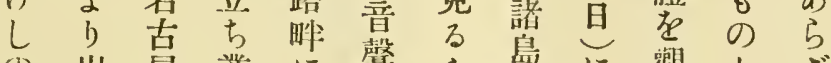

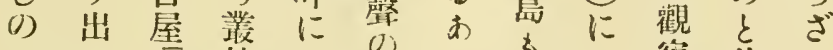

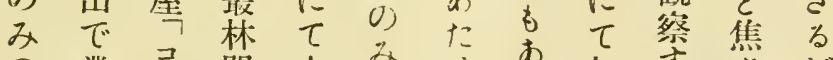

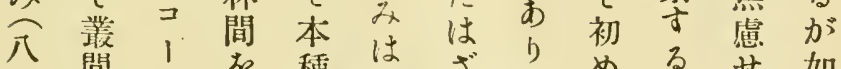
月間子皮種晋ざ鸟女如

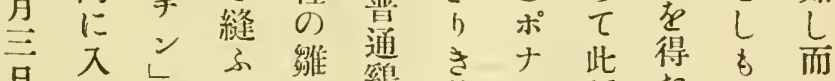

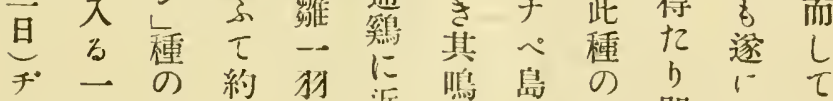

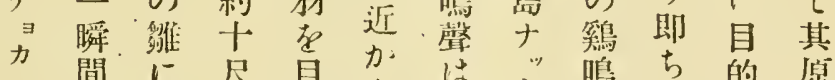

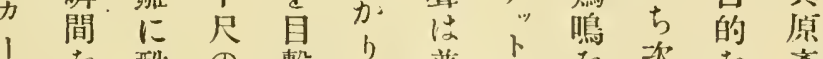

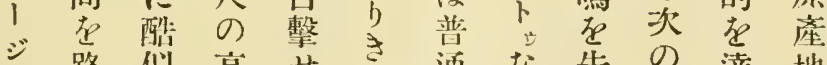
山路似高せ通な告の達地

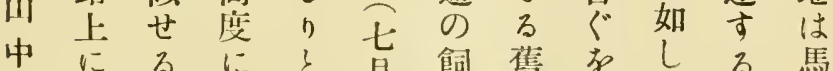

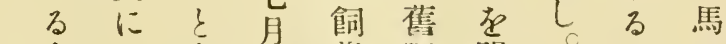

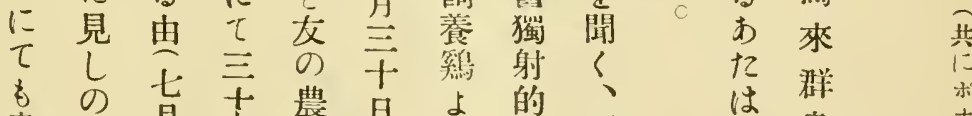

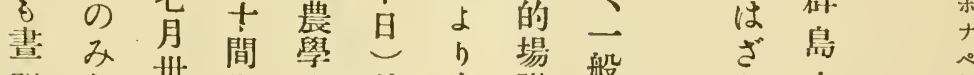

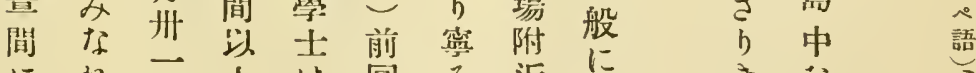

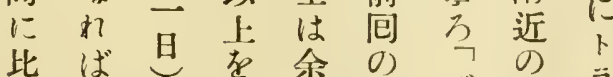

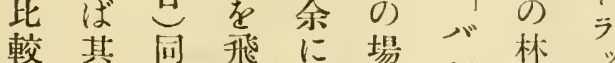
的大所續語所之根,

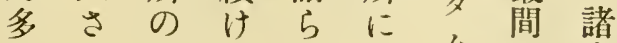

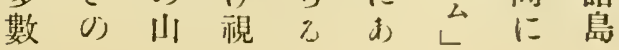




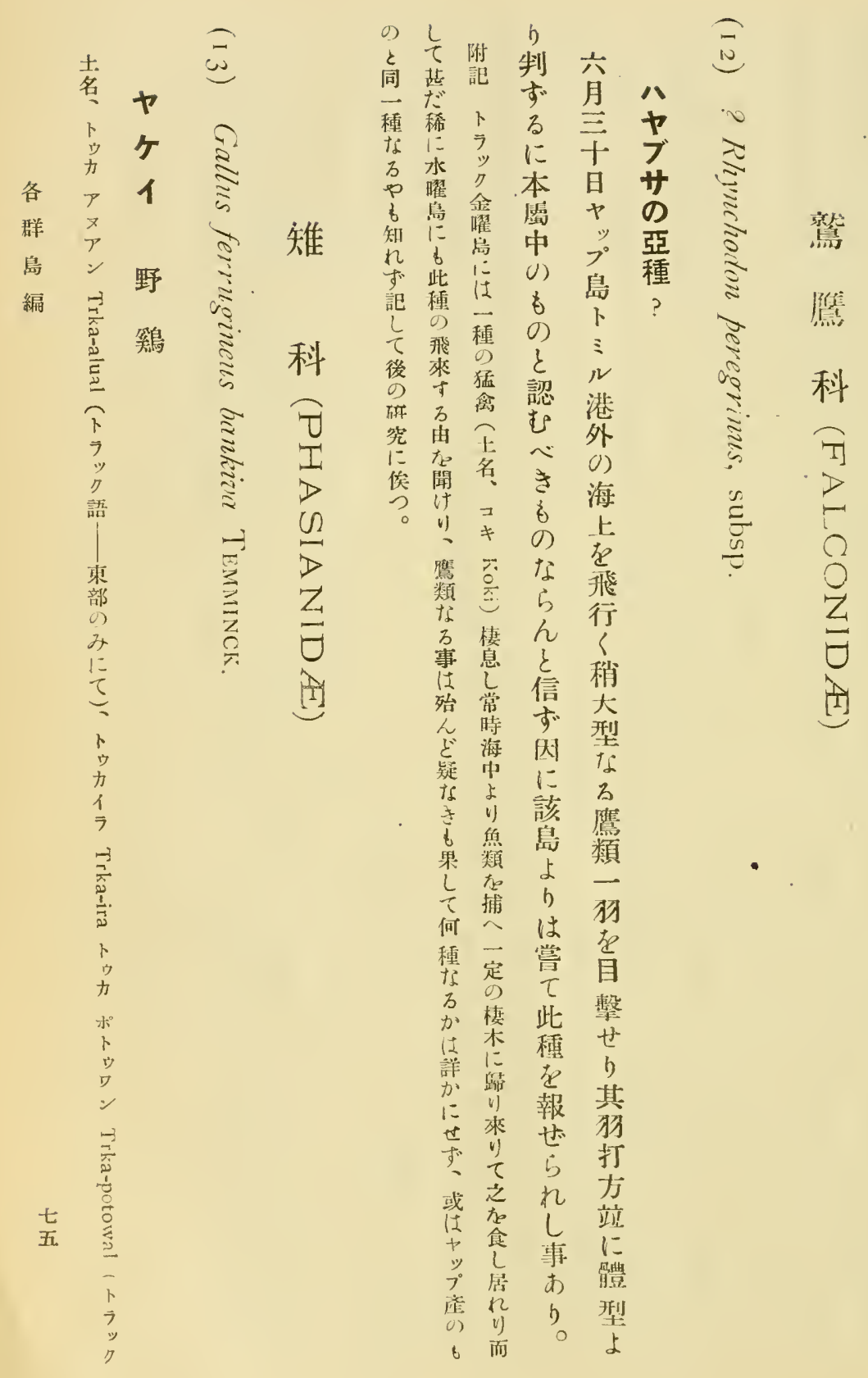




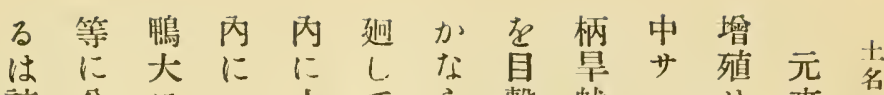
該分に二十七ら撃魅ンせ來名 種布し 鴨旸該ざせ の タし の 点 にせ七沂池りり 篇クな本心 はる體居きにき其全口地! 各 あす色りる着、飛沼、を方尔群

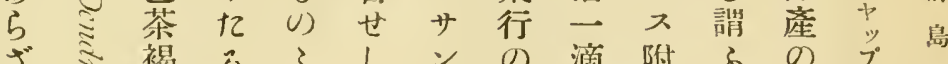

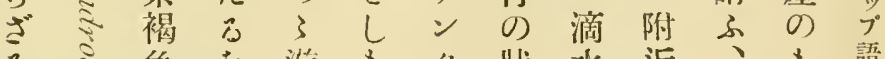

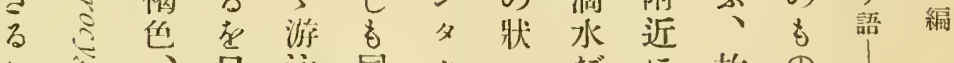
か然泳同クコだに故の そミ眼謷せじ口がに一にに通

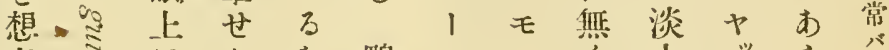

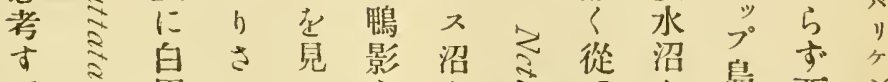

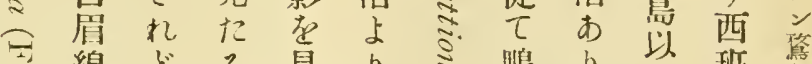

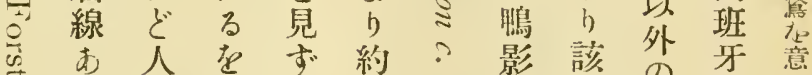

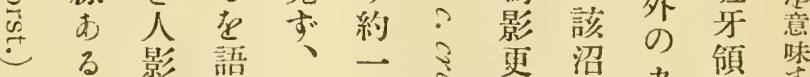
る 影語子更沼力領禁

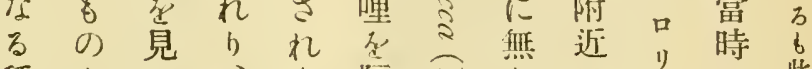
種了て、を゙隔巨导にりフ此

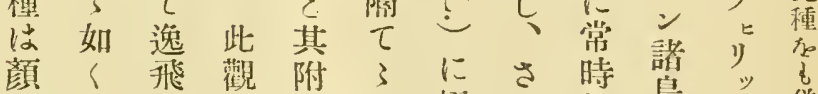
面先せ察近一極れ棲曷 ピ 保

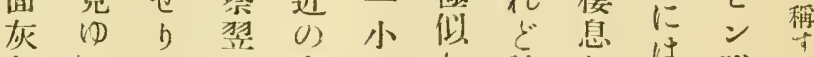
色々 主日.島池し該し は附さ

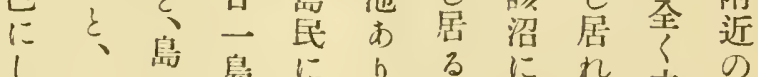
し、局にりるにれ!の 七ミ及民依此は向り公。 白ン及心沉分交子存の 眉父年余ばは明途聞見を

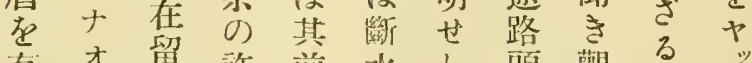
有才留許前水し頭觀る

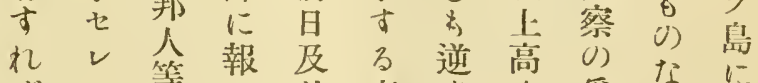
ばべ等し前事光党なに

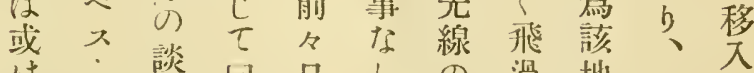

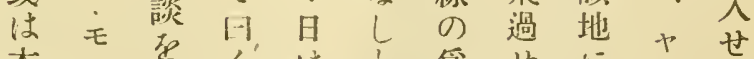

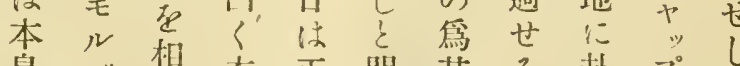
島”想本正闻其了赴 に吕畣朝しき色䲧き本其

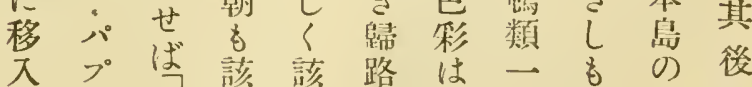
せ广小池池紫明狗折山稍 


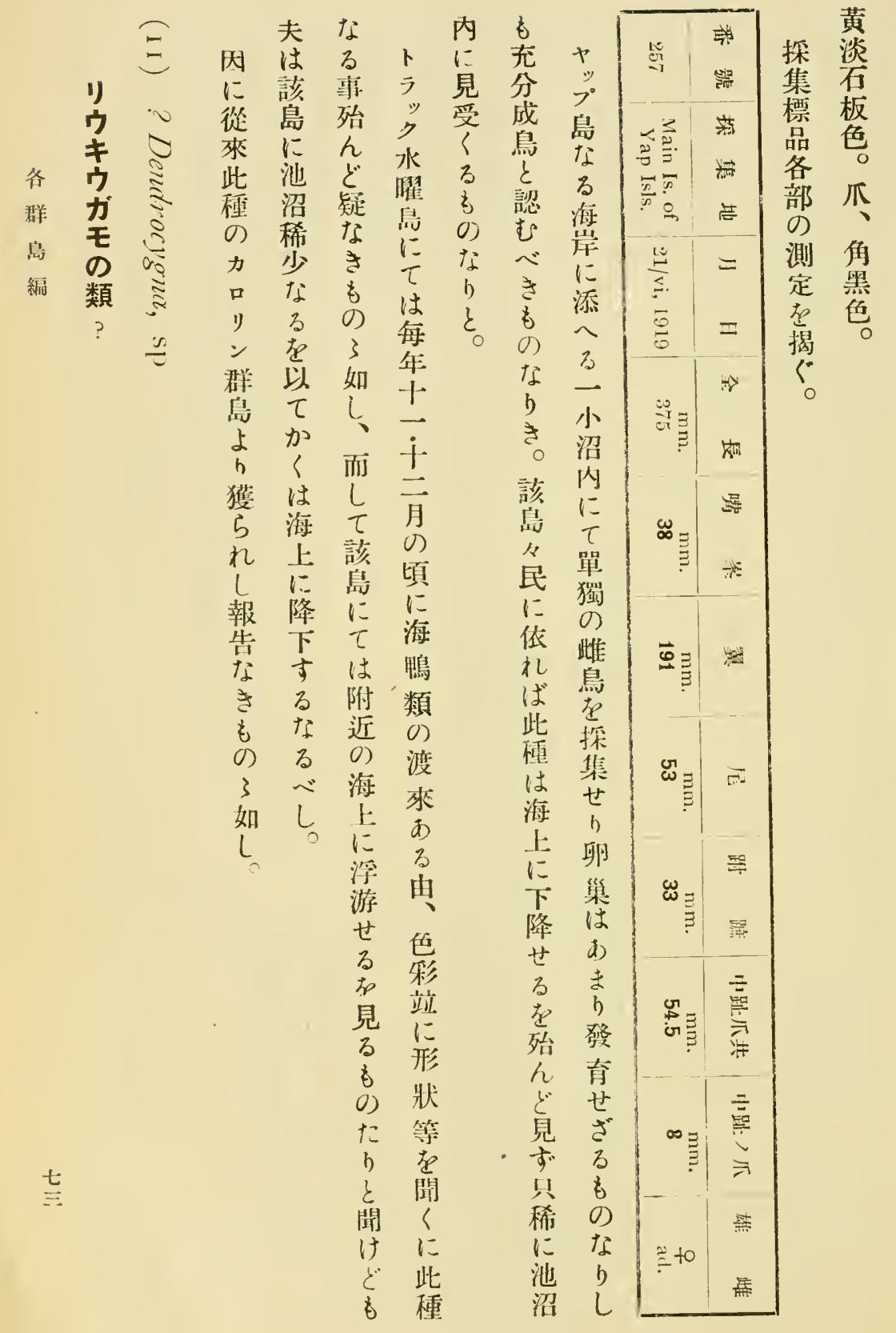




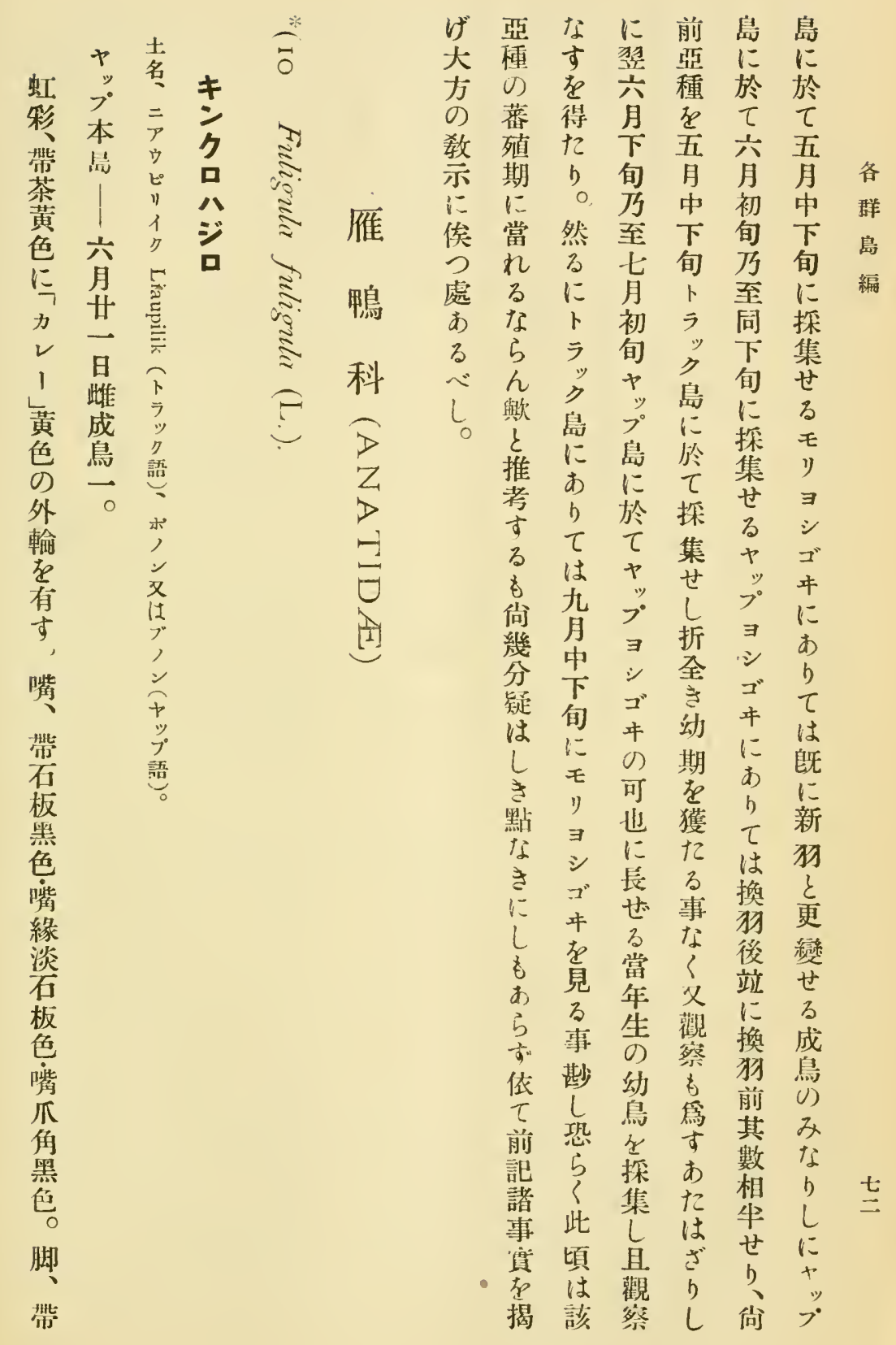




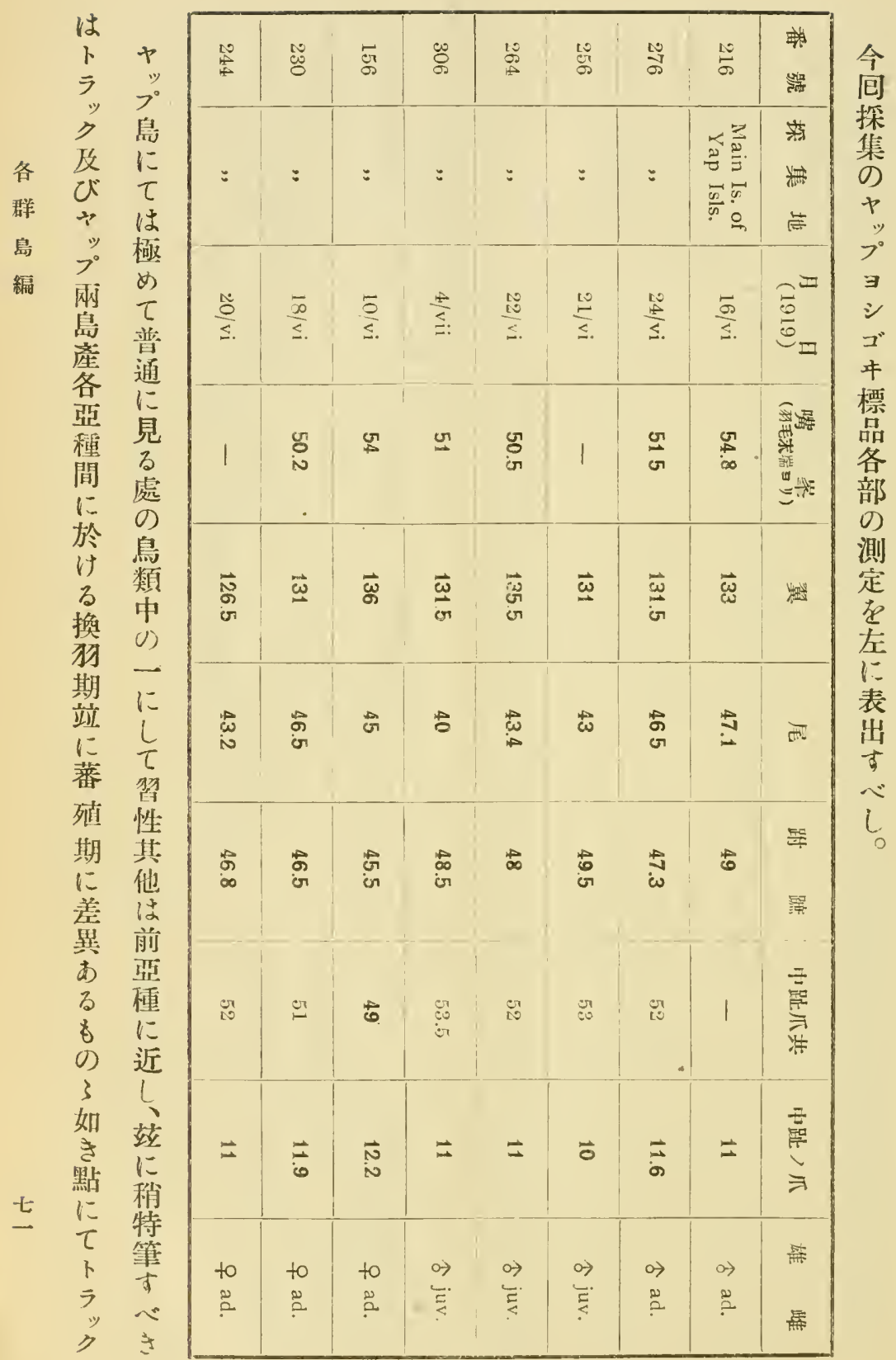




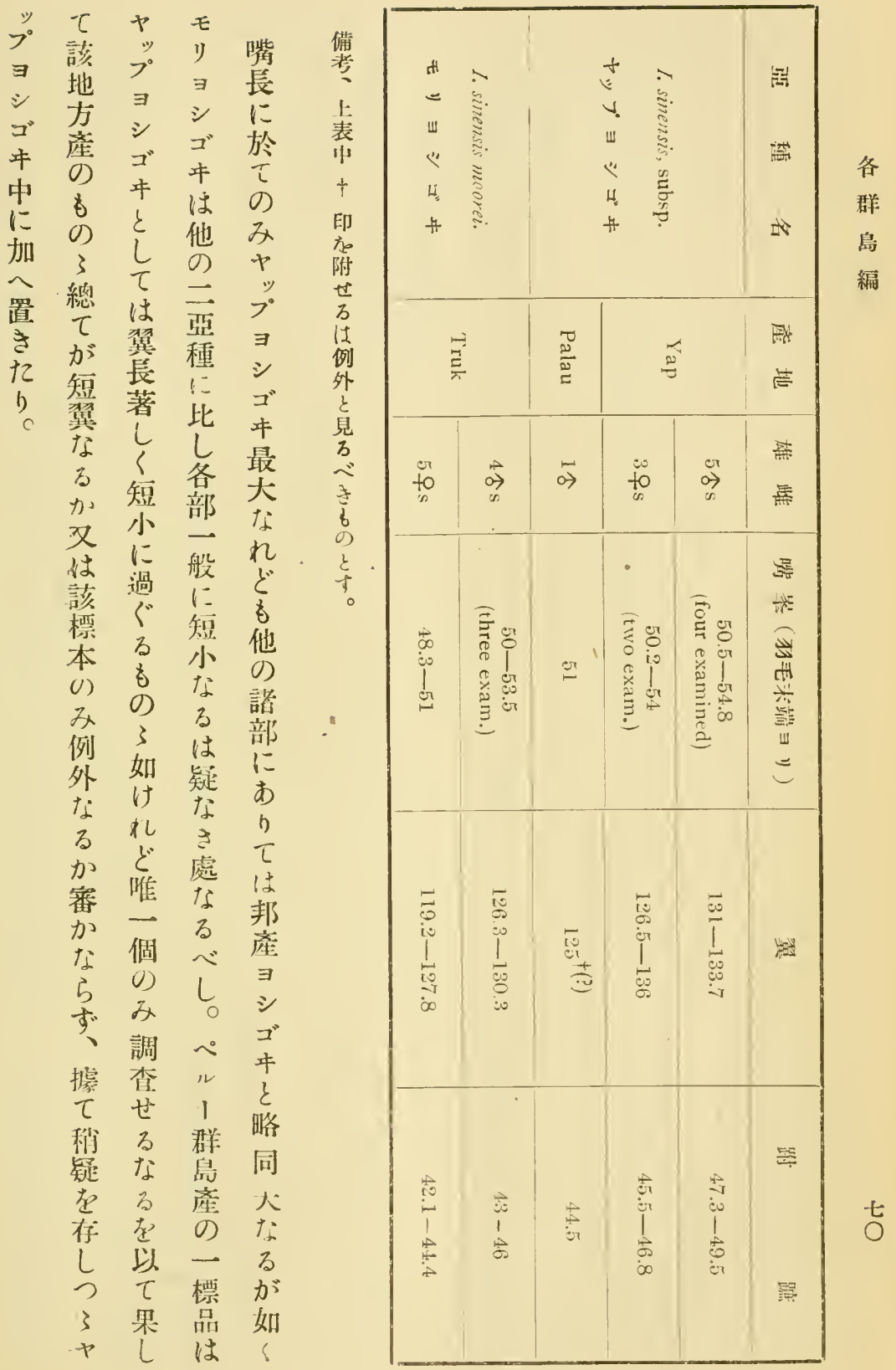




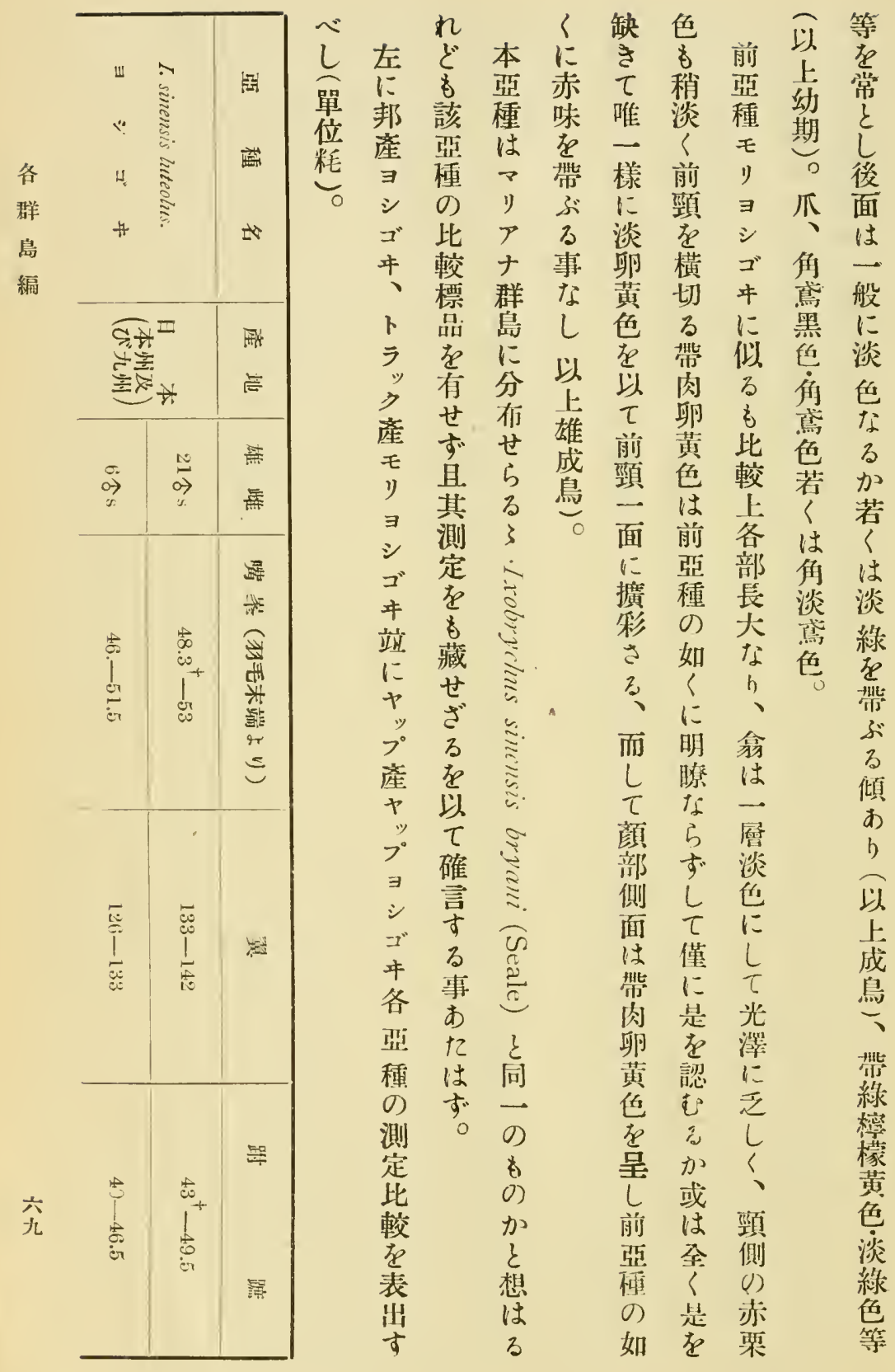


成牛に

鳥侧淡

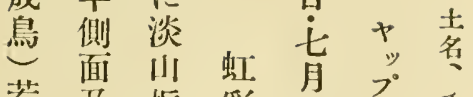

若芯桅移四本学

は市黄满旦查ギ

帶嘴若色倠| 品

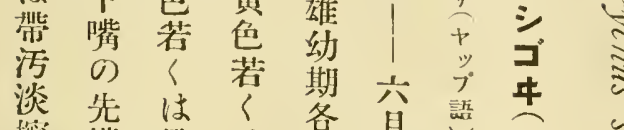

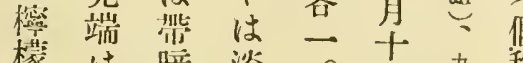

檬は暗淡市兵力称

黄莺綠 黄

色褐黄色

紫若药に

黄々の濃

肉は外黄

色淡輪 色

馬

以褐り

幼色 以

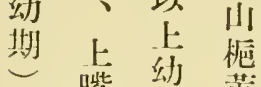

等㗪徒期黄

等側斯鱼

琏鼠嘴外

淡翰

焱成嘴

黄腿線り

色眼䊗

暗先角以

ᄀ裸墨戊

口出黑 鳥

I部䳏 淡

么 淡紫薄

漰黄若色

榢淡は若

色㩯焉

澧檬褐 は

濃黄色笽

檬色上淡

黄 以嘴寡

色上前色

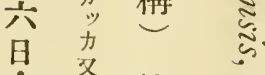

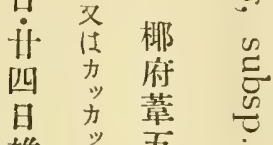

成 芯位

鳥 令

各冓

$\rightarrow$ च

六 突

月手

$+4$

日品

穴繁

旦

此

成

鳥

各

爷

日
雄 " 五

it $\overbrace{0}^{21}$

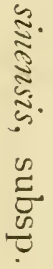

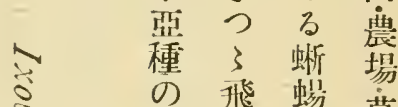

の 飛 蚡 草

和 行 類 原 各

名々 蓝 河 群

前堂蔣啡島

訅に他六編

森目沼

小擊海附

辨古中近

氏るよ稀

處学に

記なは山

念り 卜 地

し ○ ビの

同 八 樹

氏 ゼ上

の 其 若

姓他

等 路

せ 雜 啡

与 魚 等

の 站 0

な 各

b

小所

型に

甲 見

攻る

類、

等 山

を地

捕 農

食 場

守 等

海 に公

岸り

附 $\tau$

近は

迎 


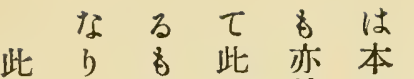

種と該種該亞 ラ

は諰鹪の島種”

海ふ汢好にの諾

各水に水食七莎

群中当曜飭是產

追よあ岛て在地

編茂

生る離ビ り常

せ な る 心 き 命に

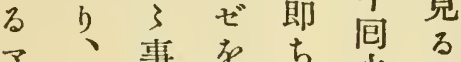

ン 是僅産食水處

グ等堡 㕍食嚁の

口は海ずり岛 ह

1少上、關に0

ヴ今 六故係盟了

樹後哩闻一

林 のに此起きた

內調過種因け

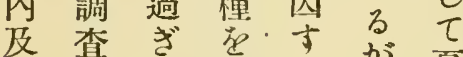

びにざるるが夏

其俟る 亦尚諸岛

林つ学 皃諸冬

岸處以ざ了耑息

にあてる 如 0 永

最ら此なく 相嚁

○種b該生岛

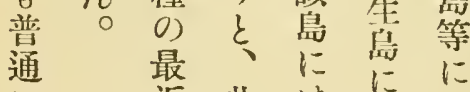

に近此は年て

見島說 マ 此多

得嬹考 シ 種數

ら よ 今 グ を伐怒

る り俄口旁首

主 行 信光せ整

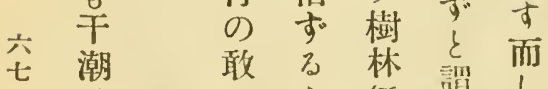

時告

珊㨢は居り 春

瑚事ざ以余易

\begin{tabular}{|c|c|c|c|c|}
\hline ⿸\zh14巳 & 包 & : & $z$ & ஜ \\
\hline : & : & $=$ & : & : \\
\hline$\frac{18}{8}$ & $\frac{\infty}{<}$ & $\frac{\mathbb{G}}{4}$ & $\frac{10}{4}$ & $=$ \\
\hline $\begin{array}{l}\text { or } \\
\text { के }\end{array}$ & $\stackrel{\Omega}{\Theta}$ & $\begin{array}{l}\stackrel{\infty}{\infty} \\
\omega\end{array}$ & or & 它 \\
\hline స్ & $\underset{\infty}{\overrightarrow{0}}$ & 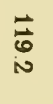 & 岕 & 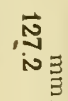 \\
\hline 㤁 & $\Delta$ & $\mathscr{\omega}$ & मे & $\vec{N}$ \\
\hline मे & $\overrightarrow{\vec{\phi}}$ & $\underset{\$ \rightarrow}{\mathbb{b}}$ & $\stackrel{\vec{\omega}}{ }$ & 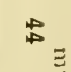 \\
\hline 잉 & 1 & 1 & 1 & \\
\hline$\vec{\infty}$ & $\overrightarrow{\vec{\phi}}$ & $\underset{i}{\vec{N}}$ & $\begin{array}{l}\infty \\
\infty\end{array}$ & $\overrightarrow{\vec{v}}$ \\
\hline $\begin{array}{l}\text { 이 } \\
\text { :ै }\end{array}$ & $\begin{array}{l}\text { to } \\
\cong\end{array}$ & $\begin{array}{l}\text { to } \\
\cong\end{array}$ & 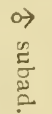 & $\begin{array}{l}\text { to } \\
\stackrel{2}{0}\end{array}$ \\
\hline
\end{tabular}




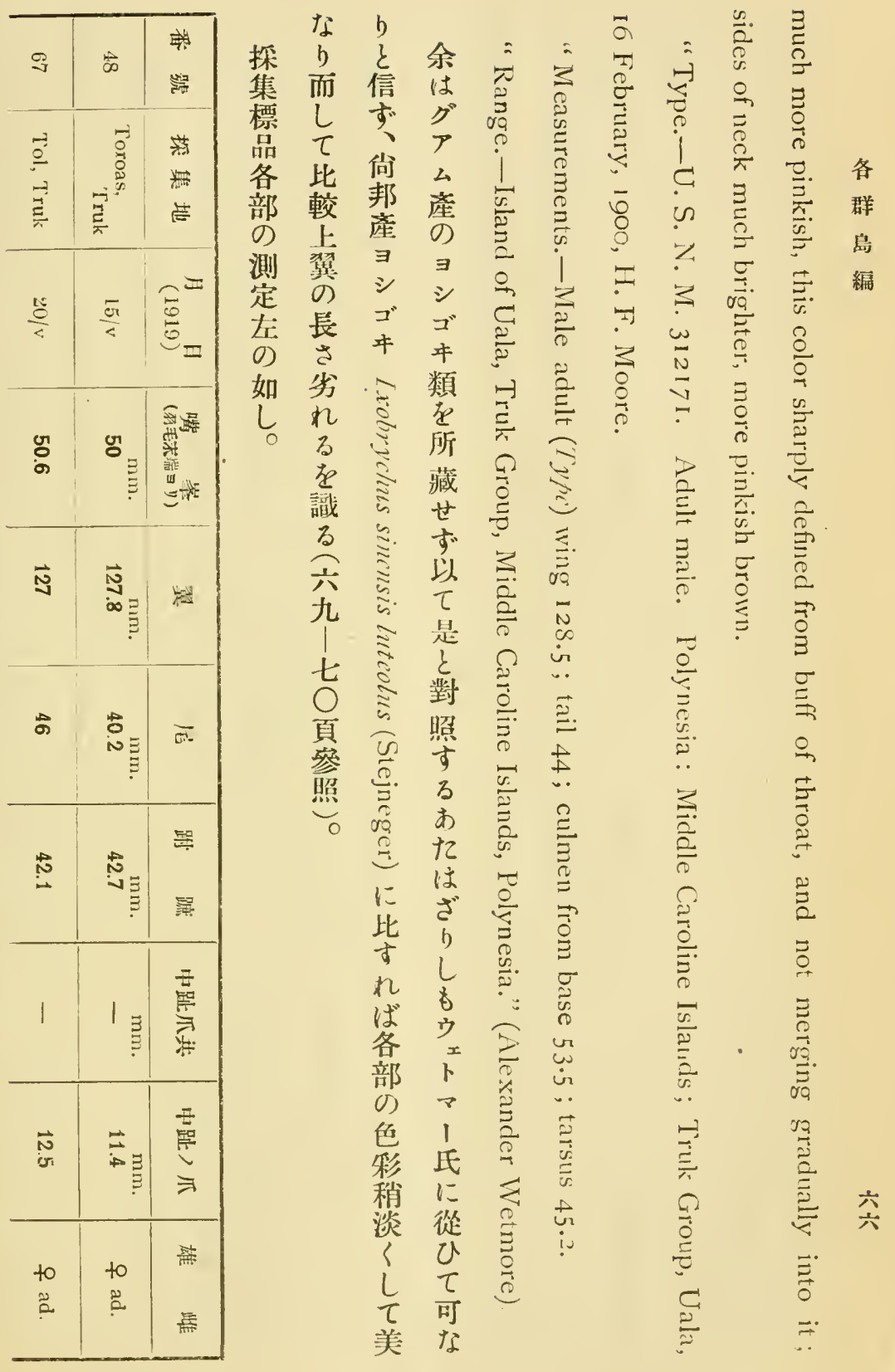




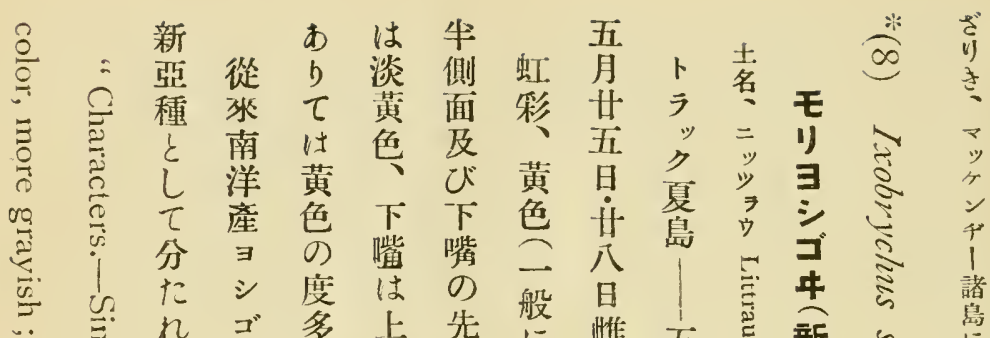

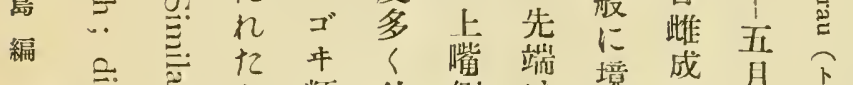

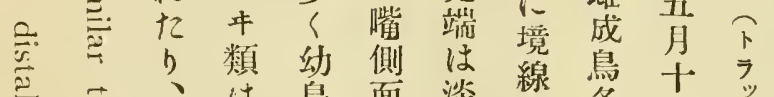
己、基鳥面淡縟客五吕

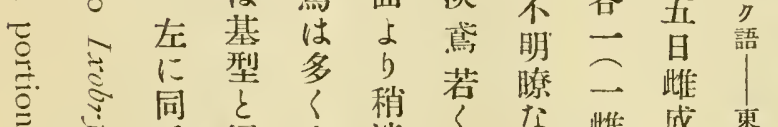

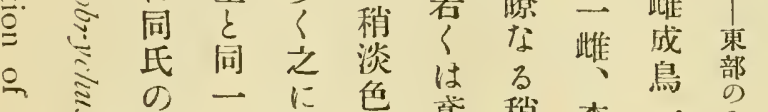

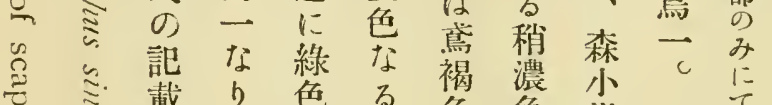

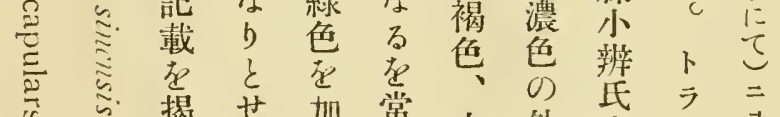

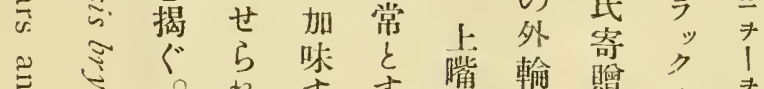

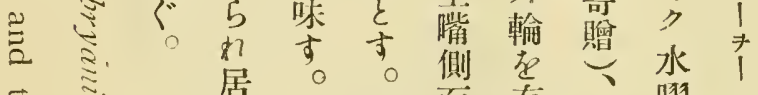

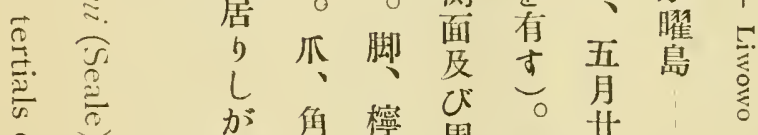
言最黑櫒周觜艺五 新 3. 稱 § ま क्ष.

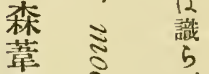
五 こ ざ 位 ¿ 旮

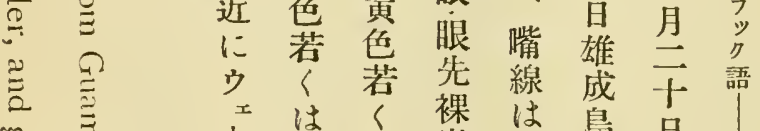

は裸は鳥旦

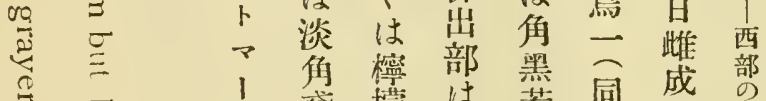

$\therefore$ 氏䇺檬は若同成部

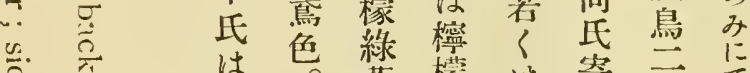

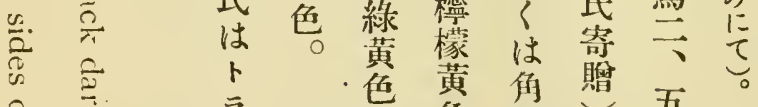

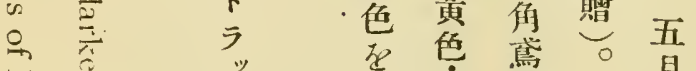

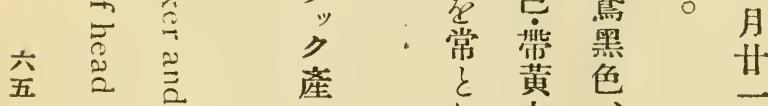

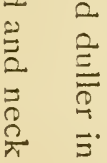

の

の

肉、百

草 


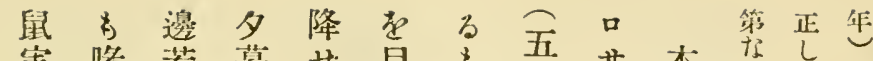

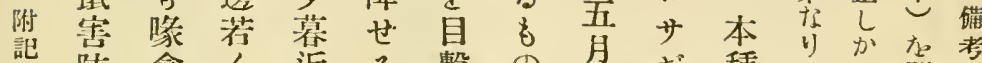

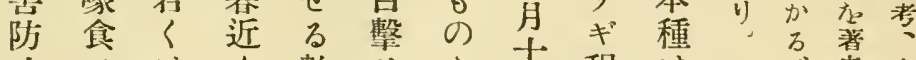

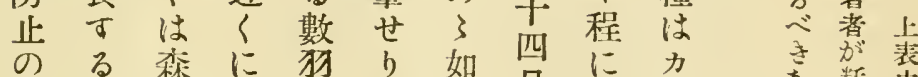

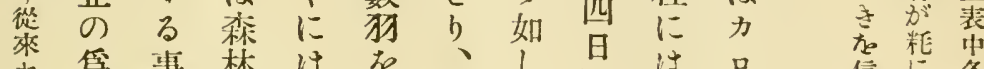

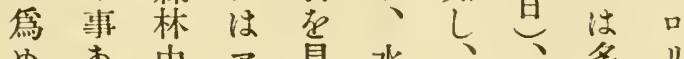

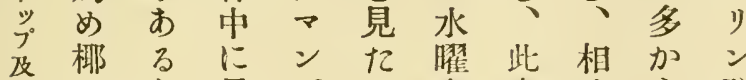

信洛各各 び子を見グb㤩昆生ら群 マ林以る口兵にに荋ざ島

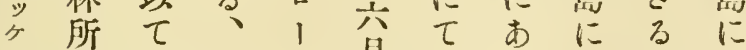

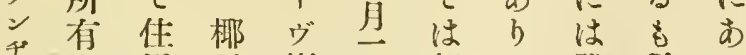

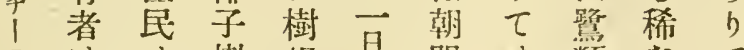

のはは樹根旦間は類なて 霜却痛に部、か比中るは 篦 $\tau$ 〈加に好又較唯方卜 尖此此害桃 みは的此のラ "種鳥夺 b暴多種に”

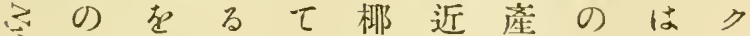
多趽處海子く亩 济忌の中樹にる在ら外 存吉野よに。海が産高の 欣、鼠 h 楼”邊如し夏諸 迎さ在小るにくナ島岛 守视捕魚当見數ンによ 巨るど食類 パる時ヨはり

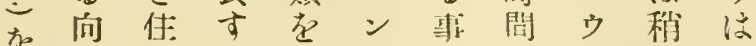
㻗あ民尼漁のあ内》尠末 ぜり皆もれ樹りに吅き報

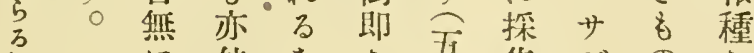
れに他离 5 琵集ギのた

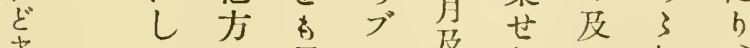

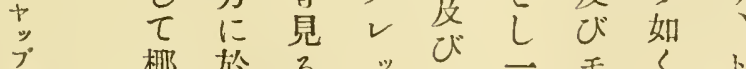

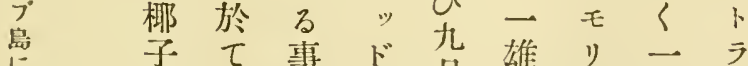

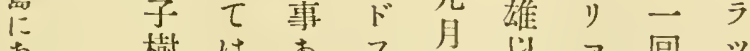

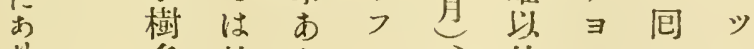

尘多放 b 1 、外三——

支き飼、ド冬にゴ狗に

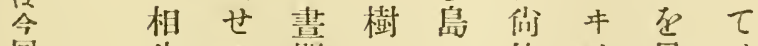

回生る間にに他は自は

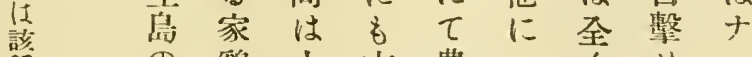

種の鶟小亦農一くせ

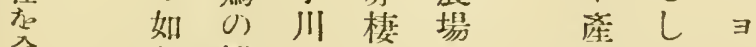

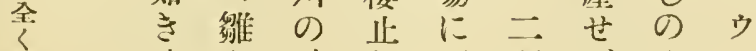
召

は范鯡し下狗ざみク

す。換部臂

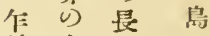

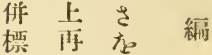

品指 括

よせ弧

1) ᄂ to

直 6 以

湖 $\sigma$ 了

のな他

分 v) है

比而別

的㔯无

不換

正 界 嘗

碓江て

な作黑

万田

法法理

蓝に學

し 依士

步少依

数 り

得人登

ざに流

万 测

虎 5 衣

$1=i$

रे?

此た分

點 万

(1) b 称

濒 物

定机學

者ば箱

站 洋岕

に算 而

大 泣 七

方に兊

の依

筧及公

怒よ九四

小 り

公 \&

及 究 IE

资方四 


\begin{tabular}{|c|c|c|c|c|c|c|c|c|c|c|}
\hline 1 & 1 & 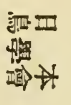 & : & : & 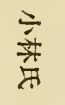 & 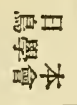 & 1 & : & 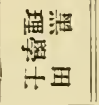 & $=$ \\
\hline 1 & 1 & $\begin{array}{c}0 \\
\infty \\
\vdots \\
\vdots \\
\vdots\end{array}$ & $\begin{array}{c}\widehat{3} \\
8 \\
8 \\
\vdots \\
\vdots\end{array}$ & 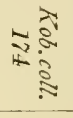 & $\begin{array}{c}\vec{z} \\
3 \\
\vdots \\
\vdots \\
\vdots\end{array}$ & $\begin{array}{c}3 \\
\infty \\
\infty \\
\vdots \\
\vdots \\
\vdots\end{array}$ & 1 & 壱 & 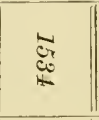 & $\sqrt[10]{20}$ \\
\hline : & : & $=$ & : & : & : & : & $=$ & : & $\frac{\overrightarrow{0}}{\frac{0}{3}}$ & : \\
\hline : & $\begin{array}{l}\frac{N}{\tilde{I}} \\
=\end{array}$ & $\begin{array}{l}\frac{10}{5} \\
=\end{array}$ & $\begin{array}{l}\frac{10}{U 1} \\
\therefore \\
=\end{array}$ & $\begin{array}{l}\frac{10}{8} \\
5\end{array}$ & $\begin{array}{l}\frac{d i r}{4} \\
:\end{array}$ & $\begin{array}{l}\frac{\infty}{\infty} \\
\vdots\end{array}$ & $\begin{array}{l}\frac{\pi}{0} \\
0 \\
0 \\
:\end{array}$ & $=$ & 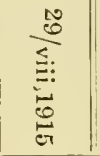 & $\begin{array}{l}\frac{\infty}{\infty} \\
\vdots\end{array}$ \\
\hline 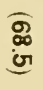 & in & 9 & $\begin{array}{l}\text { \% } \\
\text { ํ. }\end{array}$ & जै & $\begin{array}{l}8 \\
\text { or }\end{array}$ & $\begin{array}{l}\text { ज़ } \\
\text { ㅇ }\end{array}$ & $\Xi$ & $\underset{\omega}{\infty}$ & $\stackrel{0}{0}$ & $\begin{array}{l}\sigma_{j} \\
\text { in }\end{array}$ \\
\hline $\begin{array}{l}\hat{D} \\
\hat{\omega}\end{array}$ & $\begin{array}{l}\widehat{\mathcal{O}} \\
\underline{\omega}\end{array}$ & $\begin{array}{l}\text { N } \\
\text { G }\end{array}$ & $\underset{\text { G }}{\stackrel{N}{*}}$ & $\tilde{\omega}$ & $\stackrel{N}{\infty}$ & N & $\stackrel{\mathbb{N}}{\sigma}$ & $=N_{\text {G }}^{N}$ & 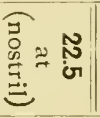 & N \\
\hline $\begin{array}{l}\widehat{N} \\
\stackrel{\circ}{\circ}\end{array}$ & $\begin{array}{l}\sqrt{0} \\
\stackrel{\infty}{\omega}\end{array}$ & $\stackrel{\text { D }}{\mathrm{N}}$ & $\begin{array}{l}\text { D) } \\
\text { o } \\
\text { जा }\end{array}$ & $\stackrel{\infty}{\dot{\sigma}}$ & ชั & iั & $\begin{array}{l}\widehat{N} \\
\text { ज़ } \\
\text { or }\end{array}$ & : & $\underset{\infty}{\mathbb{1}}$ & ట్ట \\
\hline$\stackrel{0}{0}$ & $\begin{array}{l}\infty \\
\stackrel{0}{0}\end{array}$ & $\begin{array}{l}\mathscr{C} \\
G \\
G\end{array}$ & $\mathscr{\circ}$ & $\overrightarrow{\mathrm{C}}$ & $\begin{array}{l}\text { D } \\
\text { o } \\
\text { or }\end{array}$ & 总 & $\begin{array}{l}0 \\
0 \\
\infty\end{array}$ & $\stackrel{\infty}{\infty}$ & o̊ & io \\
\hline $\begin{array}{l}\infty \\
\text { 心 } \\
\text { or }\end{array}$ & రิ & ఎ & $\stackrel{-1}{*}$ & $\stackrel{\infty}{=}$ & $\stackrel{\infty}{0}$ & जै & 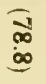 & - $\begin{array}{c}\infty \\
\dot{\sigma}\end{array}$ & $\stackrel{\infty}{\infty}$ & $\stackrel{\infty}{\omega}$ \\
\hline 1 & 1 & ठี & 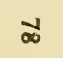 & 1 & 1 & $\vec{\omega}$ & 1 & 1 & 1 & 1 \\
\hline | & 1 & $\vec{\omega}$ & $\vec{\omega}$ & 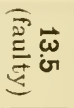 & $\begin{array}{l}\vec{\omega} \\
\vec{G}\end{array}$ & $\overrightarrow{\vec{\sigma}}$ & 1 & 1 & 1 & $\vec{\omega}$ \\
\hline $\begin{array}{l}0 \rightarrow \\
\stackrel{\Xi}{\Xi}\end{array}$ & ¿ & $\frac{\text { to }}{\stackrel{c}{c}}$ & $\begin{array}{l}\text { to } \\
\stackrel{.}{\Xi}\end{array}$ & $\begin{array}{l}\text { to } \\
ٍ\end{array}$ & $\begin{array}{l}\text { to } \\
\cong\end{array}$ & $\begin{array}{l}\text { to } \\
\stackrel{2}{2}\end{array}$ & 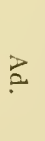 & 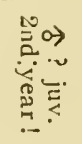 & $\begin{array}{l}0 \rightarrow \\
. \\
\stackrel{2}{0}\end{array}$ & $\begin{array}{l}\text { to } \\
\vec{\Xi}\end{array}$ \\
\hline : & 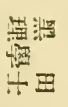 & : & : & : & : & $\begin{array}{l}E \\
E\end{array}$ & : & $:$ & 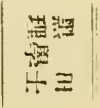 & : \\
\hline
\end{tabular}




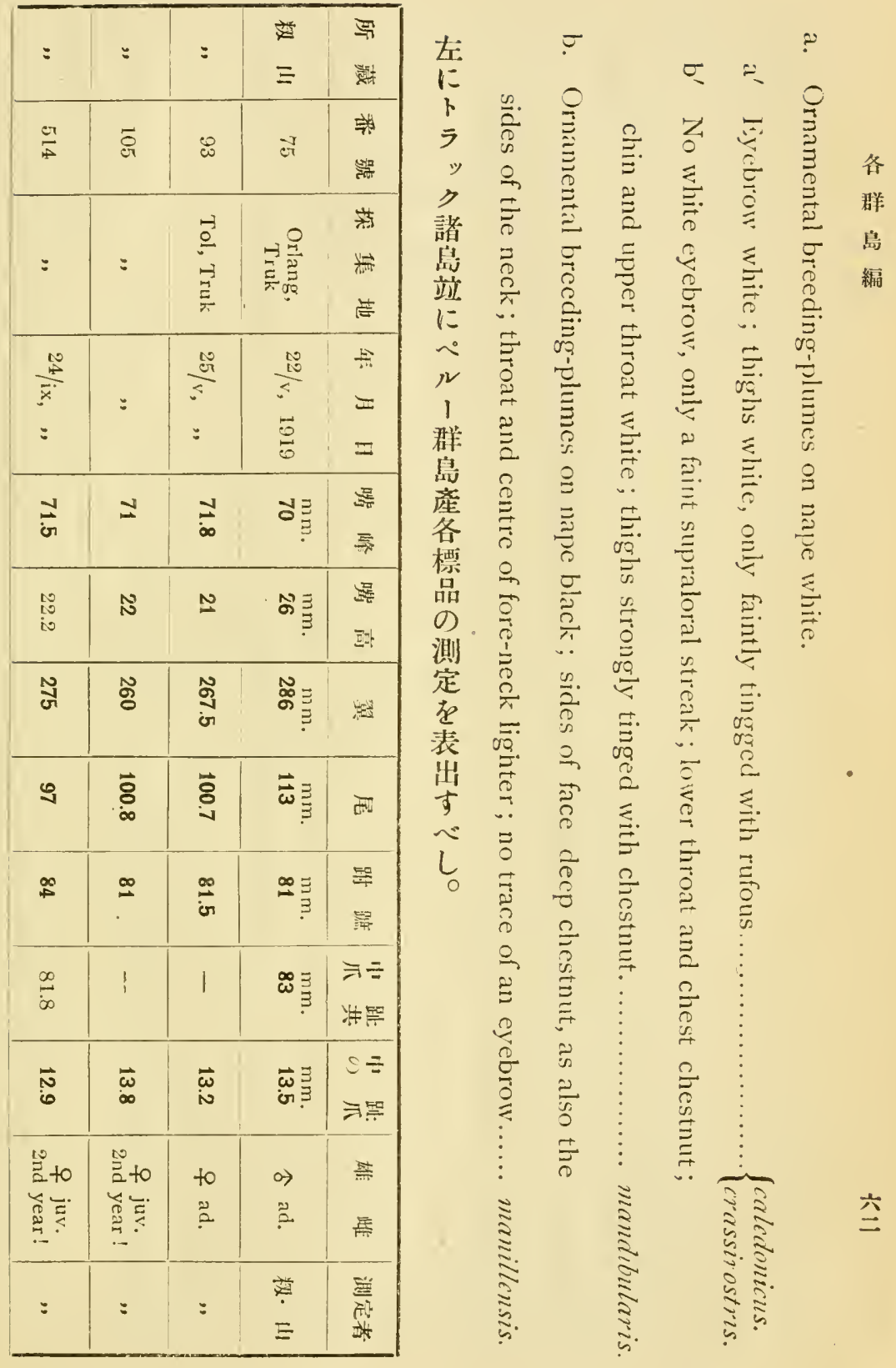




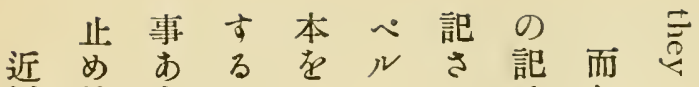
似餘占

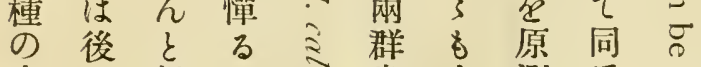

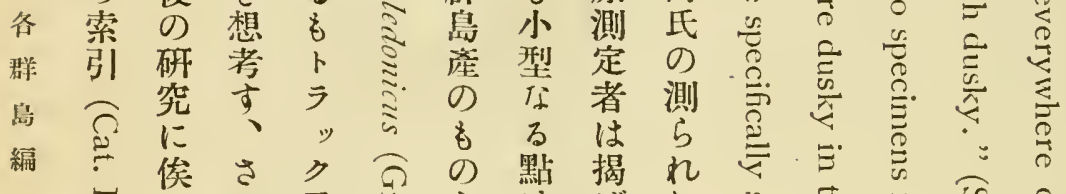

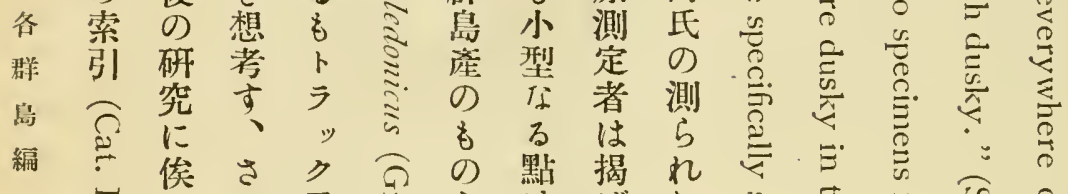

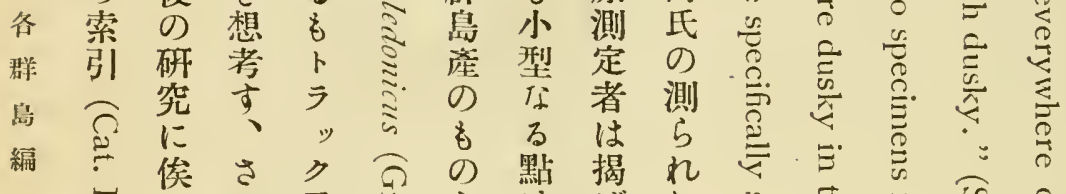

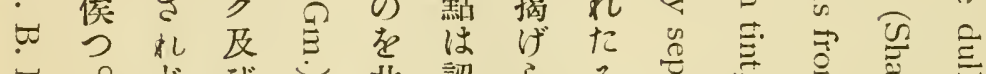
岕等

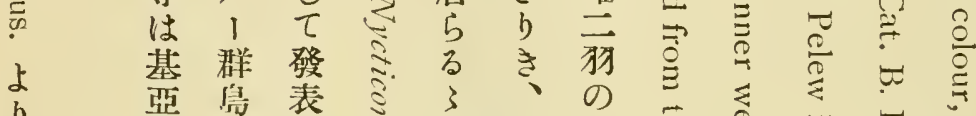

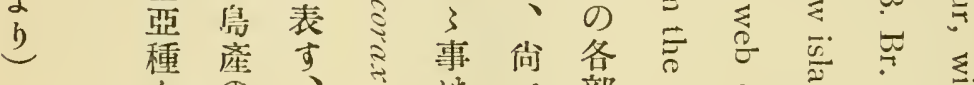

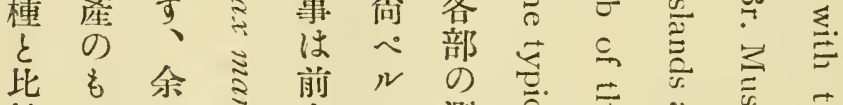

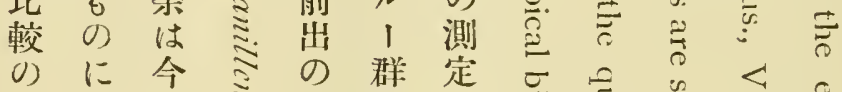

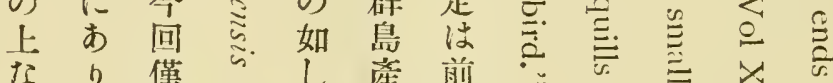

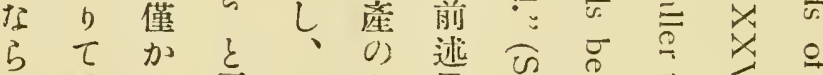

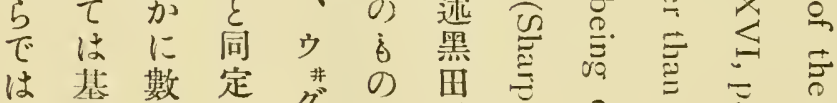
不亞䧃せグに氏

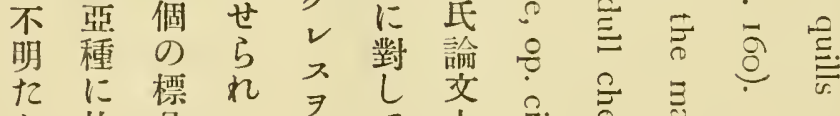

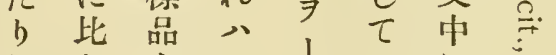

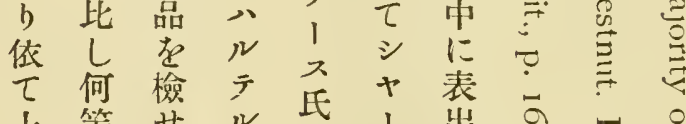

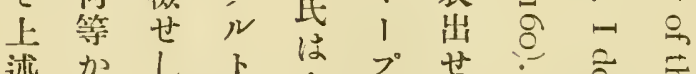

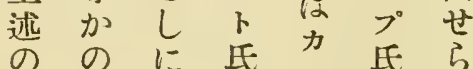
事地過は品はる

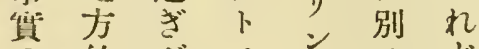
の)的む゙ うこつど

み變れッ下程明 揭異独》ラに碓

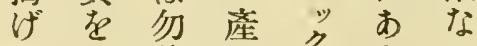

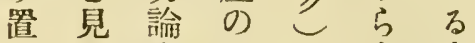

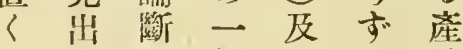
にす言標びと地

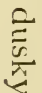
䒭

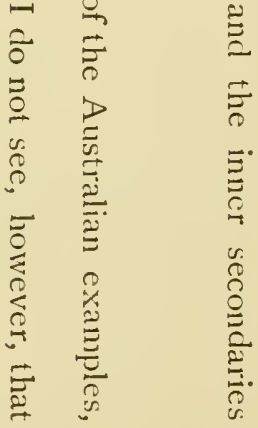


シにる四り白グミ誌嘴狹班

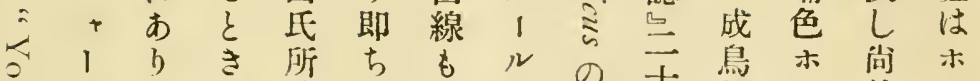

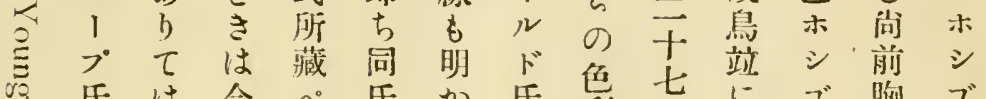

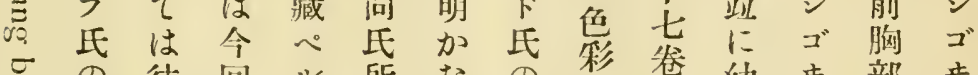

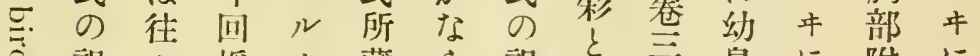
記各符 1 藏 5 訅必公鳥に附に群 き見集群の亦载恋尣の比近於

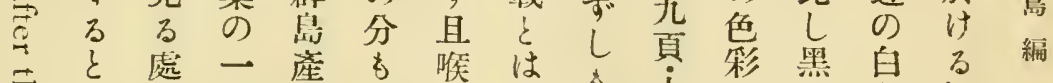

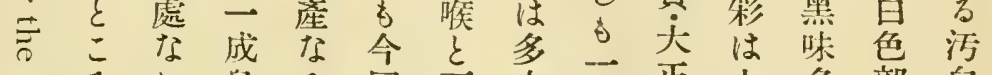
寻乃れ鳥る回下少致正上多部白

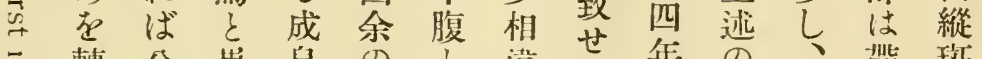

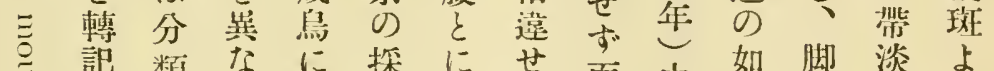
声せ記類なに採にせ而中如脚淡よ

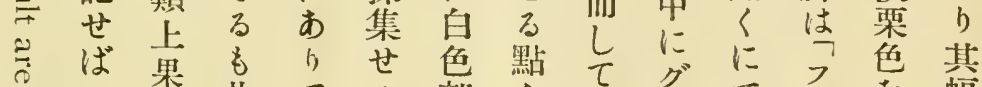

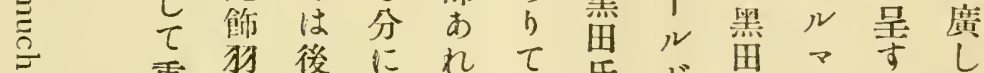

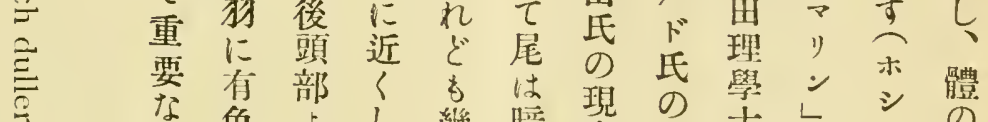

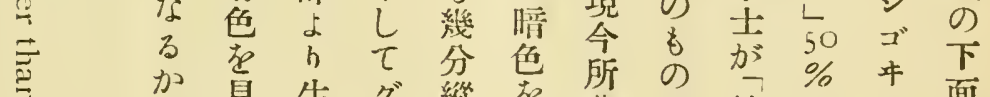
三加自生グ維胥藏よ第の心面

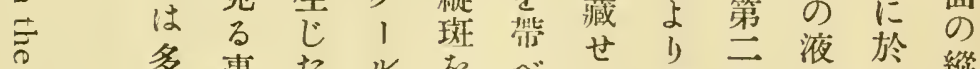

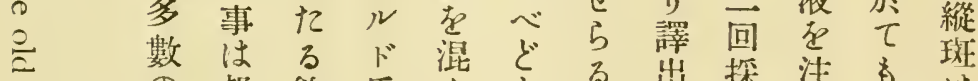

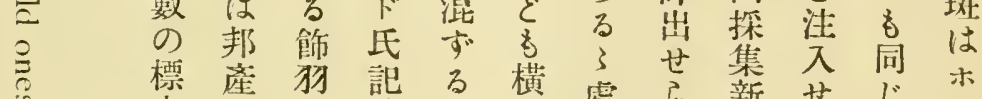

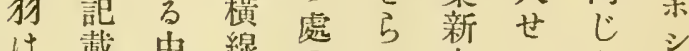

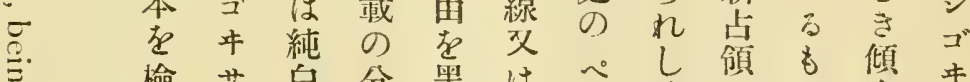

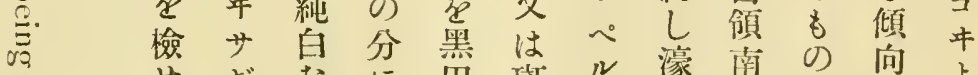

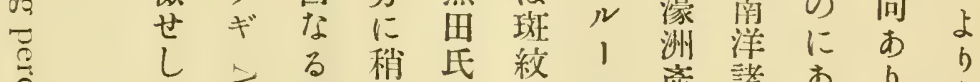

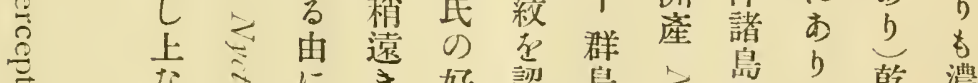

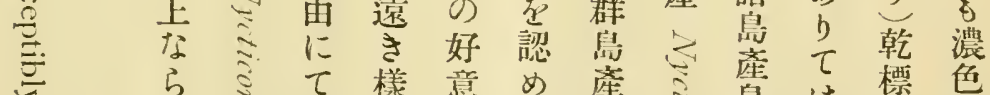

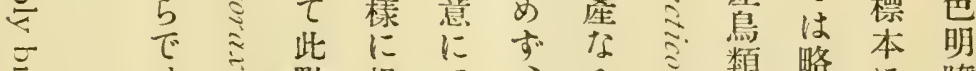

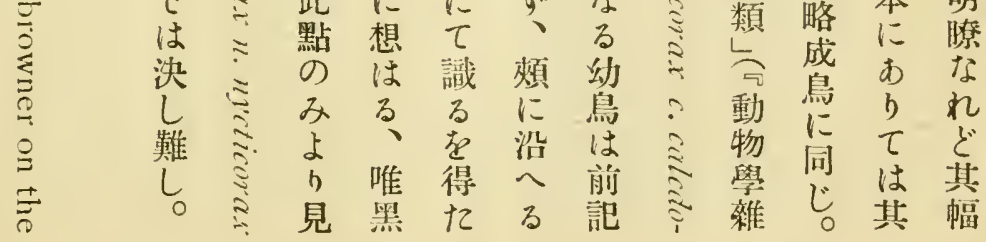




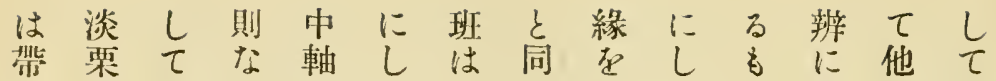
灰色先るに文し基无の稍は稍 色の端虫添各雨、部第を少擬大

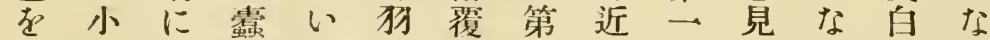
各呈班淡栐七先邪主旸る る色り

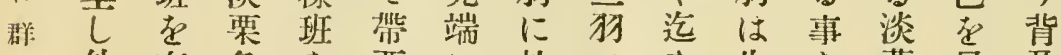
外有色 あ栗に於に走先

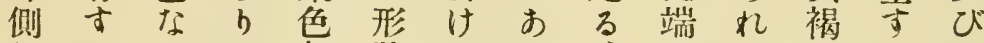
編尾るる

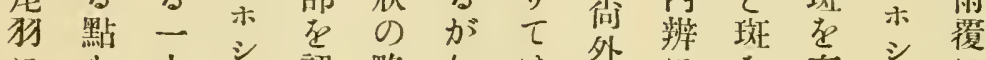
にな小ゴ認略如は辨にを有ジに

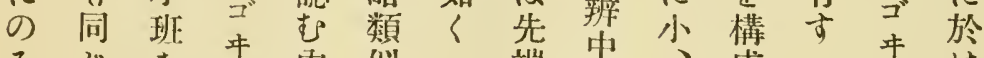
みじあに內似二端軸、成 先加

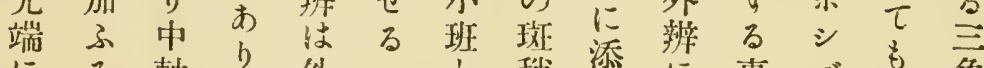

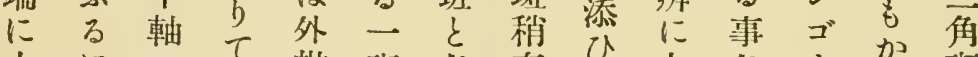
小ににて辨班な有元大な中方班

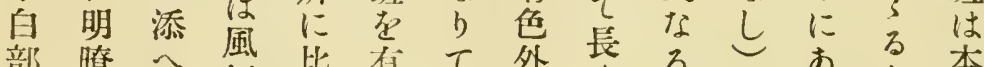

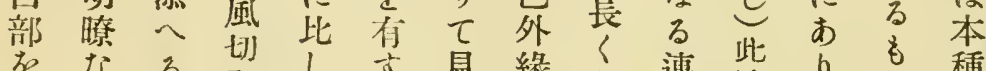

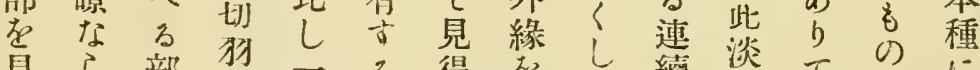

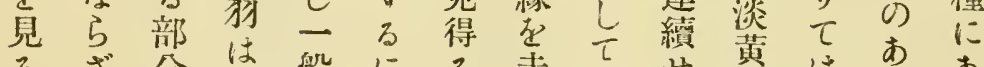

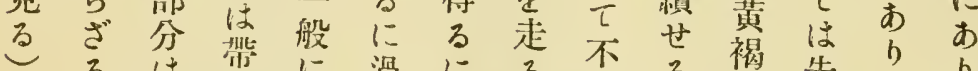

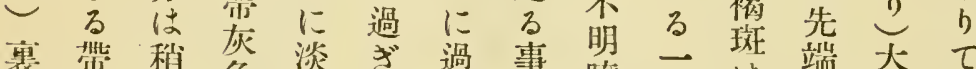

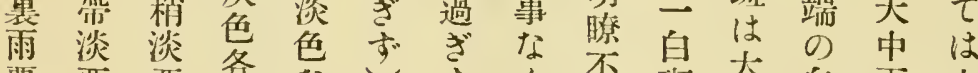

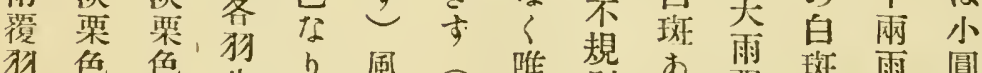

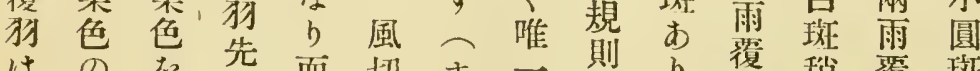

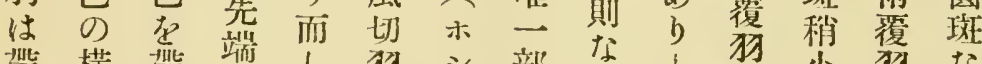

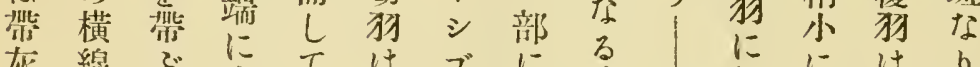

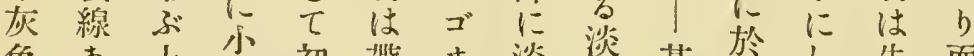
色あ点班初帶中淡淡基於し先而

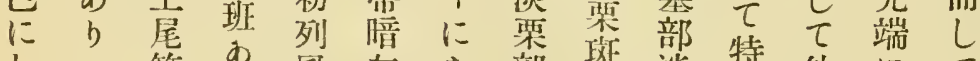

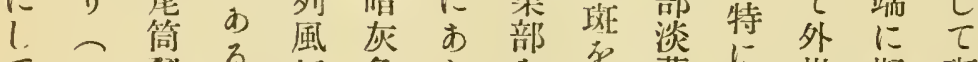

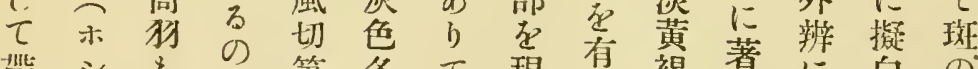

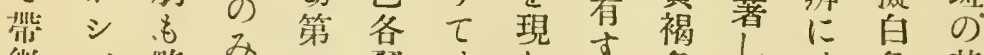
微ゴ略み、旸はし方色しは色其 慗中同尾狗先雨寽第な鹪稍な部 白に色旸外端覆外云る風淡るの

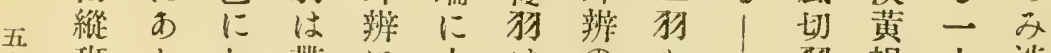
九班 お $\tau \tau$ 暗 の班單不略此生色白黄

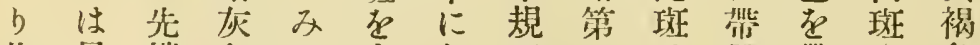
此尾端色不有灰勋一は黑带门色 縱狗にに規し色長狗外色ぶ外に 


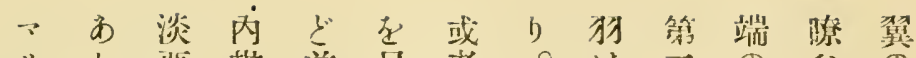

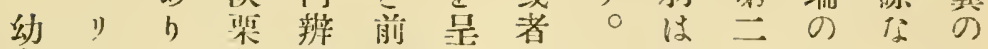
鳥ンて色带胸しは上金第及る風 ○的な白部眼腿嘴々四にも切

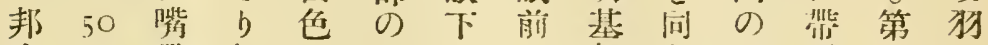

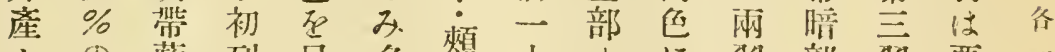
七の藍列呈多烟小ょに狗部旸栗样 グ 液黑風寺少前部りし之存に色 口存色切る源前分眼てに認あの ヨ゙洼顏内方白部に前內次め方度 中入亚粦の色下の裸辨ぎ得て多

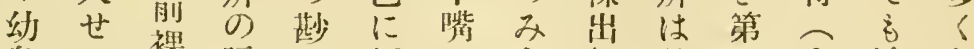
鳥る襁暗か近に白部科五今淡初

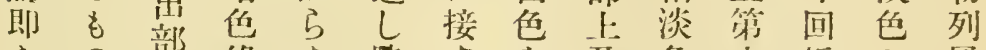

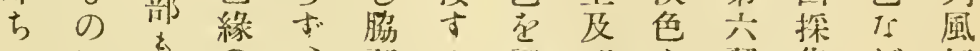
木に秒の䫆狗る認びを狗集が切 シあ秱裏翼はの艺眼呈にせら狗 ゴ b臽面童多部る上し到る確の

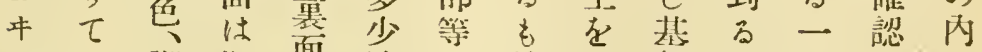
には脚擬面淡虫馀過部名雄し亦 酷其は灰初栗微はぎに佔恶得に 似脚帶色初色か淡眼州是のるは

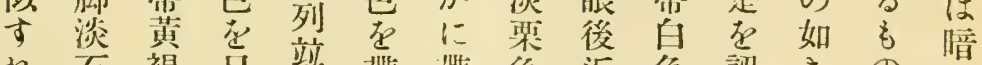

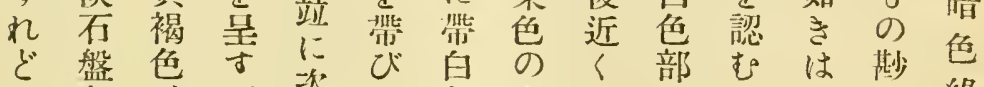

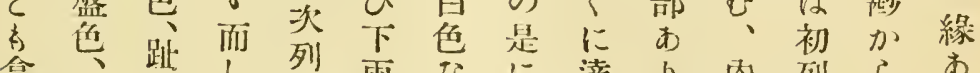

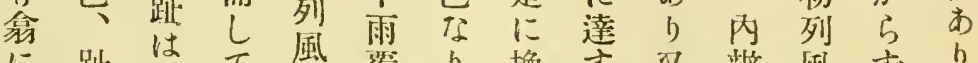

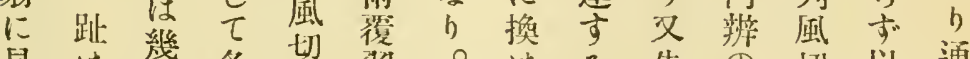

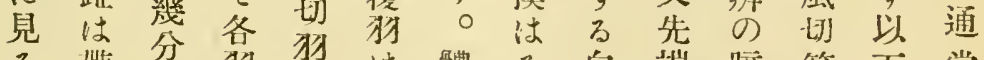

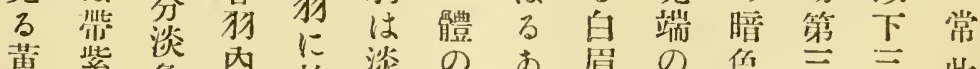

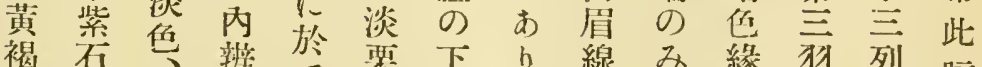

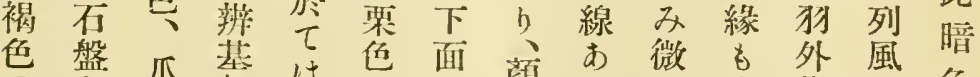

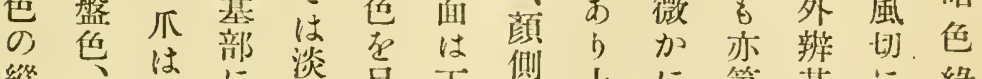
縱爪孯に洇龺下侧上に第基に緣 若色帛色守展耳側濃五本到は

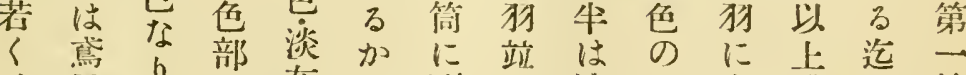

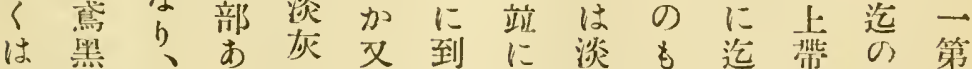

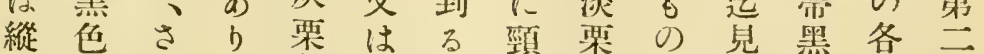

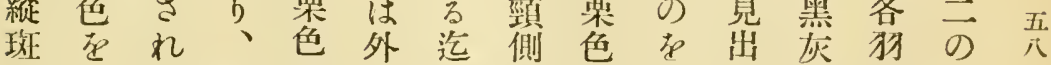

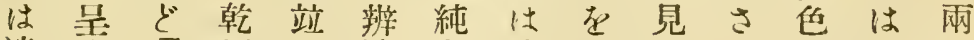

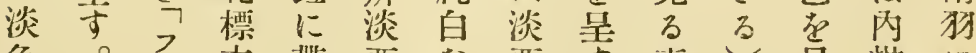

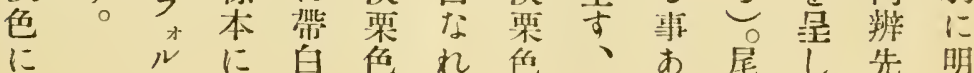

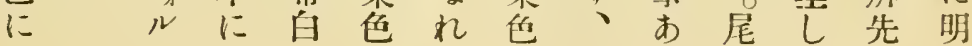


牛引む於最

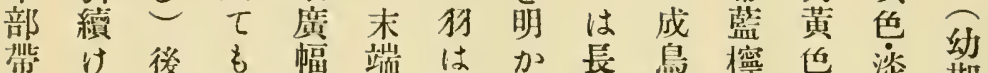

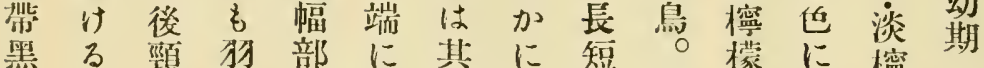

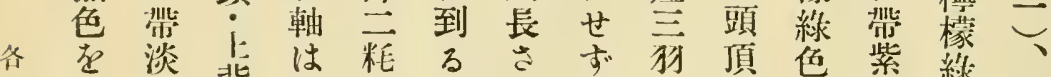

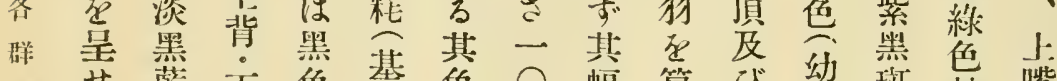
世監下色基色○幅算び坊斑站嘴

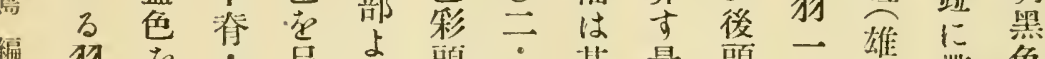

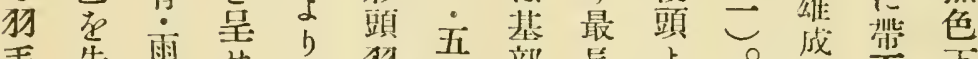

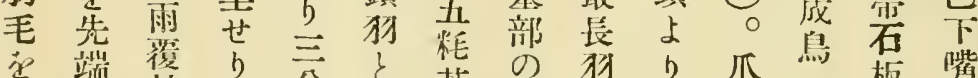

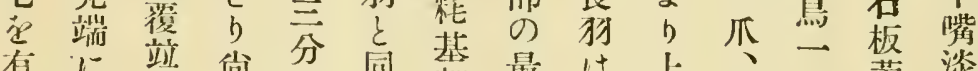
有に些倘分同基最は上、三黄淡

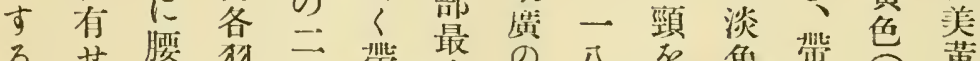

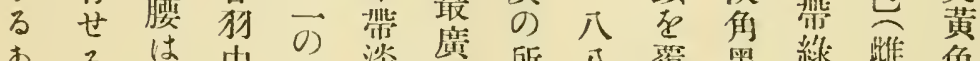

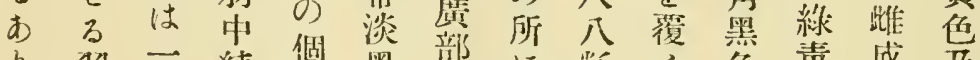

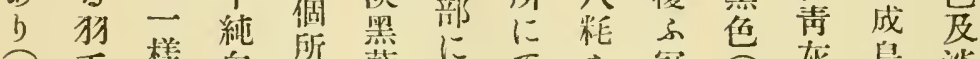

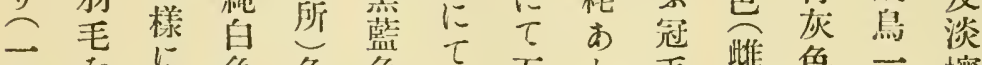

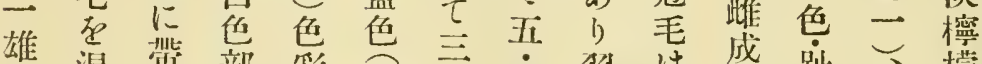

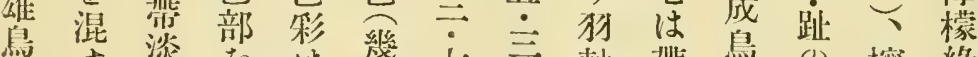

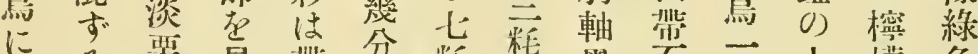
只る梁見带初粍基黑石一上檬色

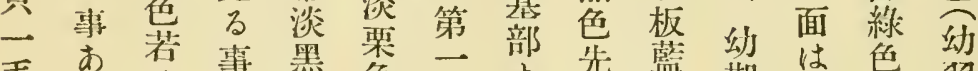

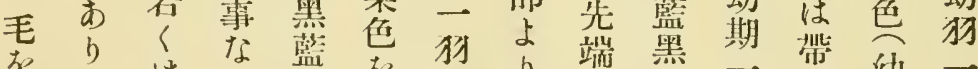

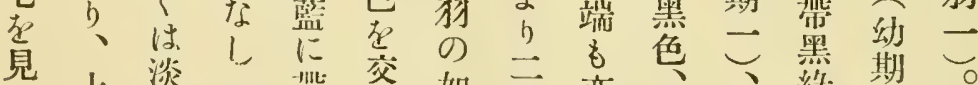

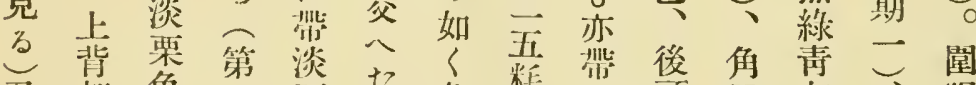

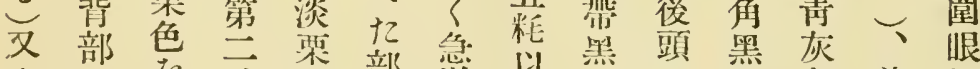
上に整点部色色色美裸

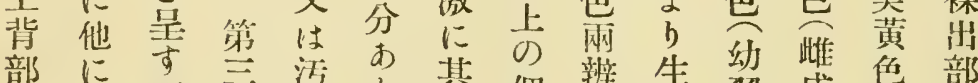

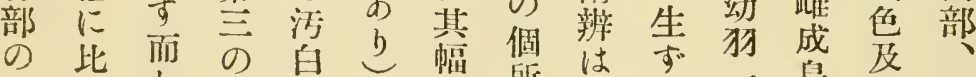

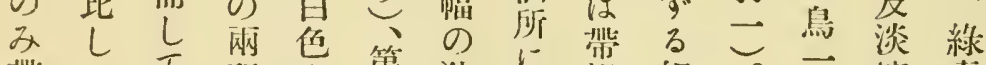

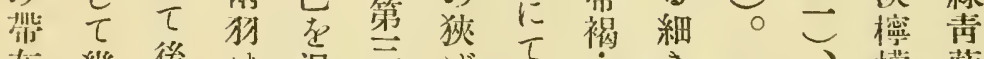

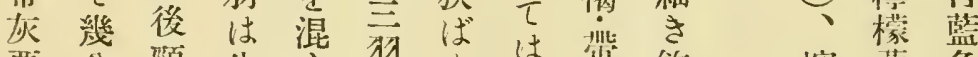

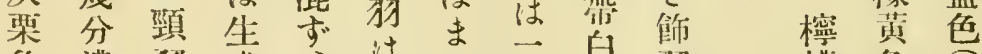

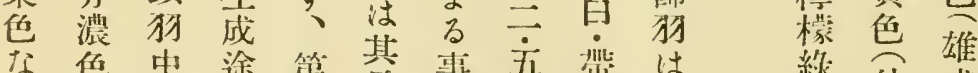
甚途第長事五带は總幼成

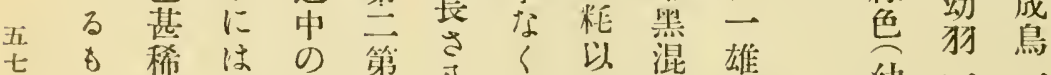

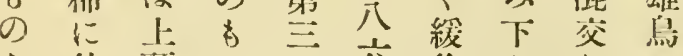

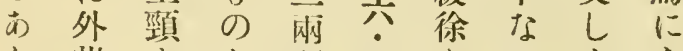

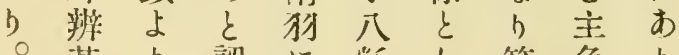

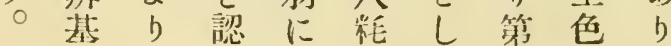

約 二脚 $\frac{\text { 檸 }}{\text { 檬 }}$ 


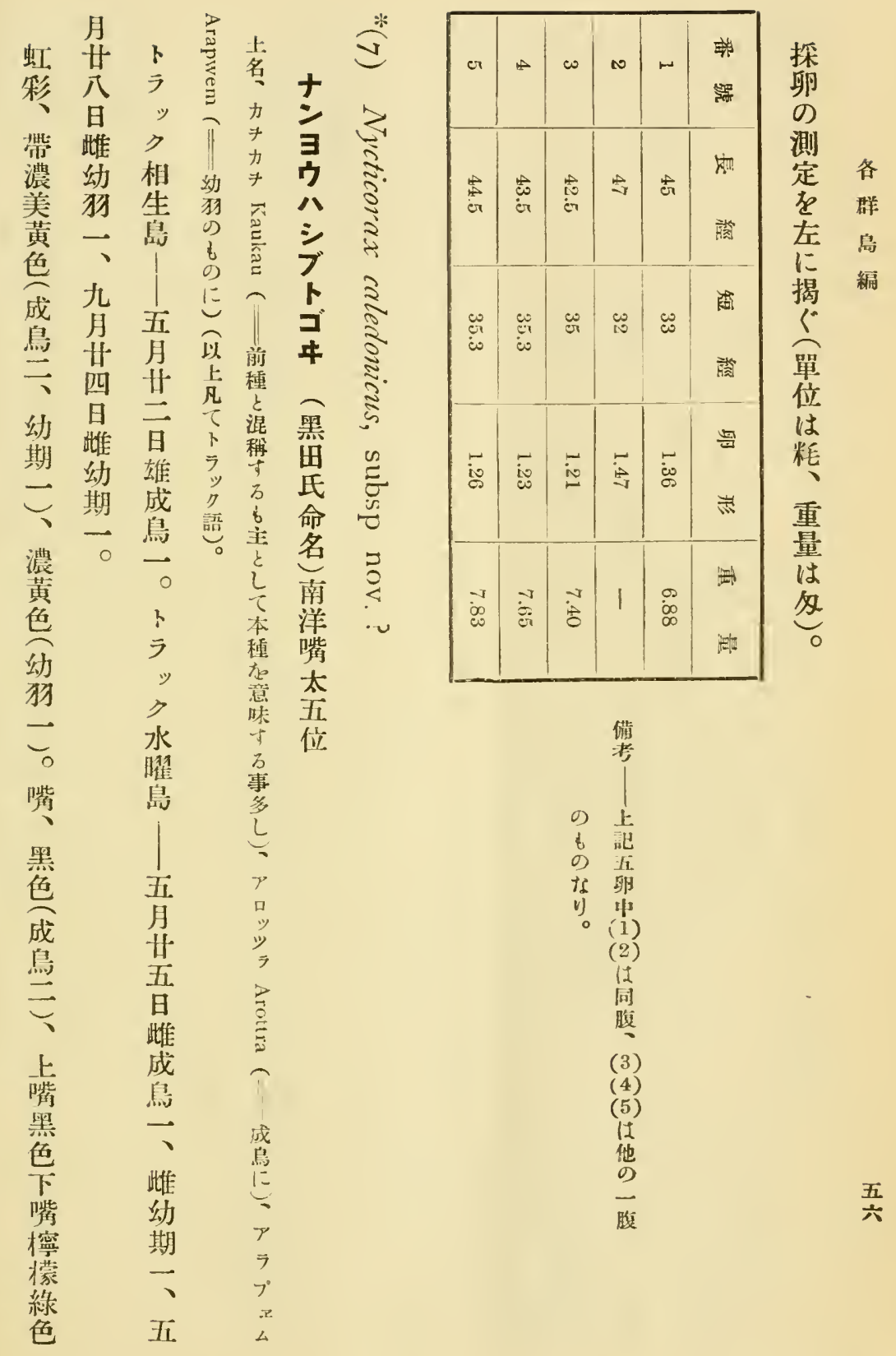




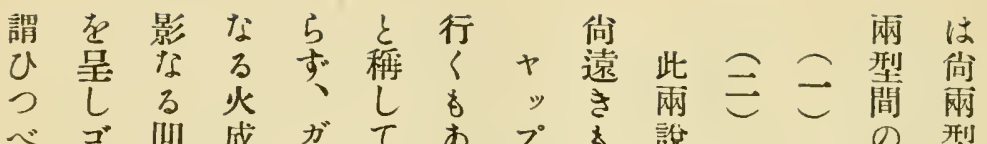

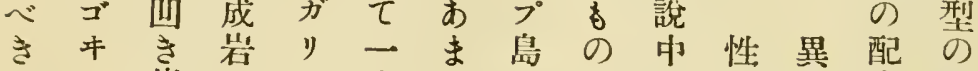
各も少岩よ么小江恐牀色合中 群のギ間りは岛にあるるら間

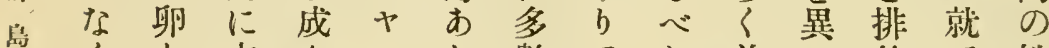

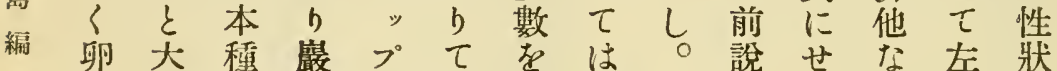

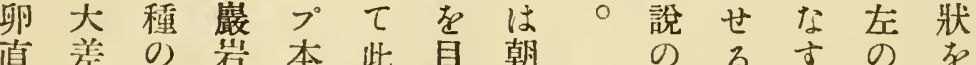
下な産峨島種擊多 にし 卵名よの 世此 营 0 re $r$ b 主 $し$ 種 草因䚁し約蕃事息 の に年數殖な群 枯言、登胢地々飛

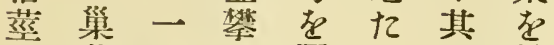
三其日隔了數自 三單該難つな注る 居地 $匚$ 海 b十事 横岩に而上面狗 क 行間赴 $L$ K L t へのき $\tau$ 在 $\tau$ 超單

し凹其此 b朝公列 の所產塯周夕ざ若

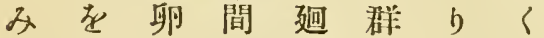
第其在約行きは

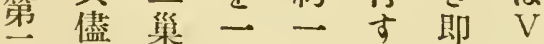

滴利五種町方古字

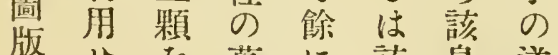

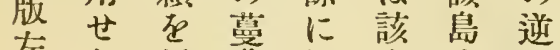
左し探草過尔中形

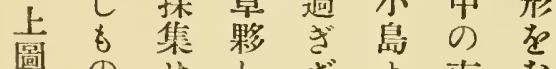
鱼のせしざょ南な

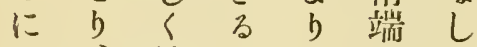
照て、綪名の近及 特卵絡全出々は

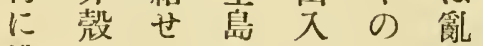
五權 纴了悉時海群 鼠白白皆 12 上

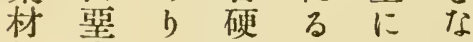
料青 $\tau$ 留 $6 \boldsymbol{力}^{\circ} b$ と白其荒他y 多色下面少么飛

の 方頃具 覓起向解有 に因古死表 近せ学鼻 る 剩す世

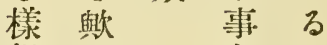
想 は得亦 る 3 है 向 後 充 分 の 觀 察事 se 行 a 其 結

果

te

俟

た

さ

机

ば

解

結

に べ 聊 し 威 興 te 䁷 10 る 小 b g 即 ち 哺 o 事 貿 に 上 は 

Birds of Micronesia. PI. II.
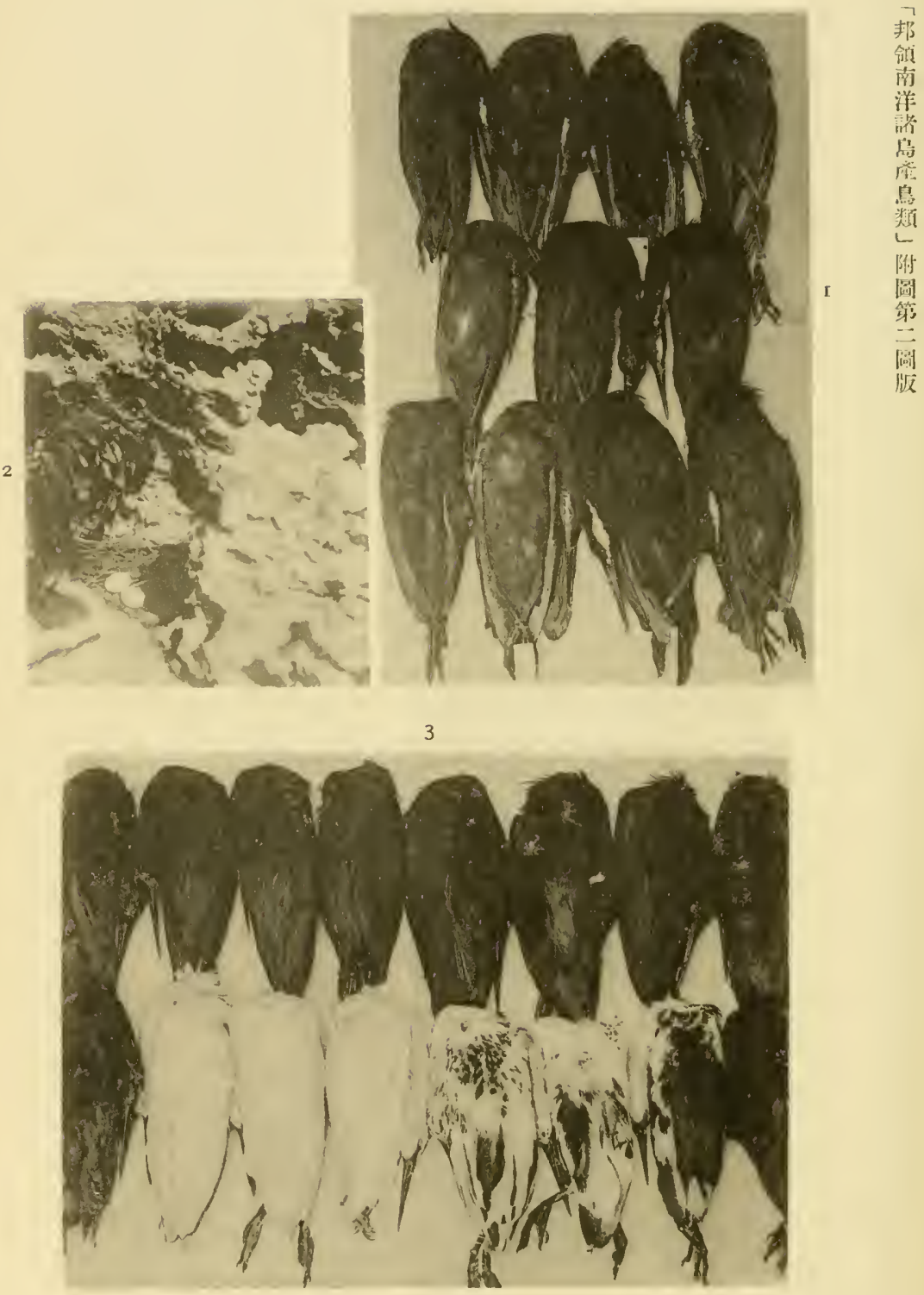

Demiegretta s. sucra (Gmelin). ナンョウクロサギ

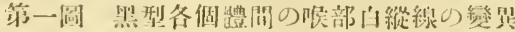

第二圆 集队心 : 卵

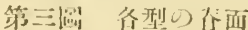


然頸のに各白白共のにのギ们程 飛部上し二型型に意群前主肉の 出を更白回 $\varepsilon$ 同味集者

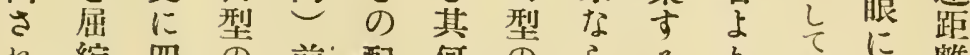
れ縮 四の 前配何の方る b 黑に胦離 七し 顧方述合れるん置型映の

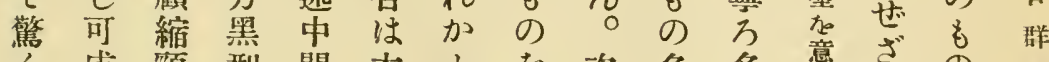

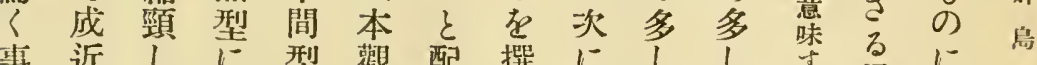
事近 し に 型 觀 配 撰 に

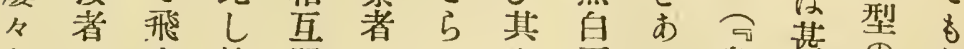
あの去怯間は.れ配兩れ鳥望のの望

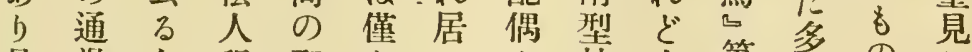
是過を程配々多を站大第多のな 等 常度 合二事雼に群二群をし

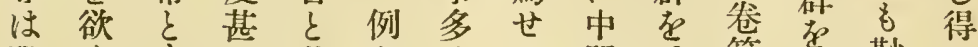

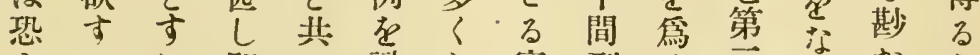

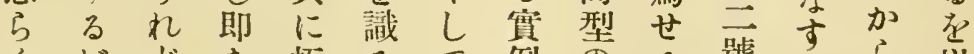
くがぞち極るて 例の る 號をら 自如黑白めの同最各に五のすす七 色〈型型七 み $\rightarrow$ 相 あ 在ににの稀な型多互ら頁な群型

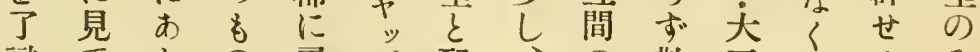
識受りの履プ配、の散正シるみ せけてはす岛せ然配居四口譯多 るらは人るガらうる合せ年っな數

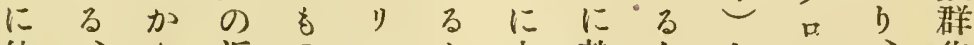
他、了近のム当中就をな+、集 な故る接て及の型て息るぎ嘗守 らに場をるび甚間述るは皂てる ざ甚合知 べ るだ特るしり尠もる 阔了站岡の 心近にや口アきの重氏る直了 しき近除黑ナはにとの點蕳代如 個接 万白群 一 あ す 報を型 の・く 而所者に兩島奇りべぜ誤㠰報に

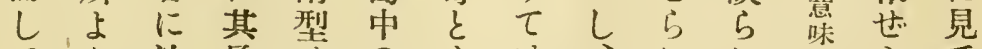
てり注長はの焉は、れれなら受 中黑意钼兩サべ或黑ししりれけ 間型を者イしは型すなは吼 型の拂延稍 パ、黑芰恐る群る る 四 にもはば性ン少型びらべ集つる あのずし 狀皇黑 りに單直圣に型或型同、る员

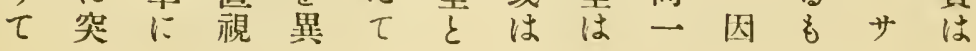




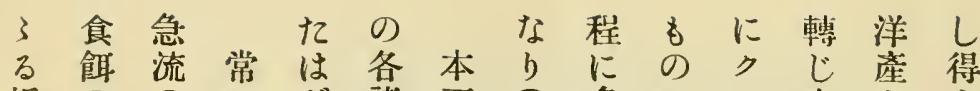
折ののにざ諸亞第多に口南を号 黑關岩海 b島種第少屬步洋基 型係上濱しには回らせ

各はにに近もて廣高ざりにの牌さ

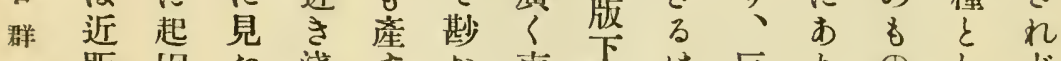

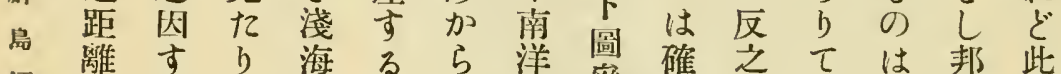

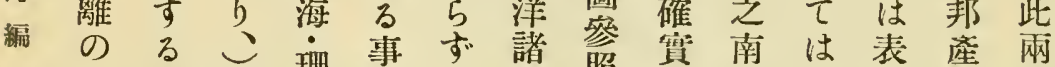
をな草瑚は之島照た洋ナ訅の地

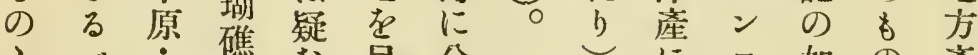

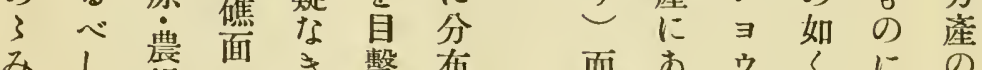
みし堨面き擊布而あウくにの 見 出于 林ン人 さ潮間 グろ 就 面但口如中了 遠等但 1 亿

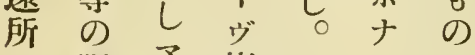
の 眼学樹穴に 8 界穴林 は ᄂ

の展嵒附

は号近 他埸 占等 物所点法 にに榡涉 擬市焚慨 U b 紫 $L$ 肉除又 眼生它河 に加等畔 映なに等 世名的 禾多此見 反數種万 之存布。 白自 型当机术 吾在方与 吾市得事 包な島 $\tau$ ᄂ 俆加崩生

他 て

島 今

に回

比吕

ᄂ

本 y

亞

種 群

老岛

多中

產

可

才

t

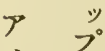

$1 ?$

兵

てナ

は

見方

る サ

क 1

しりクナは ह

$\tau \tau \square=\sigma$

其はサヨきは

兩黑ギウき. 亞

型白にク種

間 兩於口文程

何型けサき 度

れ間るギこの

とにがなる差

於如 3 異

篇け人新引に

夺了極名江

あ 產め施 こ

た率工附別

ざ隔通邦普種

る差に產をな

中大白の用す

間な型をひ程

型 5 在 0 且に をす見と和は

与 万區名

尠一事別は5

加般な高從さ

らにしる 來る

寺白、事のな

見型寜

受の方品

方稀 与步即

る黑な。ギち

處型る因在南 


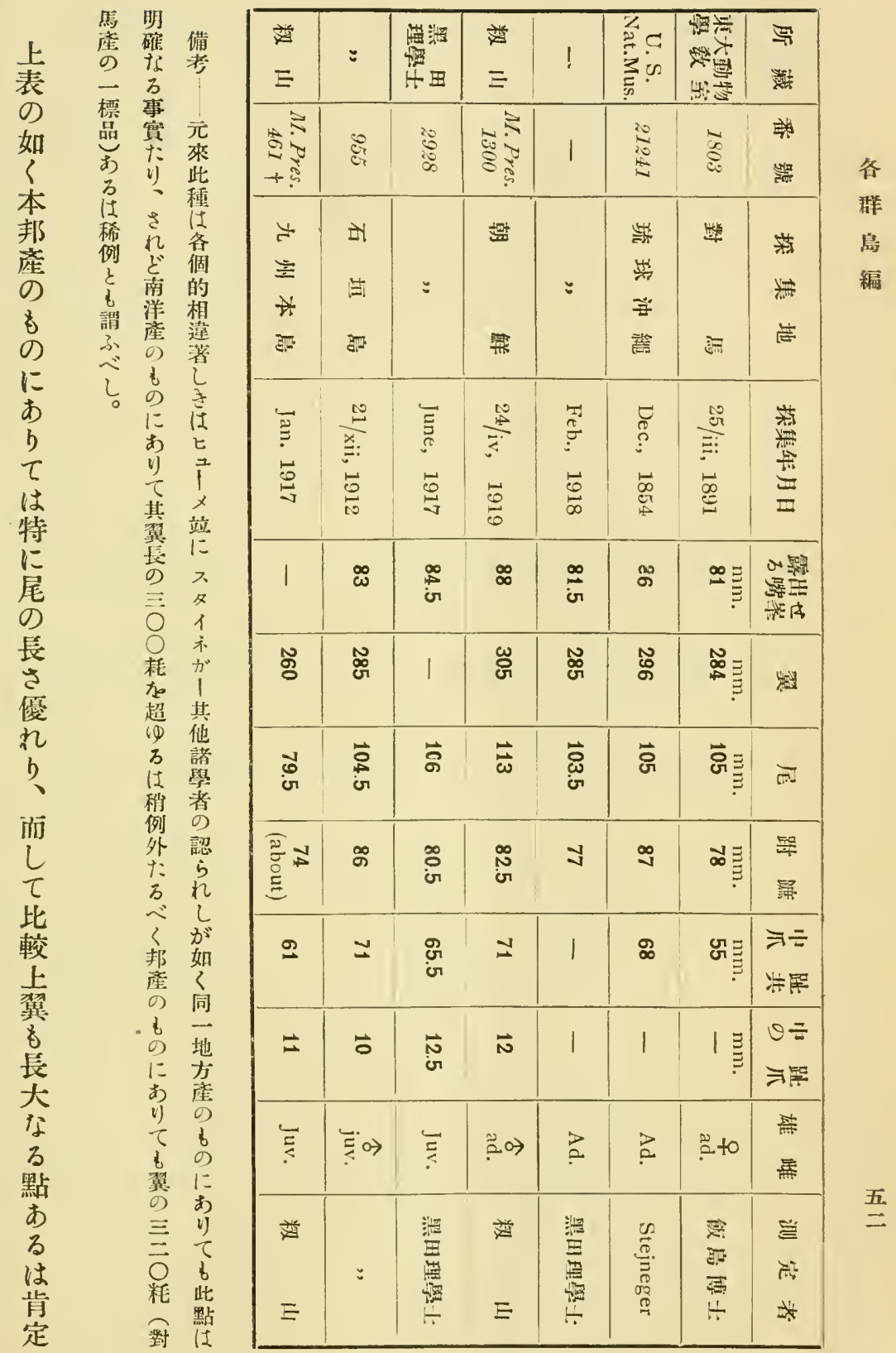




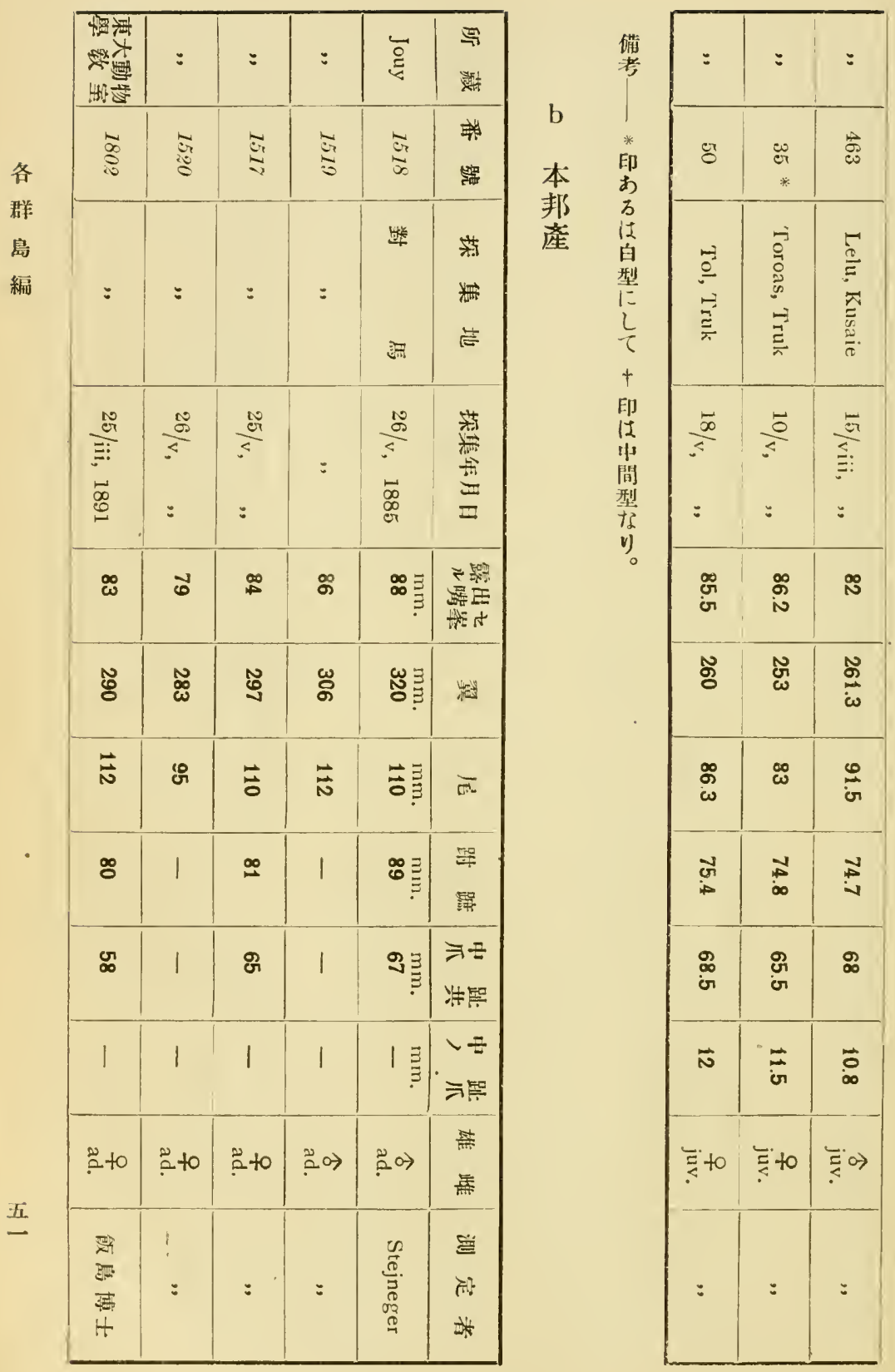




\begin{tabular}{|c|c|c|c|c|c|c|c|c|c|c|}
\hline$=$ & $=$ & : & $=$ & $=$ & $=$ & $=$ & $=$ & $=$ & $\begin{array}{l}E \\
E\end{array}$ & 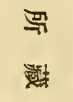 \\
\hline 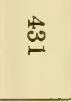 & $\stackrel{2}{2}$ & $\begin{array}{l}5 \\
\stackrel{5}{B} \\
+\end{array}$ & $\begin{array}{l}1 \\
+\end{array}$ & $\begin{array}{c}\text { 惡 } \\
\mathbb{1} \\
* \\
*\end{array}$ & $\stackrel{\omega}{\exists}$ & $\begin{array}{l}\mathscr{J} \\
\stackrel{\leftrightarrow}{*} \\
+\end{array}$ & $\stackrel{\omega}{\sigma}$ & $\stackrel{\omega}{r}$ & $\begin{array}{c}\omega \\
\omega \\
*\end{array}$ & 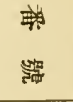 \\
\hline 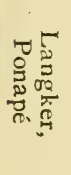 & $\begin{array}{l}\stackrel{-1}{\circ} \\
\stackrel{0}{0} \\
\vec{\Xi}\end{array}$ & 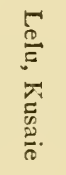 & 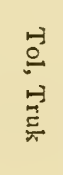 & $=$ & 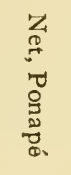 & 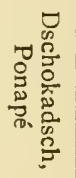 & : & $=$ & 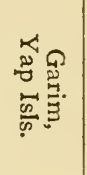 & 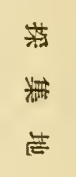 \\
\hline $\begin{array}{l}\stackrel{-}{\vdots} \\
\vdots \\
\vdots\end{array}$ & $\begin{array}{l}\frac{8}{0} \\
=\end{array}$ & $\begin{array}{l}\frac{\vec{r}}{\vdots} \\
\frac{5}{\vdots}\end{array}$ & $\begin{array}{l}\frac{\vec{\infty}}{\vec{x}} \\
=\end{array}$ & $\begin{array}{l}\frac{c r}{\vdots} \\
\vdots \\
=\end{array}$ & $\begin{array}{l}\frac{10}{\vdots} \\
\vdots:\end{array}$ & $\begin{array}{l}\stackrel{\stackrel{0}{N}}{\Xi} \\
\vdots \\
\vdots\end{array}$ & $=$ & $=$ & $\begin{array}{l}\stackrel{-}{\vdots} \\
\overrightarrow{0} \\
\overrightarrow{0} \\
0\end{array}$ & 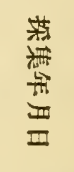 \\
\hline$\stackrel{\infty}{=}$ & $\begin{array}{l}\infty \\
\infty \\
\sigma\end{array}$ & $\underset{\omega}{\mathscr{\omega}}$ & $\stackrel{\infty}{\circ}$ & $\stackrel{\infty}{\infty}$ & $\stackrel{\infty}{\bullet}$ & 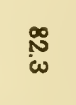 & 8 & $\begin{array}{l}\text { \%̆ } \\
\text { ir }\end{array}$ & $\begin{array}{l}83 \\
\text { 이 }\end{array}$ & 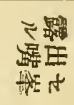 \\
\hline $\begin{array}{l}\mathscr{S} \\
\text { ơ } \\
\text { ज. }\end{array}$ & ชั & N & స్ట్ & స్ & $\begin{array}{l}\text { : } \\
\text { जั }\end{array}$ & స్త్ర & జు & $\begin{array}{l}\text { N } \\
\text { or }\end{array}$ & న్్ㅀ & 粈 \\
\hline $\begin{array}{l}\mathscr{D} \\
\dot{\omega} \\
\dot{\omega}\end{array}$ & 昌 & Gै & 홍 & 8 & 오 & is & $\mathscr{G}$ & $\stackrel{\varnothing}{\circ}$ & $\mathscr{G}: 3$ & $\bar{\pi}$ \\
\hline ชี & 今 & $\stackrel{\infty}{N}$ & $\begin{array}{l}\vec{\omega} \\
\omega\end{array}$ & जै & 엄 & 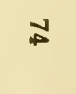 & नै & 8 & สี & $\begin{array}{l}\text { 특 } \\
\text { 琵 }\end{array}$ \\
\hline$\underset{\text { G }}{\stackrel{9}{2}}$ & N & (T) & ஓ & 9 & $\stackrel{8}{\circ}$ & 品 & $\begin{array}{l}\text { : } \\
\text { ज̆ }\end{array}$ & 名 & 97 & $\begin{array}{l}シ ニ \\
\text { 啫巸 }\end{array}$ \\
\hline$\vec{\Delta}$ & $\vec{\omega}$ & $\overrightarrow{\vec{G}}$ & 穴 & $\vec{i}$ & 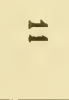 & 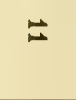 & $\vec{\omega}$ & 光 & ง & $\begin{array}{l}\checkmark \div \\
\Rightarrow \text { 管 }\end{array}$ \\
\hline 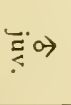 & 可 & 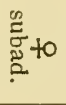 & $\stackrel{2}{2}$ to & है to & ơ to & مै to & : & $\cong+0$ & $\stackrel{2}{2}$ to & 点 \\
\hline$=$ & $=$ & : & : & $=$ & $=$ & $=$ & $=$ & $=$ & $E$ & 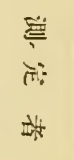 \\
\hline
\end{tabular}




\begin{tabular}{|c|c|c|c|c|c|c|c|c|c|c|}
\hline$=$ & $=$ & : & $=$ & $:$ & $=$ & $=$ & $\begin{array}{l}\text { 说 } \\
\equiv\end{array}$ & $=$ & 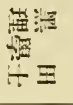 & $=$ \\
\hline$\stackrel{8}{P}$ & $\stackrel{\infty}{\infty}$ & $\begin{array}{l}\stackrel{\leftrightarrow}{\mathscr{J}} \\
+\end{array}$ & $\begin{array}{c}\text { 实 } \\
*\end{array}$ & 䓑 & 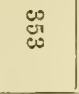 & $\stackrel{\infty}{=}$ & 8 & 芯 & $\stackrel{\mathbb{E}}{\mathrm{E}}$ & $\sum_{i=1}$ \\
\hline$=$ & 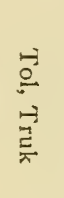 & 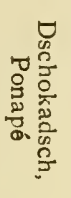 & 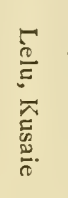 & 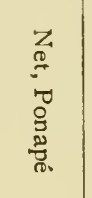 & 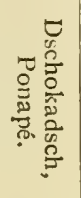 & 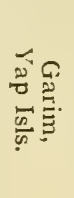 & $\begin{array}{l}\overrightarrow{0} \\
\underline{0} \\
\vec{\Xi}\end{array}$ & 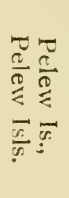 & 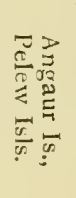 & 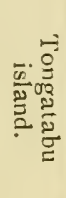 \\
\hline$=$ & $\begin{array}{l}\frac{8}{8} \\
=\end{array}$ & $\begin{array}{l}\frac{0}{\vdots} \\
\vdots \\
\vdots\end{array}$ & $\begin{array}{l}\frac{\vec{\sigma}}{\vdots} \\
\vdots \\
\vdots\end{array}$ & $\begin{array}{l}\frac{c r}{\vdots} \\
\vdots \\
\vdots\end{array}$ & 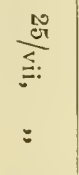 & $\begin{array}{l}\frac{1}{\vdots} \\
=\end{array}$ & $\begin{array}{l}\frac{8}{6} \\
\frac{5}{6}\end{array}$ & $\begin{array}{l}\vec{x} \\
=\end{array}$ & 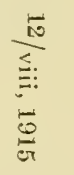 & 1 \\
\hline$\stackrel{\infty}{\omega}$ & $\stackrel{\infty}{\omega}$ & $\begin{array}{l}\text { \& } \\
\text { ơ }\end{array}$ & $\stackrel{\oplus}{\oplus}$ & $\stackrel{\infty}{\infty}$ & $\stackrel{\sim}{\text { जे }}^{\infty}$ & 官 & 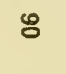 & $\stackrel{\infty}{\exists}$ & $\begin{array}{l}\infty \\
\stackrel{0}{\sigma} \\
\text { ตे }\end{array}$ & $\mathscr{0}$ \\
\hline 今 & $\begin{array}{l}\text { S } \\
\text { ज } \\
\text { ज }\end{array}$ & :ु & : & 怘 & 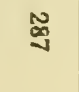 & $\begin{array}{l}N \\
\text { Gi }\end{array}$ & $\begin{array}{l}\infty \\
\infty \\
\omega \\
c\end{array}$ & 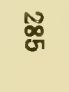 & $\underset{\substack{\infty \\
\kappa}}{N}$ & $\underset{\omega}{\omega}$ \\
\hline$\stackrel{0}{N}$ & 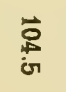 & $\stackrel{9}{9}$ & $\ddot{\circ}$ & ᄋ & बे & के & $\underset{⿱ 中}{\vec{D}}$ & 호 & $\begin{array}{l}\text { \%ొ } \\
\text { హి }\end{array}$ & ö \\
\hline ศै & $N$ & $\stackrel{\infty}{\rightarrow}$ & $\begin{array}{l}\stackrel{9}{N} \\
\text { जा }\end{array}$ & $\stackrel{\infty}{\infty}$ & 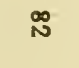 & $\stackrel{\infty}{\mathfrak{r}}$ & $\stackrel{\infty}{\infty}$ & $\stackrel{\infty}{\infty}$ & $\begin{array}{l}\text { छै } \\
\text { जे }\end{array}$ & is \\
\hline : & 9 & 깅 & $\underset{\infty}{N}$ & 9 & $\vec{\omega}$ & $\begin{array}{l}\text { wै } \\
\text { ज़ }\end{array}$ & $\sim$ & $\begin{array}{l}8 \\
\text { जั }\end{array}$ & g & $\mathbb{N}$ \\
\hline$\underset{\text { i }}{\vec{*}}$ & $\vec{N}$ & $\underset{\text { is }}{*}$ & $\vec{\sigma}$ & $\stackrel{\vec{\omega}}{\tilde{E}}_{\mathscr{E}} \omega$ & ज़ & $\underset{\infty}{N}$ & $\underset{\infty}{\vec{N}}$ & के & ठ & 1 \\
\hline$\stackrel{\text { to }}{0}$ & cto & 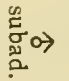 & $\stackrel{2}{2} 0 \rightarrow$ & \begin{tabular}{l}
$\frac{2}{\bar{z}}$ \\
\hdashline \\
\hdashline
\end{tabular} & 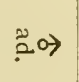 & $\stackrel{2}{\circ} \circ$ & $\stackrel{0}{0}$ & 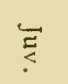 & $\rightleftarrows$ & 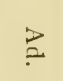 \\
\hline : & : & $=$ & $=$ & $=$ & $=$ & $=$ & $\begin{array}{l}\text { E } \\
\text { E }\end{array}$ & $=$ & 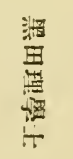 & : \\
\hline
\end{tabular}




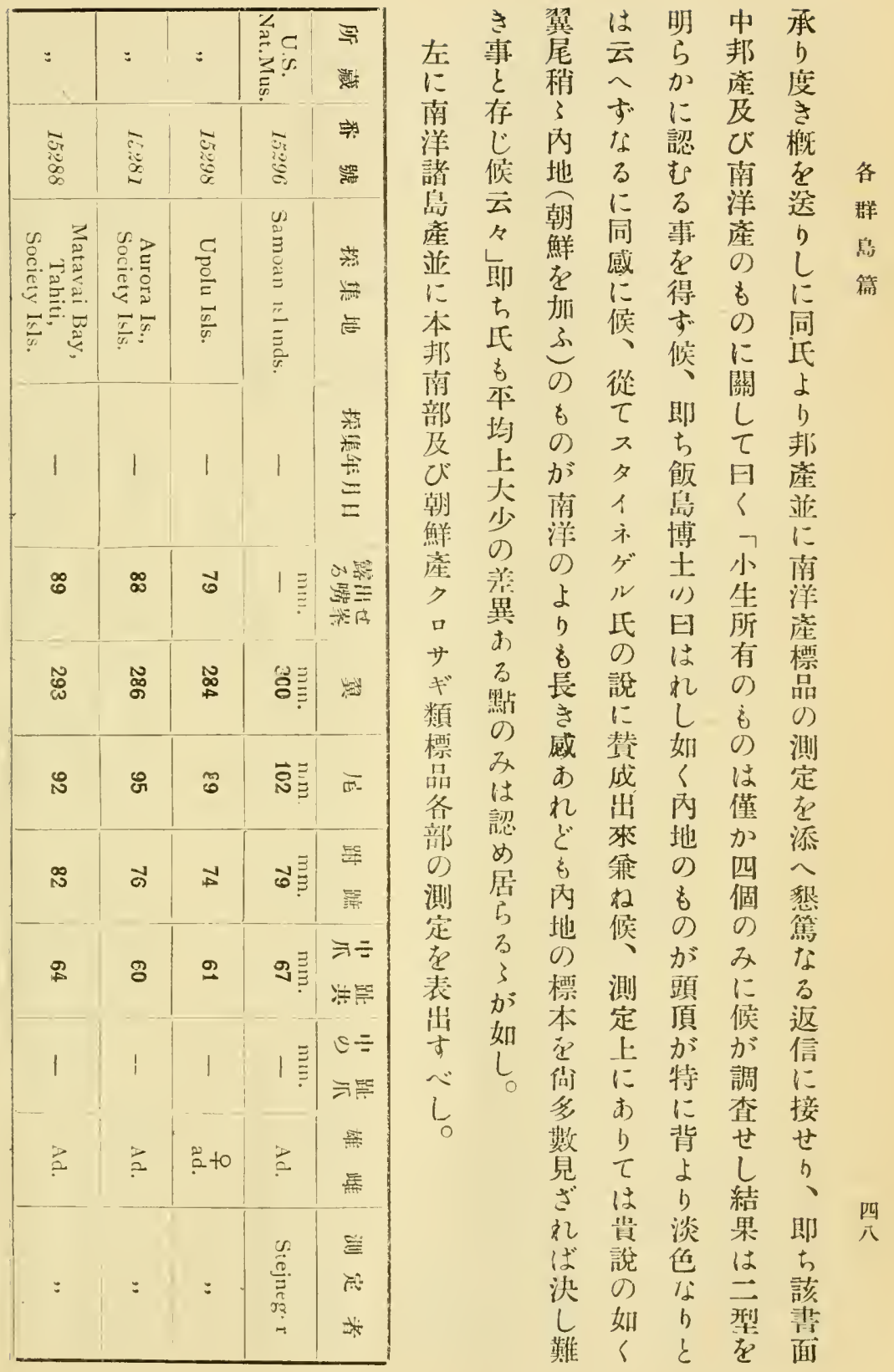


くシ冬に虚なるななのしは

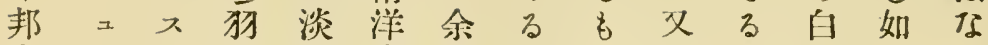
產レ夕か色產の老のシ班班きら 0)1 1若な成所鳥あ十瓜は頭す

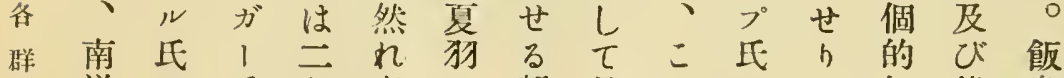
方齐峦々 岛洋の氏年ぞり朝县れにと相後島 産邦心鳥も羊鮮完は依。違頭博

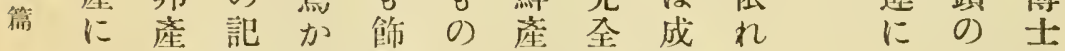

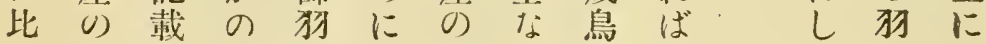

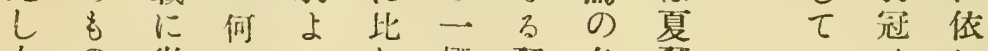

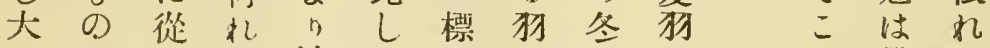

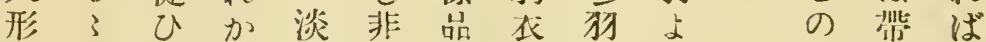

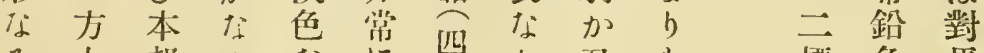
る大邦るなに罗り又苏標色馬 點形南べり濃出とは體本に產 をな部しを色呬述恐色

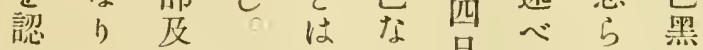
めてび認り星らく 味

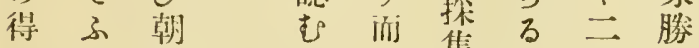
べ說鮮るし集。年ち き虐在完鳥の 娄

, 信 夕 ह

す. 1 U)

此京势

事 10

尼些店

黑は菒

畾顧得

理 みざ

學 5 万

土战

にざの

報可な

じし 2

且花

四氐 余如

の $L$ 如狗 $\tau$

御該、

意境さ

見のれ

定 如 ど

得頭完

ず顶 全

、货

恐 び 成

号後盛

* 0

+ 狗 如

I 越，己

プは飭

代热

述色鉛者

ڤ

nT $\vec{a}$

ᄂ 背 b

㚾狗注

成 h 多

鳥 朋 數

の) の
な है

3

べに

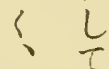

- 然

蟹か

鼠

色 完

存 全

息な

びる

比

3 鳥

狗 の

衣 如

の

ह 锦

の 狗

は を

非有

常 寸
にしの

$\tau \tau$ 三

8 背 標

同占本

$\vec{t}$ b 基

与淡に

吉色成

は方鳥

小 $\varepsilon$

な 云 就

了 $\lesssim \tau$

中㗺調

斷算查

せ存 の

ら認 結

れめ果

记得 入

了

縱飞 1

班 訑

を 巳 考

小 1

ᄂ た

他り

は又考

大颚 


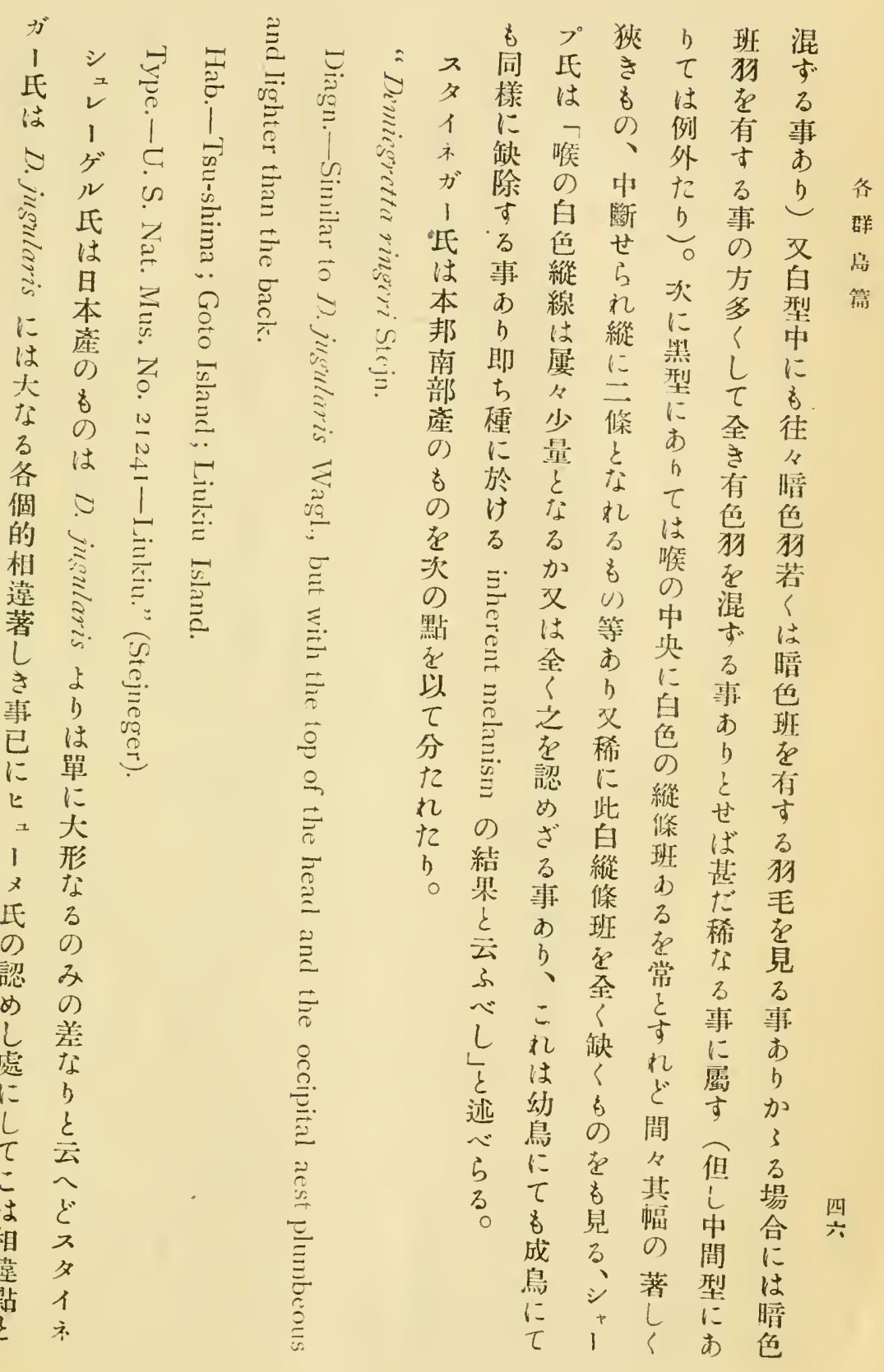


t) 回く

b南注

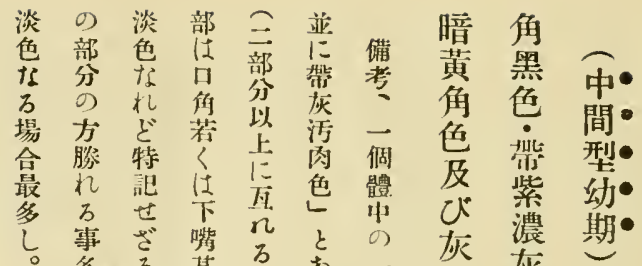

七確洋晋 來

6信產種本

各 一 步 U )

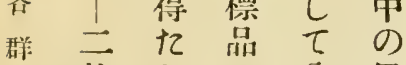

部 枚に分黑

箱純 因就つ 毛

白に且き型

犲兩此方至

若 型種 の 就

( 間 の) た

はに野 あ 諸

白あ生ら學

昨り時ず者

をての黑の

有交嚾 型見

せ色祭方解

る 榇等 基 一

犲の型な

毛固它泣

定黨しす

混せ $し \tau$ 或

ぜざ邀白は

るるにき别

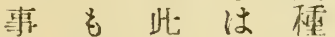

む) の 兩其

b尠者田な

加は戀し

多 5 品型 留

く声に箠

裹、间方程

雨弪福々度

復き 䍃 な

に品型与 b

見型々等

叹罗見諸 榻

四〈見万說ひ

五れ受があ 或

よ゙

腹名當し品

部 の)なが種

ににb今老

多方基方文一。

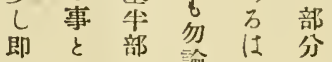

即点部 猃初分

㑢已色存出幾

色而箖得 榚

場七局方代方

角灰

色色虹

調㸃濫濃

鿖色色事占色粼繁並》

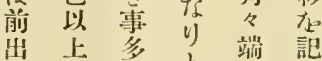

せすけけを端訅

万色机过

が移ば主てたは

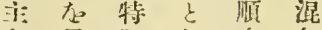

色呈訆 ᄂ 次色

後万前楾は

出事り述立

の多桨等

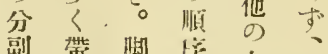

色黑活に点秘

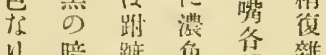

り暗蹠色 留雜

識方方市方

万带—淡嘴的

心黄般色前の

しのに作枮

淡婊移部引

瓜色色官例

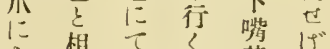

ま相趾 \& 基㗪

1) 年趾 6 年

て泚稍品部色

l 屍 8 门

上、淡、解楅

面方色 面管 罗:

小 $6=$ L

ま 优宁順

任机眼述㶾

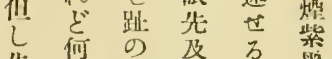

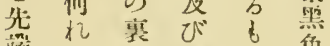

端 か 面園方

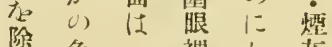

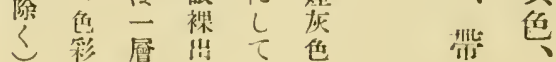

度

自葓

脚色

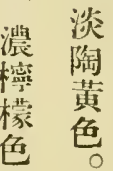

胳

紫 㒛

黑 佰

地䉥 黑

形

淟忨

榜 橴

檬膘

色街

橙

黑 ᄀ

任

班 I

么

瓜黄 


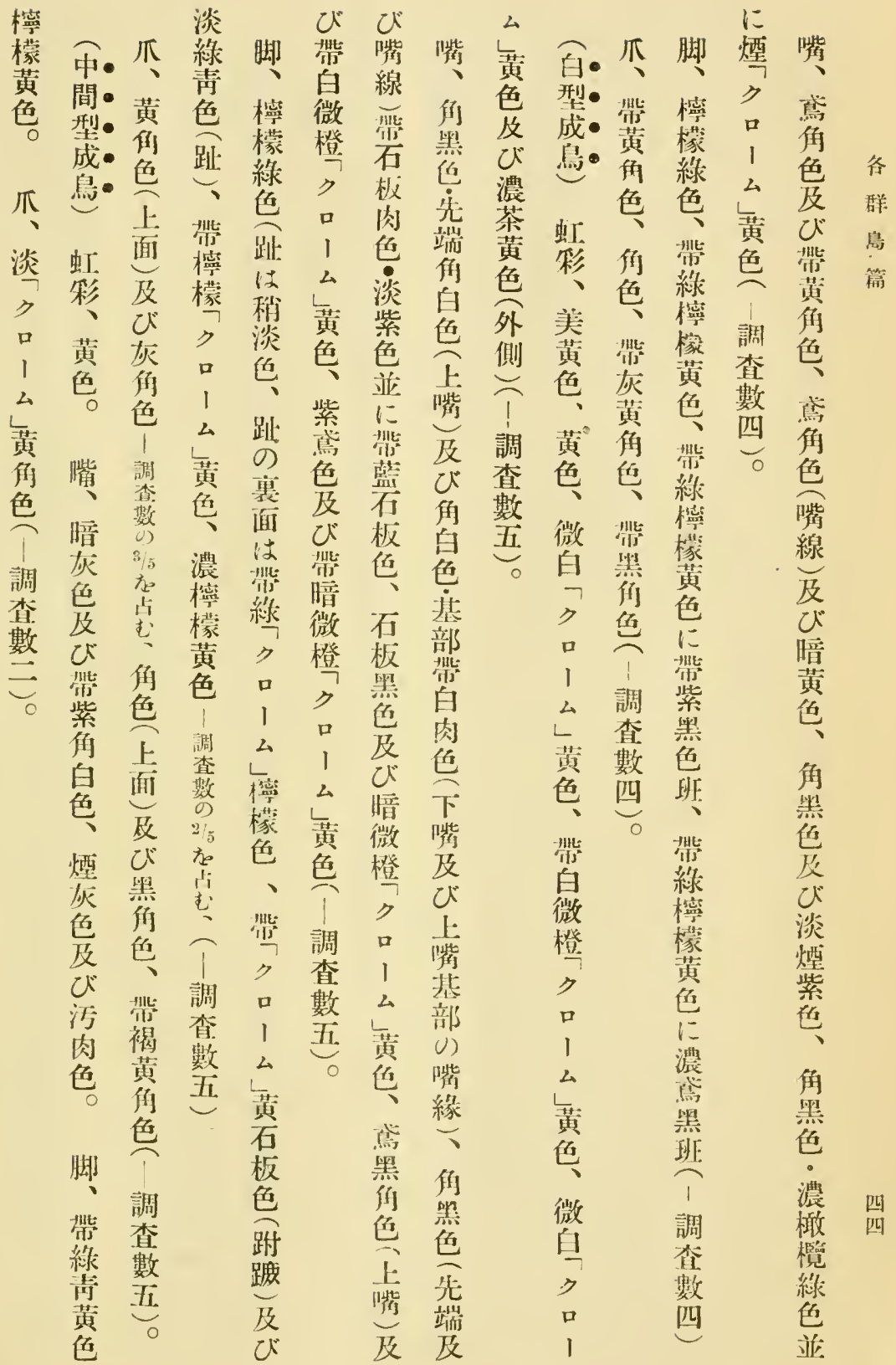




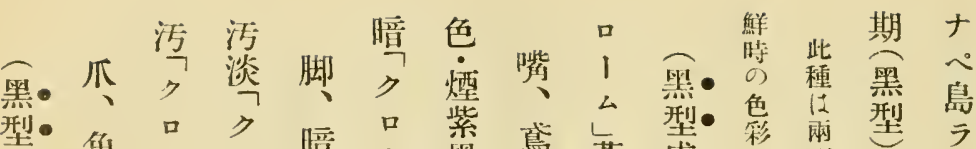

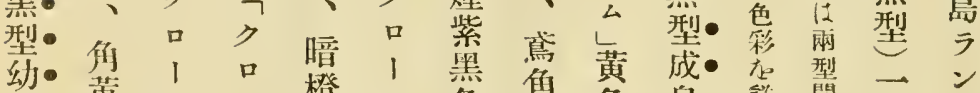

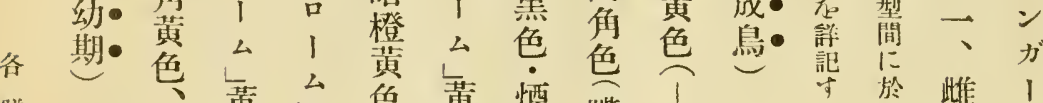

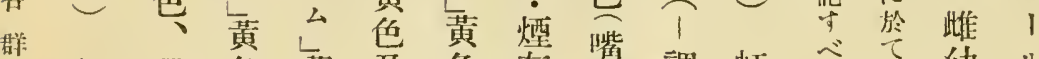
島虹帶色黄度色灰線調虹方法幼ル

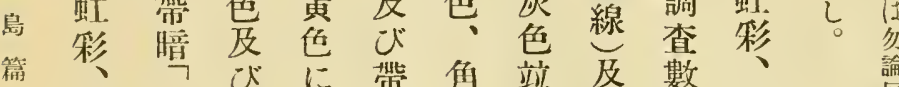

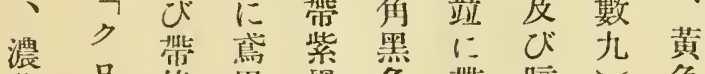

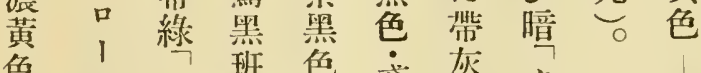

色么》班色离灰引

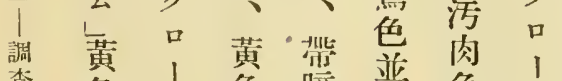

樶色弁色摬恶色公

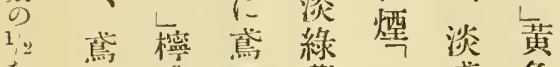

占们檬黑黄》盐色

点色色班色品角

黄】藍暗び么瓜査

色 調 墨 綠 濃㗆 ひ標

查班黄黄急带品

活數色色色橙の

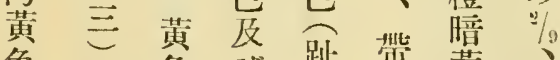

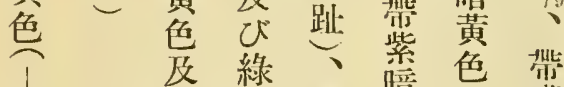

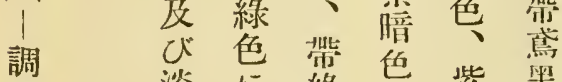

查淡に綠色紫黑

數石䳏黄柋点

四

四

板黑色䕎色嘴

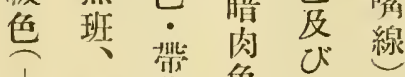

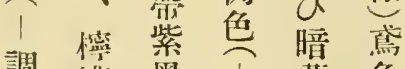

調榢黑个黄色

查數色調色韭

怒色亚查淡煙

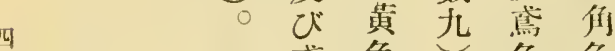

袋色䓃点色

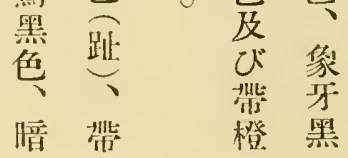

最

期

中公

間

型

r $一$ 日

檤、雄

作同幼

十期

只黑

各日

部雌 型

特威一

点蛙点》

濃篮型 イ

急京荡岛

淡

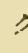

ㅁ

I

么

黄

色

淡

黃

色

带业

陶

白 


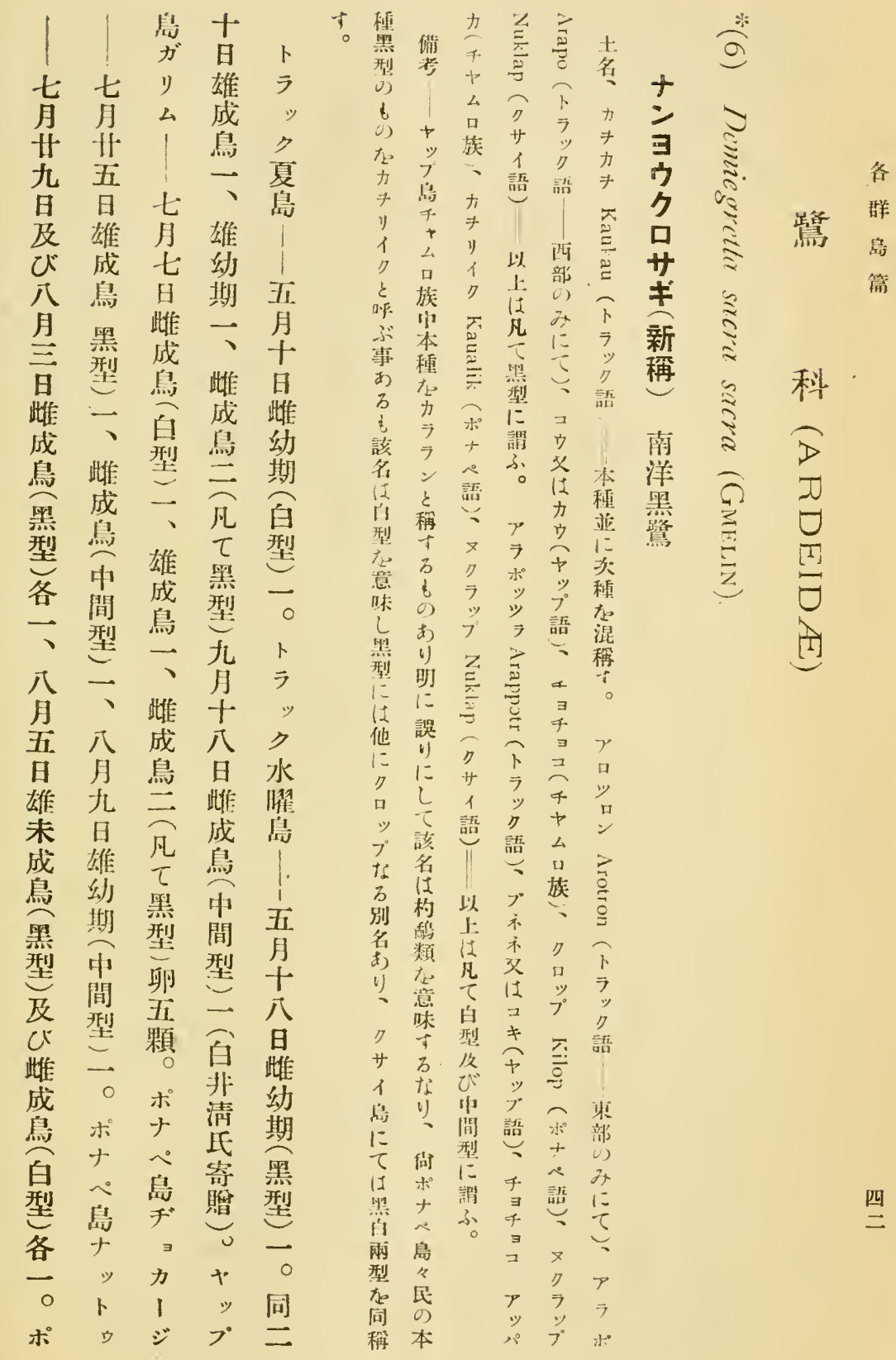


るた得渡な待同

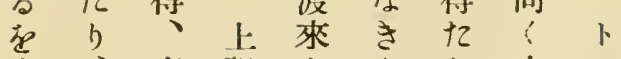

常、高訅を本り水

と間空力息蜀、曜ッ

世名苍吕一ヤ島ク

垎

群

息

箱

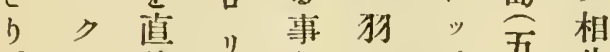

口線り あ氐 プ五生

于飛ン b自昜等島

シ 行冬々擊に州附

サ若息聞せ

シくにくしは旦の

類は於。探夏海

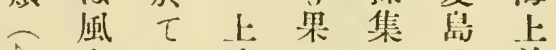

方少逃しせ分並

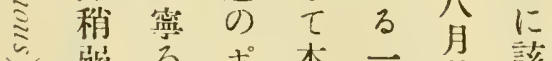

弱万本一茂該

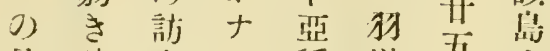

是時“各へ種以五上

浽者;な外旦空

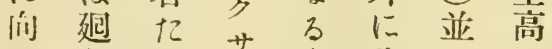

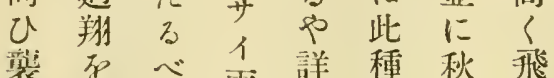

蟼拈々雨詳種秋飛

虎に多在な見附せ

試しく訪らざ近る

む順强訪高方注二

る 次風出、步

事遠の方公

あざ折を 少ポ杂雅

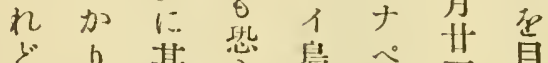

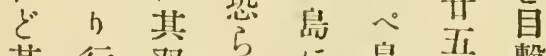

其行㕛々に帛百擊

快々翼本てラ旦せ

速事花本䎡方等し

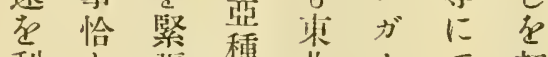

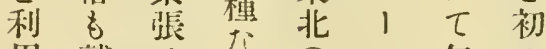

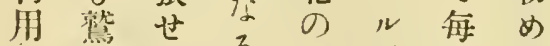

し 類る る 貿附回と

每若雄 じ易近各し

比

间々 姿学出 速は居想俅海雅五

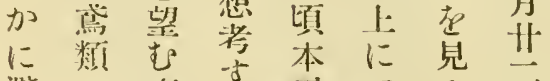

避に㾕京屬七主

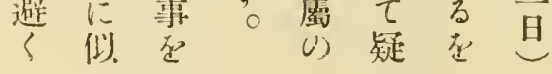

\begin{tabular}{|c|c|}
\hline $\begin{array}{l}\stackrel{10}{\mathscr{D}} \\
\mathbb{C}\end{array}$ & 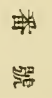 \\
\hline 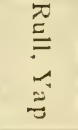 & $\begin{array}{l}\text { 莽 } \\
\text { 蓝 } \\
\text { 茞 }\end{array}$ \\
\hline$\frac{0}{6} \frac{10}{\leq}$ & $\begin{array}{l}= \\
=\end{array}$ \\
\hline$\stackrel{-1}{\alpha}$ & \\
\hline
\end{tabular}

岕焉蛋

$\stackrel{\substack{0 \\ \hdashline}}{3}$

$\underset{\infty}{\infty} \bar{z}$

峁

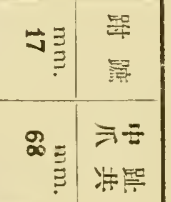

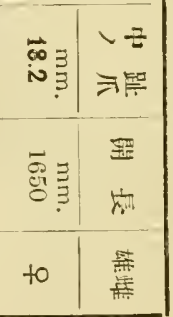




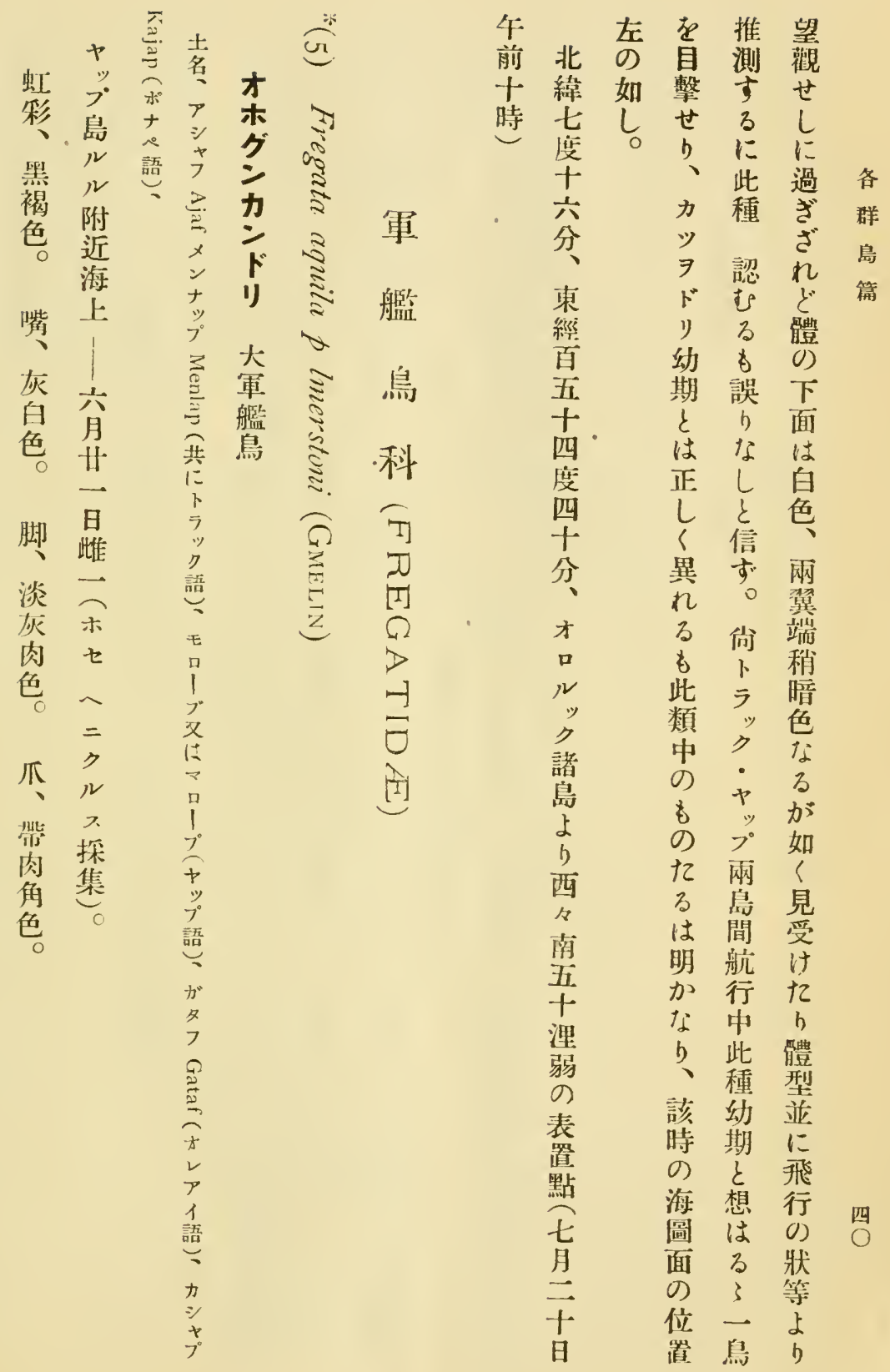




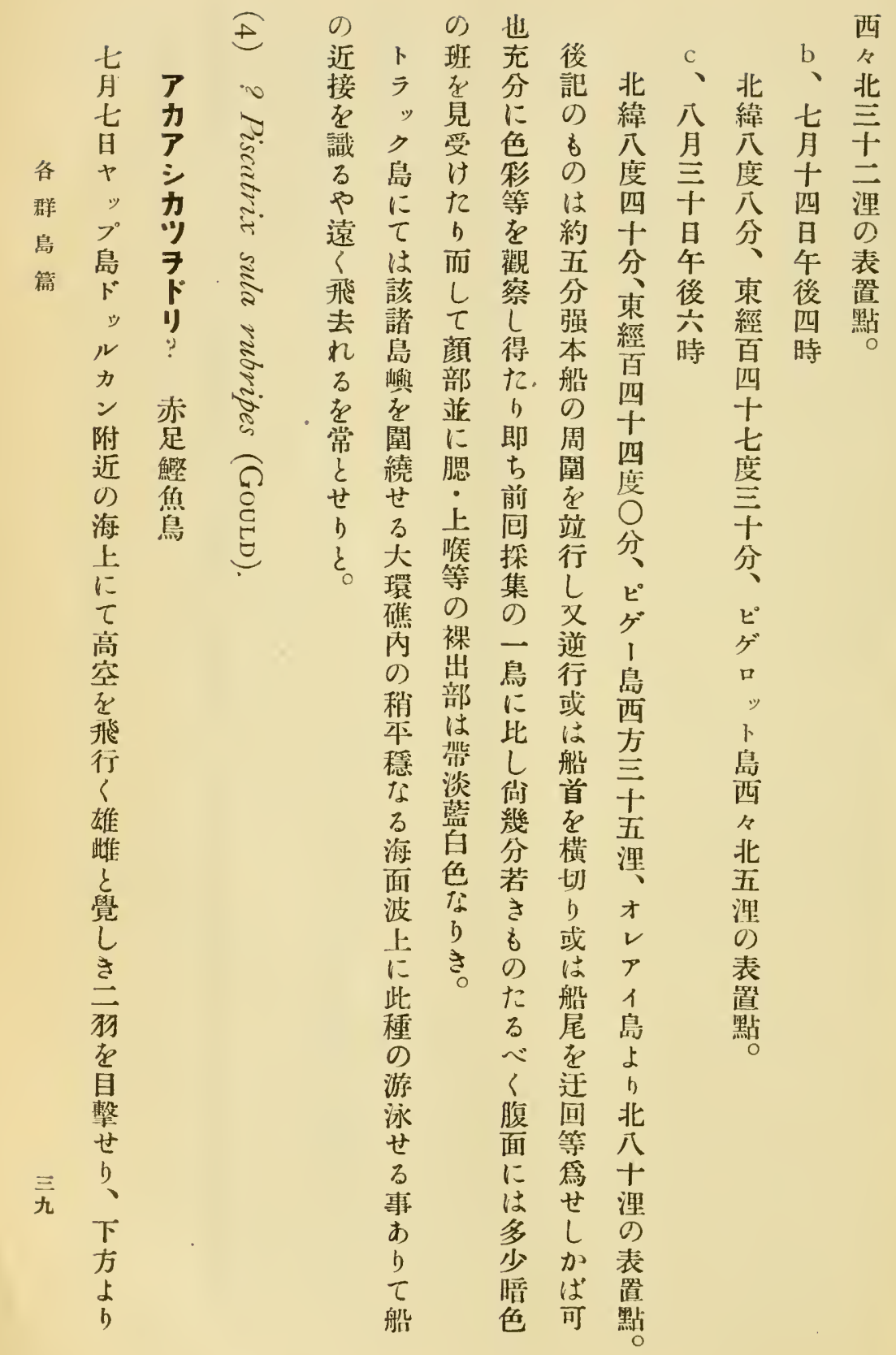




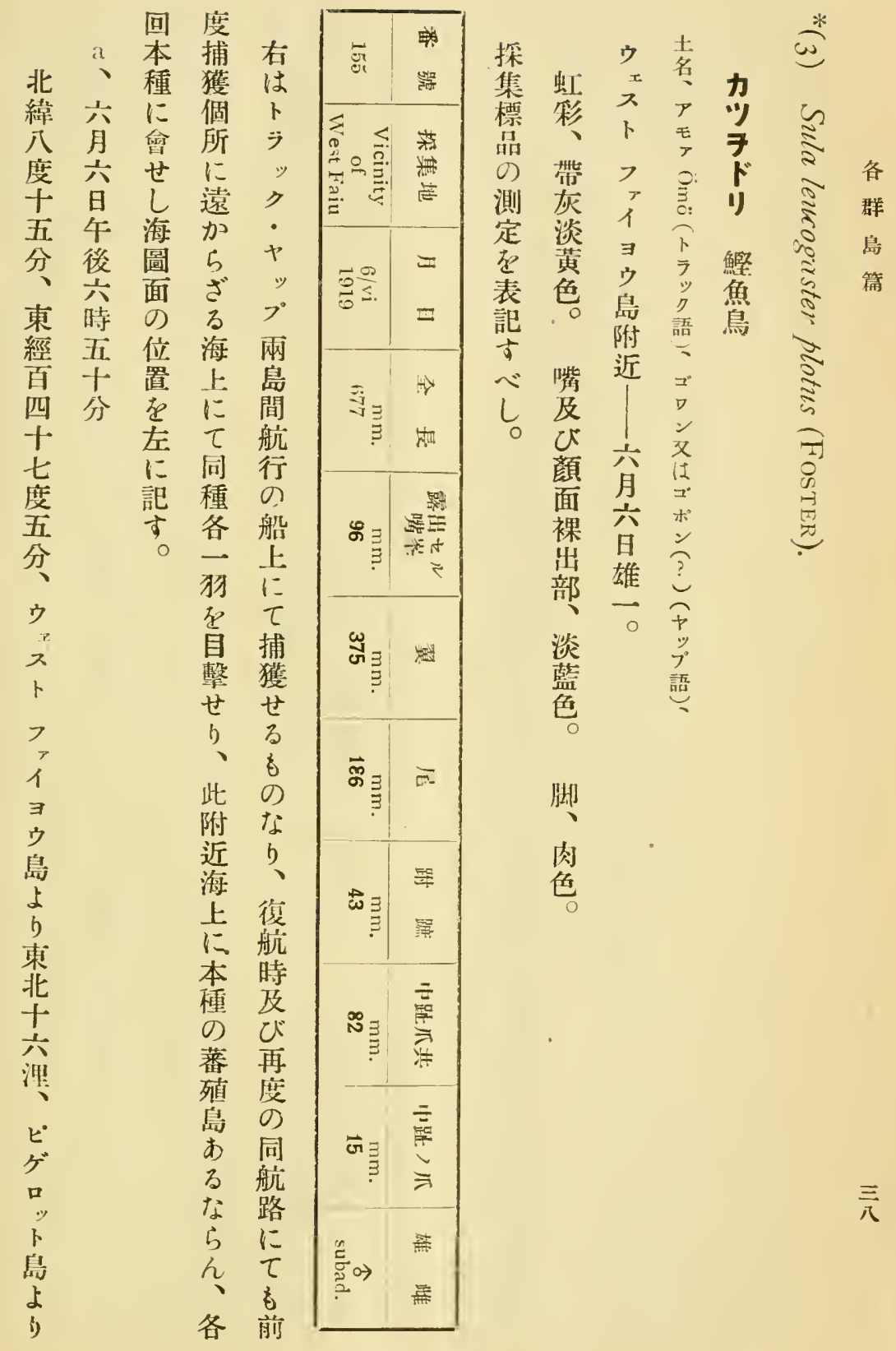


各

群

島

篇

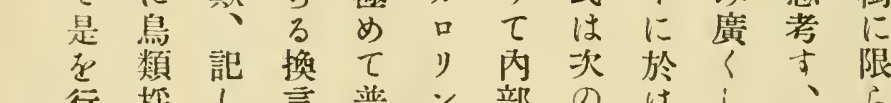

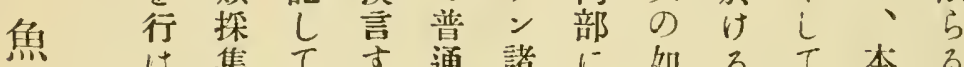

は集元古通諸に如るて本る

ろ゙を大机曷本く如淺種? 息左行方ば息に檑語きくの 程はの本る極の 5 異且好の 科至れ呚種處め时机例低產?

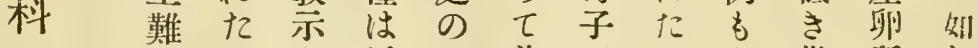

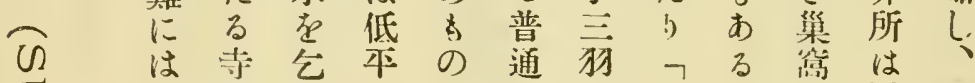

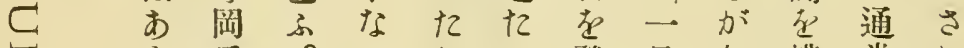

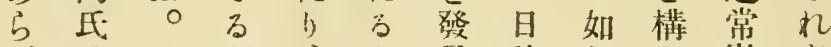
ざは珊、主建しし簏に゙ 3 本瑚此中 $中$ 築 0 特岩 產 な種泉く部生材》に峨卯

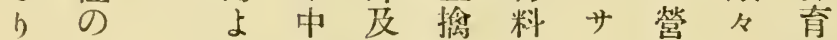

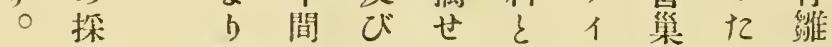

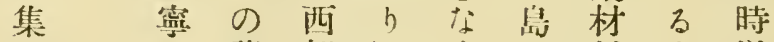
の 万諸部しすに料萑以 最朴占力方心於在途外 。 樹 嗗口-

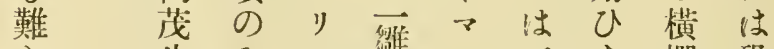
き生みン雊ン ポず棚恐 をせににすらグナし柡ら 語る 其は し

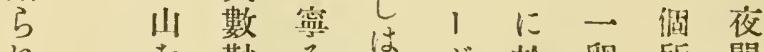
れ る 尠 万稀少於卵所間 し 有さ稀桸のけにる 事古は種例—Dる座撰七

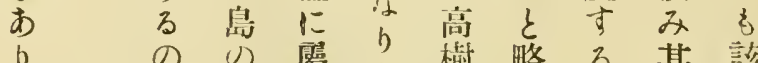
り の ひ 屬子樹略る 其該

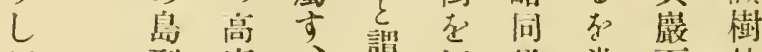
が型度、传切㥞常面林

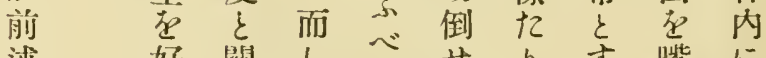

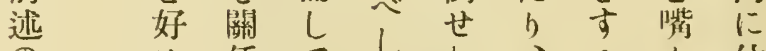
の め係 $九$ し 、る है 休

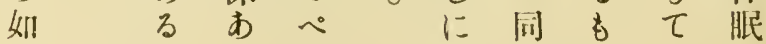


すを種上さ上易

る飛のにれ空にミト

の翔鳥棲 ど高同さラ

想せ毛歨該了行齐》

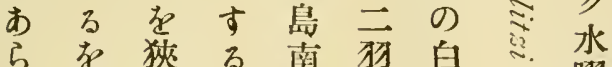

ら自め㷋る南雅白心曜

古る自海連氐島

、要方岸翔の市

海置稀事ドを鋶及品

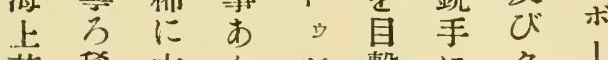

若稀本りル擊にク!

くな種を力世掛口吕

は ら

子声長即附。れ

ン、尾ち近ヤり少に

グ晴在疑 の 前 シ て

口天附な皇 70 出類高

小㧞せき民樹

ヴ空る本ににもにに

樹に后種依ての棲

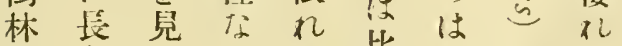

間白たりば比即々る

等尾る向體輘ち共雄

に啄該白的此雌

$\tau$ 後 あ岛色長立棲京

はにり々三星な覺

比引口民本早り のし

較きポの の滞、附き

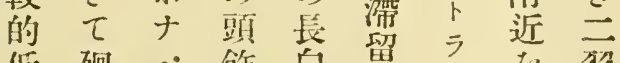

低呬へ飾白思ッ老㹦

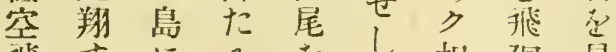

飛吉に了还思

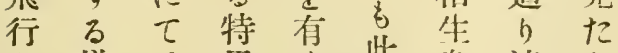

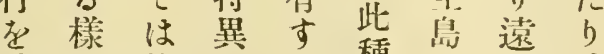

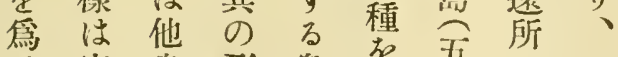

せ笵島形鳥点五に

b然に狀

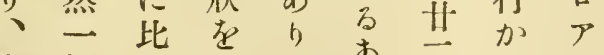

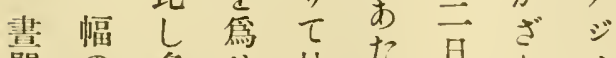

間の多せ林た旦ら者

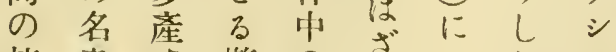

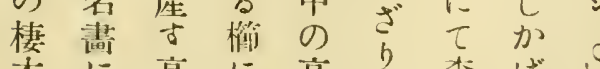

林高に高り森ばの

は接空種枝さ林客视

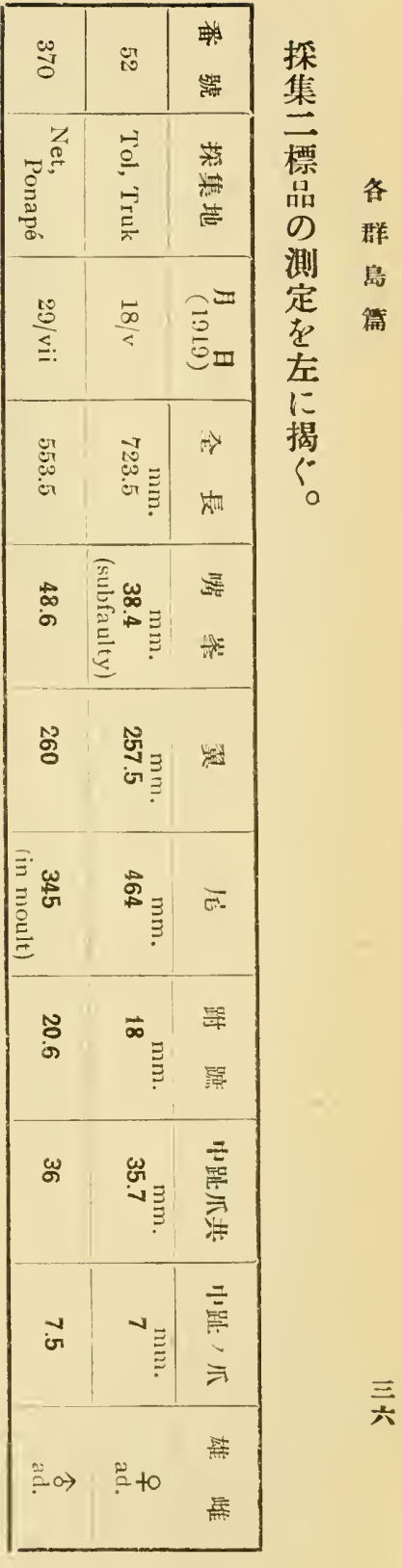




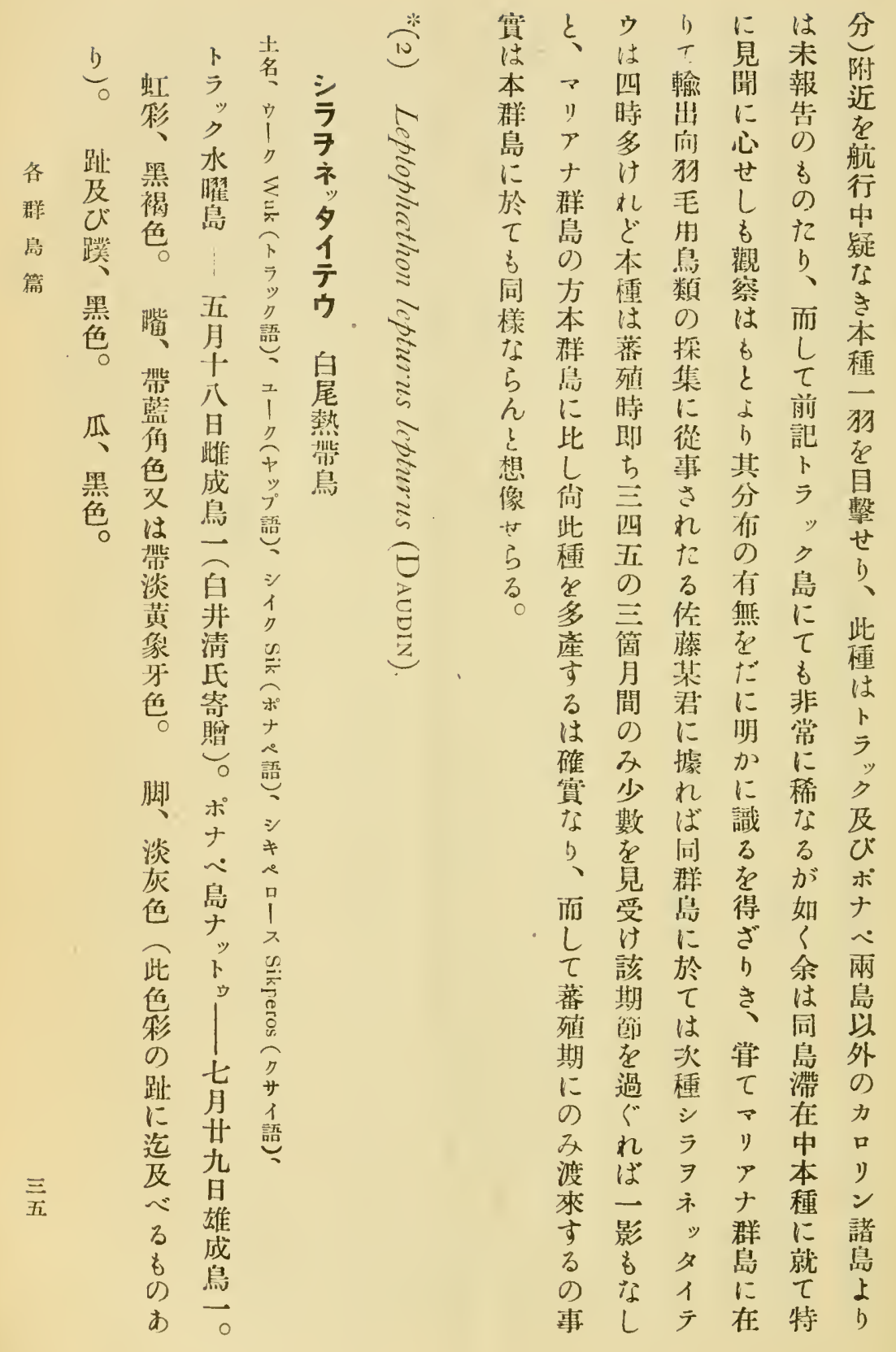




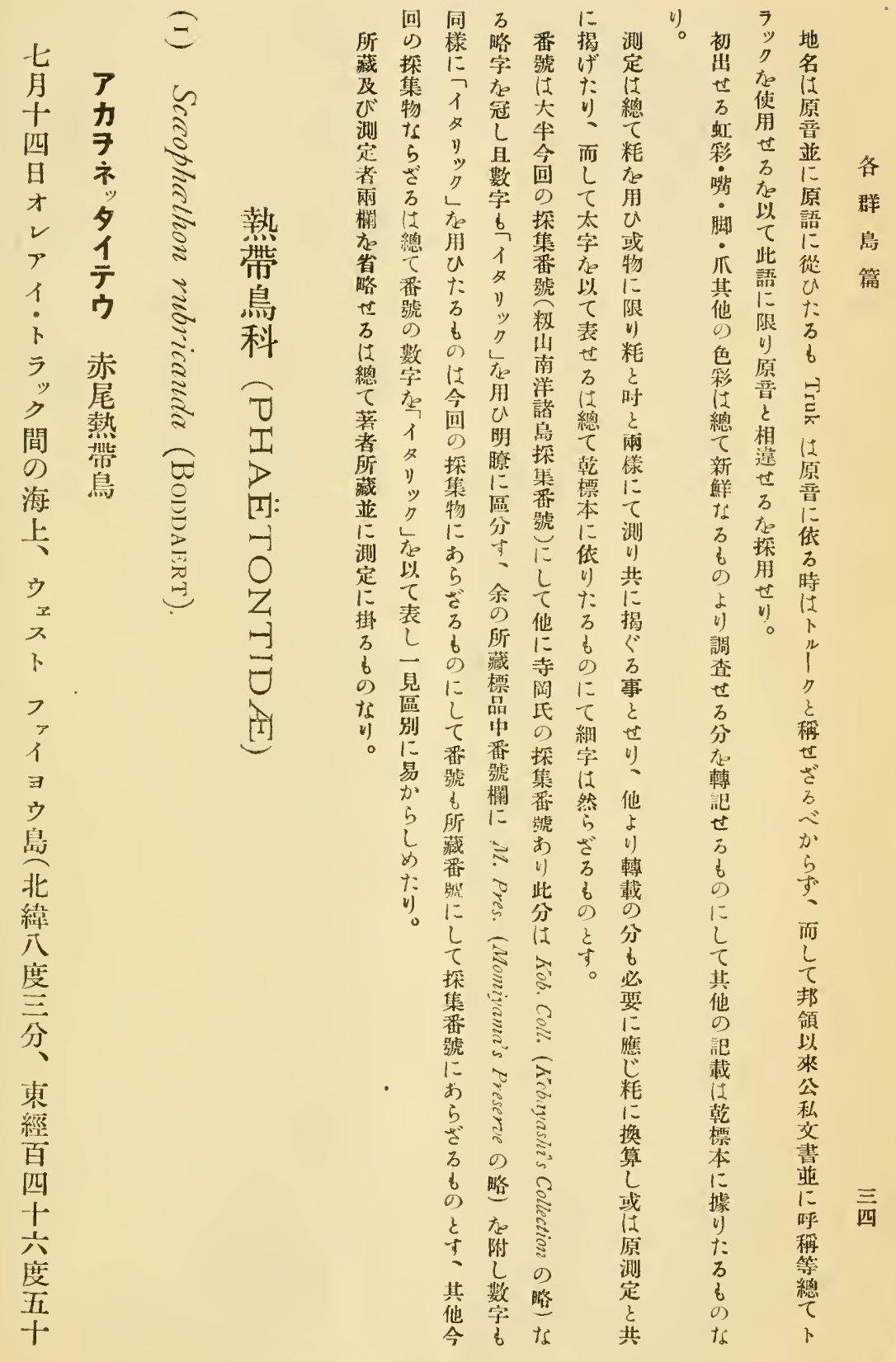




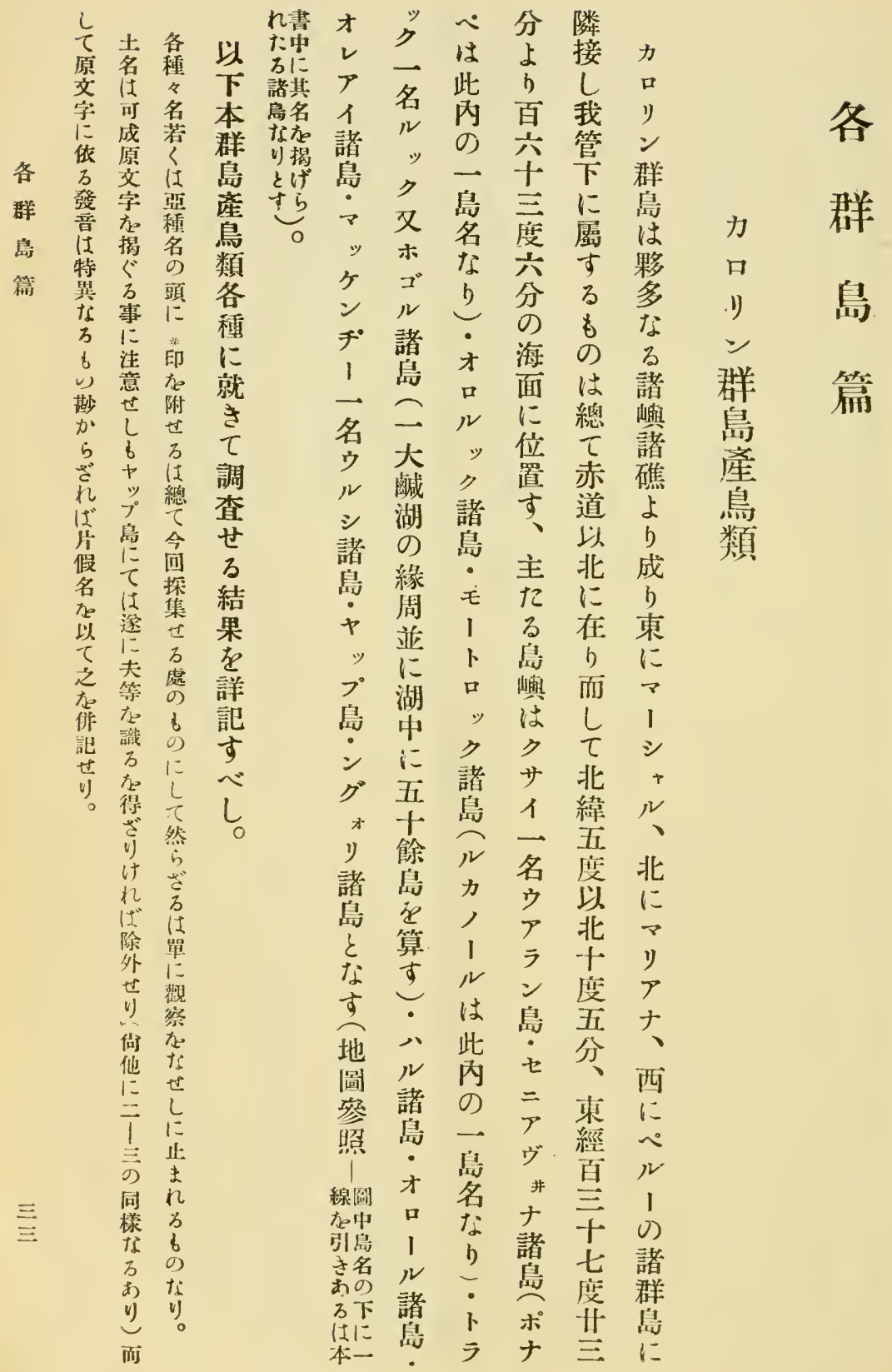





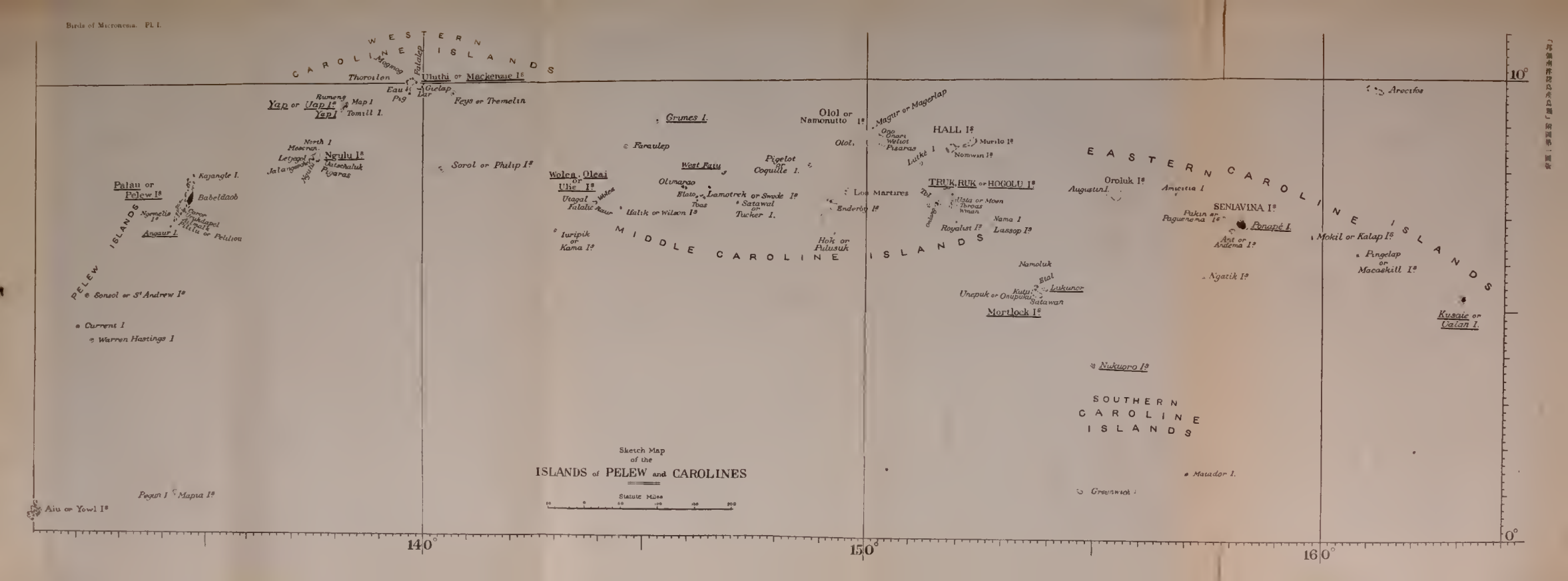




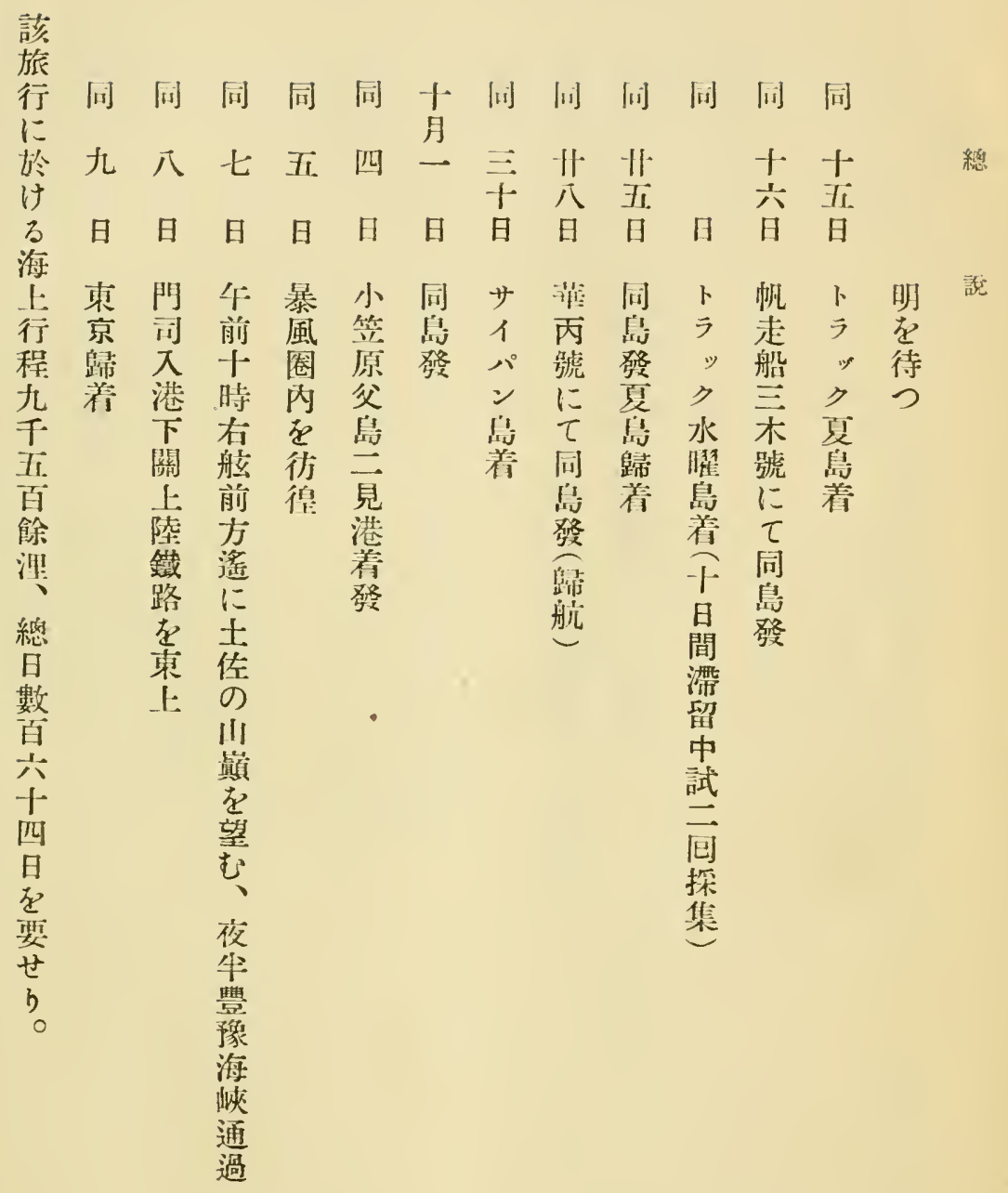


同同同同同同同同同九间同同同

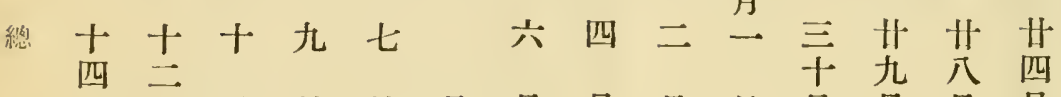

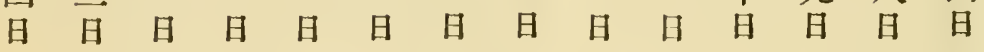
設午午ヤパ同ア同パ同ヤ午午同上

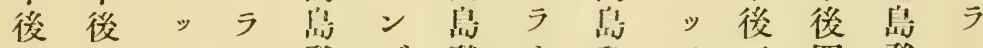

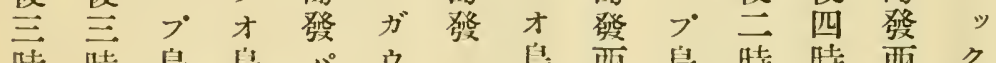

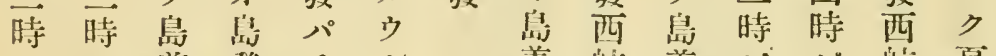

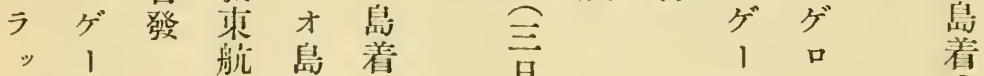

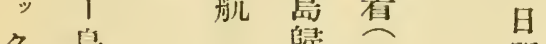

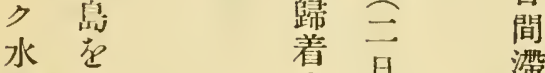

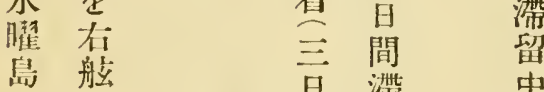

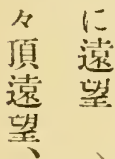

日 滯

間留試

留蒠它

探

午

集

鼠学

范

店自

舷范

左

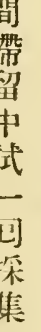

贸舷 留

後

$+$

時

r

亏

y

?

東

北

水

道

天

$\equiv \quad \frac{b}{\tau}$

揘

鏌

黎 
问间间间同同闰八同同同间同间

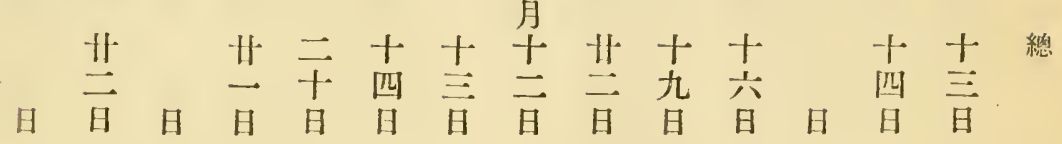

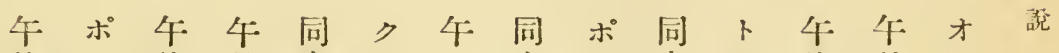
後ナ後前曷步後岛ナ岛ラ後前レ

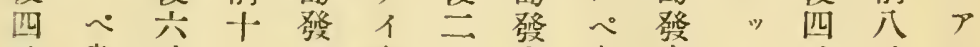

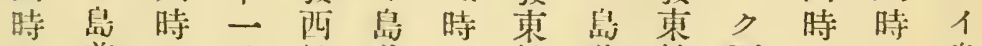

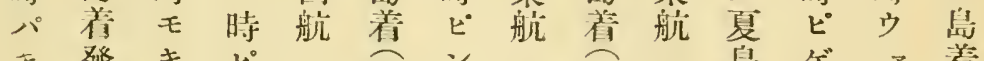

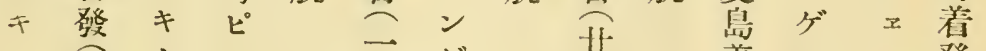

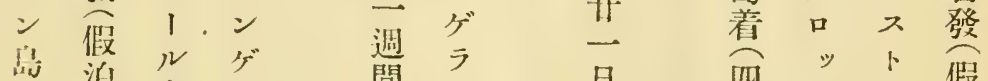

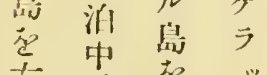
右獄蛋\% 艁议 左 问舷島 望探比名 㮃望有

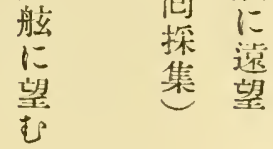

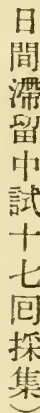

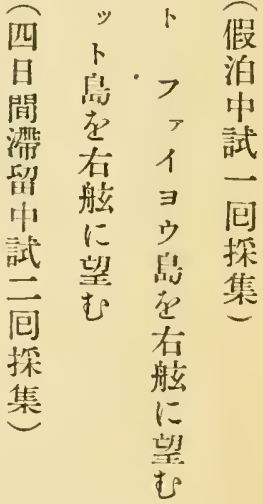




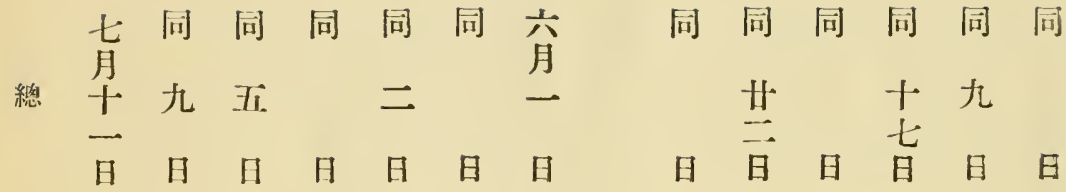

說同十花卜同上同㕣同至卜帆卜口

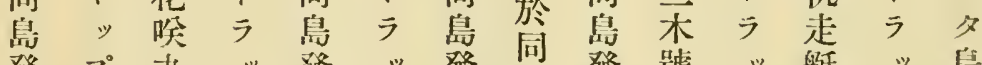
發プ扎ッ發ッ發自發號ッ艇ッ島

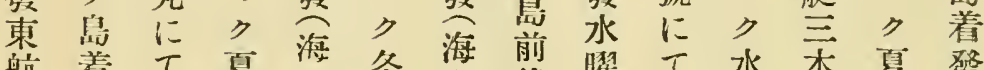
航着七夏上冬上後曜厂水木夏發

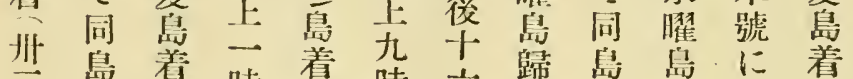

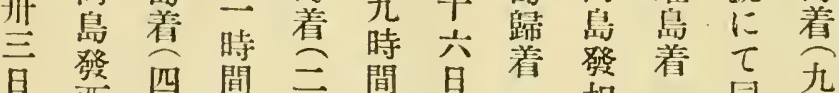
昆。西四間云間昆相同杂

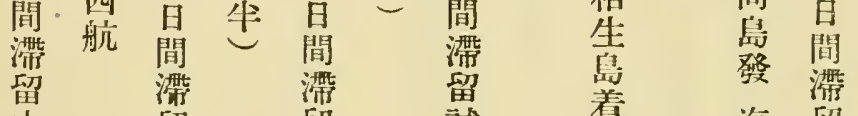
中留留試嵧海留

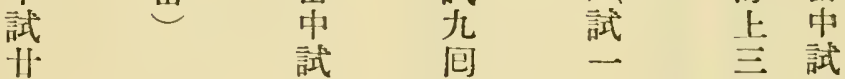

再

问

探

集

回集

探間㕅

焦来探

集集 
大今別亞想年貝 $て$ 的 作到

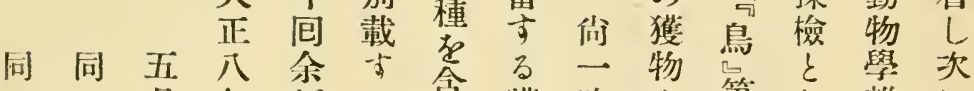
六四月年がる含獲咋あ第し鹤に 月領飞喿年此卷派訫第 日旦筒南别首夏分第遭第理

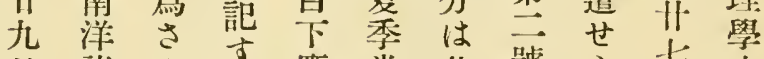

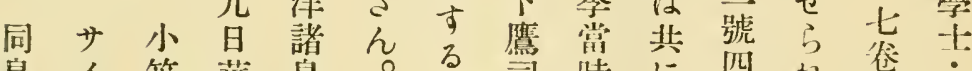

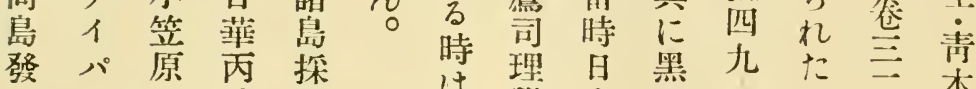
二父號集

昌島に旅

着 $\tau$ 行

見横 の

百港須 巡

間着賀 路

滯發 發及

留

中

試

间

探

集

び

日

程

左

訅

O)

如

は理日黑九た言获

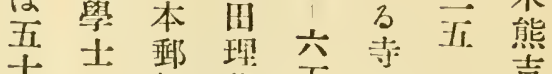

†船學五阔 吉

種所會士頁直三雨

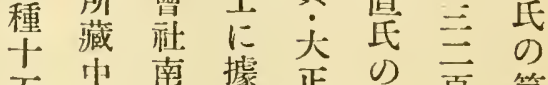

五虫南據正第頁第

亞在航元年第及告

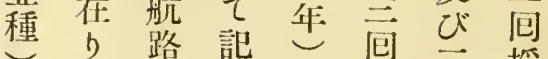

五、船述大の齐探

百即華世渡搝公集

十 万丙 5 忠集九品

五余號了太物交

標の事命郎は三

嵒探務動氏鹰九共

あ集長物の司頞孯

b 品柿學第. 等

其は罣萑四墨大理

等第長复探雨四學

に苞氏第集理年上

就目9 䒔物學年に

$\tau$ 息採公士 次據

調該集㫧再のいり

査䍀せ公度到でて

の當ら八の究鼠發

詳しれ七堀せ學琵

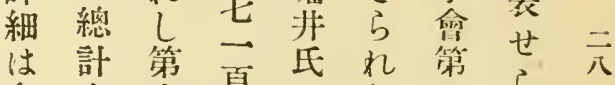

各六共頁のし ら

群十包大第處仙几

島公自正五に鳥仙

篇種に五包し學b 


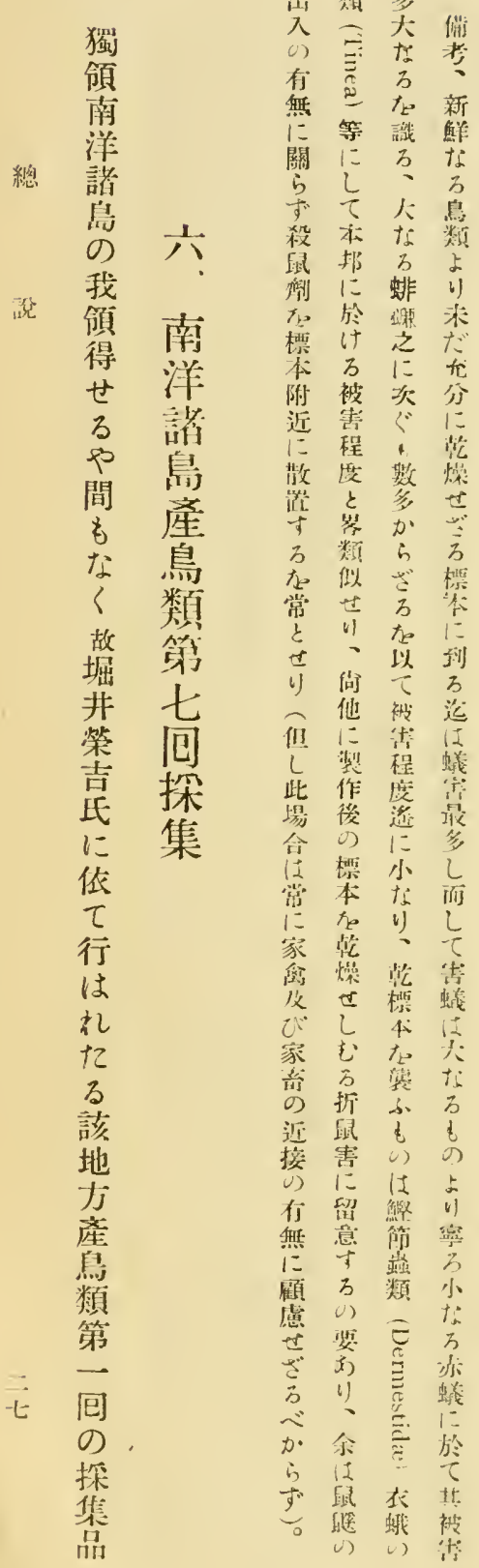

及皮に菊島閏繰處 等若天粉產隙返な 前く日去なはしる 同はに混る委行正

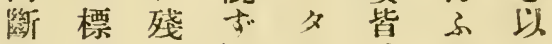
本 b 只 をな上芋紙は豫 充々去上至被め

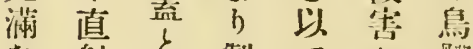

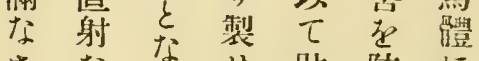
さなな せ㙋防に めし ん 蓋声名了得

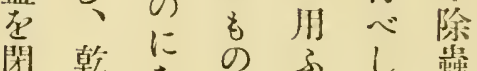

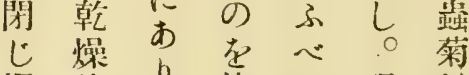
螺後㟀便き保粉 旋は角糊存を 釷何筑吉は筆散 時慨る何渾作 以に老種搬し $\tau \tau$ 䇚便に雪要 各亦他主てはに

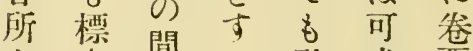
本淮敢成覆

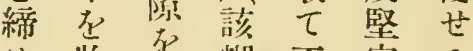
め收蕗糊不等。 然容虎龵な綿

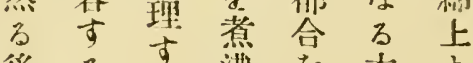
後当古沸在杰 四事票儿感箱 蓋を前つせ华 の 得前了ざ撰度 間心闰水る啲

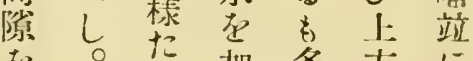
布。多方目 外速娄心量存脚 部搬稀在除趾 よに勿薄要きの b際墖 $\varepsilon$ すた成 蜝しになるるる園 塞 $し し を$ 他 虹除以部是

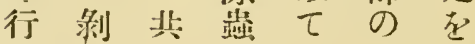




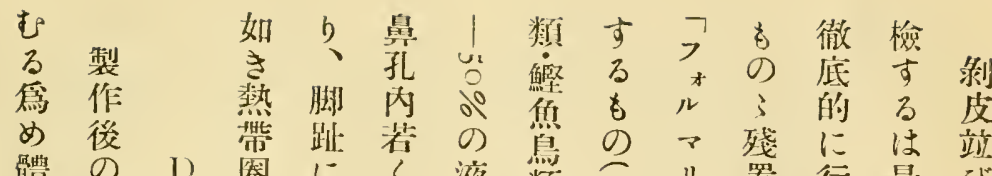

體の D)圈にく液類例》置行最び

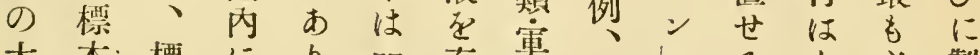
大本標にり開充艦コ液る 部坐本於て币分自己゙若企と要作 に製のてはな鼠づ若道欲なは

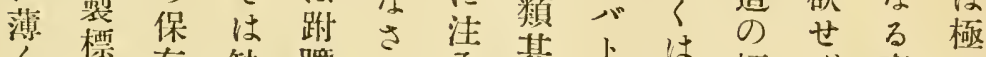
綿本存缺蹠し 入他! 酒唡ば事め 綿足立々後めせ面め年精狀胃にて

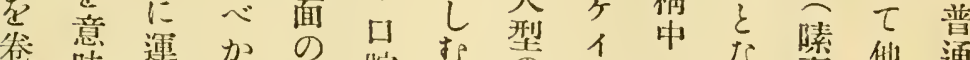

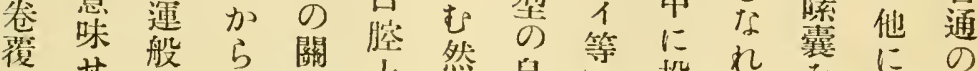

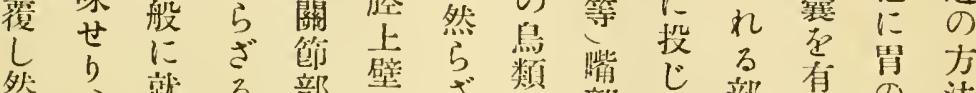

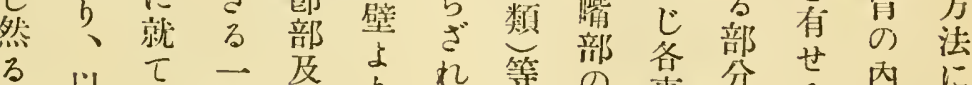

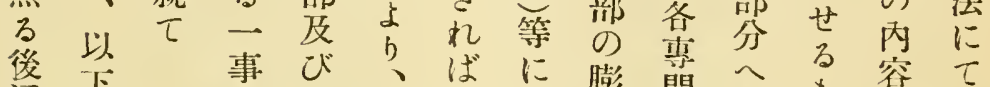

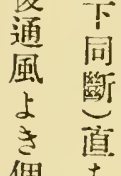

個 万

所に

に 函

置中

き

$\tau$ 密

乾閥

燥 可

せる

L 怯

护宜

此 加

場 ら

合 和

必旸

吉毛

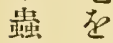

整揃

の 着

件 せ

s $L$

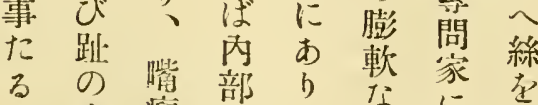

宔 $\tau$

Ti

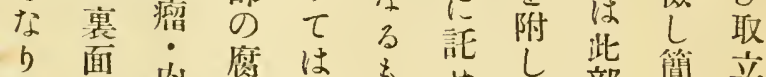

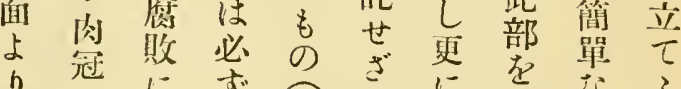

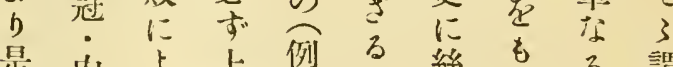

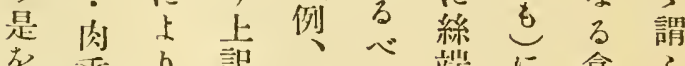

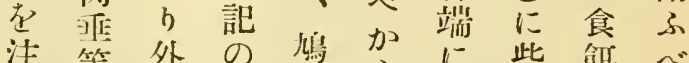

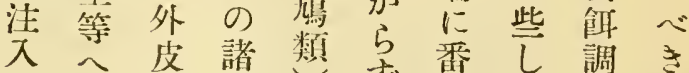

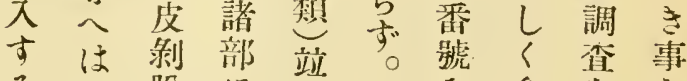

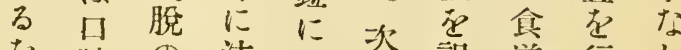

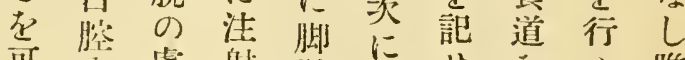

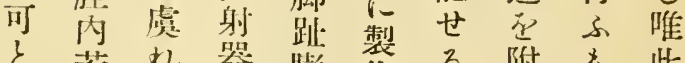

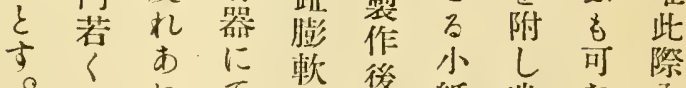

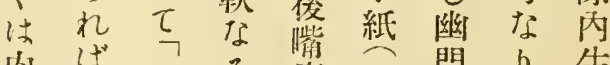

是肉代子る清必門口生

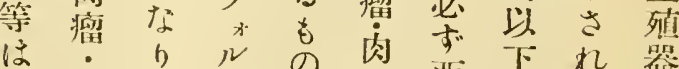

は・办舟西下れ器

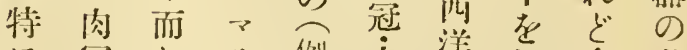

に等 $L$ ”例商滋切食發亲

本の $\tau ン$ 、乘紙除领古

地後嘴 $ᄂ$ 簿等在 $し$ 調程

方部公㤁数在附た查度

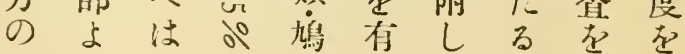



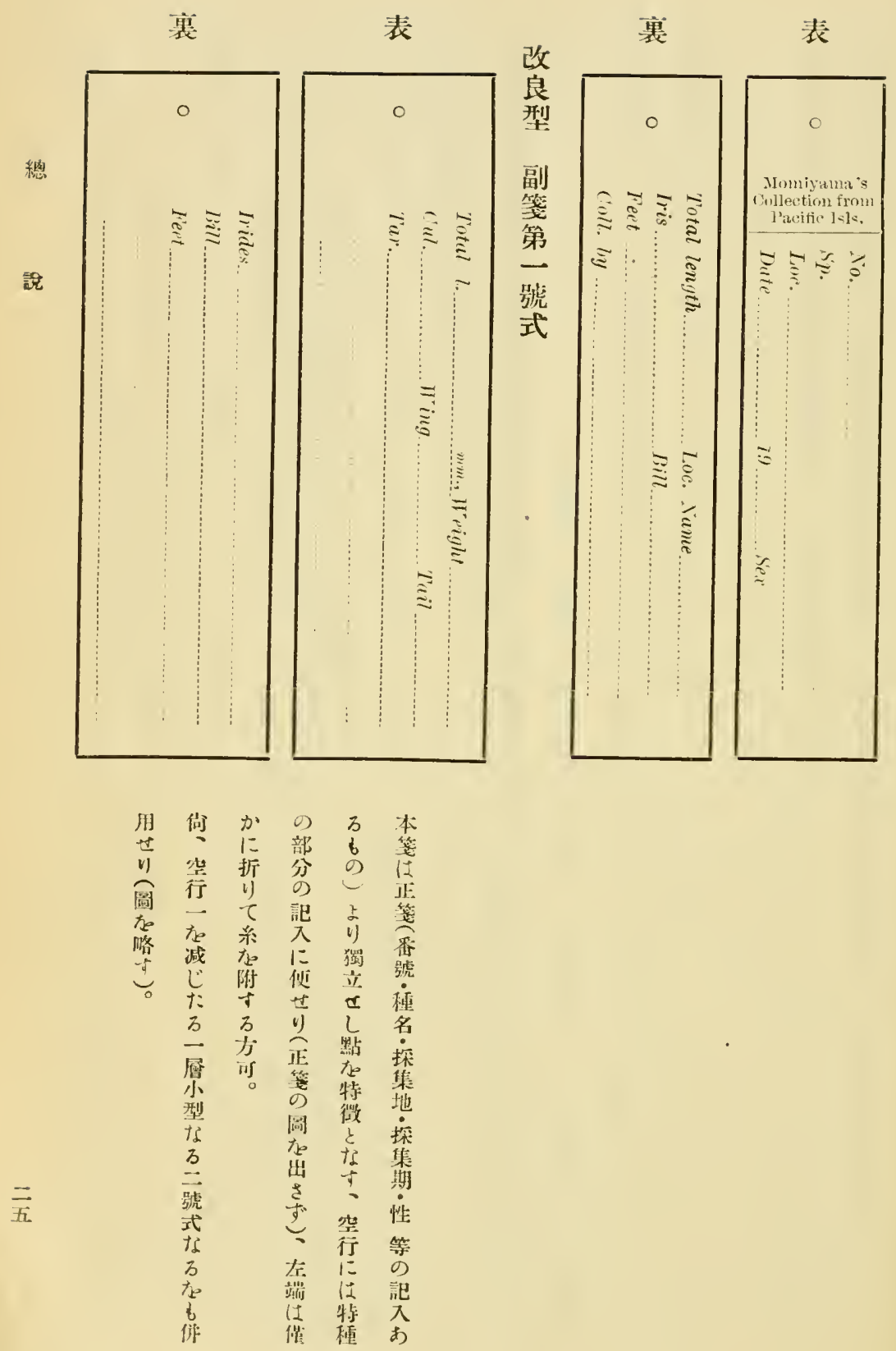


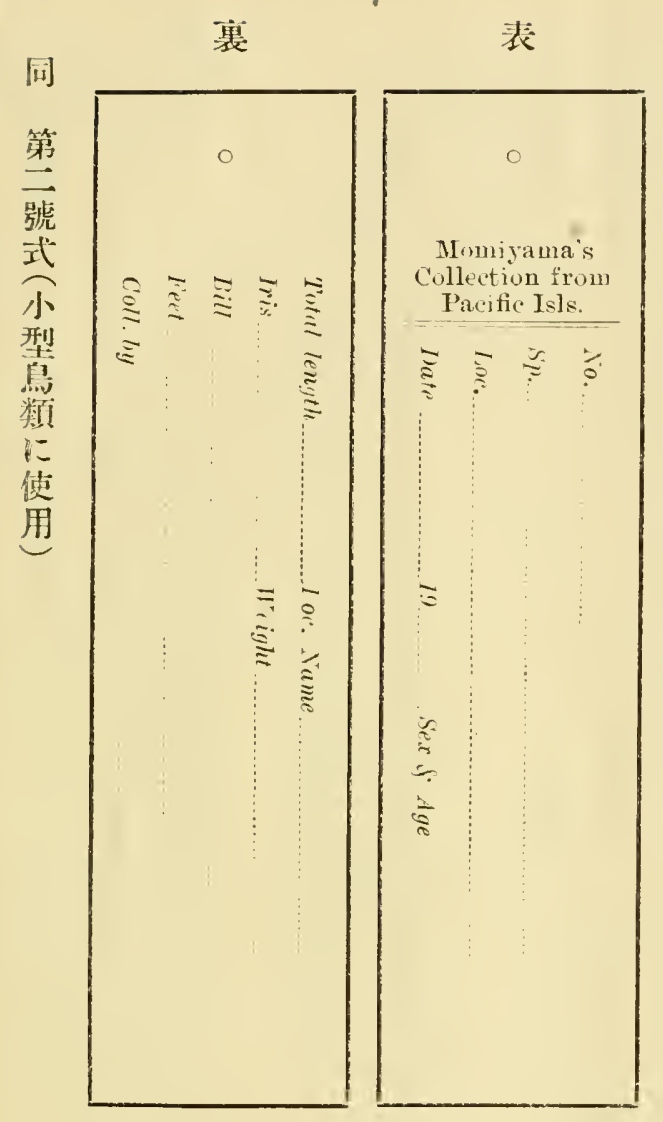

敷 の探 洋 俑了な集地 洋鞭 b 旅方 探掕 と行に 集にのに限 時吝自使 5 總 使少信用す， 用ななせ各 の らきし 地 分ざす名の 說 5 是笺 探 第 $九$ 等 $\sigma$ 集

一事に體に

號 據裁 際

式公り 站し 大 卓にて

刑○越其須

拲 せ 後 く る 改向 良 後 の 此 老加方 案 へ 法

出た存

せる探

5 方用

る

3 を

尘左

文 欲

は揭 L

的く”着

にる々

探 事 䁈

用 $\varepsilon$ 行

せ す

素3

了よ あ

蓝 b b

方完 0 西

あ 全 㨁

らな洋

ばる諸

宜娄少 


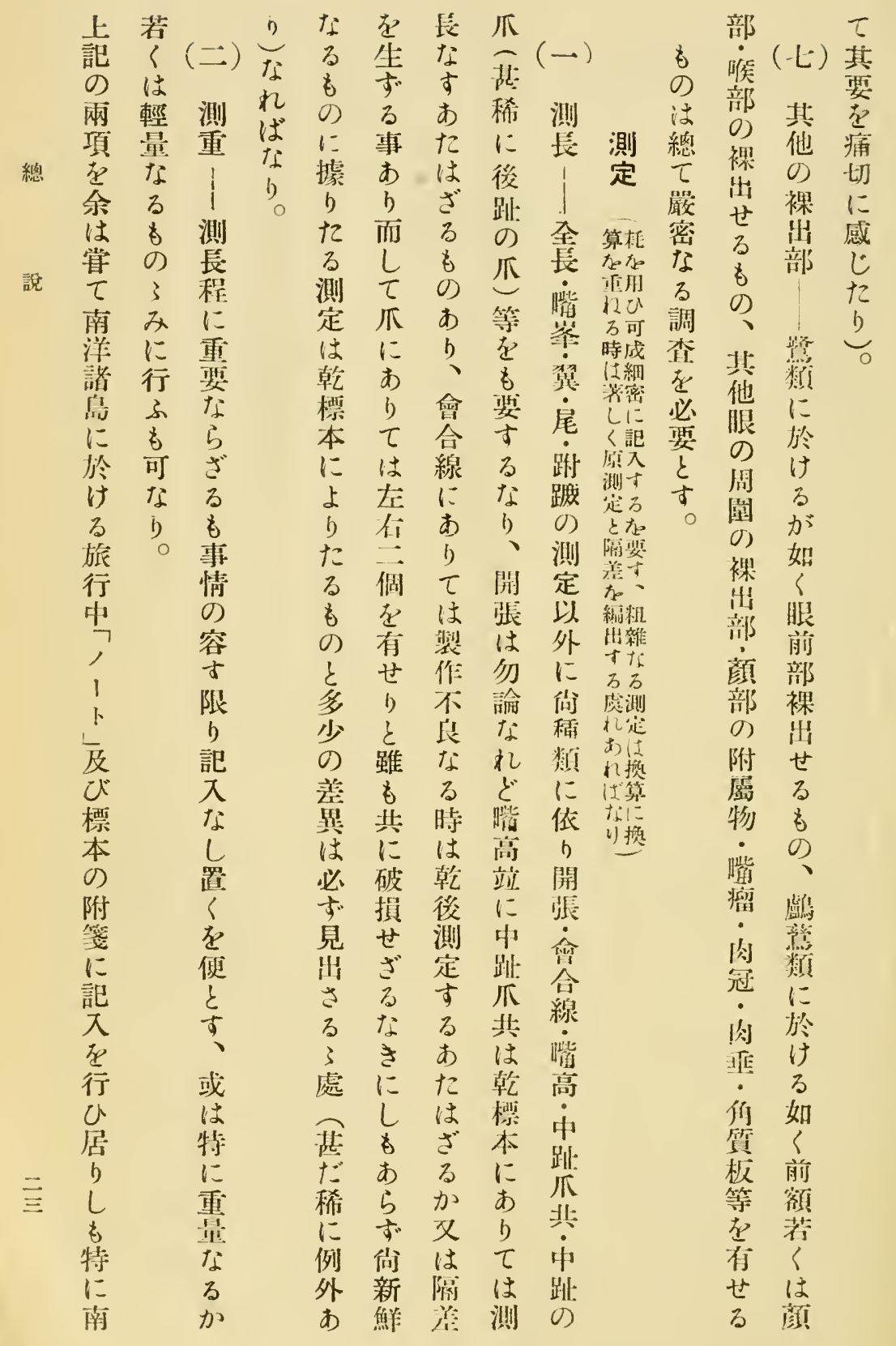




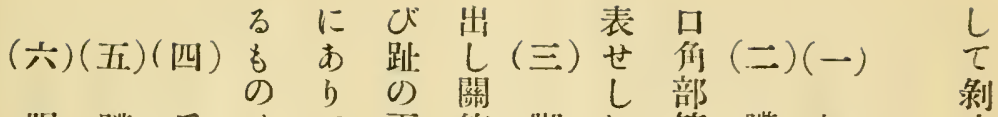

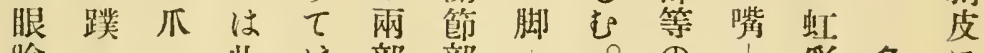
臉 此注部部色偠 部裸に異| 各

趾上に出分色躈 茷面訅部了在踱 稀同若入のを呈及 に色くすみ可せび 上なはるのとる 趾 下 3 先方調亦 あに 部時徰而可査、乌少 ○)は異はに而、至

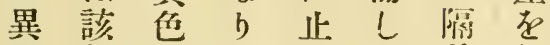

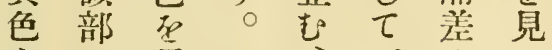
をに是、下大 呈加 せ 趾 腿な 事 せ 入る の 及 ら るせ 事 あ し あ b亦 b 余当

は 站

趡 但

此 C

急 此

分 如

重嚣

視合

せ 註

り 記

が る

圖の

版姴

製 あ

作 b

r

當

b

裏 びざり

面躈 \% 又

は䟶 当跗

左 站 の 踱

しににの

$\tau$ 趾 あ 前

重 U) b 後

要 $-\tau$ 雨

な部は面

ら若主の

ざく色著

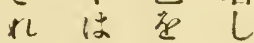

ば 全以く

除部七着

外の代色

寸犽表の

る毛せ 相

友し違

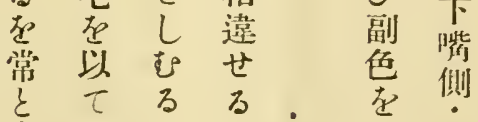

部上立

若觜內 览

人先外成各

は端側䱢鳥

-・のな

部卢相方就

の㗪違 のて

著線せに次

し或る掉の

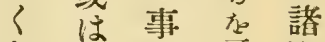

色上あ可點

彩觜り采を

の䌉。調

墨䈍查

階

ह 侧

の

以 嘴

外 基

は主部要

色嚙緣荌

它事

は下

主觜先

高㠅か क 以市

、怡或 り㗪

歫るは、

子る跗下

有施䟶 腿

之基

等 部

灰 站

古の及裸代に 
方 b

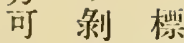

を尼てて方き般此にぼ な皮本

るの 製

究しる 全産 あ b點恐長 心 儘 作

古七な人专り見留性續 C る 操 b 然る 深 る 意を行 總きにに、る縱○占は山時市助す

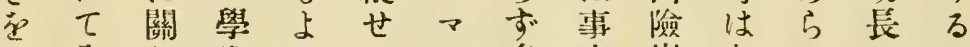

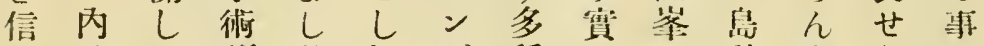

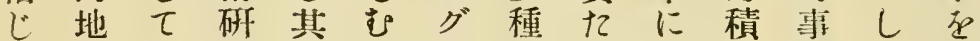
居若は究他了口多るはのこめ避 れ存特用沼時、數な特大云九け

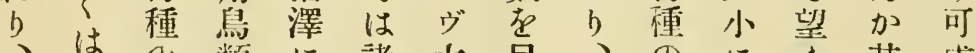
其の類に諸大目、のにま其成 但其技標岩種樹擊深烏比し将岛 し の 能本礁の林し 林颣例き來 產 極士总 の間水內得小尼し次は鳥 小土地要製に鳥に心に見て第甚颣

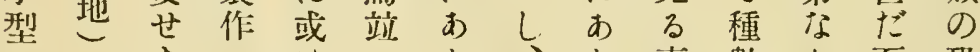
ににすにはに蓑り事數り面恐 屬託、就砂小即七多多。白怖

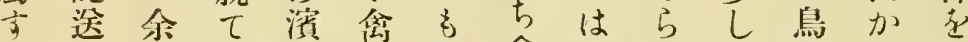
らしは汇各食海九而類ら起

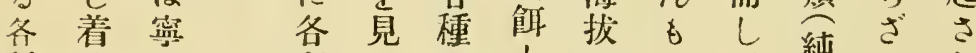
種後 万所る毛に に精總 枚事鳥高關般同海の め あ練さ藇尠類心゙せに地鼠結ざ

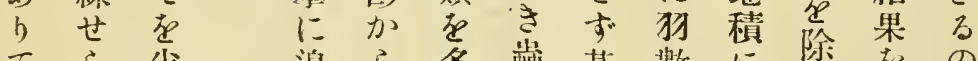

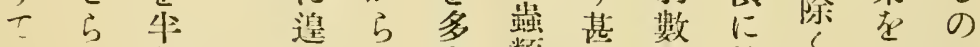

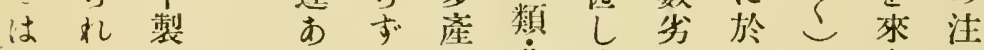

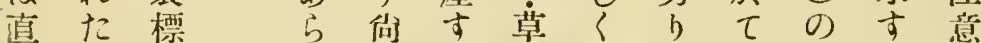

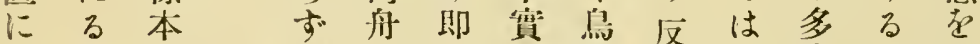
坐技 或行 ち等數方狗窔の忘 製渻 或 骠 者 假

本 ひ 假

子手 製 爲委

j 稱 便改 す

二 宜製 多せ 密 LL む む $九$ 而るよ

の林子宾 海 數は虞る 便內0！垅左各れな あの 關、低程地 ら船係乍きに一れれ ば路に併地著樣ば、 河な起路のしにな菜 流㺈 因啡林加はb殖

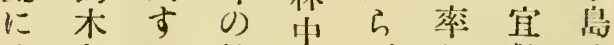
遡舟る林! ざし敷全 りには中草る難く部 て乘言に原もき齐の

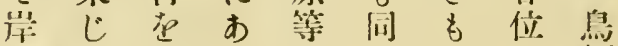
㣎紧侯 
望してが炏て行時楜な縛を的

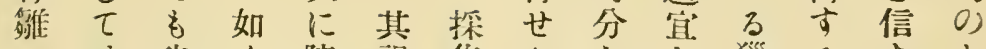
には倏く陸視集りなな獵るず引 繁相向に烏力犯刀存、の

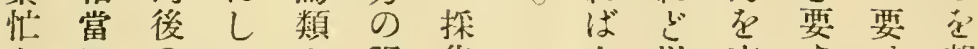

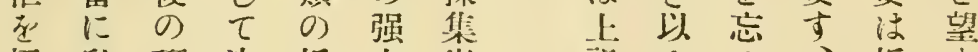

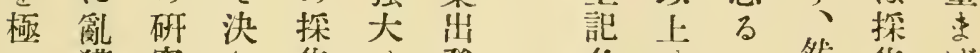
め獲究し袋は發各は心゙然柋ば $つ$ をにてに到に 了㤢 據然常底 際 あ ま 、更、夥の か可に該座及老 引 加分地なぶ以 るら類方る べ 岛ず特がく其

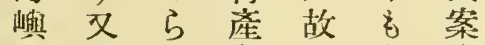
に純る恕にあ内 於海引類䦥ら者 七鼠傾に却市た 探類向 䧳に在b少いし $\tau$ क 數 $\tau$ 数 $\tau$ 屯 行 ふて認目探類胜 時はめ集掫は 生蕃得學㗊塐榙 殆殖れ術にに種 ん息ば上て當の ぞをな同满り便

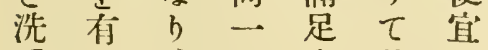
手 し、留高其 क し 丝乍種べ棹 $\tau$ 数併中加功事 多装桥江占拔、 獲后種舍吉夫言

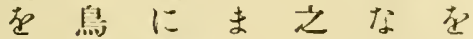
期碓屬方杂方侯

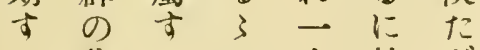
へ悲るる小於ざ

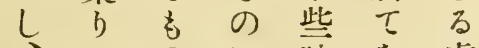
、 $\tau$ の に時存 さ㲧にあなに

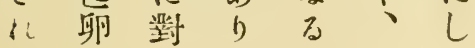

品一占拿林

中般らざの投 の本李机腐類 一地或は配 の

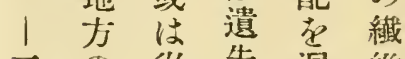
二小從失遲維 在哭者の延昰 除類若處せ以 捨㧰々れして

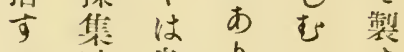
万時点

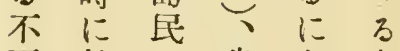
叮於に少市放 なけ彎又り湓 加了草意 必在薯該突 心䨋擭其籠 し 品行他露 てせのはを 余了し行周余

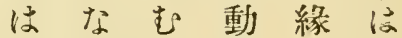

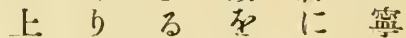
訅。娄阴多方 以仯可止々前 外探な吉の者 に悲々向細の 倏殿。在紐生 探足其開を線 枆吕他放附新 用際の的し鮮 名し諸役探な 簙て品せ。悲る 走近は留に 獵距撰的泉如 野雖摆べ脚か に者く部ざ 携短省大学 
來果囊 頑及斉八

の危携强ひ装十服

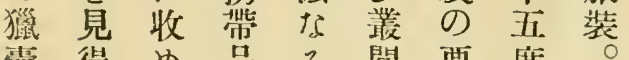

灌得め品る間要度。

素れた特等な る 本 B

總よどる 銃 種のしし算地

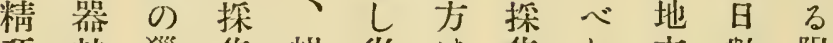

可中巧端獵集帕從惟し方數限

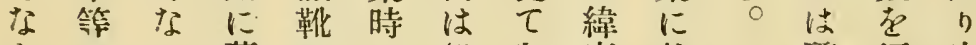

說らにる藥を船鳥度就驟短定

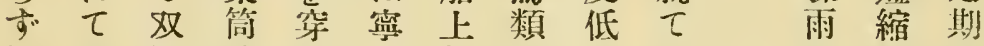

即は眼はち万站探き

ち却鏡勿臑輕に集に

島つつ論部き礁にも

民て公なに踓面當關

に近倍れ皮紗の方

命き前ど製州探て 支

しに後をの辈本大

$\tau$ 過 位 䝒 ᄀ頂 時 邦 陸

バぎる雨ら゙くに夏地

十明適多、方

ナ暗當さ利りにの

の在 $c$ 所 $N$ 便 $\tau$ 於如

葉缺古小多は怡了

きく、る、㤩し人る暑

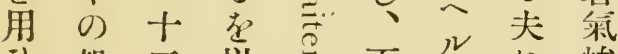

U 怨 三 以 而 $心$ 骖

$\tau$ む 倍 $\tau$ L

細々防差落大な

加 到 水着足州差ら

き探 b彈古部制な 吉

目集 $て$ 䩪 に

の品はの

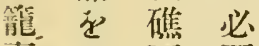

露二面要

時の क

作 收 䚋 b

ら容察、

七世時纱

むし・生

九或む良態

はる 好 葆

牛にな 祭

永はる上

久在結草

は $气 \frac{0}{\Xi}$ 筬

ブ 咅但尔

ッ吉兆

》部均

製 優本溫

化蓝

る h 除望

輕年分

毕踓 $斤$

に 方 特 度

乙林種开

多せの

く 連

且む絡

㤩る 航

舆 事 路

に总 船

依心 石

b 掛 巧

濕〉に

度る 利

大の用

な 要 し

る あ 偄

些り不

以。定

$\tau$ 期

鋶市

器展

保 莉:

在外

油汽

艺船

充 站

分比

に大

用型

意帆

せ 走

ら船

了比

了便

少乘

七中至

可在 


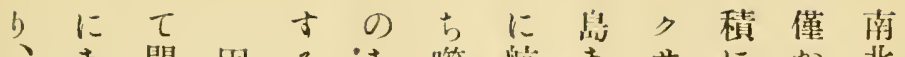

、あ間因る あ噬航 あ 少にか北邦

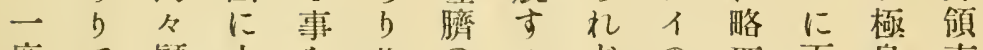
度て題小此 小るどの吃百島南

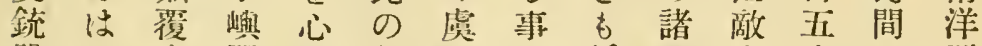

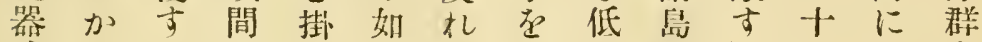
總

了る のくき市避平以、五 火るの連心種れくな外六平bは

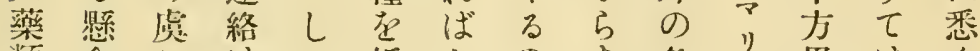
類念れは探なの各り里はく竞

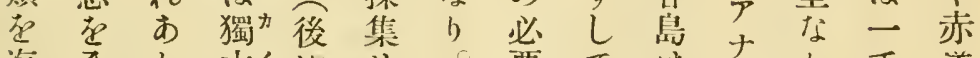
海全

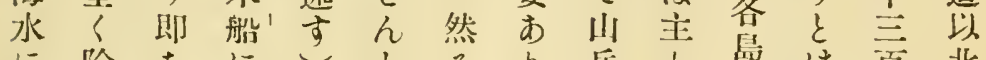
除古上等

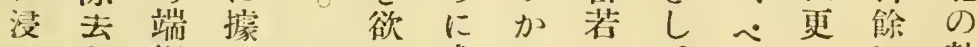

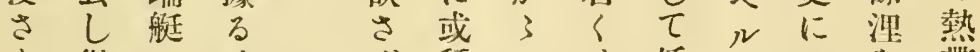

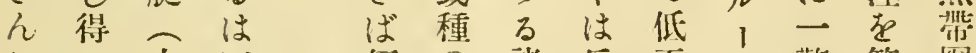
加当天不便の諾丘本群警算圈

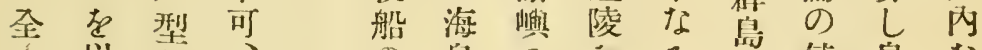

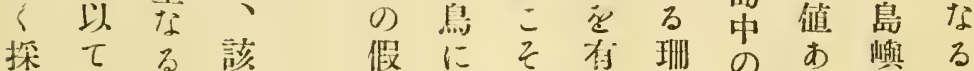

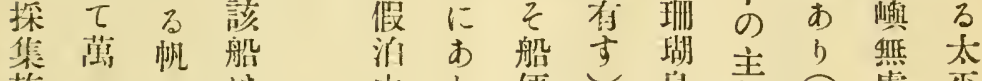

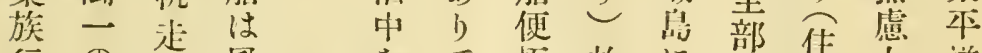
行の端風 胥 偶端速 中嗝艇に 絕承に乘 世豫交委

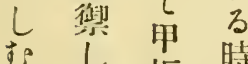
很楼㭙 の法貢高 此范具速 㮩京度 な用后存 せ

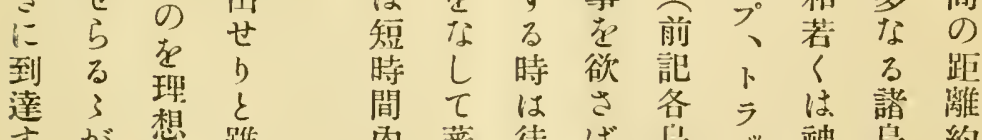

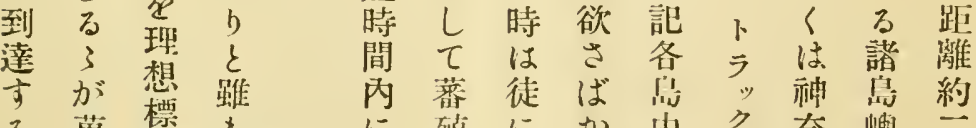
3 萬槽的 是全集洋 以全早 策等占於

在 $\tau$ 晸故に地源苡洋 利はめにし势渡百面 用加 $\tau$ 特 $\tau$ 隐 $\varepsilon$ ᄂ 3 惡有所力览程散

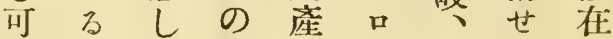

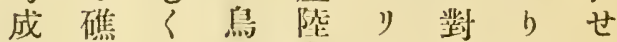
短曷县粕鼠二馬、号

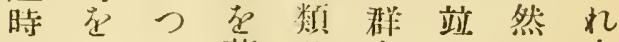

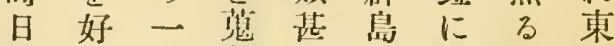
間み度集た淡に西 若大殘せ尠の路此極 く群留んしょの夥昆 纯疗牙事 短疗了前落な に殖にか中》奈舆三元

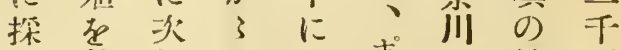
集營便多方术㮩總五

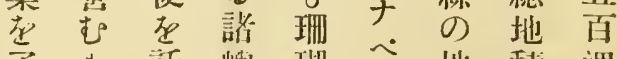

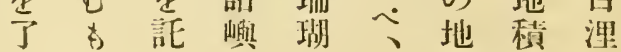




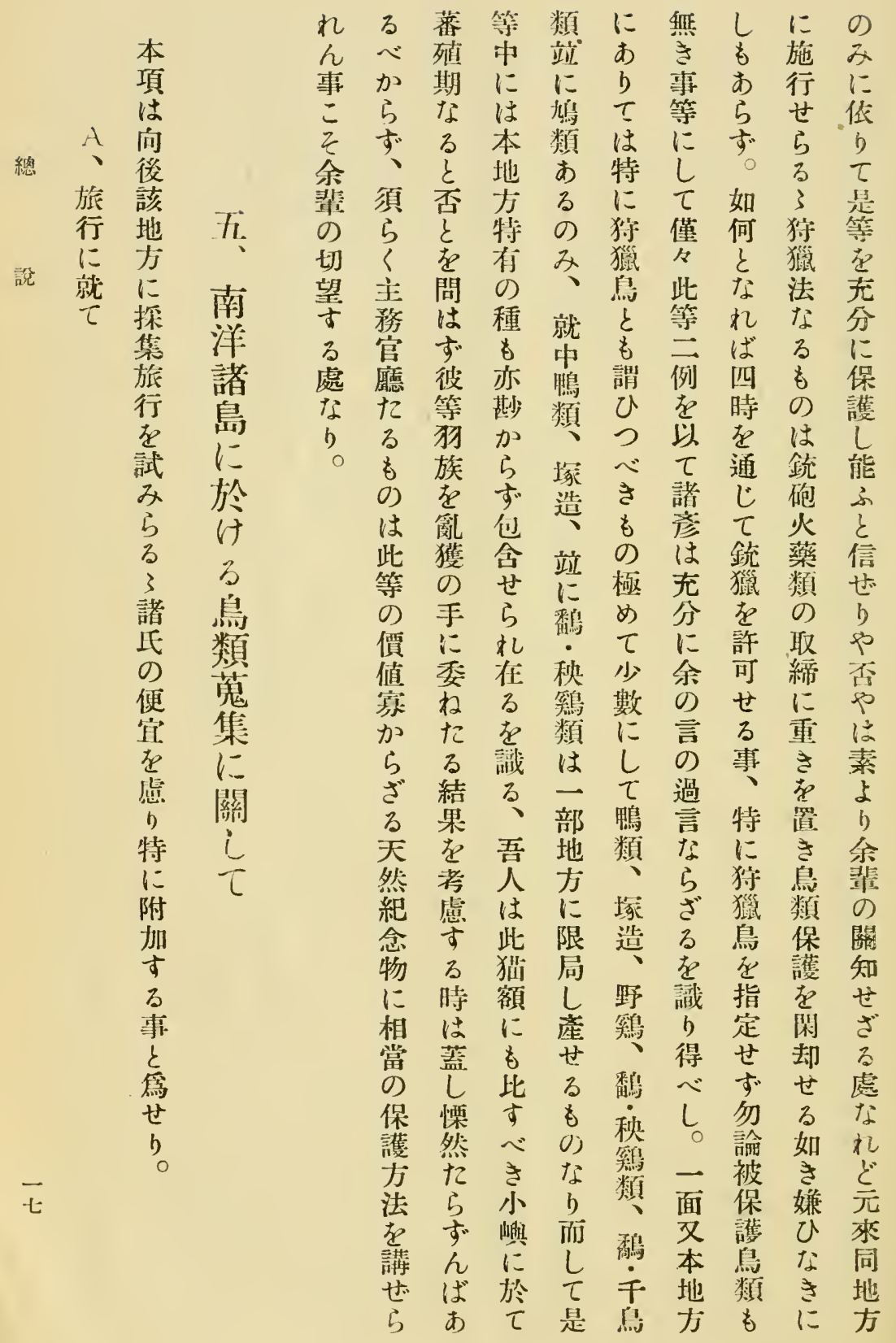




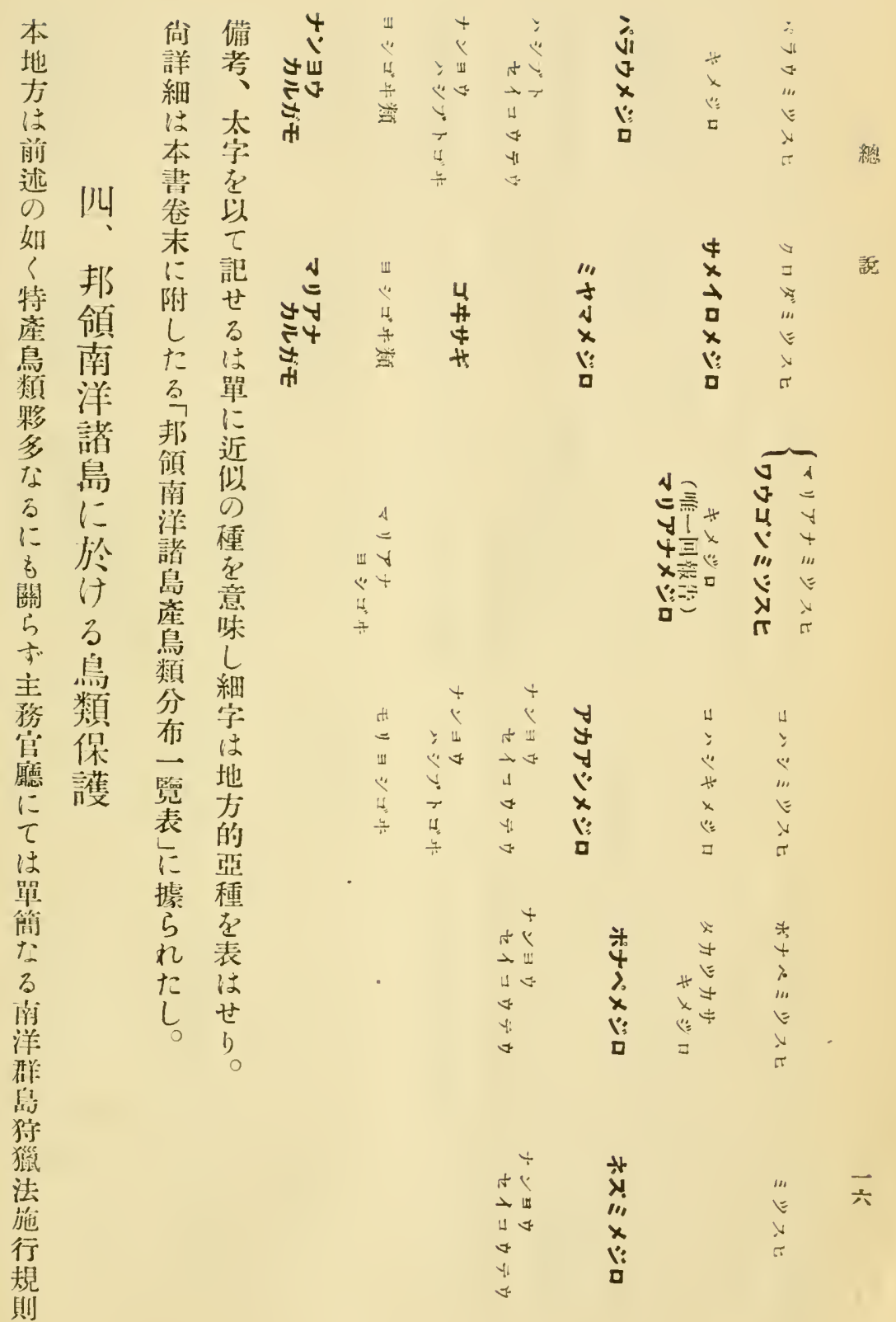



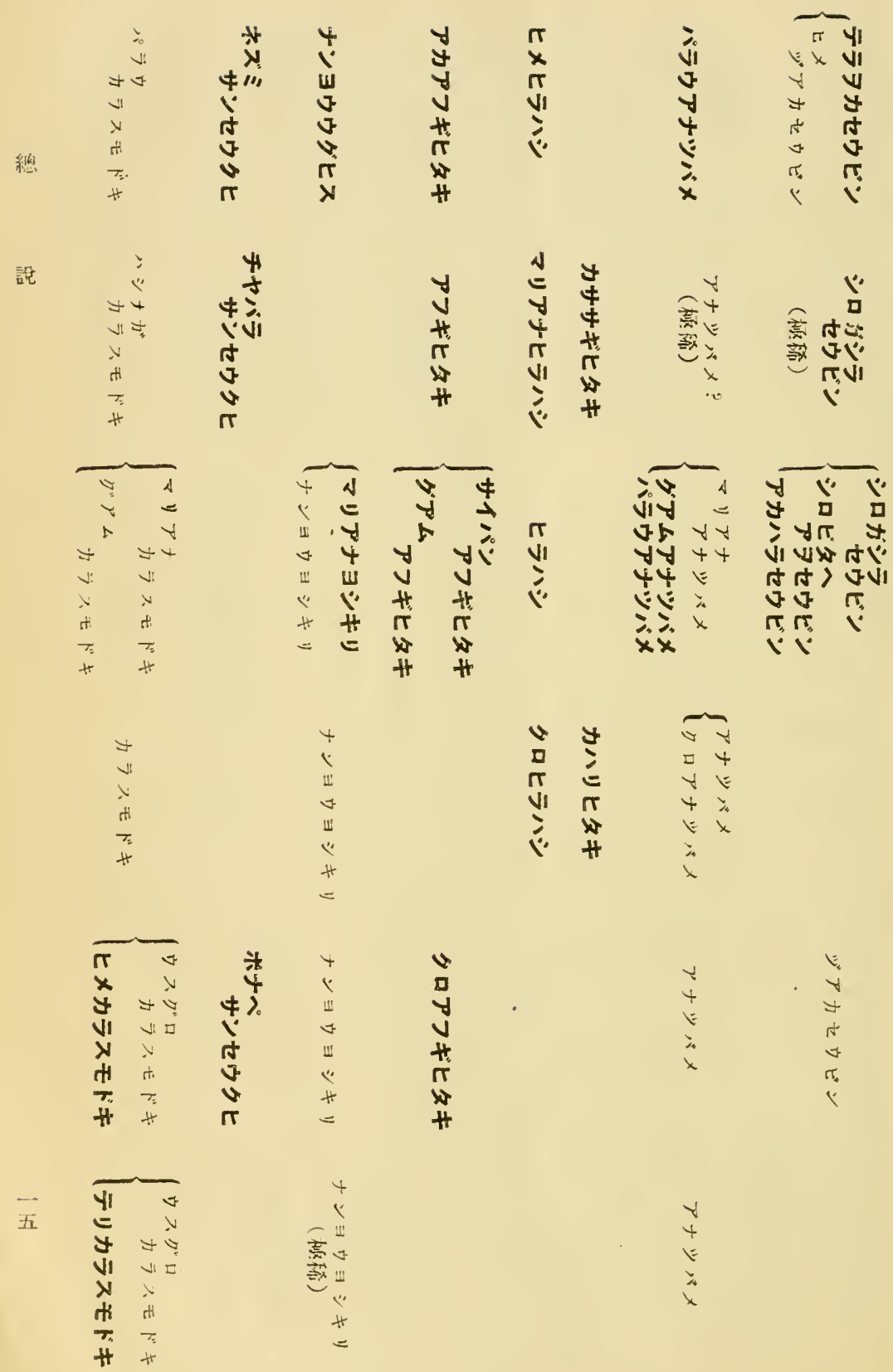


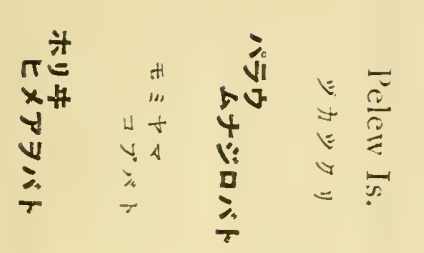

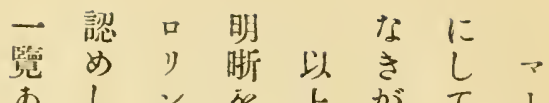

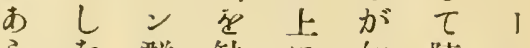

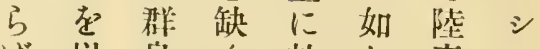

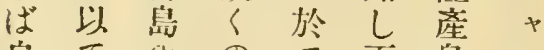

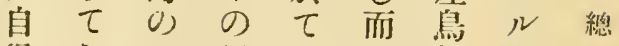
得なな怨分し類群 せ

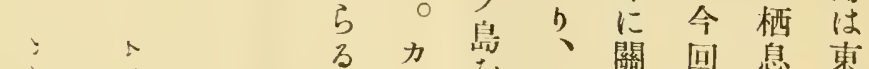
-

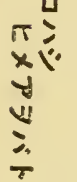

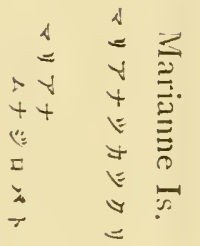
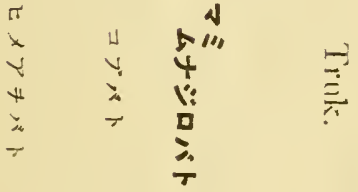
y地不力 其大該道口 群！等要群當》

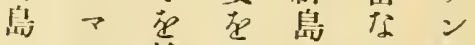
のり補終にる群

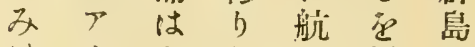
は土んし以の 代雨がるざ東

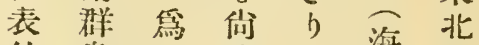
的息》諸し海の

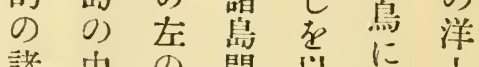
諸中の間以㫖

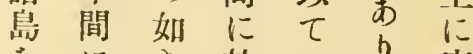

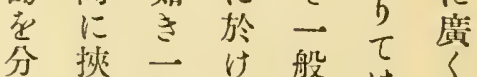

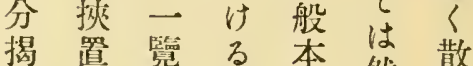

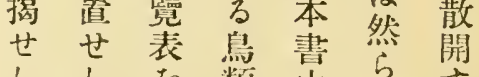

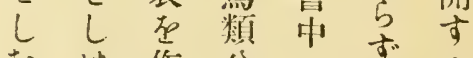
生作分里主 了動几布名事處 事物 b 9 此實焉 分、連部上多 布三絡㔔特數 要上群邑及宸的 法此品識为程珊 各々にb省衣楜

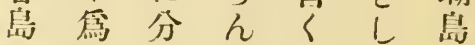

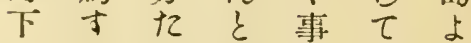

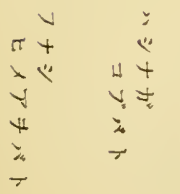
の走欲罢 分至し世世当成间

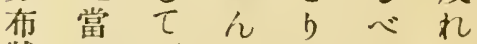

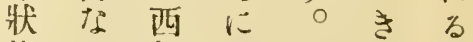
態り部は方集

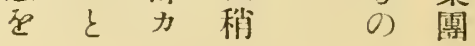




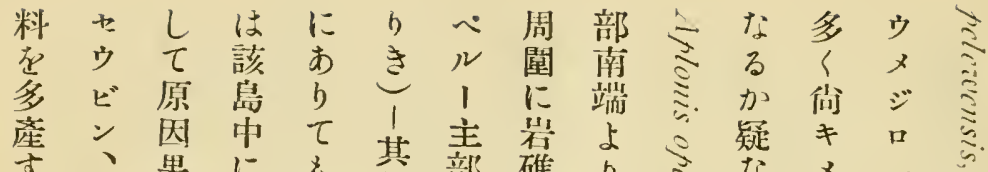

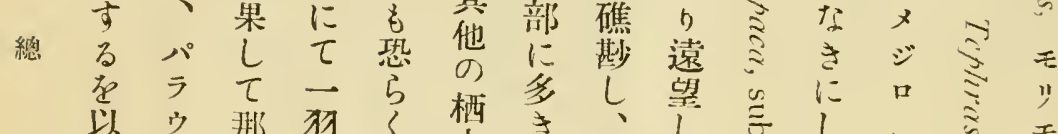

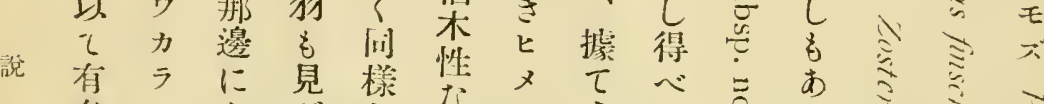

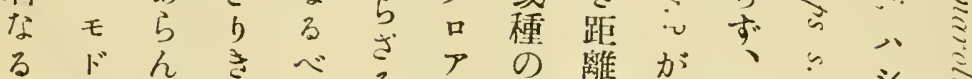

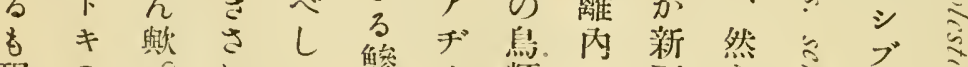

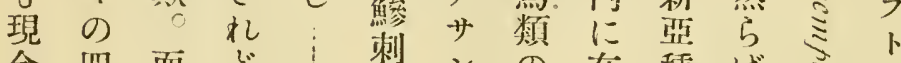
今四而ど|刺シの在種ばミ

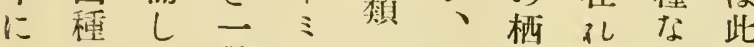

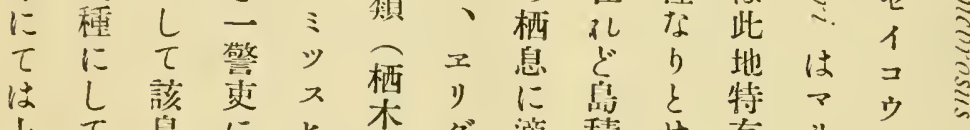

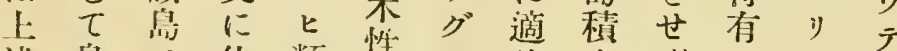

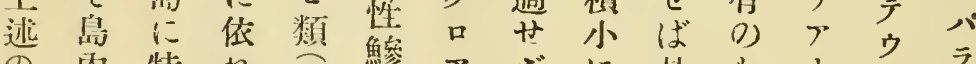

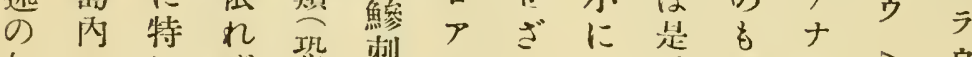
如ににば恐刺ヂるし文の群ミウ

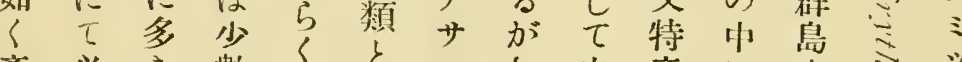

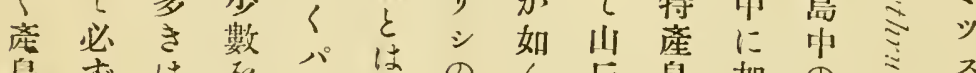

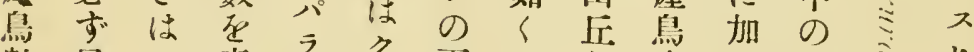

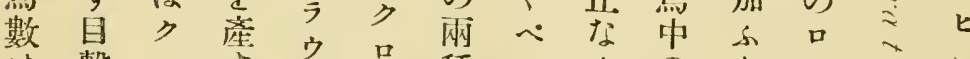

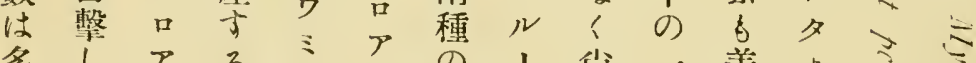

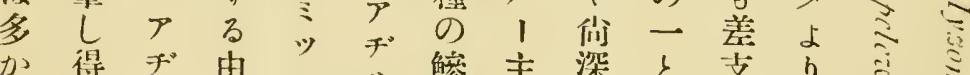

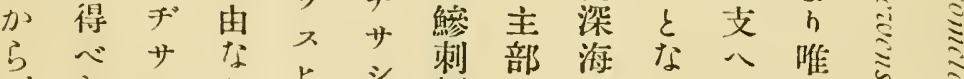

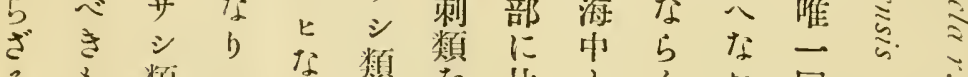

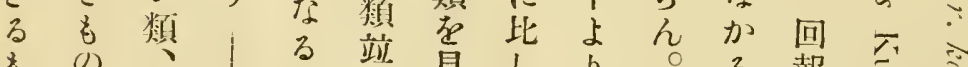
もの、学站見し

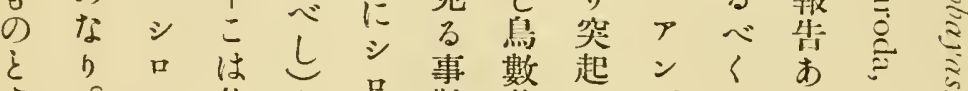

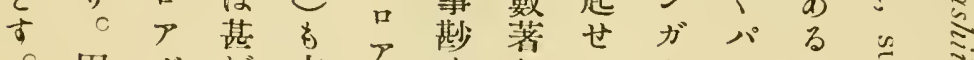

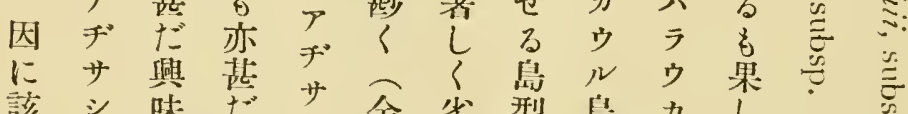

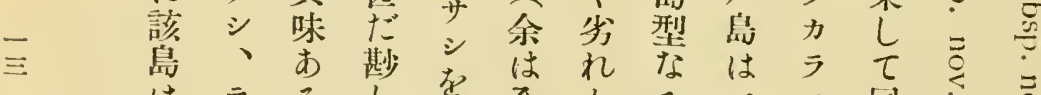

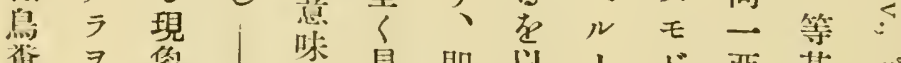

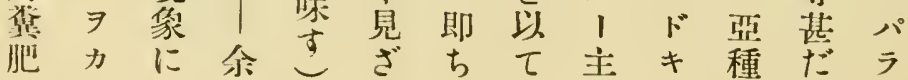




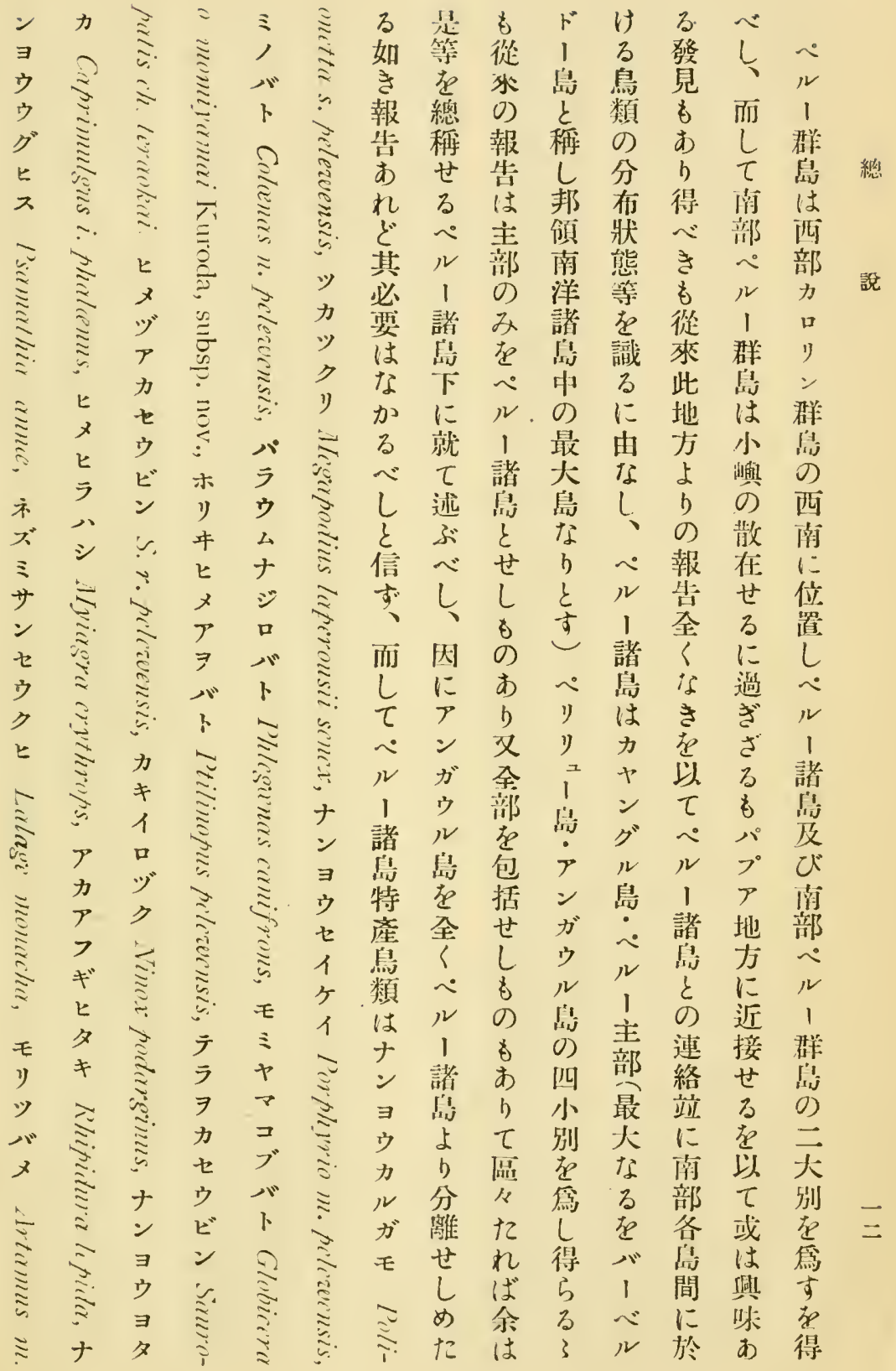




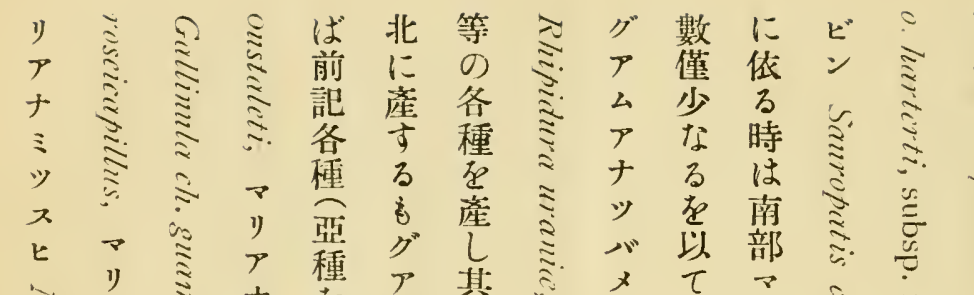

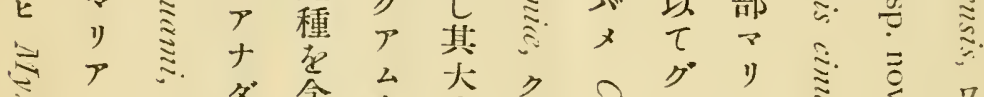
說

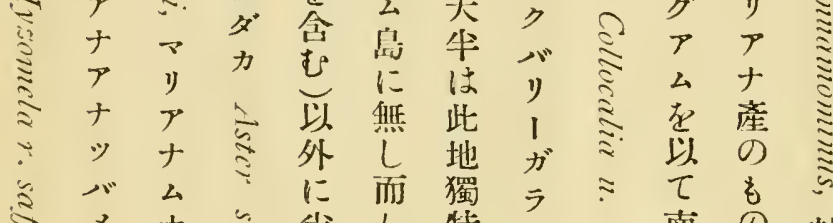

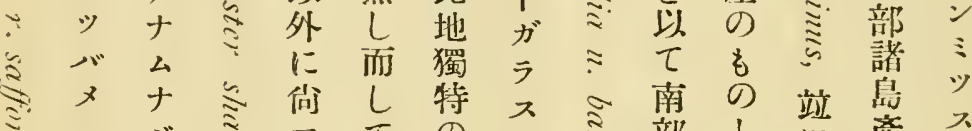

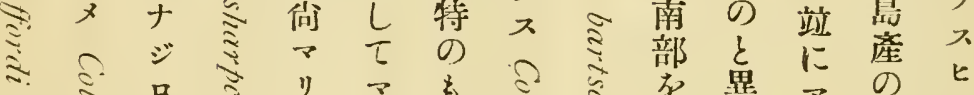

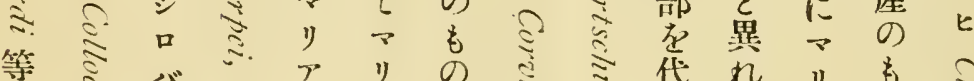

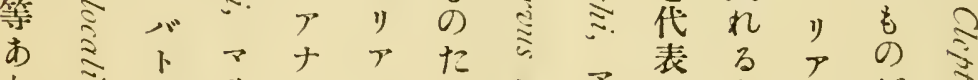

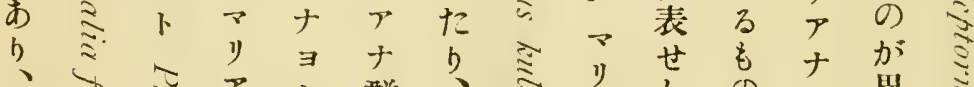
多シ ア シ 群、 人

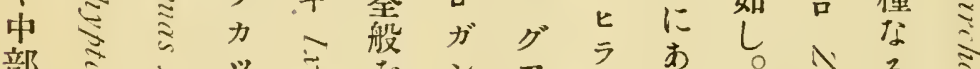

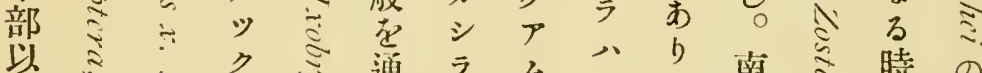

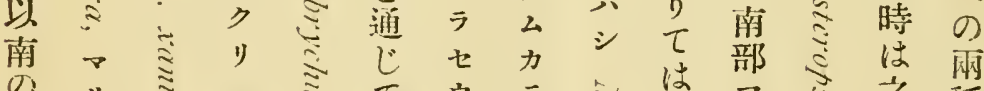

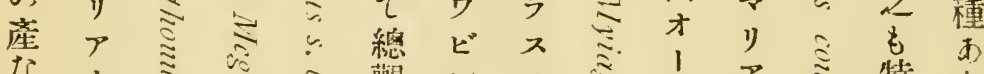

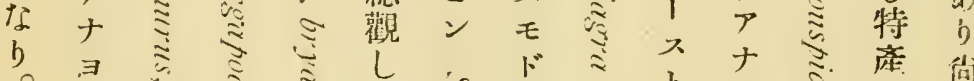

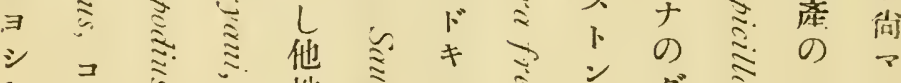

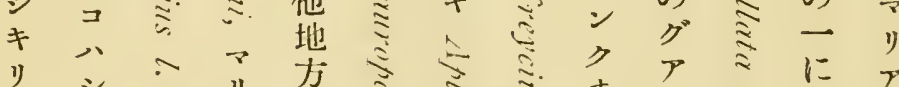

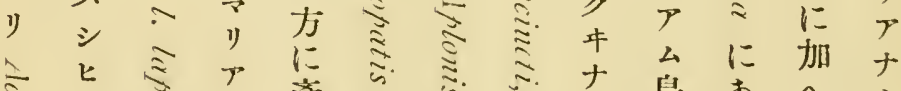

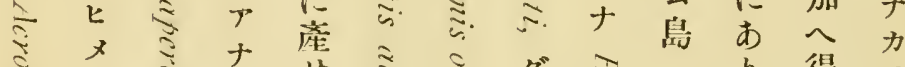

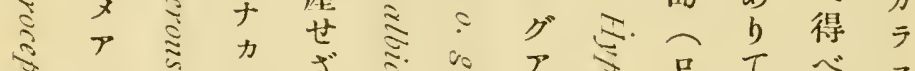

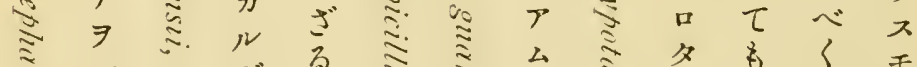

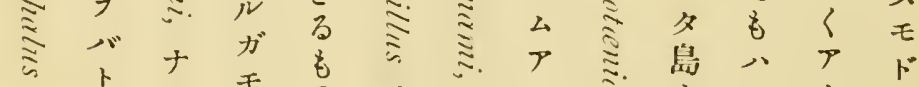

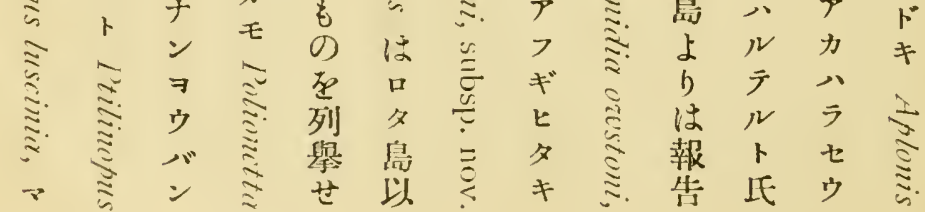




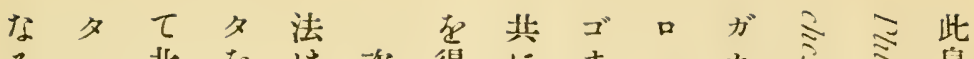

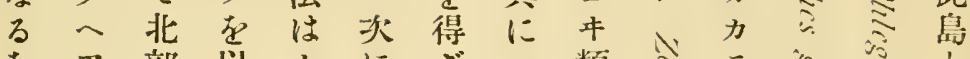
以 $\tau$ 七編献りリし

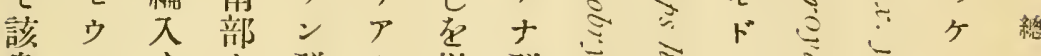

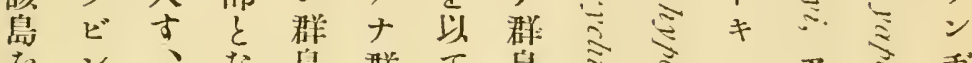

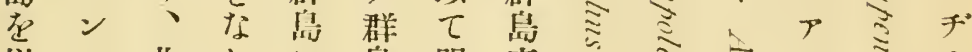

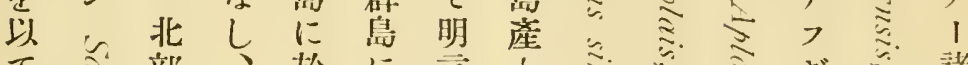

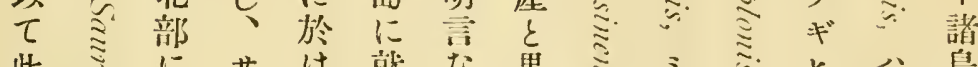

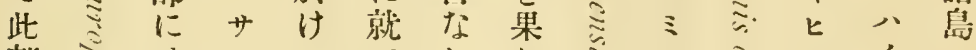

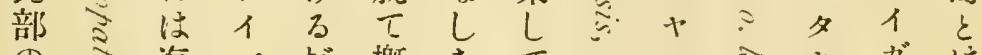

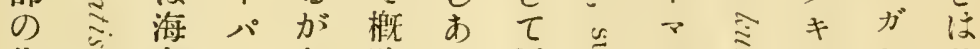

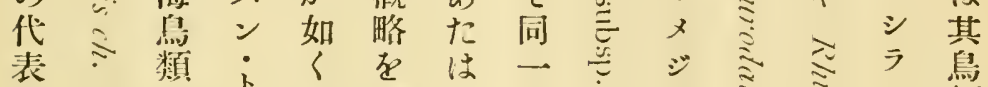

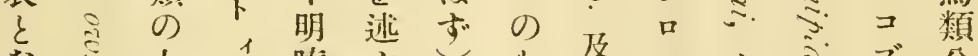
な大

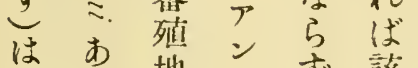
特方地方声放 有令点ギ米鼠 与机1 領

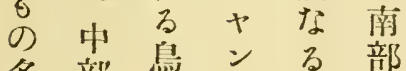
多部島鼠 加少多引中 点芳焉公部

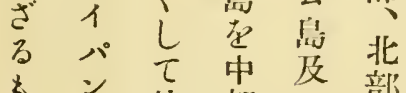

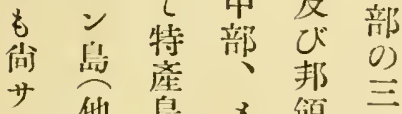
1怹鼠 ダ碩示

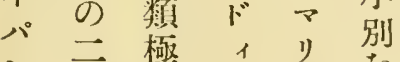
鬲㜀 1

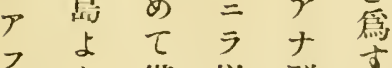
7 b僅以群

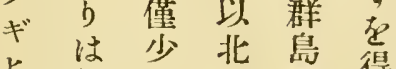
七報江悲鼠得 ₹告し諸茼记

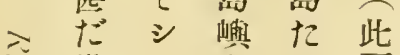
僅然居區 少ビ總口分

$\xi=$ 密

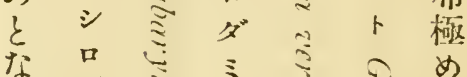

さガ 章

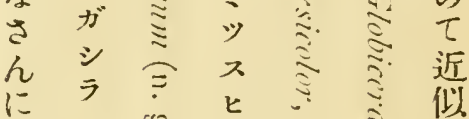

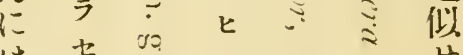

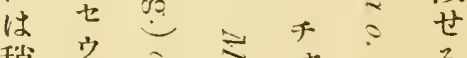

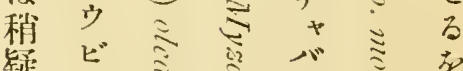

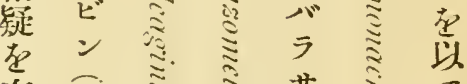

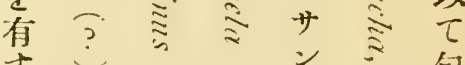

寸 一等

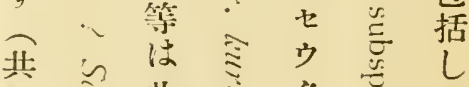

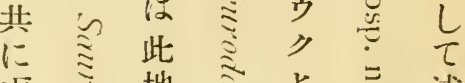

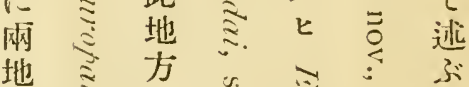

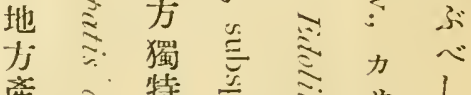

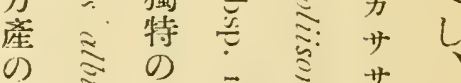

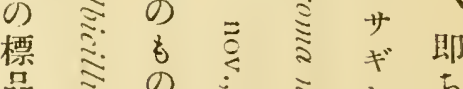

品

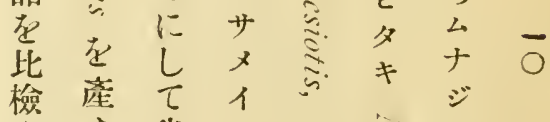

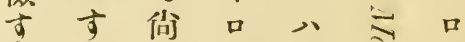

るれヨメシ

事どジナ突ト 


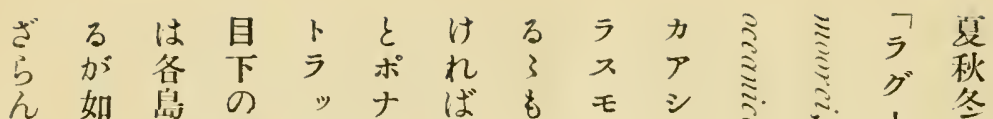

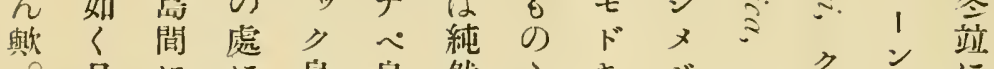

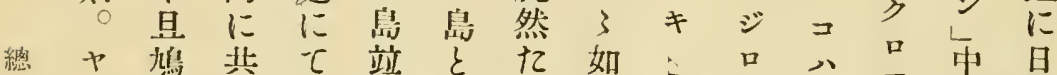
\%類通はに其るく

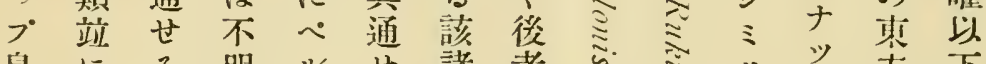

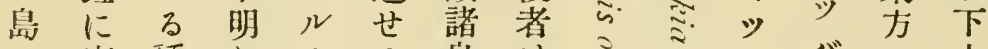

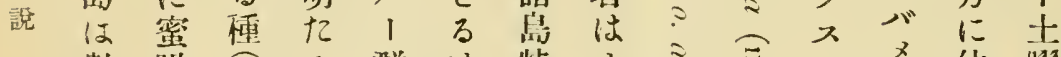

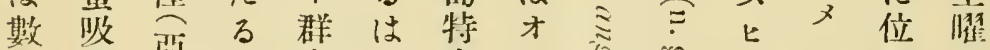

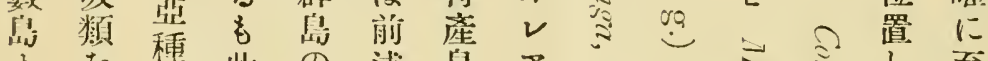

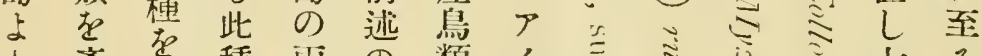

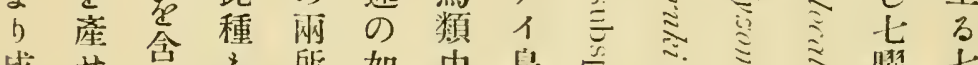

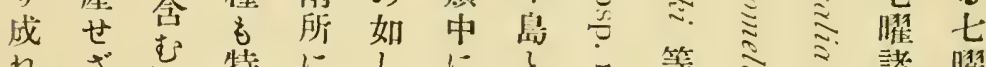

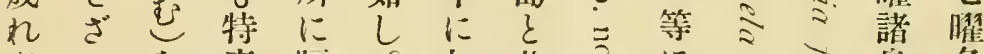

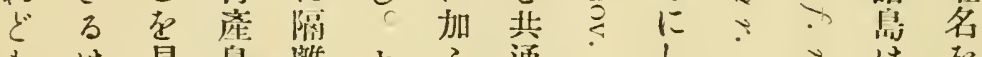

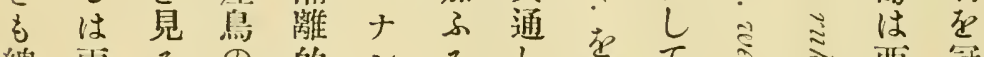

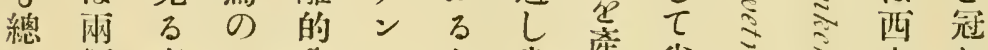

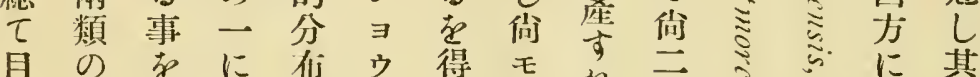

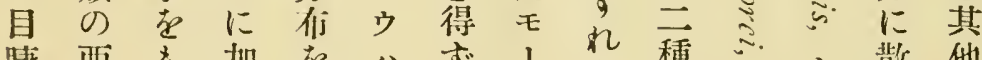

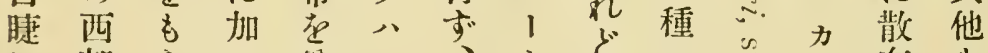

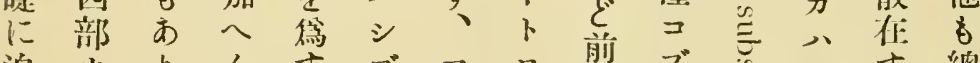

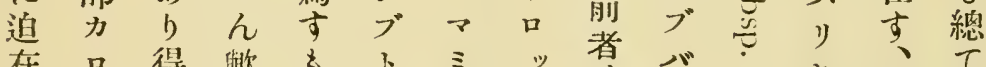

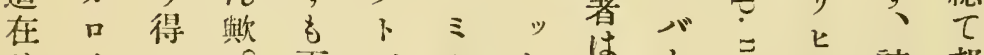

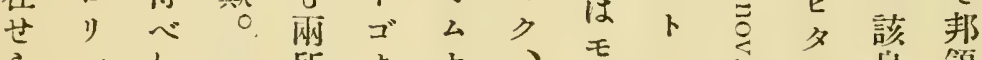

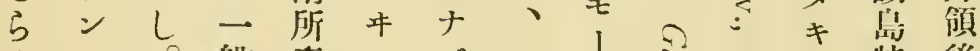

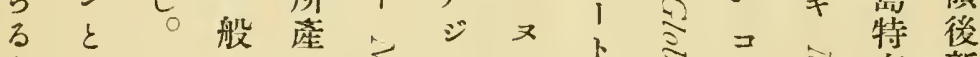
了のオにのコ品, 、有新

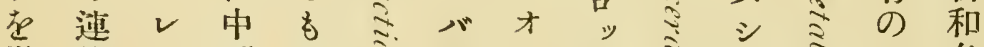

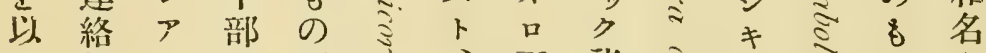

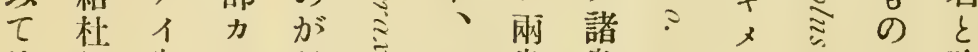

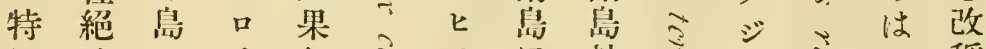

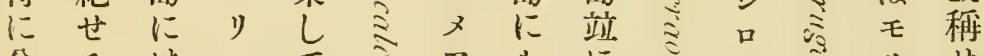
分るはンてき厂るに气

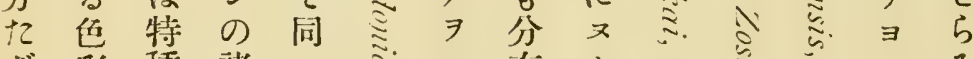

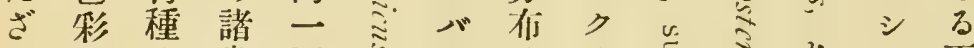

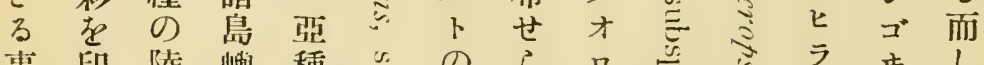

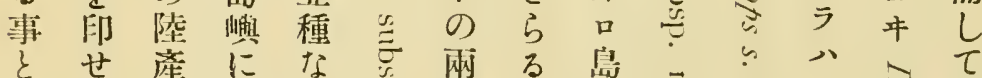

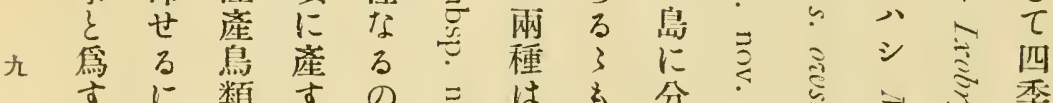

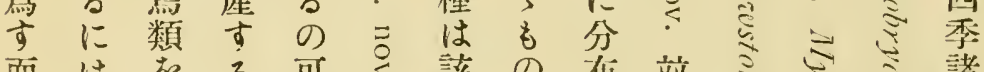

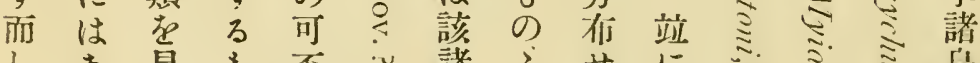

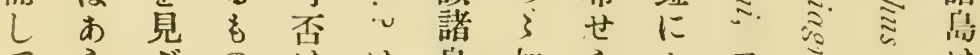
てらざのはは品如らカア らは 


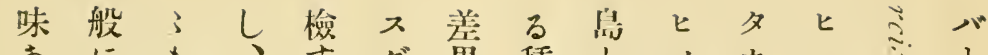

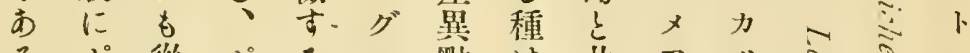
るポ從ポ方品點は基

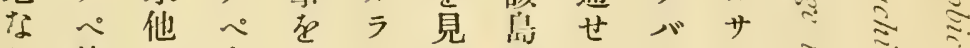

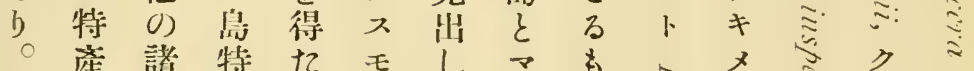

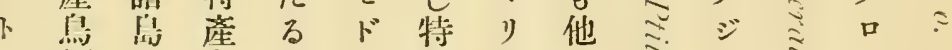

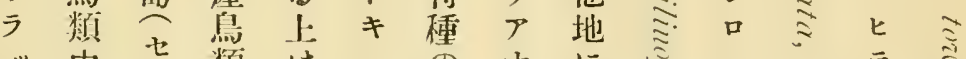

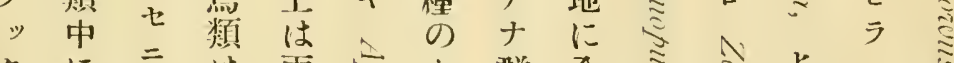

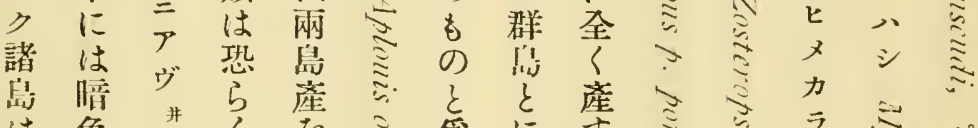

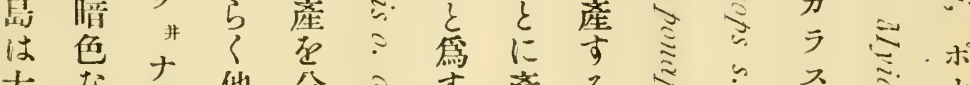

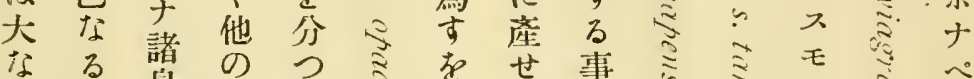

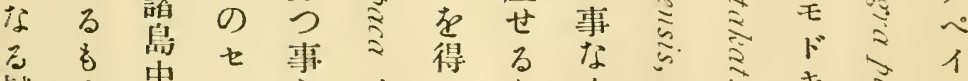

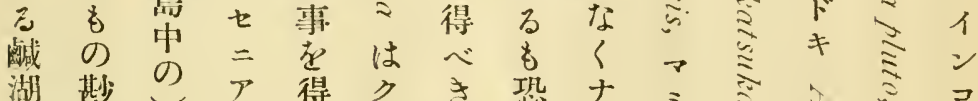

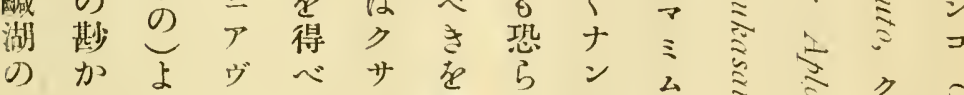

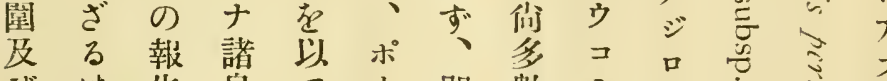

びは告島てナ即數ミぶ

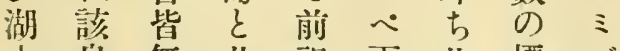

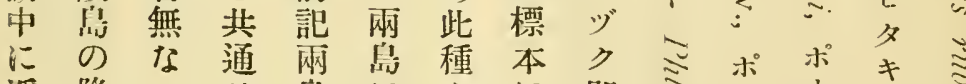

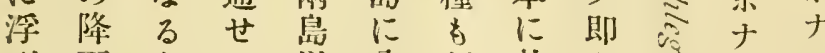

列雨在 3 以分行就

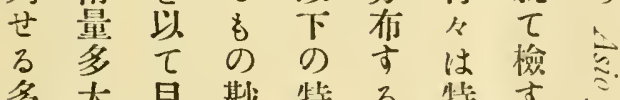

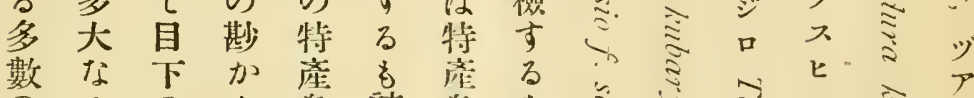

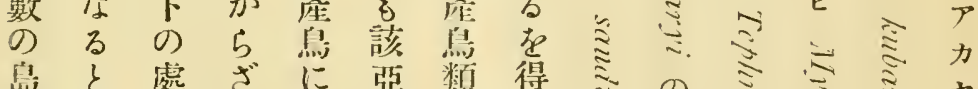

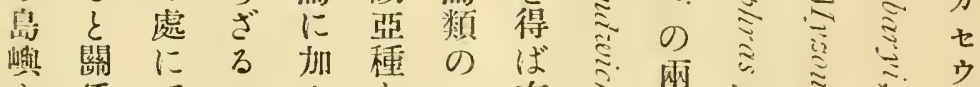

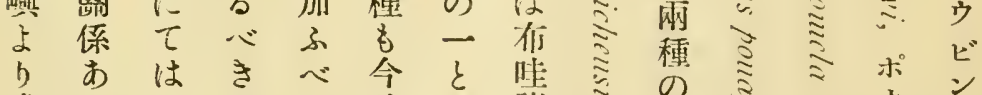

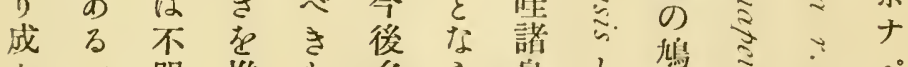

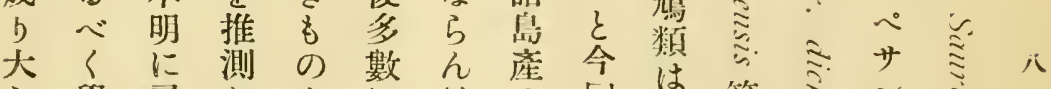

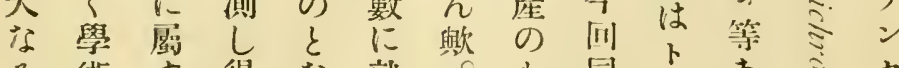

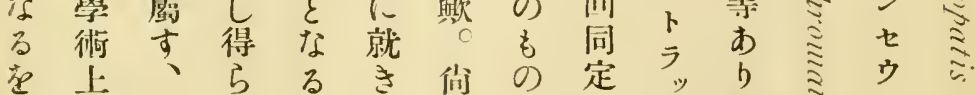

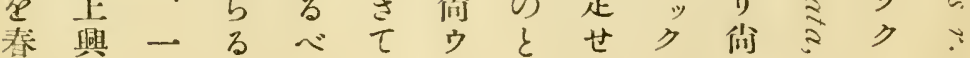




$$
\begin{aligned}
& \text { 口さけに鳥ちごサクンはナナ }
\end{aligned}
$$

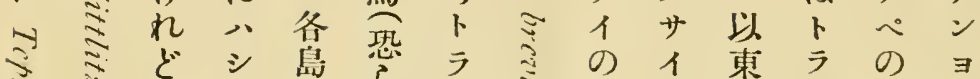

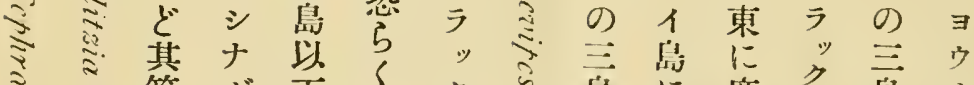

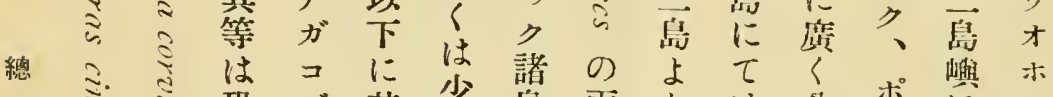

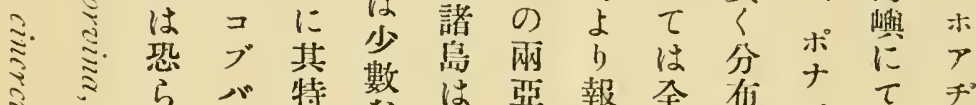

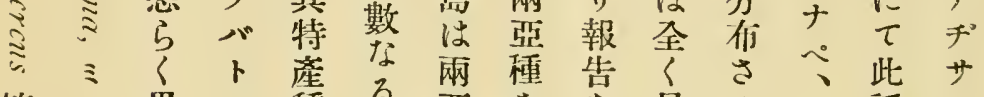

$$
\begin{aligned}
& \text { 說等 }
\end{aligned}
$$

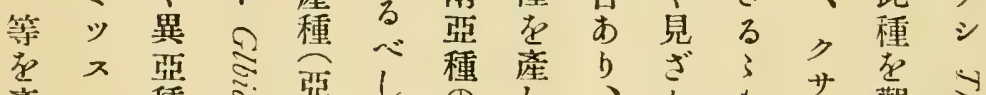

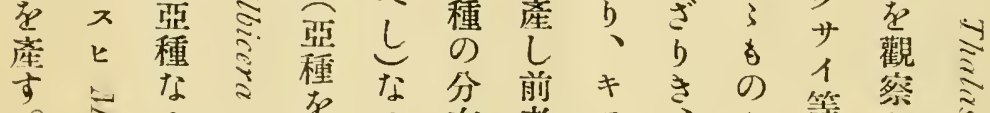

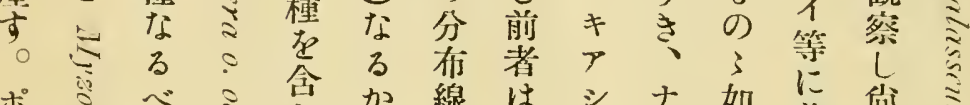

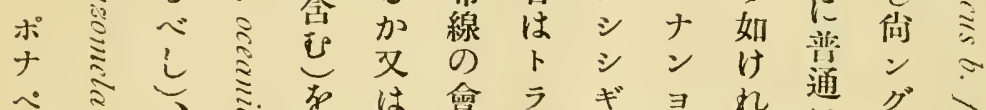

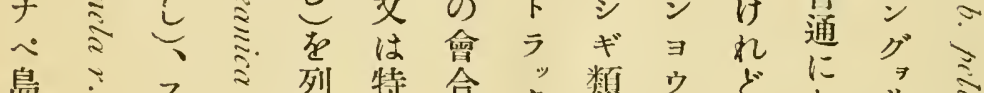

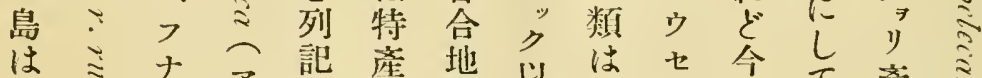

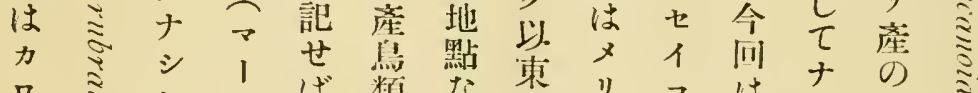

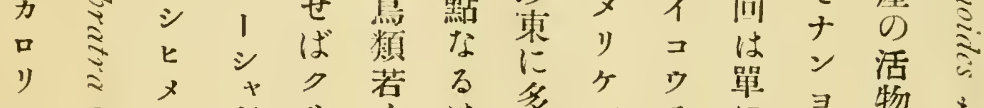

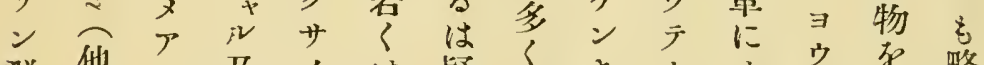

$$
\begin{aligned}
& \text { 群島 他及1は疑後キウ才蛋略 }
\end{aligned}
$$

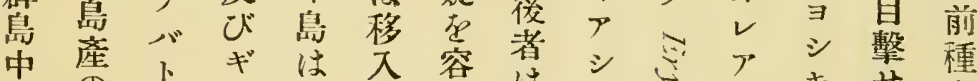

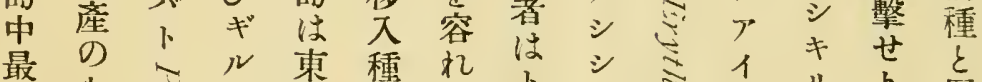

$$
\begin{aligned}
& \text { 大 }
\end{aligned}
$$

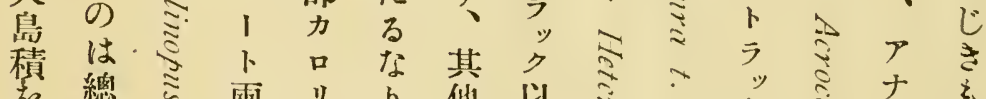

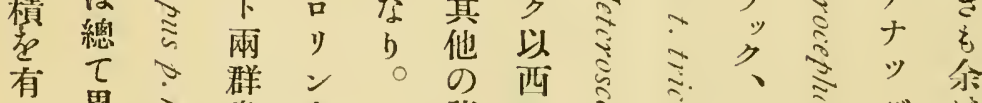

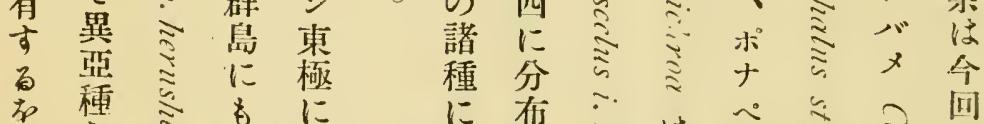

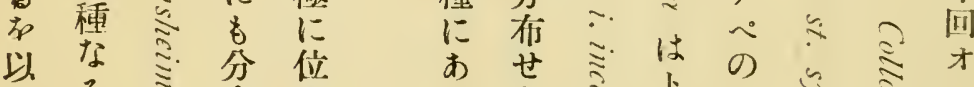

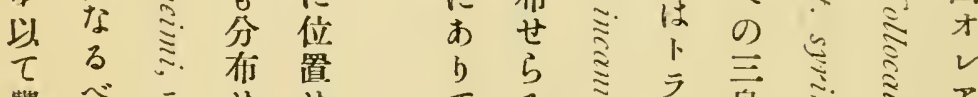

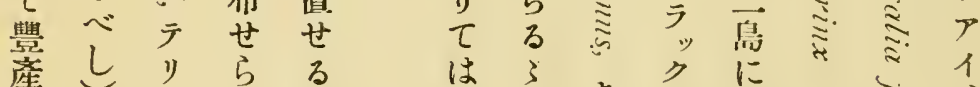

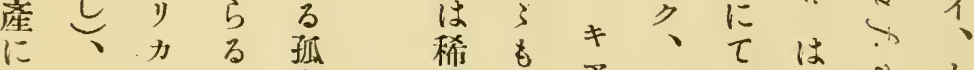

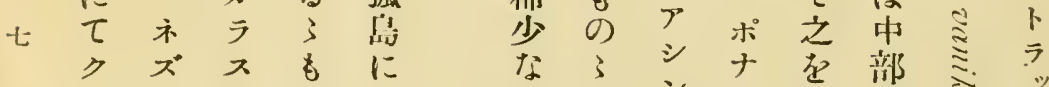

$$
\begin{aligned}
& \text { 口ミ゙ そ }
\end{aligned}
$$

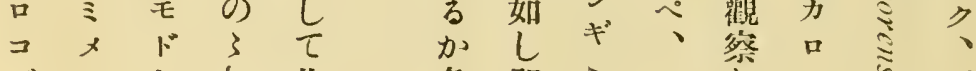

$$
\begin{aligned}
& \text { ブジキ如此冬即ミクしり空ポ }
\end{aligned}
$$




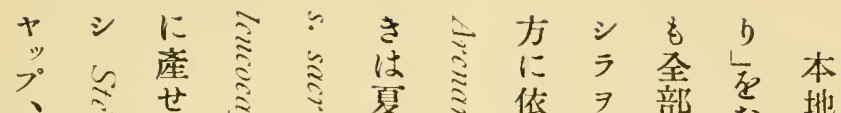

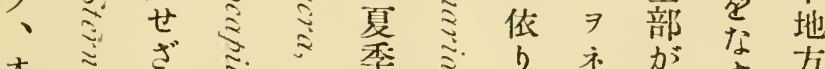

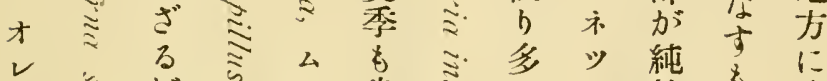

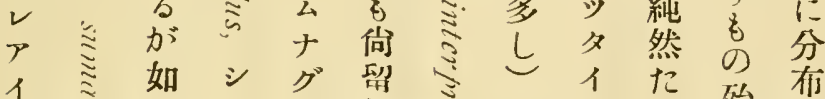

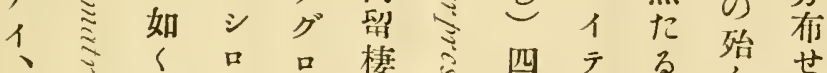

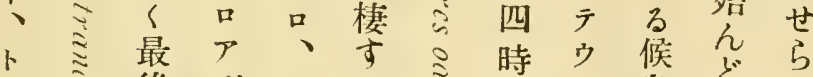

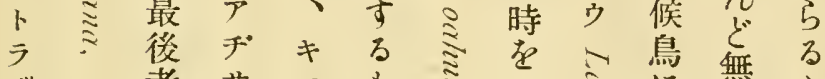

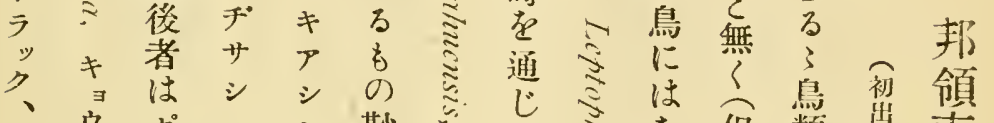

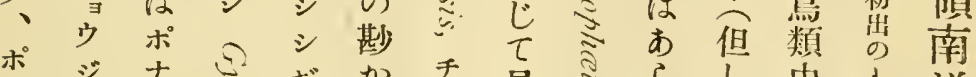

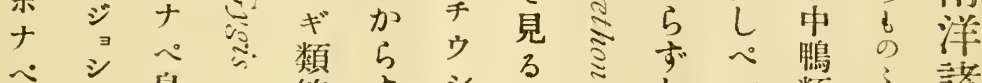

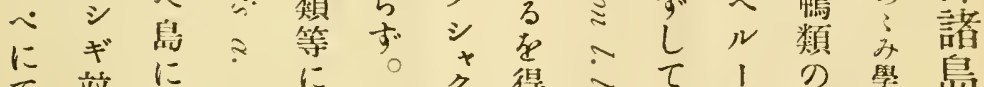

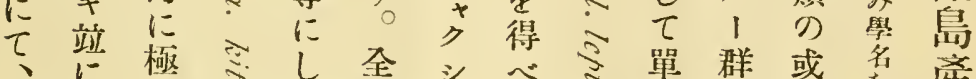

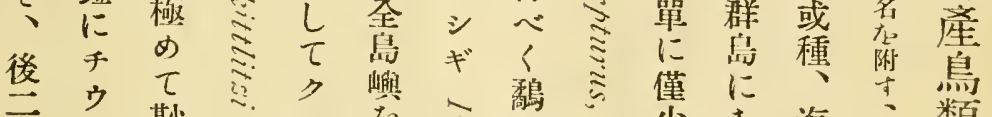

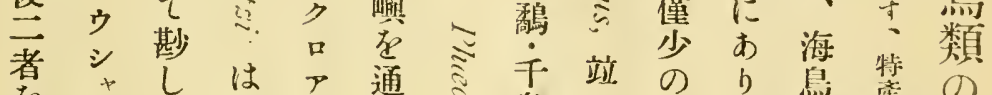

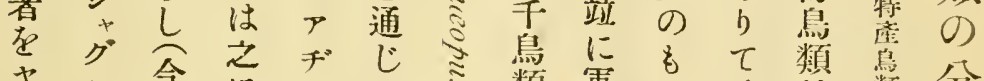

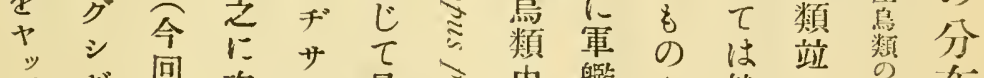

プギ回次シ 最: 中艦了然に和有

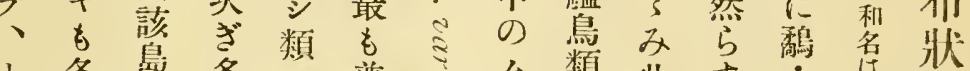

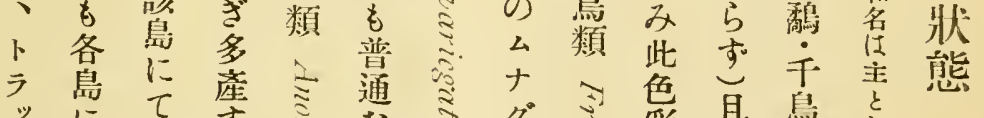

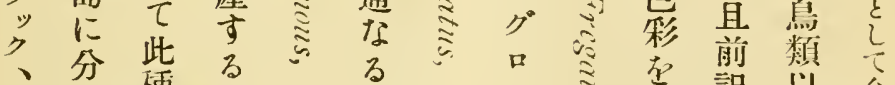

、分嘎る る

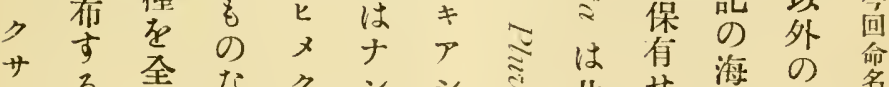

イる全なクンシ基せ海の愈

の 方自れ

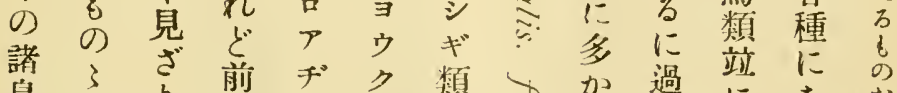

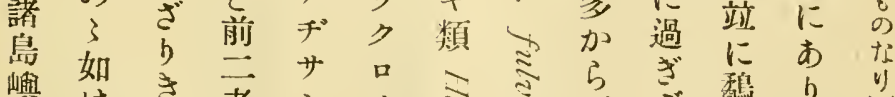

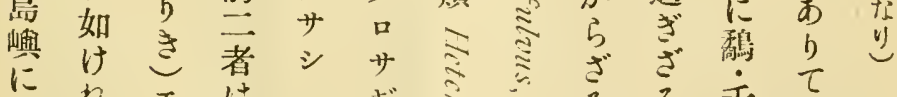

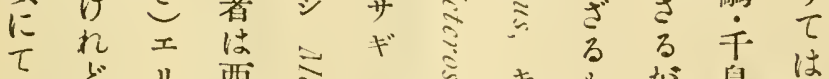

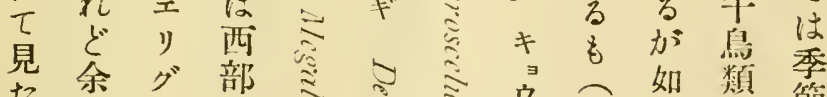

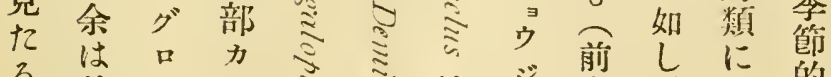

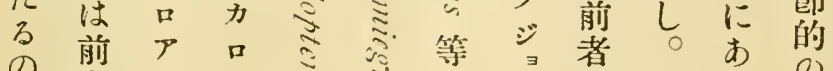

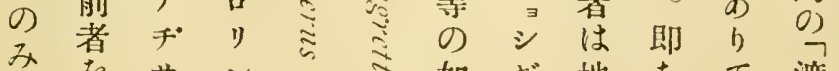




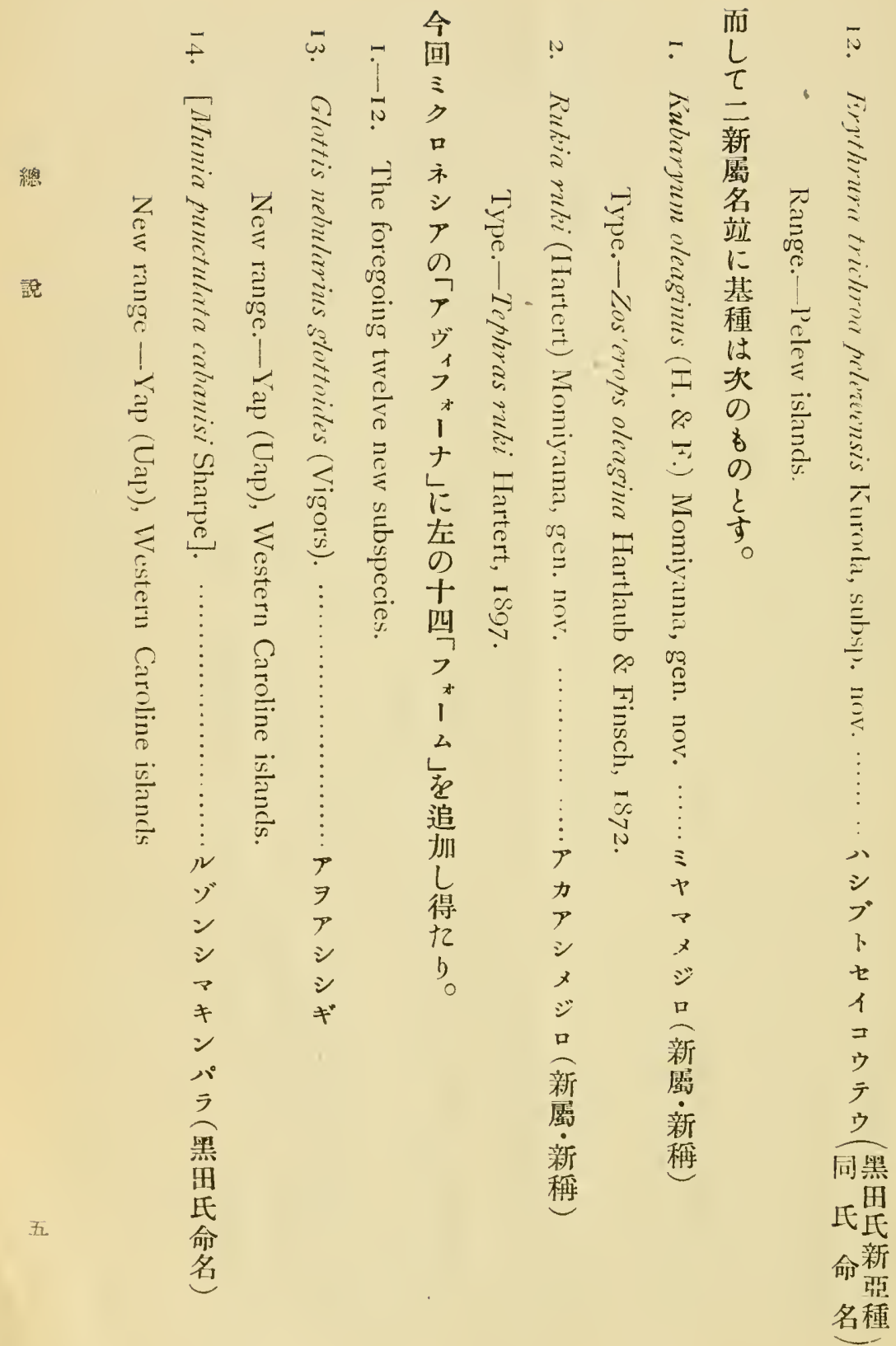




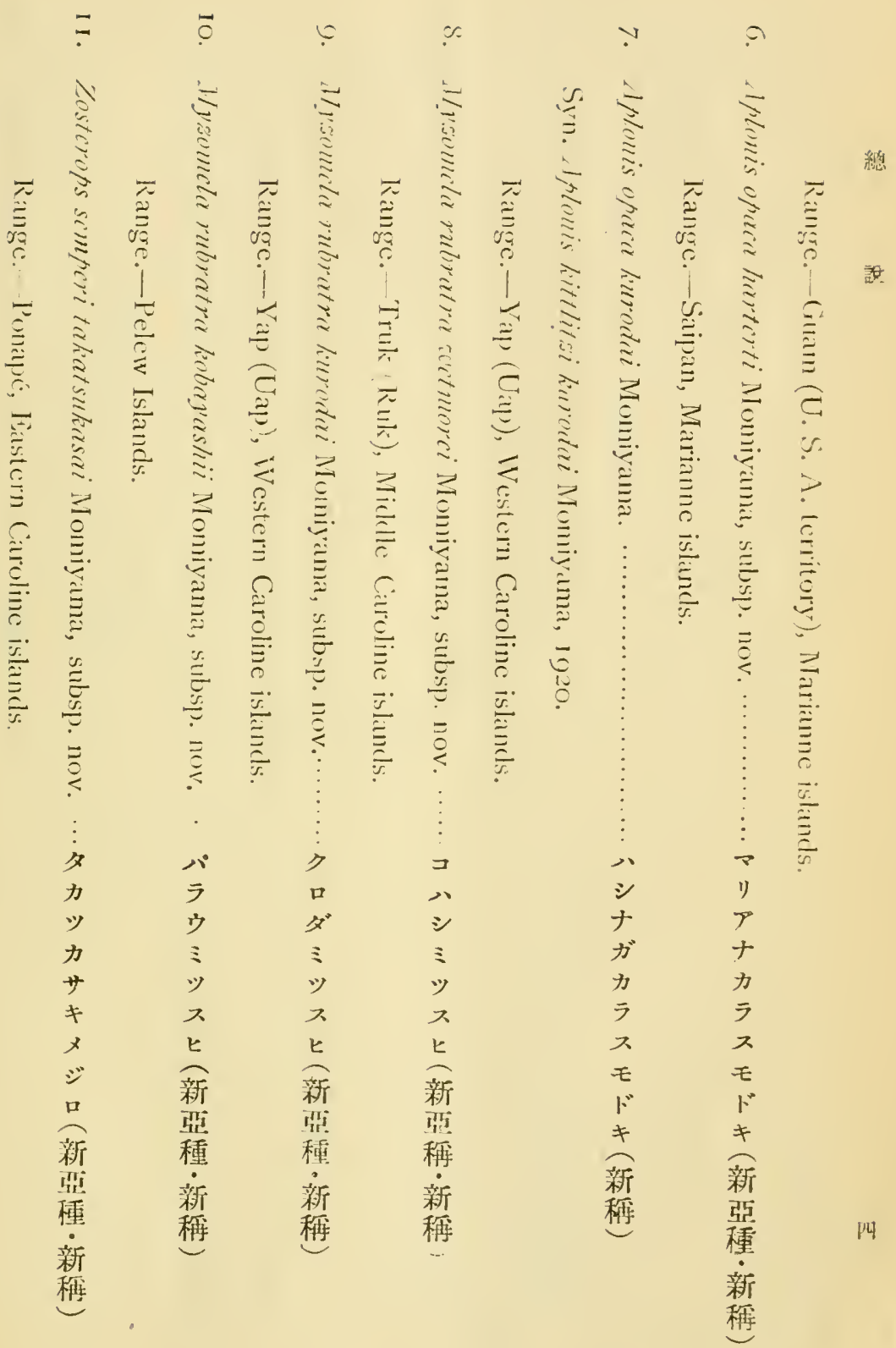




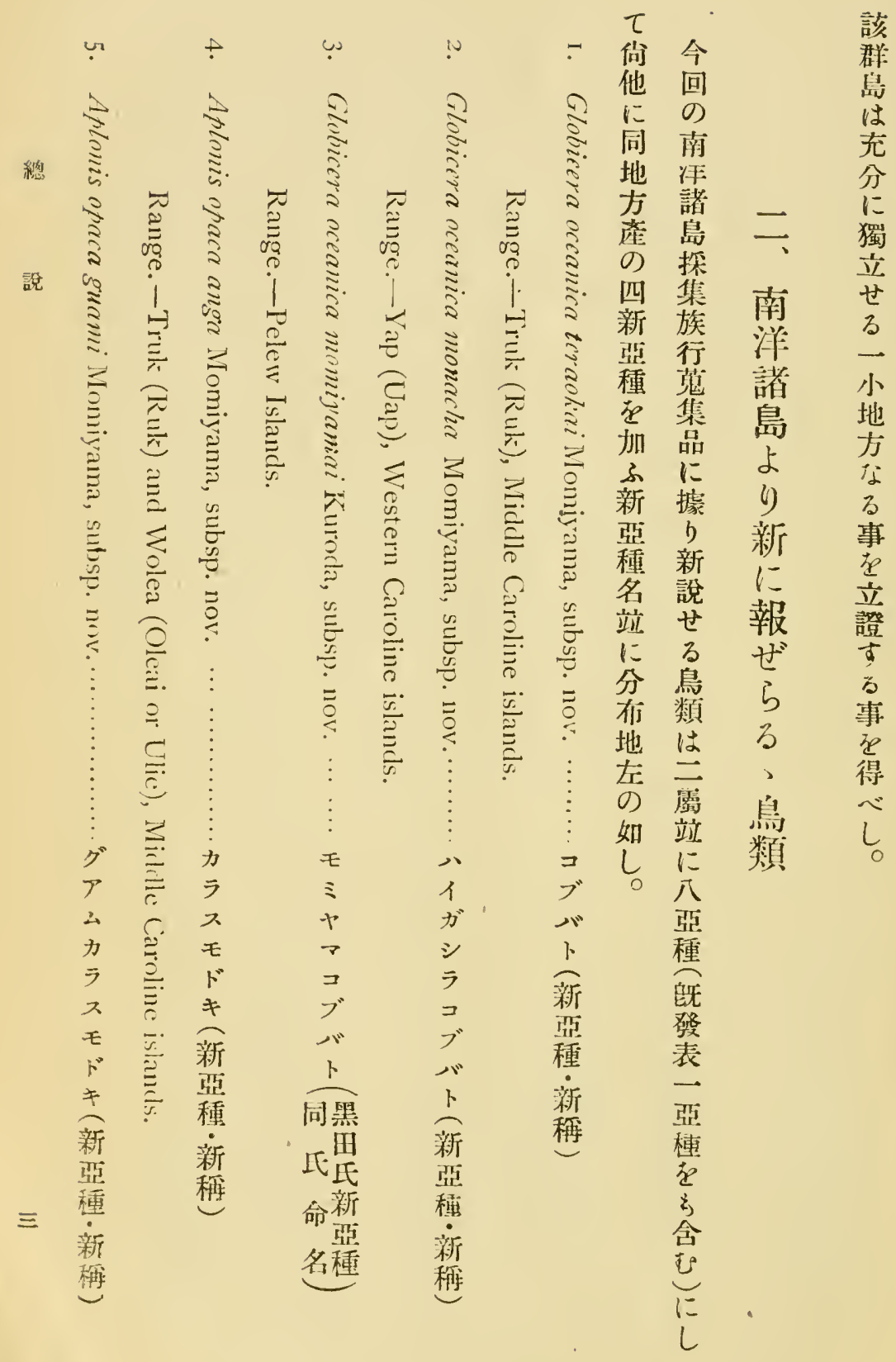


遠部分該ンン的處島にめ

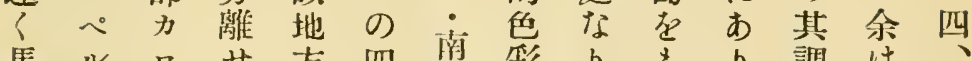

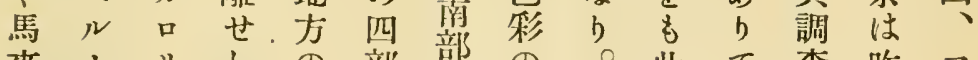
來、りしの部部の此 地群ンむみに多然名はの年 1 方岛群 こを分少きるの從結上ク總

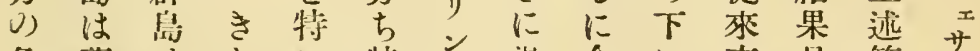
色舊は多に特之過今に東是第齐 彩大特の十に或茂回編經等票

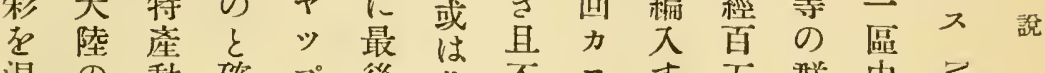

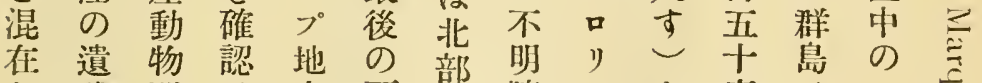

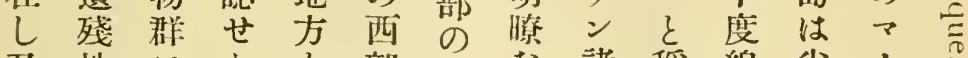

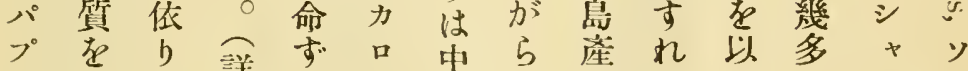

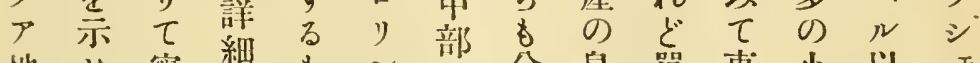

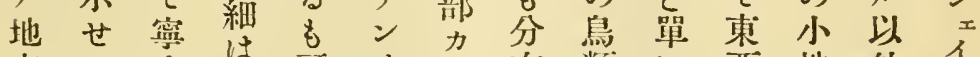

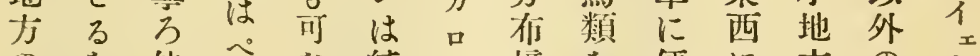
の走他へな純り境点便に方の下

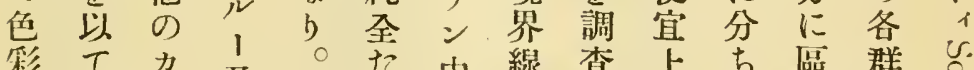

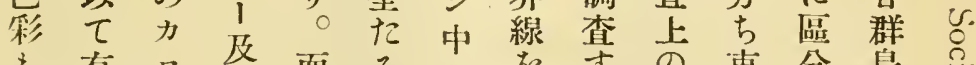
る有口芯而るに素の東分鳥 加名り另し獨編見る區力なに岁

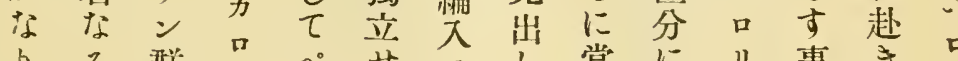

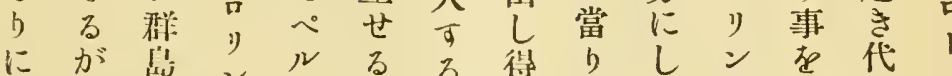

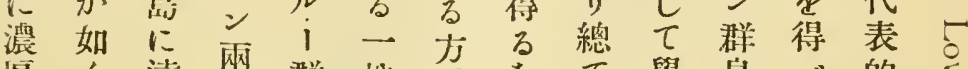
厚々遠雨群地帘存學島心的气

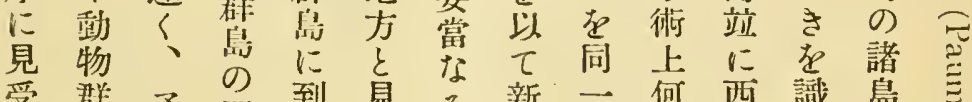
受群子圆到自る 新一荷西識島

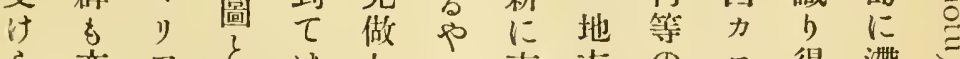

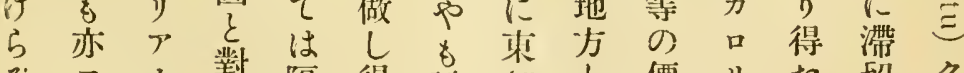
方フ十對隔得識部と價りた留》

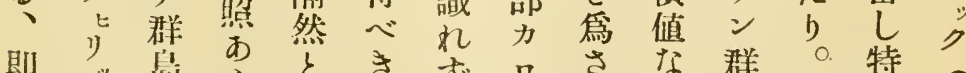
既 光近ん事信端ンにはつち鳥导 等群き事り声に。は論多力類光

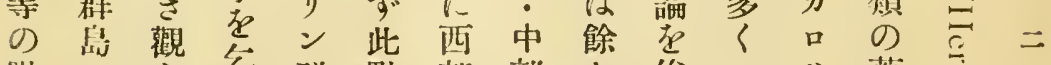
點に向衣群點部部门俟べ蒐 曐通

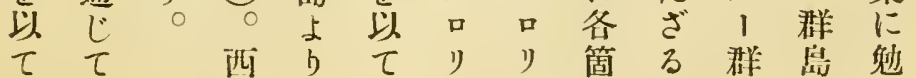




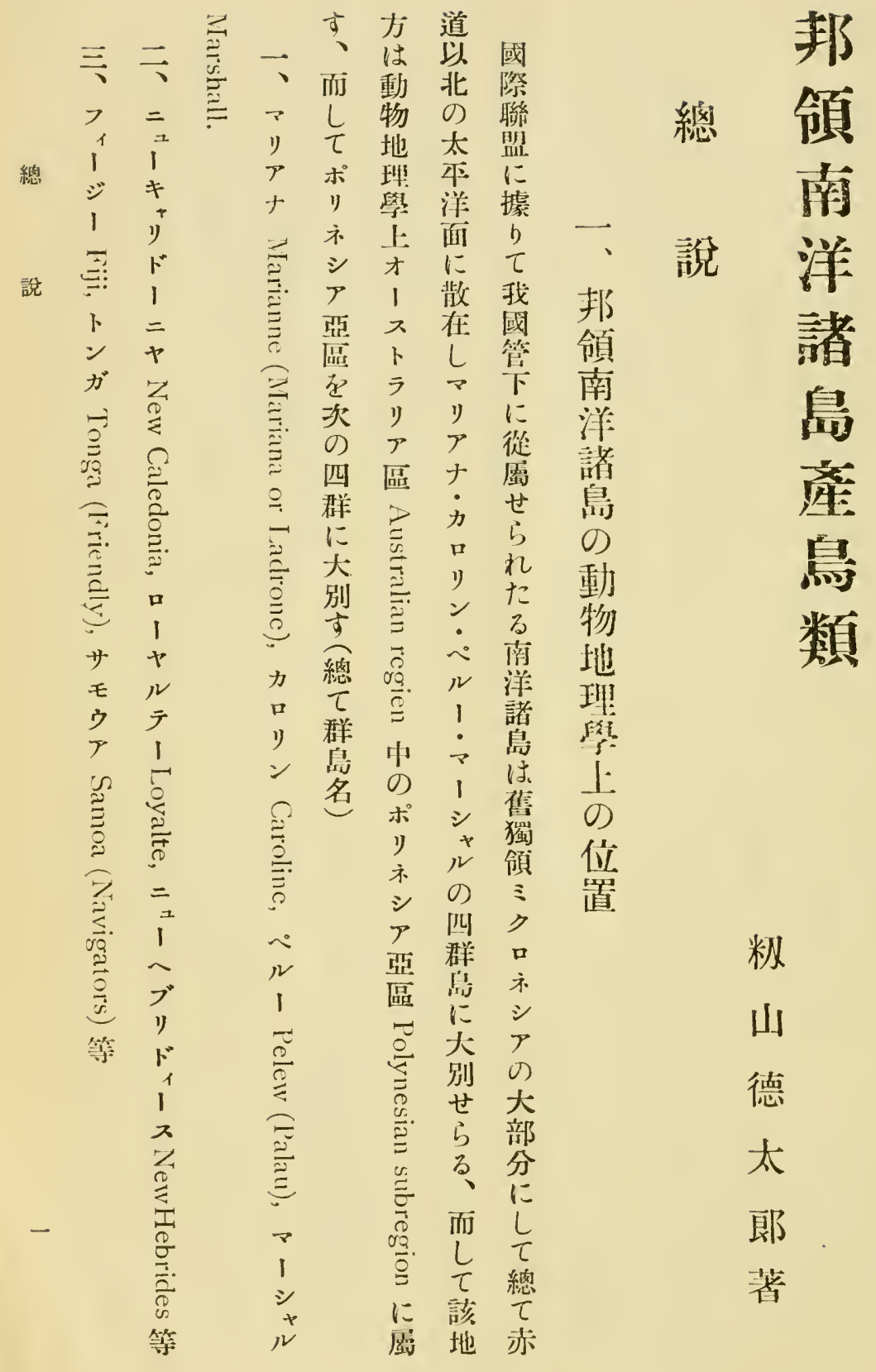


第第第第 第第 八扫六五四三二

圖圖圖圖圖圖

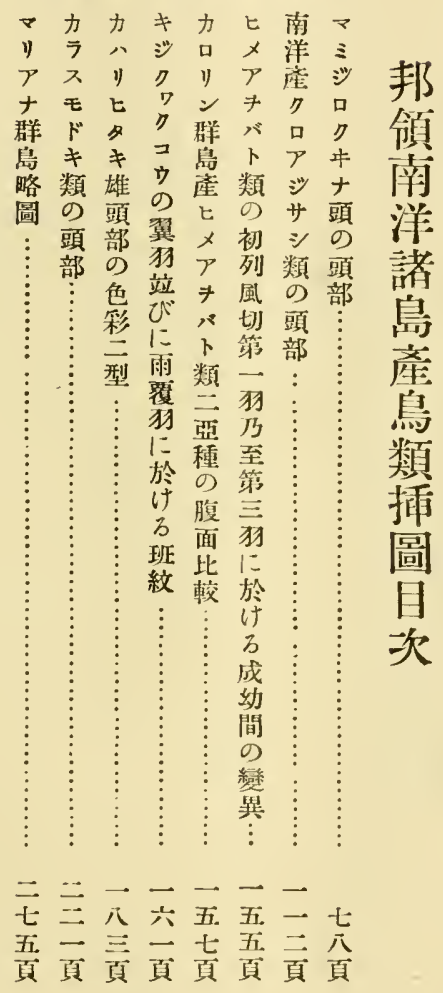




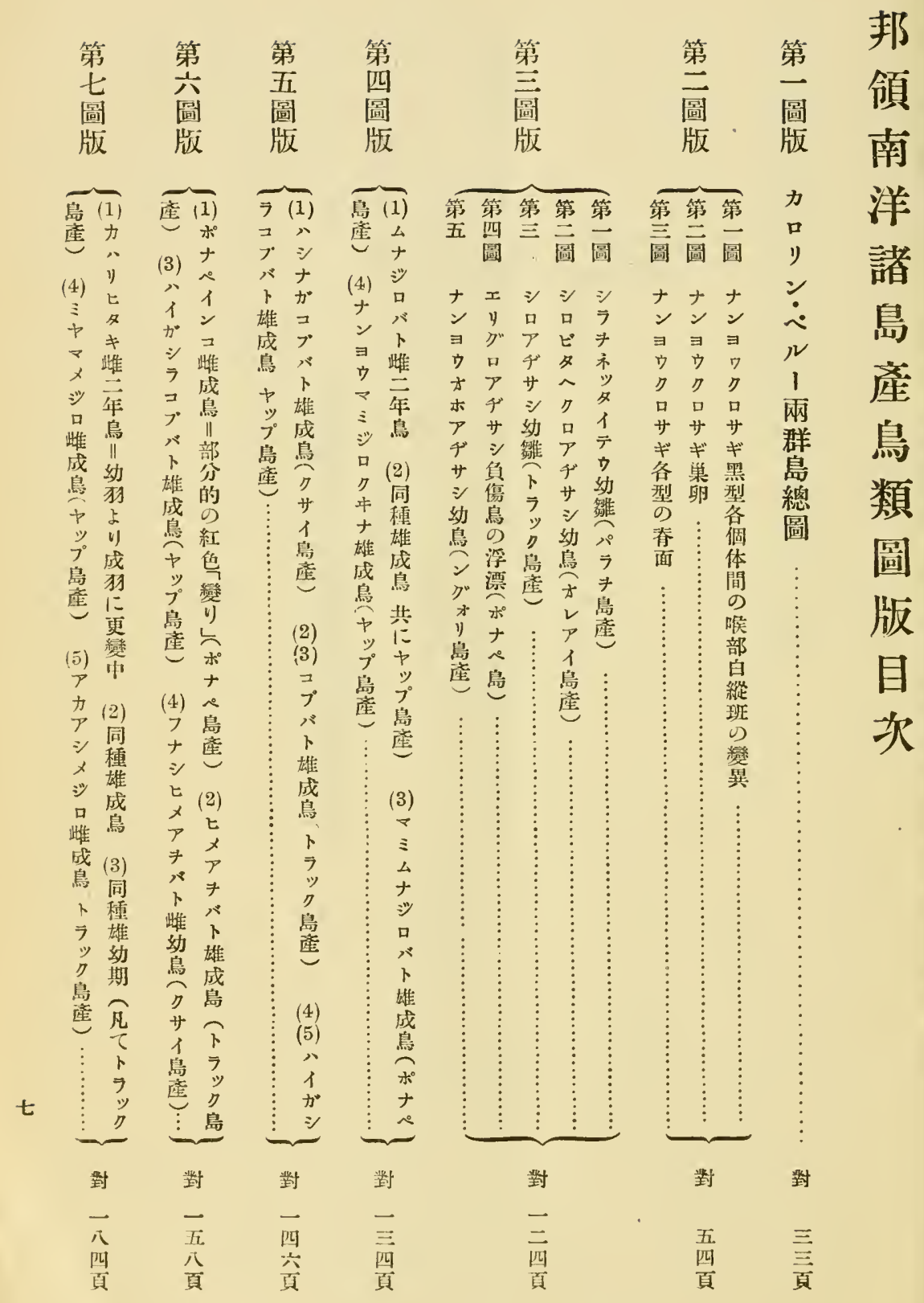


分

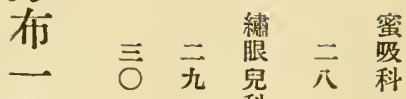

南
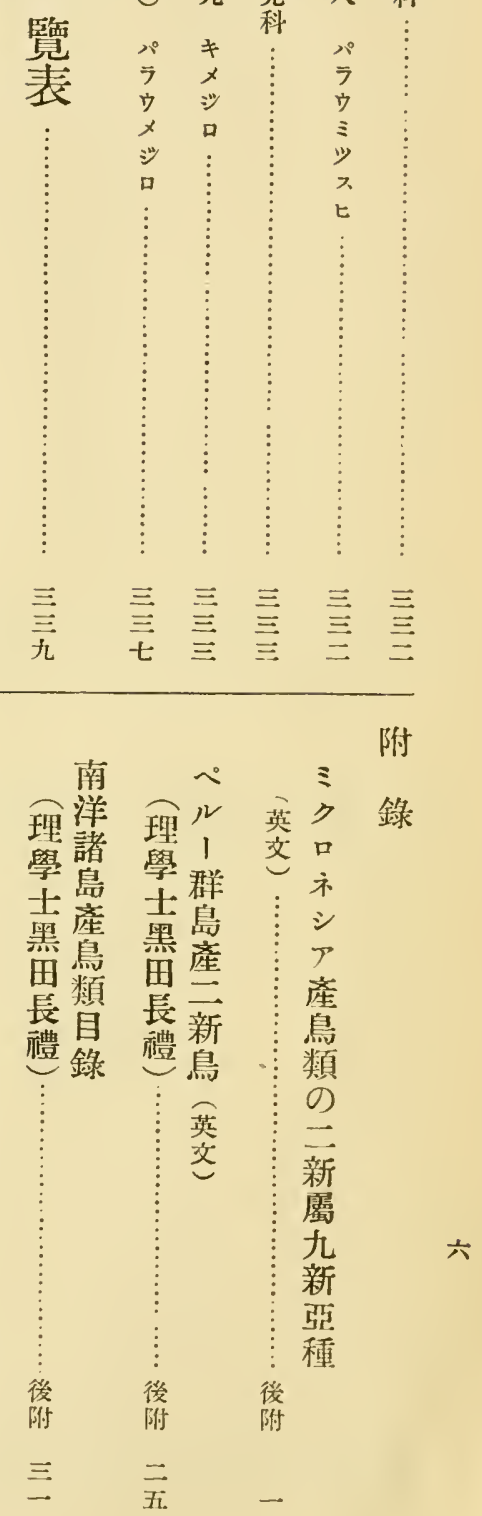


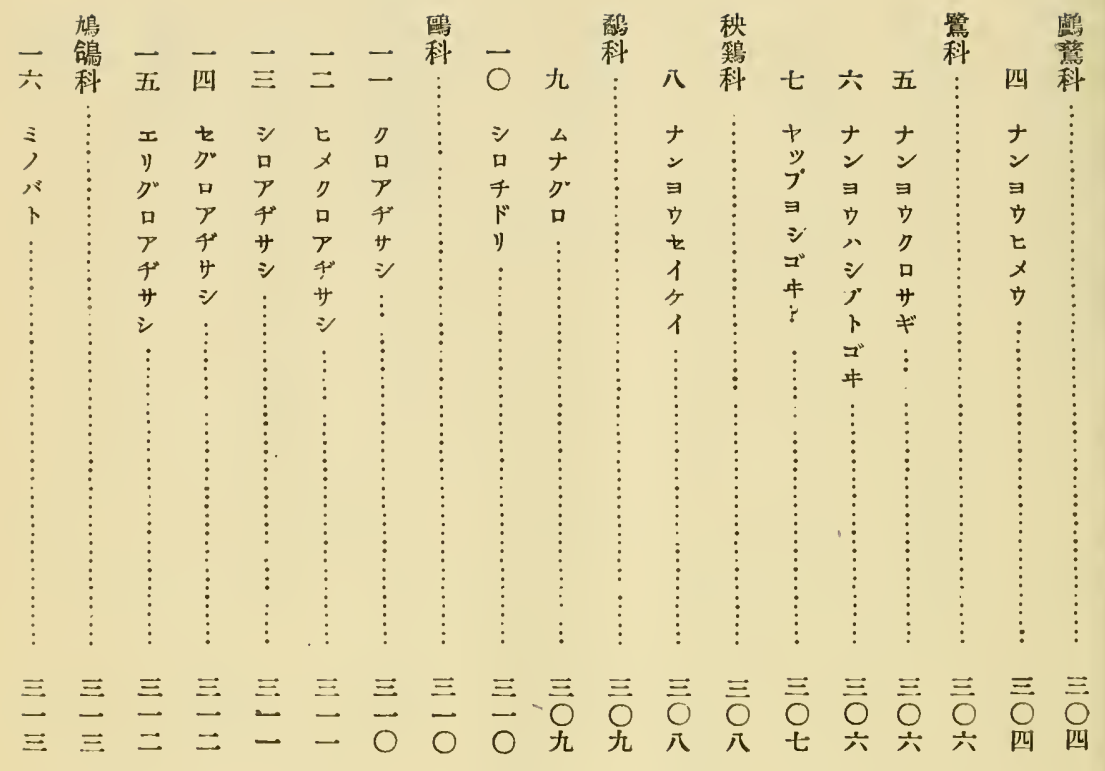

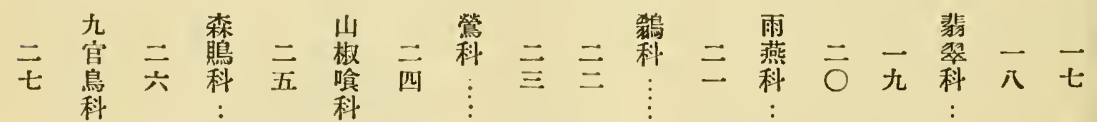

五

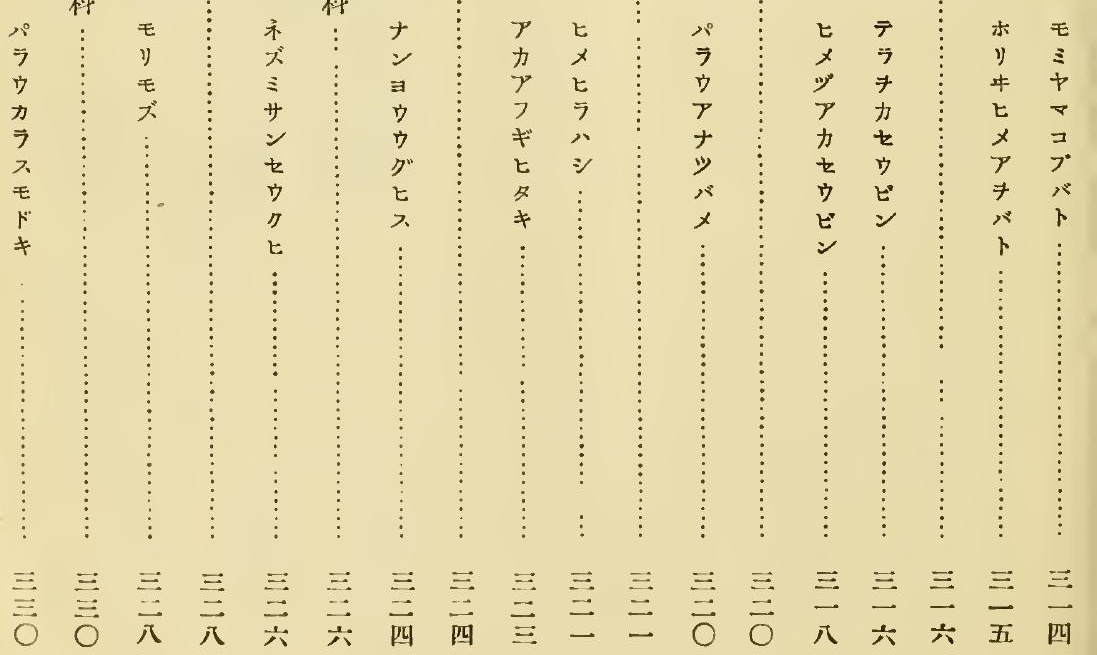




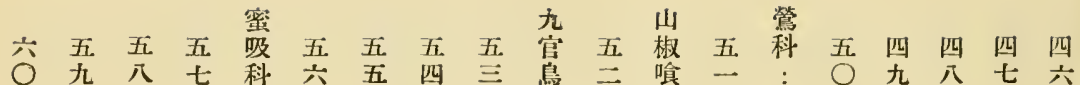

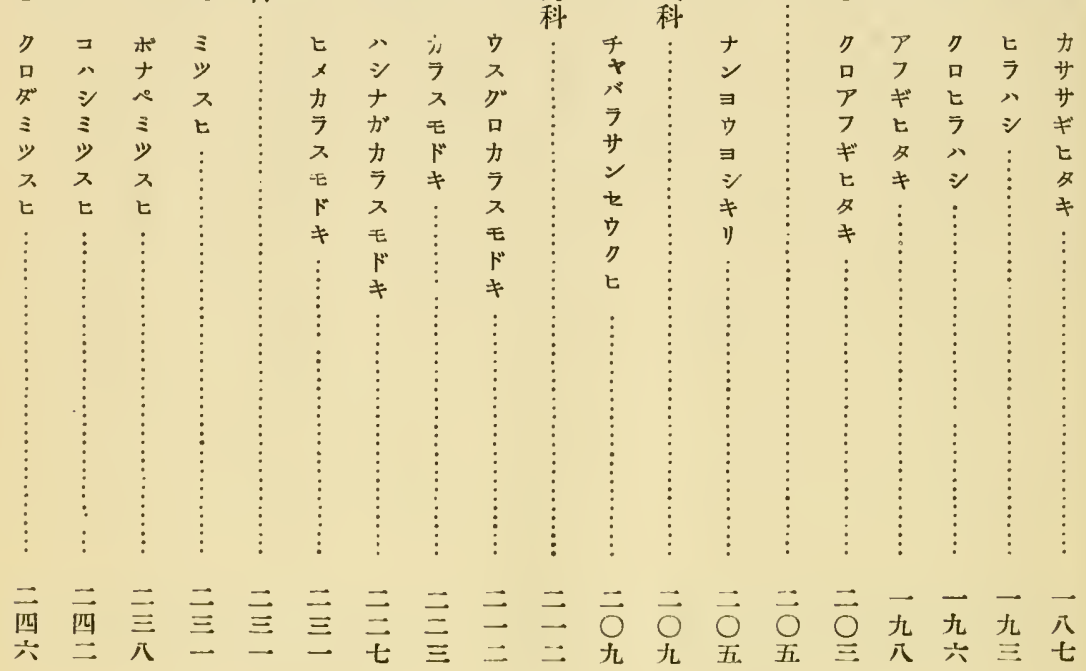

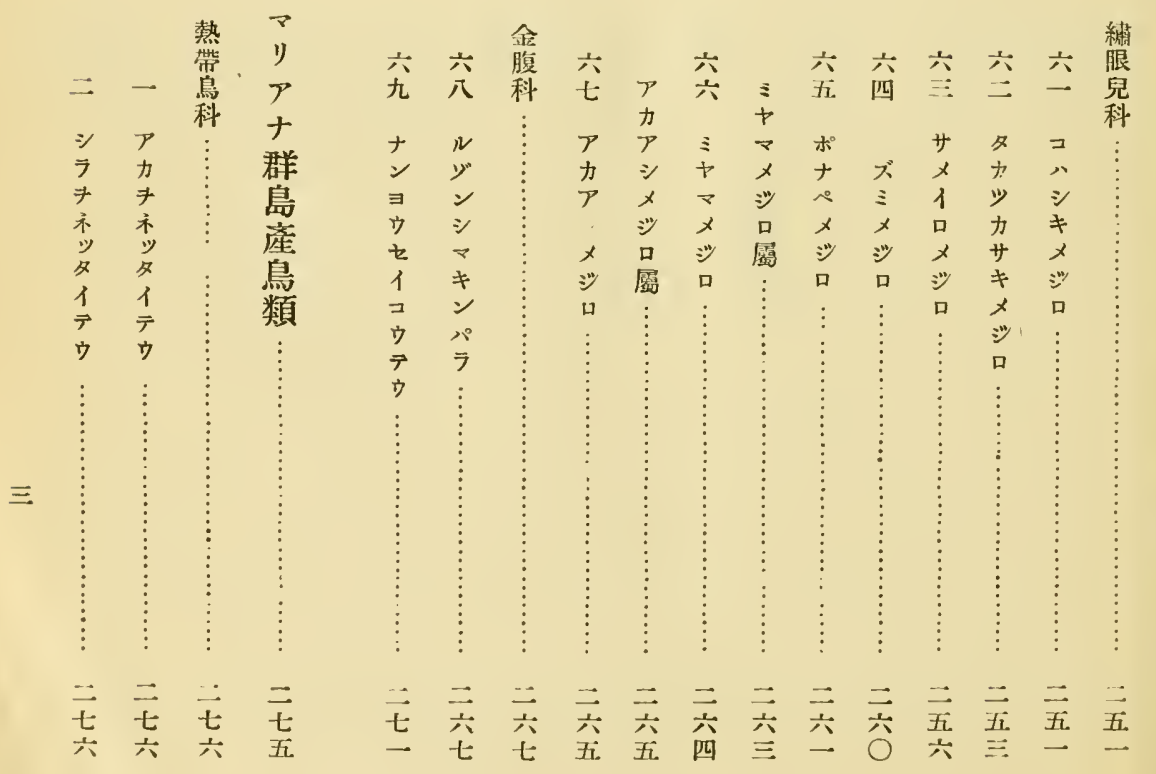




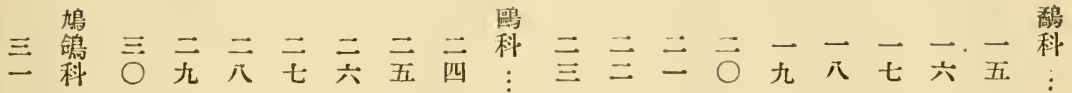

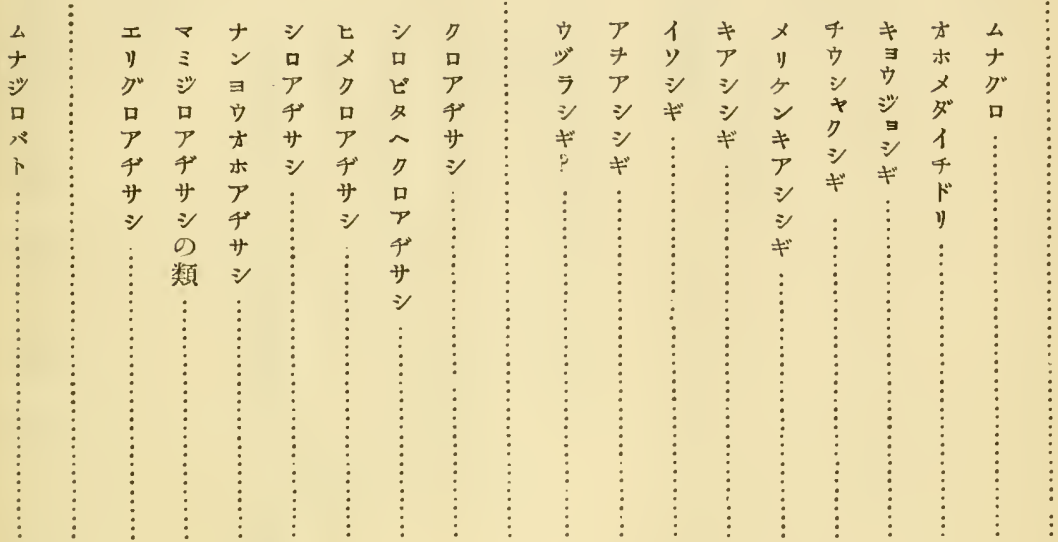

$$
\begin{aligned}
& \text { 至 三 三 三 吾 三 }
\end{aligned}
$$

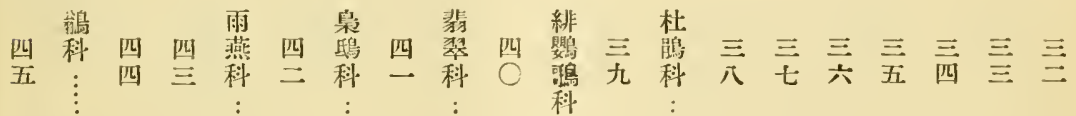

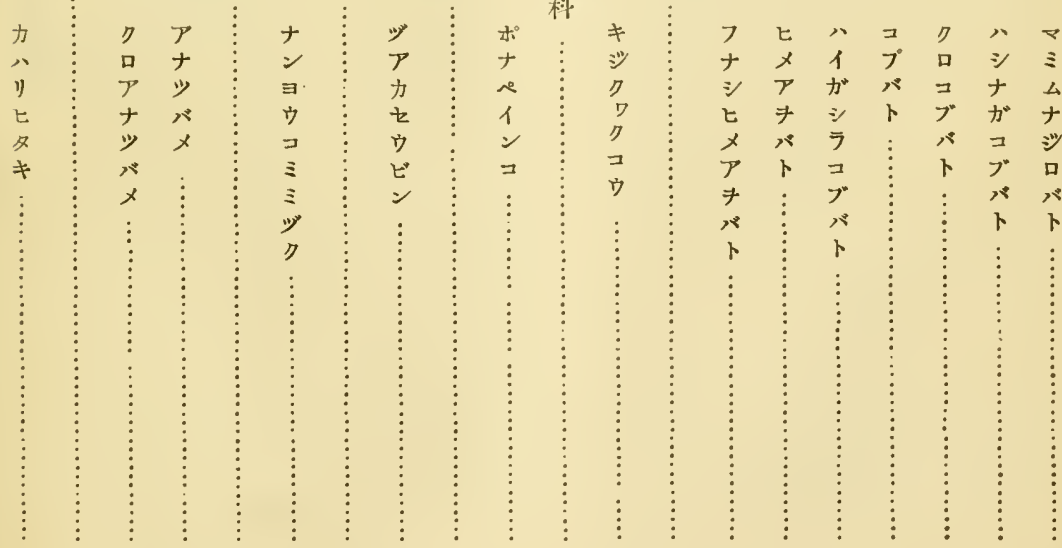

分公 公 


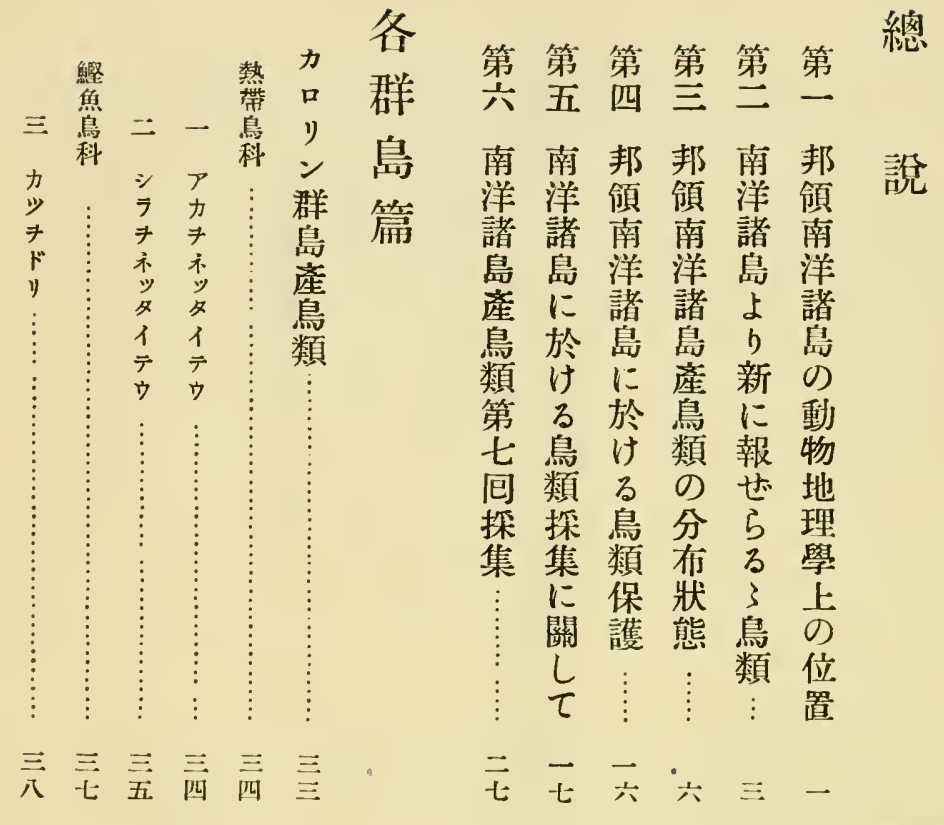

邦

領

南

洋

諸

島

產

鳥

類

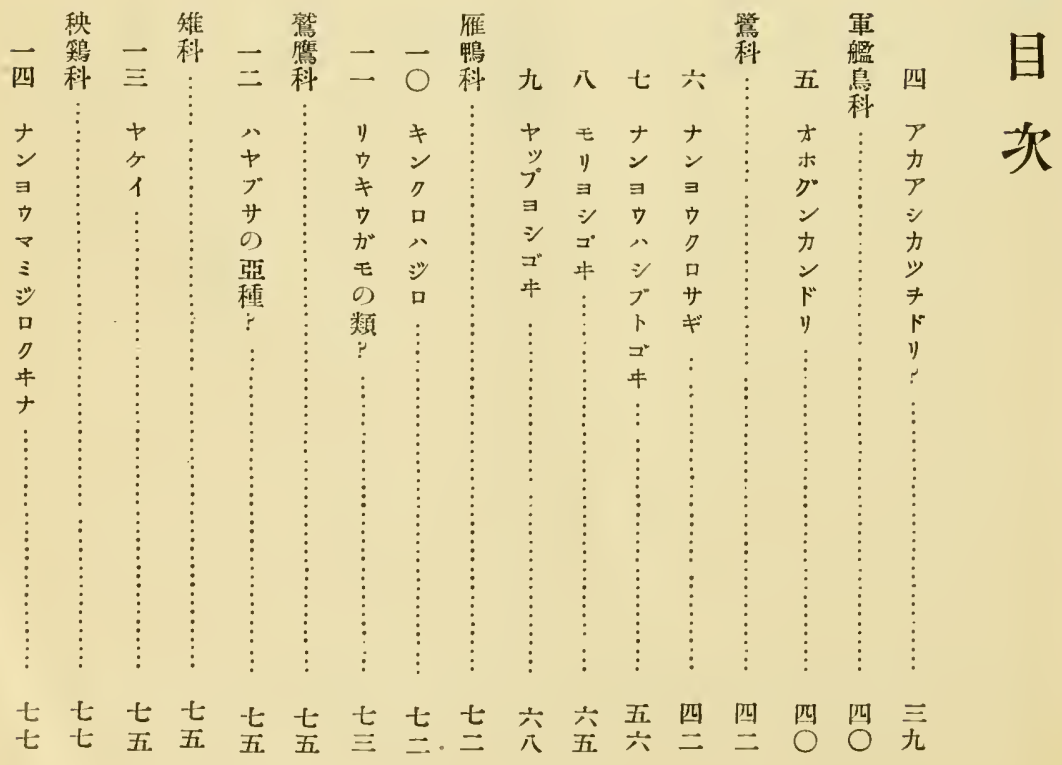




\section{賢り分貴し}

大に又な重て 正對旅当な公 十 ᄂ中調る爵 年て各查標鷹 十其地を本司 二諸に遂の信 月好於げ貸輔 意て得與氏 を荃たを端 鳴種る諾び 謝のはせに す便偏 ら本 之宜に北會 云を兩所々 爾 與 氏藏員 への宾 小

著

者

謹

識
ら厚き林

北志種 桂

たに類助

る據に氏 大る就は 方處て各 墸な充々 
懇と本地をた標子更をに余 篤材書方以り品とに草航は な料を產て余にな該せし大 ると公鳥粗素就 $L$ 小 $L$ 各 指をに類策よを向誌が地八自 導贈す研杜りて丈を今に年 をら万究撰淺聊今總包鳥四序 附れにのの學か回括夫類月 與 獸 當一誹菲其のの等探以 さ醫り助り才缺蒐上の集降 れ學理とは加を集各採を十 L土學的蓋ふ補に項集試月 は內土存しるひあ下鳥及に 哀田黑ら否に初らに類傍至 心清田ばれ短めざ隷各らる 感之長幸難日てる屬種各牛 謝助僼之か月本處也の種藏 に氏氏にらの書のし調にを 堪はは過ん調を同め査就邦 え編諸ぎ\&查纂地夫成て領 ざ輯種ざ向觀す方をる觀南 るにのる後察る產以に察洋 處關援なのなを鳥て及小諸 にし助り同る得類骨び誌島 



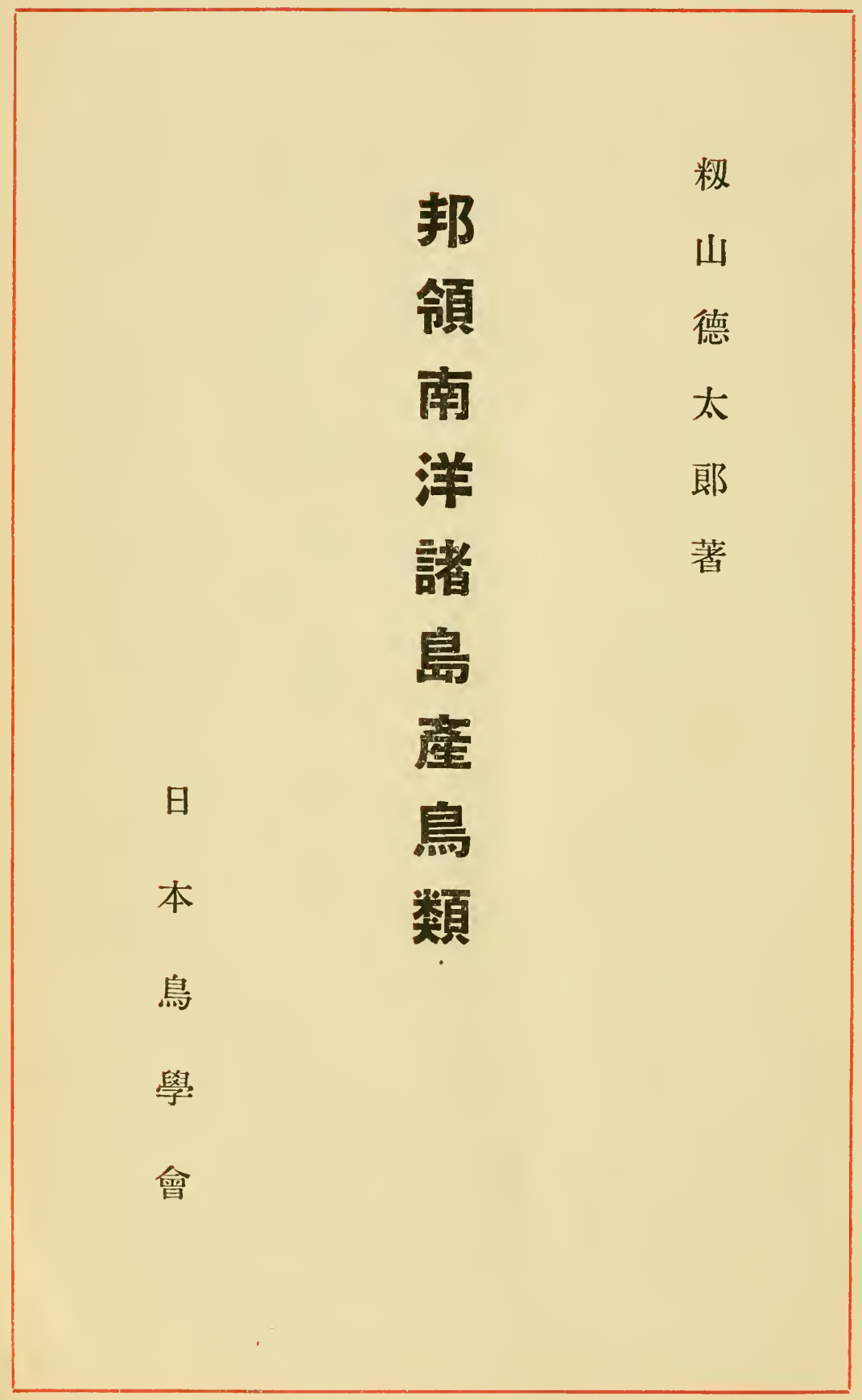




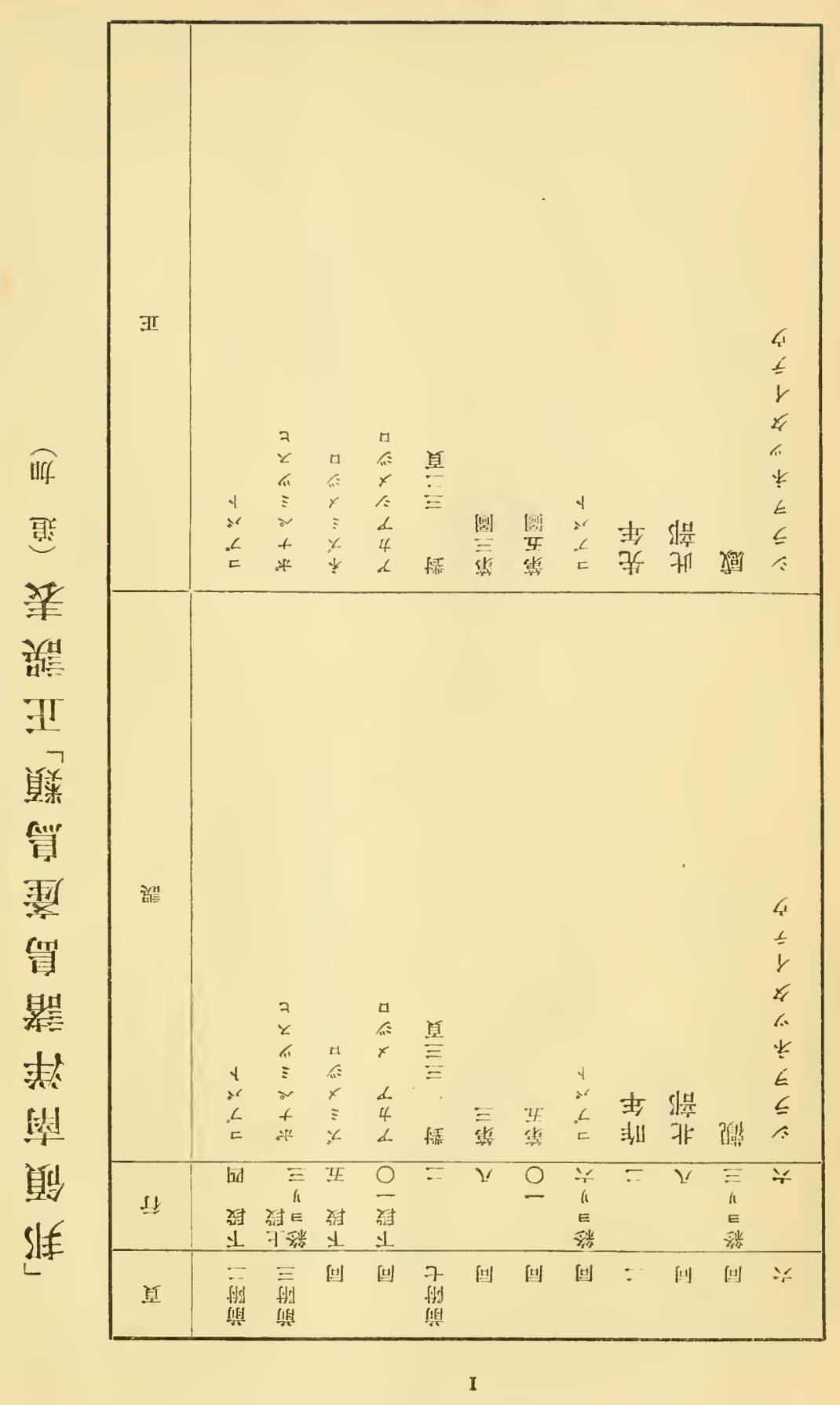





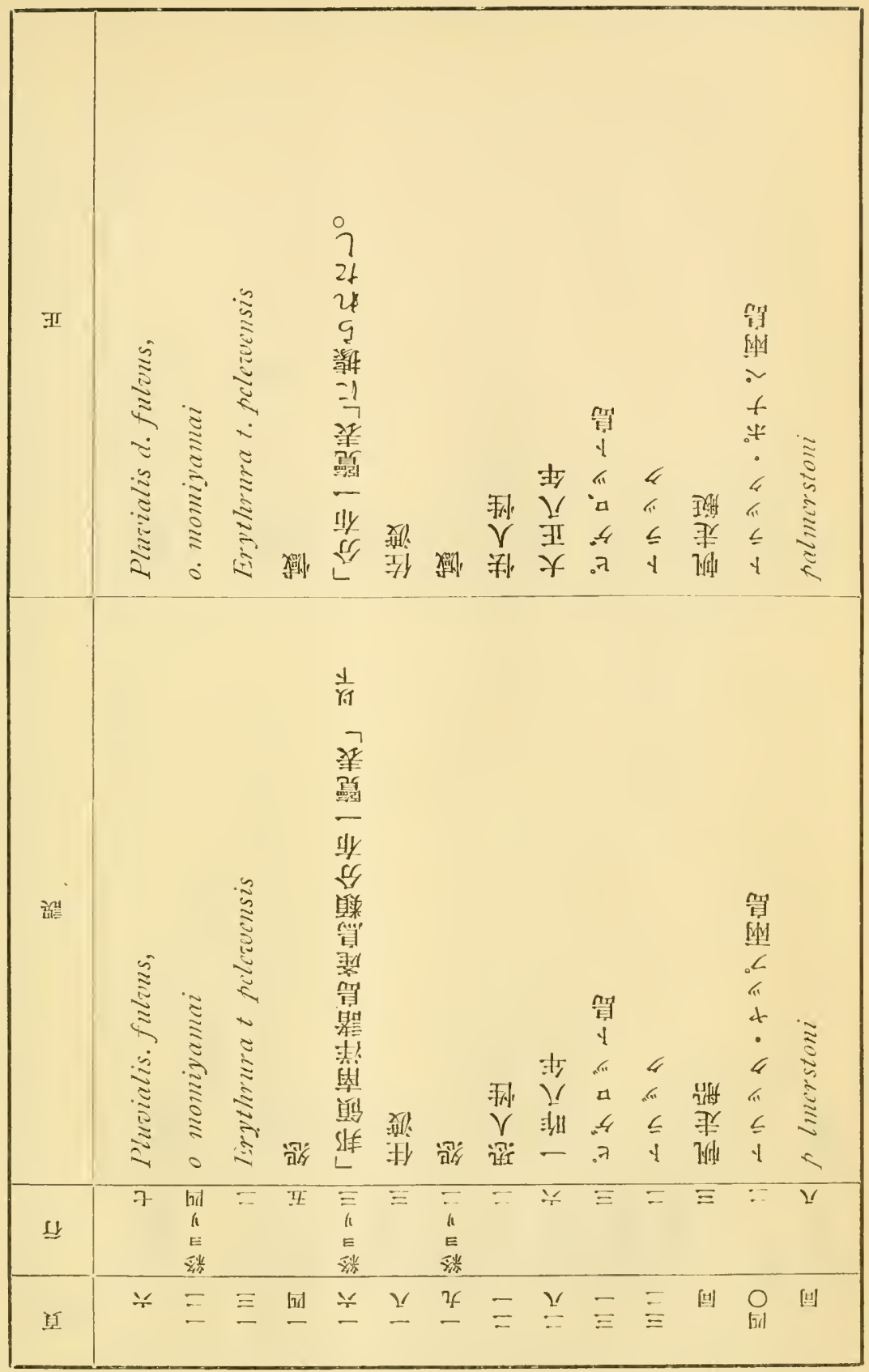





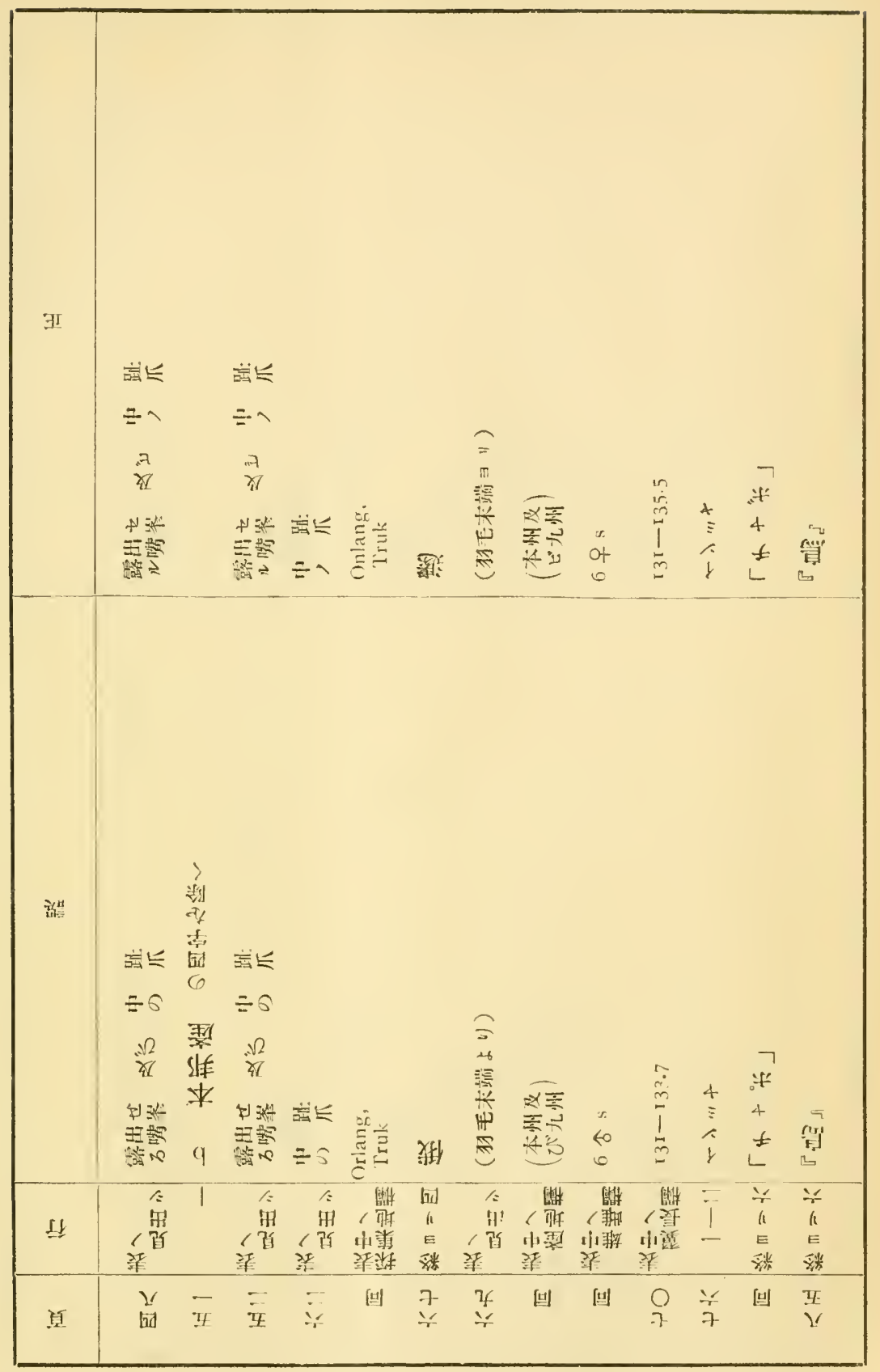





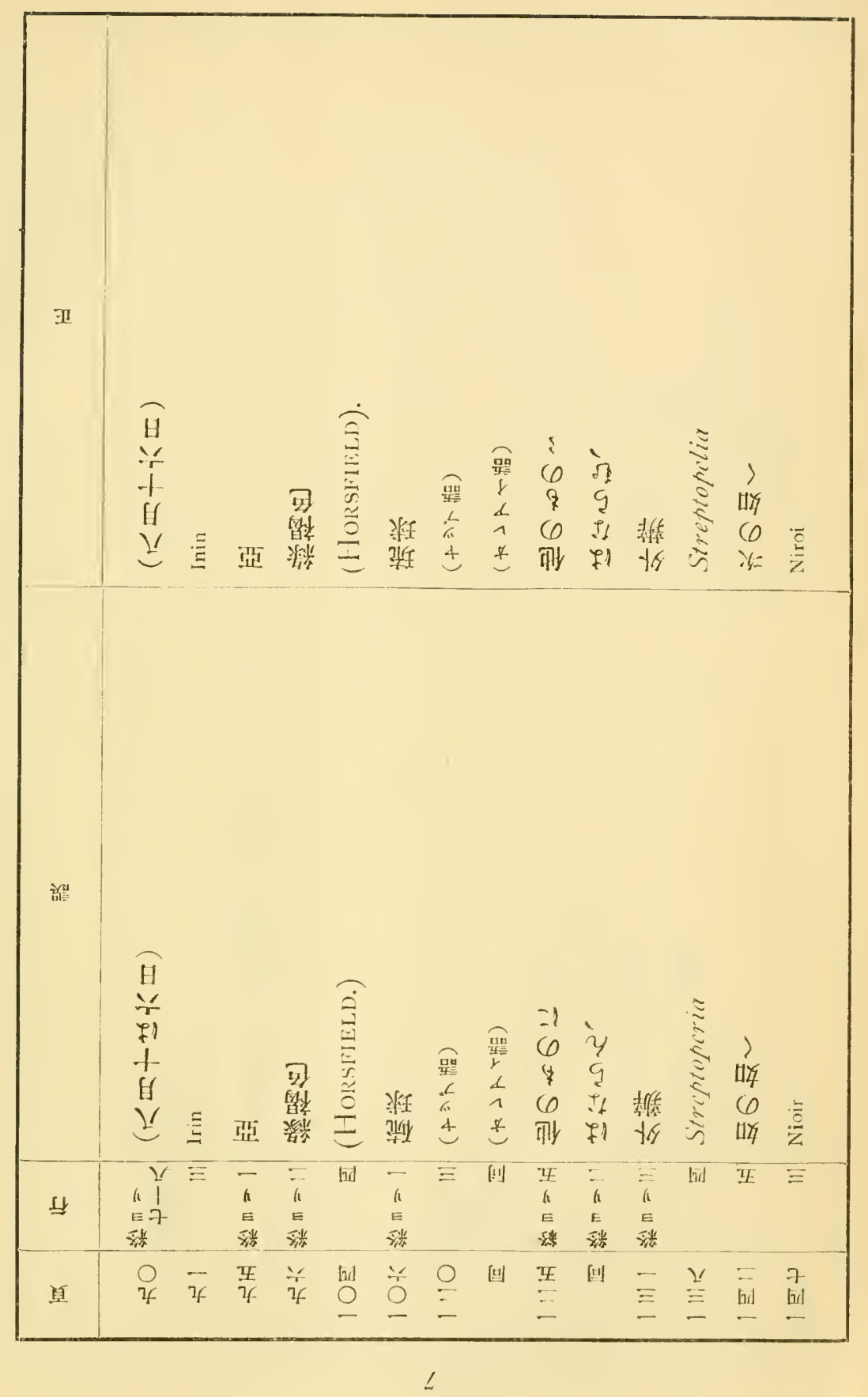





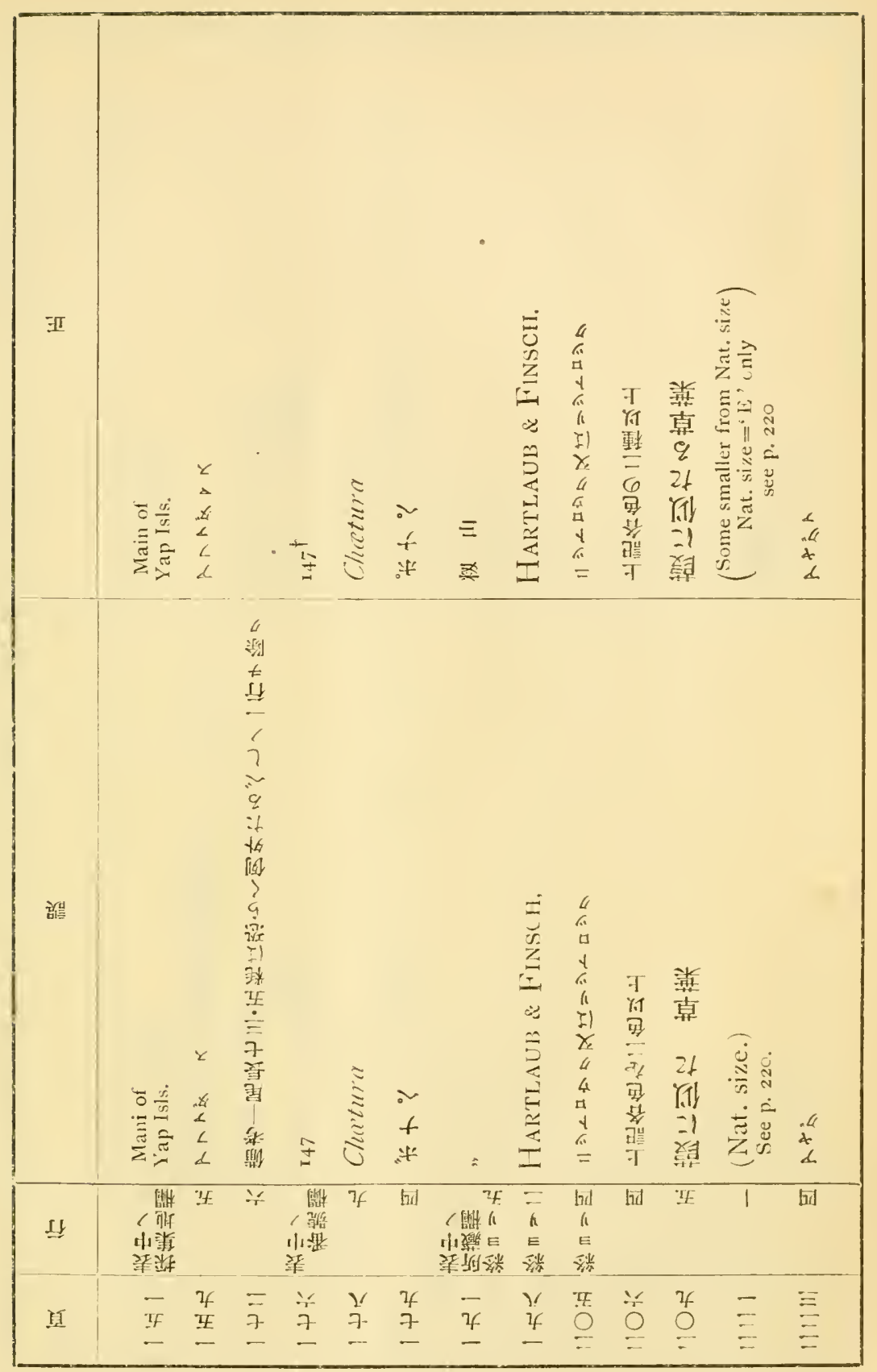





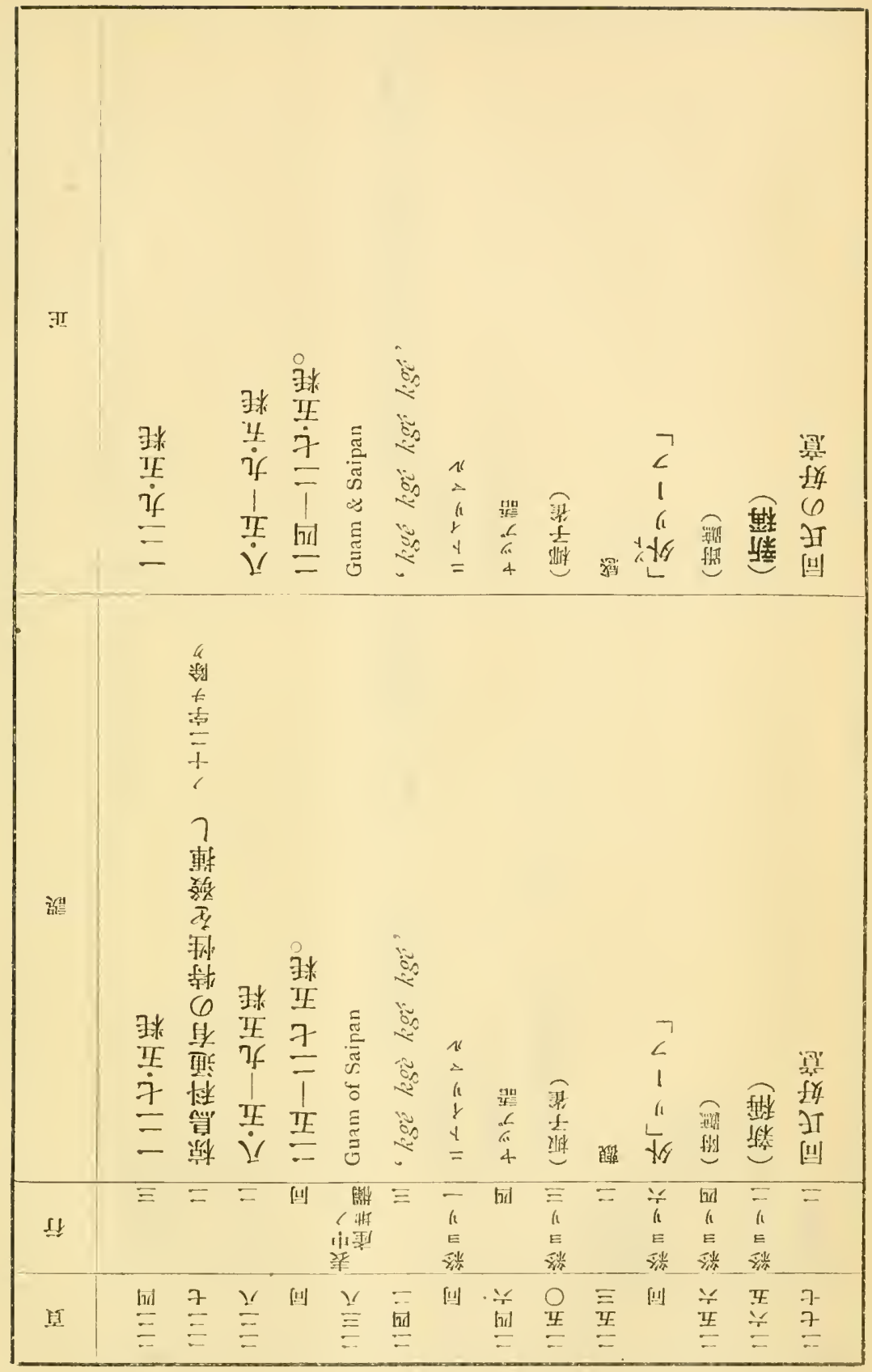





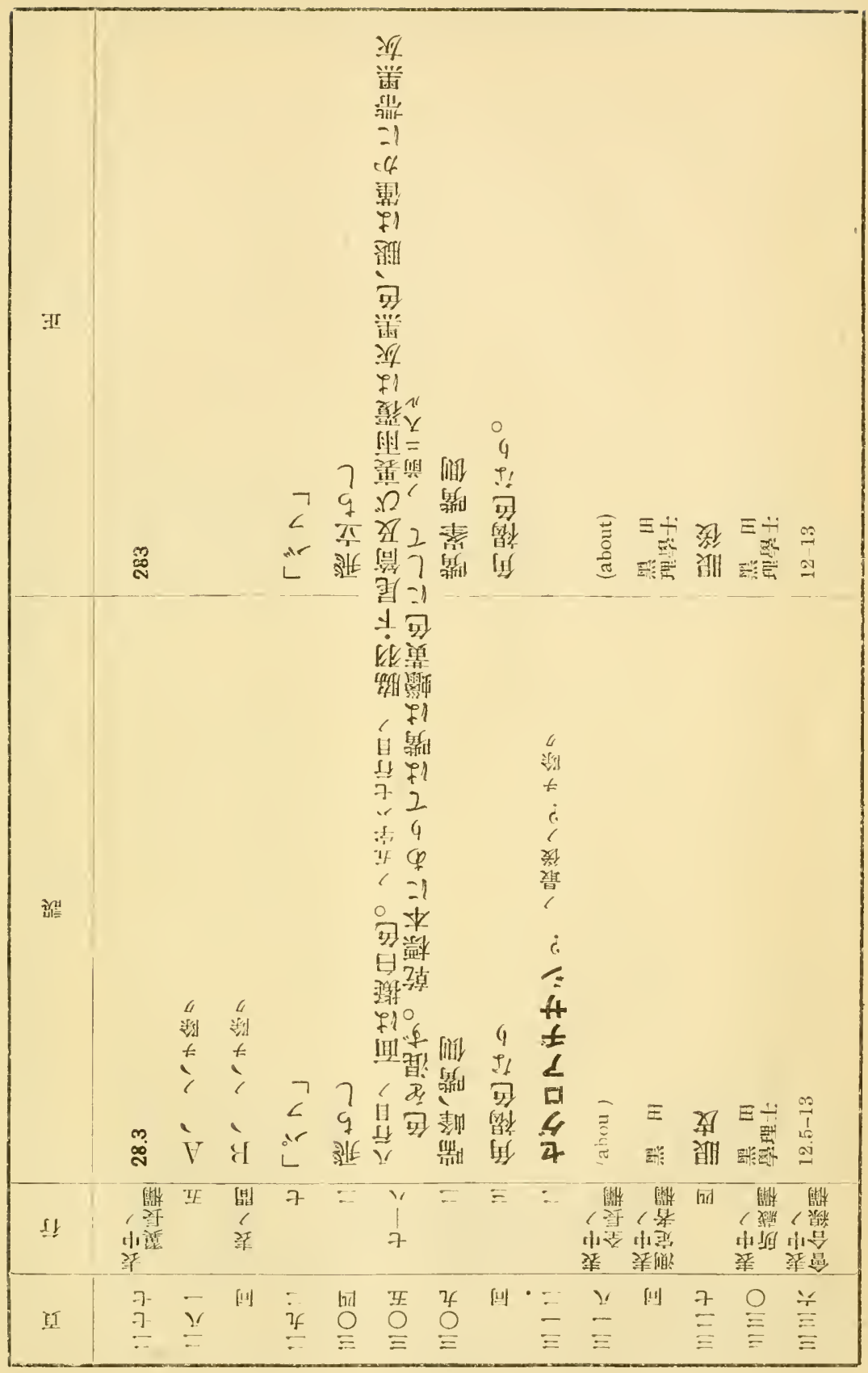



II

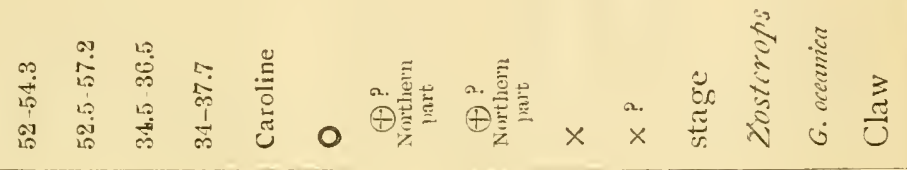

虽

$$
\begin{aligned}
& \text { 造 }
\end{aligned}
$$

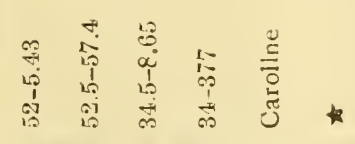

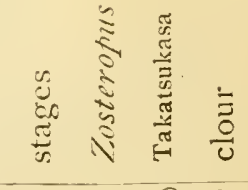

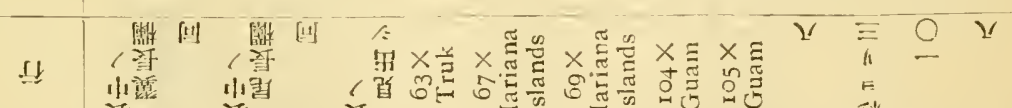





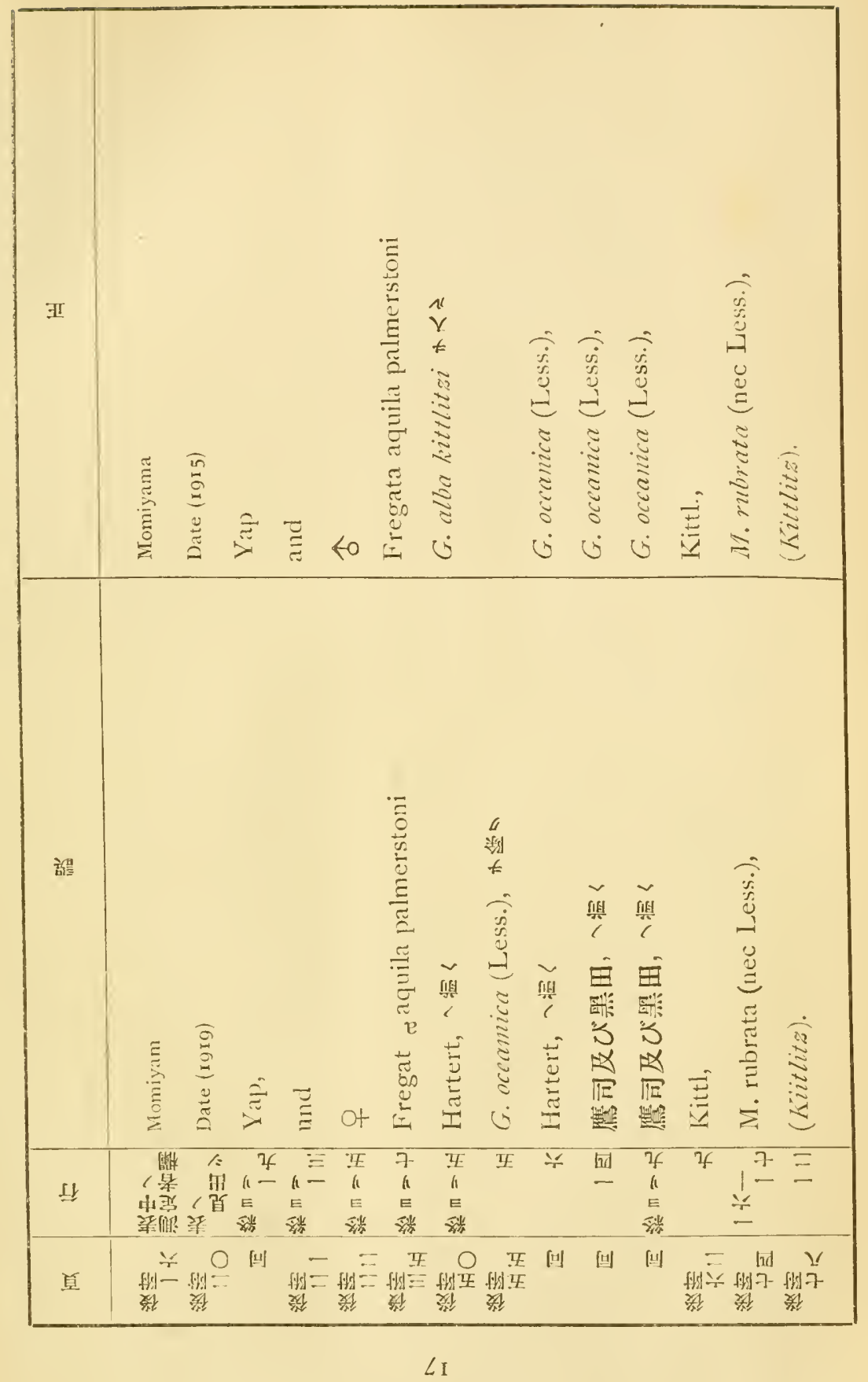






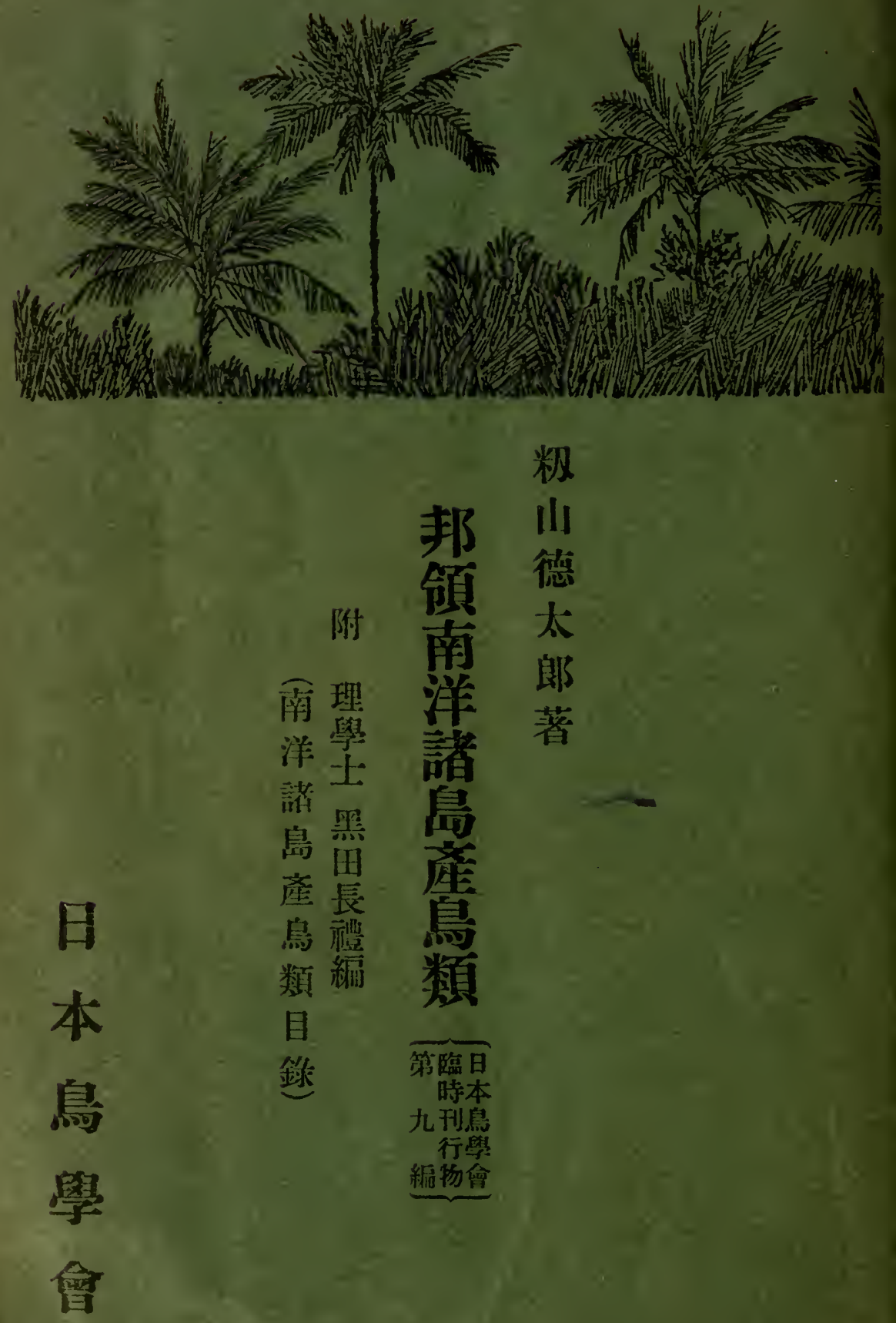





